\title{
Carboxylate-Assisted Ruthenium(II)-Catalyzed C-H Alkylation and Alkenylation
}

\author{
Dissertation \\ zur Erlangung des mathematisch-naturwissenschaftlichen Doktorgrades \\ "Doctor rerum naturalium" \\ der Georg-August-Universität Göttingen \\ im Promotionsprogramm Chemie \\ der Georg-August University School of Science (GAUSS)
}

vorgelegt von

Carina Tirler

aus Engelskirchen

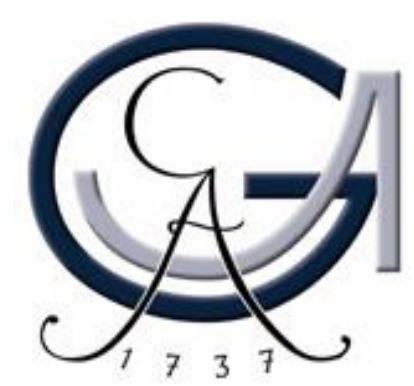

Göttingen, 2015 


\section{Betreuungsausschuss}

Prof. Dr. L. Ackermann, Institut für Organische und Biomolekulare Chemie

Prof. Dr. D. Stalke, Institut für Anorganische Chemie

\section{$\underline{\text { Mitglieder der Prüfungkommission }}$}

Referent: Prof. Dr. L. Ackermann, Institut für Organische und Biomolekulare Chemie

Korreferent: Prof. Dr. D. Stalke, Institut für Anorganische Chemie

Weitere Mitglieder der Prüfungskommission:

Dr. A. Breder, Institut für Organische und Biomolekulare Chemie

Prof. Dr. B. Geil, Arbeitsgruppe Prof. Dr. Andreas Janshoff, Institut für Physikalische Chemie

Prof. Dr. C. Höbartner, Institut für Organische und Biomolekulare Chemie

Prof. Dr. S. Schneider, Institut für Anorganische Chemie

Tag der mündlichen Prüfung: 29. 9. 2015 


\section{Danksagung}

Mein besonderer Dank gilt meinem Doktorvater Herr Prof. Dr. Lutz Ackermann für die gute Betreuung während der Anfertigung meiner Dissertation und für die mir gegebene Möglichkeit, auf interessanten Themengebieten zu forschen.

Herrn Prof. Dr. Dietmar Stalke danke ich für die freundliche Übernahme des Zweitgutachtens und die gute Unterstützung als Zweitbetreuer.

Frau Prof. Dr. C. Höbartner und den Herren Dr. A. Breder, Prof. Dr. B. Geil und Prof. Dr. S. Schneider danke ich für die Teilnahme an der Prüfungskommission.

Der gesamten Belegschaft der analytischen Abteilungen unter Herr Machinek und Dr. Frauendorf danke ich für die schnellen und gewissenhaften Messungen und besonders Herr Machinek persönlich möchte ich für die interessanten und lehrreichen Diskussionen danken.

Meinen Kollegen Fanzhi Yang, Sebastian Lackner und Phani Kumar danke ich besonders für das aufmerksame und zügige Korrekturlesen dieser Arbeit.

Spezieller Dank gebührt auch Stefan Beußhausen, „Gabi“ Keil-Knepel und Karsten Rauch für ihre unentbehrliche Unterstützung im Zusammenhang mit EDV, Verwaltung und Laborequipment.

Ich bin natürlich auch allen Arbeitskreismitgliedern, die mich in technischer, fachlicher oder freundschaftlicher Weise unterstützt haben, dankbar. Den vielen Mitarbeitern und Mitstreitern, die mit mir das Labor geteilt haben, danke ich für das entspannte Arbeitsklima. Mein besonderer Dank gilt hierbei Dr. Christoph Kornhaaß und den ehemaligen Laborkollegen aus den Laboren 203 und P123.

Ganz besonders möchte ich mich bei meinen Freunden Jennifer Więcek und Laura Eiden bedanken, die immer für mich da waren.

Mein größter Dank geht an meine Familie. Meine Eltern und meine Schwester Claudia, die mich immer unterstütz haben. 



\section{Contents}

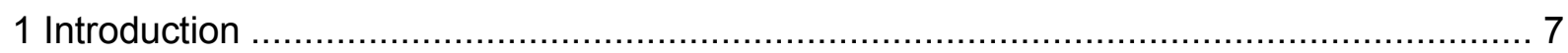

1.1 Transition Metal Catalyzed C-H Bond Functionalization ....................................

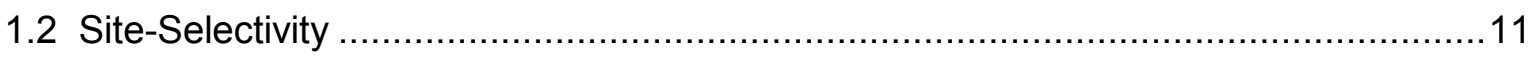

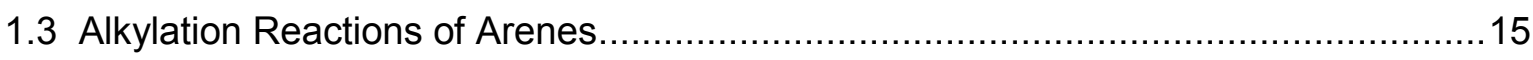

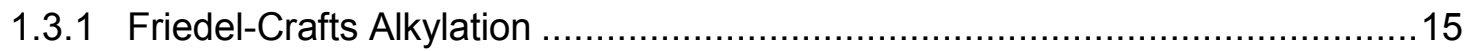

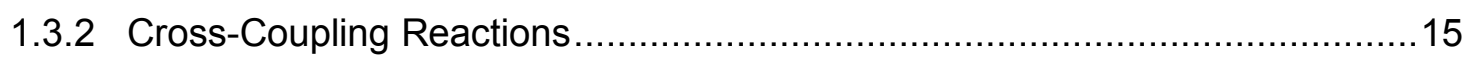

1.3.3 Transition Metal-Catalyzed C-H Bond Alkylation ................................. 16

1.4 Transition Metal-Catalyzed C-H Bond Alkenylation ..........................................19

$1.5 \mathrm{C}-\mathrm{H}$ Bond Functionalization for the Efficient Synthesis of Heterocyclic

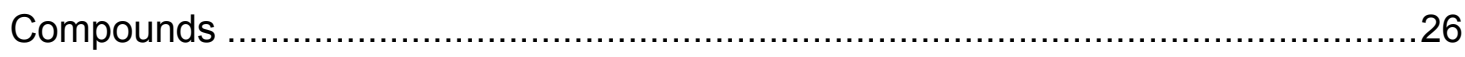

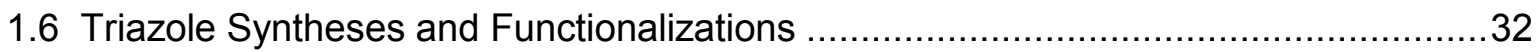

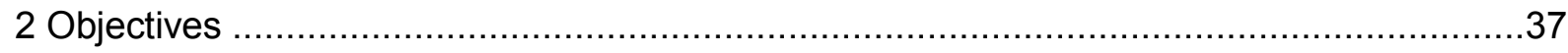

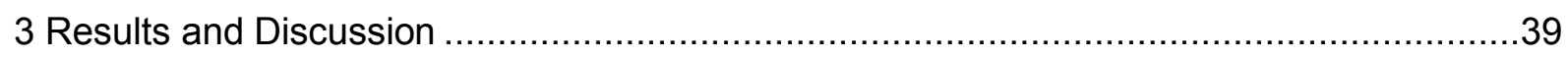

3.1 Ruthenium(II)-Catalyzed Direct Alkylation of N-Aryl-1,2,3-triazoles with primary-

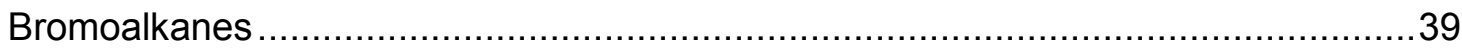

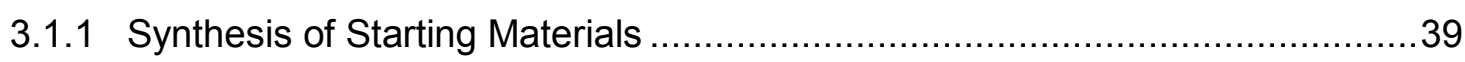

3.1.2 Optimization Studies for the $\mathrm{C}-\mathrm{H}$ Alkylation of $\mathrm{N}$-Aryl-1,2,3-triazoles with Primary Bromoalkanes

3.1.3 Scope and Limitations for the C-H Alkylation of $\mathrm{N}$-Aryl-1,2,3-triazoles with Alkyl Bromides.......................................................................... 48

3.2 Ruthenium(II)-Catalyzed C-H Methylation of $\mathrm{N}$-Aryl-1,2,3-triazoles .51

3.2.1 Optimization Studies and Scope for the C-H Methylation of $\mathrm{N}$-Aryl-1,2,3triazoles

3.3 Ruthenium(II)-Catalyzed Oxidative C-H Alkenylation of $\mathrm{N}$-Aryl-1,2,3-triazoles with Acrylates.

3.3.1 Optimization Studies for the C-H Alkenylation of N-Aryl-1,2,3-triazoles with Acrylates

3.3.2 Scope and Limitations for the Direct Alkenylation of N-Aryl-1,2,3-triazoles with Acrylates 
3.4 Annulation of Acrylates through Ruthenium(II)-Catalyzed Direct $\mathrm{C}-\mathrm{H} / \mathrm{N}-\mathrm{H}$ Bond Functionalization of $N$-Tosylbenzamides

3.4.1 Optimization Studies for the Annulation of Acrylates through

Ruthenium(II)-Catalyzed Direct $\mathrm{C}-\mathrm{H} / \mathrm{N}-\mathrm{H}$ Bond Functionalization of $\mathrm{N}$ Tosylbenzamides.

3.4.2 Scope and Limitations for the Direct $\mathrm{C}-\mathrm{H} / \mathrm{N}-\mathrm{H}$ Bond Functionalization of $N$-Tosylbenzamides with Acrylates ................................................. 76

3.4.3 Mechanistic Studies

3.5 Annulation of Acrylates through Ruthenium(II)-Catalyzed Direct $\mathrm{C}-\mathrm{H} / \mathrm{N}-\mathrm{H}$ Bond Functionalization of $\mathrm{N}$-Tosylbenzamides with Oxygen as Oxidant

3.5.1 Optimization Studies for the Annulation of Acrylates through

Ruthenium(II)-Catalyzed Direct $\mathrm{C}-\mathrm{H} / \mathrm{N}-\mathrm{H}$ Bond Functionalization of $\mathrm{N}$ Tosylbenzamides with Oxygen as Oxidant

3.5.2 Scope of the Aerobic Annulation of Acrylates through Ruthenium(II)-

Catalyzed Direct $\mathrm{C}-\mathrm{H} / \mathrm{N}-\mathrm{H}$ Functionalization of $\mathrm{N}$-Tosylbenzamides 88

3.5.3 Mechanistic Studies

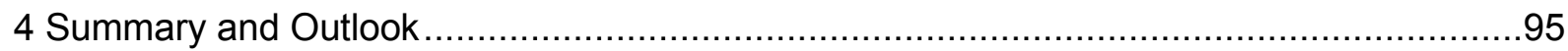

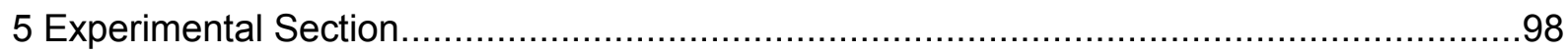

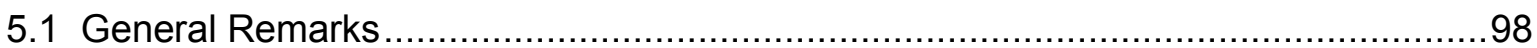

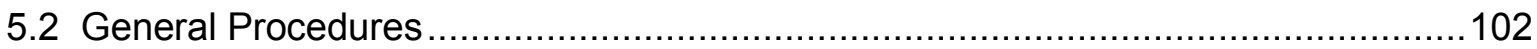

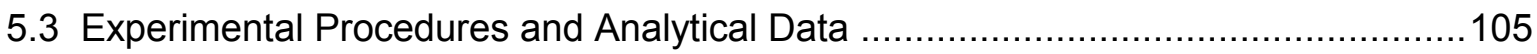

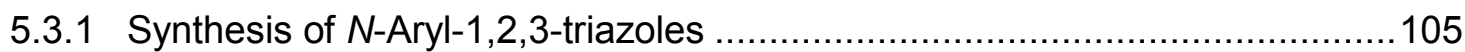

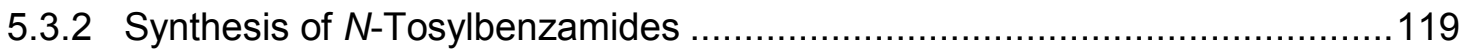

5.3.3 Synthesis of Alkylated $N$-Aryl-1,2,3-triazoles ....................................128

5.3.4 Synthesis of Methylated N-Aryl-1,2,3-triazoles ....................................... 134

5.3.5 Synthesis of Alkenylated N-Aryl-1,2,3-triazoles ....................................136

5.3.6 Intermolecular Competition Experiment for the Ruthenium-Catalyzed Synthesis of Alkenylated N-Aryl-1,2,3-triazoles

5.3.7 Mechanistic Studies on the Ruthenium(II)-Catalyzed Synthesis of Alkenylated $\mathrm{N}$-Aryl-1,2,3-triazoles 161

5.3.8 Ruthenium(II)-Catalyzed Synthesis of Isoindolinones 163 
5.3.9 Intermolecular Competition Experiment for the Ruthenium(II)-Catalyzed Synthesis of Isoindolinones 183

5.3.10 Mechanistic Studies on the Ruthenium(II)-Catalyzed Synthesis of Isoindolinones...... 184

5.3.11 Ruthenium(II)-Catalyzed Synthesis of Isoindolinones using Oxygen as Sole Oxidant 186

5.3.12 Intermolecular Competition Experiment for the Ruthenium(II)-Catalyzed Synthesis of Isoindolinones 195

Curriculum Vitae 196 


\section{Abbreviations}

Ac

$\mathrm{Ad}$

Alk

AMLA

aq.

$\mathrm{Ar}$

atm

9-BBN

$\mathrm{Bn}$

Boc

bpy

$\mathrm{Bu}$

cat.

CMD

$\mathrm{Cp}^{*}$

Cy

dba

DCE

DG

diglyme

DMA

DMAP

DME

DMEDA

DMF

DMSO

DoM

EI

ESI

Et

EWG

FTICR

GC-MS

gem

$\mathrm{h}$

Hex
Acetyl

Adamantyl

Alkyl

Ambiphilic metal-ligand activation

aqueous

Aryl

Atmosphere

9-Borabicyclo[3.3.1]nonan

Benzyl

tert-Butyloxycarbonyl

2,2'-Bipyridine

Butyl

Catalytic

Concerted metalation-deprotonation

1,2,3,4,5-Pentamethylcyclopentadienyl

Cyclohexyl

Dibenzylidenaceton

1,2-Dichloroethane

Directing group

Diglycol methyl ether

$N, N$-Dimethylacetamide

4-(Dimethylamino)-pyridin

1,2-Dimethoxyethane

$N, N$-Dimethylethylenediamine

$\mathrm{N}, \mathrm{N}$-Dimethylformamide

Dimethylsulfoxide

Directed ortho-metalation

Electron ionization

Electronspray ionization

Ethyl

Electron withdrawing group

Fourier transform ion cyclotron resonance

Gas transform ion cyclotron resonance

Geminal

Hour

Hexyl 


\begin{tabular}{|c|c|}
\hline HMDS & Hexamethyldisilazan \\
\hline HR-MS & High resolution mass spectrometry \\
\hline IES & Internal electrophilic substitution \\
\hline$i-\operatorname{Pr}$ & iso-Propyl \\
\hline IR & Infrared \\
\hline LDA & Lithiumdiisopropylamid \\
\hline M & Metal \\
\hline Mes & 2,4,6-Trimethylphenyl \\
\hline $\mathrm{Me}$ & Methyl \\
\hline$m$ & meta \\
\hline mol. & Molecular \\
\hline M.p. & Melting point \\
\hline M.r. & Melting range \\
\hline NMP & N-Methyl-2-pyrrolidone \\
\hline 0 & ortho \\
\hline$p$ & para \\
\hline cymene & 4-iso-Propyltoluene \\
\hline PEG & Polyethylene glycol \\
\hline Pent. & Pentyl \\
\hline Phen. & Phenanthroline \\
\hline $\mathrm{Ph}$ & Phenyl \\
\hline Piv & Pivalyl \\
\hline PMP & para-Methoxyphenyl \\
\hline ppm & Parts per million \\
\hline $\mathrm{S}_{\mathrm{E}} \mathrm{Ar}$ & Electrophilic aromatc substitution \\
\hline SPO & Secondary phosphine oxid \\
\hline $\mathrm{T}$ & Temperature \\
\hline$t-A m$ & tert-Amyl \\
\hline Tf & Triflouromethanesulfonyl \\
\hline TFA & Triflouroacetic acid \\
\hline THF & Tetrahydrofuran \\
\hline TLC & Thin layer chromatography \\
\hline TM & Transition metal \\
\hline TMS & Trimethylsilyl \\
\hline TS & Transition state \\
\hline UV & Ultraviolet \\
\hline$x$ & Halide \\
\hline
\end{tabular}





\section{Introduction}

Sustainability is important, because our natural sources are limited and our environment needs protection. Organic chemistry has to face this challenge.

Thus, one of the major goals of sustainable chemistry is the site- and chemo-selective synthesis of organic compounds, without side-products and waste, in a step-economical fashion under mild reaction conditions.

During the last decades, progress has been made in the important field of $\mathrm{C}-\mathrm{C}$ bond formations. ${ }^{1}$ The transition metal-catalyzed cross-coupling reactions, ${ }^{2}$ forming chemo- and site-selective C-C bonds, were developed by several research groups. ${ }^{3}$ Because of their pioneering work Heck, Negishi and Suzuki were awarded with the Nobel prize in chemistry in 2010, thus illustrating the importance of this methodology. ${ }^{4}$

The traditional cross coupling reaction is presented in Scheme 1.1.

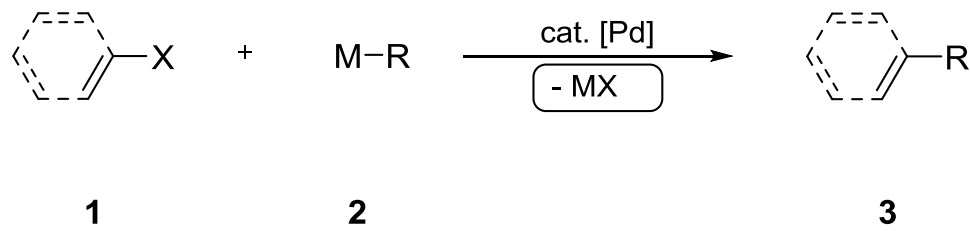

Scheme 1.1: Traditional cross-coupling reaction.

In general, an aryl, alkenyl or alkyl (pseudo)halide reacts as an electrophile with an organometallic reagent as a nucleophile via transition metal catalysis. The key features of the mechanism of cross-coupling reactions are the oxidative addition of the (pseudo)halide to the active catalyst, the transmetalation with the organometallic reagent and the subsequent reductive elimination to give the coupled product. In the Mizoroki-Heck reaction the product is formed via syn-insertion, followed by $\sigma$-bond rotation and $\beta$-hydride elimination. ${ }^{5}$ Because of the use of prefunctionalized starting materials and the stoichiometric amounts of metal salts produced as side products this transformation is not ideal. To avoid the disadvantages of the

\footnotetext{
(a) A. Behr, Angewandte homogene Katalyse, Wiley-VCH, Weinheim, 2008; (b) Modern Arylation Methods, (Ed.: L. Ackermann), Wiley-VCH, Weinheim, 2009; (c) G. Fu, Acc. Chem. Res. 2008, 41, 1555-1564; (d) R. Martin, S. L. Buchwald, Acc. Chem. Res. 2008, 41, 1461-1473.

2 (a) C. C. C. Johansson Seechurn, M. O. Kitching, T.J. Colacot, V. Snieckus, Angew. Chem. Int. Ed. 2012, 51, 5062-5086. (b) Metal-Catalyzed Cross-Coupling Reactions (Eds. de Meijere, A.; Diederich, F.), 2nd ed., WileyVCH: Weinheim, 2004. (c) Transition Metals for Organic Synthesis (Eds. Beller, M.; Bolm, C.), 2nd ed., WileyVCH: Weinheim, 2004.

${ }^{3}$ For recent reviews on conventional cross-coupling reactions, see: (a) Chem. Soc. Rev. 2011, 40, Special Issue 10 "Cross coupling reactions in organic synthesis", 4877-5208; (b) B. M. Rosen, K. W. Quasdorf, D. A. Wilson, N. Zhang, A.-M. Resmerita, N. K. Garg, V. Percec, Chem. Rev. 2011, 111, 1346-1416; (c) G. Cahiez, A. Moyeux, A. Chem. Rev. 2010, 110, 1435-1462.

4 "The Nobel Prize in Chemistry 2010 - Press Release". Nobelprize.org. Nobel Media AB 2013. Web. 25 Feb. 2014. http://www.nobelprize.org/nobel_prizes/chemistry/laureates/2010/press.html

5 J. P. Corbet, G. Mignani, Chem. Rev. 2006, 106, 2651-2710.
} 
cross-coupling reactions several research groups studied the transition metal-catalyzed direct functionalization of $\mathrm{C}-\mathrm{H}$ bonds. ${ }^{6}$

\subsection{Transition Metal Catalyzed C-H Bond Functionalization}

Unlike traditional cross-coupling reactions, direct $\mathrm{C}-\mathrm{H}$ bond functionalizations ${ }^{6}$ have the advantage that prefunctionalized starting materials are not needed. Scheme 1.2 shows three different strategies for transition metal-catalyzed direct $\mathrm{C}-\mathrm{H}$ bond functionalizations. ${ }^{7}$

a)

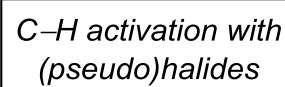
(pseudo)halides

b)

$\mathrm{C}-\mathrm{H}$ activation with organometallic reagent

c)

dehydrogenative $C-H$ activation<smiles>[X]c1ccccc1C#CC</smiles><smiles>C1=CCCC=C1</smiles>

4

2

î<smiles>[R][IH+]c1ccccc1</smiles>

4

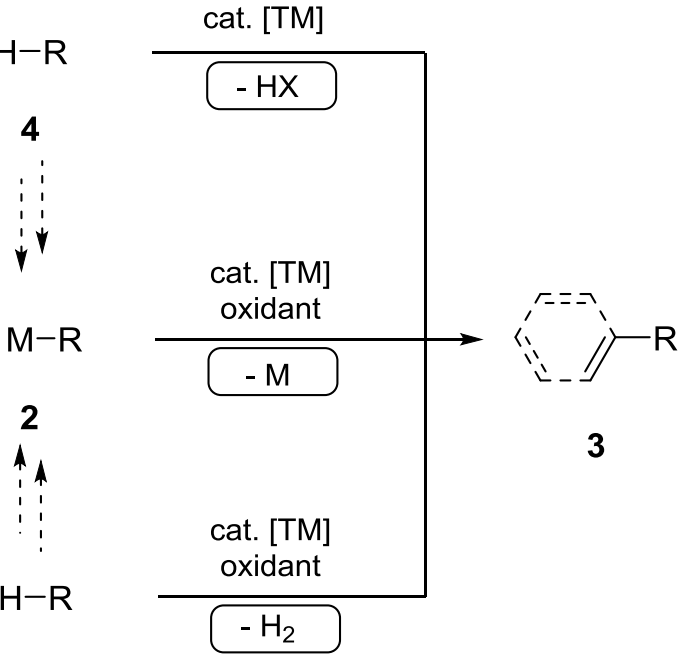

$\mathrm{R}=$ aryl, alkenyl, alkyl

Scheme 1.2: Strategies for transition metal-catalyzed $\mathrm{C}-\mathrm{H}$ bond functionalization

In reference to traditional cross-coupling reactions, Scheme 1.2 a presents the coupling of aryl or alkenyl substrates with an unactivated $\mathrm{C}-\mathrm{H}$ bond and aryl or alkenyl (pseudo)halides. In contrast, the reaction in Scheme $1.2 \mathrm{~b}$ displays the coupling between arenes or alkenes with organometallic reagents. The last strategy demonstrates the dehydrogenative coupling by activation of two $\mathrm{C}-\mathrm{H}$ bonds (Scheme $1.2 \mathrm{c}$ ). For the latter two transformations,

\footnotetext{
${ }^{6}$ For recent reviews on $\mathrm{C}-\mathrm{H}$ bond functionalizations, see (a) S. De Sarkar, W. Liu, S. I. Kozhushkov, L. Ackermann, Adv. Synth. Catal. 2014, 356, 1461-1479; (b) K. Gao, N. Yoshikai, Acc. Chem. Res. 2014, 47, 1208-1219; (c) B. Li, P. H. Dixneuf, Chem. Soc. Rev. 2013, 42, 5744-5767; (d) T. A. Ramirez, B. G. Zhao, Y. Shi, Chem. Soc. Rev. 2012, 41, 931-942; (e) Z.-Z. Shi, C. Zhang, C.-H. Tang, N. Jiao, Chem. Soc. Rev. 2012 41, 3381-3430; (f) D. A. Colby, A. S. Tsai, R. G. Bergman, J. A. Ellman, Acc. Chem. Res. 2012, 45, 814-825; (g) J. L. Bras, J. Muzart, Chem. Rev. 2011, 111, 1170-1214; (h) L. Ackermann, Chem. Comm. 2010, 46, 48664877; (i) T.W. Lyons, M. S. Sanford, Chem. Rev. 2010, 110, 1147-1169; (j) A. A. Kulkarni, O. Daugulis, Synthesis, 2009, 4087-4109; (k) R. Giri, B.-F. Shi, K. M. Engle, N. Maugel, J.-Q. Yu, Chem. Soc. Rev. 2009, 38, 3242-3272; (I) X. Chen, K. M. Engle, D.-H. Wang, J.-Q. Yu. Angew. Chem. Int. Ed. 2009, 48, 5094-5115. For reports on atom- and step-economy, see: (m) B. M. Trost, Acc. Chem. Res. 2002, 35, 695-705; (n) B. M. Trost, Science, 1991, 254, 1471-1477; (o) P. A. Wender, V. A. Verma, T. J. Paxton, T. H. Pillow, Acc. Chem. Res. 2008, 41, 40-49.

${ }^{7}$ L. Ackermann, R. Vicente, A. R. Kapdi, Angew. Chem. Int. Ed. 2009, 48, 9792-9826.
} 
stoichiometric amounts of oxidants are essential. While the two first strategies still need at least some prefunctional starting materials, the dehydrogenative coupling is the most stepand atom-economical reaction, as it does not require any prefunctionalized starting materials. This is in accordance with the concept of green chemistry. ${ }^{8}$

The transition metal-catalyzed $\mathrm{C}-\mathrm{H}$ bond functionalization emerged also from the concept of green chemistry. The $\mathrm{C}-\mathrm{H}$ bond functionalizations could be carried out chemo-, site-, and enantioselectively with a variety of transition metals such as palladium, ${ }^{6 \mathrm{~g}, 6 \mathrm{k}, 61}{ }^{\text {ruthenium, }},{ }^{6 \mathrm{a}, 6 \mathrm{c}}$ rhodium, ${ }^{6 f}$ cobalt $^{6 b, 6 j}$ and nickel. ${ }^{6 j}$ The varieties of these reactions lead to intensive investigations of the catalyst's working mode. As a consequence, four generally accepted mechanistic pathways ${ }^{9}$ for the $\mathrm{C}-\mathrm{H}$ bond metalation step were postulated (Scheme 1.3). Computational studies of these mechanisms were summarized by Eisenstein and coworkers. ${ }^{10}$

a) oxidative addition

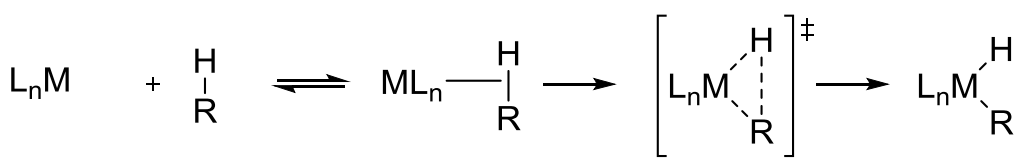

b) $\sigma$-bond metathesis

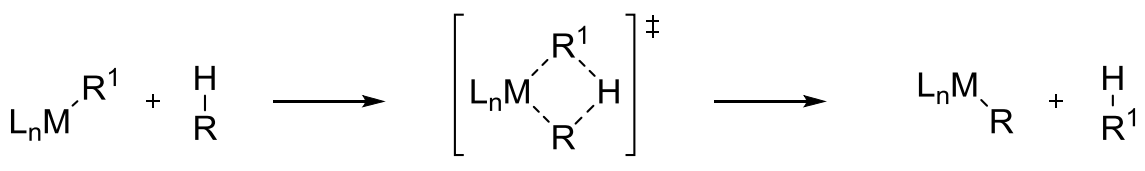

c) electrophilic substitution

$\stackrel{\oplus}{L_{n} M^{\prime X}}+$

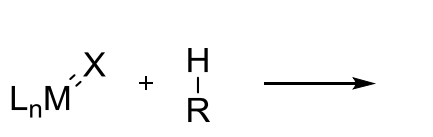<smiles>[X][M][R]</smiles><smiles>C=C</smiles><smiles></smiles><smiles>[R][Y14]([H])=CCCCC</smiles>

Scheme 1.3: Possible mechanisms for $\mathrm{C}-\mathrm{H}$ bond metalation by transition metal complexes. ${ }^{8 \mathrm{c}}$

The first pathway considered, is the oxidative addition (Scheme $1.3 \mathrm{a}$ ), which can be performed by electron rich and low-valent complexes of late transition metals. Whereas early transition metals with $d^{0}$-configuration cannot undergo oxidative addition, $\sigma$-bond metathesis (Scheme $1.3 \mathrm{~b}$ ) takes usually place here. While electrophilic substitution (Scheme $1.3 \mathrm{c}$ ) occurs with electron deficient late transition metals, alkylidene or imido complexes of early transition metals display the possibility of $\mathrm{C}-\mathrm{H}$ activation via 1,2-additions (Scheme $1.3 \mathrm{~d}$ ).

\footnotetext{
${ }^{8}$ Ackermann, L.; Kapdi, A. R.; Potukuchi, H. K.; Kozhushkov, S. I. In Handbook of Green Chemistry (Ed. Li, C.-J.), Wiley-VCH: Weinheim, 2012, 259-305.

9 (a) Y. Boutadla, D. L. Davies, S. A. Macgregor, A. I. Poblador-Bahamonde, Dalton Trans. 2009, 5820-5831; (b) L. Ackermann, Chem. Rev. 2011, 111, 1315-1345.

${ }^{10}$ D. Balcells, E. Clot, O. Eisenstein, Chem. Rev. 2010, 110, 749-823.
} 
New developments display a bifunctional process, which involves $\mathrm{C}-\mathrm{H}$ activation by an electrophilic metal working synergistically with secondary phosphine oxides or carboxylates. Six membered transition states are formed during this mechanism, which was coined as $\mathrm{CMD}^{11}$ (concerted-metalation-deprotonation) or $\mathrm{AMLA}^{9 a}$ (ambiphilic metal-ligand activation) (Scheme 1.4).

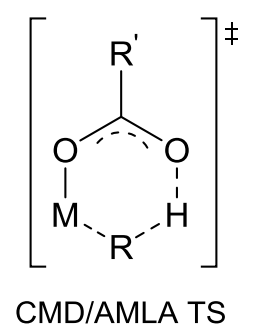

Scheme 1.4: Proposed transition states for the CMD/AMLA activation.

These mechanistical investigations are the foundation of the transition metal-catalyzed $\mathrm{C}-\mathrm{H}$ bond functionalization, which has gained a lot of attention in recent years and is used for the catalyzed synthesis of biaryls. ${ }^{1 \mathrm{~b}, 12}$ Transition metals used in $\mathrm{C}-\mathrm{H}$ bond functionalization are relatively expensive. The prices of gold, platinum, rhodium, palladium, iridium and ruthenium are $1174,1084,900,671,550$ and 45 US $\$$ per troy oz, respectively. ${ }^{13}$

Ruthenium, a relatively inexpensive transition metal, proved to be broadly applicable in the $\mathrm{C}-\mathrm{H}$ bond functionalization. Early studies on chelation-assisted ruthenium(II)-catalyzed direct arylations were performed by the Ackermann group in 2005. The ruthenium-catalyzed arylation of aryl pyridines or aromatic imines with easily accessible aryl chlorides proceeded with excellent chemo- and site-selectivity. This reaction featured a notable functional group tolerance and an excellent catalytic activity (Scheme 1.5). ${ }^{14}$

\footnotetext{
${ }_{11}^{11}$ D. Lapointe, K. Fagnou, Chem. Lett. 2010, 39, 1118-1126.

12 Selected reviews: (a) L. Ackermann, A. R. Kapdi, H. K. Potukuchi, S. I. Kozhushkov, In Handbook of Green Chemistry (Ed. Li, C.-J.), Wiley-VCH: Weinheim, 2012, 259-305; (b) A. A. Kulkarni, O. Daugulis, Synthesis, 2009, 4087-4109; (c) O. Daugulis, H.-Q. Do, D. Shabashov, Acc. Chem. Res. 2009, 42, 1074-1086; (d) D. Alberico, M. E. Scott, M. Lautens, Chem. Rev. 2007, 107, 174-238; (e) F. Bellina, R. Rossi, Chem. Rev. 2010, 110, 1082-1146; (f) I. V. Seregin, V. Gevorgyan, Chem. Soc. Rev. 2007, 36, 1173-1193; (g) T. Brückl, R. D. Baxter, Y. Ishihara, P. S. Baran, Acc. Chem. Res. 2012, 45, 826-839; (h) S. H. Cho, J. Y. Kim, J. Kwak, S. Chang, Chem. Soc. Rev. 2011, 40, 5068-5083.

${ }_{14}^{13}$ Price metals https://www.quandl.com/collections/markets/palladium 1. 7. 2015.

${ }^{14}$ L. Ackermann, Org. Lett. 2005, 7, 3123-3125.
} 


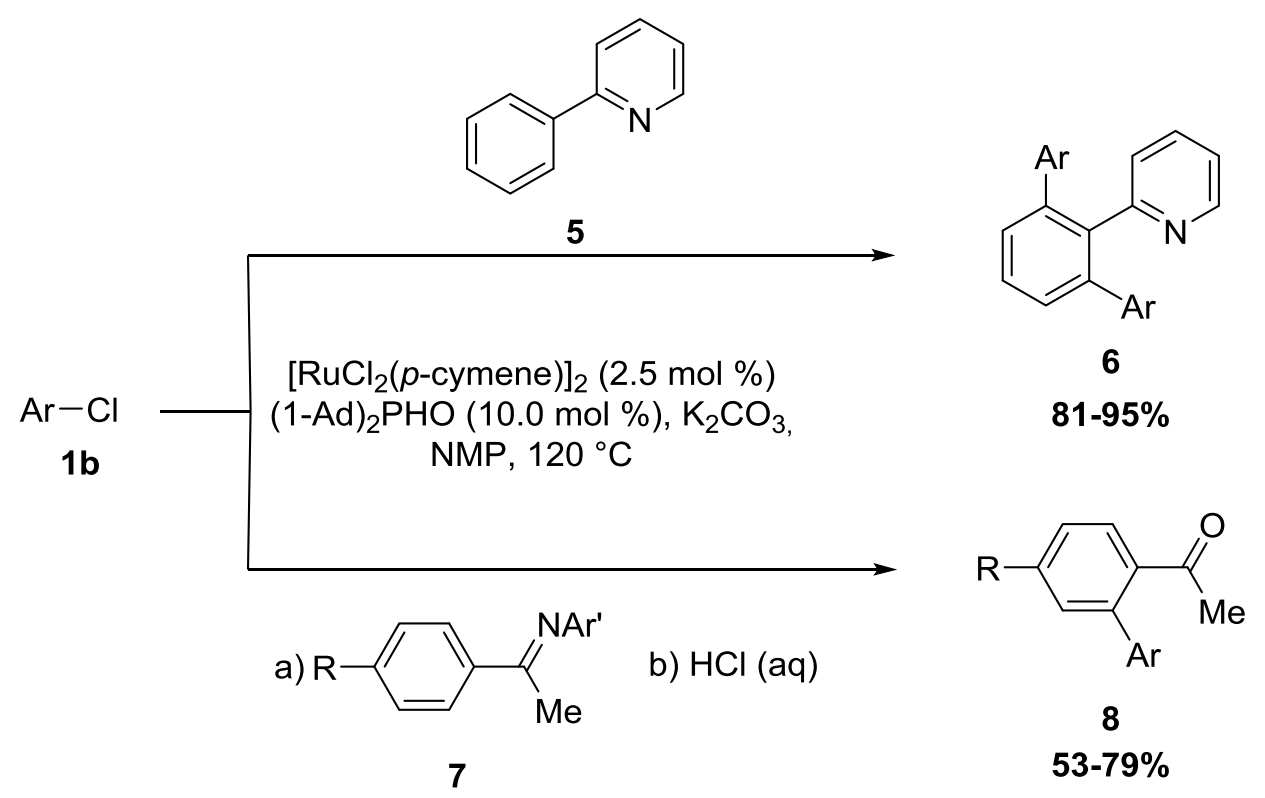

Scheme 1.5: Ruthenium-catalyzed arylations with aryl chlorides. ${ }^{14}$

Inspired by this inexpensive catalytic system the group of Prof. Ackermann focused on ruthenium(II)-catalyzed $\mathrm{C}-\mathrm{H}$ bond functionalization. An extensive screening of different additives for ruthenium(II)-catalyzed arylations of aryl triazoles identified hindered carboxylic acids to be excellent ligands. ${ }^{15}$ As can be seen in the previous example of ruthenium(II)catalyzed arylation reaction, the site-selectivity is of great importance in $\mathrm{C}-\mathrm{H}$ bond activation and remains a challenging issue.

\subsection{Site-Selectivity}

In particular site-selectivity was either obtained by enhanced acidity of a specific (hetero)aromatic $\mathrm{C}-\mathrm{H}$ bond or by a Lewis basic directing group for the conversion of substrates into ortho-functionalized derivatives (Scheme 1.6). ${ }^{16}$

\footnotetext{
15 (a) L. Ackermann, M. Mulzer, Org. Lett. 2008, 10, 5043-5045; (b) L. Ackermann, R. Born, R. Vicente, ChemSusChem, 2009, 546-549; (c) L. Ackermann, R. Vicente, A. Althammer, Org. Lett. 2008, 10, $2299-2302$.

${ }^{16}$ (a) D. A. Colby, R. G. Bergman, J. A. Ellman, Chem. Rev. 2010, 110, 624-655; (b) For a review on removable directing groups (DG) see: C. Wang, Y. Huang, Synlett, 2013, 24, 145-149.
} 
a)

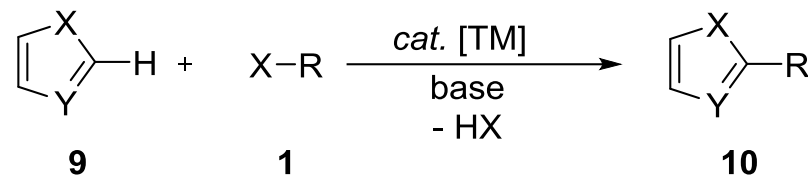

b)
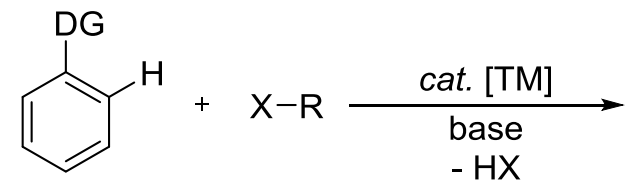<smiles>[R]c1ccccc1[O-]</smiles>

11

1

12

Scheme 1.6: Two strategies for site-selective $\mathrm{C}-\mathrm{H}$ bond functionalization

In both cases stoichiometric amounts of bases are necessary. The latter is the most common approach in direct $\mathrm{C}-\mathrm{H}$ bond activation. The directing group contains a heteroatom with a lone pair of electrons that coordinates to the transition metal. During the last years, several heteroatom bearing directing groups (Scheme 1.7) have been introduced in palladium-, nickel-, rhodium-, ruthenium-, or iridium-catalyzed $\mathrm{C}-\mathrm{C}$ bond formation. ${ }^{7,6 \mathrm{~h}, 17}$<smiles></smiles><smiles></smiles><smiles>Cn1cc[nH]c1=O</smiles><smiles></smiles><smiles></smiles><smiles></smiles><smiles>OC(O)=C1CCCC1</smiles><smiles>[R16]NC(=O)OC</smiles><smiles>[R]C(=O)OC</smiles><smiles>CCCCCCCO</smiles><smiles>[R]/C(C)=N/C</smiles>

Scheme 1.7: Directing groups in transition metal catalyzed $C-C$ bond formation.

The directed ortho-metalation (DoM) mandates a similar approach, however using stoichiometric amounts of main group metals. ${ }^{18}$ This concept was initially developed by Gilman $^{19}$ and Wittig $^{20}$ utilizing organolithium compounds (Scheme 1.8) and was extensively investigated by Snieckus. ${ }^{21}$

\footnotetext{
17 (a) D. Alberico, M. E. Scott, M. Lautens, Chem. Rev. 2007, 107, 174-238; (b) S. R. Neufeldt, M. S. Sanford Acc. Chem. Res. 2012, 45, 936-946; (c) S. I. Kozhushkov, L. Ackermann, Chem. Sci. 2013, 4, 886-896.

18 J. P. Fleming, M. B. Berry, J. M. Brown, Org. Biomol. Chem. 2008, 6, 1215-1221.

${ }^{19}$ Gilman, H.; Bebb, R.L. J. Am. Chem. Soc. 1939, 61, 109-112.

${ }^{20}$ B. G. Hashiguchi, S. M. Bischof, M. M. Konnick, R. A. Periana, Acc. Chem. Res. 2012, 45, 885-898.

${ }^{21}$ Snieckus, V. Chem. Rev. 1990, 90, 879-933.
} 
<smiles>O=C(N[N+](=O)[O-])c1ccccn1</smiles>

13

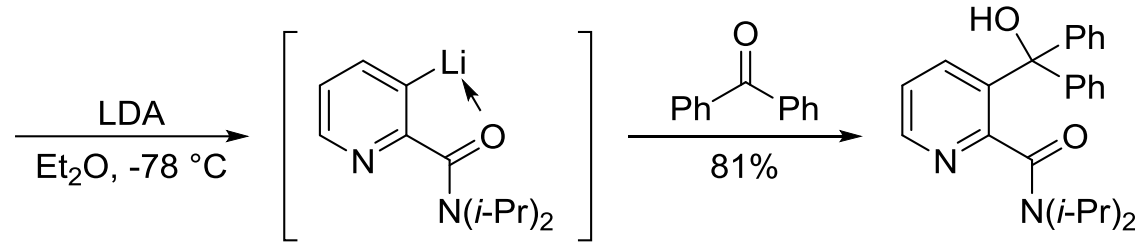

14

Scheme 1.8: DoM of a pyridine derivative. ${ }^{22}$

A great disadvantage of this strategy is the formation of stoichiometric amounts of lithium salts, as by-products. Moreover, the limited functional group tolerance is a major drawback, which is due to the high reactivity of the strong bases.

However, ortho-functionalization could be achieved quite easily, while meta- and parafunctionalization remained challenging. Recently, Knochel made some progress in meta- and para-selective functionalization, using stoichiometric amounts of organomagnesium compounds in combination with several directing groups. ${ }^{23}$ Furthermore, Brown and coworkers developed a meta-selective substitution with organolithiums and sulfoxides as removable directing group. ${ }^{18}$

Nevertheless, because of the disadvantages of the stoichiometric DoM-type reactions, such as the stoichiometric use of strong bases and the removal of the directing group, they cannot be considered as step- or atom-economical.

In 2012, Yu and co-workers developed a meta-selective palladium-catalyzed direct alkenylation applying an end-on template (Scheme 1.9) with easily removable directing group. $^{24}$<smiles>[R]C=C[C@@H](OCCC)C(C#N)(CCC)c1cc(C(C)(C)C)cc(C(C)(C)C)c1OCc1ccccc1</smiles>

16

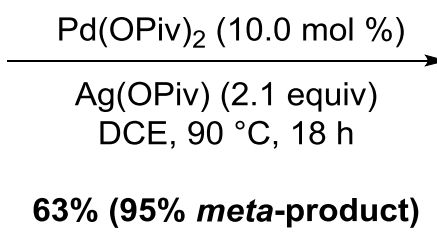

17<smiles>[R]C=Cc1cccc(COc2c(C(C)(C)C)cc(C(C)(C)C)cc2C(C#N)(CCC)C(C)(C)C)c1</smiles>

18

Scheme 1.9: Direct meta-alkenylation by $\mathrm{Yu}^{24}$

Meta-selective reactions catalyzed by transition metals remained scarce. In 2009, the Gaunt group published a copper-catalyzed meta-arylation of anilides. ${ }^{25}$ Shortly after this, the

\footnotetext{
${ }^{22}$ S. R. Neufeldt, M. S. Sanford, Acc. Chem. Res. 2012, 45, 936-946.

${ }^{23}$ (a) C. J. Rohbogner, G. C. Clososki, P. Knochel, Angew. Chem. Int. Ed. 2008, 47, 1503-1507; (b) G. Monzón, I. Tirotta, P. Knochel, Angew. Chem. Int. Ed. 2012, 51, 10624-10627.

24 (a) D. Leow, G. Li, T.-S. Mei, J.-Q. Yu, Nature, 2012, 486, 518-522; (b) J. Li, S. De Sarkar, L. Ackermann, Top. Organomet. Chem. 2015, DOI:10.1007/3418_2015_130.
} 
research group published the para-selective arylation of phenols and anilines. ${ }^{26}$ Both reactions were subsequently being shown to be Brønsted-acid-catalyzed transformations.

Ruthenium-catalyzed meta-selective $\mathrm{C}-\mathrm{H}$ bond functionalizations are rare. Frost and coworkers reported the ruthenium-catalyzed meta-selective sulfonylation of 2-phenylpyridines (Scheme 1.10). ${ }^{27} \mathrm{~A}$ drawback of the directing group is that it cannot be cleaved.<smiles>[R]c1cccc(-c2ccccn2)c1</smiles>

19
$\stackrel{\left[\mathrm{RuCl}_{2}(p \text {-cymene })\right]_{2}(2.5 \mathrm{~mol} \%)}{\longrightarrow}$
$\mathrm{K}_{2} \mathrm{CO}_{3}(2.0$ equiv $)$
$\mathrm{MeCN}, 115^{\circ} \mathrm{C}, 15 \mathrm{~h}$

up to $72 \%$<smiles>[R]O[Na]</smiles>

21

Scheme 1.10: Meta-selective sulfonylation of 2-phenylpyridine reported by Frost.

Outstandingly, Ackermann and co-workers published the first ruthenium-catalyzed metaselective alkylation of arenes (Scheme 1.11). ${ }^{28}$<smiles>[R1]1ccnc(-c2ccccc2)c1</smiles>

22<smiles>[R]C(C)Br</smiles>

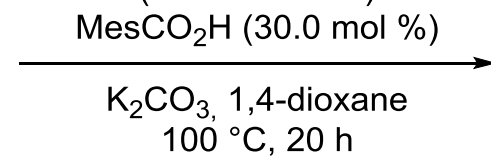

23<smiles>[R1]c1cccnc1-c1cccc(C([R])[NH2+])c1</smiles>

24

Scheme 1.11: Meta-selective C-H alkylation by Ackermann.

In spite of this example of meta-selectivity in alkylation reactions there is still a challenge, which has to be faced in the site-selective transition metal-catalyzed alkylation. In the past decade several research groups extensively investigated the site-selective alkylation reaction via $\mathrm{C}-\mathrm{H}$ bond functionalization. ${ }^{29}$

\footnotetext{
${ }^{25}$ (a) R. J. Phipps, M. J. Gaunt, Science, 2009, 323, 1593-1597. For mechanistic DFT calculations, see: (b) S.-I. Zhang, Y. Ding, Chin. J. Chem. Phys. 2011, 24, 711-723; (c) B. Chen, X.-L. Hou, Y.-X. Li, Y.-D. Wu, J. Am. Chem. Soc. 2011, 133, 7668-7671.

${ }^{26}$ C.-L. Ciana, R. J. Phipps, J. R. Brandt, F.-M. Meyer, M. Gaunt, J. Angew. Chem. Int. Ed. 2011, 50, $458-462$.

${ }^{27}$ O. Saidi, J. Marafie, A. E. W. Ledger, P. M. Liu, M. F. Mahon, G. Kociok-Köhn, M. K. Whittlesey, C. G. Frost, J. Am. Chem. Soc. 2011, 133, 19298-19301.

${ }^{28}$ N. Hofmann, L. Ackermann, J. Am. Chem. Soc. 2013, 135, 5877-5884.

${ }^{29}$ L. Ackermann, Chem. Commun. 2010, 46, 4866-4877.
} 


\subsection{Alkylation Reactions of Arenes}

\subsubsection{Friedel-Crafts Alkylation}

The beginning of alkylation reaction was constituted by the Friedel-Crafts alkylation. ${ }^{30}$ Untill today the reaction plays an important role and is employed on industrial scale. The synthesis of ethylbenzene from benzene and ethylene is arguably the largest $\mathrm{C}-\mathrm{C}$ bond formation process used in industry (Scheme 1.12). ${ }^{3}$

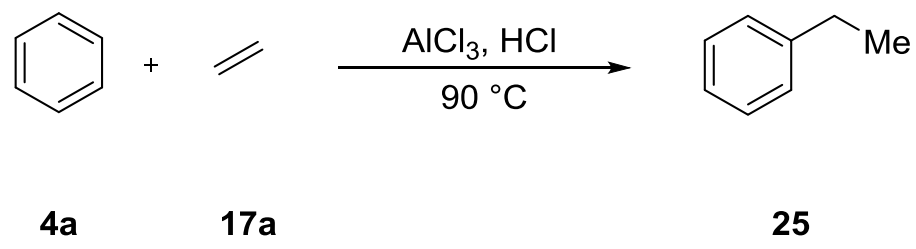

Scheme 1.12: Friedel-Crafts reaction of benzene 4a.

Still this alkylation reactions face some disadvantages, which include the use of corrosive reagents, harsh reaction conditions and undesired side products. Besides these problems the reaction was continously impoved. ${ }^{31}$

An elegant solution to avoid the disadvatages of the Friedel-Crafts alkylation reaction is represented by the homogenous transition metal catalysis.

\subsubsection{Cross-Coupling Reactions}

Transition metal-catalyzed cross-coupling alkylating reactions are rare and have some difficulties when using unactivated alkyl (pseudo)halides. Two difficulties have to be faced in these reactions specifically for the alkyl halides. First, they process low reactivity, because of their electron-rich character. Second, they easily undergo $\beta$-hydride eliminations. Nevertheless, among this Fu demonstrated sucessfully the nickel-catalyzed Suzuki-Miyaura cross-coupling with tertiary alkyl halides (Scheme 1.13). ${ }^{32}$

\footnotetext{
${ }^{30}$ (a) C. Friedel, J. M. Crafts, Compt. Rend. 1877, 84, 1392-1450; (b) C. Friedel, J. M. Crafts, J. Chem. Soc. 1877, 32, 725-791.

${ }^{31}$ (a) M. Rüping, B. J. Nachtsheim, Beilstein J. Org. Chem. 2010, 6, 1-24; (b) T. Tsuchimoto, K. Tobita, T. Hiyama, S.-I. Fukuzawa, Synlett, 1996, 557-559; (c) Catalytic Asymmetric Friedel-Crafts Alkylations (Eds.: Bandini, M.; Umani-Ronchi, A.), Wyley-VCH: Weinheim, 2009.

${ }^{32}$ S. L. Zultanski, G. C. Fu, J. Am. Chem. Soc. 2013, 135, 624-627.
} 


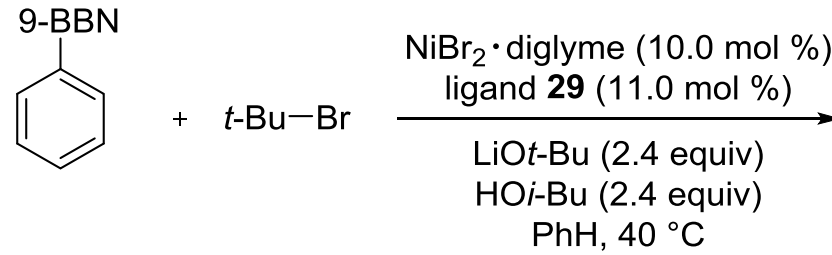

26

$84 \%$<smiles>CC(C)(C)c1ccccc1</smiles>

ligand $=$<smiles>CC(C)(C)c1ccnc(-c2cc(C(C)(C)C)ccn2)c1</smiles>

29

Scheme 1.13: Nickel-catalyzed cross-coupling of tert. alkyl halides.

Moreover, Fu put a lot of effort in the development of alkyl cross coupling reactions, which succeeded in the alkyl-alkyl Negishi ${ }^{33}$ and Suzuki-Miyaura ${ }^{34}$ couplings in recent years.

Despite these improvements the advantages of transition metal-catalyzed $\mathrm{C}-\mathrm{H}$ bond functionalization dominate.

\subsubsection{Transition Metal-Catalyzed C-H Bond Alkylation}

The transition metal-catalyzed $\mathrm{C}-\mathrm{H}$ bond alkylation can be achieved by two different ways, namely the hydroarylation of alkenes (Scheme $1.14 \mathrm{a}$ ) and the alkylation with unactivated alkyl halides (Scheme 1.14 b).

a)<smiles>[R]C=Cc1ccccc1[O+]</smiles>

11

b)<smiles>Oc1ccccc1</smiles>

11
17<smiles>[R]CC[X]</smiles>

30<smiles>[R]CCc1ccccc1[O+]</smiles>

30

Scheme 1.14: Transition metal-catalyzed alkylation.

Pioneering work on the regioselective ortho-alkylation by hydroarylation of alkenes was done by Lewis and Smith in 1986 (Scheme 1.15). ${ }^{35}$

\footnotetext{
${ }^{33}$ (a) J. T. Binder, C. J. Cordier, G. C. Fu, J. Am. Chem. Soc. 2012, 134, 17003-17006. (b) J. Choi, G. C. Fu, J. Am. Chem. Soc. 2012, 134, 9102-9105. (c) Oelke, A. J.; Sun, J.; Fu, G. C. J. Am. Chem. Soc. 2012, 134, 2966-2969. (d) S. W. Smith, G. C. Fu, J. Am. Chem. Soc. 2008, 130, 12645-12647.

${ }^{34}$ (a) A. Wilsily, F. Tramutola, N. A. Owston, G. C. Fu, J. Am. Chem. Soc. 2012, 134, 5794-5797. (b) S. L. Zultanski. G. C. Fu, J. Am. Chem. Soc. 2011, 133, 15362-15364. (c) B. Saito, G. C. Fu, J. Am. Chem. Soc. 2008, 130, 6694-6695. (d) S. Lu, G. C. Fu, Angew Chem. In. Ed. 2010, 49, 6676-6678. (e) B. Saito, G. C. Fu, J. Am. Chem. Soc. 2007, 129, 9602-9603.

${ }^{35}$ A review: (a) L. N. Lewis, J. F. Smith, J. Am. Chem. Soc. 1986, 108, 2728-2735; (b) P. B. Arockiam, C. Bruneau, P. H. Dixneuf, Chem. Rev. 2012, 112, 5879-5918.
} 


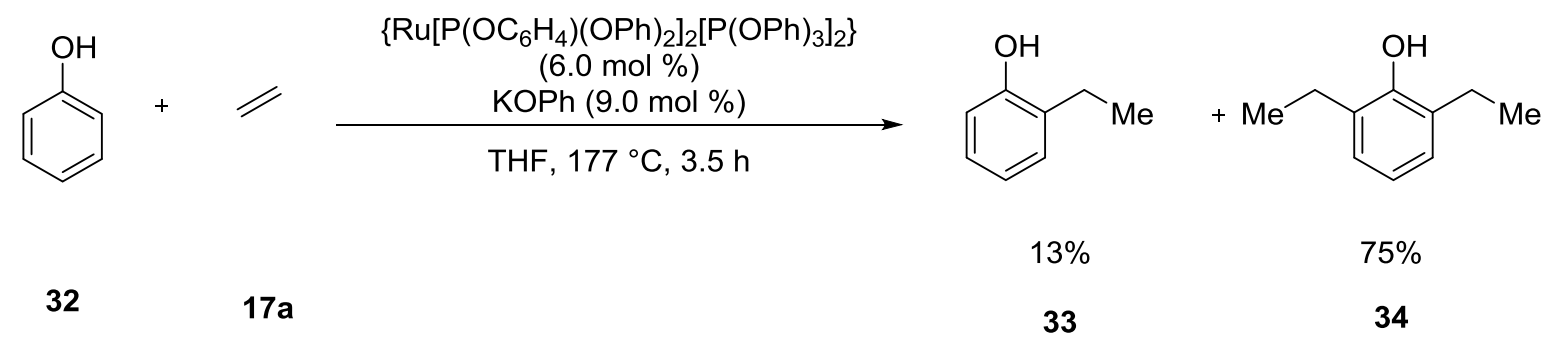

Scheme 1.15: Ruthenium(0)-catalyzed alkylation of phenol with ethylene.

The hyroarylation using ruthenium hydride complexes as catalysts was extended by Murai, Chatani and Kakiuchi in $1993^{36}$ and is today known as the Murai reaction (Scheme 1.16).

The main disadvantage of this reaction, the air sensitivity of the catalyst, could be solved by Darses and Genet using the in situ formed catalyst $\left.\left[\mathrm{RuH}_{2}(\mathrm{PPh})_{3}\right)_{4}\right] .{ }^{37}$<smiles>[R][C-]=C[R]</smiles>

35

17

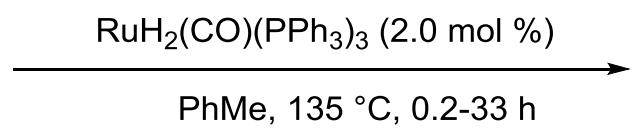<smiles>[R]CCC1=CC=C[R1]C=C1C([R])=O</smiles>

36

Scheme 1.16: Ruthenium(0)-catalyzed Murai-reaction.

An early example of the transition metal-catalyzed alkylation with alkyl (pseudo)halides was the palladium-catalyzed entropically-favored intramolecular direct alkylation for the synthesis of oxindoles 38 by Hennessy and Buchwald (Scheme 1.17). ${ }^{38}$<smiles>[R]N(C(=O)CCl)C1=CC#[R]=CC=C1</smiles>

37
$\operatorname{Pd}(\mathrm{OAc})_{2}(1.0-3.0 \mathrm{~mol} \%)$ ligand $39(2.0-6.0 \mathrm{~mol} \%)$ $\mathrm{NEt}_{3}, \mathrm{PhMe}$ $80^{\circ} \mathrm{C}, 2.5-6 \mathrm{~h}$<smiles>[R]N1C(=O)Cc2cc[R]#cc21</smiles>

38

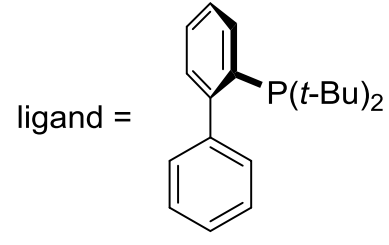

39

Scheme 1.17: Palladium-catalyzed intramolecular direct alkylation for the synthesis of oxindoles $\mathbf{4 0 .}$

\footnotetext{
${ }^{36}$ (a) S. Murai, F. Kakiuchi, S. Sekine, Y. Tanaka, A. Kamatani, M. Sonoda, N. Chatani, Nature, 1993, 366, 529531. (b) F. Kakiuchi, S. Murai, Acc. Chem. Res. 2002, 35, 826-834. For DFT-calculations, see: (c) U. Helmstedt, E. Clot, Chem. Eur. J. 2012, 18, 11449-11458. For ruthenium-catalyzed Murai-type carbonylations, see: (d) N. Chatani, Y. le, F. Kakiuchi, S. Murai, Org. Chem. 1997, 62, 2604-2610.

${ }^{37}$ (a) R. Martinez, R. Chevalier, S. Darses, J.-P. Genet, Angew. Chem. Int. Ed. 2006, 45, 8232-8235; (b) R. Martinez, M.-O. Simon, R. Chevalier, C. Pautigny, J.-P. Genet, S. Darses, J. Am. Chem. Soc. 2009, 131, 78877895.

${ }^{38}$ E. Hennessy, S. L. Buchwald, J. Am. Chem. Soc. 2003, 125, 12084-12085.
} 
A number of nickel- and palladium-catalyzed alkylation reactions limited to heteroarenes were reported by $\mathrm{Hu}^{39}$ Ackermann ${ }^{40}$ and Miura and Satoh. ${ }^{41}$

In spite of this challenging task, the transition metal-catalyzed direct ortho-alkylation with inexpensive ruthenium catalysts was achieved by Ackermann and co-workers. In 2009, Ackermann reported the ruthenium(II)-catalyzed $\mathrm{C}-\mathrm{H}$ alkylation of arylpyridines with unactivated alkyl halides (Scheme 1.18). The scope was not limited to pyridines as directing group, but could be extended to pyrazoles and ketimines (Scheme 1.18). ${ }^{42}$<smiles>[R][X]1ccccc1-c1ccccn1</smiles>

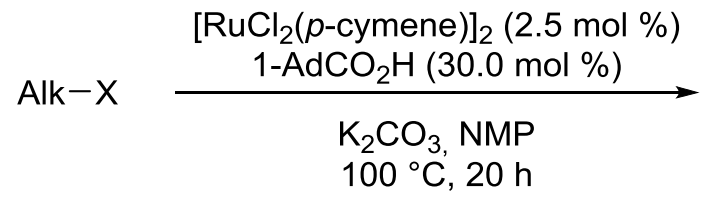

$\mathrm{X}=\mathrm{Br}(\mathbf{4 0})$

$X=I \quad(41)$<smiles>[R]1ccccc1-n1cccn1</smiles>

43

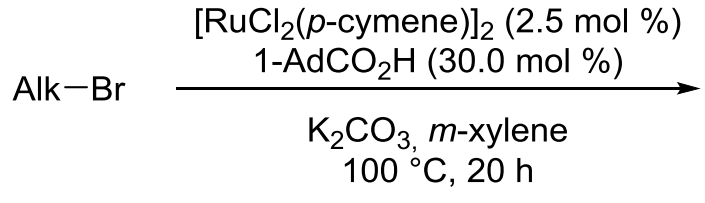

40<smiles></smiles>

42<smiles>[R][X]c1cccc(-n2cccn2)c1</smiles>

44

Scheme 1.18: Ruthenium(II)-catalyzed direct ortho-alkylation by Ackermann.

The benefits of the ruthenium(II)-catalyzed direct alkylations are that no $\beta$-hydride elimination of the alkyl halides takes place. Furthermore, inexpensive non prefunctionalized starting materials could be used. Fortunately, the inexpensive carboxylate-assisted catalytic system developed in the ruthenium(II)-catalyzed arylation reactions ${ }^{15 c}$ proved to be broadly applicable in the ruthenium-catalyzed alkylation. These outstanding site-selective $\mathrm{C}-\mathrm{C}$ bond formations represent a further element in the transition metal-catalyzed $\mathrm{C}-\mathrm{H}$ bond functionalization and therefore improved sustainability of organic chemistry.

\footnotetext{
${ }^{39}$ (a) P. Ren, I. Salihu, R. Scopelliti, X. Hu, Org. Lett. 2012, 14, 1748-1751; (b) O. Vechorkin, V. Proust, X. Hu, Angew. Chem. Int. Ed. 2010, 49, 3061-3064.

${ }^{40}$ L. Ackermann, B. Punji, W. Song, Adv. Synth. Catal. 2011, 353, 3325-3329.

${ }^{41}$ T. Yao, K. Hirano, T. Satoh, M. Miura, Chem. Eur. J. 2010, 16, 12307-12311.

${ }^{42}$ L. Ackermann, P. Novák, R. Vicente, N. Hofmann, Angew. Chem. Int. Ed. 2009, 48, 6045-6048.
} 


\subsection{Transition Metal-Catalyzed C-H Bond Alkenylation}

The first synthesis of economically relevant styrene derivatives, which are key structural motifs in natural products, via transition metal-catalyzed oxidative alkenylation was published in 1967 by Fujiwara and Moritani. ${ }^{43}$ The reaction was first conducted with a palladiumstyrene-complex, which reacted with the arene, yielding the stilbene (Scheme $1.19 \mathrm{a}$ ). Immediately after this the amount of the palladium complex could be reduced to catalytic amounts (Scheme $1.19 \mathrm{~b}$ ).

a)

3<smiles></smiles>

45

b)<smiles>[R]C=C</smiles>

17
4<smiles></smiles>

4b

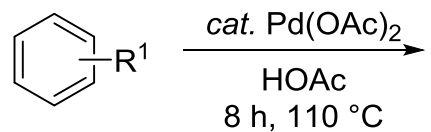

4b<smiles>CC(OC(C)c1ccc(C=Cc2ccccc2)cc1)C(=O)c1ccccc1</smiles>

46

47

Scheme 1.19: Fujiwara-Moritani-Reaction.

Thereupon, various applications of palladium catalysts with different oxidants and additives on different substrates were systematically studied. ${ }^{44}$

The search of efficient transition metal-catalysts for $\mathrm{C}-\mathrm{C}$ bond formation led to rhodium catalysis. In recent years various efficient and selective, yet relatively expensive rhodium catalysts were used for the oxidative alkenylation (Scheme 1.20). ${ }^{45}$

\footnotetext{
43 (a) I. Moritani, Y. Fujiwara, Tetrahedron Lett. 1967, 12, 1119-1122; (b) Y. Fujiwara, I. Moritani, M. Matsuda, Tetrahedron 1968, 24, 4819-4824.

${ }^{44}$ (a) S. R. Kandukuri, J. A. Schiffner, M. Oestreich, Angew. Chem. Int. Ed. 2012, 51, 1265-1269; (b) Y.-H. Xu, J. K. Cheng, M. T. Low, T.-P. Loh, Angew. Chem. Int. Ed. 2012, 51, 5701-5705; (c) C. Wang, H. Ge, Chem.-Eur. J. 2011, 17, 14371-14374; (d) H.-X. Dai, A. F. Stepan, M. S. Plummer, Y.-H. Zhang, J.-Q. Yu, J. Am. Chem. Soc. 2011, 133, 7222-7228; (e) D.-H. Wang, K. M. Engle, B.-F. Shi and J.-Q. Yu, Science, 2010, 327, 315-319; (f) M. Miyasaka, K. Hirano, T. Satoh, M. Miura, J. Org. Chem. 2010, 75, 5421-5424; (g) B.-F. Shi, Y.-H. Zhang, J. K. Lam, D.-H. Wang, J.-Q. Yu, J. Am. Chem. Soc. 2010, 132, 460-461; (h) Y.-H. Zhang, B.-F. Shi, J.-Q. Yu, J. Am. Chem. Soc. 2009, 131, 5072-5074; (i) A. Maehara, H. Tsurugi, T. Satoh, M. Miura, Org. Lett. 2008, 10, 1159-1162; (j) N. P. Grimster, C. Gauntlett, C. R. A. Godfrey, M. J. Gaunt, Angew. Chem. Int. Ed. 2005, 44, 3125-3129; (k) M. Dams, D. E. De Vos, S. Celen and P. A. Jacobs, Angew. Chem. Int. Ed. 2003, 42, 35123515; (I) M. D. K. Boele, G. P. F. van Strijdonck, A. H. M. de Vries, P. C. J. Kamer, J. G. de Vries P. W. N. M. van Leeuwen, J. Am. Chem. Soc. 2002, 124, 1586-1587; (m) M. Miura, T. Tsuda, T. Satoh, S. Pivsa-Art, M. Nomura, J. Org. Chem. 1998, 63, 5211-5215.
} 
<smiles>[R]C=Cc1cccc2cc([R12])[nH]c(=O)c12</smiles>

49<smiles>[R]C=CC1=CC=C[R1]C=C1P(C)(C)=O</smiles>

51
Wang 2013<smiles>[R]C=Cc1cc2ccccc2n1C(=O)NC</smiles>

53<smiles>[R]c1cc2ccccc2c(=O)[nH]1</smiles>
48

\section{Miura 2013}<smiles>[R]C=Cc1c[R1]c(C(=O)O)s1</smiles>

55

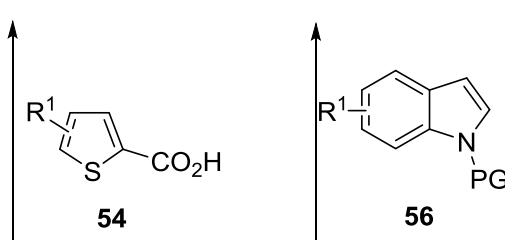<smiles>[R]C=CC1=C[R1]([R6])C=Cc2ccn(P)c21</smiles>
7<smiles>[R]C=Cc1ccc([R1])cc1C(=O)N(C)O[N+](C)([O-])[O-]</smiles>

59
53<smiles>CC(C)(C)NC(=O)n1ccc2ccccc21</smiles>

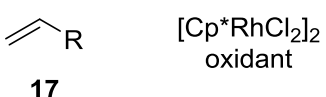

17

$\downarrow$

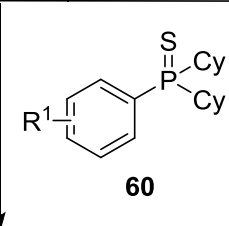<smiles>O=S1(=O)N=C(c2ccccc2)c2ccccc21</smiles><smiles>[R]C=CC1=C(P(=O)([Na])[Hg])C=C[R1]C=C1</smiles>

61<smiles>[R]C=Cc1ccccc1C1=NS(=O)(=O)c2ccccc21</smiles>

63<smiles>[Y]c1cccc(C2SCCCS2)c1</smiles>

Wang 2013 Nicholls 2014 Miura 2014

Wei 2014<smiles>[R]C=Cc1ccc[R1]c1C1SCCCS1</smiles>

65

Scheme 1.20: Selected examples of rhodium-catalyzed alkenylations.

The use of cheaper ruthenium-catalysts was reported by Milstein in 2001 (Scheme 1.21). ${ }^{46}$

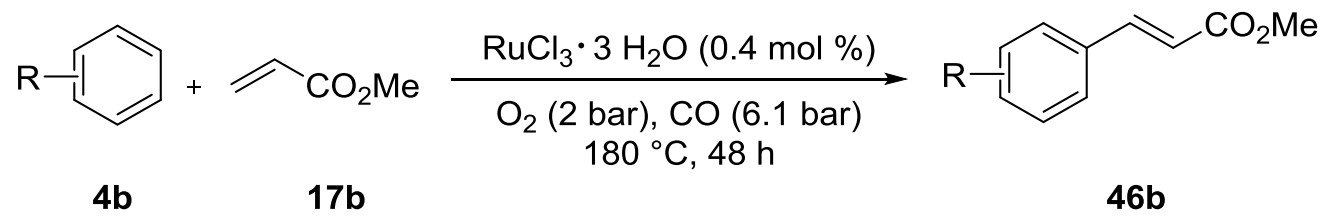

Scheme 1.21: Oxidative alkenylation of arenes by Milstein.

The scope of this reaction was limited to simple arenes and methyl acrylate as alkene. Notably, the reaction worked without directing group and with oxygen as the terminal oxidant, albeit under high pressure and harsh reaction conditions. The ruthenium-catalyzed reaction

\footnotetext{
45 (a) J. Mo, S. Lim, S. Park, T. Ryu, S. Kim, P. H. Lee, RSC Adv. 2013, 3, 18296-18299; (b) Y. Yokoyama, Y. Unoh, K. Hirano, T. Satoh, M. Miura, J. Org. Chem. 2014, 79, 7649-7655; (c) T. litsuka, P. Schaal, K Hirano, T. Satoh, C. Bolm, M. Miura, J. Org. Chem. 2013, 78, 7216-7222; (d) S. Kathiravan, I. A. Nicholls, Eur. J. Org. Chem. 2014, 7211-7219; (e) B. Li, J. Ma, W. Xie, H. Song, S. Xu, B. Wang, Chem. Eur. J. 2013, 19, 1186311868; (f) Z. Song, R. Samanta, A. P. Antonchick, Org. Lett. 2013, 15, 5662-5665. (g) N.-J. Wang, S.-T. Mei, L. Shuai, Y. Yuan, Y. Wie, Org. Lett. 2014, 16, 3040-3043; (h) P. Zhao, R. Niu, F. Wang, K. Han, X. Li, Org. Lett. 2012, 14, 4166-4169; (i) Y. Unoh, K. Hirano, T. Satoh, M. Miura, Org. Lett. 2015, 17, 704-707; (j) Y. Wang, C. Li, Y. Li, F. Yin, X.-S. Wanga, Adv. Synth. Catal. 2013, 355, 1724-1728.

${ }^{46}$ H. Weissman, X. Song, D. Milstein, J. Am. Chem. Soc. 2001, 123, 337-338.
} 
was continuously extended by Ackermann, Miura and Satoh. ${ }^{47}$ Selected examples from Miura and Ackermann are represented in Scheme 1.22, including the use of the air-stable catalyst $\left[\mathrm{RuCl}_{2}(p \text {-cymene })\right]_{2}$, copper(II) acetate as the oxidant and an additive.

\section{a) Ackermann}<smiles>O=C(O)c1c[R1]ccc1</smiles>

66<smiles>[R]C=[C+]</smiles>

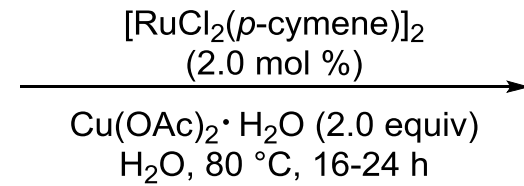

17<smiles>[R]CC1OC(=O)C2=CC=[R][R]C=C21</smiles>

67

b) Miura<smiles>[R2]NC(=O)c1ccc[R]([R])c1</smiles>

68

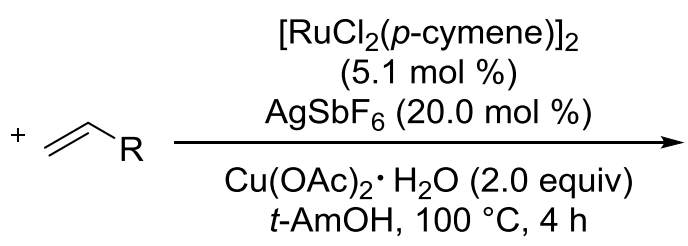
17<smiles>[R]C=Cc1cc[R1]([R])cc1C([R12])=O</smiles>

69

\section{c) Ackermann}<smiles>[R]NC(=O)c1cccc[R]1[R]</smiles>

$68 a$

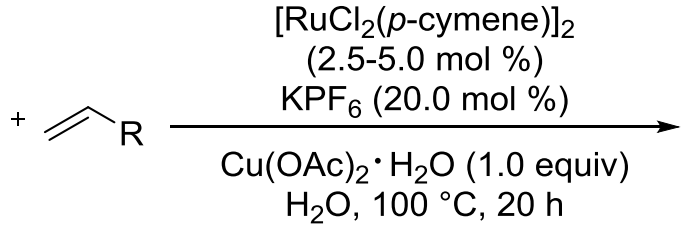

17<smiles>[R]C=Cc1cc[R1]([R])cc1C(=O)N[R]</smiles>

$69 a$

Scheme 1.22: Ruthenium(II)-catalyzed oxidative alkenylation of benzamides.

Further improvements in the ruthenium(II)-catalyzed reactions were achieved because of the combination of reduced amounts of copper acetate monohydrate and an aerobic atmosphere (Scheme 1.23 a). ${ }^{48}$ Particularly notable, is the functionalization of benzaldehydes (Scheme $1.23 \mathrm{~b})$.

\footnotetext{
47 (a) Y. Hashimoto, T. Ortloff, K. Hirano, T. Satoh, C. Bolm, M. Miura, Chem. Lett. 2012, 41, 151-153; (b) L. Ackermann, L. Wang, R. Wolfram, A. V. Lygin, Org. Lett. 2012, 14, 728-731; L. Ackermann, J. Pospech, Org. Lett. 2011, 13, 4153-4155.

48 (a) K. Graczyk, W. Ma, L. Ackermann, Org. Lett. 2012, 14, 4110-4113; (b) K. Padala, S. Pimparkar, P. Madasamy, M. Jeganmohan, Chem. Commun. 2012, 48, 7140-7142; (c) K. Padala, M. Jeganmohan, Org. Lett. 2011, 13, 6144-6147; (d) K. Padala, M. Jeganmohan, Org. Lett. 2012, 14, 1134-1137.
} 
a)<smiles>[R]C(=O)c1ccccc1</smiles>

35 $+\gamma \mathrm{R}$

17

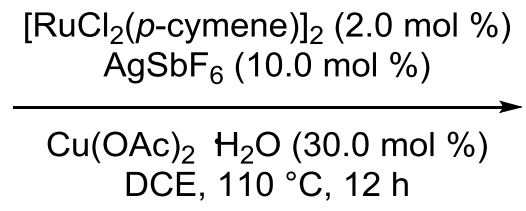

DCE, $110{ }^{\circ} \mathrm{C}, 12 \mathrm{~h}$<smiles>[R]C=Cc1cc[R1]([R])cc1C([R])=O</smiles>

b)<smiles>O=Cc1c[R1]ccc1</smiles>

$35 a$<smiles>[R]C=[13CH]</smiles>

17
$\left[\mathrm{RuCl}_{2}(p \text {-cymene })\right]_{2}(5.1 \mathrm{~mol} \%)$ $\mathrm{KPF}_{6}(20.0 \mathrm{~mol} \%)$

$\mathrm{Cu}(\mathrm{OAc})_{2} \cdot \mathrm{H}_{2} \mathrm{O}(1.0$ equiv)

$\mathrm{H}_{2} \mathrm{O}, 100^{\circ} \mathrm{C}, 20 \mathrm{~h}$<smiles>[R]C=Cc1cc[R1]([OH2+])cc1C=O</smiles>

$70 a$<smiles>[R]C=Cc1cc[R1]([R])cc1C(=O)O[R2]</smiles>

72

$\left[\mathrm{RuCl}_{2}(p \text {-cymene })\right]_{2}(3.0-5.0 \mathrm{~mol} \%)$ $\mathrm{AgSbF}_{6}(20.0-40.0 \mathrm{~mol} \%)$

$\mathrm{Cu}(\mathrm{OAc})_{2} \mathrm{H}_{2} \mathrm{O}(30.0 \mathrm{~mol} \%)$ DCE, $100{ }^{\circ} \mathrm{C}, 12-16 \mathrm{~h}$, air

71

Scheme 1.23: Ruthenium(II)-catalyzed oxidative alkenylation of arenes under air.

Meanwhile, the standard reaction conditions using copper acetate as the oxidant is indeed convenient, however, heavy metal waste is still produced as by-product.

An elegant way of ruthenium-catalyzed reactions avoiding this waste is the use of prefunctionalized starting materials, bearing a directing group containing an internal oxidant (Scheme 1.24). ${ }^{49}$

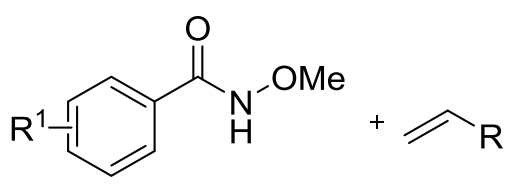

$68 b$

17

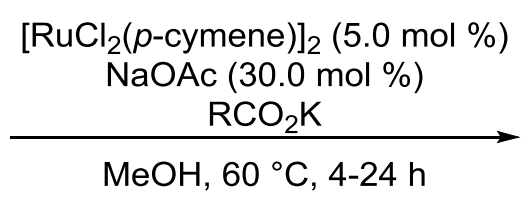<smiles>[R]C=Cc1cc[R1]([R6])cc1C(N)=O</smiles>

$69 \mathrm{~b}$

Scheme 1.24: Ruthenium-catalyzed oxidative alkenylation with internal oxidants.

The most abundant and inexpensive oxidant that can be used in oxidative $\mathrm{C}-\mathrm{H}$ bond functionalization is air. So far, there are only few examples of $\mathrm{C}-\mathrm{H}$ bond functionalization using air as the sole oxidant (Scheme 1.25). The palladium-catalyzed synthesis of chromene 
structures by 6-endo cyclization of ortho-allylic phenols with excellent yields was reported by Larock in $1998 .^{50}$ Ideally, the reaction was accomplished with air as the oxidant. Unfortunately, full conversion of this reaction was obtained only after three days.<smiles>CC=CCc1ccccc1O</smiles>

73

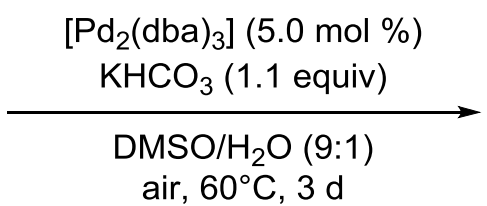

$80 \%$

Scheme 1.25: 6-endo Cyclization of ortho-allylic phenols with air as sole oxidant.

Recently, the first rhodium-catalyzed example using air as sole oxidant was published by $Y u$ in 2015 (Scheme 1.26). ${ }^{51}$ There, $\mathrm{N}$-perfluoroaryl benzamides 68c led to the orthoalkenylation. The $y$-lactam products are readily converted to the olefinated products, by treating the lactam with $\mathrm{LiHMDS}, \mathrm{Boc}_{2} \mathrm{O}$ and sodium ethanolate.<smiles>O=C(NC(F)(F)F)c1ccccc1</smiles>

$68 \mathrm{c}$<smiles>[R]CC1c2ccc(F)cc2C(=O)N1Cc1cccs1</smiles>

75

$$
\gamma_{\mathrm{R}} 17
$$

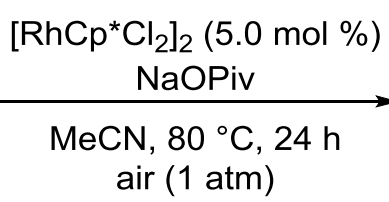
air (1 atm)<smiles>[R]CC1c2ccccc2C(=O)N1C(F)(F)F</smiles>

75

Scheme 1.26: Rhodium-catalyzed direct alkenylation with air as terminal oxidant.

Despite this progress, applying these economic conditions remained an extremely challenging task. In contrary, the use of ambient oxygen in transition metal-catalyzed $\mathrm{C}-\mathrm{H}$ bond functionalization gained more attention in recent years. In 1999, Uemura published the palladium-catalyzed oxidative ring cleavage of tert-cyclobutanols under an oxygen

\footnotetext{
${ }^{50}$ (a) R. C. Larock, T. R. Hightower, L. A. Haswold, K. P- Peterson, J. Org. Chem. 1996, 61, 3584-3585; (b) R. C. Larock, L. Wei, T. R. Hightower, Synlett, 1998, 5, 522-524.

${ }^{51}$ Y. Lu, H.-W. Wang, J. E. Spangler, K. Chen, P.-P. Cui, Y. Zhao, W.-Y. Sun, J.-Q. Yu, Chem. Sci. 2015, 6, 1923-1927.
} 
atmosphere. ${ }^{52}$ Based on this publication Stoltz developed the first palladium-catalyzed cyclization of heteroatoms onto pedant olefins in 2005 (Scheme 1.27)..$^{53}$

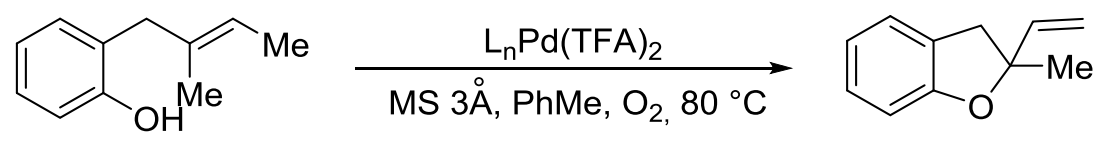

76

Scheme 1.27: Palladium-catalyzed cyclization with $\mathrm{O}_{2}$ as the oxidant.

In 2009, Jiao succeeded in the synthesis of indoles from simple anilines and alkynes (Scheme 1.28). ${ }^{54}$ The palladium catalyst used ambient oxyen and was limited to alkynes with electron withdrawing substituents.<smiles></smiles>

78

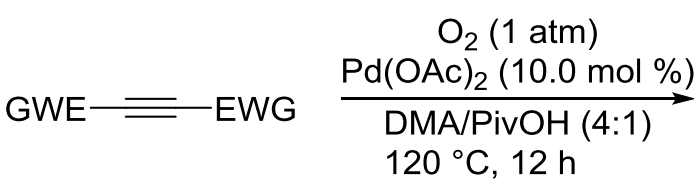

$\mathrm{CO}_{2} \mathrm{Me}=79$

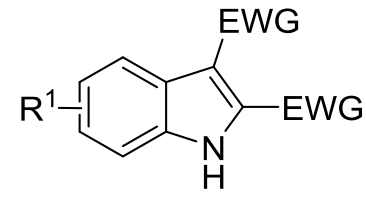

80

Scheme 1.28: Palladium-catalyzed oxidative alkyne annulation with oxygen.

Subsequently, several groups reported on the palladium-catalyzed oxidative $\mathrm{C}-\mathrm{H}$ bond functionalization with oxygen. ${ }^{55}$

In spite of this progress in palladium-catalyzed oxidative reactions with oxygen as the terminal oxidant, the use of other metals remained difficult. The first rhodium-catalyzed reaction using molecular oxygen was reported by Huang in 2013, exploring a rhodium catalyst in the oxidative alkyne annulation of phenylpyridines (Scheme 1.29). ${ }^{56}$ In 2014 , Huang could expand this system for the synthesis of alkenylated indole derivatives. ${ }^{57}$

\footnotetext{
${ }^{52}$ T. Nishimura, K. Ohe, S. Uemura, J. Am. Chem. Soc. 1999, 121, 2645-2646.

${ }^{53}$ R. M. Trend, Y. K. Ramtohul, B. M. Stoltz, J. Am. Soc. 2005, 127, 17778-17788.

${ }^{54}$ Z. Shi, C. Zhang, S. Li, D. Pan, S. Ding, Y. Cui, N. Jiao, Angew. Chem. Int. Ed. 2009, 48, 4572-4576.

55 (a) Y. Dong, S. Mao, Y.-R. Gao, D.-D. Guo, S.-H. Guo, B. Li, Y.-Q. Wang, RSC Adv. 2015, 5, 23727-23736; (b) Z.-L. Yan, W.-L. Chen, Y.-R. Gao, S. Mao, Y.-L. Zhang, Y.-Q. Wanga, Adv. Synth. Catal. 2014, 356, 10851092; (c) G. Zhang, H. Yu, G. Qin, H. Huang, Chem. Commun. 2014, 50, 4331-4334; (d) P. Gandeepan, C.-H. Cheng, J. Am. Chem. Soc. 2012, 134, 5738-5741; (e) Y.-H. Xu, Y. K. Chok, T.-P. Loh, Chem. Sci. 2011, 2, 1822-1825.

${ }^{56}$ G. Zhang, L. Yang, Y. Wang, Y. Xie, H. Huang, J. Am. Chem. Soc. 2013, 135, 8850-8853.

${ }^{57}$ L. Yang, G. Zhang, H. Huang, Adv. Synth. Catal. 2014, 356, 1509-1515.
} 
<smiles>[R][R]1ccccc1-c1ccccn1</smiles>

19

$$
\begin{aligned}
& \mathrm{R}^{2}=\mathrm{R}^{3} \\
& \frac{\mathrm{Cp}^{*} \mathrm{Rh}\left(\mathrm{H}_{2} \mathrm{O}\right)_{3}(\mathrm{OTf})_{2}(1.0 \mathrm{~mol} \%)}{\mathrm{MeOH}} \\
& 120{ }^{\circ} \mathrm{C}, 22 \mathrm{~h} \\
& \mathrm{O}_{2} \text { (1 atm) }
\end{aligned}
$$<smiles>[R]c1c([R])[n+]2ccccc2c2c([R])cccc12</smiles>

82

Scheme 1.29: Rhodium-catalyzed oxidative alkyne annulation with oxygen as the oxidant.

The first ruthenium-catalyzed oxidative $\mathrm{C}-\mathrm{H}$ bond functionalization with molecular oxygen was published in 2015 by Rueping. ${ }^{58}$ The group of Rueping used a combination of $\left[\mathrm{RuCl}_{2}(p \text {-cymene })\right]_{2}$ and an expensive iridium photoredox-catalyst with oxygen as oxidant and silver hexaflouroantimonate as additive (Scheme 1.30).<smiles>[R]c1cccc(Oc2ccccn2)c1</smiles>

83<smiles>C=CCOCC</smiles>

$17 \mathrm{c}$
$\left[\mathrm{RuCl}_{2}(p \text {-cymene })\right]_{2}(5.0 \mathrm{~mol} \%)$ $\mathrm{AgSbF}_{6}(20.0 \mathrm{~mol} \%)$

$\underset{\text { DMA }}{\stackrel{\left[\operatorname{lr}(\mathrm{bpy})(\mathrm{ppy})_{2}\right] \mathrm{PF}_{6}(3.0 \mathrm{~mol} \%)}{\longrightarrow}}$

$11 \mathrm{~W}$ light, $16 \mathrm{~h}$ $\mathrm{O}_{2}(1 \mathrm{~atm})$<smiles>[R][R]C(=O)/C=C/c1ccccc1Oc1ccccn1</smiles>

84

Scheme 1.30: Ruthenium-photoredox-catalyzed oxidative alkenylation of phenoxypyridines with oxygen.

Shortly after Rueping's report, Ackermann published the ruthenium-catalyzed $\mathrm{C}-\mathrm{H}$ activation/alkyne annulation with oxygen as the sole oxidant (Scheme 1.31). ${ }^{59}$ The mild reaction conditions with sodium acetate as carboxylate ligand in methanol at $45{ }^{\circ} \mathrm{C}$ represents a special key feature in the advancement of ruthenium(II)-catalyzed aerobic functionalization and in the synthesis of heterocyclic compounds, such as isocoumarins or phthalides.

\footnotetext{
${ }^{58}$ D. C. Fabry, M. A. Ronge, J. Zoller, M. Rueping, Angew. Chem. Int. Ed. 2015, 54, 2801-2805.

${ }^{59}$ S. Warratz, C. Kornhaaß, A. Cajaraville, B. Niepötter, D. Stalke, L. Ackermann, Angew. Chem. Int. Ed. 2015, $54,5513-5517$.
} 
<smiles>[R]C#C[R]</smiles>

66<smiles>[R][X]c1ccc(C(=O)O)cc1</smiles>

66

81<smiles>[R]C=C</smiles>

17

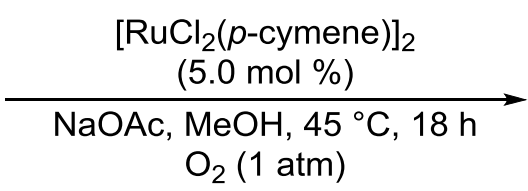<smiles>[R]c1ccc2c(=O)oc([R])c([R])c2c1</smiles>

85<smiles>[R]CC1OC(=O)c2ccccc21</smiles>

67

Scheme 1.31: Ruthenium-catalyzed oxidative annulations of carboxylic acids with oxygen as oxidant.

\subsection{C-H Bond Functionalization for the Efficient Synthesis of Heterocyclic Compounds}

Heterocyclic compounds are important key structural motifs in pharmaceutical and medicinal products. ${ }^{60}$ Scheme 1.32 presents some selected substances with heterocyclic moieties. The heterocyclic core is highlighted with red colour. The core of the diazepam is a diazepinone structure. ${ }^{61}$ Valsartan, which is used for hypertension medication, is produced up to 1000 tonnes per year. ${ }^{62}$ The heterocycle contained in this molecule is a tetrazole. The last key structural motif in this Scheme is an imidazole containing antibiotikum. ${ }^{63}$<smiles>CN1C(=O)CN=C(c2ccccc2)c2cc(Cl)ccc21</smiles>

Diazepam<smiles>CCCCCC(C(=O)O)(C(=O)Br)N(Cc1ccc(-c2ccccc2-c2nnn[nH]2)cc1)C(=O)O</smiles>

Valsartan<smiles>Clc1ccccc1C(c1ccccc1)(c1ccc[nH]1)c1ncc[nH]1</smiles>

Clotrimazol

Scheme 1.32: Examples of heterocyclic containing pharmaceuticals.

\footnotetext{
${ }^{60}$ Selected Reviews: a) A. Lauria, R. Delisi, F. Mingoia, A. Terenzi, A. Martorana, G. Barone, A. M. Almerico, Eur. J. Org. Chem. 2014, 16, 3289-3306; b) D. Gonzaga, G. Tadeu, D. R. da Rocha, F. de C. da Silva, V. F. Ferreira, Med. Chem. 2013, 13, 2850-2865; c) M. Juricek, P. H. Kouwer, A. E. Rowan, Chem. Comm. 2011, 47, 8740-8749; d) S. G. Agalve, S. R. Maujan, V. S. Pore, Chem. Asian J. 2011, 6, 2696-2718; e) C. O. Kappe, E. Van der Eycken, Chem. Soc. Rev. 2010, 39, 1280-1290; f) K. D. Hänn, D. A. Leigh, Chem. Soc. Rev. 2010, 39 , 1240-1251; g) A. H. El-Sagheer, T. Brown, Chem. Soc. Rev. 2010, 39, 1388-1405; h) A. Qin, J. W. Y. Lam, B. Z. Tang, Chem. Soc. Rev. 2010, 39, 2522-2544.

${ }^{61}$ Martin Wehling, Klinische Pharmakologie. 1. Aufl., Georg Thieme Verlag, Stuttgart, 2005, S. 487.

62 (a) N. B. Mistry, A. S. Westheim, S. E. Kjeldsen, Expert Opin. Pharmacother. 2006, 7, 575-581; (b) S. E. Kjeldsen, H. R. Brunner, G. T. Mclnnes, P. Stolt, Aging Health, 2005, 1, 27-36.

${ }^{63}$ (a) M. Plempel, K. Bartmann, K. H. Büchel, E. Regel, Deutsche Medizinische Wochenschrift, 1969, 94, 13561367; (b) K. H. Büchel, W. Draber, E. Regel, M. Plempel, Arzneimittel-Forschung / Drug Research, 1972, 22, 1260-1272.
} 
Because of the widespread use of heterocycles, there is a continued strong desire to synthesize these molecules in an economic way. The transition metal-catalyzed synthesis of heterocycles by alkyne annulation is of major significance. Especially cobalt-catalyzed annulations play an important role in heterocyclic chemistry, for example the Pauson-Khand reaction, ${ }^{64}$ the Bönnemann-pyridine synthesis ${ }^{65}$ and the Vollhardt-pyridine-synthesis, ${ }^{66}$ which is shown in Scheme 1.33, including the reaction mechanism.

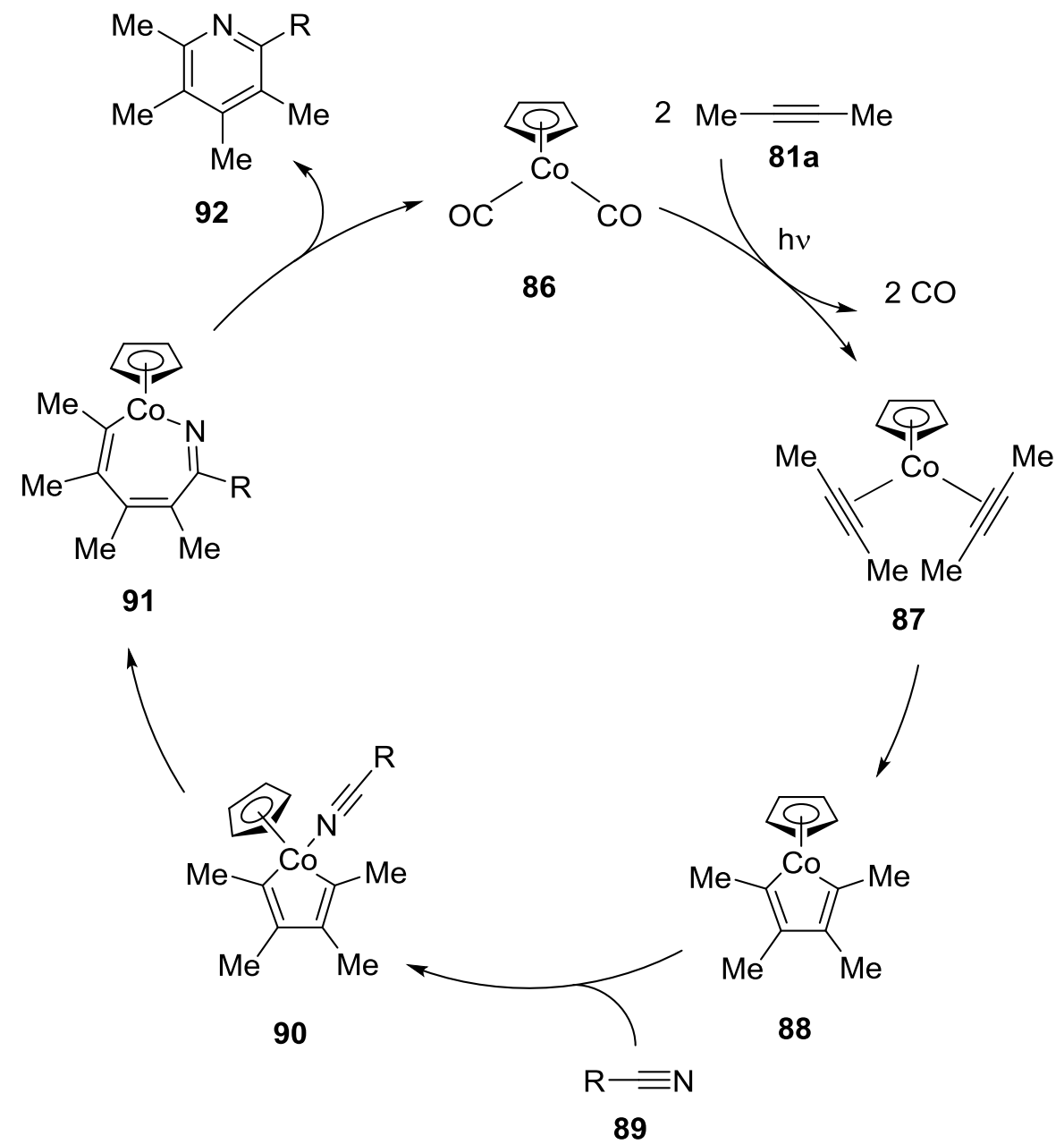

Scheme 1.33: Cobalt-catalyzed Vollhardt-pyridine-synthesis.

An important example of the palladium-catalyzed cross-coupling reaction is the Larocksynthesis of indoles (Scheme 1.34). ${ }^{67}$ In this reaction ortho-iodoanilinine reacts with an alkyne to give the indole.

\footnotetext{
${ }^{64}$ I. U. Khand, G. R. Knox, P. L. Pauson, W. E. Watts, Chem. Comm. 1971, 1, 36

${ }^{65}$ H. Bönnemann, Angew. Chem. Int. Ed. Engl. 1978, 17, 505-515.

${ }^{66}$ (a) K. P. Vollhardt, Angew. Chem. Int. Ed. Engl. 1984, 23, 539-556; (b) B. Heller, M. Hapke, Chem. Soc. Rev. 2007, 36, 1085-1094.
${ }^{67}$ (a) R. C. Larock, E. K. Yum, J. Am. Chem. Soc. 1991, 113, 6690-6692; (b) R. C. Larock, E. K. Yum, M. D. Refvik, J. Org. Chem. 1998, 63, 7652-7662.




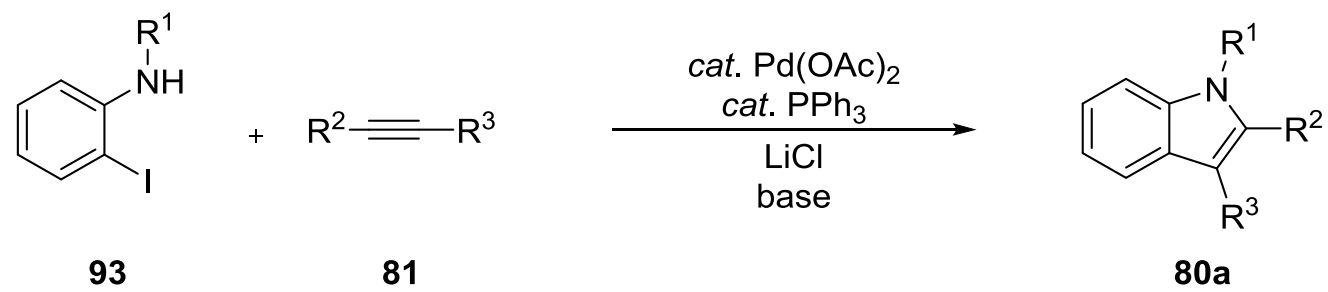

Scheme 1.34: Larock-synthesis of indole.

The access to heterocyclic core structures via transition metal-catalyzed alkyne annulation is a very important aim and was extensively investigated by Ackermann, Fagnou, Miura and others. ${ }^{68,69}$ Selected examples of rhodium-catalyzed alkyne annulations are presented in Scheme $1.35 .^{55,70}$

a)

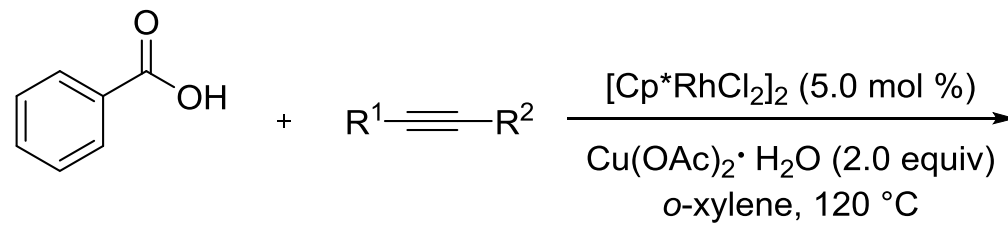

66<smiles>[R]c1oc(=O)c2ccccc2c1[R]</smiles>

85

b)<smiles>CC(C)Nc1ccccc1</smiles>

94<smiles>[R]C#[R]</smiles>

81

$$
\begin{gathered}
\underset{\left.\mathrm{Cu} \mathrm{Cp}^{*} \mathrm{RhCl}_{2}\right]_{2}(2.5 \mathrm{~mol} \%)}{\mathrm{AgSbF}_{6}(10 \mathrm{~mol} \%)} \\
\underset{t-\mathrm{AmOH})_{2} \cdot \mathrm{H}_{2} \mathrm{O}(2.0 \text { equiv })}{\mathrm{Cu}\left(20{ }^{\circ} \mathrm{C}\right.}
\end{gathered}
$$<smiles>[R]c1c([R])n([C])c2ccccc12</smiles>

80b

Scheme 1.35: Rhodium-catalyzed alkyne annulation.

However, the ruthenium-catalyzed alkyne annulation was also achieved with various substrates and economical catalyst. Selected examples for ruthenium-catalyzed alkyne annulations are shown in Scheme 1.36. The ruthenium-catalyzed annulation of alkynes with benzamides leading to pyridinones is shown in Scheme 1.36 a. ${ }^{68 b}$ Interestingly, Ackermann

\footnotetext{
${ }^{68}$ (a) G. Song, F. Wang, X. Li, Chem. Soc. Rev. 2012, 41, 3651-3678; (b) L. Ackermann, A. V. Lygin, N. Hofmann, Angew. Chem. Int. Ed. 2011, 50, 6379-6382; (c) T. Satoh, M. Miura, Chem. Eur. J. 2010, 16, 1121211222; (d) S. Mochida, N. Umeda, K. Hirano, T. Satoh, M. Miura, Chem. Lett. 2010, 39, 744-746; (e) D. R. Stuart, P. Alsabeh, M. Kuhn, K. Fagnou, J. Am. Chem. Soc. 2010, 132, 18326-18339; (f) N. Guimond, K. Fagnou, J. Am. Chem. Soc. 2009, 131, 12050-12051.

${ }^{69}$ (g) D. R. Stuart, M. Bertrand-Laperle, K. M. N. Burgess, K. Fagnou, J. Am. Chem. Soc. 2008, 130, 1647416475.

${ }^{70}$ K. Ueura, T. Satoh, M. Miura, J. Org. Chem. 2007, 72, 5362-5367.
} 
and co-workers managed to find appropriate reaction conditions for the successful alkyne annulation with naphtholes and 2-phenylpyrazoles (Scheme $1.36 \mathrm{~b}$ and c). ${ }^{71}$

a) Ruthenium(II)-catalyzed annulation of alkynes by benzamides.<smiles>[R]NC(=O)c1cc[R1]cc1</smiles>

$68 a$<smiles>[R]C#[R][CH]</smiles>

81

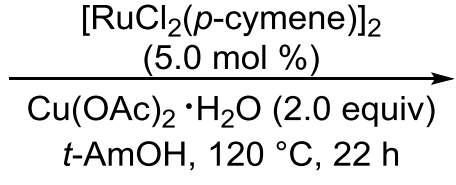

$t-\mathrm{AmOH}, 120^{\circ} \mathrm{C}, 22 \mathrm{~h}$

$R^{1}$<smiles>[R]c1c2c(c(=O)n([R])c1[R])C=C[Z10]C=C2</smiles>

$48 a$

b) Ruthenium(II)-catalyzed annulation of alkynes by naphthols.<smiles>[R1]c1ccc2cccc(O)c2c1</smiles>

95

$$
\begin{gathered}
\underset{\left[\mathrm{RuCl}_{2}(p \text {-cymene })\right]_{2}}{(2.0 \mathrm{~mol} \%)} \\
\underset{\mathrm{Cu}(\mathrm{OAc})_{2} \cdot \mathrm{H}_{2} \mathrm{O}(2.0 \text { equiv })}{\mathrm{m} \text {-xylene, } 80-110{ }^{\circ} \mathrm{C}, 22 \mathrm{~h}}
\end{gathered}
$$

81<smiles>[R]C=c1c([R])c([R])oc2cccc3cccc1c32</smiles>

96

c) Ruthenium(II)-catalyzed annulation of alkynes by arene pyrazoles.<smiles>[R]c1[nH]c(-c2ccccc2)c([R])c1[R]</smiles>

97

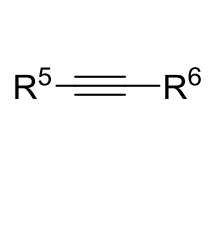

81<smiles>[R][R]1C=CC=c2c([R])c([R8])n3c([R])c([R])c([R])c3c2=C1</smiles>

98

Scheme 1.36: Ruthenium(II)-catalyzed annulation of alkynes.

The transition metal-catalyzed synthesis of heterocycles by alkyne annulation is an important research area.

A second important field is the annulation with alkenes. In contrast to the alkyne annulation, the cyclization is due to an oxa- or aza-Michael reaction.

An early example was reported by Miura on the alkene annulation of benzoic and acrylic acids with acrylates (Scheme 1.37). ${ }^{72}$ A stoichiometric amount of copper acetate was not necessary.

${ }^{11}$ (a) L. Ackermann, L. Wang, A. V. Lygin, Chem. Sci. 2012, 3, 177-180; (b) V. S. Thirunavukkarasu, M. Donati, L. Ackermann, Org. Lett. 2012, 14, 3416-3419. 


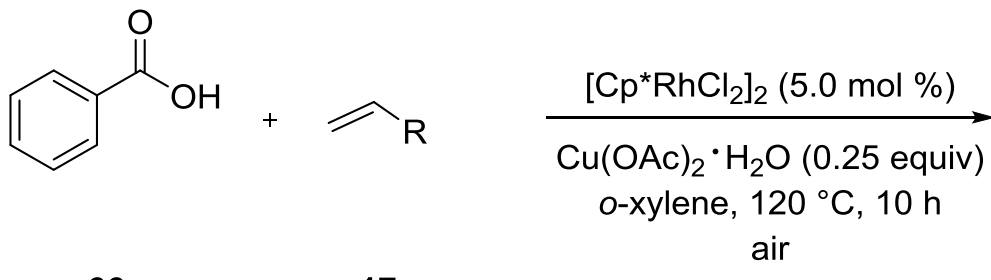

66<smiles>[R]CC1OC(=O)c2ccccc21</smiles>

67

Scheme 1.37: Rhodium-catalyzed annulation of alkynes with benzoic acids 66 .

The proposed mechanism of this transformation is shown in Scheme $1.38 .^{73}$ In the first step the benzoic acid coordinates to the rhodium-catalyst to give $\mathbf{1 0 0}$. Thereafter, the cyclorhodation takes place and affords the rhodacycle 101. Subsequent alkene insertion occurs to produce the corresponding seven-membered rhodacycle 102 , which undergoes $\beta$ hydride elimination. Afterwards, the nucleophilic cyclization results in $\mathbf{6 7}$. Reoxidation in the presence of copper(II) acetate regenerates the catalytic species.

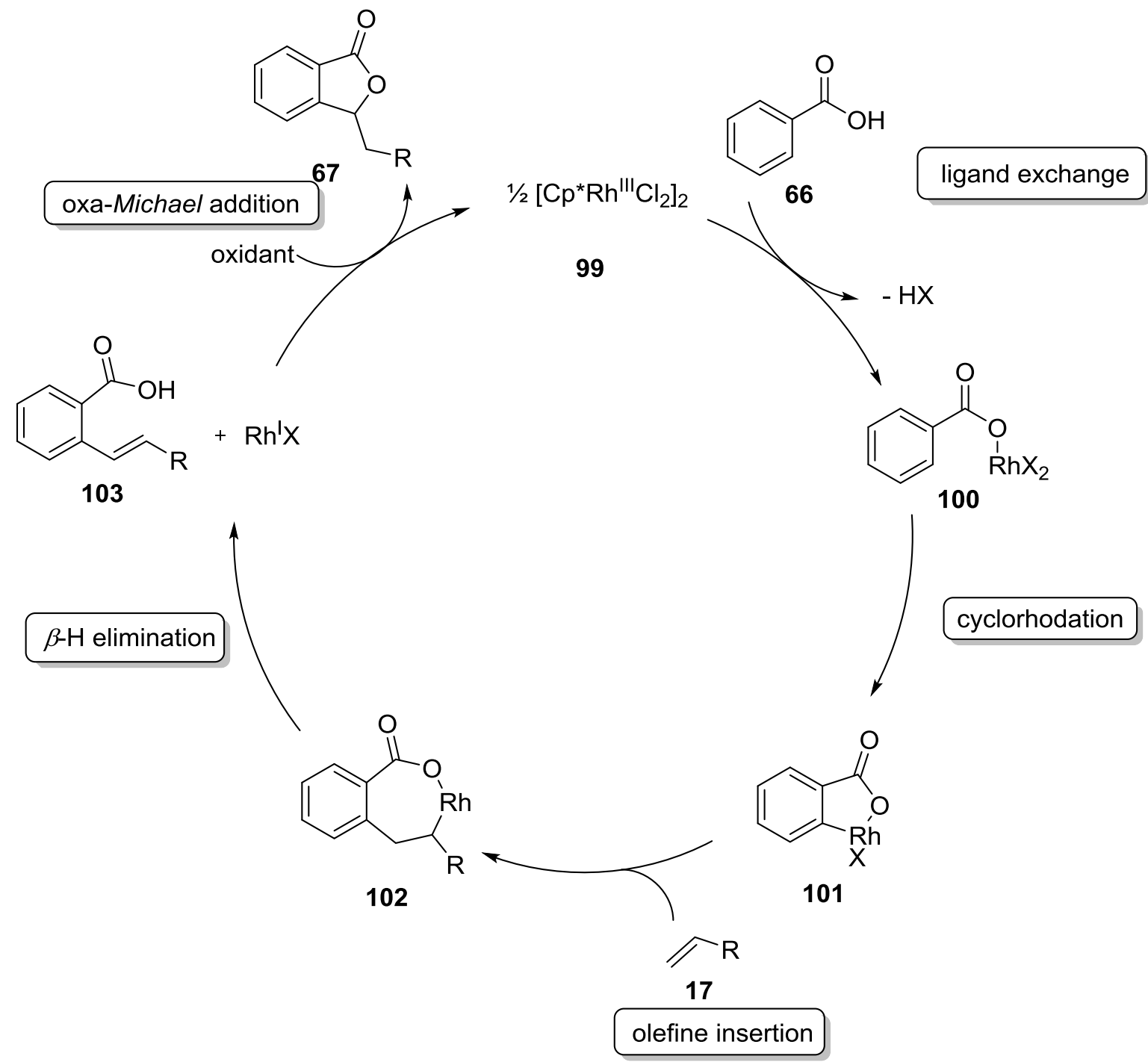

Scheme 1.38: Mechanism of rhodium-catalyzed synthesis of phthalides 67.

\footnotetext{
${ }^{72}$ K. Ueura, T. Satoh, M. Miura, Org. Lett. 2007, 9, 1407-1409.

${ }^{73}$ S. Mochida, K. Hirano, T. Satoh, M. Miura, J. Org. Chem. 2009, 74, 6295-6298.
} 
In 2013, Lee published the rhodium-catalyzed synthesis of benzoxaphosphol oxides. ${ }^{74}$ Subsequently, various other rhodium-catalyzed reactions were developed. ${ }^{62,75}$

Several rhodium-catalyzed alkene cyclization reactions were published in recent years (Scheme 1.39). ${ }^{68 \mathrm{~b}, 68 \mathrm{~d}-\mathrm{f}, 73,76}$ In Scheme 1.39 the versatility of this reaction is presented.<smiles>[R]CC1OP(=O)(OCC)c2ccccc21</smiles>

105 Lee 2013<smiles>[R]C=c1c2cc[R]([18OH])ccc=2c(=O)n1CC</smiles>

Carretero 2014<smiles>[R]CC1c2ccccc2CN1[Tl]</smiles>

108

Kim 2014<smiles>[R]CC1OC(=O)C([R])C1[R]</smiles>

114

Miura 2009

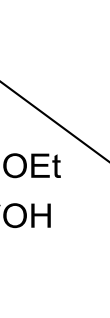<smiles>[R]C1CCCCC1</smiles>

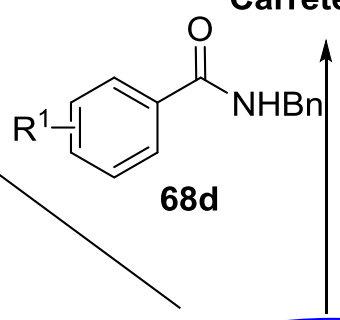

$\mathrm{R}^{1}$<smiles>c1ccc(CC2CCCCCC2)cc1</smiles>

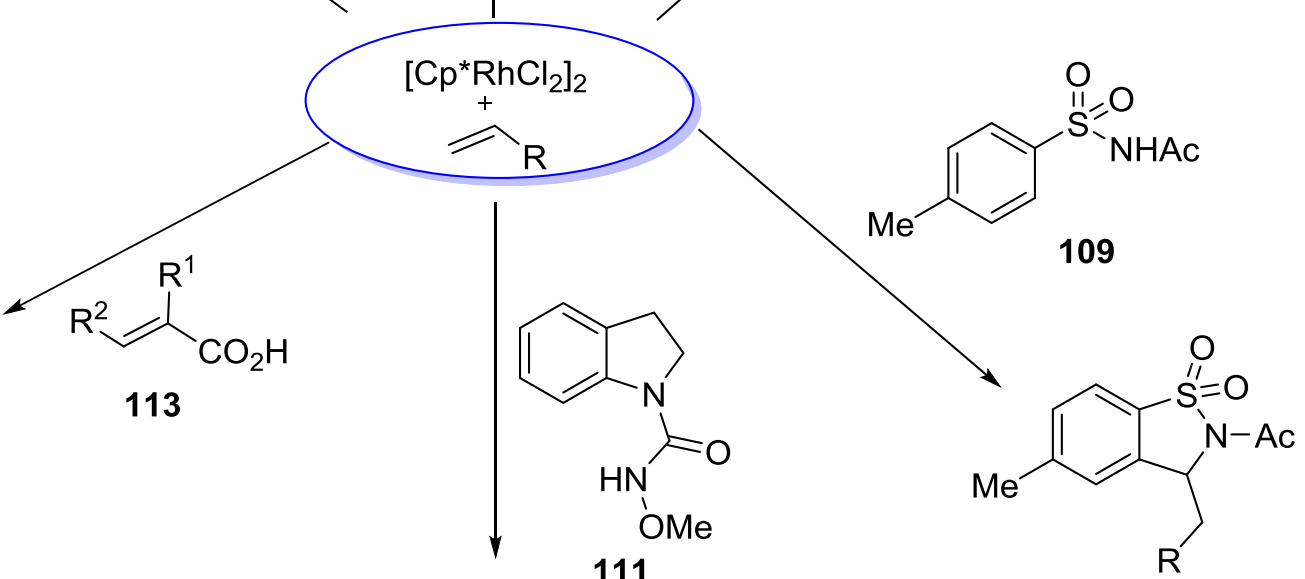

111<smiles>[R]CC1NC(=O)N2CCc3cccc1c32</smiles>

Li 2014

Zhou 2015

Scheme 1.39: Rhodium-catalyzed C-H olefination followed by oxa- and aza-Michael-reactions.

In 2011, Ackermann and co-workers succeeded in the first ruthenium-catalyzed $\mathrm{C}-\mathrm{H}$ olefination followed by oxa-Michael reaction using benzoic acids for the synthesis of

\footnotetext{
${ }^{74}$ T. Ryu, J. Kim, Y. Park, S. Kim, P. H. Lee, Org. Lett. 2013, 15, 3986-3989.

75 Selected examples: (a) X. Wang, H. Tang, H. Feng, Y. Li, Y. Yang, B. Zhou, J. Org. Chem. 2015, 80, 6238-6249; (b) S. Han, Y. Shin, S. Sharma, N. K. Mishra, J. Park, M. Kim, M. Kim, J. Jang, I. S. Kim, Org. Lett. 2014, 16, 2494-2497; (c) N. K. Mishra, J. Park, S. Sharma, S. Han, M. Kim, Y. Shin, J. Jang, J. H. Kwak, Y. H. Jung, I. S. Kim, Chem. Commun. 2014, 50, 2350-2352; (d) A. M. Martínez, N. Rodríguez, R. G. Arrayás, J. C. Carretero, Chem. Commun. 2014, 50, 6105-6107; (d) W. Xie, J. Yang, B. Wang, B. Li, J. Org. Chem. 2014, 79, 8278-8287.

${ }^{76}$ (a) T. Ryu, J. Kim, Y. Park, S. Kim, P. H. Lee, Org. Lett. 2013, 15, 3986-3989
} 
phthalides. ${ }^{77}$ Further studies by Ackermann resulted in sultams. ${ }^{78}$ Studies by Xuang resulted in the synthesis of quinazolinones (Scheme 1.40). ${ }^{79}$<smiles>[R]C=C[CH2+][Na]</smiles>

66

17

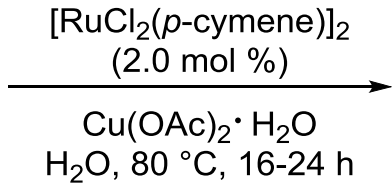<smiles>[R]C=C[NH2+]S(=O)(=O)c1ccc[R1]([H])c1</smiles>

$107 a$ 17

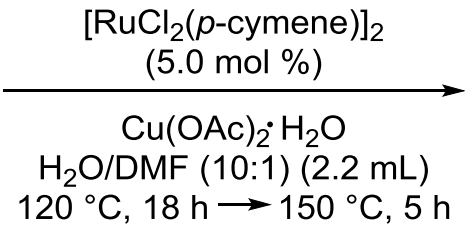<smiles>[R]C=C[R]1ccc(-c2nc3ccccc3c(=O)[nH]2)cc1</smiles>

115<smiles>[R]CC1OC(=O)C2=CC=[R][X]C=C21</smiles>

67<smiles>[R]CC1c2ccccc2S(=O)(=O)N1[R]</smiles>

$108 \mathrm{a}$<smiles>[R]CC1c2ccccc2-c2nc3ccccc3c(=O)n21</smiles>

116

Scheme 1.40: Ruthenium-catalyzed C-H olefination followed by oxa- and aza-Michael-reactions.

\subsection{Triazole Syntheses and Functionalizations}

Triazoles are of great importance because of their biological and pharmaceutical properties. The core structure of 1,2,3-triazoles can be synthesized by two main ways. In general, 1,2,3triazoles are synthesized by the thermal 1,3-dipolar cycloadditions of alkynes and azides leading to 1,4-disubstituted 1,2,3-triazoles. This reaction was pioneered by Rolf Huisgen in $1963{ }^{80} \mathrm{~A}$ major problem of this reaction was the separation of the different regioisomeric products. This problem was solved by Meldal, using copper $(\mathrm{I})$ catalysts. ${ }^{81} \mathrm{~A}$ robust and useful reaction procedure was developed by Sharpless and Fokin (Scheme 1.41). ${ }^{82}$

\footnotetext{
${ }_{77}^{77}$ L. Ackermann, J. Pospech, Org. Lett. 2011, 13, 4153-4155.

${ }^{78}$ W. Ma, R. Mei, G. Tenti, L. Ackermann, Chem. Eur. J. 2014, 20, 15248-15251.

${ }^{79}$ Y. Zheng, W.-B. Song, S.-W. Zhang, L.-J. Xuan, Org. Biomol. Chem. 2015, 13, 6474-6478.

${ }^{80}$ R. Huisgen, Angew. Chem. Int. Ed. Engl. 1963, 2, 565-598.

${ }^{81}$ C. W. Tornoe, C. Christensen, M. Meldal, J. Org. Chem. 2002, 67, 3057-3064.

${ }^{82}$ V. V. Rostovtsev, L. G. Green, V. V. Fokin, K. B. Sharpless, Angew. Chem. Int. Ed. 2002, 41, 2596-2599.
} 


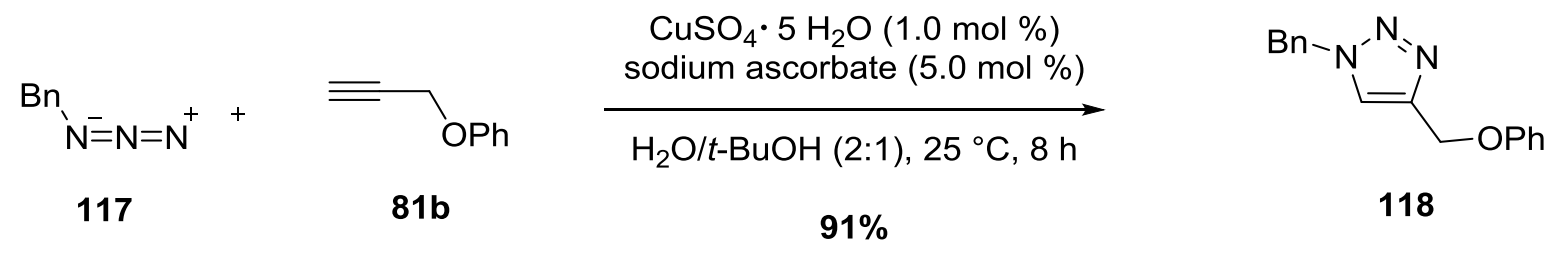

Scheme 1.41: Copper-catalyzed [3+2]-cycloaddition for the synthesis of 1,2,3-triazoles.

The complementary selectivity can be achieved by using ruthenium instead of copper catalysts, giving 1,5-disubstituted triazoles (Scheme 1.42).

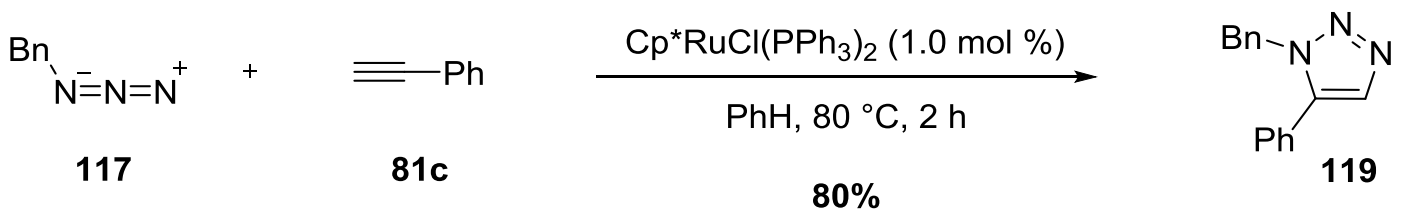

Scheme 1.42: Ruthenium-catalyzed [3+2]-cycloaddition for the synthesis of 1,2,3-triazoles.

While 1,4-disubstituted triazoles can be obtained by using catalytic amounts of copper(II) acetate, the use of stoichiometric amounts of copper salts led to fully substituted 1,2,3triazoles (Scheme 1.43). ${ }^{83}$

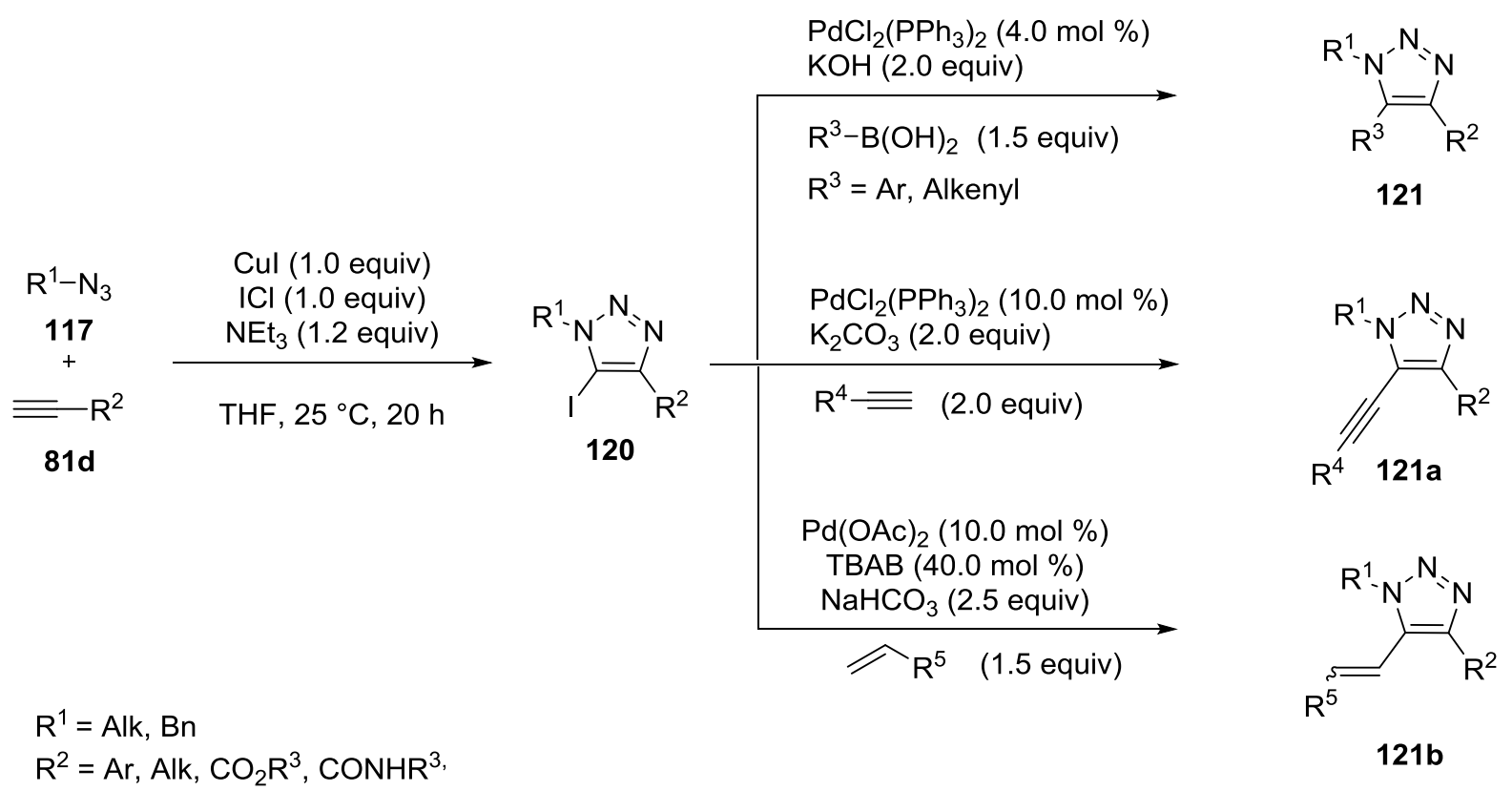

Scheme 1.43: Copper-catalyzed synthesis of fully substituted 1,2,3-triazoles.

Fully substituted 1,2,3-triazoles can also be prepared by functionalization of the 1,4disubstituted triazoles, with bromoalkanes and palladium complexes as catalyst (Scheme 
1.44). ${ }^{84}$ Several arylation reactions were studied with different arylating reagents, such as chlorides or tosylates. ${ }^{85}$<smiles>[R]c1cn([R1])nn1</smiles>

122<smiles>[R]c1cccc(Br)c1</smiles>

1b

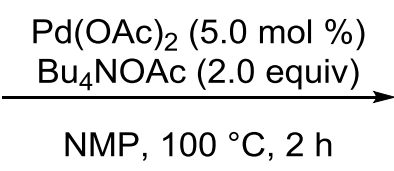

NMP, $100^{\circ} \mathrm{C}, 2 \mathrm{~h}$<smiles>[R]c1ccccc1-c1c([R])nnn1[R1]</smiles>

$121 \mathrm{c}$

Scheme 1.44: Palladium-catalyzed arylation of 1,4 disubstituted 1,2,3-triazoles.

Functionalization of 1,4-substituted triazoles through twofold $\mathrm{C}-\mathrm{H}$ activation could be obtained in an intramolecular fashion (Scheme 1.45). ${ }^{86}$<smiles></smiles>

$122 a$

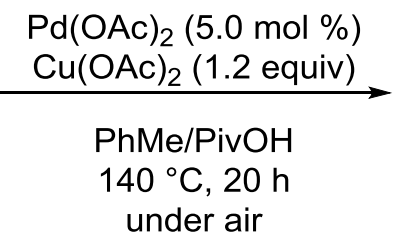

under air<smiles></smiles>

$120 d$

Scheme 1.45: Palladium-catalyzed intramolecular arylation of 1,4-disubstituted 1,2,3-triazoles.

Also the use of the triazole moiety as a directing group led to several functionalized substrates. One representative example is shown in Scheme 1.46. ${ }^{85,87}$<smiles>[R]c1cn(-c2ccccc2)nn1</smiles>

123<smiles>[R]c1cccc(Cl)c1</smiles>

$1 \mathrm{a}$
$\left[\mathrm{RuCl}_{2}(p \text {-cymene })\right]_{2}(2.5 \mathrm{~mol} \%)$ $\mathrm{PCy}_{3}(10.0 \mathrm{~mol} \%)$

NMP, $100^{\circ} \mathrm{C}, 2 \mathrm{~h}$<smiles>[R]c1cccc(-c2ccccc2-n2cc([R])nn2)c1</smiles>

124

Scheme 1.46: Triazole assisted arylation.

\footnotetext{
84 (a) J. Deng, Y.-M. Wu and Q.-Y. Chen, Synthesis 2005, 2730-2738; (b) S. Chuprakov, N. Chernyak, A. S. Dudnik, V. Gevorgyan, Org. Lett. 2007, 9, 2333-2336.

85 (a) L. Ackermann, R. Vicente and R. Born, Adv. Synth. Catal. 2008, 350, 741-748; (b) L. Ackermann, A. Althammer and S. Fenner, Angew. Chem. Int. Ed. 2009, 48, 201-204.

${ }^{86}$ L. Ackermann, R. Jeyachandran, H. K. Potukuchi, P. Novák, L. Büttner, Org. Lett. 2010, 12, 2056-2059.

87 (a) L. Ackermann, S. Barfüßer, J. Pospech, Org. Lett. 2010, 12, 724-726. (b) L. Ackermann, R. Born, R. Vicente, ChemSusChem 2009, 546-549; (c) L. Ackermann, R. Vicente, Org. Lett. 2009, 11, 4922-4925; (d) L. Ackermann, H. K. Potukuchi, D. Landsberg, R. Vicente, Org. Lett. 2008, 10, 3081-3084.
} 
While the synthesis of 1-aryl-1,2,3-triazoles was largely described, the synthesis of 2-aryl1,2,3-triazoles was studied less. Still some ways to synthesize these substrates were developed.

The first regioselective approach was published by Buchwald in $2011 .^{88} 2 H$-1,2,3-triazoles were arylated with either aryl bromides or chlorides with a palladium catalyst (Scheme 1.47).<smiles>Brc1ccccc1</smiles>

$1 b$

125

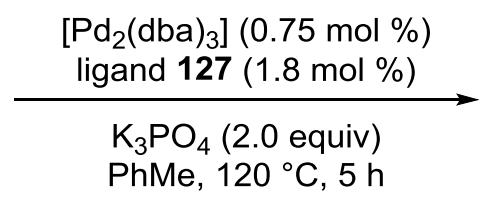<smiles>c1ccc(-n2nccn2)cc1</smiles>

126<smiles>CCCCc1cc([In]CC)cc(I)c1-c1c(C)c(C)c(C)c(C)c1P(CCC)C(C)C</smiles>

ligand 127

Scheme 1.47: Palladium-catalyzed arylation of $2 H-1,2,3$-triazoles.

Mongin and co-workers reported the copper-catalyzed cyclization of glyoxal with (aryl)hydrazones (Scheme 1.48). ${ }^{89}$<smiles>[R]c1ccc(NN)cc1</smiles>

128<smiles>[R]c1ccc(-n2nccn2)cc1</smiles>

126

Scheme 1.48: Copper-catalyzed synthesis of 2-aryl 1,2,3-triazoles.

Since the established synthesis of the core structures of $2 \mathrm{H}-1,2,3$-triazoles, versatile functionalizations of these molecules were done. This includes the palladium-catalyzed halogenation, arylation, alkoxylation and acylation. ${ }^{90}$ The acylation as representative $\mathrm{C}-\mathrm{H}$ bond functionalization is shown in Scheme $1.49 .^{90 \mathrm{~d}}$ The palladium-catalyzed acylation of $2 \mathrm{H}$ 1,2,3-triazoles worked with inexpensive toluene derivatives.

\footnotetext{
${ }^{88}$ S. Ueda, M. Su, S. L. Buchwald, Angew. Chem. Int. Ed. 2011, 50, 8944-8947.

${ }^{89}$ F. Chevallier, T. Blin, E. Nagaradja, F. Lassagne, T. Roisnel, Y. S. Halauko, V. E. Matulis, O. A. Ivashkevichc, F. Mongin, Org. Biomol. Chem. 2012, 10, 4878-4885.

${ }^{90}$ Q. Tian, X. Chen, W. Liu, Z. Wang, S. Shi, C. Kuang, Org. Biomol. Chem. 2013, 11, 7830-7833; (b) S. Shi, W. Liu, P. He, C. Kuang, Org. Biomol. Chem. 2014, 12, 3576-3580; (c) S. Shi, C. Kuang, J. Org. Chem. 2014, 79, 6105-6112; (d) P. He, Q. Tian, C. Kuang, Synthesis 2015, 1309-1316.
} 
<smiles>[R][R]1ccccc1-n1nccn1</smiles>

126<smiles>[R]c1cccc(C)c1</smiles>

4b

$$
\underset{\mathrm{PCE}, 80{ }^{\circ} \mathrm{C}, 15 \mathrm{~h}}{\frac{\mathrm{Pd}(\mathrm{OAc})_{2}(10.0 \mathrm{~mol} \%)}{\mathrm{DuOOH}(12.0 \text { equiv })}}
$$<smiles>[R][R]c1cccc(C(=O)c2ccccc2-n2nccn2)c1</smiles>

129

Scheme 1.49: Palladium-catalyzed acylation of 2-aryl 1,2,3-triazoles.

The synthesis of 1,2,3-triazoles was investigated by many research groups. However, the synthesis of 1,5-disubstituted 1,2,4-triazoles was studied less. The synthesis of the core structure could be obtained by condensation of phenylhydrazine with $\mathrm{N}$-formylbenzamide to give the desired triazoles (Scheme 1.50). ${ }^{91}$<smiles>O=CNC(=O)c1ccccc1</smiles>

130<smiles></smiles>

131

Scheme 1.50: Condensation reaction to yield 1,5-disubstituted 1,2,4-triazoles.

An early transition metal-catalyzed synthesis of 1,2,4-triazoles was performed by Nagasawa in 2009. ${ }^{92}$ Amidines were copper-catalyzed coupled with nitriles. Another access, directly using nitriles, was developed by Ren. ${ }^{93}$ The copper-catalyzed synthesis of 1,2,4-triazoles by a one-pot reaction directly using nitriles is presented in Scheme 1.51.

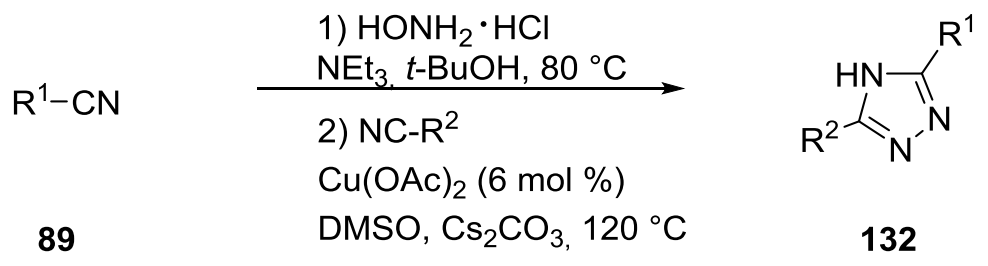

Scheme 1.51: Copper-catalyzed synthesis of 1,5-disubstituted 1,2,4-triazoles.

\footnotetext{
${ }^{91}$ Q. Thompson, J. Am. Chem. Soc. 1951, 73, 5914-5915.

${ }^{92}$ S. Ueda, H. Nagasawa, J. Am. Chem. Soc. 2009, 131, 15080-15081.

${ }^{93}$ H. Xu, S. Ma, Y. Xu, L. Bian, T. Ding, X. Fang, W. Zhang, Y. Ren, J. Org. Chem. 2015, 80, 1789-1794.
} 


\section{Objectives}

Transition metal-catalyzed $\mathrm{C}-\mathrm{H}$ bond functionalization emerged as an important topic of research in organic synthesis. These $\mathrm{C}-\mathrm{H}$ bond functionalizations are step-economical methods for the preparation of chemo- and site-selectively arylated, alkenylated and alkylated products. They avoid the use of prefunctionalized starting materials as are needed, for example, in cross-coupling reactions. The key task of this thesis was the ruthenium(II)catalyzed synthesis and functionalization of heterocyclic compounds. Thus recently, Prof. Ackermann and co-workers developed the direct alkylation reaction of aryl-pyridines, -pyrazoles and -ketimines with primary and secondary alkyl halides (Scheme 2.1). ${ }^{27,42,94}$

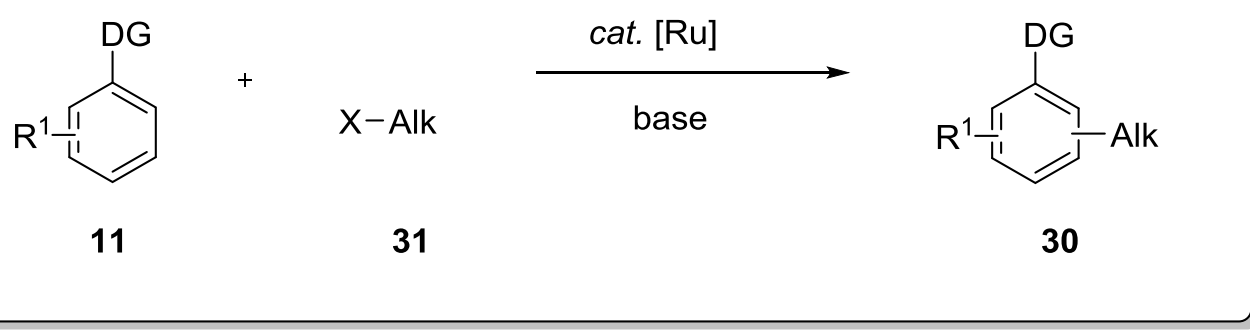

Scheme 2.1: Ruthenium(II)-catalyzed alkylation of arylpyridines, -pyrazoles and -ketimines.

Herein we want to present the challenging alkylation of compounds bearing a triazole moiety, which is found in a variety of important pharmaceuticals and other valuable chemicals (Scheme 2.2).

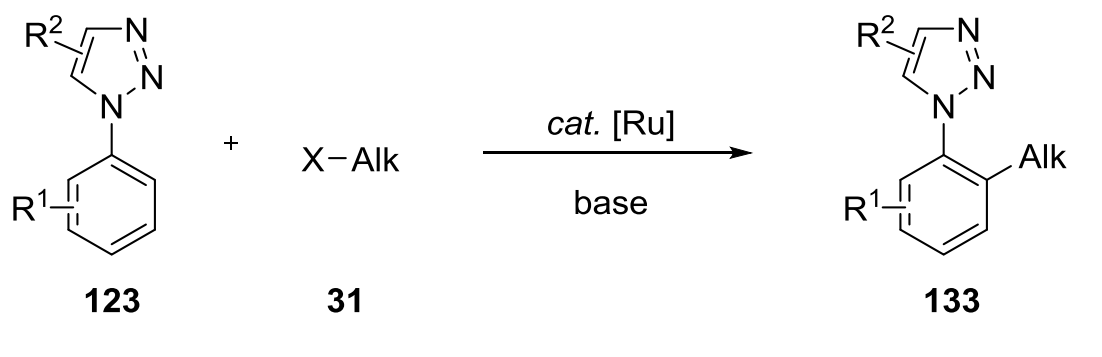

Scheme 2.2: Ruthenium(II)-catalyzed alkylation of triazoles 123.

Further efforts focused on the extension of the ruthenium(II)-catalyzed alkenylation reactions of the aryl triazole (Scheme 2.3). 


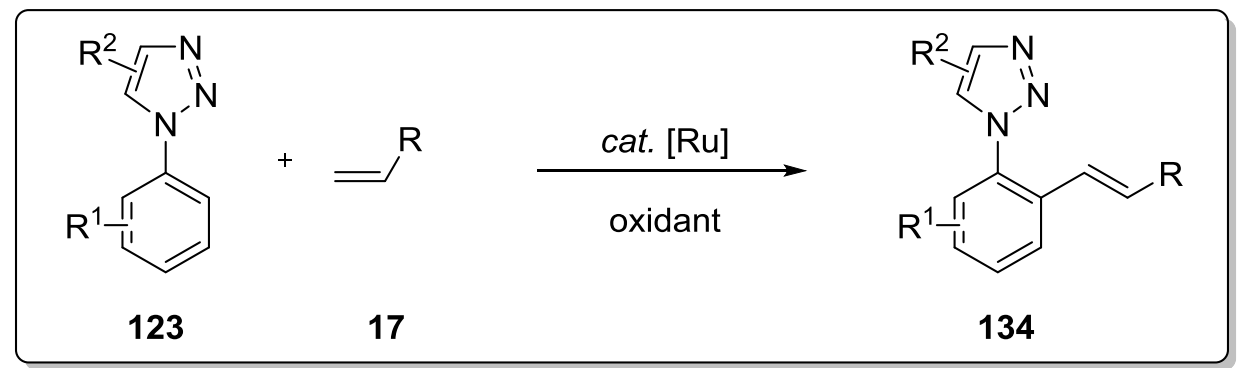

Scheme 2.3: Ruthenium(II)-catalyzed alkenylation of triazoles 123.

Besides the ruthenium(II)-catalyzed functionalization of arenes with alkyl or aryl moieties, heterocyclic compounds were synthesized, mostly by annulation reactions with alkynes and alkenes. ${ }^{56,69-72}$ This part of the Ph.D. thesis adresses the development of a ruthenium(II)catalyzed synthesis of isoindolinones 136 (Scheme 2.4).

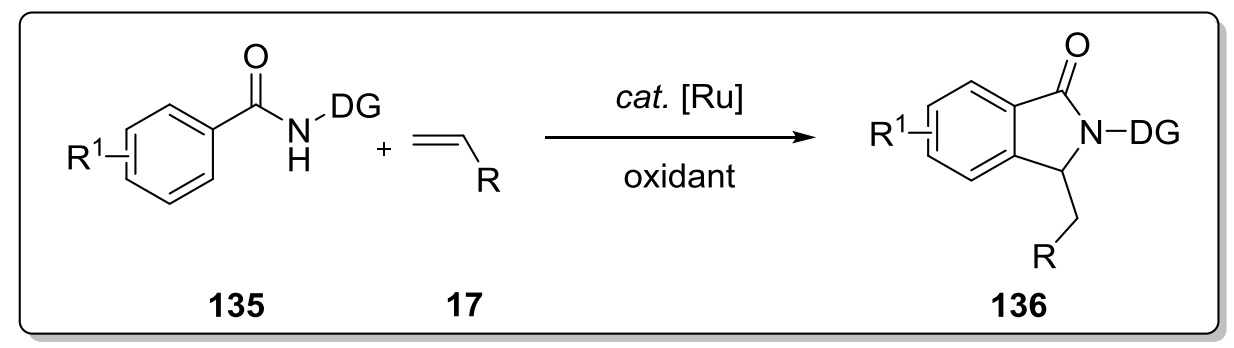

Scheme 2.4: Ruthenium(II)-catalyzed annulation of benzamides 135.

Further investigations to provide mechanistic insights into this annulation reaction have also been envisaged.

The most ecological and atom-economic synthesis would proceed without producing sideproducts or chemical waste. Recently, major improvements in this field have been achieved by metal catalyzed synthesis. ${ }^{53,55 a-b, 55 d-e, 58,95}$ Hence, the ruthenium(II)-catalyzed oxidative alkyne annulation of benzoic acids with molecular oxygen as the sole oxidant was developed in the Ackermann research group. ${ }^{59}$

Thus, the last challenging part comprised the use of the previously developed catalytic system with oxygen as the terminal oxidant for the isoindolinone synthesis.

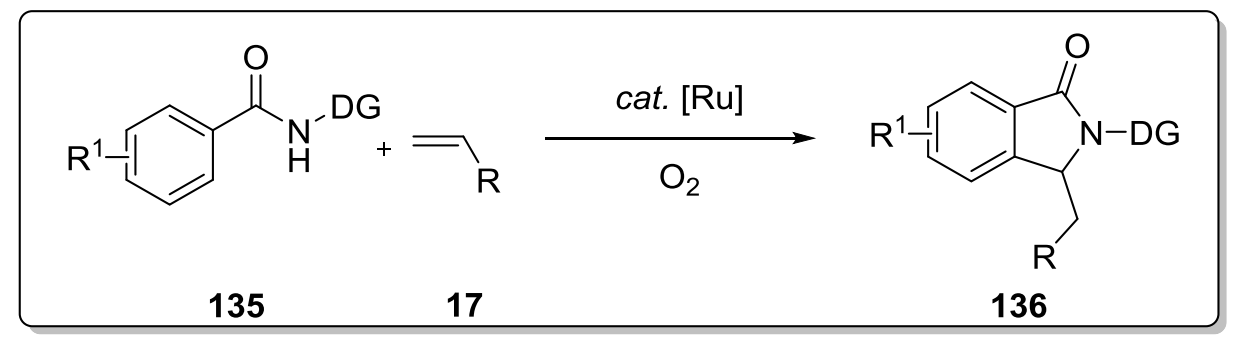

Scheme 2.5: Ruthenium-catalyzed annulation of benzamides 135 with oxygen as sole oxidant.

\footnotetext{
${ }^{95}$ P. Zhao, D. Chen, G. Song, K. Han and X. Li, J. Org. Chem. 2012, 77, 1579-1584.
} 


\section{Results and Discussion}

\subsection{Ruthenium(II)-Catalyzed Direct Alkylation of $\mathrm{N}$-Aryl-1,2,3-triazoles with primary-Bromoalkanes}

Triazoles are key structural motifs of various compounds with significant relevance to biological and medicinal chemistry. ${ }^{60}$ Drug potency and the drug bioavailability are the most important factors regarding drug effectiveness. Frequently, the drug potency is not the issue, but the lack of drug delivery. If the lipophilicity is high, the membrane permeability is improved, but some different problems occur, such as increasing the rate of oxidative metabolism by enzymes. Therefore, the lipophilicity of biologically active compounds has to be balanced carefully to improve the bioavailability. ${ }^{96}$ The alkylation of biologically active molecules is one of the amenable ways to tune their lipophilicity. For this purpose, the direct metal-catalyzed $\mathrm{C}-\mathrm{H}$ bond activation is an excellent tool, avoiding the pre-functionalized substrates, which are used in traditional cross-coupling reactions.

The ruthenium-catalyzed ortho-alkylations via $\mathrm{C}-\mathrm{H}$ bond cleavage has primarily been examined by Ackermann et al. in 2009 using aryl pyridines and aromatic ketimines as substrates. ${ }^{94 a}$

With respect to the significance of the triazole moiety ${ }^{60}$ in drugs we investigated the alkylation reaction on $\mathrm{N}$-aryl-1,2,3-triazoles.

\subsubsection{Synthesis of Starting Materials}

The starting materials, 1,4-disubstituted 1,2,3-triazoles were synthesized via Huisgen`s 1,3dipolar [3+2] cycloaddition of azides and alkynes, ${ }^{81}$ according to a literature-known procedure without optimization of the reaction conditions (Table 1). ${ }^{97}$

\footnotetext{
${ }^{6}$ M. Ambikanandan, S. Ganesh, S. Aliasgar, J. Pharm. Pharmaceut Sci. 2003, 6, 252-273.

7 J. Andersen, S. Bolving, X. Liang, Synlett 2005, 2941-2947.
} 
Table 1: Substrate scope of starting materials. ${ }^{a}$

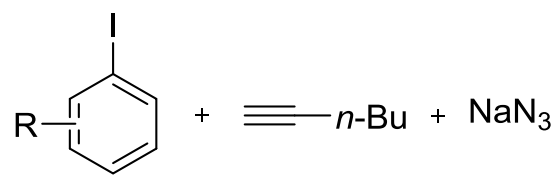

$1 \mathrm{c}$

entry

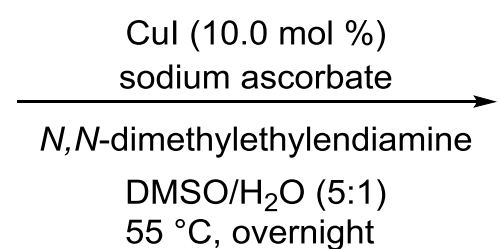

$55^{\circ} \mathrm{C}$, overnight<smiles>[R][R]1ccccc1-n1cc(CCCC)nn1</smiles>

123

yield [\%]

2<smiles>Cc1ccccc1I</smiles>

$1 d$<smiles>Ic1ccccc1</smiles>

$1 e$<smiles>Cc1cccc(I)c1</smiles>

$1 f$<smiles>COc1cccc(I)c1</smiles>

$1 \mathrm{~g}$ product 123<smiles>Cc1ccccc1-n1cc(C(C)(C)C)nn1</smiles><smiles>CCCc1cn(-c2ccccc2)nn1</smiles><smiles>Cc1cccc(-n2cc(CC(C)C)nn2)c1</smiles>

$123 c$<smiles>COc1cccc(-n2cc(CC(C)C)nn2)c1</smiles> 
5<smiles>Fc1cccc(I)c1</smiles>

$1 \mathrm{~h}$<smiles>Fc1ccccc1I</smiles>

$1 \mathrm{i}$<smiles>COc1ccccc1I</smiles>

$1 \mathrm{j}$<smiles>Ic1cccc2ccccc12</smiles>

$1 k$<smiles>Cc1ccc(I)cc1</smiles><smiles>CCCCc1cn(-c2cccc(F)c2)nn1</smiles>

$123 e$

$n-\mathrm{Bu}$<smiles>Cc1cn(-c2ccccc2F)nn1</smiles>

$123 f$<smiles>CCCCc1cn(-c2ccccc2OC)nn1</smiles>

$123 \mathrm{~g}$<smiles>CCCCc1cn(-c2cccc3ccccc23)nn1</smiles>

$123 h$<smiles>CCCCc1cn(-c2ccc(C)cc2)nn1</smiles>

$123 i$
88

86

89

80

76 
10<smiles>Clc1ccc(I)cc1</smiles><smiles>CCCCc1cn(-c2ccc(Cl)cc2)nn1</smiles><smiles>COc1ccc(I)cc1</smiles><smiles>CCCCc1cn(-c2ccc(OC)cc2)nn1</smiles>

1n

123k<smiles>COC(=O)c1ccc(I)cc1</smiles><smiles>CCCCc1cn(-c2ccc(C(=O)OC)cc2)nn1</smiles>

10

$123 \mid$<smiles>CCCCc1cn(-c2cccc(C(F)(F)F)c2)nn1</smiles>

$1 p$

$123 m$<smiles>CCCCc1cn(-c2cccc(C(C)=O)c2)nn1</smiles>

87<smiles>CC(=O)c1cccc(I)c1</smiles>

60 $123 n$ 
15<smiles>Cn1cc(I)c2ccccc21</smiles>

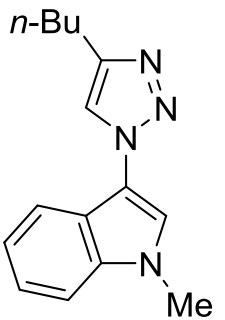

1230

$1 \mathrm{r}$

37

${ }^{a}$ General reaction conditions: 1c (1.00 equiv), 81e (1.00 equiv), $\mathrm{NaN}_{3}$ (1.05 equiv), Cul (10.0 mol \%), sodium ascorbate (10.0 mol \%), $\mathrm{N}, \mathrm{N}$-dimethylethylendiamine (15.0 mol \%), DMSO/ $\mathrm{H}_{2} \mathrm{O}(0.3 \mathrm{M}), 55{ }^{\circ} \mathrm{C}, 12-15 \mathrm{~h}$.

\subsubsection{Optimization Studies for the $\mathrm{C}-\mathrm{H}$ Alkylation of $\mathbf{N}$-Aryl-1,2,3-triazoles with primary-Bromoalkanes}

The ruthenium(II)-catalyzed ortho-alkylations via $\mathrm{C}-\mathrm{H}$ bond activation have primarily been examined by Ackermann and co-workers. ${ }^{40,94 b}$ An extensive screening of the reaction conditions established the in-situ generated catalytic system, using $\left[\mathrm{RuCl}_{2}(p \text {-cymene })\right]_{2}$ as the catalyst and 1-adamantyl carboxylic acid as cocatalyst, to be most efficient. Using the established catalytic system to the triazole substrate $123 a$ with increased reaction temperature gave no conversion, of 123aa (Scheme 3.1).

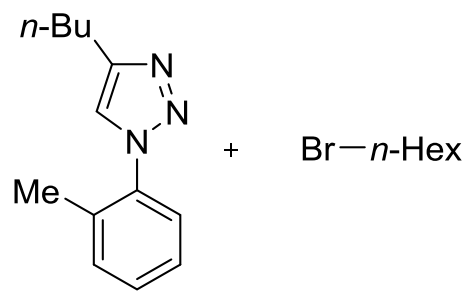

$123 a$

$40 a$

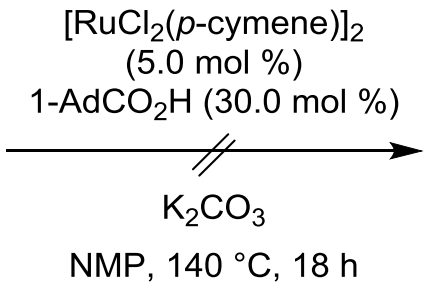<smiles>CCCCCCCCCCOc1cccc(C)c1-n1cc(C(C)C)nn1</smiles>

133aa

Scheme 3.1: Transferred reaction conditions ${ }^{94 b}$ on $\mathrm{N}$-aryl-1,2,3-triazole 140 a

Hence, an extensive screening of prosperous reaction conditions was applied, starting with investigations of different solvents and reaction temperatures (Table 2). 
Table 2: Optimization studies for the direct alkylation of $N$-aryl-1,2,3-triazole 123a: Solvent. ${ }^{a}$
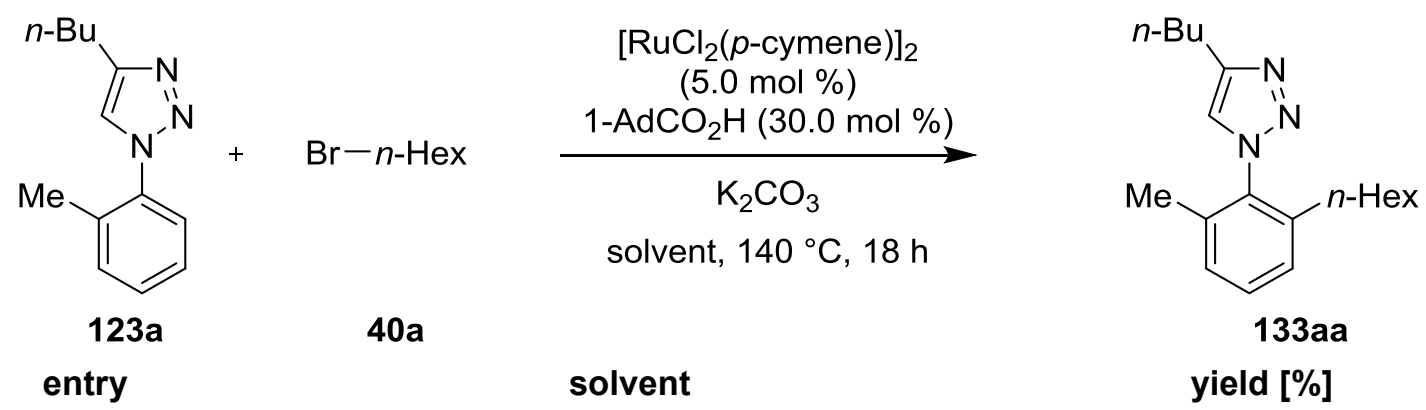

\begin{tabular}{ccc}
\hline \hline 1 & PhMe & $(16)^{\mathrm{b}}$ \\
2 & PhMe & $20(33)$ \\
3 & NMP & $(0)$ \\
4 & NMP & $(0)$ \\
5 & DMSO & $(0)$ \\
6 & o-xylene & $(10)$ \\
7 & $m$-xylene & $(20)$ \\
8 & $n$-Bu 20 & $(19)$ \\
9 & $\mathrm{H}_{2} \mathrm{O}$ & $(0)$ \\
10 & $1,4-$-dioxane & $(12)$ \\
\hline
\end{tabular}

a General reaction conditions: $123 \mathrm{a}(1.00 \mathrm{mmol}), 40 \mathrm{a}(3.00 \mathrm{mmol}),\left[\mathrm{RuCl}_{2}(p \text {-cymene })\right]_{2}(5.0 \mathrm{~mol} \%), 1-\mathrm{AdCO}_{2} \mathrm{H}$ $(30.0 \mathrm{~mol} \%), \mathrm{K}_{2} \mathrm{CO}_{3}(2.00 \mathrm{mmol})$, solvent $(4.0 \mathrm{~mL}), 18 \mathrm{~h}$, isolated yield, yields in parentheses refer to NMRconversion; ${ }^{\mathrm{b}} 110^{\circ} \mathrm{C}$.

Thus far, the yield of this reaction was very low. Furthermore, a notable conversion was observed in aprotic non-polar and polar solvents. The best isolated yield obtained was $20 \%$ in toluene as the solvent at $140{ }^{\circ} \mathrm{C}$ reaction temperature.

Extensive screening of different additives (Table 3) showed that a phosphine ligand resulted in no conversion (Table 3, entry 1 ). The use of the protected alanine resulted in no reaction. The usage of amino acids as ligands for palladium(II)-catalyzed $\mathrm{C}-\mathrm{H}$ olefination was reported by $Y u^{44 e}$

The use of aromatic carboxylic acids (Table 3, entries 5-16) revealed superior activity compared to non-aromatic carboxylic acids (Table 3, entries 2-4). The competition between the carboxylic acids and the potassium salts of the carboxylic acids revealed that the potassium salts used as additives resulted in higher yields than the corresponding carboxylic acids. The highest yield was obtained with potassium-4-(trifluoromethyl)benzoic carboxylate ${ }^{98}$

${ }^{98}$ F. Yang, L. Ackermann, J. Org. Chem. 2014, 79, 12070-12082. 
137 with $42 \%$ isolated yield (Table 3 , entry 17 ). The comparison between electron poor and electron rich carboxylic acids as additives showed no correlation with regard to the product yield.

Table 3: Optimization studies for the direct alkylation of $N$-aryl-1,2,3-triazole 123a: Additive. ${ }^{a}$<smiles>Cc1ccccc1-n1cc(C(=O)O)nn1</smiles>

$123 a$

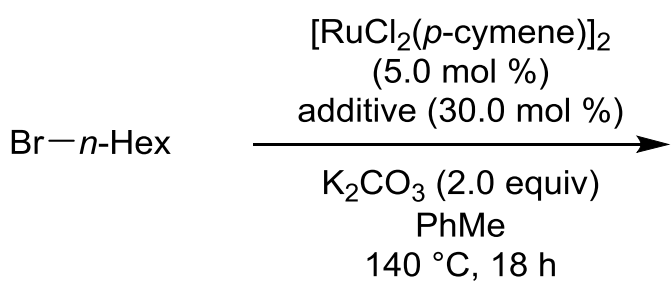

$40 a$<smiles>Cc1cccc(OCC(=O)c2ccccc2)c1-n1cc(C(C)C)nn1</smiles>

133aa

entry

Additive

yield [\%]

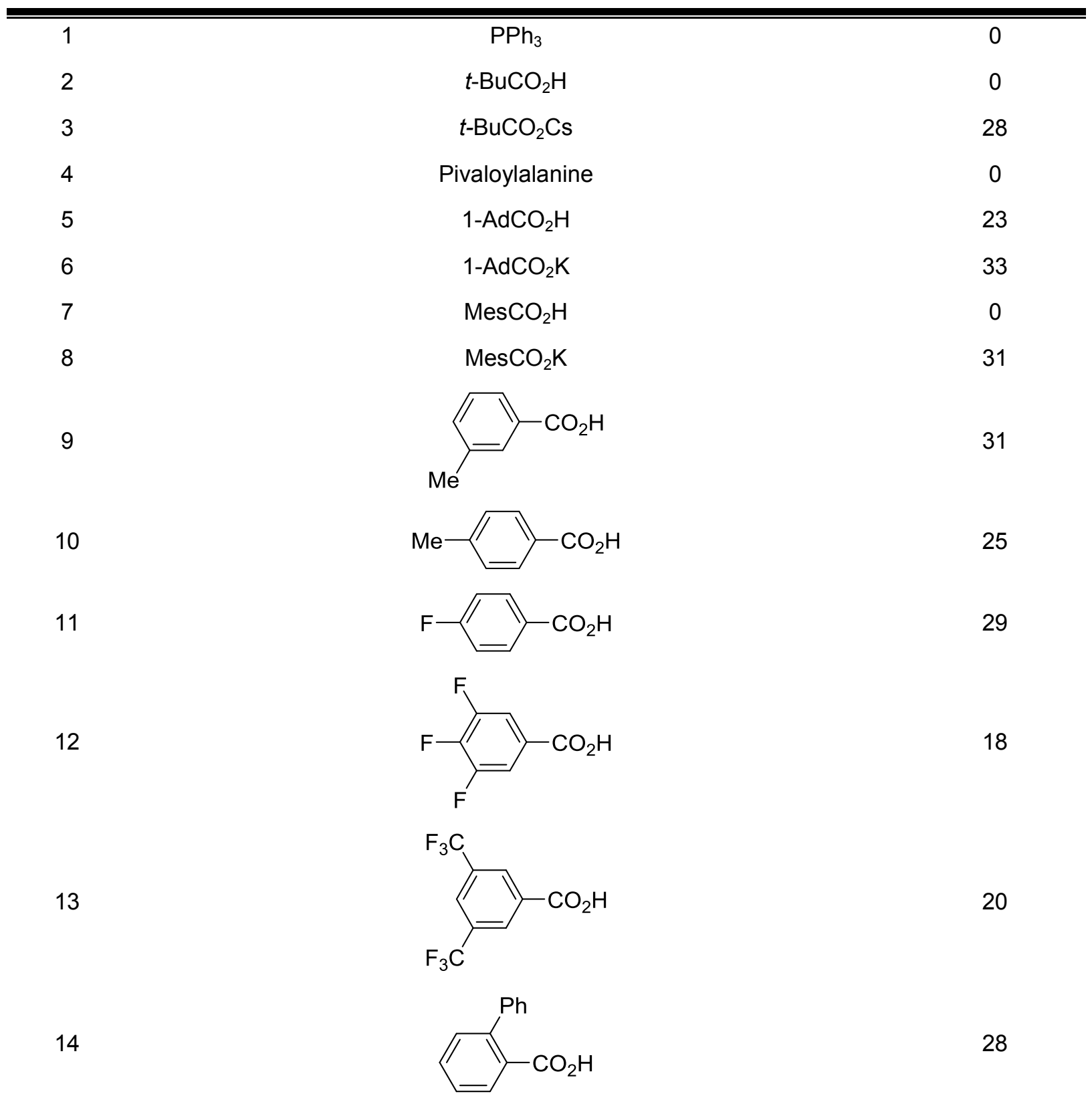


15<smiles>O=C(O)c1ccc(C(F)(F)F)cc1</smiles>

16<smiles>O=Cc1cccc(C(F)(F)F)c1</smiles>

a General reaction conditions: 123a $(1.00 \mathrm{mmol}), 40 \mathrm{a}(3.00 \mathrm{mmol}),\left[\mathrm{RuCl}_{2}(p \text {-cymene })\right]_{2}(5.0 \mathrm{~mol} \%)$, additive (30.0 mol \%), $\mathrm{K}_{2} \mathrm{CO}_{3}(2.00 \mathrm{mmol}), \mathrm{PhMe}(4.0 \mathrm{~mL}), 140{ }^{\circ} \mathrm{C}, 18 \mathrm{~h}$, isolated yields.

In order to find out whether it was possible to establish a link between the additive and the solvent, different solvents were tested with potassium-4-(trifluoromethyl)benzoic carboxylate 137 (Table 4). Unfortunately, the solvent screening showed no improvement. Furthermore, we observed the formation of a benzylated by-product in toluene (138a, 16\%) and in $m$-xylene $(138 \mathrm{~b}, 5 \%)$, reducing the amount of the desired alkylated product. Neat reaction conditions with an excess of bromohexane afforded no product.

Table 4: Optimization studies for the direct alkylation of $N$-aryl-1,2,3-triazole 123a: Solvent with additive $137 .^{a}$<smiles>CCCCCCc1cn(-c2ccccc2C)nn1</smiles>

123a

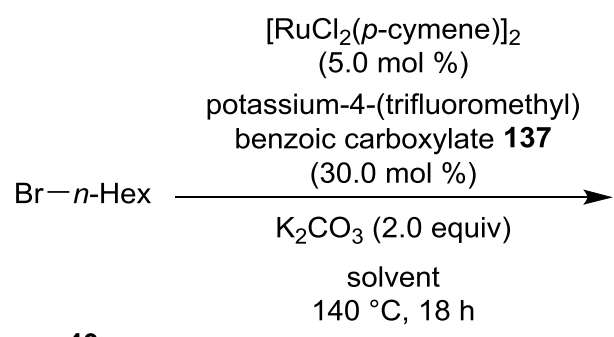

40a

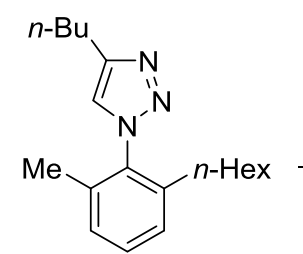

133aa<smiles>Cc1cccc(Cc2ccccc2-n2cc(CC(C)C)nn2)c1</smiles>

138

\begin{tabular}{cccc} 
entry & solvent & yield 133 [\%] & yield 138 [\%] \\
\hline \hline 1 & PhMe & 42 & 16 \\
2 & $m$-xylene & 20 & 5 \\
3 & $\mathrm{H}_{2} \mathrm{O}$ & --- & --- \\
4 & $1,4-$ dioxane & 35 & --- \\
5 & - & $---{ }^{\mathrm{b}}$ & -- \\
\hline
\end{tabular}

${ }^{a}$ General reaction conditions: $123 a(1.00 \mathrm{mmol}), 40 \mathrm{a}(3.00 \mathrm{mmol}),\left[\mathrm{RuCl}_{2}\left(p-\mathrm{cymene}_{2}\right]_{2}(5.0 \mathrm{~mol} \%)\right.$, potassium-4(trifluoromethyl)benzoic carboxylate $(30.0 \mathrm{~mol} \%), \mathrm{K}_{2} \mathrm{CO}_{3}(2.00 \mathrm{mmol})$, solvent $(4.0 \mathrm{~mL}), 140{ }^{\circ} \mathrm{C}, 18 \mathrm{~h}$, isolated yields; ${ }^{b}$ 40a (5.00 mmol). 
Next, we tested different bases, using the best additive 137 in 1,4-dioxane (Table 5) with different carbonates or $\mathrm{K}_{3} \mathrm{PO}_{4}$ as the base the yields remained comparably low (Table 5 , entry 1-4). When KOAc was used as the base, the yield dropped significantly (Table 5, entry 5).

Table 5: Optimization studies for the direct alkylation of $N$-aryl-1,2,3-triazole 123a: base. ${ }^{a}$

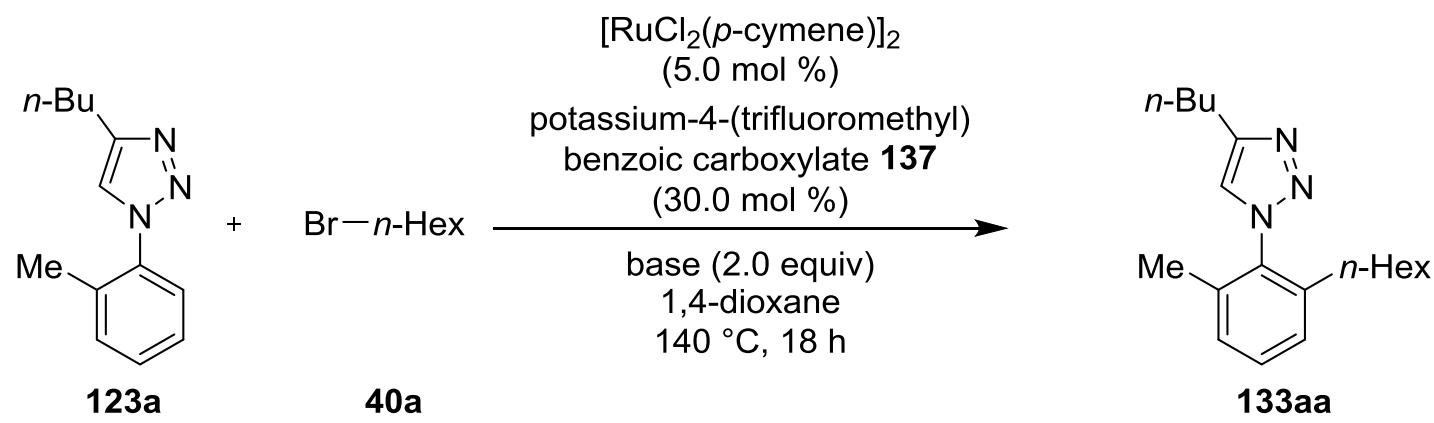

entry

\begin{tabular}{lcc}
\hline \hline 1 & $\mathrm{KOAc}$ & 6 \\
2 & $\mathrm{Na}_{2} \mathrm{CO}_{3}$ & 36 \\
3 & $\mathrm{Cs}_{2} \mathrm{CO}_{3}$ & 24 \\
4 & $\mathrm{~K}_{3} \mathrm{PO}_{4}$ & 37 \\
5 & $\mathrm{~K}_{2} \mathrm{CO}_{3}$ & 35 \\
6 & $\mathrm{~K}_{2} \mathrm{CO}_{3}$ & $11^{\mathrm{b}}$ \\
7 & $\mathrm{~K}_{2} \mathrm{CO}_{3}$ & $18^{\mathrm{b}, \mathrm{c}}$ \\
8 & $\mathrm{~K}_{2} \mathrm{CO}_{3}$ & trace \\
9 & $\mathrm{~K}_{2} \mathrm{CO}_{3}$ & $32^{\mathrm{e}, \mathrm{d}}$
\end{tabular}

${ }^{a}$ General reaction conditions: $123 a(1.00 \mathrm{mmol}), 40 \mathrm{a}(3.00 \mathrm{mmol}),\left[\mathrm{RuCl}_{2}(p-c y m e n e)\right]_{2}(5.0 \mathrm{~mol} \%)$, potassium-4(trifluoromethyl)benzoic carboxylate $(30.0 \mathrm{~mol} \%)$, base $(2.00 \mathrm{mmol}), 1,4$-dioxane $(4.0 \mathrm{~mL}), 140{ }^{\circ} \mathrm{C}, 18 \mathrm{~h}$, isolated yields; ${ }^{b} \mathrm{I}-n-\mathrm{Hex}(3.00 \mathrm{mmol}) ;{ }^{\mathrm{c}} \mathrm{PhMe} ;{ }^{\mathrm{d}} \mathrm{Cl}-n$-Hex (3.00 mmol); ${ }^{\mathrm{e}} \mathrm{Nal}(30.0 \mathrm{~mol} \%)$.

When changing the 1-bromohexane to 1 -iodohexane (Table 5, entry 6 and 7 ), the amount of the desired product did not increase. Testing the much less reactive and less expensive chlorohexane led to no conversion. The in situ generation of the 1-iodohexane via the Finkelstein reaction using sodium iodide as the additive resulted in a comparable yield (Table 5 , entry 9).

To probe if cationic complexes give higher amounts of the desired product, several further additives were tested (Table 6). Silver hexafluoroantimonate and silver hexafluorophosphate completely shut down the reaction. The presence of silver tetrafluoroborate and potassium hexafluorophosphate gave similar yields to the reaction without additive. In conclusion, 
cationic complexes are probably not involved in the present catalytic system and do not improve the reactivity of the catalyst. As a consequence we did not test further additives.

Table 6: Optimization studies for the direct alkylation of $N$-aryl-1,2,3-triazole 123a: Second additives. ${ }^{a}$
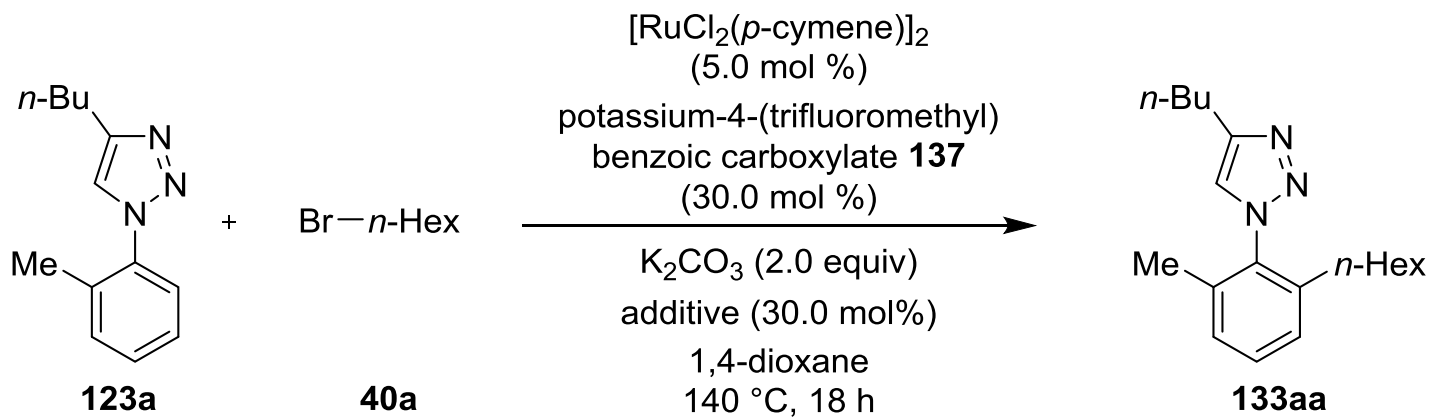

\begin{tabular}{ccc} 
entry & additive & yield [\%] \\
\hline \hline 1 & - & 35 \\
2 & $\mathrm{AgSbF}_{6}$ & 0 \\
3 & $\mathrm{AgPF}_{6}$ & trace \\
4 & $\mathrm{AgBF}_{4}$ & 36 \\
5 & $\mathrm{KPF}_{6}$ & 39 \\
\hline
\end{tabular}

a General reaction conditions: $123 a \quad(1.00 \mathrm{mmol}), 40 \mathrm{a} \quad(3.00 \mathrm{mmol}), \quad\left[\operatorname{RuCl}_{2}(p \text {-cymene })\right]_{2} \quad(5.0 \mathrm{~mol} \%), 137$ (30.0 mol \%), $\mathrm{K}_{2} \mathrm{CO}_{3}(2.00 \mathrm{mmol}), 1,4$-dioxane $(4.0 \mathrm{~mL}), 140{ }^{\circ} \mathrm{C}, 18 \mathrm{~h}$, isolated yields.

\subsubsection{Scope and Limitations for the C-H Alkylation of $\mathrm{N}$-Aryl-1,2,3-triazoles with} Alkyl Bromides

With the best catalytic system in hand, we explored different alkyl bromides $\mathbf{4 0}$ to figure out if the length of the alkyl chain has an influence on the catalytic reaction (Table 7). However, an effect on the reaction was not observed (Table 7, entry 1-4). Next, different triazole substrates 123 were investigated. The unsubstituted compound 123b afforded a comparable yield of product (entry 5), while substituents in the meta-position decreased the yield (Table 7, entry 6-7). The meta-methoxy group (Table 7 , entry 7) demonstrated that electron-rich substrates gave low yields. 
Table 7: Substrate scope for the alkylation of $N$-aryl-1,2,3-triazoles $123 .^{\text {a }}$<smiles>[R1]c1cccc(-n2cc(Br)nn2)c1</smiles>

123

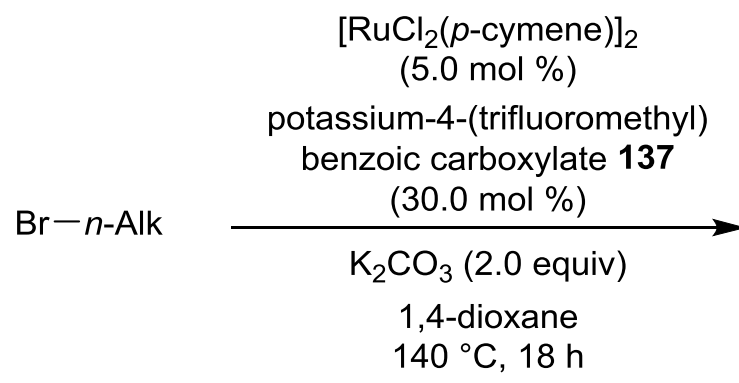

42<smiles>[R1]c1cccc([AlH][AlH2])c1-n1cc(C(C)C)nn1</smiles>

133

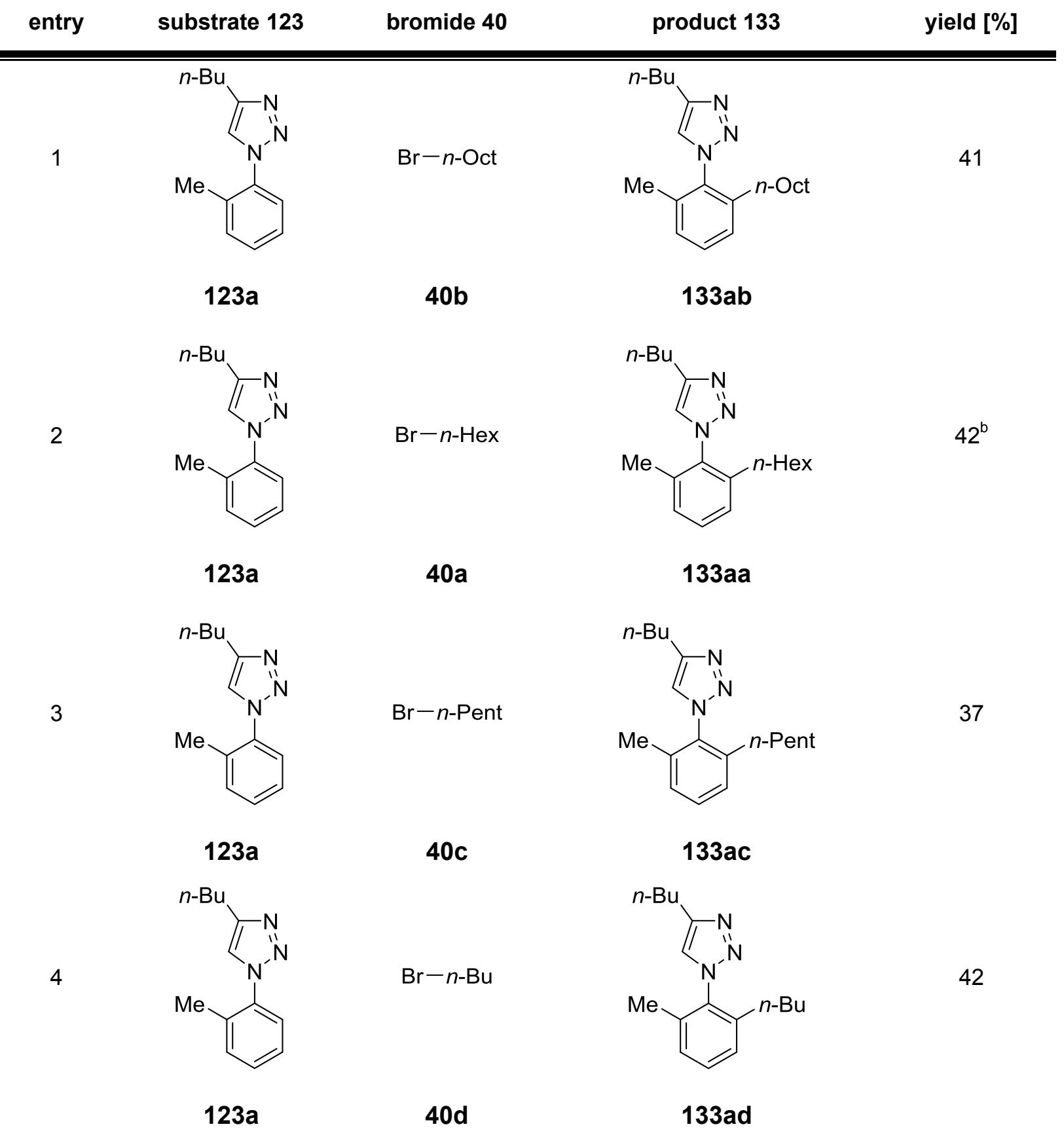


5<smiles>CCCc1cn(-c2ccccc2)nn1</smiles>

$123 b$

6<smiles>CCCCc1cn(-c2cccc(C)c2)nn1</smiles>

$123 c$

7<smiles>CCCCc1cn(-c2cccc(OC)c2)nn1</smiles>

123d
$40 a$

$\mathrm{Br}-n-\mathrm{Hex}$

$\mathrm{Br}-n-\mathrm{Hex}$

$40 a$

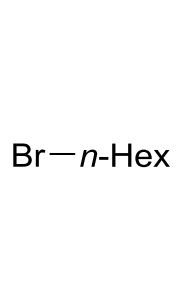

$40 a$<smiles>CCCCCCCCOc1ccccc1-n1cc(CCCC)nn1</smiles><smiles>CCCCCCCCCCOc1ccc(C)cc1-n1cc(CCCC)nn1</smiles>

$133 c a$<smiles>CCCCCCCCCOc1ccc(OC)cc1-n1cc(CCCC)nn1</smiles>

133da

a General reaction conditions: $123(1.00 \mathrm{mmol}), 40$ (3.00 mmol), $\left[\mathrm{RuCl}_{2}(p \text {-cymene })\right]_{2} \quad(5.0 \mathrm{~mol} \%), 137$ (30.0 mol \%), $\mathrm{K}_{2} \mathrm{CO}_{3}(2.00 \mathrm{mmol}), 1,4$-dioxane $(4.0 \mathrm{~mL}), 140{ }^{\circ} \mathrm{C}, 18 \mathrm{~h}$, isolated yields; ${ }^{\mathrm{b}} \mathrm{PhMe}$.

Because only moderate yields were obtained, we went on to explore other alkylating reagents. Some improvement could be possibly made by eliminating the benzylated sideproduct, which is formed using toluene as the solvent. The means of solving this, could lie in interchanging the ratio of the triazole and the primary alkyl bromides. Another problem was found to be related to the esterification of the carboxylic acid additive 137 with the alkyl bromide 40. Thus, by suppressing either of these side-reactions could improve the reaction yield afterall.

Given the challenge in alkylation reactions with alkyl bromides bearing a longer chain, we hypothesized there might be some improvement by replacing the chain by a simple methyl group. These considerations led to the second part of this project on alkylation, the methylation of $\mathrm{N}$-aryl-1,2,3-triazoles. 


\subsection{Ruthenium(II)-Catalyzed C-H Methylation of $\mathrm{N}$-Aryl-1,2,3-triazoles}

\subsubsection{Optimization Studies and Scope for the C-H Methylation of $\mathbf{N}$-Aryl-1,2,3- triazoles}

We were delighted to observe, that the methylation worked with good yield using the reaction conditions developed for the alkylation of the $N$-aryl-1,2,3-triazoles with alkyl bromides (Scheme 3.2).

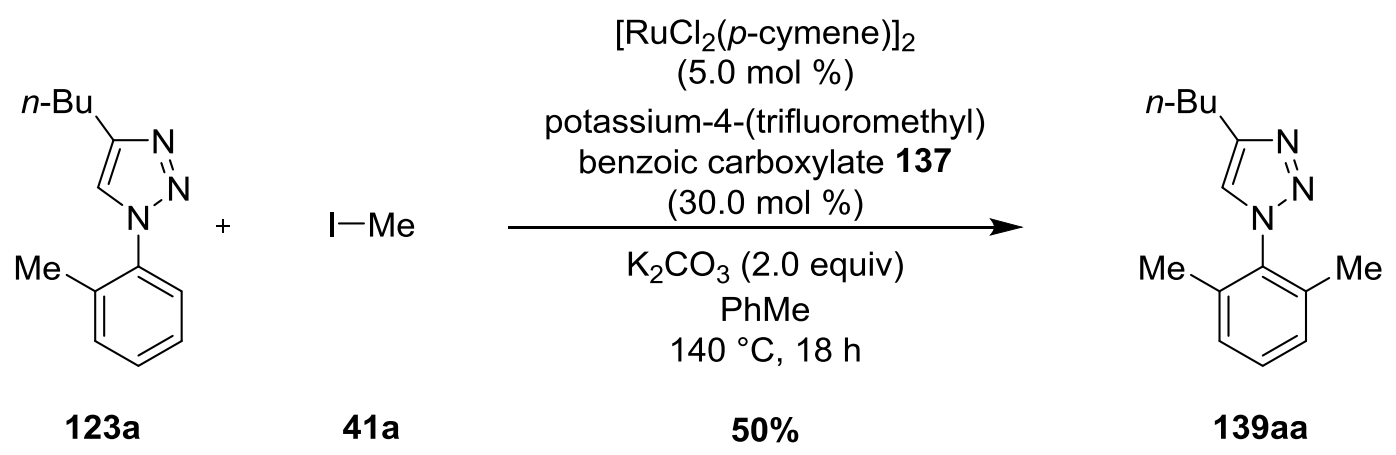

Scheme 3.2: Reaction conditions for the $\mathrm{C}-\mathrm{H}$ alkylation of $\mathrm{N}$-aryl-1,2,3-triazole 123a.

Furthermore, different reaction set ups were performed. First, we considered methyl 4methylbenzenesulfonate as an inexpensive methylation reagent, which was first applied by Gong, ${ }^{99}$ but no reaction occurred (Table 8 , entry 3 ).

Second, we set up the reaction in an microwave oven at $50 \mathrm{~W}$ for $24 \mathrm{~h}$. This resulted in a complex mixture of different products.

In order to exclude the effect of oxygen on the reaction, degassed toluene was used, leading as well to unidentified methylated by-products. The starting material 123a could be still observed by crude NMR. To guarantee an inert reaction atmosphere, the reaction was set up in the glovebox, successfully giving constant amounts of product. The reaction was performed twice with an average yield of $55 \%$ of the desired product (Table 8 , entry 4 ).

When changing the methyl substituent of the triazole to a fluoro substituent, the benzylated by-product was noticed again. Switching to 1,4-dioxane as the solvent the desired product could be obtained in $70 \%$ isolated yield (entry 6 ). Interestingly, the substrate bearing an electron donating methoxy group (entry 7 ) gave no reaction.

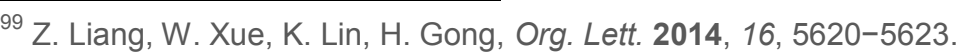


Table 8: Different reaction set ups for the methylation of $N$-aryl-1,2,3-triazoles $123 .^{a}$<smiles>[R1]Cc1cn(-c2ccccc2)nn1</smiles>

123 41a

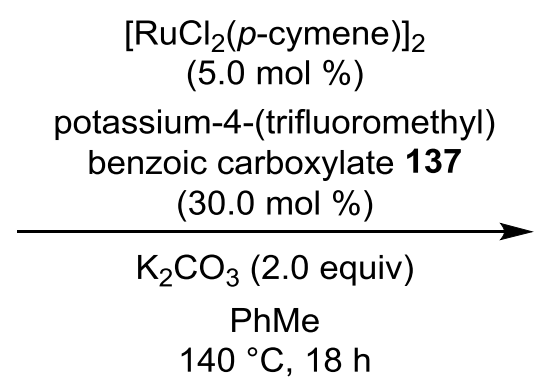

$140{ }^{\circ} \mathrm{C}, 18 \mathrm{~h}$

product 139<smiles>Cc1ccc[R1]c1-n1cc(CC(C)C)nn1</smiles>

$139 a$

entry

substrate 123<smiles>Cc1cccc(C)c1-n1cc(Br)nn1</smiles>

139aa<smiles>CCC(C)c1cn(-c2c(C)cccc2C)nn1</smiles>

139aa<smiles>CCC(=O)c1cn(-c2c(C)cccc2C)nn1</smiles>

3<smiles>Cc1ccccc1-n1cc(C(C)C)nn1</smiles>

$123 a$

4<smiles>Cc1ccccc1-n1cc(CC(C)C)nn1</smiles>

$123 a$ $55^{\mathrm{b}, \mathrm{d}}$

$50^{b}$

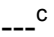

$(30)^{\text {b.d }}$<smiles>Cc1cccc(C)c1-n1cc(C(C)C)nn1</smiles>

139aa 
5<smiles>CC(C)c1cn(-c2ccccc2F)nn1</smiles>

$123 f$

6<smiles>COc1ccccc1-n1cc(CC(C)(C)C)nn1</smiles>

$123 \mathrm{~g}$<smiles>Cc1cccc(F)c1-n1cc(C(C)(C)C)nn1</smiles>

$70^{\mathrm{d}, \mathrm{e}}$

$139 f a$<smiles>COc1cccc(C)c1-n1cc(C(C)(C)C)nn1</smiles>

139ga

a General reaction conditions: $123(1.00 \mathrm{mmol}), \quad 41 \mathrm{a} \quad(3.00 \mathrm{mmol}), \quad\left[\operatorname{RuCl}_{2}(p \text {-cymene })\right]_{2} \quad(5.0 \mathrm{~mol} \%), 137$ $(30.0 \mathrm{~mol} \%), \mathrm{K}_{2} \mathrm{CO}_{3}(2.00 \mathrm{mmol}), \mathrm{PhMe}(4.0 \mathrm{~mL}), 140{ }^{\circ} \mathrm{C}, 18 \mathrm{~h}$, isolated yields, yields in parentheses refer to NMR-conversion; ${ }^{b}$ average of two reactions; ${ }^{c}$ MeOTs $(3.00 \mathrm{mmol}) ;{ }^{d}$ set up in the glovebox; ${ }^{e}$ 1,4-dioxane.

Due to the severe limitations we decided not to pursue this project any further. Still interested in the triazole substrates, because of their widespread application and inspired by the recently published patent, which describes the use of several alkenylated $\mathrm{N}$-aryl-1,2,3triazoles to treat thrombotic diseases, ${ }^{100}$ we focused on developing a methodology for the $\mathrm{C}-\mathrm{H}$ alkenylation of these derivatives. 


\subsection{Ruthenium(II)-Catalyzed Oxidative C-H Alkenylation of $\mathbf{N}$-Aryl-1,2,3- triazoles with Acrylates}

\subsubsection{Optimization Studies for the $\mathrm{C}-\mathrm{H}$ Alkenylation of $\mathrm{N}$-Aryl-1,2,3-triazoles with Acrylates}

Recently, major progress in the development of various Fujiwara-Moritani-type rutheniumcatalyzed oxidative $\mathrm{C}-\mathrm{H}$ alkenylation reactions has been done by the Ackermann research group and others. ${ }^{4 a, 486,87 a, 101}$ Because of this, the optimization studies of the direct alkenylations of triazoles started with the most common approach for direct alkenylations. Using copper acetate monohydrate as the oxidant and silver hexafluoroantimonate as the additive in toluene yielded the alkenylated product $\mathbf{1 3 4}$ in very good yield on the first attempt. Several other additives (Table 9, entry 1-7) were tested in the optimization studies (Table 9). Without any additive (Table 9, entry 1 ) as well as with acetates (Table 9, entry 2) or potassium hexafluorophosphate (Table 9 , entry 3 ) as additives, a reaction did not occur. The different silver salts and counteranions gave comparable yields, except for the weakly coordinating anion $\mathrm{Ag}\left[\mathrm{Al}\left(\mathrm{OC}_{\{}\left\{\mathrm{CF}_{3}\right\}_{3}\right)_{4}\right]^{102}$ (Table 9, entry 6), which gave only moderate yield. Investigations of different reaction conditions revealed that the established $\left[\mathrm{RuCl}_{2}(p\right.$ cymene $)]_{2}$ complex worked better than the carboxylate complex $\left[\mathrm{Ru}\left(\mathrm{O}_{2} \mathrm{CMes}\right)_{2}(p\right.$-cymene $\left.)\right]$ 140. Without catalyst there was no product formation. The crucial temperature for this reaction was $100^{\circ} \mathrm{C}$. Outstandingly, the catalytic system was found to be air stable (Table 9 , entry 11). Replacing the copper acetate monohydrate by silver acetate or manganese acetate decreased or shut down the oxidative alkenylation (Table 9, entry 12-13). The reaction could be performed in various solvents (Table 9, entry 13-16).

\footnotetext{
101 Selected recent examples of oxidative ruthenium-catalyzed C-H alkenylations: a) X. G. Li, M. Sun, K. Liu, P. N. Liu Adv. Snth. Catal. 2014, 357, 395-399; b) J. Li, M. John, L. Ackermann, Chem. Eur. J. 2014, 20, 54035408; c) M. C. Reddy, M. Jeganmohan, Eur. J. Org. Chem. 2013, 2013, 1150-1157; d) W. Ma, L. Ackermann, Chem. Eur. J. 2013, 19, 13925-13928; e) S. R. Chidipudi, M. D. Wieczysty, I. Khan, H. W. Lam, Org. Lett. 2013, 15, 570-573; f) M. C. Reddy, M. Jeganmohan, Eur. J. Org. Chem. 2013, 1150-1157; g) K. S. Singh, P. H. Dixneuf, Organometallics, 2012, 31, 7320-7323; h) J. Li, C. Kornhaaß, L. Ackermann, Chem. Commun. 2012, 48, 1134-11345; i) B. Li, K. Devaraj, C. Darcel, P. H. Dixneuf, Green Chem. 2012, 14, 2706-2709; j) B. Li, J. Ma, N. Wang, H. Feng, S. Xu, B. Wang, Org. Lett. 2012, 14, 736-739; k) R. K. Chinnagolla, M. Jeganmohan, Chem. Commun. 2012, 48, 3030-2032.

102 U. Preiss, I. Krossing, Z. Anorg. Allg. Chem. 2007, 633, 1639-1644.
} 
Table 9: Optimization studies for the oxidative $\mathrm{C}-\mathrm{H}$ alkenylation of $\mathrm{N}$-aryl-1,2,3-triazole $123 \mathbf{a}^{\mathrm{a}}$<smiles>Cc1ccccc1-n1cc(C(C)(C)C)nn1</smiles>

123a<smiles>C=CC(=O)OCC</smiles>

17c<smiles>CCOC(=O)/C=C/c1cccc(C)c1-n1cc(CC(C)C)nn1</smiles>

134ac

\begin{tabular}{|c|c|c|c|c|}
\hline entry & solvent & additive & oxidant & yield (\%) \\
\hline 1 & PhMe & - & $\mathrm{Cu}(\mathrm{OAc})_{2} \cdot \mathrm{H}_{2} \mathrm{O}$ & --- \\
\hline 2 & PhMe & $\mathrm{NaOAc}$ & $\mathrm{Cu}(\mathrm{OAc})_{2} \cdot \mathrm{H}_{2} \mathrm{O}$ & --- \\
\hline 3 & PhMe & $\mathrm{KPF}_{6}$ & $\mathrm{Cu}(\mathrm{OAc})_{2} \cdot \mathrm{H}_{2} \mathrm{O}$ & --- \\
\hline 4 & PhMe & $\mathrm{AgPF}_{6}$ & $\mathrm{Cu}(\mathrm{OAc})_{2} \cdot \mathrm{H}_{2} \mathrm{O}$ & 75 \\
\hline 5 & PhMe & $\mathrm{AgBF}_{4}$ & $\mathrm{Cu}(\mathrm{OAc})_{2} \cdot \mathrm{H}_{2} \mathrm{O}$ & 83 \\
\hline 6 & PhMe & $\mathrm{Ag}\left[\mathrm{Al}\left(\mathrm{OC}\left\{\mathrm{CF}_{3}\right\}_{3}\right)_{4}\right]$ & $\mathrm{Cu}(\mathrm{OAc})_{2} \cdot \mathrm{H}_{2} \mathrm{O}$ & 63 \\
\hline 7 & PhMe & $\mathrm{AgSbF}_{6}$ & $\mathrm{Cu}(\mathrm{OAc})_{2} \cdot \mathrm{H}_{2} \mathrm{O}$ & 82 \\
\hline 8 & PhMe & $\mathrm{AgSbF}_{6}$ & - & --- \\
\hline 9 & PhMe & $\mathrm{AgSbF}_{6}$ & $\mathrm{Cu}(\mathrm{OAc})_{2} \cdot \mathrm{H}_{2} \mathrm{O}$ & $--{ }^{b}$ \\
\hline 10 & PhMe & $\mathrm{AgSbF}_{6}$ & $\mathrm{Cu}(\mathrm{OAc})_{2} \cdot \mathrm{H}_{2} \mathrm{O}$ & $46^{c}$ \\
\hline 11 & PhMe & $\mathrm{AgSbF}_{6}$ & $\mathrm{Cu}(\mathrm{OAc})_{2} \cdot \mathrm{H}_{2} \mathrm{O}$ & $56^{d}$ \\
\hline 12 & PhMe & $\mathrm{AgSbF}_{6}$ & $\mathrm{Cu}(\mathrm{OAc})_{2} \cdot \mathrm{H}_{2} \mathrm{O}$ & $69^{e}$ \\
\hline 13 & PhMe & $\mathrm{AgSbF}_{6}$ & $\mathrm{AgOAc}$ & 55 \\
\hline 14 & PhMe & $\mathrm{AgSbF}_{6}$ & $\mathrm{Mn}(\mathrm{OAc})_{2}$ & 5 \\
\hline 15 & PhMe & $\mathrm{AgSbF}_{6}$ & $\mathrm{Cu}(\mathrm{OAc})_{2} \cdot \mathrm{H}_{2} \mathrm{O}$ & $85^{f}$ \\
\hline 16 & $\mathrm{H}_{2} \mathrm{O}$ & $\mathrm{AgSbF}_{6}$ & $\mathrm{Cu}(\mathrm{OAc})_{2} \cdot \mathrm{H}_{2} \mathrm{O}$ & $58^{f}$ \\
\hline 17 & $t-\mathrm{AmOH}$ & $\mathrm{AgSbF}_{6}$ & $\mathrm{Cu}(\mathrm{OAc})_{2} \cdot \mathrm{H}_{2} \mathrm{O}$ & $74^{f}$ \\
\hline 18 & $m$-xylene & $\mathrm{AgSbF}_{6}$ & $\mathrm{Cu}(\mathrm{OAc})_{2} \cdot \mathrm{H}_{2} \mathrm{O}$ & $89^{f}$ \\
\hline
\end{tabular}

a General reaction conditions: 123a $(1.00 \mathrm{mmol}), 17 \mathrm{c}(1.50 \mathrm{mmol}),\left[\mathrm{RuCl}_{2}(p \text {-cymene })\right]_{2}(5.0 \mathrm{~mol} \%)$, additive $(30.0 \mathrm{~mol} \%)$, oxidant $(1.20 \mathrm{mmol})$, solvent $(4.0 \mathrm{~mL}), 100{ }^{\circ} \mathrm{C}, 18 \mathrm{~h}$, yields of isolated products; ${ }^{\mathrm{b}}$ no catalyst; ${ }^{\mathrm{c}} \mathrm{T}=80{ }^{\circ} \mathrm{C} ;{ }^{\mathrm{d}}\left[\mathrm{Ru}\left(\mathrm{O}_{2} \mathrm{CMes}\right)_{2}(\mathrm{p}\right.$-cymene $\left.)\right] 140$ (5.0 mol \%); ${ }^{\mathrm{e}}$ under air $(1 \mathrm{~atm}) ; \mathrm{T}=140{ }^{\circ} \mathrm{C}$. 


\subsubsection{Scope and Limitations for the Direct Alkenylation of $\mathrm{N}$-Aryl-1,2,3-triazoles with Acrylates}

With the optimized conditions in hand, we explored the substrate scope and therefore tested different alkenes 17 (Table 10). While ethyl acrylate 17c gave the highest amount of product $(82 \%)$, the yield dropped as the steric bulk of the ester substituent increased (Table 10, entry 2-4). In contrast, when using acrylonitrile, acrylic acid or acroleine, there was only poor or no conversion (Tabele 10, entry 5-7).

Table 10: Substrate scope for oxidative alkenylations of 4-butyl-1-(o-tolyl)-1H-1,2,3-triazole 123a. ${ }^{a}$<smiles>[R]C=C</smiles>

123a

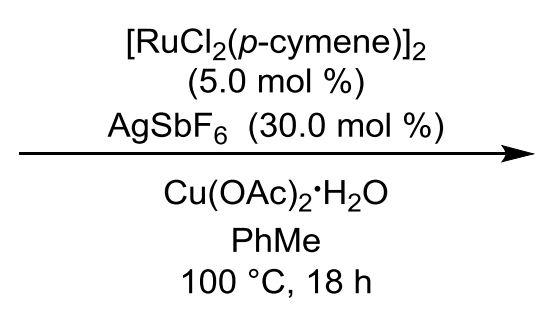

$100^{\circ} \mathrm{C}, 18 \mathrm{~h}$<smiles>[R]C=Cc1cccc(C)c1-n1cc(C(C)(C)C)nn1</smiles>

134a

entry

alkene 123

product 134

yield [\%]

$1 \quad \mathrm{CO}_{2} \mathrm{Et}$<smiles>C=COOCC</smiles>

n-Bu

$\angle{ }_{N}^{N}$<smiles>CCOC(=O)/C=C/c1cccc(C)c1[N-]</smiles>

82

2<smiles>C=CC(=O)OCc1ccccc1</smiles>

$134 a c$

$17 c$<smiles>CCC(C)c1cn(-c2c(C)cccc2/C=C/C(=O)OCc2ccccc2)nn1</smiles>

68

17d

134ad

3<smiles>CCCCc1cn(-c2c(C)cccc2/C=C/C(=O)OCC(C)C)nn1</smiles>

67 
4<smiles>C=CCOC(C)(C)C</smiles>

$17 f$

5<smiles>C=CC#N</smiles>

$17 g$

6<smiles>C=CC(=O)O</smiles>

$17 \mathrm{~h}$

7<smiles>C=CC=O</smiles><smiles>CCCCc1cn(-c2c(C)cccc2/C=C/C(=O)OC(C)(C)C)nn1</smiles>

65 15<smiles>CCCCc1cn(-c2c(C)cccc2/C=C/C#N)nn1</smiles>

134ag<smiles>CCCCc1cn(-c2c(C)cccc2/C=C/C(=O)O)nn1</smiles>
134ah<smiles>CCCCc1cn(-c2c(C)cccc2/C=C/C=O)nn1</smiles>

a General reaction conditions: 123a $(1.00 \mathrm{mmol}), 17(1.50 \mathrm{mmol}),\left[\mathrm{RuCl}_{2}(p \text {-cymene })\right]_{2}(5.0 \mathrm{~mol} \%), \mathrm{AgSbF}_{6}$ (30.0 mol \%), $\mathrm{Cu}(\mathrm{OAc})_{2} \cdot \mathrm{H}_{2} \mathrm{O}(1.20 \mathrm{mmol}), \mathrm{PhMe}(4.0 \mathrm{~mL}), 100{ }^{\circ} \mathrm{C}, 18 \mathrm{~h}$, yields of isolated products.

Not surprisingly, we obtained the alkylated product $N$-aryl-1,2,3-1H-triazole 141 , by using methylvinylketone in $65 \%$ yield (Scheme 3.3 ). This is in accordance to the previous work regarding alkylations with $\alpha, \beta$-unsaturated ketones. ${ }^{103}$ 
<smiles>C=CC(C)=O</smiles>

$123 a$

17j

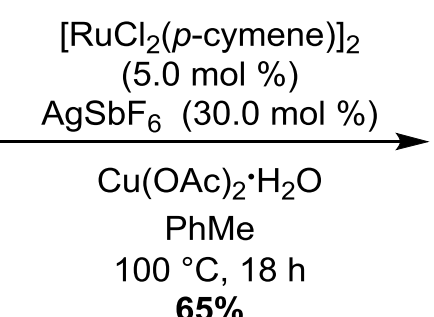

$65 \%$<smiles>CCCCc1cn(-c2c(C)cccc2CCC(C)=O)nn1</smiles>

141

Scheme 3.3: C-H alkylation with methylvinylketone 17j.

Next, we studied the influence of the different substituents on the $N$-aryl-1,2,3-triazoles 123 on the reaction efficacy. We were pleased to observe that the catalyst proved to be broadly applicable and, hence, furnished the desired products 134 in moderate to good yields (Table 11).

Table 11: Substrate scope for oxidative alkenylations of ortho-substituted $N$-aryl-1,2,3-triazoles $123 .{ }^{a}$<smiles>[R]C=C[CH2-]</smiles>

123

17

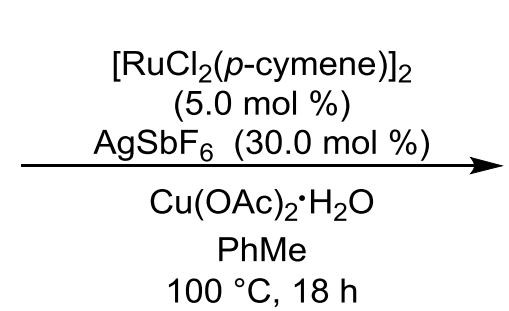<smiles>[R]C=Cc1ccc[R1]([H])c1-n1cc(CCCC)nn1</smiles>

134

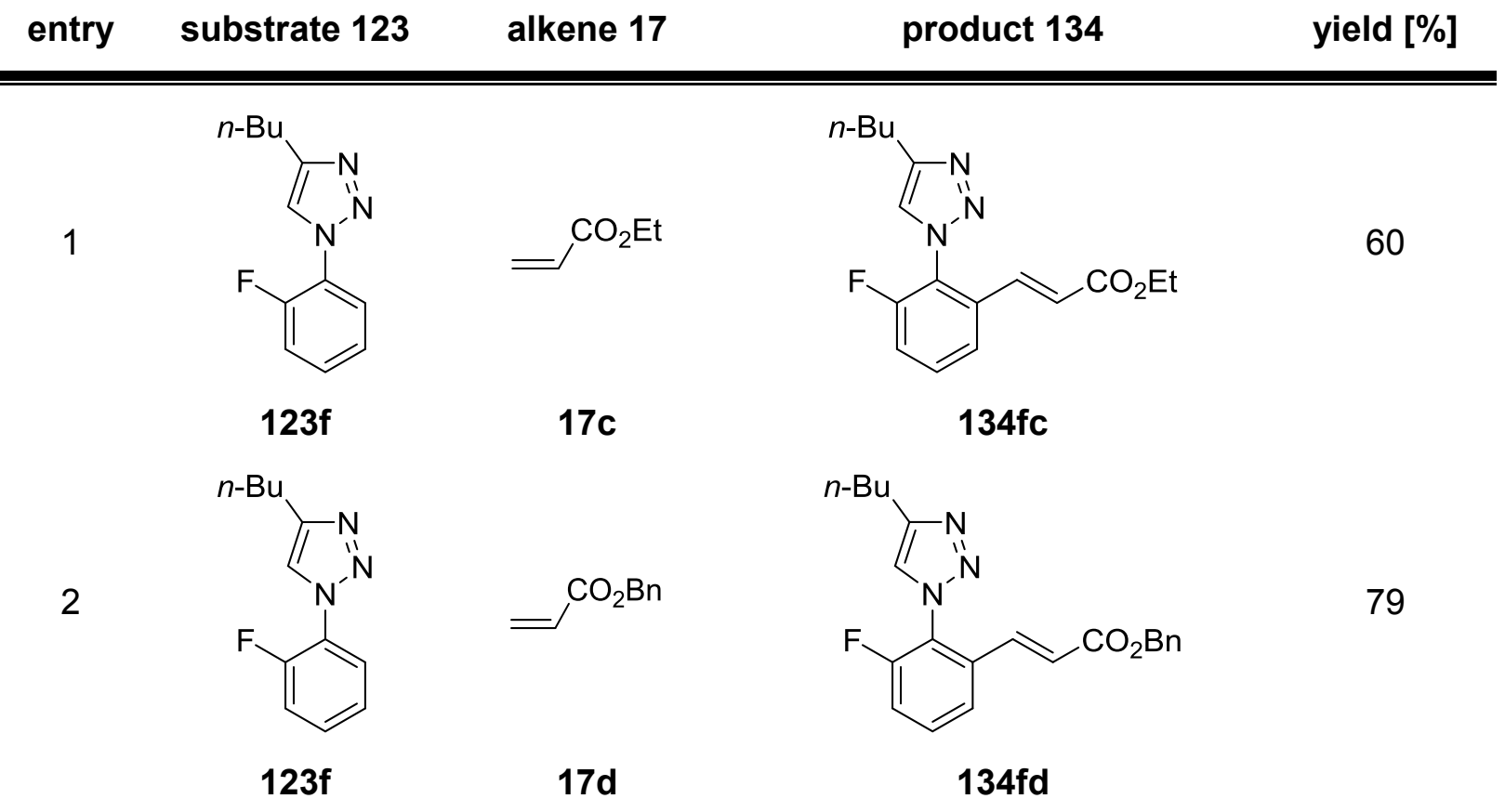


3<smiles>CCCc1cn[nH]n1</smiles><smiles>Nc1ccccc1F</smiles>

$123 f$

$n-\mathrm{Bu}$<smiles>Cc1cn(-c2ccccc2F)nn1</smiles>

$123 f$<smiles>CCCCc1cn(-c2cccc3ccccc23)nn1</smiles>

$123 \mathrm{~h}$<smiles>CCCCc1cn(-c2cccc3ccccc23)nn1</smiles>

$123 \mathrm{~h}$<smiles>CCCCc1cn(-c2cccc3ccccc23)nn1</smiles>

$123 \mathrm{~h}$<smiles>CCC(C)c1cn(-c2cccc3ccccc23)nn1</smiles>

$123 \mathrm{~h}$<smiles>C=CCOCCCCC</smiles><smiles>CCCCCCCCCCCCC</smiles>

$17 f$<smiles>CCOCCOCC</smiles>

$17 c$<smiles>C=CC(=O)OCc1ccccc1</smiles>

$17 d$<smiles>C=CCOCCCC</smiles>

$17 e$<smiles>C=CC(=O)OC(C)(C)C</smiles>

$17 f$<smiles>CCCCc1cn(-c2c(F)cccc2/C=C/C(=O)OCC(C)C)nn1</smiles>

$134 f e$<smiles>CCCCc1cn(-c2c(F)cccc2/C=C/C(=O)OC(C)(C)C)nn1</smiles>

$134 \mathrm{ff}$<smiles>CCCCc1cn(-c2c(C=CC(=O)OCC)ccc3ccccc23)nn1</smiles>

134hc<smiles>CCCCc1cn(-c2c(/C=C/C(=O)OCc3ccccc3)ccc3ccccc23)nn1</smiles>

134hd<smiles>CCCCc1cn(-c2c(/C=C/C(=O)OCCC)ccc3ccccc23)nn1</smiles>

134he<smiles>CCCCc1cn(-c2c(/C=C/C(=O)OC(C)(C)C)ccc3ccccc23)nn1</smiles>

$134 \mathrm{hf}$ 
9<smiles>COc1ccccc1-n1cc(C(C)(C)C)nn1</smiles>

$123 \mathrm{~g}$<smiles>C=CCOCC</smiles>

$17 \mathrm{c}$<smiles>CCOC(=O)/C=C/c1cccc(OC)c1-n1cc(CC(C)C)nn1</smiles>

134gc

a General reaction conditions: $123(1.00 \mathrm{mmol}), 17(1.50 \mathrm{mmol}),\left[\mathrm{RuCl}_{2}(p \text {-cymene })\right]_{2}(5.0 \mathrm{~mol} \%), \mathrm{AgSbF}_{6}$ (30.0 mol \%), $\mathrm{Cu}(\mathrm{OAc})_{2} \cdot \mathrm{H}_{2} \mathrm{O}(1.20 \mathrm{mmol}), \mathrm{PhMe}(4.0 \mathrm{~mL}), 100{ }^{\circ} \mathrm{C}, 18 \mathrm{~h}$, yields of isolated products.

By applying the optimal reaction conditions on 4-butyl-1-phenyl-1H-1,2,3-triazole $123 \mathbf{b}$ and para-substituted $\mathrm{N}$-aryl-1,2,3-triazoles 123 the yield decreased significantly (Table 12). Moreover, the problem of the double $\mathrm{C}-\mathrm{H}$ alkenylation emerged.

Table 12: Substrate scope for alkenylations of the unsubstituted $123 \mathrm{~b}$ and para-substituted $\mathrm{N}$-aryl-1,2,3-triazoles 123. ${ }^{\mathrm{a}}$

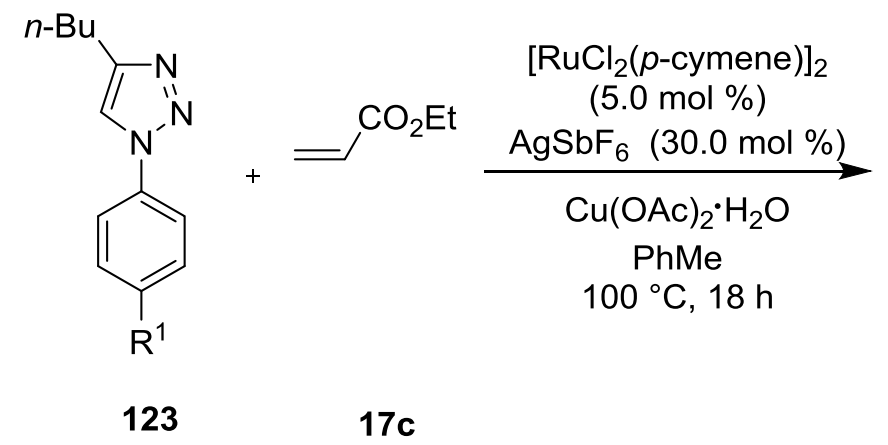<smiles>[R1]c1ccc(-n2cc(CCCC)nn2)c(/C=C/COCC)c1</smiles>

134c<smiles>[R]CCc1cn(-c2c(/C=C/C(=O)OCC)cc([R1])cc2/C=C/C(=O)OCC)nn1</smiles>

142c 


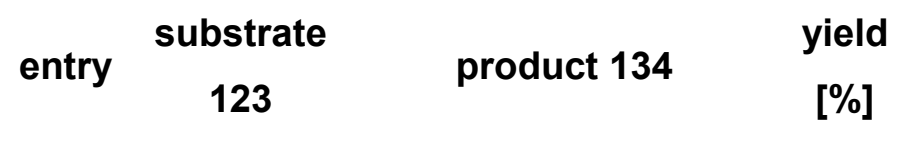

$n-\mathrm{Bu}$<smiles>Cc1c[nH]nn1</smiles>

$1 \quad \mathrm{R}^{1}=\mathrm{H}$<smiles>CCOC(=O)C=Cc1ccccc1N</smiles>

$123 b$

$134 \mathrm{bc}$

$2 \quad \mathrm{R}^{1}=\mathrm{Me}$<smiles>CCCCc1cn[nH]n1</smiles><smiles>CCOC(=O)/C=C/c1cc(C)ccc1N</smiles>

$123 i$

3

$\mathrm{R}^{1}=\mathrm{C}$

123j<smiles>CCOC(=CC=Cc1cc(Cl)ccc1-n1cc(CC)nn1)OCC</smiles>

134jc<smiles>CCCc1cn[nH]n1</smiles>

$4 \quad \mathrm{R}^{1}=\mathrm{OMe}$<smiles>CCOC(=O)/C=C/c1cc(OC)ccc1N</smiles>

123k product 142

yield

[\%]<smiles>CCCCc1cn(-c2c(/C=C/C(=O)OCC)cccc2/C=C/C(=O)OCC)nn1</smiles>

142bc
46<smiles>CCCCc1cn[nH]n1</smiles><smiles>CCOC(=O)C=Cc1cc(C)cc(C=CC(=O)OCC)c1N(C)C</smiles>

142ic

44<smiles>CCCc1cn(-c2c(/C=C/C(=O)OCC)cc(Cl)cc2/C=C/C(=O)OCC)nn1</smiles>

$142 \mathrm{jc}$

55<smiles>CCCc1cn[nH]n1</smiles><smiles>CCOC(=O)/C=C/c1cc(OC)cc(/C=C/C(=O)OCC)c1N(C)C</smiles>

142kc

a General reaction conditions: $123(1.00 \mathrm{mmol}), 17 \mathrm{c}(1.50 \mathrm{mmol}),\left[\mathrm{RuCl}_{2}(p \text {-cymene })\right]_{2}(5.0 \mathrm{~mol} \%), \mathrm{AgSbF}_{6}$ $(30.0 \mathrm{~mol} \%), \mathrm{Cu}(\mathrm{OAc})_{2} \cdot \mathrm{H}_{2} \mathrm{O}(1.20 \mathrm{mmol}), \mathrm{PhMe}(4.0 \mathrm{~mL}), 100{ }^{\circ} \mathrm{C}, 18 \mathrm{~h}$, yields of isolated products.

The usual way to suppress the double $\mathrm{C}-\mathrm{H}$ alkenylation is interchanging the ratio between the acrylate and the $\mathrm{N}$-aryl-1,2,3-triazoles 123. We tried this for several substrates (Table 13), but the results are largely unsatisfactory. The amount of product formed for the different substrates was low, but the double alkenylated products could not be observed. 
Table 13: Substrate scope for oxidative alkenylations with excess of the unsubstituted 123b and parasubstituted $N$-aryl-1,2,3-triazoles $123 .^{a}$

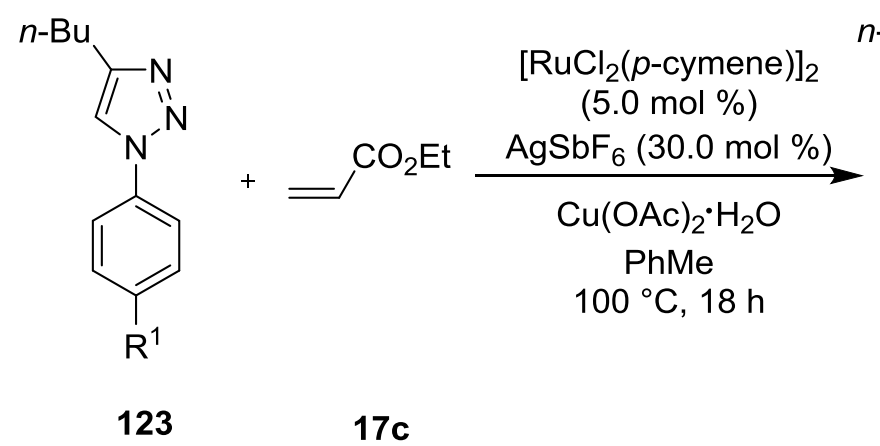<smiles>[R]COC(=CC=Cc1cc(Br)ccc1-n1cc(C(C)C)nn1)CC</smiles>

134

entry

substrate 123

product 134

yield [\%]

$1 \quad \mathrm{R}^{1}=\mathrm{H}$

n-Bu

$\sum{ }_{1}^{N}$<smiles>CCOC(=O)/C=C/c1ccccc1N</smiles>

$123 b$

$134 \mathrm{bc}$

2

$\mathrm{R}^{1}=\mathrm{Me}$<smiles>CCCCc1cn(-c2ccc(C)cc2/C=C/C(=O)OCC)nn1</smiles>

123i

134ic

3

$\mathrm{R}^{1}=\mathrm{Cl}$<smiles>CCCCc1cn(-c2ccc(Cl)cc2/C=C/C(=O)OCC)nn1</smiles>

123j

134jc

4

$\mathrm{R}^{1}=\mathrm{CO}_{2} \mathrm{Me}$<smiles>CCCCc1cn(-c2ccc(C(C)CC)cc2/C=C/C(=O)OCC)nn1</smiles> 
a General reaction conditions: $123(1.00 \mathrm{mmol}), 17 \mathrm{c}(0.50 \mathrm{mmol}),\left[\mathrm{RuCl}_{2}(p \text {-cymene })\right]_{2}(5.0 \mathrm{~mol} \%), \mathrm{AgSbF}_{6}$ $(30.0 \mathrm{~mol} \%), \mathrm{Cu}(\mathrm{OAc})_{2} \cdot \mathrm{H}_{2} \mathrm{O}(0.60 \mathrm{mmol}), \mathrm{PhMe}(2.0 \mathrm{~mL}), 100{ }^{\circ} \mathrm{C}, 18 \mathrm{~h}$, yields of isolated products.

As a consequence, we undertook a new screening and the amount of acrylate was doubled. Hence, we were pleased to observe that the reaction worked even better under air. The use of other oxidants like silver acetate, silver carbonate and copper acetate resulted in a lower yield (Table 14).

Table 14: Optimization studies for the direct alkenylation of 4-butyl-1-phenyl-1 $\mathrm{H}-1,2,3$-triazole 123b: oxidant and atmosphere. $^{\text {a }}$ $n-\mathrm{Bu}$<smiles>C=CC(=O)OCC</smiles>

$123 b$

$17 \mathrm{c}$

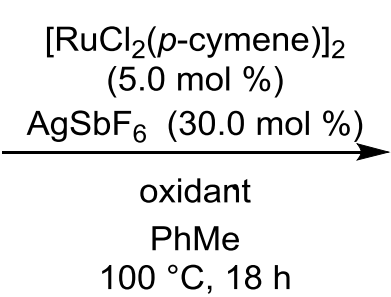<smiles>CCOC(=O)/C=C/c1ccccc1-n1cc(CC(C)C)nn1</smiles>

$134 \mathrm{bc}$

\begin{tabular}{cccc} 
entry & oxidant & atmosphere & yield (\%) \\
\hline \hline 1 & $\mathrm{Cu}(\mathrm{OAc})_{2} \cdot \mathrm{H}_{2} \mathrm{O}$ & $\mathrm{N}_{2}$ & 39 \\
2 & $\mathrm{Cu}(\mathrm{OAc})_{2} \cdot \mathrm{H}_{2} \mathrm{O}$ & air & 71 \\
3 & $\mathrm{AgOAc}$ & $\mathrm{N}_{2}$ & 31 \\
4 & $\mathrm{AgOAc}$ & air & 56 \\
5 & $\mathrm{Cu}(\mathrm{OAc})_{2}$ & $\mathrm{~N}_{2}$ & 22 \\
6 & $\mathrm{Ag}_{2} \mathrm{CO}_{3}$ & $\mathrm{~N}_{2}$ & 31 \\
\hline
\end{tabular}

${ }^{a}$ General reaction conditions: 123b $(0.50 \mathrm{mmol}), 17 \mathrm{c}(1.50 \mathrm{mmol}),\left[\mathrm{RuCl}_{2}(p-c y m e n e)\right]_{2}(5.0 \mathrm{~mol} \%), \mathrm{AgSbF}_{6}$ (30.0 mol \%), $\mathrm{Cu}(\mathrm{OAc})_{2} \cdot \mathrm{H}_{2} \mathrm{O}(0.60 \mathrm{mmol}), \mathrm{PhMe}(2.0 \mathrm{~mL}), 100{ }^{\circ} \mathrm{C}, 18 \mathrm{~h}$, yields of isolated products.

Having identified the simplified reaction conditions, which could be applied on every $\mathrm{N}$-aryl1,2,3-triazole 123 substrate, the results are summerized in Table 15. For substrates 123j (para-chloro) and $\mathbf{1 2 3 l}$ (para-ester) the reaction time was extended to $24 \mathrm{~h}$. 
Table 15: Substrate scope for the oxidative $\mathrm{C}-\mathrm{H}$ alkenylations of the unsubstituted $123 \mathrm{~b}$ and para-substituted $\mathrm{N}$-aryl-1,2,3-triazoles $123 .^{a}$<smiles>[R]c1ccc(-n2cc(CCCC)nn2)cc1</smiles>

$$
\begin{gathered}
{\left[\mathrm{RuCl}_{2}(p \text {-cymene })\right]_{2}} \\
(5.0 \mathrm{~mol} \%) \\
\mathrm{AgSbF}_{6}(30.0 \mathrm{~mol} \%) \\
\hline \mathrm{Cu}(\mathrm{OAc})_{2} \cdot \mathrm{H}_{2} \mathrm{O} \\
\mathrm{PhMe} \\
100^{\circ} \mathrm{C}, 18 \mathrm{~h} \\
\text { air }(1 \mathrm{~atm})
\end{gathered}
$$

17c<smiles>[R]O/C=C/c1cc([R])ccc1-n1cc(CCCC)nn1</smiles>

134c

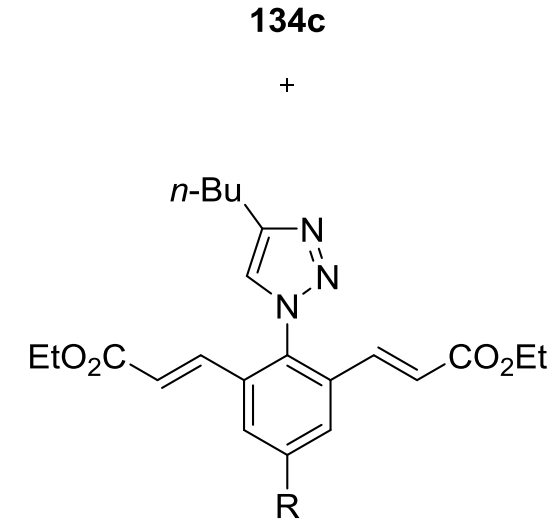

142c

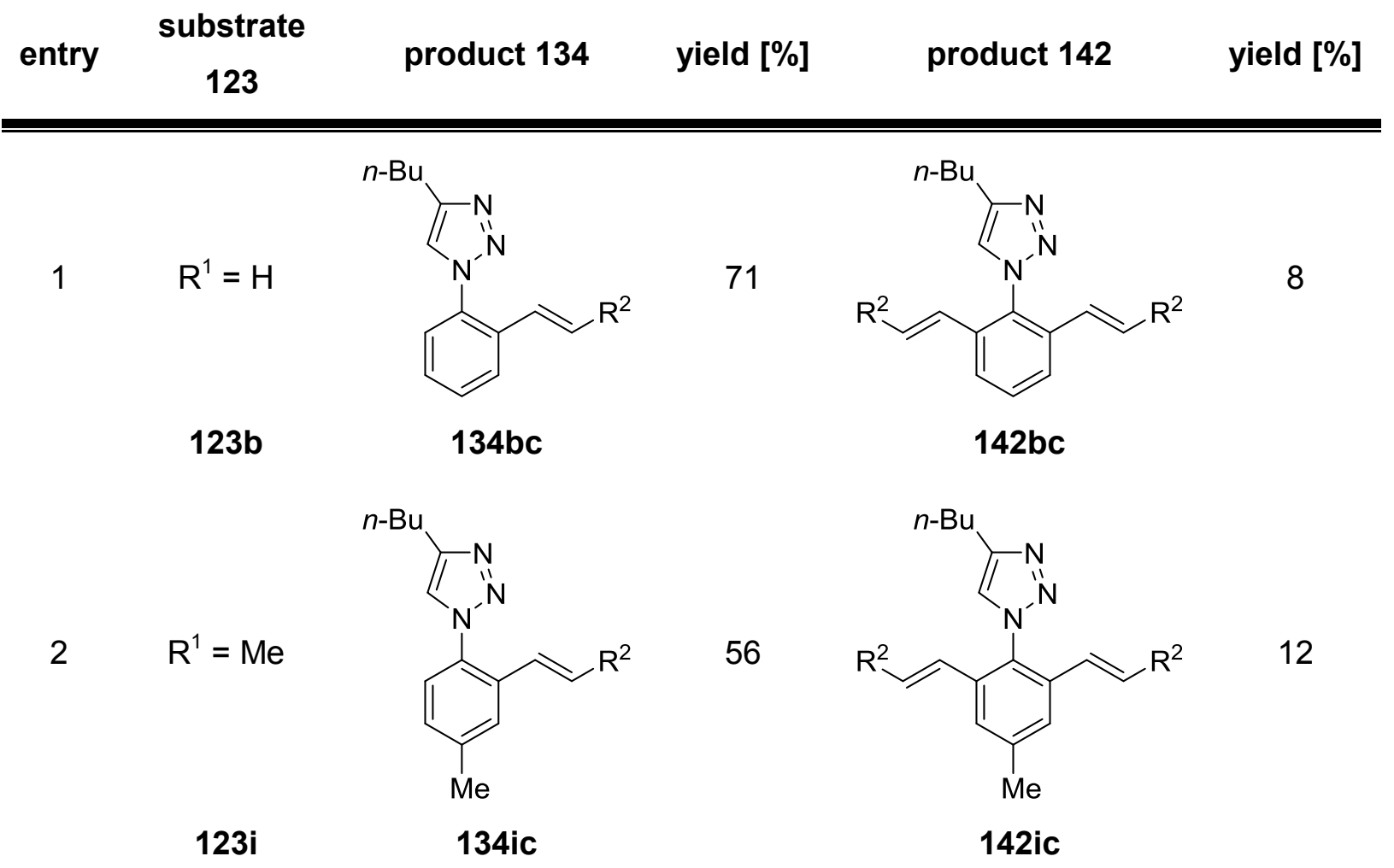


$3 \quad \mathrm{R}^{1}=\mathrm{OMe}$

4

$$
\mathrm{R}^{1}=\mathrm{Cl}
$$

123j

5

$$
\mathrm{R}^{1}=\mathrm{CO}_{2} \mathrm{Me}
$$

123I
$n-\mathrm{Bu}$<smiles>Cc1c[nH]nn1</smiles><smiles>[R]C=Cc1cc(OC)ccc1N</smiles>

134kc<smiles>CCCc1cn[nH]n1</smiles><smiles>[R]C=Cc1cc(Cl)ccc1N</smiles>

134jc

$n-\mathrm{Bu}$<smiles>Cc1c[nH]nn1</smiles><smiles>[R]C=Cc1cc(C(=O)O)ccc1N</smiles>

134IC<smiles>[R]C=Cc1cc(OC)cc(/C=C/[R])c1-n1cc(C(C)C)nn1</smiles>

142kc<smiles>[R]C=Cc1cc(Cl)cc(/C=C/[R])c1-n1cc(C(C)C)nn1</smiles>

$142 \mathrm{jc}$<smiles>[R]C=Cc1cc(C(=O)OC)cc(/C=C/[R])c1-n1cc(CCCC)nn1</smiles>

142 Ic

a General reaction conditions: $123(1.00 \mathrm{mmol}), 17 \mathrm{c}(3.00 \mathrm{mmol}),\left[\mathrm{RuCl}_{2}(p \text {-cymene })\right]_{2}(5.0 \mathrm{~mol} \%), \mathrm{AgSbF}_{6}$ (30.0 mol \%), $\mathrm{Cu}(\mathrm{OAc})_{2} \cdot \mathrm{H}_{2} \mathrm{O}(1.20 \mathrm{mmol}), \mathrm{PhMe}(4.0 \mathrm{~mL}), 100{ }^{\circ} \mathrm{C}, 18 \mathrm{~h}$, air $(1 \mathrm{~atm}), \mathrm{R}^{2}=\mathrm{CO}_{2} \mathrm{Et}$, yields of isolated products.

The aerobic conditions could also successfully be applied to the standard substrate in $69 \%$ yield (Table 16 , entry 2 ).

Table 16: Application of the new reaction conditions for selected $N$-aryl-1,2,3-triazoles 123 .<smiles>CCCCc1cn(-c2[R1]cccc2)nn1</smiles>

123<smiles>C=COOCC</smiles>

$$
\text { - }
$$$$
\underset{\mathrm{Cu}(\mathrm{OAc})_{2} \cdot \mathrm{H}_{2} \mathrm{O}}{\stackrel{\mathrm{AgSbF}}{6}(30.0 \mathrm{~mol} \%)}
$$$$
\mathrm{PhMe}
$$$$
100{ }^{\circ} \mathrm{C}, 18 \mathrm{~h}
$$<smiles>[R1]c1cccc(C=COOCC)c1-n1cc(CC(C)C)nn1</smiles> 


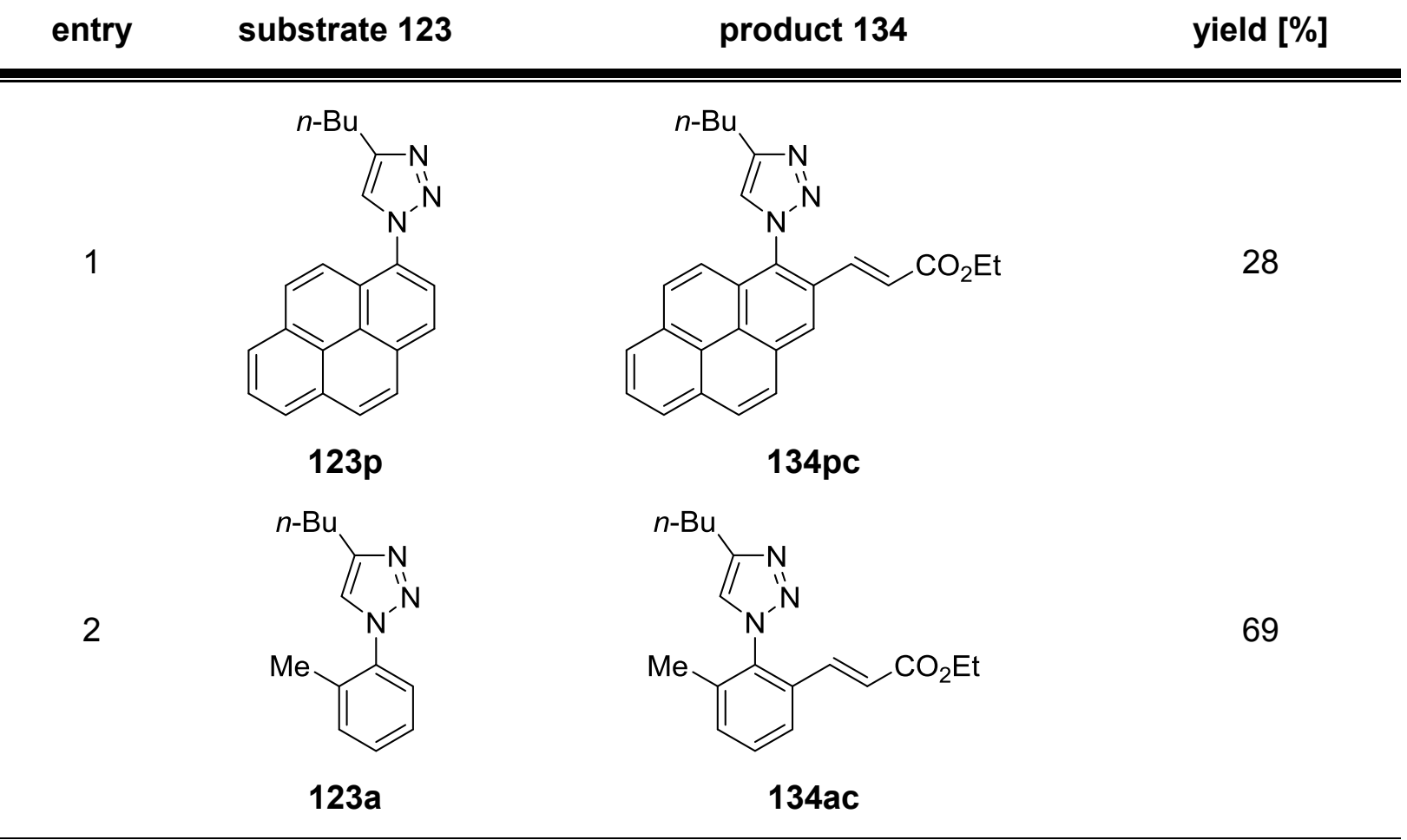

${ }^{a}$ General reaction conditions: $123(0.50 \mathrm{mmol}), 17 \mathrm{c}(1.50 \mathrm{mmol}),\left[\mathrm{RuCl}_{2}(p \text {-cymene })\right]_{2}(5.0 \mathrm{~mol} \%), \mathrm{AgSbF}_{6}$ $(30.0 \mathrm{~mol} \%), \mathrm{Cu}(\mathrm{OAc})_{2} \cdot \mathrm{H}_{2} \mathrm{O}(0.60 \mathrm{mmol}), \mathrm{PhMe}(2.0 \mathrm{~mL}), 100{ }^{\circ} \mathrm{C}, 18 \mathrm{~h}$, air $(1 \mathrm{~atm})$, yields of isolated products.

The newly developed reaction conditions also turned out to be suitable for the oxidative alkenylation of the meta-substituted substrates (Table 17). The meta-methyl $\mathbf{1 2 3 f}$ and the meta-triflouromethyl-substituted substrates 123p gave the desired product in satisfactory yield. Interestingly, we obtained an additional product, when using a fluoro or a methoxy group in meta-position, which emerged from the secondary directing effect. However, as the entry 3 illustrates, the methoxy group is not the better secondary directing group, furnishing $29 \%$ of product $134 \mathrm{dc}^{\prime}$, because of the steric effect of the methoxy group, which is bulkier than the fluoro group. With a ketone in the meta-position the yield dropped to $17 \%$. This was due to the oxidative dimerization of the starting material. The dimerized product could be isolated in $11 \%$ (143).<smiles>CCCCc1cn(-c2cc(C(C)C)ccc2-c2ccc(C(=O)OC)cc2-n2cc(CC(C)C)nn2)nn1</smiles>

Scheme 3.4: Dimerized product 143. 
Table 17: Substrate scope for alekenylations of meta-substituted $N$-aryl-1,2,3-triazoles $123{ }^{a}$

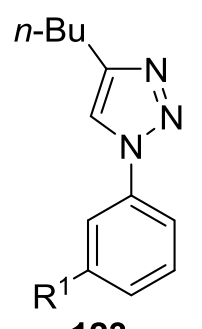

123
$17 \mathrm{c}$

$\left[\mathrm{RuCl}_{2}(p \text {-cymene })\right]_{2}$

$(5.0 \mathrm{~mol} \%)$

$\underset{\mathrm{Cu}(\mathrm{OAc})_{2} \cdot \mathrm{H}_{2} \mathrm{O}}{\stackrel{\mathrm{AgSbF}_{6}(30.0 \mathrm{~mol} \%)}{\longrightarrow}}$

PhMe

$100{ }^{\circ} \mathrm{C}, 18 \mathrm{~h}$<smiles>[R]OCC=Cc1ccc([R19])cc1-n1cc(C(=O)OC)nn1</smiles>

134<smiles>[R]OC(=O)/C=C/c1c([R])cccc1-n1cc(Br)nn1</smiles>

134'
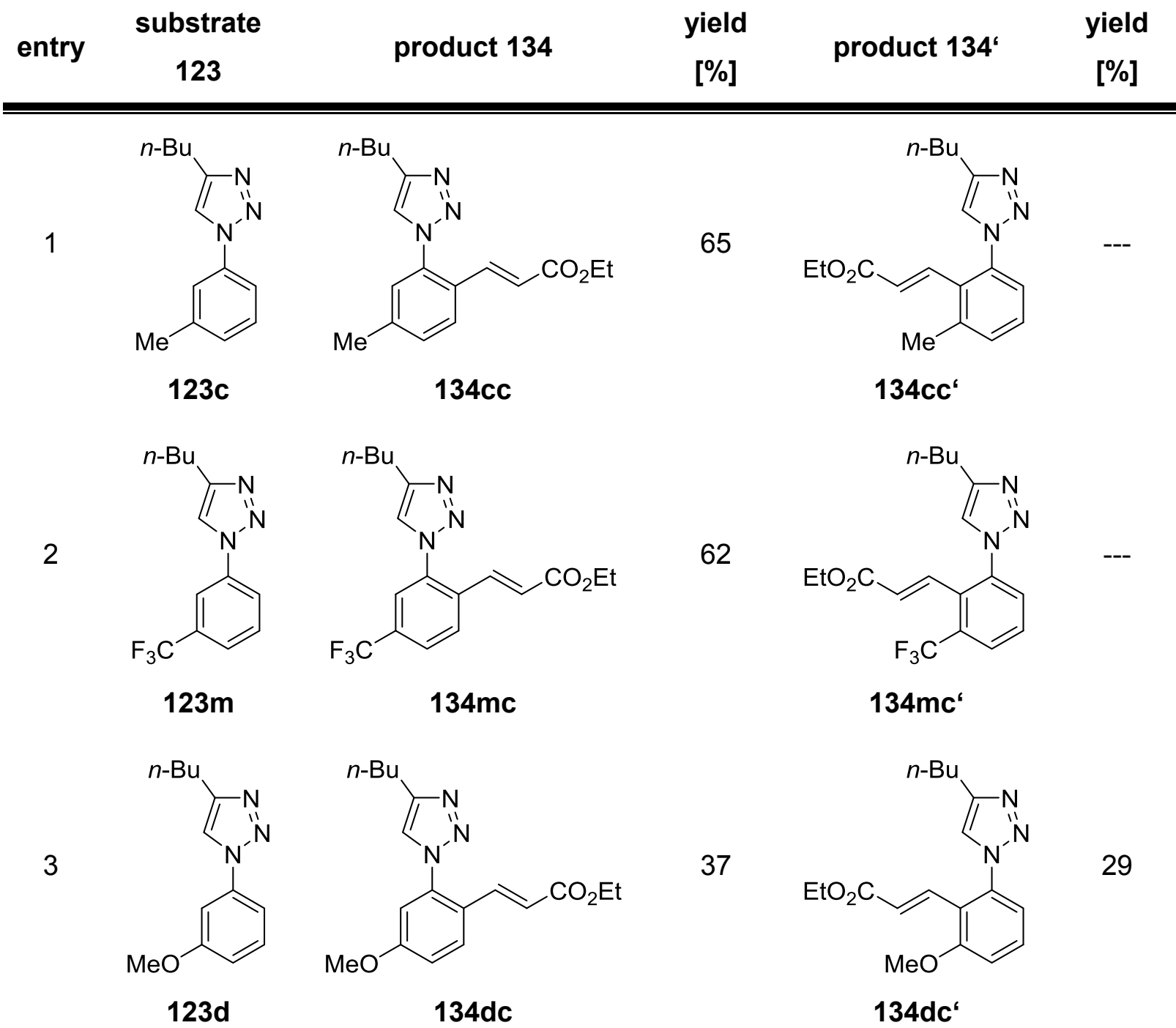
4<smiles>CCCCc1cn(-c2cccc(F)c2)nn1</smiles>

$123 e$

5<smiles>CCCCc1cn(-c2cccc(C(C)=O)c2)nn1</smiles>

$123 n$<smiles>CCCCc1cn(-c2cc(F)ccc2/C=C/C(=O)OCC)nn1</smiles>

$134 \mathrm{ec}$<smiles>CCCCc1cn(-c2cc(C(C)=O)ccc2/C=C/C(=O)OCC)nn1</smiles>

$134 \mathrm{nc}$
15<smiles>CCCCc1cn(-c2cccc(F)c2/C=C/C(=O)OCC)nn1</smiles>

17<smiles>CCCCc1cn(-c2cccc(C(C)=O)c2C=CC(=O)OCC)nn1</smiles>

$134 \mathrm{nc}^{\prime}$

a General reaction conditions: $123(1.00 \mathrm{mmol}), 17 \mathrm{c}(3.00 \mathrm{mmol}),\left[\mathrm{RuCl}_{2}(p \text {-cymene })\right]_{2}(5.0 \mathrm{~mol} \%), \mathrm{AgSbF}_{6}$ $(30.0 \mathrm{~mol} \%), \mathrm{Cu}(\mathrm{OAc})_{2} \cdot \mathrm{H}_{2} \mathrm{O}(1.20 \mathrm{mmol}), \mathrm{PhMe}(4.0 \mathrm{~mL}), 100{ }^{\circ} \mathrm{C}, 18 \mathrm{~h}$, air $(1 \mathrm{~atm})$, yields of isolated products.

The indole substrate 1230 also gave the alkenylated product $1340 \mathrm{c}$ in a site selective fashion (Scheme 3.5).<smiles>CCCCc1cn(-c2cn(C)c3ccccc23)nn1</smiles>

1230
$17 \mathrm{c}$ $\left[\mathrm{RuCl}_{2}(p \text {-cymene })\right]_{2}$ (5.0 $\mathrm{mol} \%)$ $\underset{\mathrm{AgSbF}}{\stackrel{\mathrm{Cu}(\mathrm{OAc})_{2} \cdot \mathrm{H}_{2} \mathrm{O}}{\underset{ }{\mathrm{O}}(30.0 \mathrm{~mol} \%)}}$ $\mathrm{PhMe}, 100^{\circ} \mathrm{C}, 24 \mathrm{~h}$<smiles>CCCCc1cn(-c2c(C=CC(=O)OCC)n(C)c3ccccc23)nn1</smiles>

1340c: $50 \%$

Scheme 3.5: Oxidative C-H alkenylation of 3-(4-butyl-1H-1,2,3-triazol-1-yl)-1-methyl-1H-indole 1230.

So far, we focused on the influence of different substituents on the aromatic moiety. Next, we investigated the reactivity of different substitution patterns of the triazole directing group (Table 18).

The electron-withdrawing ester group on the triazole decreased the reactivity in the $\mathrm{C}-\mathrm{H}$ bond functionalization reaction. When the ester-substituent is on the 4 position the yield was relatively low, while the ester-substituent in the 5 position of the triazole shut down the reaction. This is because the sterical effect of the ester group inhibited the alkenylation on the aryl moiety. Furthermore the ester is decreasing the electron-density of the triazole, and thereby its directing group power. A benzo[d][1,2,3]triazole as directing group also decreased the amount of alkenylated product (entry 3 ). 
Table 18: Substrate scope of alkenylations with respect to substitution of the triazole directing group. ${ }^{a}$<smiles>[R]c1ccccc1-n1nncc1[R]</smiles>

123<smiles>C=CC(=O)OCC</smiles>

$17 c$

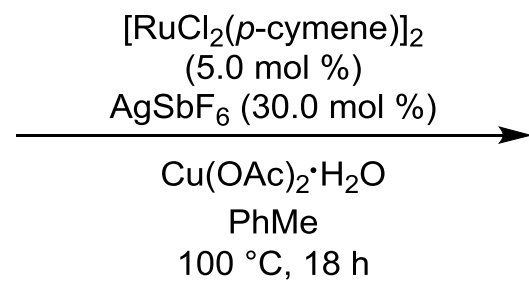

$100^{\circ} \mathrm{C}, 18 \mathrm{~h}$<smiles>[R][R]O/C=C/c1cccc([R])c1-n1ccnn1</smiles>

134

entry substrate 123

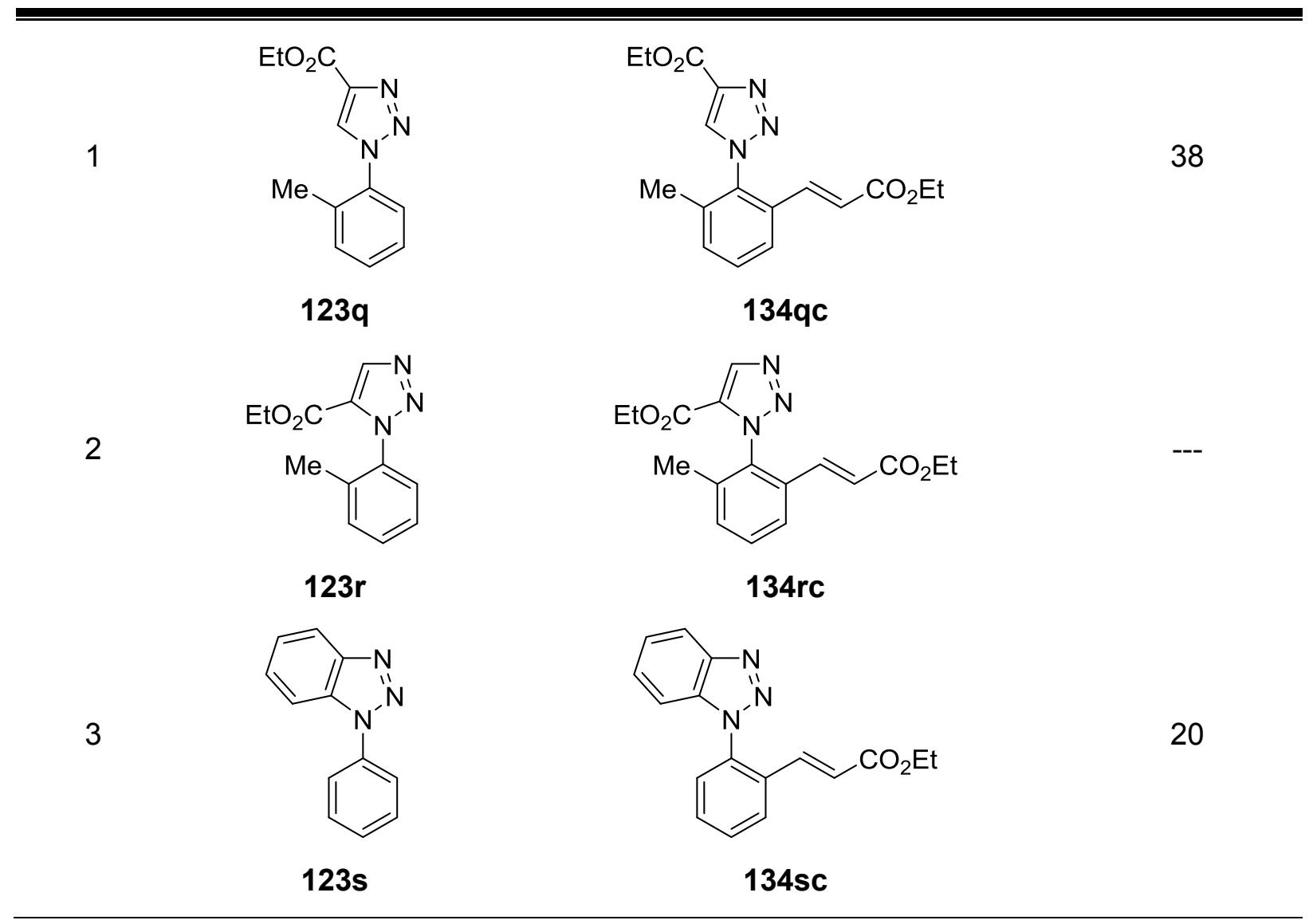

a General reaction conditions: $123(0.50 \mathrm{mmol}), 17 \mathrm{c}(1.50 \mathrm{mmol}),\left[\mathrm{RuCl}_{2}(p \text {-cymene })\right]_{2}(5.0 \mathrm{~mol} \%), \mathrm{AgSbF}_{6}$ (30.0 mol \%), $\mathrm{Cu}(\mathrm{OAc})_{2} \cdot \mathrm{H}_{2} \mathrm{O}(0.60 \mathrm{mmol}), \mathrm{PhMe}(2.0 \mathrm{~mL}), 100{ }^{\circ} \mathrm{C}, 18 \mathrm{~h}$, air $(1 \mathrm{~atm})$, yields of isolated products. 


\subsubsection{Mechanistic Studies}

\subsubsection{Intermolecular Competition Experiment}

Given the high catalytic efficacy of the optimized catalyst, we became intrigued by probing its mode of action. The competition experiment between the meta-substituted trifluoromethyl-substituted substrate $123 \mathrm{~m}$ and the methyl-substituted substrate $123 \mathrm{c}$ revealed that electron-rich substrates are preferred for this alkenylation reaction (Scheme 3.6). This reactivity pattern is in accordance with an electrophilic-type activation manifold.<smiles>CCCCc1cn(-c2cc(C(C)(C)C)ccc2/C=C/C(=O)OCC)cc1-n1cc(C(C)(C)C)nn1</smiles>

Scheme 3.6: Intermolecular competition experiment with triazoles $123 \mathrm{c}$ and $123 \mathrm{~m}$

\subsubsection{Ruthenium-Catalyzed H/D Exchange Experiment}

Further support for this mechanistic rationale was obtained from oxidative alkenylations in the presence of $D_{2} \mathrm{O}$ as a cosolvent, which indicates a significant $H / D$ scrambling in the ortho-position of the reisolated substrate $\left[D_{n}\right]-123 a$. The experiment also showed an $H / D$ exchange of the proton in position 5 of the $\mathrm{N}$-aryl-1,2,3-1H-triazole, which is due to the activation by the $\mathrm{Cu}(\mathrm{OAc})_{2} \cdot \mathrm{H}_{2} \mathrm{O}$ already known in literature (Scheme 3.7 a \& $3.7 \mathrm{~b}$ ). ${ }^{104}$ Without $\mathrm{Cu}(\mathrm{OAc})_{2} \cdot \mathrm{H}_{2} \mathrm{O}$ there is no $\mathrm{H} / \mathrm{D}$ exchange in the substrate 134a (Scheme $3.7 \mathrm{c}$ ), underlining the importance of the ruthenium(II) carboxylate complex.

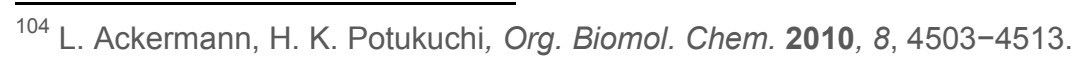


a)

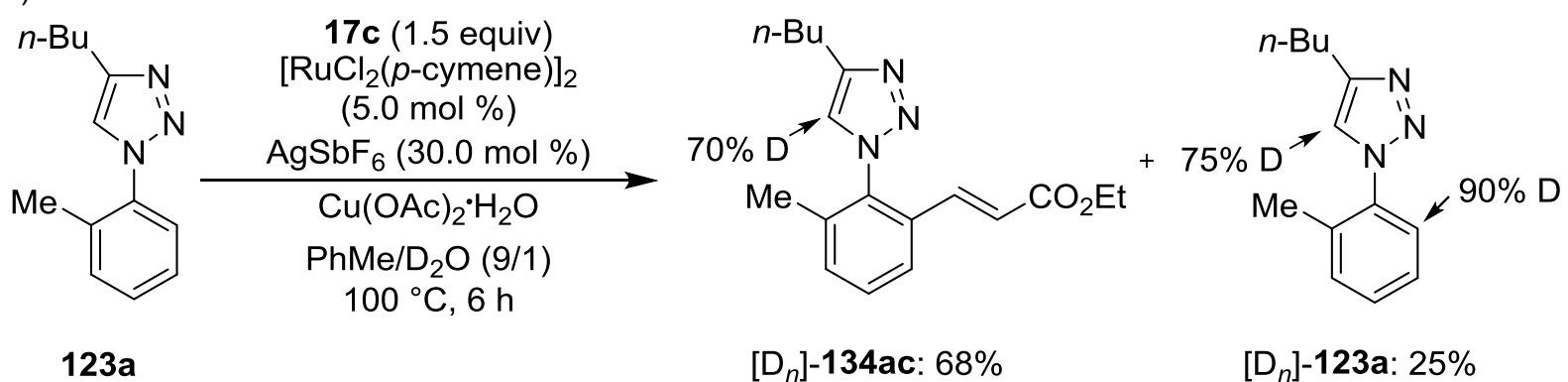

b)<smiles>CCCCc1cn(-c2ccccc2C)nn1</smiles>

$123 a$

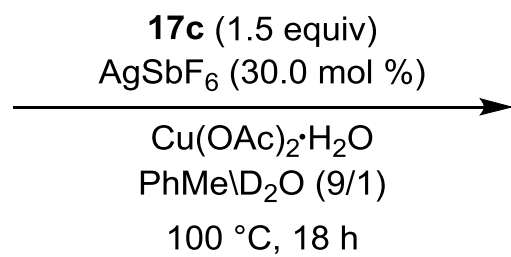

$100{ }^{\circ} \mathrm{C}, 18 \mathrm{~h}$

c)<smiles>CCCCc1cn(-c2ccccc2C)nn1</smiles>

$123 a$

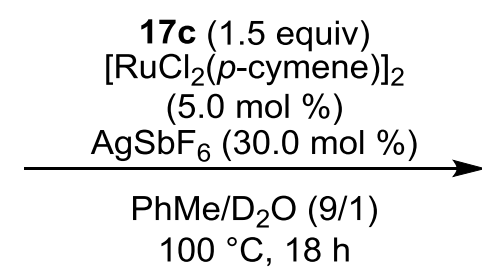

$100{ }^{\circ} \mathrm{C}, 18 \mathrm{~h}$<smiles>CCCCc1nnn(-c2c(C)cccc2C(=O)O)c1O</smiles>

$\left[D_{n}\right]-123 a c: 96 \%$

Scheme 3.7: Oxidative alkenylations in the presence of $\mathrm{D}_{2} \mathrm{O}$.

\subsubsection{Proposed Catalytic Cycle}

Based on these mechanistic studies, we propose the $\mathrm{C}-\mathrm{H}$ bond activation to occur by a reversible electrophilic-type metalation event (Scheme 3.8), which in turn explains the unique activity of the in-situ formed cationic ruthenium(II) complex. The thus-formed cycloruthenated complex 145 subsequently undergoes a migratory insertion with the alkene 17 to furnish the intermediate 146. Finally, $\beta$-hydride elimination yields the desired product 134 . Oxidation of the catalyst by $\mathrm{Cu}(\mathrm{OAc})_{2} \cdot \mathrm{H}_{2} \mathrm{O}$ regenerates the catalytically active ruthenium complex. 


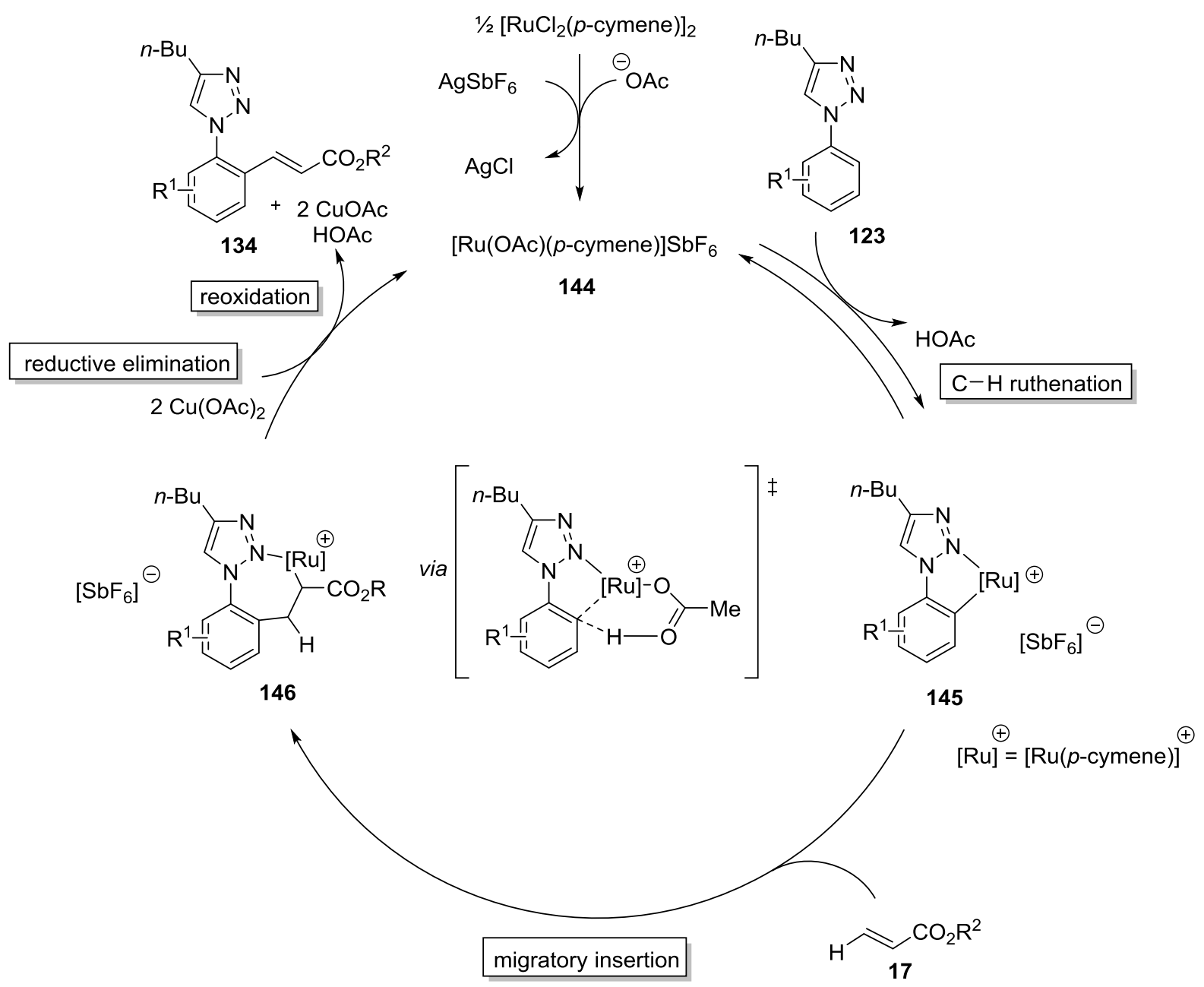

Scheme 3.8: Proposed catalytic cycle.

In conclusion, we have developed the ruthenium(II)-catalyzed direct oxidative alkenylation of $\mathrm{N}$-aryl-1,2,3-triazoles 123 . The high catalytic capability and robustness of the cationic ruthenium(II) complex was underlined by employing aerobic reaction conditions. The ruthenium-catalyzed $\mathrm{C}-\mathrm{H}$ bond functionalization proceeded with excellent chemo-, site- and diastereo-selectivities, based on the reversible formation of the five-membered ruthenacycles as the key intermediate. This successfully completed alkenylation project of the $\mathrm{N}$-aryl-1,2,3triazoles and their close connection to the pharmaceutical application, led us to our next project; the synthesis of valuable isoindolinones via direct $\mathrm{C}-\mathrm{H} / \mathrm{N}-\mathrm{H}$ bond functionalization. 


\subsection{Annulation of Acrylates through Ruthenium(II)-Catalyzed Direct $\mathrm{C}-\mathrm{H} / \mathrm{N}-\mathrm{H}$ Bond Functionalization of $\mathrm{N}$-Tosylbenzamides}

The recent years have witnessed some developments in the metal-catalyzed synthesis of isoindolinones, for instance by Falck and Zhu, ${ }^{105}$ avoiding the multiple step synthesis of the core structure, using relatively expensive palladium or rhodium catalysts for the $\mathrm{C}-\mathrm{H}$ bond functionalization.

These new developments and extensive studies on the synthesis of these substrates are due to their widespread application. For example, pagoclone, has been commercialized as an anxiolytic drug (Scheme 3.9). ${ }^{106}$ Pestalachloride $A$ is an inhibitor for the therapeutic intervention in cancer cells (Scheme 3.9). ${ }^{107}$ Another wide area of the application of isoindolinones is centered on coloring pigments in lacquers and varnish industry, with an example being the pigment yellow 110 (Scheme 3.9). ${ }^{108}$<smiles>CC(C)CCC(=O)CC1c2ccccc2C(=O)N1c1ccc2ccc(Cl)nc2n1</smiles>

Pagoclone<smiles>COc1c(Cl)c(C)c(Cl)c(O)c1C1NC(=O)c2c(O)cc(O)c(CC=C(C)C)c21</smiles>

Pestalachloride A<smiles>O=C1NC(=Nc2ccc(N=C3NC(=O)c4c(Cl)c(Cl)c(Cl)c(Cl)c43)cc2)c2c(Cl)c(Cl)c(Cl)c(Cl)c21</smiles>

pigment yellow 110

Scheme 3.9: Apllied isoindolinone derivatives.

\footnotetext{
105 a) C. Zhu and J. R. Falck, Org. Lett. 2011, 13, 1214-1217; b) C. Zhu and J. R. Falck, Chem. Comm. 2011, 13, 1214-1217.

${ }^{106}$ T. L. Stuk, B. K. Assink, R. C. Bates, J. D. T. Erdman, V. Fedij, S. M. Jennings, J. A. Lassig, R. J. Smith, T. L. Smith, Organic Process Research \& Development, 2003, 7, 851-855.

${ }^{107}$ N. Slavov, J. Cvengros, J.-M. Neudörfl, H.-G. Schmalz, Angew. Chem. Int. Ed. 2010, 49, 7588-7591.

108 IN 250748| Isoindolinone pigments and a method of manufacturing|5 Febuary 2007|S. Racherla, C. R. Shashidhur, R. Chitale, D. B. Bajirao.
} 
In this project, we focused on the ruthenium(II)-catalyzed annulation reaction of the cheap and easily accessible $N$-tosylbenzamides 135 with acrylates 17 resulting in the synthesis of isoindolinones.

\subsubsection{Optimization Studies for the Annulation of Acrylates through} Ruthenium(II)-Catalyzed Direct $\mathrm{C}-\mathrm{H} / \mathrm{N}-\mathrm{H}$ Bond Functionalization of $\mathrm{N}$ Tosylbenzamides

We started our screening with different solvents and different reaction temperatures using the standard conditions for the oxidative direct alkenylation reactions (Table 19). Good results were obtained in water at $100{ }^{\circ} \mathrm{C}$ (Table 19 , entry 5) or in methanol at $65^{\circ} \mathrm{C}$ (Table 19 , entry 14). Other solvents did not give the desired product in acceptable amounts. In the case of DCE the addition of catalytic amounts of silver hexafluoroantimonate to the reaction mixture increased the product yield dramatically, but still remained far beyond the yields obtained in methanol or water.

Table 19: Optimization studies for the annulation of $N$-tosylbenzamides 135 with ethylacrylate $17 \mathrm{c} .^{\text {a }}$<smiles>O=C(N[I-])c1ccccc1</smiles>

$135 a$

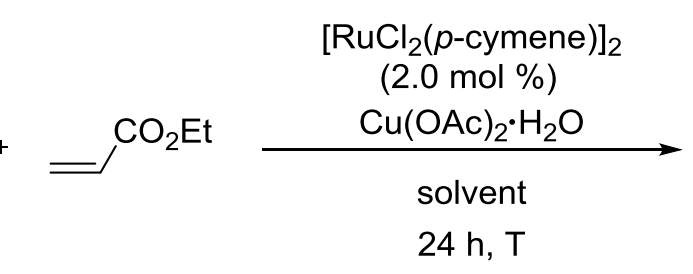

$17 \mathrm{c}$<smiles>CCOCCC1c2ccccc2C(=O)N1[AsH3-]</smiles>

$136 a c$

\begin{tabular}{cccc} 
entry & solvent & $\mathbf{T}\left[{ }^{\circ} \mathbf{C}\right]$ & yield [\%] \\
\hline \hline 1 & $\mathrm{PhMe}$ & 130 & 23 \\
2 & $\mathrm{AcOH}$ & 120 & 7 \\
3 & $\mathrm{PhMe}$ & 100 & 28 \\
4 & $\mathrm{PhCl}$ & 100 & 14 \\
5 & $\mathrm{H}_{2} \mathrm{O}$ & 100 & 48 \\
6 & $t-\mathrm{AmOH}$ & 100 & 15 \\
7 & $\mathrm{DMF}$ & 100 & 10 \\
8 & $\mathrm{DMSO}$ & 100 & 17 \\
9 & $1,4-\mathrm{dioxane}$ & 100 & -- \\
10 & $\mathrm{MeCN}$ & 82 & trace \\
11 & $\mathrm{DCE}$ & 82 & ---
\end{tabular}




$\begin{array}{lccc}12 & \text { DCE } & 82 & 43^{b} \\ 13 & \text { DCE } & 82 & -_{--^{c}} \\ 14 & \mathrm{MeOH} & 65 & 56\end{array}$

a General reaction conditions: $135 \mathrm{a}(1.00 \mathrm{mmol}), 17 \mathrm{c} \quad(1.20 \mathrm{mmol}),\left[\operatorname{RuCl}_{2}(p-\mathrm{cymene})\right]_{2} \quad(2.0 \mathrm{~mol} \%)$, $\mathrm{Cu}(\mathrm{OAc})_{2} \cdot \mathrm{H}_{2} \mathrm{O}(2.10 \mathrm{mmol})$, solvent $(5.0 \mathrm{~mL}), \mathrm{T}, 24 \mathrm{~h}$, yields of isolated products; ${ }^{\mathrm{b}} \mathrm{AgSbF}_{6}(30.0 \mathrm{~mol} \%) ;{ }^{\mathrm{c}} \mathrm{KPF}_{6}$ (30.0 $\mathrm{mol} \%)$.

Next, oxidants other than $\mathrm{Cu}(\mathrm{OAc})_{2} \cdot \mathrm{H}_{2} \mathrm{O}$ were examined, as well as various catalyst loadings (Table 20) formed to improve the amount of product. Changing the oxidant to silver acetate or using a mixture of copper bromide and sodium acetate, ${ }^{75 a}$ decreased the yield significantly (Table 20 , entry 3 ). Without the catalyst there was no conversion (entry 4 ). Increasing the catalyst loading to $5.0 \mathrm{~mol} \%$ only led to a slight increase in the yield (Table 20, entry 5). To our delight, when lowering the amount of catalyst to $1.0 \mathrm{~mol} \%$ the yield remained the same as before (Table 20, entry 6). The reduction of the amount of the acrylate to 1.05 equiv had no effect on the isolated yield (Table 20 , entry 7 ). Furthermore, the reaction was found to be feasible under air (Table 20, entry 8). Reducing the reaction time to $16 \mathrm{~h}$ and reducing the reaction temperature to $65{ }^{\circ} \mathrm{C}$ led to lower amount of the desired product (Table 20, entry 9 and 10).

Table 20: Optimization studies for the annulation of $N$-tosylbenzamides with acrylate: Oxidant and catalyst loading. ${ }^{a}$

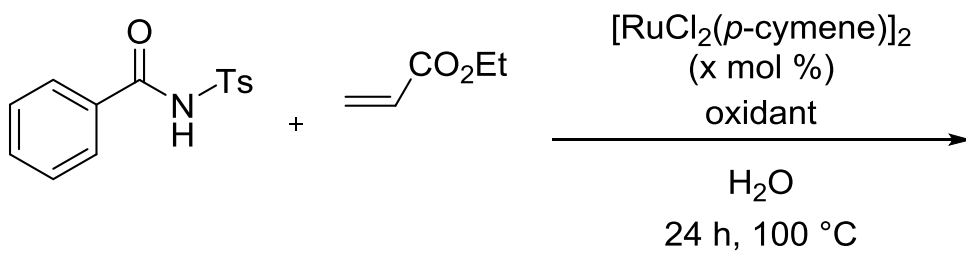

$135 a$
$17 \mathrm{c}$<smiles>CCOC(=O)CC1c2ccccc2C(=O)N1[AsH]</smiles>

136ac

\begin{tabular}{cccr} 
entry & oxidant & {$\left[\mathrm{RuCl}_{2}(\boldsymbol{p} \text {-cymene })\right]_{2}[\mathbf{m o l} \%]$} & yield [\%] \\
\hline \hline 1 & $\mathrm{Cu}(\mathrm{OAc})_{2} \cdot \mathrm{H}_{2} \mathrm{O}$ & 2 & 48 \\
2 & $\mathrm{AgOAc}$ & 2 & 30 \\
3 & $\mathrm{CuBr}_{2}(\mathrm{NaOAc}, 3.0$ equiv $)$ & 2 & --- \\
4 & $\mathrm{Cu}(\mathrm{OAc})_{2} \cdot \mathrm{H}_{2} \mathrm{O}$ & - & --- \\
5 & $\mathrm{Cu}(\mathrm{OAc})_{2} \cdot \mathrm{H}_{2} \mathrm{O}$ & 5 & 54 \\
6 & $\mathrm{Cu}(\mathrm{OAc})_{2} \cdot \mathrm{H}_{2} \mathrm{O}$ & 1 & 49 \\
7 & $\mathrm{Cu}(\mathrm{OAc})_{2} \cdot \mathrm{H}_{2} \mathrm{O}$ & 1 & $52^{\mathrm{b}}$ \\
8 & $\mathrm{Cu}(\mathrm{OAc})_{2} \cdot \mathrm{H}_{2} \mathrm{O}$ & 1 & $52^{\mathrm{b}, \mathrm{c}}$ \\
9 & $\mathrm{Cu}(\mathrm{OAc})_{2} \cdot \mathrm{H}_{2} \mathrm{O}$ & 2 & $38^{\mathrm{d}}$
\end{tabular}


10

$\mathrm{Cu}(\mathrm{OAc})_{2} \cdot \mathrm{H}_{2} \mathrm{O}$

1

$44^{\mathrm{e}}$

a General reaction conditions: 135a $(1.00 \mathrm{mmol}), 17 \mathrm{c}(1.20 \mathrm{mmol}),\left[\mathrm{RuCl}_{2}(p \text {-cymene })\right]_{2}(\mathrm{x} \mathrm{mol} \%)$, oxidant $(2.10$ mmol), solvent $(5.0 \mathrm{~mL}), \mathrm{T}, 24 \mathrm{~h}$, yields of isolated products; ${ }^{\mathrm{b}} 17 \mathrm{c}(1.05 \mathrm{mmol}) ;{ }^{\mathrm{c}}$ air $(1 \mathrm{~atm}) ;{ }^{\mathrm{d}} 16 \mathrm{~h} ;{ }^{\mathrm{e}} 65{ }^{\circ} \mathrm{C}$.

\subsubsection{Scope and Limitations for the Direct $\mathrm{C}-\mathrm{H} / \mathrm{N}-\mathrm{H}$ Bond Functionalization of}

\section{$\mathrm{N}$-Tosylbenzamides with Acrylates}

With the optimized reaction conditions in hand, we extended the substrate scope and therefore different alkenes were explored (Table 21). While ethyl acrylate 17c gave the highest yield, the yields of the other acrylates were comparable. Even with the diethyl vinylphosphonate the yield was moderate.

Table 21: Substrate scope for alkenylations of $N$-tosylbenzamide 135 with different alkenes $17 .^{a}$<smiles>[R]C=C[AsH2-][AsH3-]</smiles>

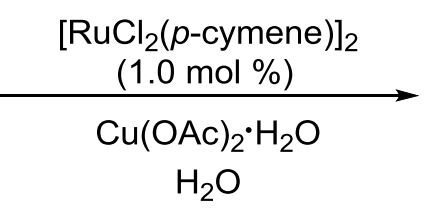

$24 \mathrm{~h}, 100^{\circ} \mathrm{C}$<smiles>[R]CC1c2ccccc2C(=O)N1[S-]</smiles>

$136 a$

$154 a$

17

product 136

yield [\%]<smiles>[B-]N1C(=O)c2ccccc2C1CC(=O)OCC</smiles>

52

1<smiles>C=C[O+]=CC</smiles>

17c

136ac

2<smiles>CCOC(=O)CC1c2ccccc2C(=O)N1[AsH]</smiles>

136ae

$17 e$<smiles>CCOP(=O)(CC1c2ccccc2C(=O)N1[13CH3])OCC</smiles> 
${ }^{a}$ General reaction conditions: $135 \mathrm{a}(1.00 \mathrm{mmol}), 17(1.05 \mathrm{mmol}),\left[\mathrm{RuCl}_{2}(p \text {-cymene })\right]_{2}(1.0 \mathrm{~mol} \%), \mathrm{Cu}(\mathrm{OAc})_{2} \cdot \mathrm{H}_{2} \mathrm{O}$ (2.10 mmol), $\mathrm{H}_{2} \mathrm{O}(5.0 \mathrm{~mL}), 100^{\circ} \mathrm{C}, 24 \mathrm{~h}$, yields of isolated products.

The following challenging alkenes (Scheme 3.10) acrylonitrile, acrylic acid or acrolein 17g17j did not give the desired product. Furthermore, no product could be obtained using unactivated alkene 1-hexene $17 \mathbf{k}$ or styrene 17l. The disubstituted alkenes ethyl methacrylate $17 \mathrm{~m}$ and cyclopentenone $17 \mathrm{n}$ were found to be unreactive as well under otherwise identical reaction conditions.<smiles></smiles>

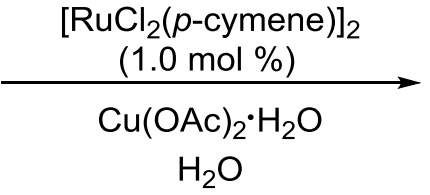

$24 \mathrm{~h}, 100^{\circ} \mathrm{C}$<smiles>[R]CC1c2ccccc2C(=O)N1[AsH3-]</smiles>

$136 a$
$135 a$<smiles>C=CC(=O)C=CC(=O)O</smiles><smiles>C=CCCCC</smiles>

$17 k$<smiles>C=CPc1ccccc1</smiles>

171<smiles>C=C(C)C(=O)OCC</smiles>

$17 \mathrm{~m}$<smiles>O=C1C=CCC1</smiles>

Scheme 3.10: Alkenes which did not react.

To probe the influence of the catalyst loading with different substrates 135 , we examined annulations with several substrates $135 \mathrm{~b}$ und $135 \mathrm{c}$ at different catalyst loadings (Scheme 3.11). Satisfactorily, we observed good yields even with $1.0 \mathrm{~mol} \%$ of the catalyst, which could be improved by using higher catalyst loadings. The yield ranged from moderate to very good. 
<smiles>[R]C=[Sb][As]NC(=O)c1ccc([R])cc1</smiles>

135

17

136<smiles>CCOC(=O)CC1c2cccc(C)c2C(=O)N1[13I]</smiles>

$136 \mathrm{bc}$<smiles>CCCCCC1c2cccc([N+](=O)[O-])c2C(=O)N1[AsH3]</smiles>

136be<smiles>CCCCC1c2cccc(F)c2C(=O)N1[AsH3-]</smiles>

$136 c c$<smiles>CCOC(=O)CC1c2cccc(F)c2C(=O)N1[AsH3-]</smiles>

$136 c c$

$52 \%$ (1.0 mol \% cat.) $\quad 45 \%$ (1.0 mol \% cat.) $64 \%$ (2.0 mol \% cat.) $\quad 67 \%$ (2.0 mol \% cat.)

$59 \%$ (1.0 mol \% cat.) $59 \%$ (1.0 mol \% cat.) $68 \%$ (2.5 mol \% cat.) $71 \%$ (2.5 mol \% cat.) $74 \%$ (5.0 mol \% cat.) $\quad 88 \%$ (5.0 mol \% cat.) $\quad 78 \%$ (3.0 mol \% cat.) $\quad 78 \%(5.0 \mathrm{~mol} \%$ cat.)

Scheme 3.11: Influence of the catalyst loading on the reaction with different substratets. ${ }^{a}$

${ }^{a}$ General reaction conditions: $\left.135(1.00 \mathrm{mmol}), 17(1.05 \mathrm{mmol}),\left[\mathrm{RuCl}_{2}(p \text {-cymene })\right]_{2}(\mathrm{x} \mathrm{mol} \%), \mathrm{Cu}(\mathrm{OAc})\right)_{2} \cdot \mathrm{H}_{2} \mathrm{O}$ (2.10 mmol), $\mathrm{H}_{2} \mathrm{O}(5.0 \mathrm{~mL}), 100{ }^{\circ} \mathrm{C}, 24 \mathrm{~h}$, yields of isolated products.

In order to explore whether stoichiometric amounts of copper acetate are needed for this reaction, we examined the reaction of 2-fluoro- $\mathrm{N}$-tosylbenzamide $135 \mathrm{c}$ with different quantities of $\mathrm{Cu}(\mathrm{OAc})_{2} \cdot \mathrm{H}_{2} \mathrm{O}$. The yield was dependent on the amount of the $\mathrm{Cu}(\mathrm{OAc})_{2} \cdot \mathrm{H}_{2} \mathrm{O}$ (Table 22), and 1.5 equivalents were found to be optimal.

Table 22: Influence of the amount of $\mathrm{Cu}(\mathrm{OAc})_{2} \cdot \mathrm{H}_{2} \mathrm{O}$.<smiles>O=C(N[13F])c1ccccc1F</smiles>

$135 c$ entry
$\left[\operatorname{RuCl}_{2}(p \text {-cymene })\right]_{2}$ $(5.0 \mathrm{~mol} \%)$

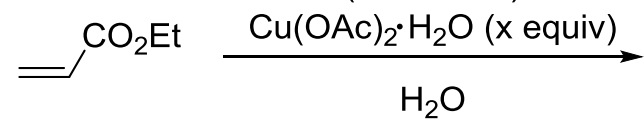

$24 \mathrm{~h}, 100^{\circ} \mathrm{C}$<smiles>CCOC(=O)CC1c2cccc(F)c2C(=O)N1[13I]</smiles>

$136 \mathrm{cc}$ yield [\%]

\section{$\mathrm{Cu}(\mathrm{OAc})_{2} \cdot \mathrm{H}_{2} \mathrm{O}$}


5

6
1.5

2.1
67

66

a General reaction conditions: $154 \mathrm{c}(1.00 \mathrm{mmol}), 17 \mathrm{c}(1.05 \mathrm{mmol}), \quad\left[\operatorname{RuCl}_{2}(p-\mathrm{cymene})\right]_{2}(5.0 \mathrm{~mol} \%)$, $\mathrm{Cu}(\mathrm{OAc})_{2} \cdot \mathrm{H}_{2} \mathrm{O}, \mathrm{H}_{2} \mathrm{O}(5.0 \mathrm{~mL}), 100^{\circ} \mathrm{C}, 24 \mathrm{~h}$, yields of isolated products.

Next, the substrate scope of the alkenylation was examined in detail. The orthomethyl-substituted substrate $135 \mathrm{~b}$ was very reactive, but with the diethyl vinylphosphonate $17 \mathrm{k}$ and the methylvinylketone $17 \mathbf{j}$ the yield dropped significantly. When using the orthomethoxy-substituted $N$-tosylbenzamide the yield was only moderate, even with $5.0 \mathrm{~mol} \%$ catalyst loading (Table 23, entry 4). Other functional groups, such as chloro or nitro groups, were well tolerated and afforded the desired product in good yields.

Table 23: Substrate scope for alkenylations of ortho-substituted $N$-tosylbenzamides 135 . $^{\text {a }}$<smiles>[R]C=[C-][AsH2-]NC(=O)c1ccccc1[R]</smiles>

135

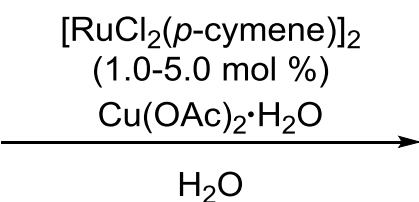

$24 \mathrm{~h}, 100{ }^{\circ} \mathrm{C}$<smiles>[R]CC1c2cccc([R])c2C(=O)N1[I-]</smiles>

136

\section{entry substrate 135}

alkene 17

product 136

yield [\%]

1<smiles>[3H]NC(=O)c1ccccc1C</smiles>

135b<smiles>[3H]NC(=O)c1ccccc1C</smiles>

$135 b$<smiles>Cc1ccccc1C(=O)N[TeH]</smiles><smiles>C=CC(=O)OCc1ccccc1</smiles>

17d<smiles>C=C[PH](O)(O)OCC</smiles>

$17 k$<smiles>C=CC(C)=O</smiles><smiles>Cc1cccc2c1C(=O)N([13S])C2CC(=O)OCc1ccccc1</smiles>

$136 \mathrm{bd}$<smiles>CCOP(=O)(CC1c2cccc(C)c2C(=O)N1[I-])OCC</smiles>

3

48

82 
$135 b$

4<smiles>[3H]NC(=O)c1ccccc1OC</smiles>

$135 d$<smiles>O=C(N[I-])c1cccc2ccccc12</smiles>

$135 e$

6<smiles>O=C(N[I-])c1cccc2ccccc12</smiles>

$135 e$<smiles>O=C(N[TeH])c1ccccc1[N+](=O)[O-]</smiles>

$135 f$<smiles>O=C(N[I-])c1ccccc1[N+](=O)[O-]</smiles>

$135 f$<smiles>O=C(N[AsH3])c1ccccc1Cl</smiles>

$135 \mathrm{~g}$ 17j

136bj<smiles>CCOC(=O)CC1c2cccc(OC)c2C(=O)N1[13I]</smiles>

$136 \mathrm{dc}$<smiles>CCOC(=O)CC1c2ccc3ccccc3c2C(=O)N1[13CH3]</smiles>

$136 \mathrm{ec}$<smiles>C=CCO[18O]C(=O)OC</smiles>

17 e<smiles>CCCCCCC1c2ccc3ccccc3c2C(=O)N1[TeH]</smiles>

136ee<smiles>CCOC(=O)c1cccc2c1C(=O)N([13CH3])C2CCO</smiles>

$136 \mathrm{fc}$<smiles>CCCCCCC1c2cccc([N+](=O)[O-])c2C(=O)N1[AsH]</smiles>

$136 \mathrm{fe}$<smiles>CCOC(=O)CC1c2cccc(Cl)c2C(=O)N1[13S]</smiles>

$136 \mathrm{gc}$

${ }^{a}$ General reaction conditions: $\left.135 \mathrm{a}(1.00 \mathrm{mmol}), 17(1.05 \mathrm{mmol}),\left[\mathrm{RuCl}_{2}(p \text {-cymene })\right]_{2}(5.0 \mathrm{~mol} \%), \mathrm{Cu}(\mathrm{OAc})\right)_{2} \cdot \mathrm{H}_{2} \mathrm{O}$ (2.10 mmol), $\mathrm{H}_{2} \mathrm{O}(5.0 \mathrm{~mL}), 100{ }^{\circ} \mathrm{C}, 24 \mathrm{~h}$, yields of isolated products; ${ }^{\mathrm{b}}\left[\mathrm{RuCl}_{2}(p \text {-cymene })\right]_{2}(1.0 \mathrm{~mol} \%)$. 
Meta- and para-substituted substrates worked well, regardless of the substitution with the methyl-, the methoxy- (Table 24, entries 1-5) or the fluoro-group.

Table 24: Substrate scope for alkenylations of meta- and para-substituted $N$-tosylbenzamides 135 . $^{\text {a }}$<smiles>[R]C=[13CH][AsH2-]NC(=O)c1c#[R]ccc1</smiles>

135

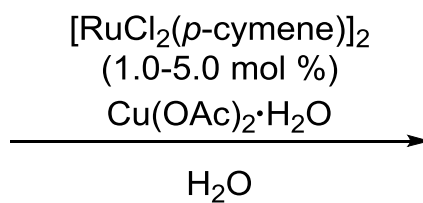

$24 \mathrm{~h}, 100^{\circ} \mathrm{C}$<smiles>[R]CC1c2cc[R1]([H])cc2C(=O)N1[AsH3-]</smiles>

136

entry substrate 135

alkene 17

product 136

yield [\%]

1<smiles>Cc1cccc(C(=O)N[As])c1</smiles><smiles>C=CCOCC</smiles><smiles>CCOC(=O)CC1c2ccc(C)cc2C(=O)N1[AsH3-]</smiles>

$17 c$

136hc

2<smiles>[3H]NC(=O)c1cccc(C)c1</smiles><smiles>C=C[14CH2]O[14CH3]</smiles>

$135 h$

$17 e$<smiles>CCOC(=O)CC1c2ccc(C)cc2C(=O)N1[AsH3-]</smiles>

3<smiles>[3H]NC(=O)c1cccc(OC)c1</smiles><smiles>C=COOCC</smiles>

$17 c$<smiles>CCOC(=O)CC1c2ccc(OC)cc2C(=O)N1[AsH]</smiles>

136ic

4<smiles>COc1cccc(C(=O)NC(F)(F)F)c1</smiles><smiles>C=CCOC(=O)OCCCC</smiles>

$17 e$

$60^{b}$

$63^{b}$ 
5<smiles>[3H]NC(=O)c1cccc(OC)c1</smiles>

$135 \mathbf{i}$

6<smiles>O=C(N[TeH])c1cccc(C(F)(F)F)c1</smiles>

135j

7<smiles>[3H]NC(=O)c1ccc(C)cc1</smiles>

$135 k$<smiles>[3H]NC(=O)c1ccc(C)cc1</smiles>

135k

9<smiles>[3H]NC(=O)c1ccc(OC)cc1</smiles>

$135 I$<smiles>COc1ccc(C(=O)NC(F)(F)F)cc1</smiles>

135I

10<smiles>C=CC(C)=O</smiles>

17j<smiles>C=CCOCC</smiles>

$17 c$<smiles>C=COC=CC</smiles>

$17 c$<smiles></smiles>

$17 e$<smiles>C=CCOCC</smiles>

$17 c$<smiles>C=CCOC(=O)OCCC</smiles>

$17 e$<smiles>COc1ccc2c(c1)C(=O)N([13S])C2CC(C)=O</smiles>

$27^{b}$

$136 \mathrm{ij}$<smiles>CCOC(=O)CC1c2ccc(C(F)(F)F)cc2C(=O)N1[AsH]</smiles>

78

136jc<smiles>CCOCCC1c2cc(C)ccc2C(=O)N1[AsH-]</smiles>

$52^{b}$ $136 \mathrm{kc}$<smiles>CCCCC1c2cc(C)ccc2C(=O)N1[AsH]</smiles>

$50^{b}$ 52 52<smiles>CCOC(=O)OCCC1c2cc(OC)ccc2C(=O)N1[13CH3]</smiles>

136le 
11<smiles>O=C(N[Te])c1ccc(F)cc1</smiles>

$135 \mathrm{~m}$<smiles>O=C(N[13F])c1ccc(F)cc1</smiles>

$135 m$<smiles>C=COOCC</smiles>

$17 c$<smiles>C=CC(C)=O</smiles>

17j<smiles>CCOC(=O)CC1c2cc(F)ccc2C(=O)N1[13S]</smiles>

$136 \mathrm{mc}$<smiles>CC(=O)CC1c2cc(F)ccc2C(=O)N1[13F]</smiles>

$136 \mathrm{mj}$

${ }^{a}$ General reaction conditions: $135(1.00 \mathrm{mmol}), 17(1.05 \mathrm{mmol}),\left[\mathrm{RuCl}_{2}(p \text {-cymene })\right]_{2}(5.0 \mathrm{~mol} \%), \mathrm{Cu}(\mathrm{OAc})_{2} \cdot \mathrm{H}_{2} \mathrm{O}$ (2.10 mmol), $\mathrm{H}_{2} \mathrm{O}(5.0 \mathrm{~mL}), 100{ }^{\circ} \mathrm{C}, 24 \mathrm{~h}$, yields of isolated products; ${ }^{\mathrm{b}}\left[\mathrm{RuCl}_{2}(p \text {-cymene })\right]_{2}(1.0 \mathrm{~mol} \%)$.

Despite the broad applicability of the reaction on various $N$-tosylbenzamides, there are some limitations. Blocking the nitrogen, which is coordinating to the ruthenium complex, with a methyl group, shuts down the reaction. Further, we did not observe the competitive alkenylation on the sulfonamide moiety. Even using several other substrates, no sulfonamide-directed alkenylation reaction was observed (Scheme 3.12).<smiles>[R]N([R])S(=O)(=O)c1ccc(C)cc1</smiles>

$107 a$<smiles>Cc1ccc(S(=O)(=O)N(C)c2ccccc2)cc1</smiles>

107b<smiles>CNS(=O)(=O)c1ccc(C)cc1</smiles>

$107 c$<smiles>Cc1ccc(S(N)(=O)=O)cc1</smiles>

$107 d$
$\left[\mathrm{RuCl}_{2}(p \text {-cymene })\right]_{2}$ (5.0 mol \%) $\mathrm{Cu}(\mathrm{OAc})_{2} \cdot \mathrm{H}_{2} \mathrm{O}$

$$
\mathrm{H}_{2} \mathrm{O}
$$

$24 \mathrm{~h}, 100^{\circ} \mathrm{C}$

$17 c$

$108 a$

Scheme 3.12: Limitations in the synthesis of sultams 108.<smiles>Cc1ccc(S(=O)(=O)N(C)S(=O)(=O)c2ccc(C)cc2)cc1</smiles>

$107 f$ 
The $\mathrm{N}$-tosyl group of the isoindolinone can be easily cleaved by a known procedure, giving the free isoindolinone $136 \mathrm{n}$ (Scheme 3.13). ${ }^{105}$<smiles>CC(C)(C)OC(=O)CC1c2ccccc2C(=O)N1[AsH3-]</smiles>

136af

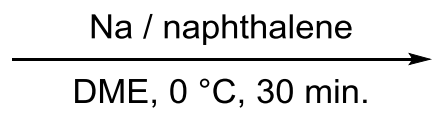

$65 \%$<smiles>CC(C)(C)OC(=O)CC1NC(=O)c2ccccc21</smiles>

$136 n$

Scheme 3.13: Cleavage of the tosyl group

\subsubsection{Mechanistic Studies}

\subsubsection{Intermolecular Competition Experiment}

To gain insight into the mechanistic course of the ruthenium-catalyzed oxidative annulation of alkenes 17 with $\mathrm{N}$-tosylbenzamides 135 via $\mathrm{C}-\mathrm{H} / \mathrm{N}-\mathrm{H}$ bond cleavages, an intermolecular competition experiment was performed (Scheme 3.14). The competition experiment between the meta-substituted substrates $135 \mathrm{j}$ and $135 \mathrm{~h}$ revealed that electron-rich substrates are preferred for this cyclization reaction.<smiles>CCOCCC1c2ccc(C(F)(F)F)cc2C(=O)N1[13CH3]</smiles>

Scheme 3.14: Intermolecular competition experiment with $N$-tosylbenzamides $135 \mathrm{j}$ and $135 \mathrm{~h}$.

\subsubsection{H/D Exchange Experiments}

Mechanistic studies on the oxidative alkenylation in the presence of $D_{2} \mathrm{O}$ were performed. Scheme 3.15 presents the result of the H/D-exchange. In the ortho-positions of the reisolated $N$-tosylbenzamide $\left[D_{n}\right]-135 c$ as well as of the product $\left[D_{n}\right]-136$, we observed a significant $H / D$ scrambling, which revealed the reversible nature of the $\mathrm{C}-\mathrm{H}$ ruthenation step. Further $\mathrm{H} / \mathrm{D}-$ exchange of the inserted alkene is strong evidence for an aza-Michael reaction (Scheme 3.15). 


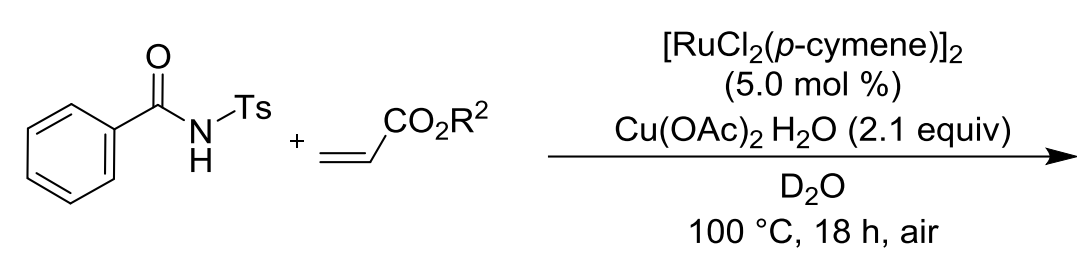

$135 a$
$17 \mathrm{c}$

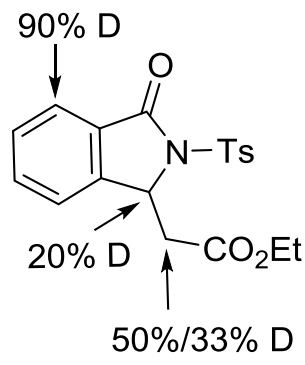

$\left[D_{n}\right]-136 a c: 94 \%$

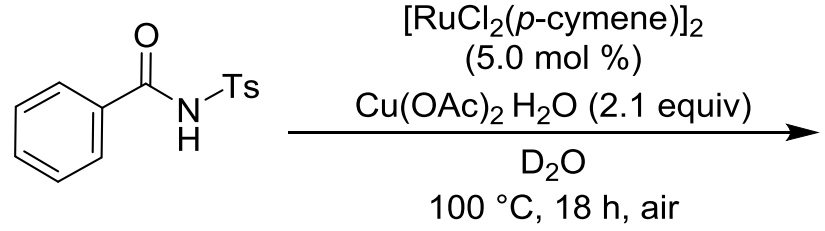

$135 a$<smiles></smiles>

$\left[\mathrm{D}_{n}\right]-135 \mathrm{a}: 94 \%$

Scheme 3.15: Oxidative alkenylation in the presence of $\mathrm{D}_{2} \mathrm{O}$.

\subsubsection{Proposed Catalytic Cycle}

Based on these mechanistic studies, we propose the $\mathrm{C}-\mathrm{H}$ bond activation to involve a reversible electrophilic-type metalation event (Scheme 3.16) with a ruthenium(II) complex forming 147. Subsequently, this intermediate undergoes migratory insertion with the alkene 17. The intermediate 149 undergoes reductive elimination, to yield the alkenylated $\mathrm{N}$ tosylbenzamide. Afterwards the nucleophilic cyclization resulted in the desired isoindolinone 136. Oxidation by $\mathrm{Cu}(\mathrm{OAc})_{2}$ regenerates the catalytically active ruthenium complex. 


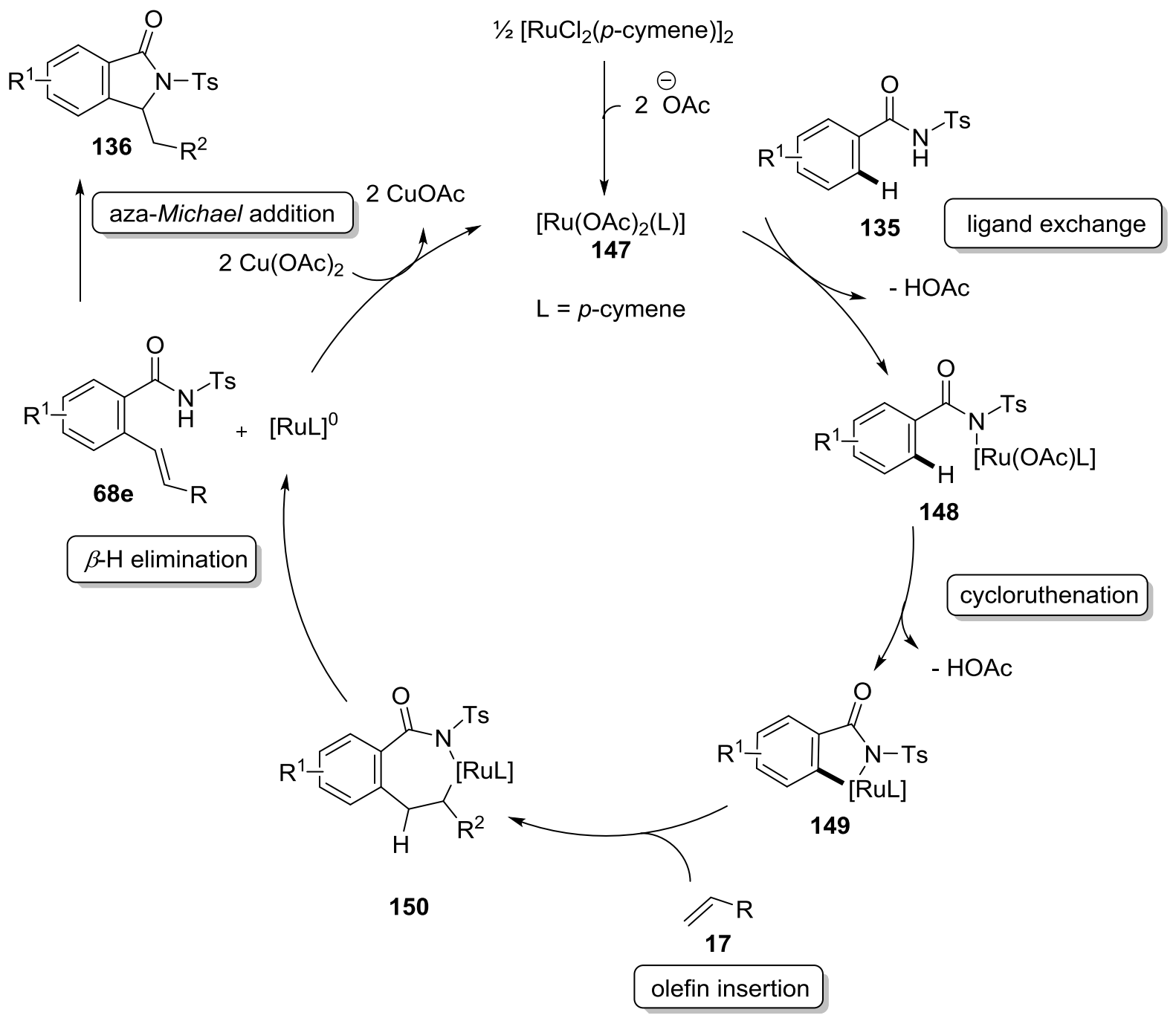

Scheme 3.16: Propsed catalytic cycle.

In summary, we have developed the unpredented ruthenium(II)-catalyzed oxidative alkenylation/annulation of arenes through $\mathrm{C}-\mathrm{H} / \mathrm{N}-\mathrm{H}$ bond functionalization. This led us to the final project of this thesis, the oxidative alkenylation of $N$-tosylbenzamides with oxygen as the terminal oxidant and water as the sole by-product. 


\subsection{Annulation of Acrylates through Ruthenium(II)-Catalyzed Direct $\mathrm{C}-\mathrm{H} / \mathrm{N}-\mathrm{H}$ Bond Functionalization of $\mathrm{N}$-Tosylbenzamides with Oxygen as Oxidant}

Thus far all ruthenium(II)-catalyzed alkenylations and alkene annulations proceeded only in the presence of additional oxidants, such as copper(II) or silver(I) salts, leading to the formation of undesired stoichiometric metal containing by-products. However, some developments on the metal-catalyzed $\mathrm{C}-\mathrm{H}$ bond functionalization with oxygen as the sacrificial oxidant has been made recently, ${ }^{53,55 a-b, 55 d-e, 58,95}$ the ruthenium-catalyzed annulation with alkenes and oxygen as sole oxidant, as of yet has proven elusive. Recently, our research group developed the first ruthenium(II)-catalyzed $\mathrm{C}-\mathrm{H}$ bond activation/alkyne annulation by benzoic acids under ambient oxygen atmosphere. ${ }^{59}$ Inspired by these conditions, we adjusted the reaction temperature for the $N$-tosylbenzamide 135. Unfortunately, the amount of the desired product was rather low, but indicated the possibility of an aerobic $\mathrm{C}-\mathrm{H}$ functionalization (Scheme 3.17).

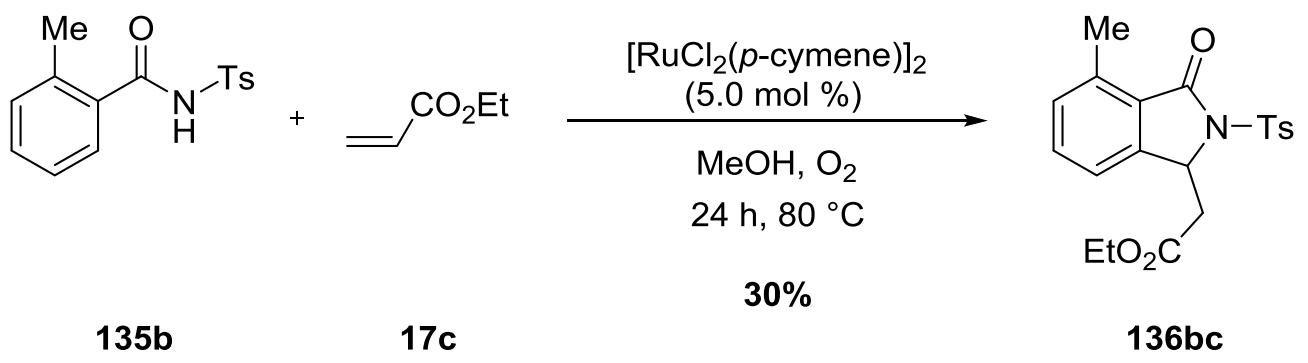

Scheme 3.17: Aerobic ruthenium(II)-catalyzed annulation of ethyl acrylate 17c.

Herein we present the first ruthenium(II)-catalyzed aerobic alkene annulation of $\mathrm{N}$ tosylbenzamides with alkenes leading to biologically active isoindolinones.

\subsubsection{Optimization Studies for the Annulation of Acrylates through Ruthenium(II)-Catalyzed Direct $\mathrm{C}-\mathrm{H} / \mathrm{N}-\mathrm{H}$ Bond Functionalization of $\mathrm{N}$ - Tosylbenzamides with Oxygen as Oxidant}

At the outset of our studies we probed reaction conditions for the oxidative alkene annulation of $N$-tosylbenzamides $153 \mathrm{~b}$ with ethyl acrylate 17c under an atmosphere of oxygen (Table 25). Using DMF instead of methanol decreased the isolated yield of the product $136 \mathrm{~b}$. Rising the reaction temperature in DMF to $100{ }^{\circ} \mathrm{C}$-which was not possible for methanol-, increased the yield slightly (Table 25 , entry 3 and 4 ). 
Interestingly, the best reaction conditions were without solvents (Table 25, entry 5 and 6) using a slight excess of ethyl acrylate, which was found by Keshav Raghuvanshi. Testing the different acetates in DMF or under neat reaction conditions revealed that KOAc gave better conversions than $\mathrm{CsOAc}$ or $\mathrm{NaOAc}$. Importantly, the $\mathrm{C}-\mathrm{H}$ bond functionalization did not occur in the absence of the ruthenium(II)-catalyst or the acetate (Table 25 , entry 9 and 10 ).

Table 25: Optimization studies for the annulation of $N$-tosylbenzamides with acrylates. ${ }^{a}$<smiles>[3H]NC(=O)c1ccccc1C</smiles>

$135 b$

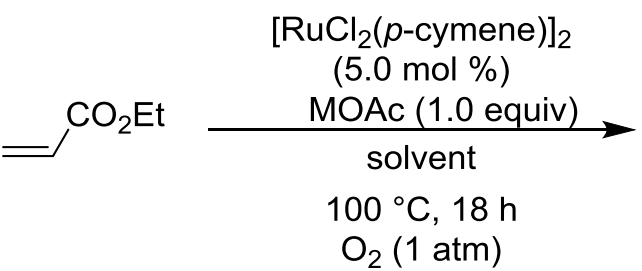

$17 \mathrm{c}$<smiles>CCOC(=O)CC1c2cccc(C)c2C(=O)N1[I-]</smiles>

$136 \mathrm{bc}$

\begin{tabular}{ccccc} 
entry & solvent & MOAc & $\mathbf{T}\left[{ }^{\circ} \mathbf{C}\right]$ & yield \\
\hline \hline 1 & MeOH & CsOAc & 80 & 30 \\
2 & DMF & CsOAc & 80 & 20 \\
3 & DMF & CsOAc & 100 & 26 \\
4 & DMF & KOAc & 100 & 35 \\
5 & - & CsOAc & 100 & $68^{\mathrm{b}}$ \\
6 & - & KOAc & 100 & $86^{\mathrm{b}}$ \\
7 & - & NaOAc & 100 & $70^{\mathrm{b}}$ \\
8 & - & CsOAc & 100 & $45^{\mathrm{b}, \mathrm{c}}$ \\
9 & - & CsOAc & 100 & $--{ }^{\mathrm{d}}$ \\
10 & - & - & 100 & --- \\
\hline
\end{tabular}

${ }^{a}$ Reactions conditions: 135b (0.50 mmol), 17c (1.50 mmol), $\left[\mathrm{RuCl}_{2}(p \text {-cymene) }]_{2}(5.0 \mathrm{~mol} \%)\right.$, MOAc (1.0 equiv), solvent $(2.0 \mathrm{~mL}), 100{ }^{\circ} \mathrm{C}, 18 \mathrm{~h}, \mathrm{O}_{2}(1 \mathrm{~atm})$, yield of isolated product; ${ }^{\mathrm{b}} 17 \mathrm{c}(2.50 \mathrm{mmol})$, without solvent; ${ }^{\mathrm{c}}$ with $\left[\mathrm{Ru}\left(\mathrm{O}_{2} \mathrm{CMes}\right)_{2} p\right.$-cymene] $140(5.0 \mathrm{~mol} \%) ;{ }^{d}$ without $\left[\mathrm{RuCl}_{2}(p \text {-cymene })\right]_{2}$.

\subsubsection{Scope of the Aerobic Annulation of Acrylates through Ruthenium(II)- Catalyzed Direct $\mathrm{C}-\mathrm{H} / \mathrm{N}-\mathrm{H}$ Functionalization of $\mathrm{N}$-Tosylbenzamides}

To compare the reactivity of cesium and potassium acetate, we tested their reactivity in the annulation with different $\mathrm{N}$-tosylbenzamides 135 (Table 26). Hence the yields of the desired products were comparable. Table 26 also shows that sterically more demanding acrylates 
were less reactive. Furthermore, sterically hindered substrates $135 \mathrm{~g}$ with ortho-substitution gave lower yields of products than unhindered substrates $135 \mathrm{~b}$.

Table 26: Substrate scope for alkenylations of meta- and para-substituted $N$-tosylbenzamides. ${ }^{a}$<smiles>[R]C=C=[As]NC(=O)c1ccccc1[R1]</smiles>

135

17

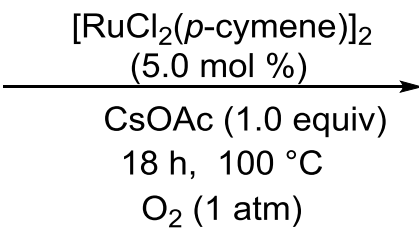<smiles>[R]CC1c2cccc([R])c2C(=O)N1[AsH3-]</smiles>

136

entry substrate 135 yield [\%] [\%]

${ }^{a}$ General reaction conditions: $135(0.50 \mathrm{mmol}), 17(2.50 \mathrm{mmol}),\left[\mathrm{RuCl}_{2}(p-\mathrm{cymene})\right]_{2}(5.0 \mathrm{~mol} \%), \mathrm{CsOAc}$ $(0.50 \mathrm{mmol}), 100{ }^{\circ} \mathrm{C}, 18 \mathrm{~h}, \mathrm{O}_{2}(1 \mathrm{~atm})$, yields of isolated products; ${ }^{\mathrm{b}} \mathrm{KOAc}(2.50 \mathrm{mmol})$. 
With the optimized catalytic system in hand, we evaluated the scope of the aerobic $\mathrm{C}-\mathrm{H} / \mathrm{N}-\mathrm{H}$ bond functionalization (Table 27). Ortho-, meta- and para-substituted $N$-tosylbenzamides 135 were efficiently converted into the corresponding isoindolinones 136 . We were pleased to find that various important electrophilic functional groups, such as nitro- or chloro- moieties, were well tolerated under the optimized reaction conditions.

Table 27: Substrate scope for alkenylations of meta- and para-substituted $N$-tosylbenzamides 135 . $^{\text {a }}$<smiles>[R]C=C[AsH2-]NC(=O)c1ccc([R])cc1</smiles>

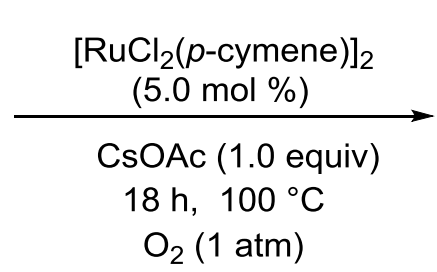

17<smiles>[R]CC1c2cc[R1]([H])cc2C(=O)N1[I-]</smiles>

136
135

entry substrate 135<smiles>O=C(N[I-])c1ccccc1</smiles>

$135 a$<smiles>[3H]NC(=O)c1ccccc1C</smiles>

$135 b$<smiles>O=C(N[13F])c1ccccc1F</smiles>

$135 c$<smiles>O=C(N[TeH])c1ccccc1F</smiles>

$135 c$

4 alkene 17

product 136

yield [\%]<smiles>[B-]N1C(=O)c2ccccc2C1CC(=O)OCC</smiles>

136ae<smiles>CCCCCC1c2cccc(C)c2C(=O)N1[AsH3-]</smiles>

17 e

136be<smiles>C=C[C+]OCC</smiles>

$17 c$<smiles>CCOC(=O)CC1c2cccc(F)c2C(=O)N1[13I]</smiles>

$136 \mathrm{cc}$<smiles>CCCCC1c2cccc(F)c2C(=O)N1[13I-]</smiles><smiles>C=CCOC(=O)OCCC</smiles> 
5<smiles>[3H]NC(=O)c1ccccc1OC</smiles>

$135 d$<smiles>O=C(N[I-])c1ccccc1[N+](=O)[O-]</smiles>

$135 f$<smiles>O=C(N[I-])c1cccc2ccccc12</smiles>

$135 e$<smiles>[3H]NC(=O)c1cccc(C)c1</smiles>

$135 h$

9<smiles>[3H]NC(=O)c1cccc(C)c1</smiles>

$135 \mathrm{~h}$<smiles>[3H]NC(=O)c1cccc(OC)c1</smiles>

$135 i$<smiles>O=C(N[As])c1cccc(C(F)(F)F)c1</smiles>

11<smiles>C=C[C+]O[CH]C</smiles>

17c<smiles>C=C[C+]OCC</smiles>

$17 c$<smiles>C=C[C+]O[Ga]CC</smiles>

17c<smiles>C=CCOCC</smiles>

$17 \mathrm{c}$<smiles>C=CCOC(=O)OCCC</smiles>

17 e<smiles>C=CCOCC</smiles>

$17 c$

$\mathrm{CO}_{2} \mathrm{Et}$<smiles>C=CC(=O)OCC</smiles><smiles>CCOC(=O)CC1c2cccc(OC)c2C(=O)N1[13CH3]</smiles><smiles>CCOC(=O)CC1c2ccc(C(F)(F)F)cc2C(=O)N1[AsH3]</smiles> 
135j

12<smiles>[3H]NC(=O)c1ccc(C)cc1</smiles>

135k

13<smiles>[3H]NC(=O)c1ccc(OC)cc1</smiles>

135I

14<smiles>O=C(N[I-])c1ccc(F)cc1</smiles>

$135 \mathrm{~m}$ 17c<smiles>C=C[C+]O[Mg]CC</smiles>

$17 c$<smiles>C=C[C+]O[C]C</smiles>

17c<smiles>C=COOCC</smiles>

$17 \mathrm{c}$ 136jc<smiles>CCOC(=O)CC1c2cc(C)ccc2C(=O)N1[I-]</smiles>

$136 \mathrm{kc}$<smiles>CCOC(=O)CC1c2cc(OC)ccc2C(=O)N1[AsH]</smiles>

136Ic<smiles>CCOC(=O)CC1c2cc(F)ccc2C(=O)N1[AsH3]</smiles>

$136 \mathrm{mc}$

a General reaction conditions: $135(0.50 \mathrm{mmol}), 17(2.50 \mathrm{mmol}),\left[\mathrm{RuCl}_{2}(p \text {-cymene })\right]_{2}(5.0 \mathrm{~mol} \%), \mathrm{CsOAc}$ $(0.50 \mathrm{mmol}), 100^{\circ} \mathrm{C}, 18 \mathrm{~h}, \mathrm{O}_{2}(1 \mathrm{~atm})$, yields of isolated products. 


\subsubsection{Mechanistic Studies}

\subsubsection{Intermolecular Competition Experiment}

The competition experiment between the meta-substituted trifluoromethyl substrate $135 \mathrm{j}$ and the methyl analogue $135 \mathrm{~h}$ revealed that the electron-rich substrate $135 \mathrm{~h}$ are preferred for this alkene annulation reaction (Scheme 3.18 ). This reactivity pattern is in accordance with the results of previously published oxidative alkyne annulation reactions. ${ }^{59}$

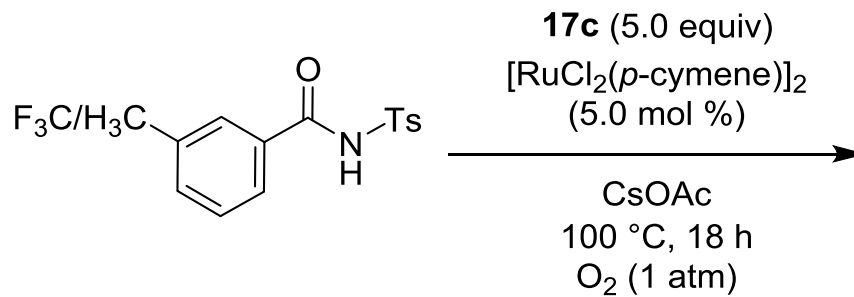

$135 \mathrm{j} / 135 \mathrm{~h}$<smiles>CCOCCC1c2ccc(C(F)(F)F)cc2C(=O)N1[As]</smiles>

136jc: $33 \%$<smiles>CCOC(=O)CC1c2ccc(C)cc2C(=O)N1[AsH3-]</smiles>

136hc: $86 \%$

Scheme 3.18: Intermolecular competition experiment.

\subsubsection{Proposed Catalytic Cycle}

Based on these mechanistic studies we propose the catalytic cycle to involve an initial cycloruthenation with the ruthenium(II) bisacetate complex 147 (Scheme 3.19). Thereby, ruthenacycle 148 is generated, along with two equivalents of acetic acid. Afterwards, coordination and migratory insertion of the alkene 17 results in the seven-membered ruthenacycle 149. The intermediate 150 undergoes $\beta$-hydride elimination, to yield the alkenylated $N$-tosylbenzamide. Thereafter, the nucleophilic cyclization resulted in the desired isoindolinone 136 and water as the sole by-product. Reoxidation of the catalyst ruthenium(0) species with oxygen regenerates the catalytic reactive ruthenium species. 


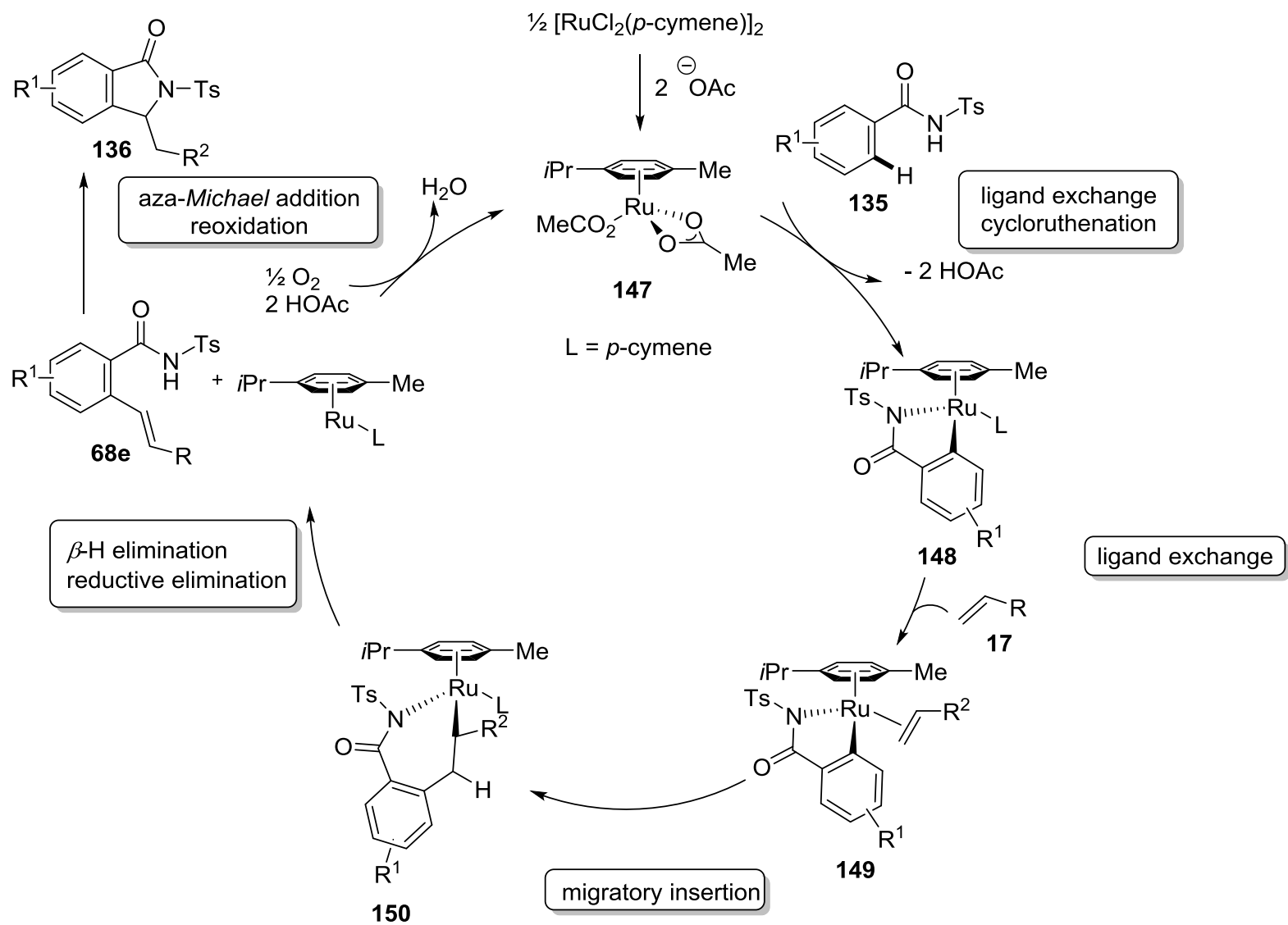

Scheme 3.19: Proposed catalytic cycle for alkene annulation with oxygen.

In summary, this ruthenium(II)-catalyzed oxidative alkenylation reaction is the most economical way to synthesize isoindolinones. In comparison, with the reaction with stoichiometric amounts of $\mathrm{Cu}(\mathrm{OAc})_{2} \cdot \mathrm{H}_{2} \mathrm{O}$ there are advantages and disadvantages. With the ortho-substituted substrates the yield is higher using copper acetate as an oxidant. With the para-substituted substrates the relation is vice versa. In addition, the overall reaction time is shorter for the aerobic reaction. No $\mathrm{Cu}(\mathrm{OAc})$ by-poduct, but an excess of substrate thus far is required. 


\section{Summary and Outlook}

The first project focused on the alkylation of biologically active $N$-aryl-1,2,3-triazoles 123 . In spite of detailed screening efforts, the alkylation of these substrates resulted in only moderate yields, which is due to some interfering side-reactions. Promising results were, however, achieved in the methylation of the $N$-aryl-1,2,3-triazoles 123 (Scheme 4.1).

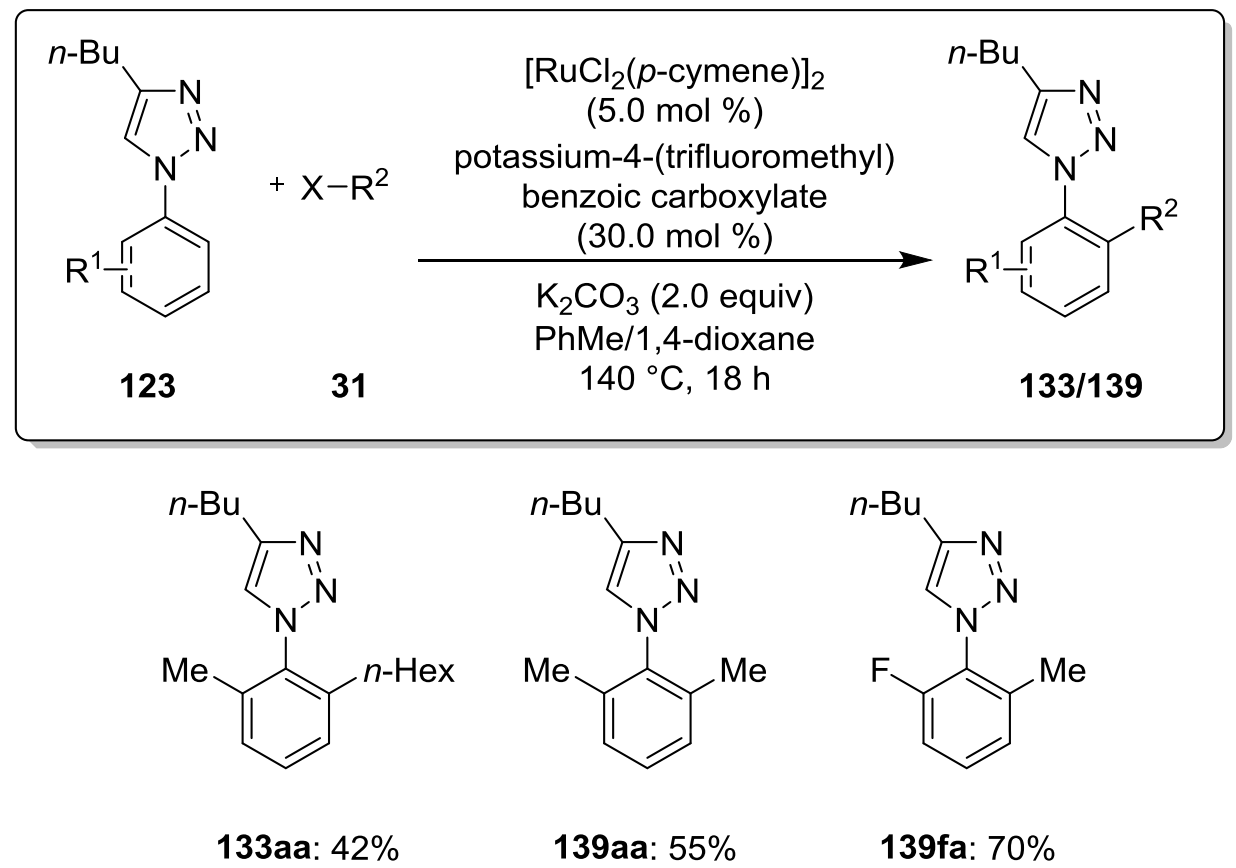

Scheme 4.1: Ruthenium(II)-catalyzed alkylation of $N$-aryl-1,2,3-triazoles.

The main disadvantage of this reaction is the set up, which has to be accomplished under completely inert conditions for yet unknown reason. This renders the reaction less userfriendly and is an aspect that has to be improved. The alkylation reaction with $\beta$-hydrogen containing unactivated alkyl halides remains challenging. Thus, the reaction conditions have to be further optimized.

The second part of this thesis deals with the extension of the ruthenium-catalyzed alkenylation reaction on the pharmaceutical valuable $N$-aryl-1,2,3-triazoles 123 , which could be successfully established. The optimized ruthenium-catalytic system using $\mathrm{Cu}(\mathrm{OAc})_{2} \cdot \mathrm{H}_{2} \mathrm{O}$ monohydrate as the oxidant tolerated various functional groups (Scheme 4.2). ${ }^{109}$ 


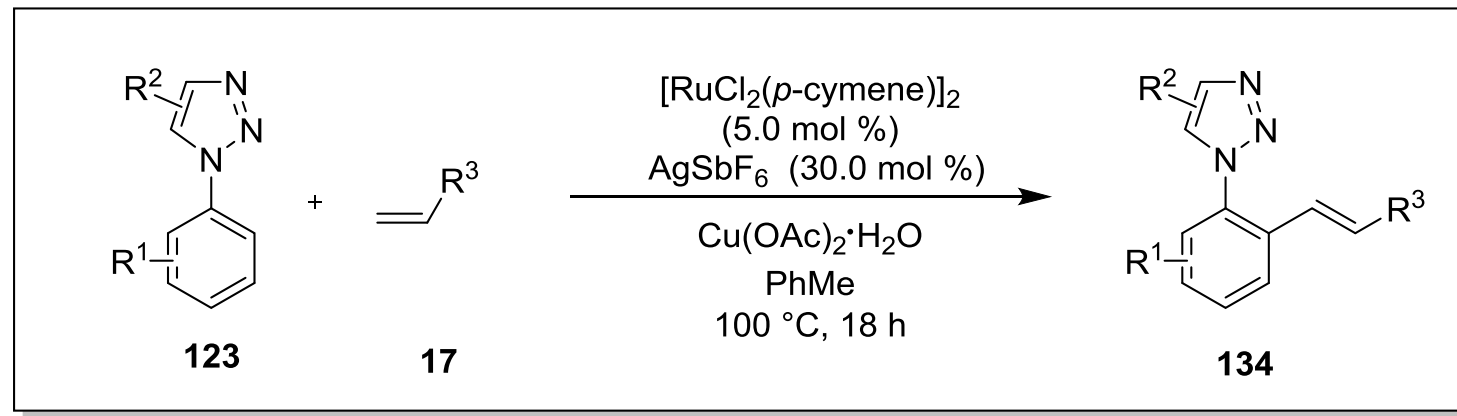<smiles>CCCc1cn(-c2c(C)cccc2C=CC=C(OCC)OCC)nn1</smiles>

134ac: $82 \%$<smiles>CCOC(=CC=Cc1cccc(F)c1-n1cc(CC(C)C)nn1)OCC</smiles>

134fc: $60 \%$<smiles>CCCc1cn(-c2ccccc2C=CC=C(OCC)OCC)nn1</smiles>

134bc: $71 \%$

Scheme 4.2: Ruthenium-catalyzed alkenylation of $\mathrm{N}$-aryl-1,2,3-triazoles.

In the next part, isoindolinones 136 were efficiently synthesized by alkene annulations with acrylates 17 using $N$-tosylbenzamides 135 as the starting materials (Scheme 4.3). Impressively, the reaction could be accomplished with only $1.0 \mathrm{~mol} \%$ of catalyst loading.

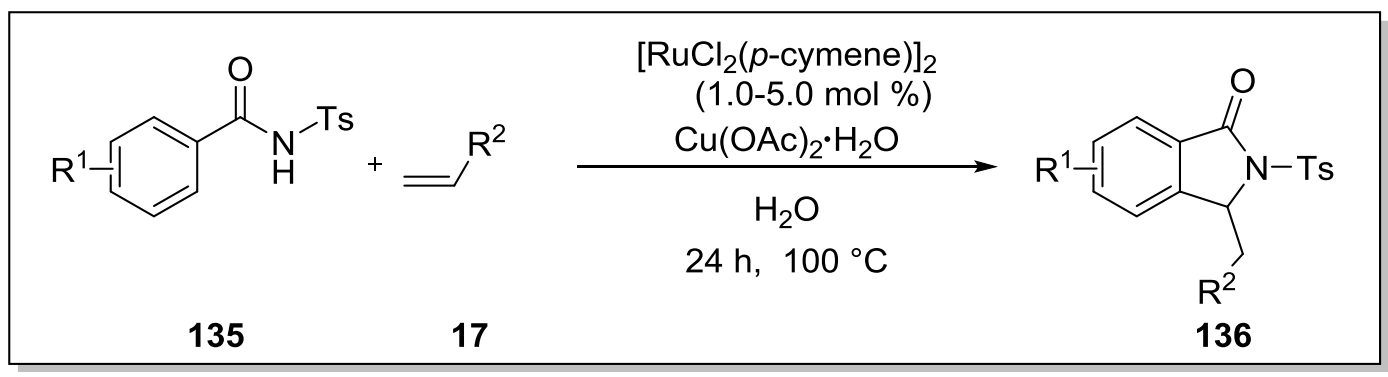<smiles>CCOC(=O)CC1c2cccc(C)c2C(=O)N1[13CH3]</smiles>

$136 \mathrm{bc}$<smiles>CCCCCC1c2cccc(C)c2C(=O)N1[13S]</smiles>

136be<smiles>CCOC(=O)CC1c2cccc(F)c2C(=O)N1[I-]</smiles>

$136 \mathrm{cc}$

$52 \%$ (1.0 mol \% cat.) $\quad 45 \%$ (1.0 mol \% cat.) $\quad 59 \%$ (1.0 mol \% cat.) $64 \%$ (2.0 mol \% cat.) $\quad 67 \%$ (2.0 mol \% cat.) $71 \%(2.5 \mathrm{~mol} \%$ cat. $)$ $74 \%$ (5.0 mol \% cat.) $\quad 88 \%$ (5.0 mol \% cat.) $\quad 78 \%$ (5.0 mol \% cat.)

Scheme 4.3: Ruthenium(II)-catalyzed annulation of $N$-tosylbenzamides.

The $N$-tosyl group of the isoindolinone 136af proofed to be easily cleaved in a traceless fashion to give the free isoindolinones $136 \mathrm{n}$. 
However, this established catalytic system produces $\mathrm{Cu}(\mathrm{OAc})$ as stoichiometric waste and could be even more ecologically, avoiding these by-products. This challenge was addressed in the final part of this thesis. Thus we devised reaction conditions as far the use of the most economical terminal oxidant oxygen for the synthesis of isoindolinones producing water as the sole by-product (Scheme 4.4).

This was achieved under conditions, avoiding the use of solvent waste.

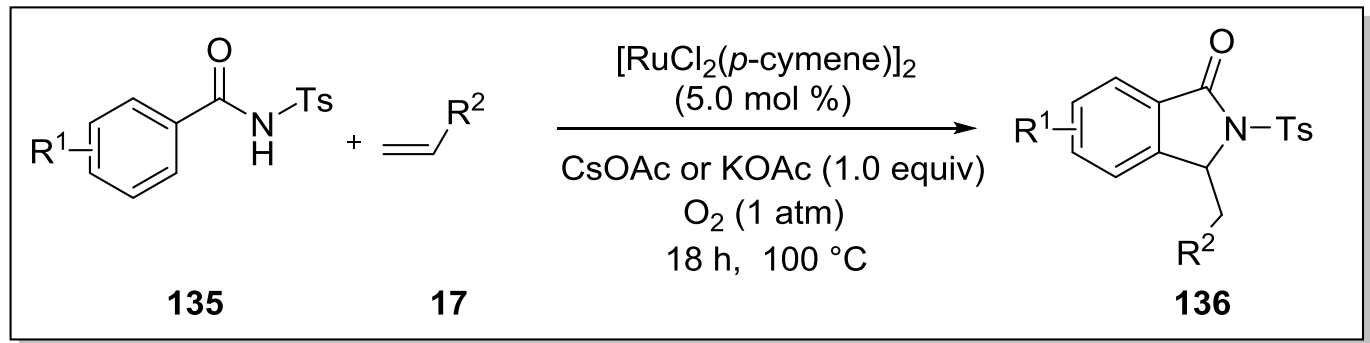<smiles>CCOC(=O)CC1c2cccc(C)c2C(=O)N1[13I]</smiles>

136bc: $68 \%$<smiles>CCOC(=O)CC1c2cccc(F)c2C(=O)N1[13I]</smiles>

136cc: $85 \%$<smiles>CCOC(=O)CC1c2ccc(C)cc2C(=O)N1[AsH3]</smiles>

136c: $65 \%$

Scheme 4.4: Ruthenium(II)-catalyzed annulation of $\mathrm{N}$-tosylbenzamides with oxygen as oxidant. 


\section{Experimental Section}

\subsection{General Remarks}

All reactions involving moisture- or air-sensitive reagents were performed under a $\mathrm{N}_{2}$ atmosphere using pre-dried glassware and standard Schlenk techniques. Syringes for handling of dry solvents were flushed with dry nitrogen threefold prior to their use.

\section{Vacuum}

The following pressures were measured on the used vacuum pump and were not corrected: membrane pump vacuum (MPV): $0.5 \mathrm{mbar}$, oil pump vacuum (OPV): $0.1 \mathrm{mbar}$.

\section{Melting points}

Melting points were measured using a Stuart $^{\circledR}$ Melting Point Apparatus SMP3 from BARLOWORLD SCIENTIFIC. Reported values are uncorrected and are given as a range (M.r.), if the melting did not occurr at a specific melting point (M.p.).

\section{Chromotography}

Analytical thin layer chromatography (TLC) was performed on $0.25 \mathrm{~mm}$ silica gel 60F-plates (MACHERY-NAGEL) with $254 \mathrm{~nm}$ fluorescent indicator from MERCK. Plates were visualized under UV-light. Chromatographic purification of products was accomplished by flash column chromatography on MERCK silica gel, grade 60 (0.040-0.063 mm and 0.063-0.200 mm, 70230 mesh estimated).

\section{Gas Chromatography}

The conversion of the reactions was monitored applying coupled gas chromatography/mass spectrometry using G1800C GCDplus with mass detector HP 5971, 5890 Series // with mass detector HP 5972 from HEWLETT-PACKARD and 7890A GC-System with mass detector 5975C (Triplex-Axis-Detector) from AGILENT TECHNOLOGIES equipped with HP-5MS columns $(30 \mathrm{~m} \times 0.25 \mathrm{~mm} \times 0.25 \mu \mathrm{m})$ were used. 


\section{Nuclear Magnetic Resonance Spectroscopy}

Nuclear magnetic resonance (NMR) spectroscopy was performed at 250,300 or $600 \mathrm{MHz}$ ( $\left.{ }^{1} \mathrm{H}-\mathrm{NMR}\right), 75.5$ or $125 \mathrm{MHz}\left({ }^{13} \mathrm{C}-\mathrm{NMR}, \mathrm{APT}\right)$ and $282 \mathrm{MHz}\left({ }^{19} \mathrm{~F}-\mathrm{NMR}\right)$ on BRUKER AM 250, VARIAN Unity-300 and Inova 500 instruments. Chemical shifts are reported as $\delta$-values in ppm relative to the residual proton peak of the deuterated solvent or its carbon atom, respectively, or the standard trimethylsilyl (TMS) peak.

$\begin{array}{lll} & { }^{1} \mathrm{H}-\mathrm{NMR} & { }^{13} \mathrm{C}-\mathrm{NMR} \\ \mathrm{CDCl}_{3}: & 7.26 \mathrm{ppm} & 77.0 \mathrm{ppm} \\ \text { DMSO-D }_{6}: & 249 \mathrm{ppm} & 49.5 \mathrm{ppm}\end{array}$

For characterization of the observed resonance multiplicities the following abbrevationsd were applied: s (singlet), $\mathrm{t}$ (triplet), $\mathrm{q}$ (quartet), $\mathrm{m}$ (multiplet), dd (doublet of doublet), td (doublet of triplet), or analogue representations. The coupling constants $J$ are given in Hertz $(\mathrm{Hz})$.

\section{Infrared spectroscopy}

Infrared spectra were recorded on a BRUKER Alpha-P ATR-spectrometer. Liquid probes have been measured as film and solid probes neat. Analysis of the spectral data has been done by using the OPUS 3.1 software from BRUKER, respectively OPUS 6. Absorption $(\tilde{v})$ is given in wave numbers $\left(\mathrm{cm}^{-1}\right)$. Spectra were recorded in the range of 4000 to $400 \mathrm{~cm}^{-1}$.

\section{Mass spectrometry}

El- and El-HR-MS spectra were measured on a Time-of-Flight mass spectrometer AccuTOF from JOEL. ESI-mass spectra were recorded on an Ion-Trap mass spectrometer LCQ from FINNIGAN or on a Time-of Flight mass spectrometer microTOF from BRUKER. ESI-HR-MS spectra were recorded on a BRUKER APEXIV or a BRUKER DALTONIC (7T, Transform Ion Cyclotron Resonance (FTCIR)) mass spectrometer. The ratios of mass to charge are indicated, intensities relative to the base peak $(I=100)$ are written in parentheses. 


\section{Solvents}

All solvents for reactions involving moisture-sensitive reagents were dried, distilled and stored under inert atmosphere (argon or nitrogen) according to the following standard procedures.

Solvent

tert-Amylalcohol

Dichloromethane

$N, N$-Dimethylformamide

N-Methyl-2-pyrrolidine

Methanol

Tetrahydrofuran

Toluene

Water

\section{1,4-Dioxane}

\section{drying Method}

was stirred over $\mathrm{Na}$ chips for $5 \mathrm{~h}$ at $120^{\circ} \mathrm{C}$ and distilled under ambient pressure.

was purified using a solvent purification system (SPS) from MBRAUN.

was dried over $\mathrm{CaH}_{2}$ for $8 \mathrm{~h}$, degassed and distilled under reduced pressure.

was stirred for $4 \mathrm{~h}$ at $150{ }^{\circ} \mathrm{C}$ over $\mathrm{CaH}_{2}$ and subsequently distilled under reduced pressure

was stirred over $\mathrm{Mg}$ chips for $3 \mathrm{~h}$ at $65^{\circ} \mathrm{C}$ prior distillation.

was purified using SPS solvent purification system from MBRAUN.

was either pre-dried over $\mathrm{KH}$ followed by distillation from sodium benzophenone ketyl or purified using a solvent purification system MBRAUN.

was degassed before its use applying repeated Freeze-PumpThaw degassing procedure.

was dried by distillation from sodium benzophenone ketyl.

\section{Reagents}

Chemicals obtained from commercial sources with purity above $95 \%$ were used without purification.

The following compounds were synthesized according to known literature procedures and were pure by comparison with the published analytical data:

Potassium 4-(trifluormethyl)benzoate $137,{ }^{110}$ potassium-3-(trifluoromethyl)benzoate, ${ }^{111}$ $N$-aryl-1,2,3-triazoles $123,{ }^{111}$ 1-phenyl-1H-benzo[d][1,2,3]triazole $123 r,{ }^{112}$ 3-iodo-1-methyl-

\footnotetext{
110 L. J. Gooßen, N. Rodríguez, P. P. Lange, C. Linder, Angew. Chem. Int. Ed. 2010, 49, 1111-1114

111 J. Andersen, S. Bolving, X. Liang, Synlett, 2005, 19, 2941-2947.

112 L. Alakonda, M. Periasamy, Synthesis, 2012, 44, 1063-1068.
} 
$1 H$-indole $\quad 123 q,{ }^{113} \quad N$-tosylbenzamides $\quad 135,{ }^{114} \quad N$-methyl- $N$-tosylacetamide, ${ }^{115}$

$\mathrm{N}$-tosylacetamide, ${ }^{116}$ methyl 4-methylbenzenesulfonate. ${ }^{117}$

The following compounds were used with the kind permission of the persons named below:

Karsten Rpauch: $\left[\mathrm{RuCl}_{2}(p \text {-cymene })\right]_{2}$, $\left[\mathrm{Ru}\left(\mathrm{O}_{2} \mathrm{CMes}\right)_{2}(p\right.$-cymene $\left.)\right]$.

Dr. Jie Li: Pivaloylalanine

Dr. Marvin Schinkel: $\mathrm{KO}_{2} \mathrm{CAd}$.

Dr. Karolina Graczyk: $\mathrm{KO}_{2} \mathrm{CMes}$.

Dr. Emelyne Diers: Diethyl vinylphosphonate.

Prof. Dr. Ingo Krossing, Freiburg University: $\left.\operatorname{Ag}\left[\mathrm{Al}\left(\mathrm{OC}_{2} \mathrm{CF}_{3}\right\}_{3}\right)_{4}\right]$.

\footnotetext{
${ }^{113}$ (a) V. Bocchi, G. Palla, Synthesis 1982, 1096; (b) F. De Simone, T. Saget, F. Benfatti, S. Almeida, J. Waser, Chem. Eur. J. 2011, 17, 14527-14538.

114 F. Peron, Chem. Eur. J. 2014, 20, 7507-7513

${ }^{115}$ Y. Inamoto, Y. Kaga, Y. Nishimoto, M. Yasuda, A. Baba, Org. Lett. 2013, 15, 3452-3455.

${ }_{116}$ M. V. Pham, B. Ye, N. Cramer, Angew. Chem . Int. Ed. 2012, 51, 10610-10614.

${ }^{117}$ A. R. Massah, M. Javaherian, F. Kazemi, Tetrahedron, 2007, 63, 5083-5087.
} 


\subsection{General Procedures}

\section{General Procedure A: Copper-Catalyzed Synthesis of 1,4-Disubstituted Triazoles 123}

To a solution of $\mathrm{DMSO} / \mathrm{H}_{2} \mathrm{O}(3 \mathrm{~mL} / \mathrm{mmol}, 5: 1)$, sodium azide (1.1 equiv), aryliodide (1) (1.0 equiv), 1-hexyne (1.0 equiv), Cul (10.0 mol \%), sodium ascorbate $(10.0 \mathrm{~mol} \%)$ and $N, N$-dimethylendiamine $(15.0 \mathrm{~mol} \%)$ were added sequentially. The mixture was stirred over night at $55^{\circ} \mathrm{C} . \mathrm{H}_{2} \mathrm{O}(5 \mathrm{~mL} / \mathrm{mmol})$ and $\mathrm{CH}_{2} \mathrm{Cl}_{2}(5 \mathrm{~mL} / \mathrm{mmol})$ were added to the reaction mixture. The separated aqueous phase was extracted with $\mathrm{CH}_{2} \mathrm{Cl}_{2}(2 \times 25 \mathrm{~mL} / \mathrm{mmol})$. The combined organic layers were washed with $\mathrm{H}_{2} \mathrm{O}$ and a mixture of sat. aq. $\mathrm{NH}_{4} \mathrm{Cl} / \mathrm{NH}_{3}(1: 1)$ until the disappearance of the blue color, as well as washed with brine $(50 \mathrm{~mL})$, dried over $\mathrm{Na}_{2} \mathrm{SO}_{4}$ and concentrated under reduced pressure. The remaining residue was purified by column chromatography on silica gel ( $n$-hexane/EtOAc) to yield the triazoles 123.

\section{General Procedure B: General Procedure for the Preparation of Substituted N-Tosylbenzamides 135}

Oxalylchloride (1.2 equiv) and DMF (1 drop) were added to a stirred solution of acid (1.1 equiv) in dry toluene $(0.8 \mathrm{~mL} / \mathrm{mmol})$ under a nitrogen atmosphere at $0{ }^{\circ} \mathrm{C}$. The reaction mixture was stirred at ambient temperature until no bubbles were observed. The reaction mixture was directly used in the next step.

The acid chloride in dry toluene was added dropwise over 15 min to a stirred solution of $p$ toluene sulfonamide (1.0 equiv), $\mathrm{NEt}_{3}$ (2.5 equiv) and DMAP (0.5 mol \%) in EtOAc $(2 \mathrm{~mL} / \mathrm{mmol})$. The reaction mixture was stirred at $55{ }^{\circ} \mathrm{C}$ for $1 \mathrm{~h}$ under a nitrogen atmosphere, cooled to ambient temperature and quenched with a solution of aqueous $\mathrm{HCl}(0.5 \mathrm{M}$, $3 \mathrm{~mL} / \mathrm{mmol})$. The resulting mixture was then extracted with EtOAc $(3 \times 50 \mathrm{~mL})$. The combined organic layers were dried over $\mathrm{MgSO}_{4}$, filtered and the solvent was evaporated under reduced pressure. The residue was purified by passing through a pad of silica gel, eluting with $\mathrm{CH}_{2} \mathrm{Cl}_{2}$ and concentrated under reduced pressure. The residue was purified by recrystallization in EtOH to give the tosylamides 135 .

Representative Procedure C: Ruthenium(II)-Catalyzed Alkylation of Substituted N-Aryl1,2,3-triazoles 133

A suspension of $\mathrm{N}$-aryl-1,2,3-triazoles 123 (1.00 mmol, 1.0 equiv), alkyl bromide 40 (3.00 mmol, 3.0 equiv), $\quad\left[\operatorname{RuCl}_{2}(p \text {-cymene })\right]_{2} \quad(30.5 \mathrm{mg}, \quad 0.05 \mathrm{mmol}, \quad 5.0 \mathrm{~mol} \%), \quad \mathrm{K}_{2} \mathrm{CO}_{3}$ (267.0 mg, $2.00 \mathrm{mmol}, 2.0$ equiv) and 4-(trifluormethyl)benzoate $(68.9 \mathrm{mg}, 0.30 \mathrm{mmol}$, 
$30.0 \mathrm{~mol} \%$ ) in 1,4-dioxane $(4 \mathrm{~mL})$, was stirred at $140{ }^{\circ} \mathrm{C}$ for $18 \mathrm{~h}$ under $\mathrm{N}_{2}$. At ambient temperature, the reaction mixture was concentrated in vacuo. The crude product was purified by column chromatography on silica gel ( $n$-pentane/EtOAc).

Representative Procedure D: Ruthenium(II)-Catalyzed Methylation of Substituted N-Aryl-1,2,3-triazoles 139

In a pre-dried sealed tube, $N$-aryl-1,2,3-triazoles 123 (1.00 mmol, 1.0 equiv), methyl iodide 41a (442 mg, $3.00 \mathrm{mmol}, 3.0$ equiv), $\left[\mathrm{RuCl}_{2}(p \text {-cymene) }]_{2}(30.5 \mathrm{mg}, 0.05 \mathrm{mmol}, 5.0 \mathrm{~mol} \%)\right.$, $\mathrm{K}_{2} \mathrm{CO}_{3}(267.0 \mathrm{mg}, 2.00 \mathrm{mmol}, 2.0$ equiv) and 4-(trifluormethyl)benzoate $(68.9 \mathrm{mg}, 0.30 \mathrm{mmol}$, $30.0 \mathrm{~mol} \%)$ in 1,4-dioxane $(4 \mathrm{~mL})$ or toluene $(4 \mathrm{~mL})$, were set up in the glovebox. The reaction mixture was stirred at $140{ }^{\circ} \mathrm{C}$ for $18 \mathrm{~h}$ under $\mathrm{N}_{2}$ atmosphere. At ambient temperature, the reaction mixture was concentrated in vacuo. The crude product was purified by column chromatography on silica gel ( $n$-pentane/EtOAc).

\section{Representative Procedure E: Ruthenium(II)-Catalyzed Oxidative Alkenylation with Substituted N-Aryl-1,2,3-triazoles 134}

A suspension of $N$-aryl-1,2,3-triazoles 123 (1.00 mmol, 1.0 equiv), acrylate 17 (1.5-3.0 equiv), $\quad\left[\mathrm{RuCl}_{2}(p \text {-cymene })\right]_{2} \quad(30.5 \mathrm{mg}, \quad 5.0 \mathrm{~mol} \%), \quad \mathrm{Cu}(\mathrm{OAc})_{2} \cdot \mathrm{H}_{2} \mathrm{O} \quad(239.8 \mathrm{mg}$, $1.20 \mathrm{mmol})$ and $\mathrm{AgSbF}_{6}(103.0 \mathrm{mg}, 30.0 \mathrm{~mol} \%)$ in toluene $(4 \mathrm{~mL})$, was stirred at $100{ }^{\circ} \mathrm{C}$ for $18 \mathrm{~h}$ under $\mathrm{N}_{2}$. At ambient temperature, the reaction mixture was diluted with sat. aq. $\mathrm{NH}_{4} \mathrm{Cl} / \mathrm{NH}_{3}(1: 1,10 \mathrm{~mL})$ and extracted with $\mathrm{CH}_{2} \mathrm{Cl}_{2}(3 \times 25 \mathrm{~mL})$. The combined organic layers were dried over $\mathrm{Na}_{2} \mathrm{SO}_{4}$. After filtration and evaporation of the solvents in vacuo, the crude product was purified by column chromatography on silica gel ( $n$-pentane/EtOAc).

\section{Representative Procedure F: Synthesis of Isoindolinones 136 via Ruthenium(II)- Catalyzed C-H/N-O-Bond Functionalization}

A suspension of $N$-tosylbenzamides 135 (1.00 mmol, 1 equiv), acrylate 17 (1.50-3.00 mmol, 1.5-3.0 equiv), $\left[\mathrm{RuCl}_{2}(p \text {-cymene })\right]_{2}(0.01-0.05 \mathrm{mmol}, 1.0-5.0 \mathrm{~mol} \%)$ and $\mathrm{Cu}(\mathrm{OAc})_{2} \cdot \mathrm{H}_{2} \mathrm{O}$ (419.7 mg, 2.10 mmol, 2.1 equiv) in $\mathrm{H}_{2} \mathrm{O}(5 \mathrm{~mL})$, was stirred at $100{ }^{\circ} \mathrm{C}$ for $24 \mathrm{~h}$ under air. At ambient temperature, the reaction mixture was diluted with sat. aq. $\mathrm{NH}_{4} \mathrm{Cl} / \mathrm{NH}_{3}(1: 1,10 \mathrm{~mL})$ and EtOAc $(10 \mathrm{~mL})$. The separated aqueous phase was extracted with EtOAc $(2 \times 25 \mathrm{~mL} / \mathrm{mmol})$. The combined organic layers were washed with $\mathrm{H}_{2} \mathrm{O}$ and a mixture of sat. aq. $\mathrm{NH}_{4} \mathrm{Cl} / \mathrm{NH}_{3}(1: 1)$ until the disappearance of the blue color, as well as with brine $(50 \mathrm{~mL})$ 
and dried over $\mathrm{Na}_{2} \mathrm{SO}_{4}$. After filtration and evaporation of the solvents in vacuo, the crude product was purified by column chromatography on silica gel ( $n$-hexane/EtOAc).

Representative Procedure G: Synthesis of Isoindolinones 136 via Aerobic Ruthenium(II)-Catalyzed C-H/N-O-Bond Functionalization

A suspension of $N$-tosylbenzamides 135 (1.00 mmol, 1 equiv), acrylate 17 (5.00 mmol, 5.0 equiv), $\left[\mathrm{RuCl}_{2}(p \text {-cymene })\right]_{2}(30.5 \mathrm{mg}, 0.05 \mathrm{mmol}, 5.0 \mathrm{~mol} \%)$ and MOAc (1.00 mmol, 1.0 equiv) was stirred at $100{ }^{\circ} \mathrm{C}$ for $18 \mathrm{~h}$ under an oxygen atmosphere. At ambient temperature, the reaction mixture was concentrated in vacuo. The crude product was purified by column chromatography on silica gel ( $n$-pentane/EtOAc). At ambient temperature, the reaction mixture was concentrated in vacuo. The crude product was purified by column chromatography on silica gel ( $n$-pentane/EtOAc). 


\subsection{Experimental Procedures and Analytical Data}

\subsubsection{Synthesis of $\mathbf{N}$-Aryl-1,2,3-triazoles}

\section{Synthesis of 4-n-Butyl-1-(o-tolyl)-1H-1,2,3-triazole (123a):}<smiles>CCCCc1cn(-c2ccccc2C)nn1</smiles>

The general procedure A was followed using 1-iodo-2-methylbenzene (1d) (4.36 g, 20 $\mathrm{mmol}$ ), 1-hexyne (1.64 g, $20.0 \mathrm{mmol}), \mathrm{NaN}_{3}(1.36 \mathrm{~g}, 21.0 \mathrm{mmol})$, Cul $(0.38 \mathrm{~g}, 2.0 \mathrm{mmol}$ ) and DMEDA $(0.26 \mathrm{~g}, 3.0 \mathrm{mmol})$. Purification by column chromatography ( $n$-pentane/EtOAc 5/1) yielded $123 \mathrm{a}(2.94 \mathrm{~g}, 63 \%)$ as a colorless oil.

${ }^{1} \mathrm{H}-\mathrm{NMR}\left(300 \mathrm{MHz}, \mathrm{CDCl}_{3}\right): \delta=7.46(\mathrm{~s}, 1 \mathrm{H}), 7.43-7.27(\mathrm{~m}, 4 \mathrm{H}), 2.90-2.73(\mathrm{~m}, 2 \mathrm{H}), 2.20(\mathrm{~s}$, $3 \mathrm{H}), 1.83-1.63(\mathrm{~m}, 2 \mathrm{H}), 1.54-1.35(\mathrm{~m}, 2 \mathrm{H}), 0.96(\mathrm{t}, J=7.3 \mathrm{~Hz}, 3 \mathrm{H})$.

${ }^{13} \mathrm{C}-\mathrm{NMR}\left(125 \mathrm{MHz}, \mathrm{CDCl}_{3}\right): \delta=148.3\left(\mathrm{C}_{\mathrm{q}}\right), 136.9\left(\mathrm{C}_{\mathrm{q}}\right), 133.8\left(\mathrm{C}_{\mathrm{q}}\right), 131.5(\mathrm{CH}), 129.7(\mathrm{CH})$, $126.9(\mathrm{CH}), 126.1(\mathrm{CH}), 122.4(\mathrm{CH}), 31.6\left(\mathrm{CH}_{2}\right), 25.4\left(\mathrm{CH}_{2}\right), 22.5\left(\mathrm{CH}_{2}\right), 18.0\left(\mathrm{CH}_{3}\right), 14.0$ $\left(\mathrm{CH}_{3}\right)$.

IR (ATR): $\tilde{v}=2956,2929,2860,1552,1502,1214,1117,1039,988,760 \mathrm{~cm}^{-1}$.

MS (ESI) $m / z$ (relative intensity): $238(2)\left[\mathrm{M}+\mathrm{Na}^{+}\right], 216(100)\left[\mathrm{M}+\mathrm{H}^{+}\right]$.

HR-MS (ESI) $m / z$ calcd for $\mathrm{C}_{13} \mathrm{H}_{18} \mathrm{~N}_{3},\left[\mathrm{M}+\mathrm{H}^{+}\right]$216.1495, found 216.1507.

The spectral data are in accordance with those reported in the literature. ${ }^{15 c}$

Synthesis of 4-n-Butyl-1-phenyl-1H-1,2,3-triazole (123b)<smiles>CCCc1cn(-c2ccccc2)nn1</smiles>

The general procedure A was followed using 1-iodo-benzene (1e) $(2.01 \mathrm{~g}, 10.0 \mathrm{mmol})$, 1-hexyne $(0.82 \mathrm{~g}, 10.0 \mathrm{mmol}), \mathrm{NaN}_{3}(0.68 \mathrm{~g}, 10.5 \mathrm{mmol})$, Cul $(0.38 \mathrm{~g}, 1.0 \mathrm{mmol})$ and 
DMEDA ( $0.26 \mathrm{~g}, 1.5 \mathrm{mmol})$. Purification by column chrommatography ( $n$-pentane/EtOAc 5/1) yielded $123 \mathrm{~b}(1.57 \mathrm{~g}, 78 \%)$ as a colorless solid.

M.r.: $58-59^{\circ} \mathrm{C}$.

${ }^{1} \mathrm{H}-\mathrm{NMR}\left(300 \mathrm{MHz}, \mathrm{CDCl}_{3}\right): \delta=7.86-7.33(\mathrm{~m}, 6 \mathrm{H}), 2.55(\mathrm{t}, J=7.4 \mathrm{~Hz}, 2 \mathrm{H}), 1.53-1.35(\mathrm{~m}$, $4 \mathrm{H}), 0.88(\mathrm{t}, J=7.3 \mathrm{~Hz}, 3 \mathrm{H})$

${ }^{13} \mathrm{C}-\mathrm{NMR}\left(100 \mathrm{MHz}, \mathrm{CDCl}_{3}\right): \delta=151.3\left(\mathrm{C}_{\mathrm{q}}\right), 130.5\left(\mathrm{C}_{\mathrm{q}}\right), 128.5(\mathrm{CH}), 127.9(\mathrm{CH}), 126.6(\mathrm{CH})$, $119.4(\mathrm{CH}), 50.1\left(\mathrm{CH}_{2}\right), 32.4\left(\mathrm{CH}_{2}\right), 19.7\left(\mathrm{CH}_{2}\right), 14.4\left(\mathrm{CH}_{3}\right)$.

IR (ATR): $\tilde{v}=3109,2988,2845,1576,1475,1135,789,684 \mathrm{~cm}^{-1}$.

MS (ESI) $m / z$ (relative intensity): $202(100)\left[\mathrm{M}+\mathrm{H}^{+}\right]$.

HR-MS (EI) $m / z$ calcd for $\mathrm{C}_{16} \mathrm{H}_{9} \mathrm{~N}_{3}$, [M+] 188.1188, found 243.1184 .

The spectral data are in accordance with those reported in the literature. ${ }^{118}$

\section{Synthesis of 4-n-Butyl-1-(m-tolyl)-1H-1,2,3-triazole (123c)}<smiles>CCCCc1cn(-c2cccc(C)c2)nn1</smiles>

The general procedure A was followed using 1-iodo-3-methylbenzene (1f) $(4.36 \mathrm{~g}, 20 \mathrm{mmol}$ ), 1-hexyne (1.64 g, $20.0 \mathrm{mmol}), \mathrm{NaN}_{3}(1.36 \mathrm{~g}, 21.0 \mathrm{mmol})$, Cul $(0.38 \mathrm{~g}, 2.0 \mathrm{mmol})$ and DMEDA $(0.26 \mathrm{~g}, 3.0 \mathrm{mmol})$. Purification by column chromatography ( $n$-pentane/EtOAc 5/1) yielded $123 \mathrm{c}(2.94 \mathrm{~g}, 63 \%)$ as an orange solid.

M.r.: $44-45^{\circ} \mathrm{C}$.

${ }^{1} \mathrm{H}-\mathrm{NMR}\left(300 \mathrm{MHz}, \mathrm{CDCl}_{3}\right): \delta=7.70(\mathrm{~s}, 1 \mathrm{H}), 7.55-7.18(\mathrm{~m}, 1 \mathrm{H}), 7.49-7.41(\mathrm{~m}, 1 \mathrm{H}), 7.33(\mathrm{dd}$, $J=7.8,7.8 \mathrm{~Hz}, 1 \mathrm{H}), 7.20-7.15(\mathrm{~m}, 1 \mathrm{H}), 2.82-2.70(\mathrm{~m}, 2 \mathrm{H}), 2.40(\mathrm{~s}, 3 \mathrm{H}), 1.77-1.52(\mathrm{~m}, 2 \mathrm{H})$, 1.40 (dq, $J=14.5,7.3 \mathrm{~Hz}, 2 \mathrm{H}), 0.93(\mathrm{t}, J=7.3 \mathrm{~Hz}, 3 \mathrm{H})$.

${ }^{13} \mathrm{C}-\mathrm{NMR}\left(125 \mathrm{MHz}, \mathrm{CDCl}_{3}\right): \delta=149.1\left(\mathrm{C}_{\mathrm{q}}\right), 139.9\left(\mathrm{C}_{\mathrm{q}}\right), 137.3\left(\mathrm{C}_{\mathrm{q}}\right), 129.5(\mathrm{CH}), 129.2(\mathrm{CH})$, $121.1(\mathrm{CH}), 118.9(\mathrm{CH}), 117.5(\mathrm{CH}), 31.6\left(\mathrm{CH}_{2}\right), 25.5\left(\mathrm{CH}_{2}\right), 22.4\left(\mathrm{CH}_{2}\right), 21.5\left(\mathrm{CH}_{3}\right), 13.7$ $\left(\mathrm{CH}_{3}\right)$.

IR (ATR): $\tilde{v}=3123,2931,1591,1494,1225,1046,903,851,828,784 \mathrm{~cm}^{-1}$.

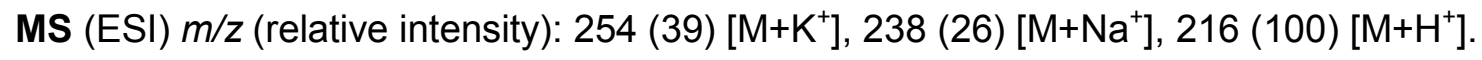

HR-MS (ESI) $m / z$ calcd for $\mathrm{C}_{13} \mathrm{H}_{18} \mathrm{~N}_{3},\left[\mathrm{M}+\mathrm{H}^{+}\right]$216.1495, found 216.1502 .

${ }_{118}$ Y. D. Bidal, M. Lesieur, M. Melaimi, D. B. Cordes, A. M. Z. Slawin, G. Bertrand, C. S. J. Cazin, Chem. Commun. 2015, 51, 4778-4781. 


\section{Synthesis of 4-n-Butyl-1-(3-methoxyphenyl)-1H-1,2,3-triazole (123d)}<smiles>CCCCc1cn(-c2cccc(OC)c2)nn1</smiles>

The general procedure A was followed using 1-iodo-3-methoxybenzene $(\mathbf{1 g})(2.18 \mathrm{~g}$, $9.3 \mathrm{mmol}$ ), 1-hexyne (0.82 g, $10.0 \mathrm{mmol}), \mathrm{NaN}_{3}(0.68 \mathrm{~g}, 10.5 \mathrm{mmol})$, Cul $(0.38 \mathrm{~g}, 1.0 \mathrm{mmol})$ and DMEDA ( $0.26 \mathrm{~g}, 1.5 \mathrm{mmol})$. Purification by column chrommatography ( $n$-pentane/EtOAc $5 / 1)$ yielded $123 \mathrm{~d}(2.00 \mathrm{~g}, 93 \%)$ as a colorless oil.

${ }^{1} \mathrm{H}-\mathrm{NMR}\left(300 \mathrm{MHz}, \mathrm{CDCl}_{3}\right): \delta=7.70(\mathrm{~s}, 1 \mathrm{H}), 7.36(\mathrm{dd}, J=8.1,8.1 \mathrm{~Hz}, 1 \mathrm{H}), 7.31(\mathrm{dd}, J=2.3$, $2.3 \mathrm{~Hz}, 1 \mathrm{H}$ ), 7.24-7.18 (m, 1H), 6.91 (ddd, $J=8.3,2.5,0.9 \mathrm{~Hz}, 1 \mathrm{H}$ ), $3.84(\mathrm{~s}, 3 \mathrm{H}), 2.88-2.62$ (m, 2H), 1.77-1.59 (m, 2H), 1.40 (ddt, $J=14.5,9.3,7.3 \mathrm{~Hz}, 2 \mathrm{H}), 0.93(\mathrm{t}, J=7.3 \mathrm{~Hz}, 3 \mathrm{H}$ ).

${ }^{13} \mathrm{C}-\mathrm{NMR}\left(125 \mathrm{MHz}, \mathrm{CDCl}_{3}\right): \delta=160.6\left(\mathrm{C}_{\mathrm{q}}\right), 149.2\left(\mathrm{C}_{\mathrm{q}}\right), 138.4\left(\mathrm{C}_{\mathrm{q}}\right), 130.5(\mathrm{CH}), 119.0(\mathrm{CH})$, $114.3(\mathrm{CH}), 112.3(\mathrm{CH}), 106.3(\mathrm{CH}), 55.7\left(\mathrm{CH}_{3}\right), 31.6\left(\mathrm{CH}_{2}\right), 25.4\left(\mathrm{CH}_{2}\right), 22.4\left(\mathrm{CH}_{2}\right), 13.9$ $\left(\mathrm{CH}_{3}\right)$.

IR (ATR): $\tilde{v}=2955,2929,2859,1608,1595,1497,1461,1292,1255,1155 \mathrm{~cm}^{-1}$.

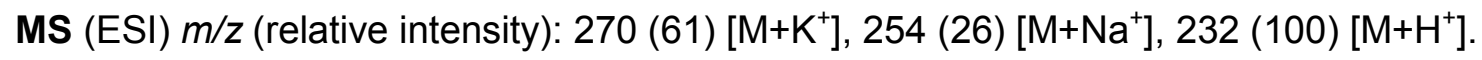

HR-MS (ESI) $m / z$ calcd for $\mathrm{C}_{13} \mathrm{H}_{18} \mathrm{~N}_{3} \mathrm{O},\left[\mathrm{M}+\mathrm{H}^{+}\right]$232.1444, found 232.1436.

\section{Synthesis of 4-n-Butyl-1-(3-fluorophenyl)-1H-1,2,3-triazole (123e)}<smiles>CC(C)(C)c1cn(-c2cccc(F)c2)nn1</smiles>

The general procedure A was followed using 1-fluoro-3-iodobenzene (1h) $(4.40 \mathrm{~g}$, $20.0 \mathrm{mmol}$ ), 1-hexyne (1.64 g, $20.0 \mathrm{mmol}), \mathrm{NaN}_{3}$ (1.36 g, $\left.21.0 \mathrm{mmol}\right)$, Cul (0.38 g, $\left.2.0 \mathrm{mmol}\right)$ and DMEDA $(0.26 \mathrm{~g}, 3.0 \mathrm{mmol})$. Purification by column chromatography ( $n$-pentane/EtOAc $5 / 1$ ) yielded $123 \mathrm{e}(3.77 \mathrm{~g}, 86 \%)$ as an orange solid.

M.p.: $41^{\circ} \mathrm{C}$. 
${ }^{1} \mathrm{H}-\mathrm{NMR}\left(300 \mathrm{MHz}, \mathrm{CDCl}_{3}\right): \delta=7.72(\mathrm{~s}, 1 \mathrm{H}), 7.54-7.38(\mathrm{~m}, 3 \mathrm{H}), 7.16-7.02(\mathrm{~m}, 1 \mathrm{H}), 2.86-$ $2.68(\mathrm{~m}, 2 \mathrm{H}), 1.70$ (dddd, $J=8.7,7.5,7.0,5.8 \mathrm{~Hz}, 2 \mathrm{H}), 1.52-1.29(\mathrm{~m}, 2 \mathrm{H}), 0.93(\mathrm{t}$, $J=7.3 \mathrm{~Hz}, 3 \mathrm{H})$.

${ }^{13} \mathrm{C}-N M R\left(125 \mathrm{MHz}, \mathrm{CDCl}_{3}\right): \delta=163.2\left({ }^{1} \mathrm{~J}_{\mathrm{C}-\mathrm{F}}=248.4 \mathrm{~Hz}, \mathrm{C}_{\mathrm{q}}\right), 149.3\left(\mathrm{C}_{\mathrm{q}}\right), 138.5$ $\left({ }^{3} J_{C-F}=10.1 \mathrm{~Hz}, C_{q}\right), 131.1\left({ }^{3} J_{C-F}=9.0 \mathrm{~Hz}, \mathrm{CH}\right), 118.7(\mathrm{CH}), 115.7\left({ }^{4} J_{C-F}=3.3 \mathrm{~Hz}, \mathrm{CH}\right), 115.3$ $\left({ }^{2} J_{\mathrm{C}-\mathrm{F}}=21.2 \mathrm{~Hz}, \mathrm{CH}\right), 108.1\left({ }^{2} J_{\mathrm{C}-\mathrm{F}}=26.3 \mathrm{~Hz}, \mathrm{CH}\right), 31.3\left(\mathrm{CH}_{2}\right), 25.2\left(\mathrm{CH}_{2}\right), 22.2\left(\mathrm{CH}_{2}\right), 13.7$ $\left(\mathrm{CH}_{3}\right)$.

${ }^{19}$ F-NMR $\left(282 \mathrm{MHz}, \mathrm{CDCl}_{3}\right): \delta=-110.1$ (ddd, $\left.J=9.3,8.1,5.7 \mathrm{~Hz}\right)$.

IR (ATR): $\tilde{v}=3137,2956,2872,1601,1499,1469,1242,1223,1144,1046 \mathrm{~cm}^{-1}$.

MS (ESI) $m / z$ (relative intensity): 258 (33) [M+K $\left.{ }^{+}\right], 242$ (33) [M+Na ${ }^{+}, 220$ (100) $\left[\mathrm{M}+\mathrm{H}^{+}\right]$.

HR-MS (ESI) $m / z$ calcd for $\mathrm{C}_{12} \mathrm{H}_{15} \mathrm{FN}_{3},\left[\mathrm{M}+\mathrm{H}^{+}\right]$220.1245, found 220.1240.

\section{Synthesis of 4-n-Butyl-1-(2-fluorophenyl)-1H-1,2,3-triazole (123f)}<smiles>CC(C)(C)c1cn(-c2ccccc2F)nn1</smiles>

The general procedure A was followed using 1-fluoro-2-iodobenzene (1i) (4.40 g, $20.0 \mathrm{mmol}$ ), 1-hexyne (1.64 g, $20.0 \mathrm{mmol}), \mathrm{NaN}_{3}(1.36 \mathrm{~g}, 21.0 \mathrm{mmol})$, Cul (0.38 g, $\left.2.0 \mathrm{mmol}\right)$ and DMEDA $(0.26 \mathrm{~g}, 3.0 \mathrm{mmol})$. Purification by column chromatography ( $n$-pentane/EtOAc $5 / 1)$ yielded $123 \mathrm{f}(3.77 \mathrm{~g}, 86 \%)$ as a colorless oil.

${ }^{1} \mathrm{H}-\mathrm{NMR}\left(300 \mathrm{MHz}, \mathrm{CDCl}_{3}\right): \delta=8.01-7.82(\mathrm{~m}, 1 \mathrm{H}), 7.78(\mathrm{dd}, J=3.0,0.7 \mathrm{~Hz}, 1 \mathrm{H}), 7.46-7.30$ $(\mathrm{m}, 1 \mathrm{H}), 7.31-7.18(\mathrm{~m}, 2 \mathrm{H}), 2.77$ (ddd, $J=7.9,7.3,0.8 \mathrm{~Hz}, 2 \mathrm{H}), 1.69$ (dddd, $J=8.8,7.7,7.1$, $5.8 \mathrm{~Hz}, 2 \mathrm{H}), 1.50-1.26(\mathrm{~m}, 2 \mathrm{H}), 0.93(\mathrm{t}, J=7.3 \mathrm{~Hz}, 3 \mathrm{H})$.

${ }^{13} \mathrm{C}-N M R\left(125 \mathrm{MHz}, \mathrm{CDCl}_{3}\right): \delta=153.4\left({ }^{1} \mathrm{~J}_{\mathrm{C}-\mathrm{F}}=250.3 \mathrm{~Hz}, \mathrm{C}_{\mathrm{q}}\right), 148.9\left({ }^{5} \mathrm{~J}_{\mathrm{C}-\mathrm{F}}=1.2 \mathrm{~Hz}, \mathrm{C}_{\mathrm{q}}\right)$, $129.9\left({ }^{3} J_{\mathrm{C}-\mathrm{F}}=7.9 \mathrm{~Hz}, \mathrm{CH}\right), 125.6\left({ }^{2} J_{\mathrm{C}-\mathrm{F}}=10.1 \mathrm{~Hz}, \mathrm{C}_{\mathrm{q}}\right), 125.3\left({ }^{4} J_{\mathrm{C}-\mathrm{F}}=3.8 \mathrm{~Hz}, \mathrm{CH}\right), 124.9(\mathrm{CH})$, $122.0\left({ }^{3} J_{\mathrm{C}-\mathrm{F}}=8.2 \mathrm{~Hz}, \mathrm{CH}\right), 117.0\left({ }^{2} J_{\mathrm{C}-\mathrm{F}}=20.1 \mathrm{~Hz}, \mathrm{CH}\right), 31.5\left(\mathrm{CH}_{2}\right), 25.4\left(\mathrm{CH}_{2}\right), 22.4\left(\mathrm{CH}_{2}\right)$, $13.9\left(\mathrm{CH}_{3}\right)$.

${ }^{19}$ F-NMR $\left(282 \mathrm{MHz}, \mathrm{CDCl}_{3}\right): \delta=-121.0-121.5(\mathrm{~m})$.

IR (ATR): $\tilde{v}=2956,2930,2860,1597,1508,1473,1274,1225,1110,1940 \mathrm{~cm}^{-1}$.

MS (ESI) $m / z$ (relative intensity): $242(22)\left[\mathrm{M}+\mathrm{Na}^{+}\right], 220(100)\left[\mathrm{M}+\mathrm{H}^{+}\right]$.

HR-MS (ESI) $m / z$ calcd for $\mathrm{C}_{12} \mathrm{H}_{14} \mathrm{FN}_{3} \mathrm{Na}$, [M+Na $\left.{ }^{+}\right]$242.1064, found 242.1064. 


\section{Synthesis of 4-n-Butyl-1-(2-methoxyphenyl)-1H-1,2,3-triazole (123g)}<smiles>COc1ccccc1-n1cc(C(C)(C)C)nn1</smiles>

The general procedure $A$ was followed using 1-iodo-2-methoxybenzene (1j) $(2.34 \mathrm{~g}$, $10.0 \mathrm{mmol}$ ), 1-hexyne (0.82 g, $10.0 \mathrm{mmol}), \mathrm{NaN}_{3}(0.68 \mathrm{~g}, 10.5 \mathrm{mmol})$, Cul $(0.38 \mathrm{~g}, 1.0 \mathrm{mmol})$ and DMEDA ( $0.26 \mathrm{~g}, 1.5 \mathrm{mmol})$. Purification by column chromatography ( $n$-pentane/EtOAc $5 / 1)$ yielded $123 \mathrm{~g}(2.06 \mathrm{~g}, 89 \%)$ as a colorless oil.

${ }^{1} \mathrm{H}-\mathrm{NMR}\left(300 \mathrm{MHz}, \mathrm{CDCl}_{3}\right): \delta=7.80(\mathrm{~s}, 1 \mathrm{H}), 7.71(\mathrm{dd}, J=8.3,1.7 \mathrm{~Hz}, 1 \mathrm{H}), 7.35$ (ddd, $J=8.4,7.4,1.7 \mathrm{~Hz}, 1 \mathrm{H}), 7.08-7.00(\mathrm{~m}, 2 \mathrm{H}), 3.84(\mathrm{~s}, 3 \mathrm{H}), 2.84-2.67(\mathrm{~m}, 2 \mathrm{H}), 1.79-1.61(\mathrm{~m}$, 2H), 1.40 (dp, $J=9.4,7.3 \mathrm{~Hz}, 2 \mathrm{H}), 0.93$ (t, $J=7.3 \mathrm{~Hz}, 3 \mathrm{H}$ ).

${ }^{13} \mathrm{C}-\mathrm{NMR}\left(125 \mathrm{MHz}, \mathrm{CDCl}_{3}\right): \delta=151.2\left(\mathrm{C}_{\mathrm{q}}\right), 147.7\left(\mathrm{C}_{\mathrm{q}}\right), 129.8(\mathrm{CH}), 126.6\left(\mathrm{C}_{\mathrm{q}}\right), 125.5(\mathrm{CH})$, $122.9(\mathrm{CH}), 121.2(\mathrm{CH}), 112.3(\mathrm{CH}), 56.0\left(\mathrm{CH}_{3}\right), 31.6\left(\mathrm{CH}_{2}\right), 25.4\left(\mathrm{CH}_{2}\right), 22.4\left(\mathrm{CH}_{2}\right), 13.9$ $\left(\mathrm{CH}_{3}\right)$.

IR (ATR): $\tilde{v}=2930,2859,1601,1504,1473,1285,1252,1285,1252,1176 \mathrm{~cm}^{-1}$.

MS (ESI) $m / z$ (relative intensity): 254 (17) $\left[\mathrm{M}+\mathrm{Na}^{+}\right], 232(100)\left[\mathrm{M}+\mathrm{H}^{+}\right]$.

HR-MS (ESI) $\mathrm{m} / \mathrm{z}$ calcd for $\mathrm{C}_{13} \mathrm{H}_{18} \mathrm{~N}_{3} \mathrm{O},\left[\mathrm{M}+\mathrm{H}^{+}\right]$232.1444, found 232.1444.

The spectral data are in accordance with those reported in the literature. ${ }^{15 c}$

\section{Synthesis of 4-n-Butyl-1-(naphthalen-1-yl)-1H-1,2,3-triazole (123h)}<smiles>CCCCc1cn(-c2cccc3ccccc23)nn1</smiles>

The general procedure A was followed using 1-iodonaphthalene (1k) $(5.08 \mathrm{~g}, 20.0 \mathrm{mmol})$, 1-hexyne $(1.64 \mathrm{~g}, 20.0 \mathrm{mmol}), \mathrm{NaN}_{3}(1.36 \mathrm{~g}, 21.0 \mathrm{mmol})$, Cul $(0.38 \mathrm{~g}, 2.0 \mathrm{mmol})$ and DMEDA (0.26 g, $3.0 \mathrm{mmol})$. Purification by column chromatography ( $n$-pentane/EtOAc 5/1) yielded $123 \mathrm{~h}(4.03 \mathrm{~g}, 80 \%)$ as an orange oil. 
${ }^{1} \mathrm{H}-\mathrm{NMR}\left(300 \mathrm{MHz}, \mathrm{CDCl}_{3}\right): \delta=7.99-7.84(\mathrm{~m}, 2 \mathrm{H}), 7.68-7.57(\mathrm{~m}, 2 \mathrm{H}), 7.57-7.45(\mathrm{~m}, 4 \mathrm{H})$, 2.95-2.81 (m, 2H), 1.87-1.69 (m, 2H), 1.55-1.38 (m, 2H), $0.98(\mathrm{t}, J=7.3 \mathrm{~Hz}, 3 \mathrm{H})$.

${ }^{13} \mathrm{C}-N M R\left(125 \mathrm{MHz}, \mathrm{CDCl}_{3}\right): \delta=148.4\left(\mathrm{C}_{\mathrm{q}}\right), 134.2\left(\mathrm{C}_{\mathrm{q}}\right), 134.0\left(\mathrm{C}_{\mathrm{q}}\right) 130.1(\mathrm{CH}), 128.7\left(\mathrm{C}_{\mathrm{q}}\right)$, $128.3(\mathrm{CH}), 127.8(\mathrm{CH}), 127.0(\mathrm{CH}), 125.0(\mathrm{CH}), 123.5(\mathrm{CH}), 123.4(\mathrm{CH}), 122.5(\mathrm{CH}), 31.6$ $\left(\mathrm{CH}_{2}\right), 25.4\left(\mathrm{CH}_{2}\right), 22.5\left(\mathrm{CH}_{2}\right), 13.7\left(\mathrm{CH}_{3}\right)$.

IR (ATR): $\tilde{v}=3056,2929,2858,1597,1512,1470,1429,1219,1038,800,771,434 \mathrm{~cm}^{-1}$. MS (ESI) m/z (relative intensity): 290 (87) [M+K $], 274$ (28) [M+Na $\left.{ }^{+}\right], 252(100)\left[\mathrm{M}+\mathrm{H}^{+}\right]$.

HR-MS (ESI) $m / z$ calcd for $\mathrm{C}_{16} \mathrm{H}_{18} \mathrm{~N}_{3},\left[\mathrm{M}+\mathrm{H}^{+}\right]$252.1495, found 252.1484.

\section{Synthesis of 4-n-Butyl-1-(p-tolyl)-1H-1,2,3-triazole (123i)}

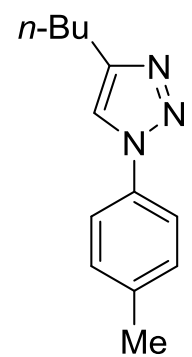

The general procedure A was followed using 1-iodo-4-methylbenzene (1I) (2.18 g, $10.0 \mathrm{mmol})$, 1-hexyne (0.82 g, $10.0 \mathrm{mmol}), \mathrm{NaN}_{3}(0.68 \mathrm{~g}, 10.5 \mathrm{mmol})$, Cul $(0.38 \mathrm{~g}, 1.0 \mathrm{mmol})$ and DMEDA (0.26 g, $1.5 \mathrm{mmol})$. Purification by column chromatography ( $n$-pentane/EtOAc $5 / 1$ ) yielded $123 \mathrm{i}(1.64 \mathrm{~g}, 76 \%)$ as a colorless solid.

M.r.: $63-64^{\circ} \mathrm{C}$.

${ }^{1} \mathrm{H}-\mathrm{NMR}\left(300 \mathrm{MHz}, \mathrm{CDCl}_{3}\right): \delta=7.65(\mathrm{~s}, 1 \mathrm{H}), 7.56(\mathrm{~d}, J=8.4 \mathrm{~Hz}, 2 \mathrm{H}), 7.25(\mathrm{~d}, J=8.4 \mathrm{~Hz}$, $2 \mathrm{H}), 2.84-2.70(\mathrm{~m}, 2 \mathrm{H}), 2.38(\mathrm{~s}, 3 \mathrm{H}), 1.77-1.61(\mathrm{~m}, 2 \mathrm{H}), 1.40(\mathrm{dq}, J=14.4,7.3 \mathrm{~Hz}, 2 \mathrm{H}), 0.93$ $(\mathrm{t}, J=7.3 \mathrm{~Hz}, 3 \mathrm{H})$.

${ }^{13}$ C-NMR (125 MHz, $\left.\mathrm{CDCl}_{3}\right): \delta=149.1\left(\mathrm{C}_{\mathrm{q}}\right), 138.5\left(\mathrm{C}_{\mathrm{q}}\right), 135.1\left(\mathrm{C}_{\mathrm{q}}\right), 130.2(\mathrm{CH}), 120.4(\mathrm{CH})$, $118.9(\mathrm{CH}), 31.7\left(\mathrm{CH}_{2}\right), 25.5\left(\mathrm{CH}_{2}\right), 22.4\left(\mathrm{CH}_{2}\right), 21.0\left(\mathrm{CH}_{3}\right), 13.8\left(\mathrm{CH}_{3}\right)$.

IR (ATR): $\tilde{v}=3130,3085,2922,2869,1523,1456,1320,1230,1198,1120 \mathrm{~cm}^{-1}$.

MS (ESI) $m / z$ (relative intensity): $238(20)\left[\mathrm{M}+\mathrm{Na}^{+}\right], 216(100)\left[\mathrm{M}^{+} \mathrm{H}^{+}\right]$.

HR-MS (ESI) $m / z$ calcd for $\mathrm{C}_{13} \mathrm{H}_{18} \mathrm{~N}_{3},\left[\mathrm{M}+\mathrm{H}^{+}\right]$216.1495, found 216.1495. 


\section{Synthesis of 4-n-Butyl-1-(chlorophenyl)-1H-1,2,3-triazole (123j)}<smiles>CCCc1cn(-c2ccc(Cl)cc2)nn1</smiles>

The general procedure A was followed using 1-chloro-4-iodobenzene (1m) $(4.77 \mathrm{~g}$, $20.0 \mathrm{mmol}$ ), 1-hexyne (1.64 g, $20.0 \mathrm{mmol}), \mathrm{NaN}_{3}(1.36 \mathrm{~g}, 21.0 \mathrm{mmol})$, Cul (0.38 g, $\left.2.0 \mathrm{mmol}\right)$ and DMEDA $(0.26 \mathrm{~g}, 3.0 \mathrm{mmol})$. Purification by column chromatography ( $n$-pentane/EtOAc $5 / 1$ ) yielded $123 \mathrm{j}(4.10 \mathrm{~g}, 87 \%)$ as a colorless solid.

M.r.: $73-74^{\circ} \mathrm{C}$.

${ }^{1} \mathrm{H}-\mathrm{NMR}\left(300 \mathrm{MHz}, \mathrm{CDCl}_{3}\right): \delta=7.70-7.60(\mathrm{~m}, 3 \mathrm{H}), 7.49-7.41(\mathrm{~m}, 2 \mathrm{H}), 2.82-2.74(\mathrm{~m}, 2 \mathrm{H})$, 1.70 (dddd, $J=8.7,7.6,7.0,5.8 \mathrm{~Hz}, 2 \mathrm{H}), 1.51-1.30(\mathrm{~m}, 2 \mathrm{H}), 0.94(\mathrm{t}, J=7.3 \mathrm{~Hz}, 3 \mathrm{H}$ ).

${ }^{13} \mathrm{C}-\mathrm{NMR}\left(125 \mathrm{MHz}, \mathrm{CDCl}_{3}\right): \delta=149.5\left(\mathrm{C}_{\mathrm{q}}\right), 135.9\left(\mathrm{C}_{\mathrm{q}}\right), 134.2\left(\mathrm{C}_{\mathrm{q}}\right), 129.9(\mathrm{CH}), 121.6(\mathrm{CH})$, $118.8(\mathrm{CH}), 31.6\left(\mathrm{CH}_{2}\right), 25.4\left(\mathrm{CH}_{2}\right), 22.4\left(\mathrm{CH}_{2}\right), 13.9\left(\mathrm{CH}_{3}\right)$.

IR (ATR): $\tilde{v}=2961,2927,1498,1462,1403,1224,1092,1047,1010,989 \mathrm{~cm}^{-1}$.

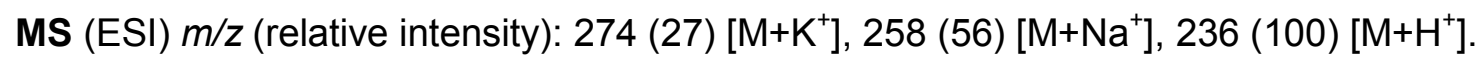

HR-MS (ESI) $\mathrm{m} / \mathrm{z}$ calcd for $\mathrm{C}_{12} \mathrm{H}_{15} \mathrm{CIN}_{3}$, $\left[\mathrm{M}+\mathrm{H}^{+}\right]$236.0949, found 236.0938 .

Synthesis of 4-n-Butyl-1-(4-methoxyphenyl)-1H-1,2,3-triazole (123k)<smiles>CCCc1cn(-c2ccc(OC)cc2)nn1</smiles>

The general procedure A was followed using 1-iodo-4-methoxybenzene (1n) $(2.34 \mathrm{~g}$, $10.0 \mathrm{mmol})$, 1-hexyne (0.82 g, $10.0 \mathrm{mmol}), \mathrm{NaN}_{3}(0.68 \mathrm{~g}, 10.5 \mathrm{mmol})$, Cul (0.38 g, $\left.1.0 \mathrm{mmol}\right)$ and DMEDA $(0.26 \mathrm{~g}, 1.5 \mathrm{mmol})$. Purification by column chromatography ( $n$-pentane/EtOAc $5 / 1)$ yielded $123 \mathrm{k}(2.10 \mathrm{~g}, 91 \%)$ as a colorless solid.

M.r.: $52-53^{\circ} \mathrm{C}$. 
${ }^{1} \mathrm{H}-\mathrm{NMR}\left(300 \mathrm{MHz}, \mathrm{CDCl}_{3}\right): \delta=7.62(\mathrm{~s}, 1 \mathrm{H}), 7.57(\mathrm{~d}, J=9.1 \mathrm{~Hz}, 2 \mathrm{H}), 6.95(\mathrm{~d}, J=7.8$, $7.8 \mathrm{~Hz}, 2 \mathrm{H}$ ), 3.81 (s, 3H), 2.80-2.67 (m, 2H), 1.67 (dddd, J = 8.8, 7.6, 7.0, 5.7 Hz, 2H), 1.47$1.32(\mathrm{~m}, 2 \mathrm{H}), 0.94(\mathrm{t}, J=7.3 \mathrm{~Hz}, 3 \mathrm{H})$.

${ }^{13} \mathrm{C}-\mathrm{NMR}\left(125 \mathrm{MHz}, \mathrm{CDCl}_{3}\right): \delta=159.6\left(\mathrm{C}_{\mathrm{q}}\right), 148.9\left(\mathrm{C}_{\mathrm{q}}\right), 130.8\left(\mathrm{C}_{\mathrm{q}}\right), 122.0(\mathrm{CH}), 119.1(\mathrm{CH})$, $114.5(\mathrm{CH}), 55.6\left(\mathrm{CH}_{3}\right), 31.6\left(\mathrm{CH}_{2}\right), 25.4\left(\mathrm{CH}_{2}\right), 22.4\left(\mathrm{CH}_{2}\right), 13.9\left(\mathrm{CH}_{3}\right)$.

IR (ATR): $\tilde{v}=3128,2955,2932,2869,1516,1440,1302,1245,1220,1191 \mathrm{~cm}^{-1}$.

MS (ESI) $m / z$ (relative intensity): $254(25)\left[\mathrm{M}+\mathrm{Na}^{+}\right], 232(100)\left[\mathrm{M}+\mathrm{H}^{+}\right]$.

HR-MS (ESI) $m / z$ calcd for $\mathrm{C}_{13} \mathrm{H}_{18} \mathrm{~N}_{3} \mathrm{O},\left[\mathrm{M}+\mathrm{H}^{+}\right]$232.1444, found 232.1450.

\section{Synthesis of Methyl 4-(4-n-butyl-1H-1,2,3-triazol-1-yl)benzoate (123I)}

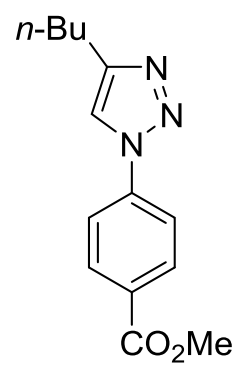

The general procedure A was followed using methyl 4-iodobenzoate (10) (4.36 g, $20.0 \mathrm{mmol}$ ), 1-hexyne (1.64 g, $20.0 \mathrm{mmol}), \mathrm{NaN}_{3}(1.36 \mathrm{~g}, 21.0 \mathrm{mmol})$, Cul (0.38 g, $\left.2.0 \mathrm{mmol}\right)$ and DMEDA $(0.26 \mathrm{~g}, 3.0 \mathrm{mmol}$ ). Purification by column chromatography ( $n$-pentane/EtOAc $5 / 1$ ) yielded $123 \mathrm{l}(3.23 \mathrm{~g}, 74 \%)$ as a colorless solid.

M.p.: $111^{\circ} \mathrm{C}$.

${ }^{1} \mathrm{H}-\mathrm{NMR}\left(300 \mathrm{MHz}, \mathrm{CDCl}_{3}\right): \delta=8.17(\mathrm{~d}, J=9.0 \mathrm{~Hz}, 2 \mathrm{H}), 7.82(\mathrm{~d}, J=8.9 \mathrm{~Hz}, 2 \mathrm{H}), 7.79(\mathrm{~s}$, $1 \mathrm{H}$ ), 3.94 (s, 3H), 2.80 (ddd, $J=7.9,7.3,0.7 \mathrm{~Hz}, 2 \mathrm{H}$ ), 1.71 (dddd, $J=8.7,7.6,7.0,5.7 \mathrm{~Hz}$, $2 \mathrm{H}), 1.50-1.34(\mathrm{~m}, 2 \mathrm{H}), 0.94(\mathrm{t}, J=7.3 \mathrm{~Hz}, 3 \mathrm{H})$.

${ }^{13} \mathrm{C}-N M R\left(125 \mathrm{MHz}, \mathrm{CDCl}_{3}\right): \delta=166.1\left(\mathrm{C}_{\mathrm{q}}\right), 149.7\left(\mathrm{C}_{\mathrm{q}}\right), 140.4\left(\mathrm{C}_{\mathrm{q}}\right), 131.4(\mathrm{CH}), 130.0\left(\mathrm{C}_{\mathrm{q}}\right)$, $119.8(\mathrm{CH}), 118.7(\mathrm{CH}), 52.5\left(\mathrm{CH}_{3}\right), 31.5\left(\mathrm{CH}_{2}\right), 25.4\left(\mathrm{CH}_{2}\right), 22.4\left(\mathrm{CH}_{2}\right), 13.9\left(\mathrm{CH}_{3}\right)$.

IR (ATR): $\tilde{v}=3128,2959,2929,2860,1721,1607,1518,1437,1280,1224 \mathrm{~cm}^{-1}$.

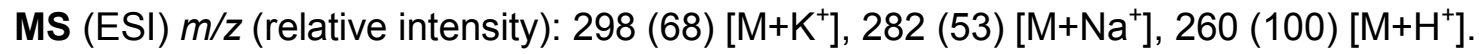

HR-MS (ESI) $m / z$ calcd for $\mathrm{C}_{14} \mathrm{H}_{18} \mathrm{~N}_{3} \mathrm{O}_{2},\left[\mathrm{M}+\mathrm{H}^{+}\right] 260.1394$, found 260.1388 . 


\section{Synthesis of 4-n-Butyl-1-[3-(trifluoromethyl)phenyl]-1H-1,2,3-triazole (123m)}<smiles>CCCc1cn(-c2cccc(C(F)(F)F)c2)nn1</smiles>

The general procedure A was followed using 1-iodo-3-(trifluoromethyl)benzene (1p) (5.44 g, $20.0 \mathrm{mmol}$ ), 1-hexyne (1.64 g, $20.0 \mathrm{mmol}), \mathrm{NaN}_{3}(1.36 \mathrm{~g}, 21.0 \mathrm{mmol})$, Cul (0.38 g, $\left.2.0 \mathrm{mmol}\right)$ and DMEDA $(0.26 \mathrm{~g}, 3.0 \mathrm{mmol})$. Purification by column chromatography ( $n$-pentane/EtOAc $5 / 1)$ yielded $123 \mathrm{~m}(4.68 \mathrm{~g}, 87 \%)$ as a colorless oil.

${ }^{1} \mathrm{H}-\mathrm{NMR}\left(300 \mathrm{MHz}, \mathrm{CDCl}_{3}\right): \delta=8.01-7.82(\mathrm{~m}, 1 \mathrm{H}), 7.78(\mathrm{dd}, J=3.0,0.7 \mathrm{~Hz}, 1 \mathrm{H}), 7.46-7.30$ (m, 1H), 7.31-7.18 (m, 2H), 2.77 (ddd, $J=7.9,7.3,0.8 \mathrm{~Hz}, 2 \mathrm{H}), 1.69$ (dddd, $J=8.8,7.7,7.1$, $5.8 \mathrm{~Hz}, 2 \mathrm{H}), 1.50-1.26(\mathrm{~m}, 2 \mathrm{H}), 0.93(\mathrm{t}, J=7.3 \mathrm{~Hz}, 3 \mathrm{H})$.

${ }^{13} \mathrm{C}-N M R\left(125 \mathrm{MHz}, \mathrm{CDCl}_{3}\right): \delta=149.8\left(\mathrm{C}_{\mathrm{q}}\right), 137.7\left(\mathrm{C}_{\mathrm{q}}\right), 132.5\left({ }^{2} J_{\mathrm{C}-\mathrm{F}}=33.2 \mathrm{~Hz}, \mathrm{C}_{\mathrm{q}}\right), 130.6$ $(\mathrm{CH}), 125.1\left({ }^{3} J_{\mathrm{C}-\mathrm{F}}=3.7 \mathrm{~Hz}, \mathrm{CH}\right), 123.5\left({ }^{4} \mathrm{~J}_{\mathrm{C}-\mathrm{F}}=1.2 \mathrm{~Hz}, \mathrm{CH}\right), 123.5\left({ }^{1} \mathrm{~J}_{\mathrm{C}-\mathrm{F}}=273.2 \mathrm{~Hz}, \mathrm{C}_{\mathrm{q}}\right)$, $118.8(\mathrm{CH}), 117.3\left({ }^{3} J_{\mathrm{C}-\mathrm{F}}=3.9 \mathrm{~Hz}, \mathrm{CH}\right), 31.6\left(\mathrm{CH}_{2}\right), 25.4\left(\mathrm{CH}_{2}\right), 22.4\left(\mathrm{CH}_{2}\right), 13.9\left(\mathrm{CH}_{3}\right)$.

${ }^{19} \mathrm{~F}-\mathrm{NMR}\left(282 \mathrm{MHz}, \mathrm{CDCl}_{3}\right): \delta=-62.9(\mathrm{~s})$.

IR (ATR): $\tilde{v}=3135,3084,2958,2932,2862,1600,1557,1485,1461,1323 \mathrm{~cm}^{-1}$.

MS (ESI) $m / z$ (relative intensity): $292(7)\left[\mathrm{M}+\mathrm{Na}^{+}\right], 270(100)\left[\mathrm{M}+\mathrm{H}^{+}\right]$.

HR-MS (ESI) $m / z$ calcd for $\mathrm{C}_{13} \mathrm{H}_{15} \mathrm{~F}_{3} \mathrm{~N}_{3},\left[\mathrm{M}+\mathrm{H}^{+}\right]$270.1213, found 270.1212.

\section{Syntheisis of 1-[3-(4-n-Butyl-1H-1,2,3-triazol-1-yl)phenyl]ethan-1-one (123n)}<smiles>CCCCc1cn(-c2cccc(C(C)C)c2)nn1</smiles>

The general procedure A was followed using 1-(3-iodophenyl) ethan-1-one (1q) (2.46 g, $10.0 \mathrm{mmol})$, 1-hexyne (0.82 g, $10.0 \mathrm{mmol}), \mathrm{NaN}_{3}$ (0.68 g, $\left.10.5 \mathrm{mmol}\right)$, Cul (0.38 g, $\left.1.0 \mathrm{mmol}\right)$ and DMEDA (0.26 g, $1.5 \mathrm{mmol}$ ). Purification by column chromatography ( $n$-pentane/EtOAc $5 / 1)$ yielded $123 \mathrm{n}(1.45 \mathrm{~g}, 60 \%)$ as an orange solid. 
M.p.: $43^{\circ} \mathrm{C}$.

${ }^{1} \mathrm{H}-\mathrm{NMR}\left(300 \mathrm{MHz}, \mathrm{CDCl}_{3}\right): \delta=8.69(\mathrm{dd}, J=1.9,1.9 \mathrm{~Hz}, 1 \mathrm{H}), 8.48-8.38(\mathrm{~m} \mathrm{2H}), 8.23(\mathrm{~s}$, $1 \mathrm{H}), 8.0(\mathrm{dd}, J=8.4 \mathrm{~Hz}, 1 \mathrm{H}), 3.40-3.17(\mathrm{~m}, 2 \mathrm{H}), 3.10(\mathrm{~s}, 3 \mathrm{H}), 2.27-2.05(\mathrm{~m}, 2 \mathrm{H}), 1.86(\mathrm{dq}$, $J=14.5,7.3 \mathrm{~Hz}, 2 \mathrm{H}), 1.39(\mathrm{t}, J=7.3 \mathrm{~Hz}, 3 \mathrm{H})$.

${ }^{13} \mathrm{C}-\mathrm{NMR}\left(125 \mathrm{MHz}, \mathrm{CDCl}_{3}\right): \delta=196.9\left(\mathrm{C}_{\mathrm{q}}\right), 149.7\left(\mathrm{C}_{\mathrm{q}}\right), 138.6\left(\mathrm{C}_{\mathrm{q}}\right), 137.8\left(\mathrm{C}_{\mathrm{q}}\right), 130.3(\mathrm{CH})$, $128.2(\mathrm{CH}), 124.8(\mathrm{CH}), 119.6(\mathrm{CH}), 118.9(\mathrm{CH}), 31.6\left(\mathrm{CH}_{2}\right), 26.9\left(\mathrm{CH}_{3}\right), 25.5\left(\mathrm{CH}_{2}\right), 22.4$ $\left(\mathrm{CH}_{2}\right), 13.9\left(\mathrm{CH}_{3}\right)$.

IR (ATR): $\tilde{v}=3139,2957,2928,2857,1682,1604,1556,1490,1398,1287 \mathrm{~cm}^{-1}$.

MS (ESI) $m / z$ (relative intensity): $238(16)\left[\mathrm{M}+\mathrm{Na}^{+}\right], 244(100)\left[\mathrm{M}+\mathrm{H}^{+}\right]$.

HR-MS (ESI) $m / z$ calcd for $\mathrm{C}_{14} \mathrm{H}_{18} \mathrm{~N}_{3} \mathrm{O},\left[\mathrm{M}+\mathrm{H}^{+}\right]$244.1444, found 244.1450.

\section{Synthesis of 3-(4-n-Butyl-1H-1,2,3-triazol-1-yl)-1-methyl-1H-indole (123o)}

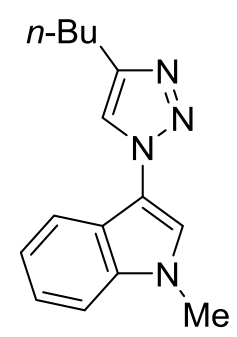

The general procedure $\mathbf{A}$ was followed using 3-iodo-1-methyl-1H-indole (1r) (3.86 g, $15.0 \mathrm{mmol}$ ), 1-hexyne (1,23 g, $15.0 \mathrm{mmol}), \mathrm{NaN}_{3}(1.02 \mathrm{~g}, 17.0 \mathrm{mmol})$, Cul (0.29 g, $\left.1.5 \mathrm{mmol}\right)$ and DMEDA $(0.29 \mathrm{~g}, 2.3 \mathrm{mmol})$. Purification by column chromatography ( $n$-pentane/EtOAc $9 / 1$ ) yielded $1230(1.41 \mathrm{~g}, 37 \%)$ as a brown oil.

${ }^{1} \mathrm{H}-\mathrm{NMR}\left(300 \mathrm{MHz}, \mathrm{CDCl}_{3}\right): \delta=7.76(\mathrm{dd}, J=7.9,1.0 \mathrm{~Hz}, 1 \mathrm{H}), 7.67(\mathrm{~s}, 1 \mathrm{H}), 7.41$ (d, $J=0.7 \mathrm{~Hz}, 1 \mathrm{H}), 7.38-7.27(\mathrm{~m}, 2 \mathrm{H}), 7.25-7.17(\mathrm{~m}, 1 \mathrm{H}), 3.82(\mathrm{~s}, 3 \mathrm{H}), 2.88-2.73(\mathrm{~m}, 2 \mathrm{H})$, 1.82-1.65 (m, 2H), 1.45 (dq, $J=14.4,7.3 \mathrm{~Hz}, 2 \mathrm{H}), 0.97(\mathrm{t}, J=7.3 \mathrm{~Hz}, 3 \mathrm{H})$.

${ }^{13} \mathrm{C}-\mathrm{NMR}\left(125 \mathrm{MHz}, \mathrm{CDCl}_{3}\right): \delta=148.3\left(\mathrm{C}_{\mathrm{q}}\right), 135.6\left(\mathrm{C}_{\mathrm{q}}\right), 123.2(\mathrm{CH}) 121.6(\mathrm{CH}), 121.3\left(\mathrm{C}_{\mathrm{q}}\right)$, $121.0(\mathrm{CH}), 120.9(\mathrm{CH}), 118.6(\mathrm{CH}), 115.2\left(\mathrm{C}_{\mathrm{q}}\right), 109.9(\mathrm{CH}), 33.2\left(\mathrm{CH}_{3}\right), 31.7\left(\mathrm{CH}_{2}\right), 25.5$ $\left(\mathrm{CH}_{2}\right), 22.5\left(\mathrm{CH}_{2}\right), 13.7\left(\mathrm{CH}_{3}\right)$.

IR (ATR): $\tilde{v}=2954,2929,2858,1730,1615,1478,1447,1334,1247,1213 \mathrm{~cm}^{-1}$.

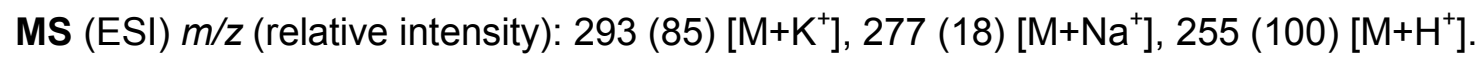

HR-MS (ESI) $m / z$ calcd for $\mathrm{C}_{15} \mathrm{H}_{18} \mathrm{~N}_{4},\left[\mathrm{M}+\mathrm{H}^{+}\right]$255.1604, found 255.1591. 


\section{Synthesis of Pyren-1-amine (123pa)}<smiles>Nc1ccc2ccc3cccc4ccc1c2c34</smiles>

A suspension of 1-nitropyrene $(5.55 \mathrm{~g}, 22 \mathrm{mmol})$ and palladium on carbon $(0.58 \mathrm{~g})$ in EtOAc $(85 \mathrm{~mL})$ and $\mathrm{HOAc}(7 \mathrm{~mL}, 17.4 \mathrm{M})$ was stired under a $\mathrm{H}_{2}$ atmosphere over night at ambient temperature. The reaction mixture was filtered over celite and the solvent was evaporated under reduced pressure. Purification by column chromatography (DCM/n-pentane 1/1) yielded 123pa (4.16 g, 84\%) as a green solid.

M.r.: $124-125^{\circ} \mathrm{C}$.

${ }^{1} \mathrm{H}-\mathrm{NMR}\left(300 \mathrm{MHz}, \mathrm{CDCl}_{3}\right): \delta=8.07$ (ddd, $\left.J=7.6,5.8,1.3 \mathrm{~Hz}, 2 \mathrm{H}\right), 8.03-7.88(\mathrm{~m}, 5 \mathrm{H}), 7.84$ (d, J = 8.9 Hz, 1H), 7.35 (d, J = 8.2 Hz, 1H), 4.44 (brs, 2H).

${ }^{13} \mathrm{C}-\mathrm{NMR}\left(125 \mathrm{MHz}, \mathrm{CDCl}_{3}\right): \delta=141.0\left(\mathrm{C}_{\mathrm{q}}\right), 132.3\left(\mathrm{C}_{\mathrm{q}}\right), 131.8\left(\mathrm{C}_{\mathrm{q}}\right), 127.7(\mathrm{CH}), 126.1(\mathrm{CH})$, $126.1(\mathrm{CH}), 126.1(\mathrm{CH}), 126.1\left(\mathrm{C}_{\mathrm{q}}\right), 125.6\left(\mathrm{C}_{\mathrm{q}}\right), 124.4\left(\mathrm{C}_{\mathrm{q}}\right), 124.2(\mathrm{CH}), 123.8(\mathrm{CH}), 123.6$ $(\mathrm{CH}), 120.2(\mathrm{CH}), 117.0\left(\mathrm{C}_{\mathrm{q}}\right), 114.1(\mathrm{CH})$.

IR (ATR): $\tilde{v}=3321,3206,3027,1616,1598,1508,1483,1432,1334,1270 \mathrm{~cm}^{-1}$.

MS (El) m/z (relative intensity): 217 (100) [M+], 200 (3), 189 (32), 163 (3), 108 (9), 94 (9), 81 (3), 63 (2), 58 (4), 43 (12).

HR-MS (EI) $m / z$ calcd for $\mathrm{C}_{16} \mathrm{H}_{11} \mathrm{~N},\left[\mathrm{M}^{+}\right] 217.0891$, found 217.0889 .

\section{Synthesis of 1-Azidopyren (123pb)}<smiles>Nc1ccc2ccc3cccc4ccc1c2c34</smiles>

A suspension of pyren-1-amine $(4.00 \mathrm{~g}, 18 \mathrm{mmol})$ in EtOAc $(30 \mathrm{~mL})$ was cooled to $0{ }^{\circ} \mathrm{C}$. $\mathrm{HCl}$ $(8 \mathrm{~mL}, 33 \mathrm{M})$ was added to the reaction mixture at $0{ }^{\circ} \mathrm{C}$. A solution of sodium nitrite $(1.66 \mathrm{~g}$, $25 \mathrm{mmol})$ in $\mathrm{H}_{2} \mathrm{O}(20 \mathrm{~mL})$ was added dropwise to the cooled reaction mixture over 10 minutes and was stirred for $1 \mathrm{~h}$. Then $\mathrm{NaN}_{3}$ in $\mathrm{H}_{2} \mathrm{O}(20 \mathrm{~mL})$ was added to the suspension and stirred for further $4 \mathrm{~h}$ at ambient temperatures. The reaction mixture was extracted with 
EtOAc $(3 \times 50 \mathrm{~mL})$, dried over $\mathrm{Na}_{2} \mathrm{SO}_{4}$. After filtration and evaporation of the solvent in vacuo, the crude brown product was used without further purification in the next step.

M.r.: $113-114^{\circ} \mathrm{C}$.

${ }^{1} \mathrm{H}-\mathrm{NMR}\left(300 \mathrm{MHz}, \mathrm{CDCl}_{3}\right): \delta=8.22(\mathrm{~d}, J=9.2 \mathrm{~Hz}, 1 \mathrm{H}), 8.17-7.90(\mathrm{~m}, 7 \mathrm{H}), 7.72(\mathrm{~d}$, $J=8.2 \mathrm{~Hz}, 1 \mathrm{H})$.

${ }^{13} \mathrm{C}$-NMR $\left(125 \mathrm{MHz}, \mathrm{CDCl}_{3}\right): \delta=133.2\left(\mathrm{C}_{\mathrm{q}}\right), 131.6\left(\mathrm{C}_{\mathrm{q}}\right), 131.4\left(\mathrm{C}_{\mathrm{q}}\right), 128.4\left(\mathrm{C}_{\mathrm{q}}\right), 127.6(\mathrm{CH})$, $127.2(\mathrm{CH}), 126.8(\mathrm{CH}), 126.5(\mathrm{CH}), 125.6(\mathrm{CH}), 125.5(\mathrm{CH}), 125.3\left(\mathrm{C}_{\mathrm{q}}\right), 125.2(\mathrm{CH}), 124.5$ $\left(\mathrm{C}_{\mathrm{q}}\right), 122.6\left(\mathrm{C}_{\mathrm{q}}\right), 121.6(\mathrm{CH}), 115.4(\mathrm{CH})$.

IR (ATR): $\tilde{v}=3037,2156,2107,1731,1597,1503,1487,1457,1434,1322 \mathrm{~cm}^{-1}$.

MS (El) m/z (relative intensity): 243 (13) [M+], 214 (100), 200 (3), 187 (22), 163 (5), 107 (14), 93 (23), 81 (3), 74 (3), 63 (3).

HR-MS (EI) $m / z$ calcd for $\mathrm{C}_{16} \mathrm{H}_{9} \mathrm{~N}_{3}$, [M $\left.\mathrm{M}^{+}\right] 243.0896$, found 243.0891 .

\section{Synthesis of 4-n-Butyl-1-(pyren-1-yl)-1H-1,2,3-triazole (123p)}<smiles>CCCCc1cn(-c2ccc3ccc4cccc5ccc2c3c45)nn1</smiles>

A suspension of 1-azidopyren (4.42 g, $18 \mathrm{mmol})$, 1-hexyne (1.64 g, $20.0 \mathrm{mmol})$, Cul (0.38 g, $2.0 \mathrm{mmol})$ and DMEDA $(0.26 \mathrm{~g}, 3.0 \mathrm{mmol})$ in DMSO $(20 \mathrm{~mL})$ and $\mathrm{H}_{2} \mathrm{O}(5 \mathrm{~mL})$ was stirred at $55{ }^{\circ} \mathrm{C}$ over night. The reaction mixture was extracted with $\mathrm{CH}_{2} \mathrm{Cl}_{2}(3 \times 50 \mathrm{~mL})$. Purification by column chromatography ( $n$-pentane/EtOAc $9 / 1)$ yielded $123 \mathrm{p}(0.48 \mathrm{~g}, 8 \%)$ as a brown solid.

M.r.: $103-104^{\circ} \mathrm{C}$.

${ }^{1} \mathrm{H}-\mathrm{NMR}\left(300 \mathrm{MHz}, \mathrm{CDCl}_{3}\right): \delta=8.23-8.14(\mathrm{~m}, 3 \mathrm{H}), 8.13-7.95(\mathrm{~m}, 5 \mathrm{H}), 7.83(\mathrm{~d}, J=9.2 \mathrm{~Hz}$, $1 \mathrm{H}), 7.74(\mathrm{~s}, 1 \mathrm{H}), 2.99-2.82(\mathrm{~m}, 2 \mathrm{H}), 1.93-1.75(\mathrm{~m}, 2 \mathrm{H}), 1.52(\mathrm{dq}, J=14.5,7.3 \mathrm{~Hz}, 2 \mathrm{H}), 1.03$ (t, $J=7.3 \mathrm{~Hz}, 3 \mathrm{H})$.

${ }^{13} \mathrm{C}-N M R\left(125 \mathrm{MHz}, \mathrm{CDCl}_{3}\right): \delta=148.6\left(\mathrm{C}_{\mathrm{q}}\right), 132.1\left(\mathrm{C}_{\mathrm{q}}\right), 131.1\left(\mathrm{C}_{\mathrm{q}}\right), 130.8\left(\mathrm{C}_{\mathrm{q}}\right), 130.7\left(\mathrm{C}_{\mathrm{q}}\right)$, $129.5(\mathrm{CH}), 128.8(\mathrm{CH}), 127.0(\mathrm{CH}), 126.7(\mathrm{CH}), 126.3(\mathrm{CH}), 126.2\left(\mathrm{C}_{\mathrm{q}}\right), 126.0(\mathrm{CH}), 125.0$ $\left(\mathrm{C}_{\mathrm{q}}\right), 124.7(\mathrm{CH}), 124.2\left(\mathrm{C}_{\mathrm{q}}\right), 123.9(\mathrm{CH}), 123.4(\mathrm{CH}), 121.3(\mathrm{CH}), 31.7\left(\mathrm{CH}_{2}\right), 25.6\left(\mathrm{CH}_{2}\right)$, $22.6\left(\mathrm{CH}_{2}\right), 14.0\left(\mathrm{CH}_{3}\right)$.

IR (ATR): $\tilde{v}=3130,2949,2919,2851,1693,1601,1459,1057,841,763 \mathrm{~cm}^{-1}$. 
MS (EI) m/z (relative intensity): 325 (3) [ $\left.\mathrm{M}^{+}\right], 297$ (40), 254 (100), 241 (8), 227 (16), $216(10)$, 201 (61), 174 (3), 150 (2), 127 (5), 100 (7), 58 (3), 43 (8).

HR-MS (EI) $m / z$ calcd for $\mathrm{C}_{22} \mathrm{H}_{19} \mathrm{~N}_{3}$, [M+] 325.1597, found 325.1573.

Synthesis of Ethyl 1-(o-tolyl)-1H-1,2,3-triazole-4-carboxylate (123q) and Ethyl 1-(otolyl)-1H-1,2,3-triazole-5-carboxylate (123r)

In a $25 \mathrm{~mL}$ microwave flask a mixture of 1-azido-2-methylbenzene $(0.67 \mathrm{~g}, 5 \mathrm{mmol})$ and ethyl propionate $(5.00 \mathrm{~g}, 50 \mathrm{mmol})$ were stirred at $100{ }^{\circ} \mathrm{C}(50 \mathrm{~W})$ for $1.5 \mathrm{~h}$. Purification by column chromatography ( $n$-pentane/EtOAc 9/1) yielded 123q (0.05 g, 43\%) and 123r (0.15 g, 13\%) as orange oils. ${ }^{105}$<smiles>CCOC(=O)c1cn(-c2ccccc2C)nn1</smiles>

${ }^{1} \mathrm{H}-\mathrm{NMR}\left(300 \mathrm{MHz}, \mathrm{CDCl}_{3}\right): \delta=8.27(\mathrm{~s}, 1 \mathrm{H}), 7.50-7.29(\mathrm{~m}, 4 \mathrm{H}), 4.27(\mathrm{q}, J=7.1 \mathrm{~Hz}, 2 \mathrm{H})$, $2.23(\mathrm{~s}, 3 \mathrm{H}), 1.44(\mathrm{t}, J=7.1 \mathrm{~Hz}, 3 \mathrm{H})$.

${ }^{13} \mathrm{C}$-NMR $\left(125 \mathrm{MHz}, \mathrm{CDCl}_{3}\right): \delta=160.9\left(\mathrm{C}_{\mathrm{q}}\right), 140.4\left(\mathrm{C}_{\mathrm{q}}\right), 135.9\left(\mathrm{C}_{\mathrm{q}}\right), 133.8\left(\mathrm{C}_{\mathrm{q}}\right), 131.7(\mathrm{CH})$, $130.6(\mathrm{CH}), 130.1(\mathrm{CH}), 129.1(\mathrm{CH}), 127.2(\mathrm{CH}), 61.6\left(\mathrm{CH}_{2}\right), 18.0\left(\mathrm{CH}_{3}\right), 14.5\left(\mathrm{CH}_{3}\right)$.

IR (ATR): $\tilde{v}=3133,2982,1719,1541,1503,1374,1335,1292,1244,1226 \mathrm{~cm}^{-1}$.

MS (EI) m/z (relative intensity): 231 (7) [M+], 186 (8), 175 (8), 158 (23), 144 (12), 130 (100), 118 (15), 103 (15), 91 (47), 77 (19), 65 (45), 51 (11), 43 (13).

HR-MS (EI) $m / z$ calcd for $\mathrm{C}_{12} \mathrm{H}_{13} \mathrm{~N}_{3} \mathrm{O}_{2},\left[\mathrm{M}^{+}\right]$231.1008, found 231.1014.

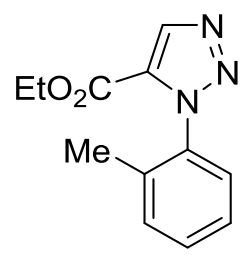

${ }^{1} \mathrm{H}-\mathrm{NMR}\left(400 \mathrm{MHz}, \mathrm{CDCl}_{3}\right): \delta=8.29(\mathrm{~s}, 1 \mathrm{H}), 7.46$ (dddd, $J=7.3,1.4,0.4 \mathrm{~Hz}, 1 \mathrm{H}$ ), 7.39-7.21 (m, 2H), 7.26-7.21 (m, 1H), $4.24(\mathrm{q}, J=7.1 \mathrm{~Hz}, 2 \mathrm{H}), 2.02(\mathrm{~s}, 3 \mathrm{H}), 1.22(\mathrm{t}, J=7.1 \mathrm{~Hz}, 3 \mathrm{H})$.

${ }^{13} \mathrm{C}$-NMR $\left(100 \mathrm{MHz}, \mathrm{CDCl}_{3}\right): \delta=157.7\left(\mathrm{C}_{\mathrm{q}}\right), 137.7(\mathrm{CH}), 136.2\left(\mathrm{C}_{\mathrm{q}}\right), 135.2\left(\mathrm{C}_{\mathrm{q}}\right), 130.9(\mathrm{CH})$, $130.6(\mathrm{CH}), 130.1\left(\mathrm{C}_{\mathrm{q}}\right), 127.1(\mathrm{CH}), 126.6(\mathrm{CH}), 61.9\left(\mathrm{CH}_{2}\right), 17.3\left(\mathrm{CH}_{3}\right), 13.4\left(\mathrm{CH}_{3}\right)$.

IR (ATR): $\tilde{v}=2981,1730,1499,1464,1367,1307,1291,1277,1184,1048 \mathrm{~cm}^{-1}$.

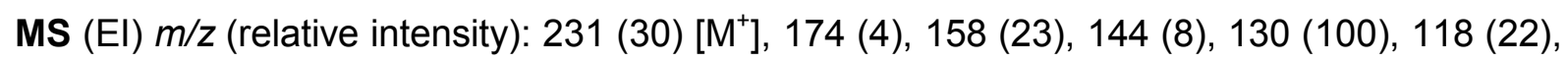
103 (26), 91 (43), 77 (35), 65 (29), 51 (12), 43 (16). 
HR-MS (EI) $m / z$ calcd for $\mathrm{C}_{12} \mathrm{H}_{13} \mathrm{~N}_{3} \mathrm{O}_{2},\left[\mathrm{M}^{+}\right]$231.1008, found 231.1009.

\section{Synthesis of 1-Phenyl-1H- 4-n-Butyl-1H-benzo[d]1,2,3-triazole (123s)}<smiles>c1ccc(-n2nnc3ccccc32)cc1</smiles>

To a 250-mL schlenk flask, containing a magnetic stirring bar and equipped with an air condenser (without water circulation), were added $\mathrm{Fe}_{2} \mathrm{O}_{3}$ (399 mg, $10 \mathrm{~mol} \%$ ), $1 \mathrm{H}$ benzo[d][1,2,3]triazole (2,98 mg, $25 \mathrm{mmol}), t$-BuOK (5.60 g, $50 \mathrm{mmol})$, DMSO (75 mL), and iodobenzene 1c $(10,2 \mathrm{~g}, 50 \mathrm{mmol})$ in an open atmosphere. The contents were stirred for $24 \mathrm{~h}$ at $120^{\circ} \mathrm{C}$ and allowed to cool to $25^{\circ} \mathrm{C}$. The mixture was diluted with EtOAc $(25 \mathrm{~mL})$ and $\mathrm{H}_{2} \mathrm{O}(25 \mathrm{~mL})$ and stirring was continued for a further $10 \mathrm{~min}$. The organic layer was separated and the aqueous layer was extracted with EtOAc $(3 \times 50 \mathrm{~mL})$. The combined organic extracts were washed with $\mathrm{H}_{2} \mathrm{O}$, brine and were dried over $\mathrm{Na}_{2} \mathrm{SO}_{4}$. The solvent was evaporated and the residue was purified by column chromatography ( $n$-pentane/EtOAc 9/1) to give $147 \mathrm{c}(1.44 \mathrm{~g}, 30 \%)$ as an orange solid.

M.r.: $90-91^{\circ} \mathrm{C}$.

${ }^{1} \mathrm{H}-\mathrm{NMR}\left(400 \mathrm{MHz}, \mathrm{CDCl}_{3}\right): \delta=8.16(\mathrm{dd}, J=8.4,1.0 \mathrm{~Hz}, 1 \mathrm{H}), 7.83-7.78(\mathrm{~m} \mathrm{2H}), 7.76(\mathrm{dd}$, $J=8.4,1.0 \mathrm{~Hz}, 1 \mathrm{H}), 7.66-7.59(\mathrm{~m} \mathrm{2H}), 7.58-7.48(\mathrm{~m} \mathrm{2H}), 7.44$ (ddd, $J=8.4,7.0,1.0 \mathrm{~Hz}$, $1 \mathrm{H})$.

${ }^{13} \mathrm{C}-\mathrm{NMR}\left(100 \mathrm{MHz}, \mathrm{CDCl}_{3}\right): \delta=146.7\left(\mathrm{C}_{\mathrm{q}}\right), 137.2\left(\mathrm{C}_{\mathrm{q}}\right), 132.5\left(\mathrm{C}_{\mathrm{q}}\right), 130.0(\mathrm{CH}), 128.8(\mathrm{CH})$, $128.4(\mathrm{CH}), 124.5(\mathrm{CH}), 123.0(\mathrm{CH}), 120.5(\mathrm{CH}), 110.5(\mathrm{CH})$.

IR (ATR): $\tilde{v}=3057,1595,1499,1459,1447,1384,1326,1291,1276,1089 \mathrm{~cm}^{-1}$.

MS (ESI) $m / z$ (relative intensity): $218(25)\left[\mathrm{M}+\mathrm{Na}^{+}\right], 196(100)\left[\mathrm{M}+\mathrm{H}^{+}\right]$.

HR-MS (ESI) $m / z$ calcd for $\mathrm{C}_{12} \mathrm{H}_{10} \mathrm{~N}_{3},\left[\mathrm{M}+\mathrm{H}^{+}\right]$196.0869, found 196.0871 .

The spectral data are in accordance with those reported in the literature. ${ }^{112}$ 


\subsubsection{Synthesis of $\mathbf{N}$-Tosylbenzamides}

\section{Synthesis of $N$-Tosylbenzamide (135a)}<smiles>O=C(N[I-])c1ccccc1</smiles>

The general procedure B was followed using benzoyl chloride (7.80 g, $55.0 \mathrm{mmol}, 1.1$ equiv) in PhMe (44 mL), p-toluene sulfonamide $\left(8.50 \mathrm{~g}, 50.0 \mathrm{mmol}, 1.0\right.$ equiv), $\mathrm{NEt}_{3}(12.80 \mathrm{~g}$, $125.0 \mathrm{mmol}, 2.5$ equiv) and DMAP (3 mg, $0.025 \mathrm{mmol}, 0.5 \mathrm{~mol} \%)$ in EtOAc $(100 \mathrm{~mL})$. Recrystallization from EtOH yielded $135 \mathrm{a}(9.49 \mathrm{~g}, 69 \%)$ as a colorless solid.

M.p.: $149^{\circ} \mathrm{C}$.

${ }^{1} \mathrm{H}-\mathrm{NMR}\left(300 \mathrm{MHz}, \mathrm{CDCl}_{3}\right): \delta=9.08$ (brs, $\left.1 \mathrm{H}\right), 8.05(\mathrm{~d}, \mathrm{~J}=8.4 \mathrm{~Hz}, 2 \mathrm{H}), 7.83-7.70(\mathrm{~m}, 2 \mathrm{H})$ 7.63-7.50 (m, 1H), 7.46-7.39 (m, 2H), 7.39-7.33 (m, 2H), $2.44(\mathrm{~s}, 3 \mathrm{H})$.

${ }^{13} \mathrm{C}-\mathrm{NMR}\left(125 \mathrm{MHz}, \mathrm{CDCl}_{3}\right): \delta=164.3\left(\mathrm{C}_{\mathrm{q}}\right), 145.4\left(\mathrm{C}_{\mathrm{q}}\right), 135.5\left(\mathrm{C}_{\mathrm{q}}\right), 133.6(\mathrm{CH}), 131.3\left(\mathrm{C}_{\mathrm{q}}\right)$, $129.8(\mathrm{CH}), 129.1(\mathrm{CH}), 128.8(\mathrm{CH}), 127.9(\mathrm{CH}), 21.9\left(\mathrm{CH}_{3}\right)$.

IR (neat): 3309, 1699, 1597, 1494, 1450, 1417, 1333, 1233, 1185, $1162 \mathrm{~cm}^{-1}$.

MS (ESI) m/z (relative intensity): 314 (10) [M+K $\left.{ }^{+}\right], 298$ (100) $\left[\mathrm{M}+\mathrm{Na}^{+}\right], 276(74)\left[\mathrm{M}+\mathrm{H}^{+}\right]$.

HR-MS (ESI) $m / z$ calcd for $\mathrm{C}_{14} \mathrm{H}_{14} \mathrm{NO}_{3} \mathrm{~S}$, [M+H $\left.{ }^{+}\right] 276.0689$, found 276.0688 .

The spectral data are in accordance with those reported in the literature. ${ }^{114}$

\section{Synthesis of 2-Methyl-N-tosylbenzamide (135b)}<smiles>[3H]NC(=O)c1ccccc1C</smiles>

The general procedure B was followed using 2-methylbenzoyl chloride $(2.72 \mathrm{~g}, 17.6 \mathrm{mmol}$, 1.1 equiv) in PhMe (14 mL), p-toluene sulfonamide ( $2.91 \mathrm{~g}, 16.0 \mathrm{mmol}, 1.0$ equiv), $\mathrm{NEt}_{3}$ (4.05 g, $40.0 \mathrm{mmol}, 2.5$ equiv) and DMAP (1 mg, $0.008 \mathrm{mmol}, 0.5 \mathrm{~mol} \%)$ in EtOAc (32 mL). Recrystallization from EtOH yielded $135 \mathrm{~b}(2.11 \mathrm{~g}, 46 \%)$ as a colorless solid.

M.r.: $113-115^{\circ} \mathrm{C}$ 
${ }^{1} \mathrm{H}-\mathrm{NMR}\left(300 \mathrm{MHz}, \mathrm{CDCl}_{3}\right): \delta=9.02$ (brs, $\left.1 \mathrm{H}\right), 7.98(\mathrm{~d}, J=8.4 \mathrm{~Hz}, 2 \mathrm{H}), 7.40$ (dd, $J=8.1$, $1.4 \mathrm{~Hz}, 1 \mathrm{H}$ ), 7.32 (dd, $J=7.6,1.3 \mathrm{~Hz}, 3 \mathrm{H}), 7.15$ (dd, $J=7.0,7.0 \mathrm{~Hz}, 2 \mathrm{H}), 2.43(\mathrm{~s}, 3 \mathrm{H}), 2.32$ (s, 3H).

${ }^{13} \mathrm{C}-N M R\left(125 \mathrm{MHz}, \mathrm{CDCl}_{3}\right): \delta=166.5\left(\mathrm{C}_{\mathrm{q}}\right), 145.2\left(\mathrm{C}_{\mathrm{q}}\right), 138.0\left(\mathrm{C}_{\mathrm{q}}\right), 135.7\left(\mathrm{C}_{\mathrm{q}}\right), 132.2\left(\mathrm{C}_{\mathrm{q}}\right)$, $131.8(\mathrm{CH}), 131.7(\mathrm{CH}), 129.7(\mathrm{CH}), 128.6(\mathrm{CH}), 127.5(\mathrm{CH}), 126.0(\mathrm{CH}), 21.8\left(\mathrm{CH}_{3}\right), 20.1$ $\left(\mathrm{CH}_{3}\right)$.

IR (neat): 3259, 1711, 1595, 1409, 1335, 1291, 1242, 1182, 1165, $1119 \mathrm{~cm}^{-1}$.

MS (ESI) $\mathrm{m} / \mathrm{z}$ (relative intensity): $328(9)\left[\mathrm{M}+\mathrm{K}^{+}\right], 312(100)\left[\mathrm{M}+\mathrm{Na}^{+}\right], 290(78)\left[\mathrm{M}+\mathrm{H}^{+}\right]$.

HR-MS (ESI) $m / z$ calcd for $\mathrm{C}_{15} \mathrm{H}_{16} \mathrm{NO}_{3} \mathrm{~S}$, $\left[\mathrm{M}+\mathrm{H}^{+}\right]$290.0845, found 290.0848 .

The spectral data are in accordance with those reported in the literature. ${ }^{114}$

\section{Synthesis of 2-Fluoro-N-tosylbenzamide (135c)}<smiles>O=C(N[I-])c1ccccc1F</smiles>

The general procedure B was followed using oxalylchloride $(4.55 \mathrm{~g}, 45.0 \mathrm{mmol}, 1.2$ equiv) and 2-fluorobenzoic acid (5.24 g, $37.4 \mathrm{mmol}, 1.1$ equiv) in PhMe (30 mL). The crude product, 2-fluorobenzoyl chloride $(5.93 \mathrm{~g}, 37.4 \mathrm{mmol}, 1.1$ equiv) in PhMe (30 mL) was added to a solution of $p$-toluene sulfonamide $\left(5.82 \mathrm{~g}, 34.0 \mathrm{mmol}, 1.0\right.$ equiv), $\mathrm{NEt}_{3}(8.10 \mathrm{~g}, 80.0 \mathrm{mmol}$, 2.5 equiv) and DMAP ( $2 \mathrm{mg}, 0.016 \mathrm{mmol}, 0.5 \mathrm{~mol} \%)$ in EtOAc $(68 \mathrm{~mL})$. Recrystallization from $\mathrm{EtOH}$ yielded $135 \mathrm{c}(7.52 \mathrm{~g}, 78 \%)$ as a colorless solid.

M.r.: $134-135^{\circ} \mathrm{C}$.

${ }^{1} \mathrm{H}-\mathrm{NMR}\left(300 \mathrm{MHz}, \mathrm{CDCl}_{3}\right): \delta=9.02(\mathrm{~d}, J=14.9 \mathrm{~Hz}, 1 \mathrm{H}), 8.09-7.98(\mathrm{~m}, 2 \mathrm{H}), 7.95(\mathrm{dd}$, $J=7.9,1.9 \mathrm{~Hz}, 1 \mathrm{H}), 7.53$ (dddd, $J=8.4,7.9,5.3,1.9 \mathrm{~Hz}, 1 \mathrm{H}), 7.38-7.29(\mathrm{~m}, 2 \mathrm{H}), 7.26-7.19$ (m, 1H), 7.13 (ddd, $J=12.3,8.4,1.1 \mathrm{~Hz}, 1 \mathrm{H}), 2.41$ (s, 3H).

${ }^{13} \mathrm{C}-N M R\left(125 \mathrm{MHz}, \mathrm{CDCl}_{3}\right): \delta=160.8\left({ }^{1} J_{\mathrm{C}-\mathrm{F}}=249.0 \mathrm{~Hz}, \mathrm{C}_{\mathrm{q}}\right), 160.2\left({ }^{3} \mathrm{~J}_{\mathrm{C}-\mathrm{F}}=3.0 \mathrm{~Hz}, \mathrm{C}_{\mathrm{q}}\right)$, $145.4\left(C_{q}\right), 135.7\left({ }^{3} J_{C-F}=9.7 \mathrm{~Hz}, C H\right), 135.5\left(C_{q}\right), 132.2\left({ }^{4} J_{C-F}=1.2 \mathrm{~Hz}, C H\right), 129.7(\mathrm{CH})$, $128.9(\mathrm{CH}), 125.2\left({ }^{3} J_{\mathrm{C}-\mathrm{F}}=3.2 \mathrm{~Hz}, \mathrm{CH}\right), 118.5\left({ }^{3} J_{\mathrm{C}-\mathrm{F}}=10.4 \mathrm{~Hz}, \mathrm{C}_{\mathrm{q}}\right), 116.3\left({ }^{2} J_{\mathrm{C}-\mathrm{F}}=24.6 \mathrm{~Hz}\right.$, $\mathrm{CH}), 21.6\left(\mathrm{CH}_{3}\right)$.

${ }^{19} \mathrm{~F}-\mathrm{NMR}\left(282 \mathrm{MHz}, \mathrm{CDCl}_{3}\right): \delta=-104.7--115.1(\mathrm{~m})$.

IR (neat): 3324, 1701, 1613, 1595, 1454, 1426, 1345, 1279, 1209, $1186 \mathrm{~cm}^{-1}$.

MS (ESI) $m / z$ (relative intensity): $316(100)\left[\mathrm{M}+\mathrm{Na}^{+}\right], 294(68)\left[\mathrm{M}+\mathrm{H}^{+}\right]$.

HR-MS (ESI) $m / z$ calcd for $\mathrm{C}_{14} \mathrm{H}_{13} \mathrm{FNO}_{3} \mathrm{~S}$, [M+H $\mathrm{H}^{+}$294.0595, found 294.0597.

The spectral data are in accordance with those reported in the literature. ${ }^{114}$ 


\section{Synthesis of 4-Methoxy-N-tosylbenzamide (135d)}<smiles>[3H]NC(=O)c1ccccc1OC</smiles>

The general procedure B was followed using oxalylchloride $(4.27 \mathrm{~g}, 42.2 \mathrm{mmol}, 1.2$ equiv) and 2-methoxybenzoic acid (5.35 g, $35.2 \mathrm{mmol}, 1.1$ equiv) in PhMe (28 mL). The crude product, 2-methoxybenzoyl chloride $(6.01 \mathrm{~g}, 35.2 \mathrm{mmol}, 1.1$ equiv) in PhMe (28 $\mathrm{mL})$ was added to a solution of $p$-toluene sulfonamide $\left(5.44 \mathrm{~g}, 32.0 \mathrm{mmol}, 1.0\right.$ equiv), $\mathrm{NEt}_{3}(8.10 \mathrm{~g}$, $80.0 \mathrm{mmol}, 2.5$ equiv) and DMAP (2 $\mathrm{mg}, 0.016 \mathrm{mmol}, 0.5 \mathrm{~mol} \%)$ in EtOAc $(64 \mathrm{~mL})$. Recrystallization from EtOH yielded $135 \mathrm{~d}(7.52 \mathrm{~g}, 78 \%)$ as a colorless solid.

M.r.: $128-130{ }^{\circ} \mathrm{C}$.

${ }^{1} \mathrm{H}-\mathrm{NMR}\left(300 \mathrm{MHz}, \mathrm{CDCl}_{3}\right): \delta=10.36$ (brs, $\left.1 \mathrm{H}\right), 8.17-7.98(\mathrm{~m}, 3 \mathrm{H}), 7.52$ (ddd, $J=8.5,7.3$, $1.9 \mathrm{~Hz}, 1 \mathrm{H}), 7.37-7.32(\mathrm{~m}, 2 \mathrm{H}), 7.10-6.95(\mathrm{~m}, 2 \mathrm{H}), 4.05$ (s, 3H), 2.42 (s, 3H).

${ }^{13}$ C-NMR (125 MHz, CDCl $): \delta=162.4\left(\mathrm{C}_{\mathrm{q}}\right), 157.9\left(\mathrm{C}_{\mathrm{q}}\right), 144.9\left(\mathrm{C}_{\mathrm{q}}\right), 136.2\left(\mathrm{C}_{\mathrm{q}}\right), 135.2(\mathrm{CH})$, $132.9(\mathrm{CH}), 129.6(\mathrm{CH}), 128.8(\mathrm{CH}), 121.9(\mathrm{CH}), 119.0\left(\mathrm{C}_{\mathrm{q}}\right), 111.8(\mathrm{CH}), 56.6\left(\mathrm{CH}_{3}\right), 21.7$ $\left(\mathrm{CH}_{3}\right)$.

IR (neat): 3272, 1676, 1598, 1443, 1410, 1339, 1288, 1245, 1213, $1161 \mathrm{~cm}^{-1}$.

MS (ESI) m/z (relative intensity): 344 (7) $\left[\mathrm{M}+\mathrm{K}^{+}\right], 328(100)\left[\mathrm{M}+\mathrm{Na}^{+}\right], 306(68)\left[\mathrm{M}+\mathrm{H}^{+}\right]$.

HR-MS (ESI) $\mathrm{m} / \mathrm{z}$ calcd for $\mathrm{C}_{15} \mathrm{H}_{16} \mathrm{NO}_{4} \mathrm{~S},\left[\mathrm{M}+\mathrm{H}^{+}\right]$306.0795, found 306.0795 .

The spectral data are in accordance with those reported in the literature. ${ }^{114}$

\section{Synthesis of $\mathbf{N}$-Tosyl-1-naphtamide (135e)}<smiles>O=C(N[I-])c1cccc2ccccc12</smiles>

The general procedure B was followed using oxalylchloride ( $3.06 \mathrm{~g}, 24.1 \mathrm{mmol}, 1.2$ equiv) and 1-naphthoic acid (3.46 g, $20.1 \mathrm{mmol}, 1.1$ equiv) in PhMe (16 mL). The crude product, 1naphthoyl chloride ( $3.83 \mathrm{~g}, 20.1 \mathrm{mmol}, 1.1$ equiv) in PhMe (16 mL) was added to a solution of $p$-toluene sulfonamide ( $3.11 \mathrm{~g}, 18.3 \mathrm{mmol}, 1.0$ equiv), $\mathrm{NEt}_{3}(4.62 \mathrm{~g}, 45.8 \mathrm{mmol}, 2.5$ equiv) and DMAP (1 mg, $0.009 \mathrm{mmol}, 0.5 \mathrm{~mol} \%)$ in EtOAc $(37 \mathrm{~mL})$. Recrystallization from EtOH yielded $135 \mathrm{e}(4.34 \mathrm{~g}, 73 \%)$ as a colorless solid. 
M.p.: $143^{\circ} \mathrm{C}$.

${ }^{1} \mathrm{H}-\mathrm{NMR}\left(300 \mathrm{MHz}, \mathrm{CDCl}_{3}\right): \delta=8.70(\mathrm{brs}, 1 \mathrm{H}), 8.23-8.14(\mathrm{~m}, 1 \mathrm{H}), 8.06(\mathrm{~d}, J=8.4 \mathrm{~Hz}, 2 \mathrm{H})$, 7.96 (ddd, $J=8.5,7.3,1.0 \mathrm{~Hz}, 1 \mathrm{H}$ ), 7.89-7.80 (m, 1H), 7.67 (dd, J = 7.2, $1.2 \mathrm{~Hz}, 1 \mathrm{H}$ ), 7.57$7.42(\mathrm{~m}, 2 \mathrm{H}), 7.42-7.35(\mathrm{~m}, 3 \mathrm{H}), 2.47(\mathrm{~s}, 3 \mathrm{H})$.

${ }^{13} \mathrm{C}-N M R\left(125 \mathrm{MHz}, \mathrm{CDCl}_{3}\right): \delta=166.0\left(\mathrm{C}_{\mathrm{q}}\right), 145.4\left(\mathrm{C}_{\mathrm{q}}\right), 135.6\left(\mathrm{C}_{\mathrm{q}}\right), 133.9(\mathrm{CH}), 133.0\left(\mathrm{C}_{\mathrm{q}}\right)$, $130.2\left(\mathrm{C}_{\mathrm{q}}\right), 130.1\left(\mathrm{C}_{\mathrm{q}}\right), 129.8(\mathrm{CH}), 128.8(\mathrm{CH}), 128.7(\mathrm{CH}), 128.1(\mathrm{CH}), 127.0(\mathrm{CH}), 126.6$ $(\mathrm{CH}), 125.0(\mathrm{CH}), 124.5(\mathrm{CH}), 21.9\left(\mathrm{CH}_{3}\right)$.

IR (neat): 3257, 3161, 1678, 1594, 1510, 1412, 1341, 1240, 1182, $1160 \mathrm{~cm}^{-1}$.

MS (ESI) $m / z$ (relative intensity): $348(100)\left[\mathrm{M}+\mathrm{Na}^{+}\right], 326(64)\left[\mathrm{M}+\mathrm{H}^{+}\right]$.

HR-MS (ESI) $m / z$ calcd for $\mathrm{C}_{18} \mathrm{H}_{16} \mathrm{NO}_{3} \mathrm{~S}$, $\left[\mathrm{M}+\mathrm{H}^{+}\right] 326.0845$, found 326.0843 .

The spectral data are in accordance with those reported in the literature. ${ }^{114}$

\section{Synthesis of 2-Nitro-N-tosylbenzamide (135f)}<smiles>O=C(N[I-])c1ccccc1[N+](=O)[O-]</smiles>

The general procedure B was followed using oxalylchloride $(2.14 \mathrm{~g}, 21.1 \mathrm{mmol}, 1.2$ equiv) and 2-nitrobenzoic acid (2.94 g, $17.6 \mathrm{mmol}, 1.1$ equiv) in PhMe (30 mL). The crude product, 2-nitrobenzoyl chloride (3.27 g, $17.6 \mathrm{mmol}, 1.1$ equiv) in PhMe (14 mL) was added to a solution of $p$-toluene sulfonamide $\left(2.91 \mathrm{~g}, 16.0 \mathrm{mmol}, 1.0\right.$ equiv), $\mathrm{NEt}_{3}(4.05 \mathrm{~g}, 40.0 \mathrm{mmol}$, 2.5 equiv) and DMAP ( $1 \mathrm{mg}, 0.008 \mathrm{mmol}, 0.5 \mathrm{~mol} \%)$ in EtOAc (32 mL). Recrystallization from $\mathrm{EtOH}$ yielded $135 \mathrm{f}(4.14 \mathrm{~g}, 76 \%)$ as a colorless solid.

M.p.: $121^{\circ} \mathrm{C}$

${ }^{1} \mathrm{H}-\mathrm{NMR}\left(300 \mathrm{MHz}, \mathrm{CDCl}_{3}\right): \delta=9.18(\mathrm{brs}, 1 \mathrm{H}), 8.03(\mathrm{dd}, J=8.2,1.3 \mathrm{~Hz}, 1 \mathrm{H}), 7.87(\mathrm{~d}$, $J=8.4 \mathrm{~Hz}, 2 \mathrm{H}), 7.68(\mathrm{dd}, J=7.6,1.3 \mathrm{~Hz}, 1 \mathrm{H}), 7.63-7.54(\mathrm{~m}, 1 \mathrm{H}), 7.50(\mathrm{dd}, J=7.4,1.6 \mathrm{~Hz}$, $1 \mathrm{H}), 7.42-7.26(\mathrm{~m}, 2 \mathrm{H}), 2.46(\mathrm{~s}, 3 \mathrm{H})$.

${ }^{13} \mathrm{C}-\mathrm{NMR}\left(125 \mathrm{MHz}, \mathrm{CDCl}_{3}\right): \delta=164.1\left(\mathrm{C}_{\mathrm{q}}\right), 145.7\left(\mathrm{C}_{\mathrm{q}}\right), 145.5\left(\mathrm{C}_{\mathrm{q}}\right), 134.6\left(\mathrm{C}_{\mathrm{q}}\right), 134.4(\mathrm{CH})$, $131.6(\mathrm{CH}), 130.1\left(\mathrm{C}_{\mathrm{q}}\right), 129.8(\mathrm{CH}), 128.9(\mathrm{CH}), 128.9(\mathrm{CH}), 124.7(\mathrm{CH}), 21.9\left(\mathrm{CH}_{3}\right)$.

IR (neat): 3214, 3071, 2853, 1708, 1596, 1449, 1350, 1172, $745 \mathrm{~cm}^{-1}$.

MS (ESI) $m / z$ (relative intensity): $343(100)\left[\mathrm{M}+\mathrm{Na}^{+}\right], 321$ (16) $\left[\mathrm{M}+\mathrm{H}^{+}\right]$.

HR-MS (ESI) $\mathrm{m} / \mathrm{z}$ calcd for $\mathrm{C}_{14} \mathrm{H}_{13} \mathrm{~N}_{2} \mathrm{O}_{5} \mathrm{~S}$, $\left[\mathrm{M}+\mathrm{H}^{+}\right]$321.0540, found 321.0537.

The spectral data are in accordance with those reported in the literature. ${ }^{114}$ 


\section{Synthesis of 2-Chloro-N-tosylbenzamide (135g)}<smiles>O=C(N[I-])c1ccccc1Cl</smiles>

The general procedure B was followed using 2-chlorobenzoyl chloride $(2.76 \mathrm{~g}, 17.6 \mathrm{mmol}$, 1.1 equiv) PhMe (14 mL), p-toluene sulfonamide (2.91 g, 16.0 mmol, 1.0 equiv), $\mathrm{NEt}_{3}(4.05 \mathrm{~g}$, $40.0 \mathrm{mmol}, 2.5$ equiv) and DMAP (1 $\mathrm{mg}, 0.008 \mathrm{mmol}, 0.5 \mathrm{~mol} \%$ ) in EtOAc (32 mL). Recrystallization from EtOH yielded $135 \mathrm{~g}(3.14 \mathrm{~g}, 64 \%)$ as a colorless solid.

M.r.: $125-126{ }^{\circ} \mathrm{C}$

${ }^{1} \mathrm{H}-\mathrm{NMR}\left(300 \mathrm{MHz}, \mathrm{CDCl}_{3}\right): \delta=8.90$ (brs, $\left.1 \mathrm{H}\right), 8.15-7.84(\mathrm{~m}, 2 \mathrm{H}), 7.80-7.58(\mathrm{~m}, 1 \mathrm{H}), 7.55-$ $7.27(\mathrm{~m}, 5 \mathrm{H}), 2.45(\mathrm{~s}, 3 \mathrm{H})$.

${ }^{13}$ C-NMR $\left(75 \mathrm{MHz}, \mathrm{CDCl}_{3}\right): \delta=163.2\left(\mathrm{C}_{\mathrm{q}}\right), 145.5\left(\mathrm{C}_{\mathrm{q}}\right), 135.3\left(\mathrm{C}_{\mathrm{q}}\right), 133.3(\mathrm{CH}), 131.6\left(\mathrm{C}_{\mathrm{q}}\right)$, $131.3(\mathrm{CH}), 131.0\left(\mathrm{C}_{\mathrm{q}}\right), 130.8(\mathrm{CH}), 129.8(\mathrm{CH}), 128.9(\mathrm{CH}), 127.6(\mathrm{CH}), 21.9\left(\mathrm{CH}_{3}\right)$.

IR (neat): 3208, 1704, 1592, 1436, 1342, 1315, 1277, 1232, 1155, $1105 \mathrm{~cm}^{-1}$.

MS (ESI) $m / z$ (relative intensity): 348 (12) [M+K $\left.\mathrm{K}^{+}\right], 332$ (100) [M+Na $\left.{ }^{+}\right], 310(68)\left[\mathrm{M}+\mathrm{H}^{+}\right]$.

HR-MS (ESI) $\mathrm{m} / \mathrm{z}$ calcd for $\mathrm{C}_{14} \mathrm{H}_{13} \mathrm{CINO}_{3} \mathrm{~S},\left[\mathrm{M}+\mathrm{H}^{+}\right]$310.0299, found 310.0299.

The spectral data are in accordance with those reported in the literature. ${ }^{114}$

\section{Synthesis of 3-Methyl-N-tosylbenzamide (135h)}<smiles>[3H]NC(=O)c1cccc(C)c1</smiles>

The general procedure B was followed using 3-methylbenzoyl chloride $(2.72 \mathrm{~g}, 17.6 \mathrm{mmol}$, 1.1 equiv) in PhMe (14 mL), p-toluene sulfonamide $(2.91 \mathrm{~g}, 16.0 \mathrm{mmol}, 1.0$ equiv), triethylamine ( $4.05 \mathrm{~g}, 40.0 \mathrm{mmol}, 2.5$ equiv) and DMAP (1 $\mathrm{mg}, 0.008 \mathrm{mmol}, 0.5 \mathrm{~mol} \%$ ) in EtOAc (32 mL). Recrystallization from EtOH yielded $135 \mathrm{~h}(3.77 \mathrm{~g}, 81 \%)$ as a colorless solid.

M.r.: $115-118{ }^{\circ} \mathrm{C}$.

${ }^{1} \mathrm{H}-\mathrm{NMR}\left(300 \mathrm{MHz}, \mathrm{CDCl}_{3}\right): \delta=8.77$ (brs, $\left.1 \mathrm{H}\right), 8.01$ (d, $\left.\mathrm{J}=8.2 \mathrm{~Hz}, 2 \mathrm{H}\right), 7.72-7.53(\mathrm{~m}, 2 \mathrm{H})$, 7.51-7.34 (m, 2H), 7.34-7.11 (m, 2H), 2.40 (s, 3H), $2.32(\mathrm{~s}, 3 \mathrm{H})$. 
${ }^{13} \mathrm{C}-\mathrm{NMR}\left(125 \mathrm{MHz}, \mathrm{CDCl}_{3}\right): \delta=164.4\left(\mathrm{C}_{\mathrm{q}}\right), 145.3\left(\mathrm{C}_{\mathrm{q}}\right), 139.1\left(\mathrm{C}_{\mathrm{q}}\right), 135.7\left(\mathrm{C}_{\mathrm{q}}\right), 134.4(\mathrm{CH})$, $131.3\left(\mathrm{C}_{\mathrm{q}}\right), 129.7(\mathrm{CH}), 129.0(\mathrm{CH}), 128.8(\mathrm{CH}), 128.5(\mathrm{CH}), 124.9(\mathrm{CH}), 21.8\left(\mathrm{CH}_{3}\right), 21.1$ $\left(\mathrm{CH}_{3}\right)$.

IR (neat): 3293, 1695, 1595, 1433, 1393, 1338, 1302, 1260, 1192, $1180 \mathrm{~cm}^{-1}$.

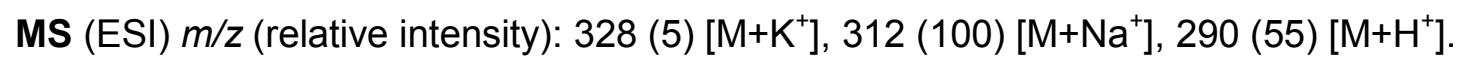

HR-MS (ESI) $m / z$ calcd for $\mathrm{C}_{15} \mathrm{H}_{16} \mathrm{NO}_{3} \mathrm{~S}$, [M+H $\left.\mathrm{H}^{+}\right] 290.0845$, found 290.0847 .

The spectral data are in accordance with those reported in the literature. ${ }^{114}$

\section{Synthesis of 3-Methoxy-N-tosylbenzamide (135i)}<smiles>[3H]NC(=O)c1cccc(OC)c1</smiles>

The general procedure B was followed using 3-methoxybenzoyl chloride $(3.00 \mathrm{~g}, 17.6 \mathrm{mmol}$, 1.1 equiv) in PhMe (14 mL), p-toluene sulfonamide $\left(2.91 \mathrm{~g}, 16.0 \mathrm{mmol}, 1.0\right.$ equiv), $\mathrm{NEt}_{3}$ (4.05 g, $40.0 \mathrm{mmol}, 2.5$ equiv) and DMAP (1 mg, $0.008 \mathrm{mmol}, 0.5 \mathrm{~mol} \%)$ in EtOAc (32 mL). Recrystallization from $\mathrm{EtOH}$ yielded $135 \mathrm{i}(4.26 \mathrm{~g}, 79 \%)$ as a colorless solid.

M.r.: $115-118^{\circ} \mathrm{C}$

${ }^{1} \mathrm{H}-\mathrm{NMR}\left(300 \mathrm{MHz}, \mathrm{CDCl}_{3}\right): \delta=9.60(\mathrm{brs}, 1 \mathrm{H}), 8.04(\mathrm{~d}, J=8.4 \mathrm{~Hz}, 2 \mathrm{H}), 7.52-7.18(\mathrm{~m}, 5 \mathrm{H})$, 7.13-7.05 (m, 1H), $3.76(\mathrm{~s}, 3 \mathrm{H}), 2.43(\mathrm{~s}, 3 \mathrm{H})$.

${ }^{13} \mathrm{C}-N M R\left(125 \mathrm{MHz}, \mathrm{CDCl}_{3}\right): \delta=164.5\left(\mathrm{C}_{\mathrm{q}}\right), 160.0\left(\mathrm{C}_{\mathrm{q}}\right), 145.4\left(\mathrm{C}_{\mathrm{q}}\right), 135.5\left(\mathrm{C}_{\mathrm{q}}\right), 132.5\left(\mathrm{C}_{\mathrm{q}}\right)$, $130.0(\mathrm{CH}), 129.7(\mathrm{CH}), 128.7(\mathrm{CH}), 120.5(\mathrm{CH}), 120.1(\mathrm{CH}), 112.2(\mathrm{CH}), 55.4\left(\mathrm{CH}_{3}\right), 21.6$ $\left(\mathrm{CH}_{3}\right)$.

IR (neat): 3261, 1698, 1585, 1455, 1439, 1401, 1337, 1292, 1268, $1210 \mathrm{~cm}^{-1}$.

MS (ESI) $m / z$ (relative intensity): 344 (11) $\left[\mathrm{M}+\mathrm{K}^{+}\right], 328(100)\left[\mathrm{M}+\mathrm{Na}^{+}\right], 306(84)\left[\mathrm{M}+\mathrm{H}^{+}\right]$.

HR-MS (ESI) $m / z$ calcd for $\mathrm{C}_{15} \mathrm{H}_{16} \mathrm{NO}_{4} \mathrm{~S}$, [M+H'] 306.0795, found 306.0792.

The spectral data are in accordance with those reported in the literature. ${ }^{114}$

Synthesis of $\mathbf{N}$-Tosyl-3-(trifluoromethyl)benzamide (135j)<smiles>O=C(N[13F])c1cccc(C(F)(F)F)c1</smiles> 
The general procedure B was followed using oxalylchloride (3.06 g, $24.1 \mathrm{mmol}, 1.2$ equiv) and 3-(trifluoromethyl)bencoic acid (3.82 g, $20.1 \mathrm{mmol}, 1.1$ equiv) in PhMe (16 mL). The crude product, 1-naphthoyl chloride $(4.19 \mathrm{~g}, 20.1 \mathrm{mmol}, 1.1$ equiv) in PhMe (16 mL) was added to a solution of $p$-toluene sulfonamide $\left(3.11 \mathrm{~g}, 18.3 \mathrm{mmol}, 1.0\right.$ equiv), $\mathrm{NEt}_{3}(4.62 \mathrm{~g}$, $45.8 \mathrm{mmol}, 2.5$ equiv) and DMAP (1 $\mathrm{mg}, 0.009 \mathrm{mmol}, 0.5 \mathrm{~mol} \%)$ in EtOAc $(40 \mathrm{~mL})$. Recrystallization from EtOH yielded $135 \mathrm{j}(6.14 \mathrm{~g}, 89 \%)$ as a colorless solid.

M.r.: $162-163^{\circ} \mathrm{C}$.

${ }^{1} \mathrm{H}-\mathrm{NMR}\left(300 \mathrm{MHz}, \mathrm{CDCl}_{3}\right): \delta=9.98(\mathrm{brs}, 1 \mathrm{H}), 8.15(\mathrm{~s}, 1 \mathrm{H}), 8.10-8.01(\mathrm{~m}, 3 \mathrm{H}), 7.77$ (dd, $J=7.9,0.9 \mathrm{~Hz}, 1 \mathrm{H}$ ), 7.55 (dd, $J=7.9,0.8 \mathrm{~Hz}, 1 \mathrm{H}$ ), 7.34 (dd, $J=8.5,0.9 \mathrm{~Hz}, 2 \mathrm{H}$ ), 2.43 (s, $3 \mathrm{H})$.

${ }^{13} \mathrm{C}-N M R\left(125 \mathrm{MHz}, \mathrm{CDCl}_{3}\right): \delta=163.6\left(\mathrm{C}_{\mathrm{q}}\right), 145.7\left(\mathrm{C}_{\mathrm{q}}\right), 135.2\left(\mathrm{C}_{\mathrm{q}}\right), 132.1\left(\mathrm{C}_{\mathrm{q}}\right), 131.5$ $\left({ }^{2} J_{\mathrm{C}-\mathrm{F}}=33.2 \mathrm{~Hz}, \mathrm{C}_{\mathrm{q}}\right), 131.2(\mathrm{CH}), 130.0\left({ }^{3} \mathrm{~J}_{\mathrm{C}-\mathrm{F}}=3.7 \mathrm{~Hz}, \mathrm{CH}\right), 129.8(\mathrm{CH}), 129.7(\mathrm{CH}), 128.7$ $(\mathrm{CH}), 123.3\left({ }^{1} J_{\mathrm{C}-\mathrm{F}}=273.0 \mathrm{~Hz}, \mathrm{CH}\right), 97.1\left(\mathrm{C}_{\mathrm{q}}\right), 21.8\left(\mathrm{CH}_{3}\right)$.

${ }^{19} \mathrm{~F}-\mathrm{NMR}\left(282 \mathrm{MHz}, \mathrm{CDCl}_{3}\right): \delta=-63.0(\mathrm{~s})$.

IR (neat): 3298, 1699, 1594, 1424, 1346, 1328, 1239, 1158, 1127, $1059 \mathrm{~cm}^{-1}$.

MS (ESI) $m / z$ (relative intensity): 366 (100) $\left[\mathrm{M}+\mathrm{Na}^{+}\right], 344$ (46) $\left[\mathrm{M}+\mathrm{H}^{+}\right]$.

HR-MS (ESI) $m / z$ calcd for $\mathrm{C}_{15} \mathrm{H}_{13} \mathrm{~F}_{3} \mathrm{NO}_{3} \mathrm{~S}$, [M+H+ $\left.\mathrm{H}^{+}\right] 344.0563$, found 344.0556 .

The spectral data are in accordance with those reported in the literature. ${ }^{114}$

\section{Synthesis of 4-Methyl-N-tosylbenzamide (135k)}<smiles>[3H]NC(=O)c1ccc(C)cc1</smiles>

The general procedure B was followed using 4-methylbenzoyl chloride $(2.72 \mathrm{~g}, 17.6 \mathrm{mmol}$, 1.1 equiv) in PhMe (14 mL), p-toluene sulfonamide $\left(2.91 \mathrm{~g}, 16.0 \mathrm{mmol}, 1.0\right.$ equiv), $\mathrm{NEt}_{3}$ (4.05 g, $40.0 \mathrm{mmol}, 2.5$ equiv) and DMAP (1 mg, $0.008 \mathrm{mmol}, 0.5 \mathrm{~mol} \%)$ in EtOAc (32 mL). Recrystallization from EtOH yielded $135 \mathrm{k}(3.56 \mathrm{~g}, 70 \%)$ as a colorless solid.

M.r.: $127-129^{\circ} \mathrm{C}$.

${ }^{1} \mathrm{H}-\mathrm{NMR}\left(300 \mathrm{MHz}, \mathrm{CDCl}_{3}\right): \delta=12.19$ (brs, $\left.1 \mathrm{H}\right), 7.88(\mathrm{~d}, J=8.2 \mathrm{~Hz}, 2 \mathrm{H}), 7.76(\mathrm{~d}, J=8.2 \mathrm{~Hz}$, 2H), $7.43(\mathrm{~d}, J=8.1 \mathrm{~Hz}, 2 \mathrm{H}), 7.28(\mathrm{~d}, J=8.0 \mathrm{~Hz}, 2 \mathrm{H}), 2.39(\mathrm{~s}, 3 \mathrm{H}), 2.39(\mathrm{~s}, 3 \mathrm{H})$.

${ }^{13} \mathrm{C}$-NMR $\left(125 \mathrm{MHz}, \mathrm{CDCl}_{3}\right): \delta=165.1\left(\mathrm{C}_{\mathrm{q}}\right), 144.1\left(\mathrm{C}_{\mathrm{q}}\right), 143.5\left(\mathrm{C}_{\mathrm{q}}\right), 136.7\left(\mathrm{C}_{\mathrm{q}}\right), 129.4(\mathrm{CH})$, $129.0(\mathrm{CH}), 128.7\left(\mathrm{C}_{\mathrm{q}}\right), 128.3(\mathrm{CH}), 127.6(\mathrm{CH}), 20.9\left(\mathrm{CH}_{3}\right), 20.9\left(\mathrm{CH}_{3}\right)$.

IR (neat): 3295, 1774, 1696, 1609, 1420, 1333, 1298, 1254, 1165, $1067 \mathrm{~cm}^{-1}$. 
MS (ESI) $m / z$ (relative intensity): 312 (82) $\left[\mathrm{M}+\mathrm{Na}^{+}\right], 290(100)\left[\mathrm{M}+\mathrm{H}^{+}\right]$.

HR-MS (ESI) $m / z$ calcd for $\mathrm{C}_{15} \mathrm{H}_{16} \mathrm{NO}_{3} \mathrm{~S}$, $\left[\mathrm{M}+\mathrm{H}^{+}\right]$290.0845, found 290.0847 .

The spectral data are in accordance with those reported in the literature. ${ }^{114}$

\section{Synthesis of 4-Methoxy-N-tosylbenzamide (135I)}<smiles>[3H]NC(=O)c1ccc(OC)cc1</smiles>

The general procedure B was followed using 4-methoxybenzoyl chloride $(2.80 \mathrm{~g}, 16.4 \mathrm{mmol}$, 1.1 equiv) in PhMe (13 mL), p-toluene sulfonamide ( $2.59 \mathrm{~g}, 15.0 \mathrm{mmol}, 1.0$ equiv), $\mathrm{NEt}_{3}$ (3.78 g, $37.4 \mathrm{mmol}, 2.5$ equiv) and DMAP (1 mg, $0.008 \mathrm{mmol}, 0.5 \mathrm{~mol} \%)$ in EtOAc $(30 \mathrm{~mL})$. Recrystallization from $\mathrm{EtOH}$ yielded $135 \mathrm{I}(2.35 \mathrm{~g}, 52 \%)$ as a colorless solid.

M.r.: $152-154{ }^{\circ} \mathrm{C}$.

${ }^{1} \mathrm{H}-\mathrm{NMR}\left(300 \mathrm{MHz}, \mathrm{DMSO}-\mathrm{d}_{6}\right): \delta=12.19$ (brs, $\left.1 \mathrm{H}\right), 8.09-7.63(\mathrm{~m}, 4 \mathrm{H}) 7.53-7.30(\mathrm{~m}, 2 \mathrm{H})$, $6.98(\mathrm{~d}, J=8.9 \mathrm{~Hz}, 2 \mathrm{H}), 3.81(\mathrm{~s}, 3 \mathrm{H}), 2.38(\mathrm{~s}, 3 \mathrm{H})$.

${ }^{13} \mathrm{C}$-NMR (125 MHz, DMSO-d $\left.\mathrm{d}_{6}\right): \delta=165.1\left(\mathrm{C}_{\mathrm{q}}\right), 162.8\left(\mathrm{C}_{\mathrm{q}}\right), 143.3\left(\mathrm{C}_{\mathrm{q}}\right), 137.7\left(\mathrm{C}_{\mathrm{q}}\right), 130.4$ $(\mathrm{CH}), 129.2(\mathrm{CH}), 127.5(\mathrm{CH}), 124.6\left(\mathrm{C}_{\mathrm{q}}\right), 113.6(\mathrm{CH}), 55.4\left(\mathrm{CH}_{3}\right), 20.9\left(\mathrm{CH}_{3}\right)$.

IR (neat): 3230, 1742, 1667, 1603, 1520, 1437, 1417, 1340, 1317, $1254 \mathrm{~cm}^{-1}$.

MS (ESI) m/z (relative intensity): 344 (9) $\left[\mathrm{M}+\mathrm{K}^{+}\right], 328(100)\left[\mathrm{M}+\mathrm{Na}^{+}\right], 306(77)\left[\mathrm{M}+\mathrm{H}^{+}\right]$.

HR-MS (ESI) $m / z$ calcd for $\mathrm{C}_{15} \mathrm{H}_{16} \mathrm{NO}_{4} \mathrm{~S}$, $\left[\mathrm{M}+\mathrm{H}^{+}\right]$306.0795, found 306.0796 .

The spectral data are in accordance with those reported in the literature. ${ }^{114}$

\section{Synthesis of 4-Fluoro-N-tosylbenzamide (135m)}<smiles>O=C(N[I-])c1ccc(F)cc1</smiles>

The general procedure B was followed using oxalylchloride $(4.55 \mathrm{~g}, 45.0 \mathrm{mmol}, 1.2$ equiv) and 4-fluorobenzoic acid (5.24 g, $37.4 \mathrm{mmol}, 1.1$ equiv) in PhMe (30 mL). The crude product, 2-fluorobenzoyl chloride $(5.93 \mathrm{~g}, 37.4 \mathrm{mmol}, 1.1$ equiv) in PhMe (30 mL) was added to a solution of $p$-toluene sulfonamide $\left(5.82 \mathrm{~g}, 34.0 \mathrm{mmol}, 1.0\right.$ equiv), $\mathrm{NEt}_{3}(8.10 \mathrm{~g}, 80.0 \mathrm{mmol}$, 2.5 equiv) and DMAP ( $2 \mathrm{mg}, 0.016 \mathrm{mmol}, 0.5 \mathrm{~mol} \%)$ in EtOAc $(68 \mathrm{~mL})$. Recrystallization from EtOH yielded $135 \mathrm{~m}(7.52 \mathrm{~g}, 69 \%)$ as a colorless solid. 
M.p.: $160^{\circ} \mathrm{C}$.

${ }^{1} \mathrm{H}-\mathrm{NMR}\left(300 \mathrm{MHz}, \mathrm{CDCl}_{3}\right): \delta=9.78(\mathrm{~s} 1 \mathrm{H}), 8.01(\mathrm{~d}, J=8.4 \mathrm{~Hz}, 2 \mathrm{H}), 7.87(\mathrm{dd}, J=8.8$, $5.1 \mathrm{~Hz}, 2 \mathrm{H}), 7.42-7.15(\mathrm{~m}, 2 \mathrm{H}), 7.04(\mathrm{~d}, J=8.6 \mathrm{~Hz}, 2 \mathrm{H}) 2.41(\mathrm{~s}, 3 \mathrm{H})$.

${ }^{13} \mathrm{C}-N M R\left(125 \mathrm{MHz}, \mathrm{CDCl}_{3}\right): \delta=165.9\left({ }^{1} \mathrm{~J}_{\mathrm{C}-\mathrm{F}}=255.5 \mathrm{~Hz}, \mathrm{C}_{\mathrm{q}}\right), 163.7\left(\mathrm{C}_{\mathrm{q}}\right), 145.5\left(\mathrm{C}_{\mathrm{q}}\right), 135.4$ $\left(\mathrm{C}_{\mathrm{q}}\right), 130.8\left({ }^{3} \mathrm{~J}_{\mathrm{C}-\mathrm{F}}=9.4 \mathrm{~Hz}, \mathrm{CH}\right), 129.8(\mathrm{CH}), 128.7(\mathrm{CH}), 127.4\left({ }^{4} J_{\mathrm{C}-\mathrm{F}}=3.0 \mathrm{~Hz}, \mathrm{C}_{\mathrm{q}}\right), 116.1$ $\left({ }^{2} J_{\mathrm{C}-\mathrm{F}}=22.2 \mathrm{~Hz}, \mathrm{CH}\right), 21.6\left(\mathrm{CH}_{3}\right)$.

${ }^{19}$ F-NMR $\left(282 \mathrm{MHz}, \mathrm{CDCl}_{3}\right): \delta=-111.8$ (dddd, $\left.J=14.4,12.9,7.9,5.4 \mathrm{~Hz}\right)$.

IR (neat): 3086, 2879, 2858, 1678, 1599, 1508, 1439, 1347, 1305, $1259 \mathrm{~cm}^{-1}$. MS (ESI) m/z (relative intensity):332 (7) [M+K $\left.{ }^{+}\right], 316(100)\left[\mathrm{M}+\mathrm{Na}^{+}\right], 294(50)\left[\mathrm{M}+\mathrm{H}^{+}\right]$.

HR-MS (ESI) $\mathrm{m} / \mathrm{z}$ calcd for $\mathrm{C}_{14} \mathrm{H}_{13} \mathrm{FNO}_{3} \mathrm{~S}$, $\left[\mathrm{M}+\mathrm{H}^{+}\right]$294.0595, found 294.0594 .

The spectral data are in accordance with those reported in the literature. ${ }^{114}$ 


\subsubsection{Synthesis of Alkylated N-Aryl-1,2,3-triazoles}

Synthesis of 4-n-Butyl-1-(2-n-hexyl-6-methylphenyl)-1H-1,2,3-triazole (133aa) and 4-nButyl-1-[2-methyl-6-(3-methylbenzyl)phenyl]-1H-1,2,3-triazole (138a)

The general procedure $\mathbf{C}$ was followed using 4- $n$-Butyl-1-(o-tolyl)-1H-1,2,3-triazole (123a) (215.0 mg, $1.00 \mathrm{mmol}), 1$-bromo- $n$-hexane (40a) (495.0 mg, $3.00 \mathrm{mmol}),\left[\mathrm{RuCl}_{2}(p \text {-cymene) }]_{2}\right.$ (30.5 mg, $5 \mathrm{~mol} \%), \mathrm{K}_{2} \mathrm{CO}_{3}(276.0 \mathrm{mg}, 2.00 \mathrm{mmol})$ and potassium 4-(trifluormethyl)benzoate $(68.9 \mathrm{mg}, 30 \mathrm{~mol} \%)$ in $m$-xylene. Purification by column chromatography ( $n$-pentane/EtOAc $19 / 1$ ) yielded 133aa (60 mg, 20\%) and 138a (16 mg, 5\%) as colorless oils.

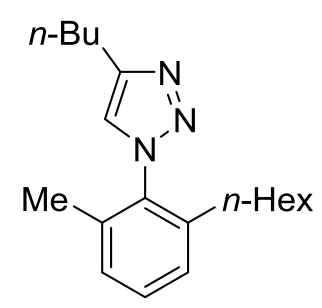

${ }^{1} \mathrm{H}-\mathrm{NMR}\left(300 \mathrm{MHz}, \mathrm{CDCl}_{3}\right): \delta=7.34(\mathrm{~s}, 1 \mathrm{H}), 7.31(\mathrm{~d}, J=7.6 \mathrm{~Hz}, 1 \mathrm{H}), 7.17(\mathrm{ddd}, J=8.5,7.3$, $1.0 \mathrm{~Hz}, 2 \mathrm{H}), 2.92-2.70(\mathrm{~m}, 2 \mathrm{H}), 2.37-2.08(\mathrm{~m}, 2 \mathrm{H}), 1.97(\mathrm{~s}, 3 \mathrm{H}), 1.74$ (ddt, $J=8.6,7.5$, $6.4 \mathrm{~Hz}, 2 \mathrm{H}), 1.51-1.34(\mathrm{~m}, 4 \mathrm{H}), 1.29-1.07(\mathrm{~m}, 6 \mathrm{H}), 0.96(\mathrm{t}, J=7.3 \mathrm{~Hz}, 3 \mathrm{H}), 0.79(\mathrm{t}$, $J=7.3 \mathrm{~Hz}, 3 \mathrm{H})$.

${ }^{13} \mathrm{C}-\mathrm{NMR}\left(125 \mathrm{MHz}, \mathrm{CDCl}_{3}\right): \delta=148.2\left(\mathrm{C}_{\mathrm{q}}\right), 140.4\left(\mathrm{C}_{\mathrm{q}}\right), 135.8\left(\mathrm{C}_{\mathrm{q}}\right), 135.7\left(\mathrm{C}_{\mathrm{q}}\right), 130.0(\mathrm{CH})$, $128.4(\mathrm{CH}), 127.6(\mathrm{CH}), 122.9(\mathrm{CH}), 31.7\left(\mathrm{CH}_{2}\right), 31.6\left(\mathrm{CH}_{2}\right), 31.3\left(\mathrm{CH}_{2}\right), 31.2\left(\mathrm{CH}_{2}\right), 29.2$ $\left(\mathrm{CH}_{2}\right), 25.5\left(\mathrm{CH}_{2}\right), 22.6\left(\mathrm{CH}_{2}\right), 22.4\left(\mathrm{CH}_{2}\right), 17.5\left(\mathrm{CH}_{3}\right), 14.4\left(\mathrm{CH}_{3}\right), 14.0\left(\mathrm{CH}_{3}\right)$.

IR (ATR): $\tilde{v}=2955,2926,2857,1599,1550,1482,1466,1410,1378,1229 \mathrm{~cm}^{-1}$.

MS (ESI) $m / z$ (relative intensity): $322(8)\left[\mathrm{M}+\mathrm{Na}^{+}\right], 300(100)\left[\mathrm{M}+\mathrm{H}^{+}\right]$.

HR-MS (ESI) $m / z$ calcd. for $\mathrm{C}_{19} \mathrm{H}_{30} \mathrm{~N}_{3},\left[\mathrm{M}+\mathrm{H}^{+}\right]$300.2434, found 300.2435.<smiles>CCCCc1cn(-c2c(C)cccc2Cc2cccc(C)c2)nn1</smiles>

${ }^{1} \mathrm{H}-\mathrm{NMR}\left(300 \mathrm{MHz}, \mathrm{CDCl}_{3}\right): \delta=7.34(\mathrm{dd}, J=7.6,0.9 \mathrm{~Hz}, 1 \mathrm{H}), 7.24-7.14(\mathrm{~m}, 2 \mathrm{H}), 7.09(\mathrm{dd}$, $J=7.2,7.2 \mathrm{~Hz}, 1 \mathrm{H}), 7.04-7.02(\mathrm{~m}, 2 \mathrm{H}), 6.96(\mathrm{~d}, J=7.8 \mathrm{~Hz}, 1 \mathrm{H}), 6.82-6.63(\mathrm{~m}, 2 \mathrm{H}), 3.62(\mathrm{~s}$, 
2H), $2.75(\mathrm{t}, J=7.7 \mathrm{~Hz}, 2 \mathrm{H}), 2.26(\mathrm{~s}, 3 \mathrm{H}), 1.97(\mathrm{~s}, 3 \mathrm{H}), 1.74-1.57(\mathrm{~m}, 2 \mathrm{H}), 1.48-1.31(\mathrm{~m}$, $2 \mathrm{H}), 0.94(\mathrm{t}, J=7.3 \mathrm{~Hz}, 3 \mathrm{H})$.

${ }^{13} \mathrm{C}-N M R\left(125 \mathrm{MHz}, \mathrm{CDCl}_{3}\right): \delta=147.9\left(\mathrm{C}_{\mathrm{q}}\right), 139.6\left(\mathrm{C}_{\mathrm{q}}\right), 138.6\left(\mathrm{C}_{\mathrm{q}}\right), 138.0\left(\mathrm{C}_{\mathrm{q}}\right), 136.0\left(\mathrm{C}_{\mathrm{q}}\right)$, $135.9\left(\mathrm{C}_{\mathrm{q}}\right), 130.0(\mathrm{CH}), 129.5(\mathrm{CH}), 129.0(\mathrm{CH}), 128.6(\mathrm{CH}), 128.3(\mathrm{CH}), 127.0(\mathrm{CH}), 125.8$ $(\mathrm{CH}), 123.1(\mathrm{CH}), 37.4\left(\mathrm{CH}_{2}\right), 31.7\left(\mathrm{CH}_{2}\right), 25.5\left(\mathrm{CH}_{2}\right), 22.5\left(\mathrm{CH}_{2}\right), 21.6\left(\mathrm{CH}_{3}\right), 17.6\left(\mathrm{CH}_{3}\right)$, $14.1\left(\mathrm{CH}_{3}\right)$.

IR (ATR): $\tilde{v}=3134,2956,2928,2860,1608,1561,1462,1434,1409,1320 \mathrm{~cm}^{-1}$.

MS (ESI) $m / z$ (relative intensity): $342(64)\left[\mathrm{M}+\mathrm{Na}^{+}\right], 320(100)\left[\mathrm{M}^{+} \mathrm{H}^{+}\right]$.

HR-MS (ESI) $m / z$ calcd. for $\mathrm{C}_{21} \mathrm{H}_{26} \mathrm{~N}_{3}$, $\left[\mathrm{M}+\mathrm{H}^{+}\right] 320.2121$, found 320.2123 .

Synthesis of 4-n-Butyl-1-(2-n-hexyl-6-methylphenyl)-1H-1,2,3-triazole (133aa) and 1-(2$n$-Benzyl-6-methylphenyl)-4-butyl-1H-1,2,3-triazole (138b)

The general procedure $\mathbf{C}$ was followed using 4- $n$-Butyl-1-(o-tolyl)-1H-1,2,3-triazole (123a) (215.0 mg, $1.00 \mathrm{mmol}), 1$-bromo- $n$-hexane (40a) (495.0 mg, $3.00 \mathrm{mmol}),\left[\mathrm{RuCl}_{2}(p \text {-cymene) }]_{2}\right.$ $(30.5 \mathrm{mg}, 5 \mathrm{~mol} \%), \mathrm{K}_{2} \mathrm{CO}_{3}(276.0 \mathrm{mg}, 2.00 \mathrm{mmol})$ and potassium 4-(trifluormethyl)benzoate (68.9 mg, $30 \mathrm{~mol} \%$ ). Purification by column chromatography ( $n$-pentane/EtOAc 19/1) yielded 133aa (127 mg, 42\%) and 138b (49 mg, 16\%) as colorless oils.

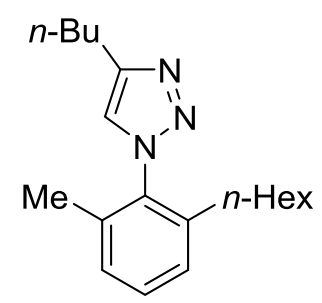

${ }^{1} \mathrm{H}-\mathrm{NMR}\left(300 \mathrm{MHz}, \mathrm{CDCl}_{3}\right): \delta=7.34(\mathrm{~s}, 1 \mathrm{H}), 7.31(\mathrm{~d}, J=7.6 \mathrm{~Hz}, 1 \mathrm{H}), 7.17(\mathrm{~d}, J=8.5 \mathrm{~Hz}$, $2 \mathrm{H}), 2.92-2.70(\mathrm{~m}, 2 \mathrm{H}), 2.37-2.08(\mathrm{~m}, 2 \mathrm{H}), 1.97(\mathrm{~s}, 3 \mathrm{H}), 1.74(\mathrm{ddt}, J=8.6,7.5,6.4 \mathrm{~Hz}, 2 \mathrm{H}$ ), 1.51-1.34 (m, 4H), 1.29-1.07 (m, 6H), $0.96(\mathrm{t}, J=7.3 \mathrm{~Hz}, 3 \mathrm{H}), 0.79(\mathrm{t}, J=7.3 \mathrm{~Hz}, 3 \mathrm{H})$.

${ }^{13} \mathrm{C}-N M R\left(125 \mathrm{MHz}, \mathrm{CDCl}_{3}\right): \delta=148.2\left(\mathrm{C}_{\mathrm{q}}\right), 140.4\left(\mathrm{C}_{\mathrm{q}}\right), 135.8\left(\mathrm{C}_{\mathrm{q}}\right), 135.7\left(\mathrm{C}_{\mathrm{q}}\right), 130.0(\mathrm{CH})$, $128.4(\mathrm{CH}), 127.6(\mathrm{CH}), 122.9(\mathrm{CH}), 31.7\left(\mathrm{CH}_{2}\right), 31.6\left(\mathrm{CH}_{2}\right), 31.3\left(\mathrm{CH}_{2}\right), 31.2\left(\mathrm{CH}_{2}\right), 29.2$ $\left(\mathrm{CH}_{2}\right), 25.5\left(\mathrm{CH}_{2}\right), 22.6\left(\mathrm{CH}_{2}\right), 22.4\left(\mathrm{CH}_{2}\right), 17.5\left(\mathrm{CH}_{3}\right), 14.4\left(\mathrm{CH}_{3}\right), 14.0\left(\mathrm{CH}_{3}\right)$. IR (ATR): $\tilde{v}=2955,2926,2857,1599,1550,1482,1466,1410,1378,1229 \mathrm{~cm}^{-1}$. MS (ESI) $m / z$ (relative intensity): $322(8)\left[\mathrm{M}+\mathrm{Na}^{+}\right], 300(100)\left[\mathrm{M}+\mathrm{H}^{+}\right]$.

HR-MS (ESI) $m / z$ calcd. for $\mathrm{C}_{19} \mathrm{H}_{30} \mathrm{~N}_{3},\left[\mathrm{M}+\mathrm{H}^{+}\right] 300.2434$, found 300.2435. 


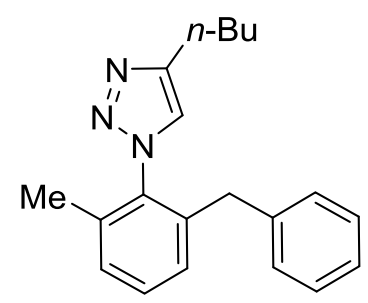

${ }^{1} \mathrm{H}-\mathrm{NMR}\left(300 \mathrm{MHz}, \mathrm{CDCl}_{3}\right): \delta=7.34(\mathrm{dd}, J=8.0,7.2 \mathrm{~Hz}, 1 \mathrm{H}), 7.19$ (ddd, $J=8.6,7.4,1.7 \mathrm{~Hz}$, $5 \mathrm{H}), 7.00(\mathrm{~s}, 1 \mathrm{H}), 6.98-6.87(\mathrm{~m}, 2 \mathrm{H}), 3.67(\mathrm{~s}, 2 \mathrm{H}), 2.86-2.62(\mathrm{~m}, 2 \mathrm{H}), 1.97(\mathrm{~s}, 3 \mathrm{H}), 1.72-1.56$ $(\mathrm{m}, 2 \mathrm{H}), 1.49-1.28(\mathrm{~m}, 2 \mathrm{H}), 1.08-0.81(\mathrm{~m}, 3 \mathrm{H})$.

${ }^{13}$ C-NMR (125 MHz, $\left.\mathrm{CDCl}_{3}\right): \delta=148.0\left(\mathrm{C}_{\mathrm{q}}\right), 139.7\left(\mathrm{C}_{\mathrm{q}}\right), 138.6\left(\mathrm{C}_{\mathrm{q}}\right), 136.1\left(\mathrm{C}_{\mathrm{q}}\right), 136.0\left(\mathrm{C}_{\mathrm{q}}\right)$, $130.0(\mathrm{CH}), 129.1(\mathrm{CH}), 128.7(\mathrm{CH}), 128.7(\mathrm{CH}), 128.4(\mathrm{CH}), 126.3(\mathrm{CH}), 123.0(\mathrm{CH}), 37.5$ $\left(\mathrm{CH}_{2}\right), 31.7\left(\mathrm{CH}_{2}\right), 25.5\left(\mathrm{CH}_{2}\right), 22.5\left(\mathrm{CH}_{2}\right), 17.6\left(\mathrm{CH}_{3}\right), 14.1\left(\mathrm{CH}_{3}\right)$.

IR (ATR): $\tilde{v}=3136,3027,2956,2928,2859,1583,1483,1454,1322,1211 \mathrm{~cm}^{-1}$.

MS (ESI) $m / z$ (relative intensity): $328(69)\left[\mathrm{M}+\mathrm{Na}^{+}\right], 306(100)\left[\mathrm{M}+\mathrm{H}^{+}\right]$.

HR-MS (ESI) $m / z$ calcd. for $\mathrm{C}_{20} \mathrm{H}_{24} \mathrm{~N}_{3},\left[\mathrm{M}+\mathrm{H}^{+}\right]$306.1965, found 306.1957.

\section{Synthesis of 4-n-Butyl-1-(2-methyl-6-n-octylphenyl)-1H-1,2,3-triazole (133ab)}<smiles>CCOc1cccc(C)c1-n1cc(CC(C)C)nn1</smiles>

The general procedure $\mathbf{C}$ was followed using 4- $n$-Butyl-1-(o-tolyl)-1H-1,2,3-triazole (123a) (215.0 mg, $1.00 \mathrm{mmol}), 1$-bromo- $n$-octane (40b) $(579.0 \mathrm{mg}, 3.00 \mathrm{mmol}),\left[\mathrm{RuCl}_{2}(p \text {-cymene })\right]_{2}$ (30.5 mg, $5 \mathrm{~mol} \%), \mathrm{K}_{2} \mathrm{CO}_{3}(276.0 \mathrm{mg}, 2.00 \mathrm{mmol})$ and potassium 4-(trifluormethyl)benzoate (68.9 mg, $30 \mathrm{~mol} \%$ ). Purification by column chromatography ( $n$-pentane/EtOAc 19/1) yielded 133ab (136 mg, 41\%) as a colorless oil.

${ }^{1} \mathrm{H}-\mathrm{NMR}\left(300 \mathrm{MHz}, \mathrm{CDCl}_{3}\right): \delta=7.34(\mathrm{~s}, 1 \mathrm{H}), 7.31(\mathrm{~d}, J=7.6 \mathrm{~Hz}, 1 \mathrm{H}), 7.21-7.05(\mathrm{~m}, 2 \mathrm{H})$, $2.84(\mathrm{t}, J=7.6 \mathrm{~Hz}, 2 \mathrm{H}), 2.35-2.10(\mathrm{~m}, 2 \mathrm{H}), 1.97(\mathrm{~s}, 3 \mathrm{H}), 1.81-1.65(\mathrm{~m}, 2 \mathrm{H}), 1.54-1.33(\mathrm{~m}$, $4 \mathrm{H}), 1.32-1.06(\mathrm{~m}, 10 \mathrm{H}), 0.96(\mathrm{t}, J=7.3 \mathrm{~Hz}, 3 \mathrm{H}), 0.86(\mathrm{t}, J=6.8 \mathrm{~Hz}, 3 \mathrm{H})$.

${ }^{13} \mathrm{C}-\mathrm{NMR}\left(125 \mathrm{MHz}, \mathrm{CDCl}_{3}\right): \delta=148.2\left(\mathrm{C}_{\mathrm{q}}\right), 140.4\left(\mathrm{C}_{\mathrm{q}}\right), 135.8\left(\mathrm{C}_{\mathrm{q}}\right), 135.7\left(\mathrm{C}_{\mathrm{q}}\right), 130.0(\mathrm{CH})$, $128.4(\mathrm{CH}), 127.6(\mathrm{CH}), 122.9(\mathrm{CH}), 32.0\left(\mathrm{CH}_{2}\right), 31.7\left(\mathrm{CH}_{2}\right), 31.3\left(\mathrm{CH}_{2}\right), 31.2\left(\mathrm{CH}_{2}\right), 29.6$ $\left(\mathrm{CH}_{2}\right), 29.4\left(\mathrm{CH}_{2}\right), 29.3\left(\mathrm{CH}_{2}\right), 25.5\left(\mathrm{CH}_{2}\right), 22.8\left(\mathrm{CH}_{2}\right), 22.4\left(\mathrm{CH}_{2}\right), 17.5\left(\mathrm{CH}_{3}\right), 14.2\left(\mathrm{CH}_{3}\right)$, $14.0\left(\mathrm{CH}_{3}\right)$.

IR (ATR): $\tilde{v}=2954,2923,2855,1600,1550,1482,1466,1410,1378,1210 \mathrm{~cm}^{-1}$. 
MS (ESI) $m / z$ (relative intensity): $350(2)\left[\mathrm{M}+\mathrm{Na}^{+}\right], 328(100)\left[\mathrm{M}+\mathrm{H}^{+}\right]$.

HR-MS (ESI) $m / z$ calcd. for $\mathrm{C}_{21} \mathrm{H}_{34} \mathrm{~N}_{3},\left[\mathrm{M}+\mathrm{H}^{+}\right]$328.2747, found 328.2751.

\section{Synthesis of 4-n-Butyl-1-(2-methyl-6-n-pentylphenyl)-1H-1,2,3-triazole (133ac)}<smiles>Cc1cccc(PO)c1-n1cc(CC(C)C)nn1</smiles>

The general procedure $\mathbf{C}$ was followed using 4-Butyl-1-(o-tolyl)-1H-1,2,3-triazole (123a) (215.0 mg, $1.00 \mathrm{mmol}), 1$-bromo- $n$-pentane (40c) (453.0 mg, $3.00 \mathrm{mmol}),\left[\mathrm{RuCl}_{2}(p \text {-cymene) }]_{2}\right.$ (30.5 mg, $5 \mathrm{~mol} \%), \mathrm{K}_{2} \mathrm{CO}_{3}(276.0 \mathrm{mg}, 2.00 \mathrm{mmol}$ ) and potassium 4-(trifluormethyl)benzoate (68.9 mg, $30 \mathrm{~mol} \%$ ). Purification by column chromatography ( $n$-pentane/EtOAc 19/1) yielded 133ac (104 mg, 37\%) as a colorless oil.

${ }^{1} \mathrm{H}-N M R\left(300 \mathrm{MHz}, \mathrm{CDCl}_{3}\right): \delta=7.34(\mathrm{~s}, 1 \mathrm{H}), 7.30(\mathrm{~d}, J=7.6 \mathrm{~Hz}, 1 \mathrm{H}), 7.22-7.12(\mathrm{~m}, 2 \mathrm{H})$, 2.96-2.69 (m, 2H), 2.30-2.12 (m, 2H), $1.97(\mathrm{~s}, 3 \mathrm{H}), 1.86-1.66(\mathrm{~m}, 2 \mathrm{H}), 1.51-1.35(\mathrm{~m}, 4 \mathrm{H})$, $1.25-1.05(\mathrm{~m}, 4 \mathrm{H}), 0.96(\mathrm{t}, J=7.3 \mathrm{~Hz}, 3 \mathrm{H}), 0.79(\mathrm{t}, J=7.3 \mathrm{~Hz}, 3 \mathrm{H})$.

${ }^{13}$ C-NMR (125 MHz, CDCl $): \delta=148.2\left(\mathrm{C}_{\mathrm{q}}\right), 140.4\left(\mathrm{C}_{\mathrm{q}}\right), 135.9\left(\mathrm{C}_{\mathrm{q}}\right), 135.7\left(\mathrm{C}_{\mathrm{q}}\right), 130.0(\mathrm{CH})$, $128.4(\mathrm{CH}), 127.6(\mathrm{CH}), 122.9(\mathrm{CH}), 31.7\left(\mathrm{CH}_{2}\right), 31.7\left(\mathrm{CH}_{2}\right), 31.3\left(\mathrm{CH}_{2}\right), 30.9\left(\mathrm{CH}_{2}\right), 25.4$ $\left(\mathrm{CH}_{2}\right), 22.4\left(\mathrm{CH}_{2}\right), 22.4\left(\mathrm{CH}_{2}\right), 17.5\left(\mathrm{CH}_{3}\right), 14.0\left(\mathrm{CH}_{3}\right), 14.0\left(\mathrm{CH}_{3}\right)$.

IR (ATR): $\tilde{v}=2954,2927,2859,1551,1482,1410,1210,1169,1107,1038 \mathrm{~cm}^{-1}$.

MS (ESI) $m / z$ (relative intensity): $308(7)\left[\mathrm{M}+\mathrm{Na}^{+}\right], 286(100)\left[\mathrm{M}+\mathrm{H}^{+}\right]$.

HR-MS (ESI) $m / z$ calcd. for $\mathrm{C}_{18} \mathrm{H}_{28} \mathrm{~N}_{3},\left[\mathrm{M}+\mathrm{H}^{+}\right]$286.2278, found 286.2281.

\section{Synthesis of 4-n-Butyl-1-(2-n-butyl-6-methylphenyl)-1H-1,2,3-triazole (133ad)}

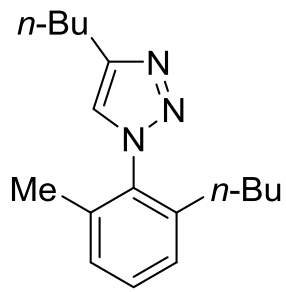

The general procedure $\mathbf{C}$ was followed using 4-n-Butyl-1-(o-tolyl)-1H-1,2,3-triazole (123a) (215.0 mg, $1.00 \mathrm{mmol}), 1$-bromo- $n$-butane (40a) $(411.0 \mathrm{mg}, 3.00 \mathrm{mmol}),\left[\mathrm{RuCl}_{2}(p \text {-cymene })\right]_{2}$ (30.5 mg, $5 \mathrm{~mol} \%), \mathrm{K}_{2} \mathrm{CO}_{3}(276.0 \mathrm{mg}, 2.00 \mathrm{mmol}$ ) and potassium 4-(trifluormethyl)benzoate 
(68.9 mg, $30 \mathrm{~mol} \%$ ). Purification by column chromatography ( $n$-pentane/EtOAc 19/1) yielded 133ad (108 mg, 42\%) as a colorless oil.

${ }^{1} \mathrm{H}-\mathrm{NMR}\left(300 \mathrm{MHz}, \mathrm{CDCl}_{3}\right): \delta=7.34(\mathrm{~s}, 1 \mathrm{H}), 7.30(\mathrm{~d}, J=7.6 \mathrm{~Hz}, 1 \mathrm{H}) .7 .21-7.12(\mathrm{~m}, 2 \mathrm{H})$, 2.92-2.74 (m, 2H), 2.30-2.14 (m, 2H), $1.96(\mathrm{~s}, 3 \mathrm{H}), 1.73$ (ddt, $J=8.5,7.4,6.4 \mathrm{~Hz}, 2 \mathrm{H}), 1.51-$ $1.26(\mathrm{~m}, 4 \mathrm{H}), 1.31-1.05(\mathrm{~m}, 2 \mathrm{H}), 0.95(\mathrm{t}, J=7.3 \mathrm{~Hz}, 3 \mathrm{H}), 0.79(\mathrm{t}, J=7.3 \mathrm{~Hz}, 3 \mathrm{H})$.

${ }^{13} \mathrm{C}-N M R\left(125 \mathrm{MHz}, \mathrm{CDCl}_{3}\right): \delta=148.2\left(\mathrm{C}_{\mathrm{q}}\right), 140.4\left(\mathrm{C}_{\mathrm{q}}\right), 135.9\left(\mathrm{C}_{\mathrm{q}}\right), 135.7\left(\mathrm{C}_{\mathrm{q}}\right), 129.9(\mathrm{CH})$, $128.3(\mathrm{CH}), 127.6(\mathrm{CH}), 122.9(\mathrm{CH}), 33.3\left(\mathrm{CH}_{2}\right), 31.7\left(\mathrm{CH}_{2}\right), 31.9\left(\mathrm{CH}_{2}\right), 25.4\left(\mathrm{CH}_{2}\right), 22.6$ $\left(\mathrm{CH}_{2}\right), 22.3\left(\mathrm{CH}_{3}\right), 17.5\left(\mathrm{CH}_{3}\right), 13.9\left(\mathrm{CH}_{3}\right), 13.8\left(\mathrm{CH}_{3}\right)$.

IR (ATR): $\tilde{v}=2955,2929,2860,1550,1482,1467,1379,1208,1170,1106 \mathrm{~cm}^{-1}$.

MS (ESI) $m / z$ (relative intensity): $294(6)\left[\mathrm{M}+\mathrm{Na}^{+}\right], 272(100)\left[\mathrm{M}+\mathrm{H}^{+}\right]$.

HR-MS (ESI) $m / z$ calcd. for $\mathrm{C}_{17} \mathrm{H}_{26} \mathrm{~N}_{3}$, $\left[\mathrm{M}+\mathrm{H}^{+}\right]$272.2121, found 272.2124.

\section{Synthesis of 4-n-Butyl-1-(2-n-hexylphenyl)-1 H-1,2,3-triazole (133ba)}<smiles>CCCCCCCCCOc1ccccc1-n1cc(CCC)nn1</smiles>

The general procedure $\mathbf{C}$ was followed using 4- $n$-Butyl-1-phenyl-1H-1,2,3-triazole (123b) (201.0 mg, $1.00 \mathrm{mmol})$, 1-bromo- $n$-hexane (40a) (495.0 mg, $3.00 \mathrm{mmol}),\left[\mathrm{RuCl}_{2}(p \text {-cymene) }]_{2}\right.$ (30.5 mg, $5 \mathrm{~mol} \%), \mathrm{K}_{2} \mathrm{CO}_{3}(276.0 \mathrm{mg}, 2.00 \mathrm{mmol})$ and potassium 4-(trifluormethyl)benzoate (68.9 mg, $30 \mathrm{~mol} \%$ ). Purification by column chromatography ( $n$-pentane/EtOAc 19/1) yielded 133ba (111 mg, 39\%) as a colorless oil.

${ }^{1} \mathrm{H}-\mathrm{NMR}\left(300 \mathrm{MHz}, \mathrm{CDCl}_{3}\right): \delta=7.44(\mathrm{~s}, 1 \mathrm{H}), 7.43-7.31(\mathrm{~m}, 2 \mathrm{H}), 7.31-7.27(\mathrm{~m}, 2 \mathrm{H}), 2.90-$ $2.72(\mathrm{~m}, 2 \mathrm{H}), 2.56-2.34(\mathrm{~m}, 2 \mathrm{H}), 1.73(\mathrm{ddt}, J=8.7,7.6,6.4 \mathrm{~Hz}, 2 \mathrm{H}), 1.54-1.36(\mathrm{~m}, 4 \mathrm{H})$, $1.31-1.08(\mathrm{~m}, 6 \mathrm{H}), 0.96(\mathrm{t}, J=7.3 \mathrm{~Hz}, 3 \mathrm{H}), 0.79(\mathrm{t}, J=7.3 \mathrm{~Hz}, 3 \mathrm{H})$.

${ }^{13} \mathrm{C}-\mathrm{NMR}\left(125 \mathrm{MHz}, \mathrm{CDCl}_{3}\right): \delta=148.2\left(\mathrm{C}_{\mathrm{q}}\right), 139.0\left(\mathrm{C}_{\mathrm{q}}\right), 136.5\left(\mathrm{C}_{\mathrm{q}}\right), 130.6(\mathrm{CH}), 129.9(\mathrm{CH})$, $126.7(\mathrm{CH}), 126.5(\mathrm{CH}), 122.7(\mathrm{CH}), 33.3\left(\mathrm{CH}_{2}\right), 31.7\left(\mathrm{CH}_{2}\right), 31.6\left(\mathrm{CH}_{2}\right), 31.3\left(\mathrm{CH}_{2}\right), 30.8$ $\left(\mathrm{CH}_{2}\right), 29.2\left(\mathrm{CH}_{2}\right), 25.4\left(\mathrm{CH}_{2}\right), 22.6\left(\mathrm{CH}_{2}\right), 14.1\left(\mathrm{CH}_{3}\right), 14.0\left(\mathrm{CH}_{3}\right)$.

IR (ATR): $\tilde{v}=3149,2956,2934,2871,1704,1639,1582,1497,1365,1320 \mathrm{~cm}^{-1}$.

MS (ESI) $m / z$ (relative intensity): $308(5)\left[\mathrm{M}+\mathrm{Na}^{+}\right], 286(100)\left[\mathrm{M}+\mathrm{H}^{+}\right]$.

HR-MS (ESI) $m / z$ calcd. for $\mathrm{C}_{18} \mathrm{H}_{28} \mathrm{~N}_{3},\left[\mathrm{M}+\mathrm{H}^{+}\right]$286.2278, found 286.2277. 


\section{Synthesis of 4-n-Butyl-1-(2-n-hexyl-5-metylphenyl)-1H-1,2,3-triazole (133ca)}<smiles>COc1ccc(C)cc1-n1cc(C(C)(C)C)nn1</smiles>

The general procedure $\mathbf{C}$ was followed using 4-n-Butyl-1-(m-tolyl)-1H-1,2,3-triazole (123c) (215.0 mg, $1.00 \mathrm{mmol}), 1$-bromo- $n$-hexane (40a) (495.0 mg, $3.00 \mathrm{mmol}),\left[\mathrm{RuCl}_{2}(p \text {-cymene) }]_{2}\right.$ $(30.5 \mathrm{mg}, 5 \mathrm{~mol} \%), \mathrm{K}_{2} \mathrm{CO}_{3}(276.0 \mathrm{mg}, 2.00 \mathrm{mmol})$ and potassium 4-(trifluormethyl)benzoate (68.9 mg, $30 \mathrm{~mol} \%$ ). Purification by column chromatography ( $n$-pentane/EtOAc 19/1) yielded $133 \mathrm{ca}(75 \mathrm{mg}, 25 \%)$ as a colorless oil.

${ }^{1} \mathrm{H}-\mathrm{NMR}\left(300 \mathrm{MHz}, \mathrm{CDCl}_{3}\right): \delta=7.42(\mathrm{~s}, 1 \mathrm{H}), 7.25-7.15(\mathrm{~m}, 2 \mathrm{H}), 7.10(\mathrm{dt}, J=1.6,0.8 \mathrm{~Hz}$, $1 \mathrm{H}), 2.92-2.67(\mathrm{~m}, 2 \mathrm{H}), 2.50-2.36(\mathrm{~m}, 2 \mathrm{H}), 2.35(\mathrm{~s}, 3 \mathrm{H}), 1.81-1.61(\mathrm{~m}, 2 \mathrm{H}), 1.52-1.30(\mathrm{~m}$, $4 \mathrm{H}$ ), 1.19 (dddd, $J=9.2,7.1,5.5,2.1 \mathrm{~Hz}, 6 \mathrm{H}$ ), $0.96(\mathrm{t}, J=7.3 \mathrm{~Hz}, 3 \mathrm{H}), 0.79(\mathrm{t}, J=7.3 \mathrm{~Hz}$, $3 \mathrm{H})$.

${ }^{13}$ C-NMR $\left(125 \mathrm{MHz}, \mathrm{CDCl}_{3}\right): \delta=148.1\left(\mathrm{C}_{\mathrm{q}}\right), 136.7\left(\mathrm{C}_{\mathrm{q}}\right), 136.3\left(\mathrm{C}_{\mathrm{q}}\right), 135.7\left(\mathrm{C}_{\mathrm{q}}\right), 130.6(\mathrm{CH})$, $130.3(\mathrm{CH}), 127.0(\mathrm{CH}), 122.6(\mathrm{CH}), 31.7\left(\mathrm{CH}_{2}\right), 31.6\left(\mathrm{CH}_{2}\right), 30.9\left(\mathrm{CH}_{2}\right), 30.9\left(\mathrm{CH}_{2}\right), 29.1$ $\left(\mathrm{CH}_{2}\right), 25.4\left(\mathrm{CH}_{2}\right), 22.6\left(\mathrm{CH}_{2}\right), 22.4\left(\mathrm{CH}_{2}\right), 20.8\left(\mathrm{CH}_{3}\right), 14.1\left(\mathrm{CH}_{3}\right), 14.0\left(\mathrm{CH}_{3}\right)$. IR (ATR): $\tilde{v}=2954,2924,2857,1619,1579,1551,1210,1459,1378,1211 \mathrm{~cm}^{-1}$. MS (ESI) $m / z$ (relative intensity): $322(10)\left[\mathrm{M}+\mathrm{Na}^{+}\right], 300(100)\left[\mathrm{M}+\mathrm{H}^{+}\right]$. HR-MS (ESI) $m / z$ calcd. for $\mathrm{C}_{19} \mathrm{H}_{30} \mathrm{~N}_{3},\left[\mathrm{M}+\mathrm{H}^{+}\right]$300.2434, found 300.2433. 


\subsubsection{Synthesis of Methylated N-Aryl-1,2,3-triazoles}

\section{Synthesis of 4-n-Butyl-1-(2,6-dimethylphenyl)-1H-1,2,3-triazole (139aa)}<smiles>Cc1cccc(C)c1-n1cc(C(C)(C)C)nn1</smiles>

The general procedure D was followed using 4- $n$-Butyl-1-(o-tolyl)-1H-1,2,3-triazole (123a) $(215.0 \mathrm{mg}, 1.00 \mathrm{mmol})$, methyl iodide (41a) $(442.0 \mathrm{mg}, 3.00 \mathrm{mmol}),\left[\mathrm{RuCl}_{2}(p \text {-cymene })\right]_{2}$ (30.5 mg, $5 \mathrm{~mol} \%), \mathrm{K}_{2} \mathrm{CO}_{3}(276.0 \mathrm{mg}, 2.00 \mathrm{mmol}$ ) and potassium 4-(trifluormethyl)benzoate (68.9 mg, $30 \mathrm{~mol} \%$ ) in $\mathrm{PhMe}(4 \mathrm{~mL})$. Purification by column chromatography $(n$-pentane/EtOAc 19/1 $\rightarrow$ 9/1) yielded 139a (138 mg, 60\%) as a colorless oil.

${ }^{1} \mathrm{H}-\mathrm{NMR}\left(300 \mathrm{MHz}, \mathrm{CDCl}_{3}\right): \delta=7.34(\mathrm{~s}, 1 \mathrm{H}), 7.32-7.23(\mathrm{~m}, 1 \mathrm{H}), 7.18-7.08(\mathrm{~m}, 2 \mathrm{H})$ 2.94$2.64(\mathrm{~m}, 2 \mathrm{H}), 1.98(\mathrm{~s}, 6 \mathrm{H}), 1.84-1.62(\mathrm{~m}, 2 \mathrm{H}), 1.42(\mathrm{dq}, J=14.5,7.3 \mathrm{~Hz}, 2 \mathrm{H}), 0.95$ (t, $J=7.3 \mathrm{~Hz}, 3 \mathrm{H})$.

${ }^{13}$ C-NMR $\left(125 \mathrm{MHz}, \mathrm{CDCl}_{3}\right): \delta=148.3\left(\mathrm{C}_{\mathrm{q}}\right), 136.3\left(\mathrm{C}_{\mathrm{q}}\right), 135.6\left(\mathrm{C}_{\mathrm{q}}\right), 129.9(\mathrm{CH}), 128.4(\mathrm{CH})$, $122.4(\mathrm{CH}), 31.6\left(\mathrm{CH}_{2}\right), 25.5\left(\mathrm{CH}_{2}\right), 22.4\left(\mathrm{CH}_{2}\right), 17.4\left(\mathrm{CH}_{3}\right), 13.9\left(\mathrm{CH}_{3}\right)$.

IR (ATR): $\tilde{v}=3131,2955,2927,2859,1550,1486,1379,1212,1179,1095 \mathrm{~cm}^{-1}$.

MS (ESI) $m / z$ (relative intensity): $252(20)\left[\mathrm{M}+\mathrm{Na}^{+}\right], 230(100)\left[\mathrm{M}+\mathrm{H}^{+}\right]$.

HR-MS (ESI) $m / z$ calcd. for $\mathrm{C}_{14} \mathrm{H}_{20} \mathrm{~N}_{3},\left[\mathrm{M}+\mathrm{H}^{+}\right]$230.1652, found 230.1647.

\section{Synthesis of 4-n-Butyl-1-(2-fluoro-6-methylphenyl)-1H-1,2,3-triazole (139fa)}<smiles>CCC(C)c1cn(-c2c(C)cccc2F)nn1</smiles>

The general procedure $\mathbf{D}$ was followed using 4- $n$-butyl-1-(2-fluorophenyl)-1H-1,2,3-triazole (123f) $(219.0 \mathrm{mg}, 1.00 \mathrm{mmol})$, methyl iodide $(41 \mathrm{a})(442.0 \mathrm{mg}, 3.00 \mathrm{mmol}),\left[\mathrm{RuCl}_{2}(p-\right.$ cymene $)]_{2}(30.5 \mathrm{mg}, 5 \mathrm{~mol} \%), \mathrm{K}_{2} \mathrm{CO}_{3}(276.0 \mathrm{mg}, 2.00 \mathrm{mmol})$ and potassium 4(trifluormethyl)benzoate $(68.9 \mathrm{mg}, 30 \mathrm{~mol} \%)$ in dioxane $(4 \mathrm{~mL})$. Purification by column 
chromatography ( $n$-pentane/EtOAc $19 / 1 \rightarrow 9 / 1)$ yielded $139 \mathrm{fa}(163 \mathrm{mg}, 70 \%)$ as a colorless oil.

${ }^{1} \mathrm{H}-\mathrm{NMR}\left(300 \mathrm{MHz}, \mathrm{CDCl}_{3}\right): \delta=7.45(\mathrm{~s}, 1 \mathrm{H}), 7.41-7.34(\mathrm{~m}, 1 \mathrm{H}), 7.17-7.05(\mathrm{~m}, 2 \mathrm{H}), 2.89-$ $2.77(\mathrm{~m}, 2 \mathrm{H}), 2.17(\mathrm{~s}, 3 \mathrm{H}), 1.81-1.69(\mathrm{~m}, 2 \mathrm{H}), 1.51-1.36(\mathrm{~m}, 2 \mathrm{H}), 0.97(\mathrm{t}, J=7.3 \mathrm{~Hz}, 3 \mathrm{H})$.

${ }^{13} \mathrm{C}-N M R\left(125 \mathrm{MHz}, \mathrm{CDCl}_{3}\right): \delta=157.0\left({ }^{1} \mathrm{~J}_{\mathrm{C}-\mathrm{F}}=252.0 \mathrm{~Hz}, \mathrm{C}_{\mathrm{q}}\right), 148.2\left(\mathrm{C}_{\mathrm{q}}\right), 137.9\left(\mathrm{C}_{\mathrm{q}}\right), 130.8$ $\left({ }^{3} J_{\mathrm{C}-\mathrm{F}}=8.5 \mathrm{~Hz}, \mathrm{C}_{\mathrm{q}}\right), 131.1\left({ }^{3} \mathrm{~J}_{\mathrm{C}-\mathrm{F}}=9.0 \mathrm{~Hz}, \mathrm{CH}\right), 126.4(\mathrm{CH}), 126.4(\mathrm{CH}), 123.1\left({ }^{4} J_{\mathrm{C}-\mathrm{F}}=1.5 \mathrm{~Hz}\right.$, $\mathrm{CH}), 113.9\left({ }^{2} J_{\mathrm{C}-\mathrm{F}}=19.8 \mathrm{~Hz}, \mathrm{CH}\right), 31.6\left(\mathrm{CH}_{2}\right), 25.5\left(\mathrm{CH}_{2}\right), 17.7\left({ }^{4} J_{\mathrm{C}-\mathrm{F}}=2.4 \mathrm{~Hz}, \mathrm{CH}_{3}\right), 14.1$ $\left(\mathrm{CH}_{3}\right)$.

${ }^{19} \mathrm{~F}-\mathrm{NMR}\left(282 \mathrm{MHz}, \mathrm{CDCl}_{3}\right): \delta=-122.7--122.8(\mathrm{~m})$.

IR (ATR): $\tilde{v}=2955,2926,2857,1550,1483,1466,1378,1210,1178,1082 \mathrm{~cm}^{-1}$.

MS (ESI) $m / z$ (relative intensity): $256(5)\left[\mathrm{M}+\mathrm{Na}^{+}\right], 234(100)\left[\mathrm{M}+\mathrm{H}^{+}\right]$.

HR-MS (ESI) $m / z$ calcd. for $\mathrm{C}_{13} \mathrm{H}_{17} \mathrm{FN}_{3}$, [M+H'] 234.1401, found 234.1408. 


\subsubsection{Synthesis of Alkenylated N-Aryl-1,2,3-triazoles}

Synthesis of Ethyl (E)-3-[2-(4-n-butyl-1H-1,2,3-triazol-1-yl)-3-methylphenyl]acrylate (134ac)<smiles>CCOC(=O)/C=C/c1cccc(C)c1-n1cc(CC(C)C)nn1</smiles>

The general procedure $\mathbf{E}$ was followed using 4- $n$-butyl-1-(o-tolyl)-1H-1,2,3-triazole (123a) $(215.0 \mathrm{mg}, 1.00 \mathrm{mmol})$, ethyl acrylate $(17 \mathrm{c})(150.0 \mathrm{mg}, 1.50 \mathrm{mmol}),\left[\mathrm{RuCl}_{2}(p \text {-cymene })\right]_{2}$ $(30.5 \mathrm{mg}, \quad 5 \mathrm{~mol} \%), \quad \mathrm{Cu}(\mathrm{OAc})_{2} \cdot \mathrm{H}_{2} \mathrm{O} \quad(239.6 \mathrm{mg}, \quad 1.20 \mathrm{mmol})$ and $\mathrm{AgSbF}_{6} \quad(103.0 \mathrm{mg}$, $30 \mathrm{~mol} \%$ ). Purification by column chromatography ( $n$-pentane/EtOAc $6 / 1 \rightarrow 2 / 1$ ) yielded 134ac (247 mg, 82\%) as a colorless oil.

${ }^{1} \mathrm{H}-\mathrm{NMR}\left(400 \mathrm{MHz}, \mathrm{CDCl}_{3}\right): \delta=7.57(\mathrm{~d}, J=7.7 \mathrm{~Hz}, 1 \mathrm{H}), 7.43(\mathrm{dd}, J=7.8,7.7 \mathrm{~Hz}, 1 \mathrm{H}), 7.39$ $7.34(\mathrm{~m}, 2 \mathrm{H}), 6.99(\mathrm{~d}, J=16.0 \mathrm{~Hz}, 1 \mathrm{H}), 6.23(\mathrm{~d}, J=16.0 \mathrm{~Hz}, 1 \mathrm{H}), 4.15(\mathrm{q}, J=7.1 \mathrm{~Hz}, 2 \mathrm{H})$, $2.84(\mathrm{t}, J=7.6 \mathrm{~Hz}, 2 \mathrm{H}), 2.03(\mathrm{~s}, 3 \mathrm{H}), 1.86-1.66(\mathrm{~m}, 2 \mathrm{H}), 1.51-1.31(\mathrm{~m}, 2 \mathrm{H}), 1.24(\mathrm{t}$, $J=7.1 \mathrm{~Hz}, 3 \mathrm{H}), 0.96(\mathrm{t}, J=7.4 \mathrm{~Hz}, 3 \mathrm{H})$.

${ }^{13} \mathrm{C}-N M R\left(100 \mathrm{MHz}, \mathrm{CDCl}_{3}\right): \delta=166.1\left(\mathrm{C}_{\mathrm{q}}\right), 148.8\left(\mathrm{C}_{\mathrm{q}}\right), 138.3(\mathrm{CH}), 136.6\left(\mathrm{C}_{\mathrm{q}}\right), 135.9\left(\mathrm{C}_{\mathrm{q}}\right)$, $132.6\left(\mathrm{C}_{\mathrm{q}}\right), 132.4(\mathrm{CH}), 130.3(\mathrm{CH}), 124.9(\mathrm{CH}), 123.4(\mathrm{CH}), 122.1(\mathrm{CH}), 60.7\left(\mathrm{CH}_{2}\right), 31.6$ $\left(\mathrm{CH}_{2}\right), 25.4\left(\mathrm{CH}_{2}\right), 22.4\left(\mathrm{CH}_{2}\right), 17.5\left(\mathrm{CH}_{3}\right), 14.3\left(\mathrm{CH}_{3}\right), 13.9\left(\mathrm{CH}_{3}\right)$.

IR (ATR): $\tilde{v}=2931,1710,1479,1236,1166,1037,979,787 \mathrm{~cm}^{-1}$.

MS (ESI) m/z (relative intensity): $352(24)\left[\mathrm{M}+\mathrm{K}^{+}\right], 336(24)\left[\mathrm{M}+\mathrm{Na}^{+}\right], 314(100)\left[\mathrm{M}+\mathrm{H}^{+}\right], 240$ (15), 216 (2).

HR-MS (ESI) $m / z$ calcd for $\mathrm{C}_{18} \mathrm{H}_{24} \mathrm{~N}_{3} \mathrm{O}_{2},\left[\mathrm{M}+\mathrm{H}^{+}\right]$314.1863, found 314.1866.

Synthesis of Benzyl (E)-3-[2-(4-n-butyl-1H-1,2,3-triazol-1-yl)-3-methylphenyl]acrylate (134ad)<smiles>CCCCc1cn(-c2c(C)cccc2/C=C/C(=O)OCc2ccccc2)nn1</smiles> 
The general procedure $\mathbf{E}$ was followed using 4- $n$-butyl-1-(o-tolyl)-1 $H-1,2,3$-triazole (123a) $(215.0 \mathrm{mg}, 1.00 \mathrm{mmol})$, benzyl acrylate $(17 \mathrm{~d})(247.0 \mathrm{mg}, 1.50 \mathrm{mmol}),\left[\mathrm{RuCl}_{2}(p \text {-cymene })\right]_{2}$ $(30.5 \mathrm{mg}, 5 \mathrm{~mol} \%), \quad \mathrm{Cu}(\mathrm{OAc})_{2} \cdot \mathrm{H}_{2} \mathrm{O}(239.6 \mathrm{mg}, 1.20 \mathrm{mmol})$ and $\mathrm{AgSbF}_{6}(103.0 \mathrm{mg}$, $30 \mathrm{~mol} \%$ ). Purification by column chromatography (n-pentane/EtOAc 6/1 $\rightarrow 2 / 1$ ) yielded 134ad (255 mg, 68\%) as a colorless oil.

${ }^{1} \mathrm{H}-\mathrm{NMR}\left(300 \mathrm{MHz}, \mathrm{CDCl}_{3}\right): \delta=7.57(\mathrm{~d}, J=7.6 \mathrm{~Hz} 1 \mathrm{H}), 7.43(\mathrm{dd}, J=7.8,7.7 \mathrm{~Hz}, 1 \mathrm{H}), 7.38-$ $7.28(\mathrm{~m}, 7 \mathrm{H}), 7.06(\mathrm{~d}, J=16.0 \mathrm{~Hz}, 1 \mathrm{H}), 6.30(\mathrm{~d}, J=16.0 \mathrm{~Hz}, 1 \mathrm{H}), 5.15(\mathrm{~s}, 2 \mathrm{H}), 2.85(\mathrm{t}$, $J=7.6 \mathrm{~Hz}, 2 \mathrm{H}), 2.03(\mathrm{~s}, 3 \mathrm{H}), 1.80-1.64(\mathrm{~m}, 2 \mathrm{H}), 1.48-1.30(\mathrm{~m}, 2 \mathrm{H}), 0.95(\mathrm{t}, J=7.3 \mathrm{~Hz}, 3 \mathrm{H})$.

${ }^{13} \mathrm{C}-\mathrm{NMR}\left(125 \mathrm{MHz}, \mathrm{CDCl}_{3}\right): \delta=165.8\left(\mathrm{C}_{\mathrm{q}}\right), 148.8\left(\mathrm{C}_{\mathrm{q}}\right), 138.9(\mathrm{CH}), 136.6\left(\mathrm{C}_{\mathrm{q}}\right), 135.9\left(\mathrm{C}_{\mathrm{q}}\right)$, $135.9\left(\mathrm{C}_{\mathrm{q}}\right), 132.6(\mathrm{CH}), 132.4\left(\mathrm{C}_{\mathrm{q}}\right), 130.3(\mathrm{CH}), 128.6(\mathrm{CH}), 128.3(\mathrm{CH}), 128.2(\mathrm{CH}), 124.9$ $(\mathrm{CH}), 123.3(\mathrm{CH}), 121.6(\mathrm{CH}), 66.5\left(\mathrm{CH}_{2}\right), 31.5\left(\mathrm{CH}_{2}\right), 25.4\left(\mathrm{CH}_{2}\right), 22.4\left(\mathrm{CH}_{2}\right), 17.4\left(\mathrm{CH}_{3}\right)$, $13.9\left(\mathrm{CH}_{3}\right)$.

IR (ATR): $\tilde{v}=2930,1715,1480,1312,1264,1163,1039,697 \mathrm{~cm}^{-1}$.

MS (ESI) m/z (relative intensity): 414 (100) [M+K $\mathrm{K}^{+}, 398(30)\left[\mathrm{M}+\mathrm{Na}^{+}\right], 376(66)\left[\mathrm{M}+\mathrm{H}^{+}\right]$.

HR-MS (ESI) $m / z$ calcd for $\mathrm{C}_{23} \mathrm{H}_{24} \mathrm{~N}_{3} \mathrm{O}_{2}$, [M+H'] 376.2020, found 376.2023.

\section{Synthesis of $n$-Butyl (E)-3-[2-(4-n-butyl-1H-1,2,3-triazol-1-yl)-3-methylphenyl]acrylate} (134ae)

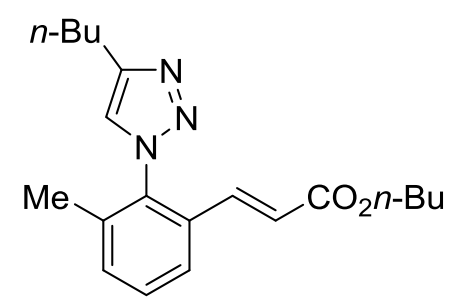

The general procedure $\mathbf{E}$ was followed using 4- $n$-butyl-1-(o-tolyl)-1H-1,2,3-triazole (123a) $(215.0 \mathrm{mg}, 1.00 \mathrm{mmol}), n$-butyl acrylate $(17 \mathrm{e})(217.0 \mathrm{mg}, 1.50 \mathrm{mmol}),\left[\mathrm{RuCl}_{2}(p \text {-cymene })\right]_{2}$ $(30.5 \mathrm{mg}, \quad 5 \mathrm{~mol} \%), \quad \mathrm{Cu}(\mathrm{OAc})_{2} \cdot \mathrm{H}_{2} \mathrm{O} \quad(239.6 \mathrm{mg}, \quad 1.20 \mathrm{mmol})$ and $\mathrm{AgSbF}_{6} \quad(103.0 \mathrm{mg}$, $30 \mathrm{~mol} \%$ ). Purification by column chromatography ( $n$-pentane/EtOAc 6/1 $\rightarrow 2 / 1$ ) yielded 134ae (229 $\mathrm{mg}, 67 \%)$ as a colorless oil.

${ }^{1} \mathrm{H}-\mathrm{NMR}\left(400 \mathrm{MHz}, \mathrm{CDCl}_{3}\right): \delta=7.58(\mathrm{~d}, J=7.3 \mathrm{~Hz}, 1 \mathrm{H}), 7.43(\mathrm{dd}, J=7.7,7.7 \mathrm{~Hz}, 1 \mathrm{H}), 7.38-$ $7.33(\mathrm{~m}, 2 \mathrm{H}), 6.99(\mathrm{~d}, J=16.0 \mathrm{~Hz}, 1 \mathrm{H}), 6.25(\mathrm{~d}, J=16.0 \mathrm{~Hz}, 1 \mathrm{H}), 4.10(\mathrm{t}, J=6.7 \mathrm{~Hz}, 2 \mathrm{H})$, $2.85(\mathrm{t}, J=7.6 \mathrm{~Hz}, 2 \mathrm{H}), 2.03(\mathrm{~s}, 3 \mathrm{H}), 1.82-1.70(\mathrm{~m}, 2 \mathrm{H}), 1.65-1.53(\mathrm{~m}, 2 \mathrm{H}), 1.50-1.26(\mathrm{~m}$, $4 \mathrm{H}), 0.96(\mathrm{t}, J=7.4 \mathrm{~Hz}, 3 \mathrm{H}), 0.91(\mathrm{t}, J=7.4 \mathrm{~Hz}, 3 \mathrm{H})$. 
${ }^{13}$ C-NMR $\left(100 \mathrm{MHz}, \mathrm{CDCl}_{3}\right): \delta=166.2\left(\mathrm{C}_{\mathrm{q}}\right), 148.8\left(\mathrm{C}_{\mathrm{q}}\right), 138.3(\mathrm{CH}), 136.7\left(\mathrm{C}_{\mathrm{q}}\right), 135.9\left(\mathrm{C}_{\mathrm{q}}\right)$, $132.6\left(\mathrm{C}_{\mathrm{q}}\right), 132.5(\mathrm{CH}), 130.3(\mathrm{CH}), 124.9(\mathrm{CH}), 123.3(\mathrm{CH}), 122.1(\mathrm{CH}), 64.7\left(\mathrm{CH}_{2}\right), 31.6$ $\left(\mathrm{CH}_{2}\right), 30.7\left(\mathrm{CH}_{2}\right), 25.4\left(\mathrm{CH}_{2}\right), 22.4\left(\mathrm{CH}_{2}\right), 19.3\left(\mathrm{CH}_{2}\right), 17.5\left(\mathrm{CH}_{3}\right), 13.9\left(\mathrm{CH}_{3}\right), 13.8\left(\mathrm{CH}_{3}\right)$.

IR (ATR): $\tilde{v}=2955,1713,1634,1261,1167,1037,817,750 \mathrm{~cm}^{-1}$

MS (ESI) m/z (relative intensity): 380 (100) $\left[\mathrm{M}+\mathrm{K}^{+}\right], 364$ (41) $\left[\mathrm{M}+\mathrm{Na}^{+}\right], 342(90)\left[\mathrm{M}+\mathrm{H}^{+}\right], 286$ (3), 240 (7), 173 (3).

HR-MS (ESI) $m / z$ calcd for $\mathrm{C}_{20} \mathrm{H}_{28} \mathrm{~N}_{3} \mathrm{O}_{2},\left[\mathrm{M}+\mathrm{H}^{+}\right]$342.2176, found 342.2177.

Synthesis of tert-Butyl (E)-3-[2-(4-n-butyl-1H-1,2,3-triazol-1-yl)-3-methylphenyl]acrylate (134af)<smiles>Cc1cccc(/C=C/C(=O)OC(C)(C)C)c1-n1cc(C(C)(C)C)nn1</smiles>

The general procedure $\mathbf{E}$ was followed using 4- $n$-butyl-1-(o-tolyl)-1H-1,2,3-triazole (123a) $(215.0 \mathrm{mg}, 1.00 \mathrm{mmol})$, tert-butyl acrylate $(\mathbf{1 7 f})(193.3 \mathrm{mg}, 1.50 \mathrm{mmol}),\left[\mathrm{RuCl}_{2}(p \text {-cymene })\right]_{2}$ $(30.5 \mathrm{mg}, 5 \mathrm{~mol} \%), \mathrm{Cu}(\mathrm{OAc})_{2} \cdot \mathrm{H}_{2} \mathrm{O}(239.6 \mathrm{mg}, 1.20 \mathrm{mmol})$ and $\mathrm{AgSbF}_{6}(103.0 \mathrm{mg}$, $30 \mathrm{~mol} \%$ ). Purification by column chromatography ( $n$-pentane/EtOAc 6/1 $\rightarrow 2 / 1$ ) yielded 134af (223 mg, 65\%) as a colorless solid.

M.r.: $77-79^{\circ} \mathrm{C}$.

${ }^{1} \mathrm{H}-\mathrm{NMR}\left(300 \mathrm{MHz}, \mathrm{CDCl}_{3}\right): \delta=7.56(\mathrm{~d}, J=7.7 \mathrm{~Hz}, 1 \mathrm{H}), 7.46-7.30(\mathrm{~m}, 3 \mathrm{H}), 6.89(\mathrm{~d}, J=$ $16.0 \mathrm{~Hz}, 1 \mathrm{H}), 6.18(\mathrm{~d}, J=16.0 \mathrm{~Hz}, 1 \mathrm{H}), 2.84(\mathrm{t}, J=7.6 \mathrm{~Hz}, 2 \mathrm{H}), 2.02(\mathrm{~s}, 3 \mathrm{H}), 1.87-1.65(\mathrm{~m}$, $2 \mathrm{H}), 1.50-1.36(\mathrm{~m}, 2 \mathrm{H}), 1.43(\mathrm{~s}, 9 \mathrm{H}), 0.96(\mathrm{t}, J=7.3 \mathrm{~Hz}, 3 \mathrm{H})$.

${ }^{13}$ C-NMR $\left(76 \mathrm{MHz}, \mathrm{CDCl}_{3}\right): \delta=165.4\left(\mathrm{C}_{\mathrm{q}}\right), 148.7\left(\mathrm{C}_{\mathrm{q}}\right), 137.3(\mathrm{CH}), 136.6\left(\mathrm{C}_{\mathrm{q}}\right), 135.8\left(\mathrm{C}_{\mathrm{q}}\right)$, $132.7\left(\mathrm{C}_{\mathrm{q}}\right), 132.2(\mathrm{CH}), 130.2(\mathrm{CH}), 124.9(\mathrm{CH}), 123.9(\mathrm{CH}), 123.3(\mathrm{CH}), 80.9\left(\mathrm{C}_{\mathrm{q}}\right), 31.7$ $\left(\mathrm{CH}_{2}\right), 28.2\left(\mathrm{CH}_{3}\right), 25.4\left(\mathrm{CH}_{2}\right), 22.4\left(\mathrm{CH}_{2}\right), 17.5\left(\mathrm{CH}_{3}\right), 13.9\left(\mathrm{CH}_{3}\right)$. IR (ATR): $\tilde{v}=2956,1712,1637,1498,1367,1179,1038,765 \mathrm{~cm}^{-1}$. MS (ESI) m/z (relative intensity): 380 (100) $\left[\mathrm{M}+\mathrm{K}^{+}\right], 364$ (27) $\left[\mathrm{M}+\mathrm{Na}^{+}\right], 342(41)\left[\mathrm{M}+\mathrm{H}^{+}\right], 324$ (8), 308 (10), 286 (86), 240 (5).

HR-MS (ESI) $\mathrm{m} / \mathrm{z}$ calcd for $\mathrm{C}_{20} \mathrm{H}_{28} \mathrm{~N}_{3} \mathrm{O}_{2},\left[\mathrm{M}+\mathrm{H}^{+}\right]$342.2176, found 342.2176. 


\section{Synthesis of (E)-3-[2-(4-Butyl-1H-1,2,3-triazol-1-yl)-3-methylphenyl]acrylonitrile (134ag)}<smiles>Cc1cccc(/C=C/C#N)c1-n1cc(CC(C)C)nn1</smiles>

The general procedure $\mathbf{E}$ was followed using 1-iodo-2-methylbenzene (123a) $(215.0 \mathrm{mg}$, $1.00 \mathrm{mmol})$, acrylonitrile $(\mathbf{1 7 g})(98.0 \mathrm{mg}, 1.50 \mathrm{mmol}),\left[\mathrm{RuCl}_{2}(p \text {-cymene })\right]_{2}(30.5 \mathrm{mg}, 5 \mathrm{~mol} \%)$, $\mathrm{Cu}(\mathrm{OAc})_{2} \cdot \mathrm{H}_{2} \mathrm{O}(239.6 \mathrm{mg}, 1.20 \mathrm{mmol})$ and $\mathrm{AgSbF}_{6}(103.0 \mathrm{mg}, 30 \mathrm{~mol} \%)$. Purification by column chromatography ( $n$-pentane/EtOAc $3 / 1 \rightarrow 1 / 1)$ yielded 134ag (39 mg, 15\%) as a colorless oil.

${ }^{1} \mathrm{H}-\mathrm{NMR}\left(300 \mathrm{MHz}, \mathrm{CDCl}_{3}\right): \delta=7.54-7.41(\mathrm{~m}, 3 \mathrm{H}), 7.39(\mathrm{~s}, 1 \mathrm{H}), 6.73(\mathrm{~d}, J=16.7 \mathrm{~Hz}, 1 \mathrm{H})$, $5.75(\mathrm{~d}, J=16.7 \mathrm{~Hz}, 1 \mathrm{H}), 2.86(\mathrm{t}, J=7.8 \mathrm{~Hz}, 2 \mathrm{H}), 2.04(\mathrm{~s}, 3 \mathrm{H}), 1.77(\mathrm{p}, J=7.6 \mathrm{~Hz}, 2 \mathrm{H}) 1.46$ (dt, $J=14.8,7.4 \mathrm{~Hz}, 2 \mathrm{H}), 0.98(\mathrm{t}, J=7.3 \mathrm{~Hz}, 3 \mathrm{H}$ ).

${ }^{13} \mathrm{C}-N M R\left(125 \mathrm{MHz}, \mathrm{CDCl}_{3}\right): \delta=149.2\left(\mathrm{C}_{\mathrm{q}}\right), 144.8(\mathrm{CH}), 137.0\left(\mathrm{C}_{\mathrm{q}}\right), 135.5\left(\mathrm{C}_{\mathrm{q}}\right), 133.5(\mathrm{CH})$, $131.6\left(\mathrm{C}_{\mathrm{q}}\right), 130.5(\mathrm{CH}), 124.2(\mathrm{CH}), 123.3(\mathrm{CH}), 117.4\left(\mathrm{C}_{\mathrm{q}}\right), 100.1(\mathrm{CH}), 31.5\left(\mathrm{CH}_{2}\right), 25.4$ $\left(\mathrm{CH}_{2}\right), 22.5\left(\mathrm{CH}_{2}\right), 17.4\left(\mathrm{CH}_{3}\right), 14.0\left(\mathrm{CH}_{3}\right)$.

IR (ATR): $\tilde{v}=3135,3060,2956,2928,2860,2219,1620,1586,1549,1478 \mathrm{~cm}^{-1}$.

MS (ESI) $m / z$ (relative intensity): $289(5)\left[\mathrm{M}+\mathrm{Na}^{+}\right], 267(100)\left[\mathrm{M}+\mathrm{H}^{+}\right]$.

HR-MS (ESI) $\mathrm{m} / \mathrm{z}$ calcd for $\mathrm{C}_{16} \mathrm{H}_{19} \mathrm{~N}_{4},\left[\mathrm{M}+\mathrm{H}^{+}\right]$267.1604, found 267.1607 .

\section{Synthesis of 4-[2-(4-n-Butyl-1H-1,2,3-triazol-1-yl)-3-methylphenyl]butan-2-on (141)}<smiles>CCCCc1cn(-c2c(C)cccc2CCC(C)=O)nn1</smiles>

The general procedure $\mathbf{E}$ was followed using 4- $n$-butyl-1-(o-tolyl)-1H-1,2,3-triazole (123a) $(215.0 \mathrm{mg}, 1.00 \mathrm{mmol})$, methyl vinyl ketone $(17 \mathrm{j})(112.0 \mathrm{mg}, 1.50 \mathrm{mmol}),\left[\mathrm{RuCl}_{2}(p \text {-cymene })\right]_{2}$ $(30.5 \mathrm{mg}, 5 \mathrm{~mol} \%), \mathrm{Cu}(\mathrm{OAc})_{2} \cdot \mathrm{H}_{2} \mathrm{O} \quad(239.8 \mathrm{mg}, 1.20 \mathrm{mmol})$ and $\mathrm{AgSbF}_{6}(103.0 \mathrm{mg}$, $30 \mathrm{~mol} \%$ ). Purification by column chromatography ( $n$-pentane/EtOAc $6 / 1 \rightarrow 3 / 1 \rightarrow 1 / 1$ ) yielded 141 (186 $\mathrm{mg}, 65 \%)$ as a colorless oil. 
${ }^{1} \mathrm{H}-\mathrm{NMR}\left(300 \mathrm{MHz}, \mathrm{CDCl}_{3}\right): \delta=7.39(\mathrm{~s}, 1 \mathrm{H}), 7.37-7.29(\mathrm{~m}, 1 \mathrm{H}), 7.18(\mathrm{~d}, J=7.7 \mathrm{~Hz}, 2 \mathrm{H})$, $2.79(\mathrm{~d}, J=7.6 \mathrm{~Hz}, 2 \mathrm{H}), 2.64-2.56(\mathrm{~m}, 2 \mathrm{H}), 2.54-2.42(\mathrm{~m}, 2 \mathrm{H}), 2.03(\mathrm{~s}, 3 \mathrm{H}), 1.97(\mathrm{~s}, 3 \mathrm{H})$, $1.80-1.67(\mathrm{~m}, 2 \mathrm{H}), 1.50-1.48-1.32(\mathrm{~m}, 2 \mathrm{H}), 0.96(\mathrm{t}, J=7.3 \mathrm{~Hz}, 3 \mathrm{H})$.

${ }^{13} \mathrm{C}-N M R\left(100 \mathrm{MHz}, \mathrm{CDCl}_{3}\right): \delta=207.4\left(\mathrm{C}_{\mathrm{q}}\right), 148.5\left(\mathrm{C}_{\mathrm{q}}\right), 138.7\left(\mathrm{C}_{\mathrm{q}}\right), 136.0\left(\mathrm{C}_{\mathrm{q}}\right), 136.0\left(\mathrm{C}_{\mathrm{q}}\right)$, $130.2(\mathrm{CH}), 128.9(\mathrm{CH}), 127.8(\mathrm{CH}), 122.9(\mathrm{CH}), 44.8\left(\mathrm{CH}_{2}\right), 31.6\left(\mathrm{CH}_{2}\right), 29.9\left(\mathrm{CH}_{3}\right), 25.5$ $\left(\mathrm{CH}_{2}\right), 25.5\left(\mathrm{CH}_{2}\right), 22.4\left(\mathrm{CH}_{2}\right), 17.5\left(\mathrm{CH}_{3}\right), 13.9\left(\mathrm{CH}_{3}\right)$.

IR (ATR): $\tilde{v}=2929,1714,1483,1363,1214,1163,781,417 \mathrm{~cm}^{-1}$.

MS (ESI) $m / z$ (relative intensity): 324 (73) $\left[\mathrm{M}+\mathrm{K}^{+}\right], 308(35)\left[\mathrm{M}+\mathrm{Na}^{+}\right], 286(100)\left[\mathrm{M}+\mathrm{H}^{+}\right]$.

HR-MS (ESI) $m / z$ calcd for $\mathrm{C}_{17} \mathrm{H}_{24} \mathrm{~N}_{3} \mathrm{O}$, [M+H $\left.\mathrm{H}^{+}\right]$286.1914, found 286.1920.

Synthesis of Ethyl (E)-3-[2-(4-n-Butyl-1H-1,2,3-triazol-1-yl)-3-fluorophenyl]acrylate (134fc)<smiles>CCOC(=O)/C=C/c1cccc(F)c1-n1cc(CC(C)C)nn1</smiles>

The general procedure $\mathbf{E}$ was followed using 4-n-butyl-1-(2-fluorophenyl)-1H-1,2,3-triazole (123f) $(219.0 \mathrm{mg}, 1.00 \mathrm{mmol})$, ethyl acrylate (17c) $(150.0 \mathrm{mg}, 1.50 \mathrm{mmol}),\left[\mathrm{RuCl}_{2}(p-\right.$ cymene) $]_{2}(30.5 \mathrm{mg}, 5 \mathrm{~mol} \%), \mathrm{Cu}(\mathrm{OAc})_{2} \cdot \mathrm{H}_{2} \mathrm{O}(239.6 \mathrm{mg}, 1.20 \mathrm{mmol})$ and $\mathrm{AgSbF}_{6}(103.0 \mathrm{mg}$, $30 \mathrm{~mol} \%$ ). Purification by column chromatography ( $n$-pentane/EtOAc $7 / 1 \rightarrow 2 / 1$ ) yielded $134 \mathrm{fc}(191 \mathrm{mg}, 60 \%)$ as a colorless oil.

${ }^{1} \mathrm{H}-\mathrm{NMR}\left(300 \mathrm{MHz}, \mathrm{CDCl}_{3}\right): \delta=7.57-7.44(\mathrm{~m}, 3 \mathrm{H}), 7.32-7.23(\mathrm{~m}, 1 \mathrm{H}), 7.20(\mathrm{~d}, J=16.0 \mathrm{~Hz}$, $1 \mathrm{H}), 6.31(\mathrm{~d}, J=16.0 \mathrm{~Hz}, 1 \mathrm{H}), 4.17(\mathrm{q}, J=7.1 \mathrm{~Hz}, 2 \mathrm{H}), 2.83(\mathrm{~d}, J=7.6 \mathrm{~Hz}, 2 \mathrm{H}), 1.80-1.67$ (m, 2H), 1.53-1.34 (m, 2H), $1.25(\mathrm{t}, J=7.1 \mathrm{~Hz}, 3 \mathrm{H}), 0.95(\mathrm{t}, J=7.3 \mathrm{~Hz}, 3 \mathrm{H})$.

${ }^{13} \mathrm{C}-N M R\left(75 \mathrm{MHz}, \mathrm{CDCl}_{3}\right): \delta=165.8\left(\mathrm{C}_{\mathrm{q}}\right), 158.7\left({ }^{1} \mathrm{~J}_{\mathrm{C}-\mathrm{F}}=253 \mathrm{~Hz}, \mathrm{C}_{\mathrm{q}}\right), 148.7\left(\mathrm{C}_{\mathrm{q}}\right), 137.1$ $\left({ }^{5} J_{\mathrm{C}-\mathrm{F}}=3 \mathrm{~Hz}, \mathrm{CH}\right), 134.2\left(\mathrm{C}_{\mathrm{q}}\right), 131.3\left({ }^{2} J_{\mathrm{C}-\mathrm{F}}=9 \mathrm{~Hz}, \mathrm{CH}\right), 124.7\left({ }^{2} J_{\mathrm{C}-\mathrm{F}}=13 \mathrm{~Hz}, \mathrm{C}_{\mathrm{q}}\right), 123.8$ $\left({ }^{4} J_{\mathrm{C}-\mathrm{F}}=2 \mathrm{~Hz}, \mathrm{CH}\right), 132.1(\mathrm{CH}), 123.0\left({ }^{3} J_{\mathrm{C}-\mathrm{F}}=4 \mathrm{~Hz}, \mathrm{CH}\right), 117.6\left({ }^{2} J_{\mathrm{C}-\mathrm{F}}=20 \mathrm{~Hz}, \mathrm{CH}\right), 60.9$ $\left(\mathrm{CH}_{2}\right), 31.5\left(\mathrm{CH}_{2}\right), 25.3\left(\mathrm{CH}_{2}\right), 22.4\left(\mathrm{CH}_{2}\right), 14.3\left(\mathrm{CH}_{3}\right), 13.9\left(\mathrm{CH}_{3}\right)$.

${ }^{19} \mathrm{~F}-\mathrm{NMR}\left(283 \mathrm{MHz}, \mathrm{CDCl}_{3}\right): \delta=-121.2--121.3(\mathrm{~m})$.

IR (ATR): $\tilde{v}=3149,2934,1705,1639,1365,1321,1255,1192,1039,790 \mathrm{~cm}^{-1}$.

MS (ESI) m/z (relative intensity): $356(25)\left[\mathrm{M}+\mathrm{K}^{+}\right], 340(25)\left[\mathrm{M}+\mathrm{Na}^{+}\right], 318(100)\left[\mathrm{M}+\mathrm{H}^{+}\right], 244$ (10), 202 (1), 173 (3), 146 (1).

HR-MS (ESI) $m / z$ calcd for $\mathrm{C}_{17} \mathrm{H}_{21} \mathrm{FN}_{3} \mathrm{O}_{2},\left[\mathrm{M}+\mathrm{H}^{+}\right]$318.1612, found 318.1623. 
Synthesis of Benzyl (E)-3-[2-(4-n-Butyl-1H-1,2,3-triazol-1-yl)-4-fluorophenyl]acrylate (134fd)<smiles>CCCc1cn(-c2c(F)cccc2/C=C/C(=O)OCc2ccccc2)nn1</smiles>

The general procedure $\mathbf{E}$ was followed using 4-n-butyl-1-(2-fluorophenyl)-1H-1,2,3-triazole (123f) $(219.0 \mathrm{mg}, 1.00 \mathrm{mmol})$, benzyl acrylate $(\mathbf{1 7 d})(494.0 \mathrm{mg}, 3.00 \mathrm{mmol}),\left[\mathrm{RuCl}_{2}(p-\right.$ cymene) $]_{2}(30.5 \mathrm{mg}, 5 \mathrm{~mol} \%), \mathrm{Cu}(\mathrm{OAc})_{2} \cdot \mathrm{H}_{2} \mathrm{O}(399.3 \mathrm{mg}, 2.00 \mathrm{mmol})$ and $\mathrm{AgSbF}_{6}(103.0 \mathrm{mg}$, $30 \mathrm{~mol} \%$ ). Purification by column chromatography ( $n$-pentane/EtOAc 6/1) yielded 134fd (298 $\mathrm{mg}, 79 \%)$ as a colorless oil.

${ }^{1} \mathrm{H}-\mathrm{NMR}\left(300 \mathrm{MHz}, \mathrm{CDCl}_{3}\right): \delta=7.59-7.45(\mathrm{~m}, 3 \mathrm{H}), 7.41-7.22(\mathrm{~m}, 7 \mathrm{H}), 6.39(\mathrm{~d}, J=15.9 \mathrm{~Hz}$, $1 \mathrm{H}), 5.18(\mathrm{~s}, 2 \mathrm{H}), 2.83(\mathrm{t}, J=7.8 \mathrm{~Hz}, 2 \mathrm{H}), 1.84-1.64(\mathrm{~m}, 2 \mathrm{H}), 1.52-1.36(\mathrm{~m}, 2 \mathrm{H}), 0.96(\mathrm{t}$, $J=7.3 \mathrm{~Hz}, 3 \mathrm{H})$.

${ }^{13} \mathrm{C}-N M R\left(125 \mathrm{MHz}, \mathrm{CDCl}_{3}\right): \delta=165.6\left(\mathrm{C}_{\mathrm{q}}\right), 157.0\left({ }^{1} \mathrm{~J}_{\mathrm{C}-\mathrm{F}}=254 \mathrm{~Hz}, \mathrm{C}_{\mathrm{q}}\right), 148.7\left(\mathrm{C}_{\mathrm{q}}\right), 137.9$ $\left({ }^{4} J_{\mathrm{C}-\mathrm{F}}=3 \mathrm{~Hz}, \mathrm{CH}\right), 135.8\left(\mathrm{C}_{\mathrm{q}}\right), 134.0\left(\mathrm{C}_{\mathrm{q}}\right), 131.3\left({ }^{3} \mathrm{~J}_{\mathrm{C}-\mathrm{F}}=8 \mathrm{~Hz}, \mathrm{CH}\right), 128.7(\mathrm{CH}), 128.4(\mathrm{CH})$, $128.3(\mathrm{CH}), 124.8\left({ }^{2} J_{\mathrm{C}-\mathrm{F}}=13 \mathrm{~Hz}, \mathrm{C}_{\mathrm{q}}\right), 123.9(\mathrm{CH}), 123.0\left({ }^{4} J_{\mathrm{C}-\mathrm{F}}=4 \mathrm{~Hz}, \mathrm{CH}\right), 122.9(\mathrm{CH})$, $117.7\left({ }^{2} J_{\mathrm{C}-\mathrm{F}}=20 \mathrm{~Hz}, \mathrm{CH}\right), 66.7\left(\mathrm{CH}_{2}\right), 31.4\left(\mathrm{CH}_{2}\right), 25.4\left(\mathrm{CH}_{2}\right), 22.4\left(\mathrm{CH}_{2}\right), 13.9\left(\mathrm{CH}_{3}\right)$.

${ }^{19} \mathrm{~F}-\mathrm{NMR}\left(282 \mathrm{MHz}, \mathrm{CDCl}_{3}\right): \delta=-121.2$ (ddd, $\left.J=9.7,4.8,1.5 \mathrm{~Hz}\right)$.

IR (ATR): $\tilde{v}=2957,1716,1497,1477,1250,1161,1038,797 \mathrm{~cm}^{-1}$.

MS (ESI) m/z (relative intensity): 418 (100) $\left[\mathrm{M}+\mathrm{K}^{+}\right], 402(15)\left[\mathrm{M}+\mathrm{Na}^{+}\right], 380(28)\left[\mathrm{M}^{+} \mathrm{H}^{+}\right], 217$ (6), 169 (2) 152 (8), 108 (4).

HR-MS (ESI) $m / z$ calcd for $\mathrm{C}_{22} \mathrm{H}_{23} \mathrm{FN}_{3} \mathrm{O}_{2}$, $\left[\mathrm{M}+\mathrm{H}^{+}\right] 380.1769$, found 380.1758 .

Synthesis of $n$-Butyl (E)-3-[2-(4-n-Butyl-1H-1,2,3-triazol-1-yl)-3-fluorophenyl]acrylate (134fe)<smiles>CCCCOC(=O)/C=C/c1cccc(F)c1-n1cc(CCCC)nn1</smiles> 
The general procedure $\mathbf{E}$ was followed using 4-n-butyl-1-(2-fluorophenyl)-1H-1,2,3-triazole (123f) $(219.0 \mathrm{mg}, 1.00 \mathrm{mmol}), n$-butyl acrylate $(17 \mathrm{e})(434.0 \mathrm{mg}, 3.00 \mathrm{mmol}),\left[\mathrm{RuCl}_{2}(p-\right.$ cymene) $]_{2}(30.5 \mathrm{mg}, 5 \mathrm{~mol} \%), \mathrm{Cu}(\mathrm{OAc})_{2} \cdot \mathrm{H}_{2} \mathrm{O}$ (399.3 mg, $\left.2.00 \mathrm{mmol}\right)$ and $\mathrm{AgSbF}_{6}(103.0 \mathrm{mg}$, $30 \mathrm{~mol} \%$ ). Purification by column chromatography ( $n$-pentane/EtOAc 6/1) yielded 134fe (262 $\mathrm{mg}, 76 \%)$ as a colorless oil.

${ }^{1} \mathrm{H}-\mathrm{NMR}\left(400 \mathrm{MHz}, \mathrm{CDCl}_{3}\right): \delta=7.56-7.42(\mathrm{~m}, 3 \mathrm{H}), 7.30-7.22(\mathrm{~m}, 1 \mathrm{H}), 7.18(\mathrm{~d}, J=16.0 \mathrm{~Hz}$, $1 \mathrm{H}), 6.31(\mathrm{~d}, J=16.0 \mathrm{~Hz}, 1 \mathrm{H}), 4.11(\mathrm{t}, J=6.7 \mathrm{~Hz}, 2 \mathrm{H}), 2.82(\mathrm{t}, J=6.7 \mathrm{~Hz}, 2 \mathrm{H}) 1.78-1.69(\mathrm{~m}$, $2 \mathrm{H}), 1.63-1.53(\mathrm{~m}, 2 \mathrm{H}), 1.47-1.38(\mathrm{~m}, 2 \mathrm{H}), 1.37-1.27(\mathrm{~m}, 2 \mathrm{H}), 0.94(\mathrm{t}, J=7.4 \mathrm{~Hz}, 3 \mathrm{H}), 0.90$ $(\mathrm{t}, J=7.4 \mathrm{~Hz}, 3 \mathrm{H})$.

${ }^{13} \mathrm{C}$-NMR $\left(100 \mathrm{MHz}, \mathrm{CDCl}_{3}\right): \delta=165.8\left(\mathrm{C}_{\mathrm{q}}\right), 157.0\left({ }^{1} \mathrm{~J}_{\mathrm{C}-\mathrm{F}}=254 \mathrm{~Hz}, \mathrm{C}_{\mathrm{q}}\right), 148.7\left(\mathrm{C}_{\mathrm{q}}\right), 137.2$ $\left({ }^{4} J_{\mathrm{C}-\mathrm{F}}=3 \mathrm{~Hz}, \mathrm{CH}\right), 134.1\left(\mathrm{C}_{\mathrm{q}}\right), 131.3\left({ }^{3} \mathrm{~J}_{\mathrm{C}-\mathrm{F}}=9 \mathrm{~Hz}, \mathrm{CH}\right), 124.7\left({ }^{2} J_{\mathrm{C}-\mathrm{F}}=13 \mathrm{~Hz}, \mathrm{C}_{\mathrm{q}}\right), 123.8$ $\left({ }^{5} J_{\mathrm{C}-\mathrm{F}}=2 \mathrm{~Hz}, \mathrm{CH}\right), 123.3(\mathrm{CH}), 123.0\left({ }^{4} J_{\mathrm{C}-\mathrm{F}}=4 \mathrm{~Hz}, \mathrm{CH}\right), 117.6\left({ }^{2} J_{\mathrm{C}-\mathrm{F}}=20 \mathrm{~Hz}, \mathrm{CH}\right), 64.8$ $\left(\mathrm{CH}_{2}\right), 31.4\left(\mathrm{CH}_{2}\right), 30.7\left(\mathrm{CH}_{2}\right), 25.3\left(\mathrm{CH}_{2}\right), 22.4\left(\mathrm{CH}_{2}\right), 19.2\left(\mathrm{CH}_{2}\right), 13.9\left(\mathrm{CH}_{3}\right), 13.8\left(\mathrm{CH}_{3}\right)$.

${ }^{19}$ F-NMR (376 MHz, $\left.\mathrm{CDCl}_{3}\right): \delta=-121.2--121.3(\mathrm{~m})$.

IR (ATR): $\tilde{v}=2958,1713,1497,1250,1179,1038,795,730 \mathrm{~cm}^{-1}$.

MS (ESI) $m / z$ (relative intensity): 384 (100) $\left[\mathrm{M}+\mathrm{K}^{+}\right], 368$ (14) $\left[\mathrm{M}+\mathrm{Na}^{+}\right], 346(83)\left[\mathrm{M}^{+} \mathrm{H}^{+}\right]$. HR-MS (ESI) $m / z$ calcd for $\mathrm{C}_{19} \mathrm{H}_{25} \mathrm{FN}_{3} \mathrm{O}_{2},\left[\mathrm{M}+\mathrm{H}^{+}\right] 346.1925$, found 346.1922 .

Synthesis of tert-Butyl (E)-3-[1-(4-n-butyl-1H-1,2,3-triazol-1-yl)-3-fluorophenyl]acrylate (134ff)<smiles>CCCCc1cn(-c2c(F)cccc2/C=C/C(=O)OC(C)(C)C)nn1</smiles>

The general procedure $\mathbf{E}$ was followed using 4-n-butyl-1-(2-fluorophenyl)-1H-1,2,3-triazole (123f) $(219.0 \mathrm{mg}, 1.00 \mathrm{mmol})$, tert-butyl acrylate (17f) $(386.6 \mathrm{mg}, 3.00 \mathrm{mmol}),\left[\mathrm{RuCl}_{2}(p-\right.$ cymene)] $]_{2}(30.5 \mathrm{mg}, 5 \mathrm{~mol} \%), \mathrm{Cu}(\mathrm{OAc})_{2} \cdot \mathrm{H}_{2} \mathrm{O}(399.3 \mathrm{mg}, 2.00 \mathrm{mmol})$ and $\mathrm{AgSbF}_{6}(103.0 \mathrm{mg}$, $30 \mathrm{~mol} \%$ ). Purification by column chromatography (n-pentane/EtOAc 6/1) yielded 134ff (193 mg, 56\%) as a colorless solid.

M.r.: $85-86^{\circ} \mathrm{C}$.

${ }^{1} \mathrm{H}-\mathrm{NMR}\left(300 \mathrm{MHz}, \mathrm{CDCl}_{3}\right): \delta=7.58-7.43(\mathrm{~m}, 3 \mathrm{H}), 7.32-7.21(\mathrm{~m}, 1 \mathrm{H}), 7.10(\mathrm{~d}, J=15.9 \mathrm{~Hz}$, $1 \mathrm{H}), 6.26(\mathrm{~d}, J=15.9 \mathrm{~Hz}, 1 \mathrm{H}), 2.84(\mathrm{t}, J=7.8 \mathrm{~Hz}, 2 \mathrm{H}), 1.83-1.63(\mathrm{~m}, 2 \mathrm{H}), 1.52-1.36(\mathrm{~m}$, $2 \mathrm{H}), 1.45(\mathrm{~s}, 9 \mathrm{H}), 0.96(\mathrm{t}, J=7.3 \mathrm{~Hz}, 3 \mathrm{H})$. 
${ }^{13} \mathrm{C}-N M R\left(125 \mathrm{MHz}, \mathrm{CDCl}_{3}\right): \delta=165.1\left(\mathrm{C}_{\mathrm{q}}\right), 157.2\left({ }^{1} \mathrm{~J}_{\mathrm{C}-\mathrm{F}}=254 \mathrm{~Hz}, \mathrm{C}_{\mathrm{q}}\right), 148.7\left(\mathrm{C}_{\mathrm{q}}\right), 136.2$ $\left({ }^{4} J_{\mathrm{C}-\mathrm{F}}=3 \mathrm{~Hz}, \mathrm{CH}\right), 134.4\left(\mathrm{C}_{\mathrm{q}}\right), 131.3\left({ }^{3} \mathrm{~J}_{\mathrm{C}-\mathrm{F}}=9 \mathrm{~Hz}, \mathrm{CH}\right), 125.2(\mathrm{CH}), 124.8\left({ }^{2} \mathrm{~J}_{\mathrm{C}-\mathrm{F}}=13 \mathrm{~Hz}, \mathrm{C}_{\mathrm{q}}\right)$, $123.9(\mathrm{CH}), 122.9\left({ }^{4} J_{\mathrm{C}-\mathrm{F}}=4 \mathrm{~Hz}, \mathrm{CH}\right), 117.4\left({ }^{2} J_{\mathrm{C}-\mathrm{F}}=20 \mathrm{~Hz}, \mathrm{CH}\right), 81.2\left(\mathrm{C}_{\mathrm{q}}\right), 31.6\left(\mathrm{CH}_{2}\right), 28.2$ $\left(\mathrm{CH}_{3}\right), 25.4\left(\mathrm{CH}_{2}\right), 22.4\left(\mathrm{CH}_{2}\right), 13.9\left(\mathrm{CH}_{3}\right)$.

${ }^{19} \mathrm{~F}-\mathrm{NMR}\left(282 \mathrm{MHz}, \mathrm{CDCl}_{3}\right): \delta=-121.2--121.4(\mathrm{~m})$.

IR (ATR): $\tilde{v}=2956,1697,1475,1289,1230,1156,969,806 \mathrm{~cm}^{-1}$.

MS (ESI) m/z (relative intensity): $384(100)\left[\mathrm{M}+\mathrm{K}^{+}\right], 368(21)\left[\mathrm{M}+\mathrm{Na}^{+}\right], 346(21)\left[\mathrm{M}+\mathrm{H}^{+}\right]$.

HR-MS (ESI) $\mathrm{m} / \mathrm{z}$ calcd for $\mathrm{C}_{19} \mathrm{H}_{24} \mathrm{FN}_{3} \mathrm{O}_{2} \mathrm{~K},\left[\mathrm{M}+\mathrm{K}^{+}\right]$384.1484, found 384.1474.

Synthesis of Ethyl (E)-3-[1-(4-n-butyl-1H-1,2,3-triazol-1-yl)naphtalen-2-yl]acrylate (134hc)

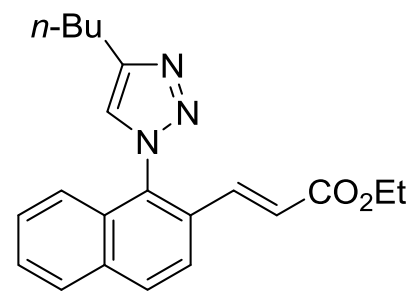

The general procedure $\mathbf{E}$ was followed using 4-n-butyl-1-(naphtalen-2-yl)-1H-1,2,3-triazole (123h) $(251.0 \mathrm{mg}, 1.00 \mathrm{mmol})$, ethyl acrylate $(17 \mathrm{c})(151.0 \mathrm{mg}, 1.50 \mathrm{mmol}),\left[\mathrm{RuCl}_{2}(p-\right.$ cymene $)]_{2}(30.5 \mathrm{mg}, 5 \mathrm{~mol} \%), \mathrm{Cu}(\mathrm{OAc})_{2} \cdot \mathrm{H}_{2} \mathrm{O}(239.6 \mathrm{mg}, 1.20 \mathrm{mmol})$ and $\mathrm{AgSbF}_{6}(103.0 \mathrm{mg}$, $30 \mathrm{~mol} \%$ ). Purification by column chromatography ( $n$-pentane/EtOAc 6/1 $\rightarrow 2 / 1$ ) yielded 134hc (203 mg, 58\%) as a colorless oil.

${ }^{1} \mathrm{H}-\mathrm{NMR}\left(300 \mathrm{MHz}, \mathrm{CDCl}_{3}\right): \delta=7.99(\mathrm{~d}, J=8.7 \mathrm{~Hz}, 1 \mathrm{H}), 7.89(\mathrm{~d}, J=8.3 \mathrm{~Hz}, 1 \mathrm{H}), 7.78$ (d, $J=8.8 \mathrm{~Hz}, 1 \mathrm{H}), 7.62-7.50(\mathrm{~m}, 2 \mathrm{H}), 7.48(\mathrm{ddd}, J=8.3,6.9,1.4 \mathrm{~Hz}, 1 \mathrm{H}), 7.18(\mathrm{~d}, J=16.0 \mathrm{~Hz}$, $1 \mathrm{H}), 7.12(\mathrm{dd}, J=8.4,1.1 \mathrm{~Hz}, 1 \mathrm{H}), 6.46(\mathrm{~d}, J=16.0 \mathrm{~Hz}, 1 \mathrm{H}), 4.19(\mathrm{q}, J=7.1 \mathrm{~Hz}, 2 \mathrm{H}), 1.79$ (t, $J=7.6 \mathrm{~Hz}, 2 \mathrm{H}), 1.87-1.74(\mathrm{~m}, 2 \mathrm{H}) 1.56-1.36(\mathrm{~m}, 2 \mathrm{H}), 1.26(\mathrm{t}, J=7.1 \mathrm{~Hz}, 3 \mathrm{H}), 0.99(\mathrm{t}$, $J=7.3 \mathrm{~Hz}, 3 \mathrm{H})$.

${ }^{13}$ C-NMR $\left(125 \mathrm{MHz}, \mathrm{CDCl}_{3}\right): \delta=166.0\left(\mathrm{C}_{\mathrm{q}}\right), 148.8\left(\mathrm{C}_{\mathrm{q}}\right), 137.8(\mathrm{CH}), 134.4\left(\mathrm{C}_{\mathrm{q}}\right), 133.3\left(\mathrm{C}_{\mathrm{q}}\right)$, $130.8(\mathrm{CH}), 130.5\left(\mathrm{C}_{\mathrm{q}}\right), 129.5\left(\mathrm{C}_{\mathrm{q}}\right), 128.6(\mathrm{CH}), 128.1(\mathrm{CH}), 128.1(\mathrm{CH}), 124.8(\mathrm{CH}), 123.2$ $(\mathrm{CH}), 122.7(\mathrm{CH}), 122.7(\mathrm{CH}), 60.8\left(\mathrm{CH}_{2}\right), 31.6\left(\mathrm{CH}_{2}\right), 25.4\left(\mathrm{CH}_{2}\right), 22.4\left(\mathrm{CH}_{2}\right), 14.3\left(\mathrm{CH}_{3}\right)$, $13.9\left(\mathrm{CH}_{3}\right)$.

IR (ATR): $\tilde{v}=2931,1712,1635,1292,1262,1178,819,751 \mathrm{~cm}^{-1}$.

MS (ESI) m/z (relative intensity): 388 (100) [M+K $\left.\mathrm{K}^{+}\right], 372(30)\left[\mathrm{M}+\mathrm{Na}^{+}\right], 350(88)\left[\mathrm{M}+\mathrm{H}^{+}\right], 324$ (2), 276 (6).

HR-MS (ESI) $m / z$ calcd for $\mathrm{C}_{21} \mathrm{H}_{24} \mathrm{~N}_{3} \mathrm{O}_{2}$, $\left[\mathrm{M}+\mathrm{H}^{+}\right]$350.1863, found 350.1867. 
Synthesis of Benzyl (E)-3-[1-(4-n-butyl-1H-1,2,3-triazol-1-yl)naphtalen-2-yl]acrylate (134hd)<smiles>CCCCc1cn(-c2c(/C=C/C(=O)OCc3ccccc3)ccc3ccccc23)nn1</smiles>

The general procedure $\mathbf{E}$ was followed using 4-n-butyl-1-(naphthalene-1-yl)-1H-1,2,3-triazole (123h) (251.0 mg, $1.00 \mathrm{mmol})$, benzyl acrylate (17d) $(494.0 \mathrm{mg}, 3.00 \mathrm{mmol}),\left[\mathrm{RuCl}_{2}(p-\right.$ cymene) $]_{2}(30.5 \mathrm{mg}, 5 \mathrm{~mol} \%), \mathrm{Cu}(\mathrm{OAc})_{2} \cdot \mathrm{H}_{2} \mathrm{O}(399.3 \mathrm{mg}, 2.00 \mathrm{mmol})$ and $\mathrm{AgSbF}_{6}(103.0 \mathrm{mg}$, $30 \mathrm{~mol} \%$ ). Purification by column chromatography ( $n$-pentane/EtOAc 6/1) yielded 134hd (287 mg, 70\%) as a colorless oil.

${ }^{1} \mathrm{H}-\mathrm{NMR}\left(300 \mathrm{MHz}, \mathrm{CDCl}_{3}\right): \delta=7.99(\mathrm{~d}, J=8.7 \mathrm{~Hz}, 1 \mathrm{H}), 7.89(\mathrm{~d}, J=7.2 \mathrm{~Hz}, 1 \mathrm{H}), 7.77(\mathrm{~d}$, $J=8.8 \mathrm{~Hz}, 1 \mathrm{H}), 7.65-7.52(\mathrm{~m}, 2 \mathrm{H}), 7.52-7.45(\mathrm{~m}, 1 \mathrm{H}), 7.41-7.30(\mathrm{~m}, 5 \mathrm{H}), 7.25(\mathrm{~d}$, $J=16.0 \mathrm{~Hz}, 1 \mathrm{H}), 7.13(\mathrm{~d}, J=9.0 \mathrm{~Hz}, 1 \mathrm{H}), 6.53(\mathrm{~d}, J=16.0 \mathrm{~Hz}, 1 \mathrm{H}), 5.19(\mathrm{~s}, 2 \mathrm{H}), 2.90(\mathrm{t}$, $J=7.4 \mathrm{~Hz}, 2 \mathrm{H}), 1.80(\mathrm{ddt}, J=8.8,7.6,6.4 \mathrm{~Hz}, 2 \mathrm{H}), 1.56-1.40(\mathrm{~m}, 2 \mathrm{H}), 1.00(\mathrm{t}, J=7.3 \mathrm{~Hz}$, $3 \mathrm{H})$.

${ }^{13} \mathrm{C}-\mathrm{NMR}\left(125 \mathrm{MHz}, \mathrm{CDCl}_{3}\right): \delta=165.8\left(\mathrm{C}_{\mathrm{q}}\right), 148.8\left(\mathrm{C}_{\mathrm{q}}\right), 138.4(\mathrm{CH}), 135.9\left(\mathrm{C}_{\mathrm{q}}\right), 134.5\left(\mathrm{C}_{\mathrm{q}}\right)$, $133.4\left(\mathrm{C}_{\mathrm{q}}\right), 130.8(\mathrm{CH}), 130.5\left(\mathrm{C}_{\mathrm{q}}\right), 129.4\left(\mathrm{C}_{\mathrm{q}}\right), 128.7(\mathrm{CH}), 128.6(\mathrm{CH}), 128.3(\mathrm{CH}), 128.2$ $(\mathrm{CH}), 128.2(\mathrm{CH}), 128.1(\mathrm{CH}), 124.8(\mathrm{CH}), 123.2(\mathrm{CH}), 122.6(\mathrm{CH}), 122.2(\mathrm{CH}), 66.6\left(\mathrm{CH}_{2}\right)$, $31.5\left(\mathrm{CH}_{2}\right), 25.4\left(\mathrm{CH}_{2}\right), 22.4\left(\mathrm{CH}_{2}\right), 13.9\left(\mathrm{CH}_{3}\right)$.

IR (ATR): $\tilde{v}=2929,1712,1634,1261,866,734,696 \mathrm{~cm}^{-1}$.

MS (ESI) $m / z$ (relative intensity): 450 (100) $\left[\mathrm{M}+\mathrm{K}^{+}\right], 434$ (29) $\left[\mathrm{M}+\mathrm{Na}^{+}\right], 412(88)\left[\mathrm{M}^{+} \mathrm{H}^{+}\right], 324$ (2), 276 (6).

HR-MS (ESI) $m / z$ calcd for $\mathrm{C}_{26} \mathrm{H}_{26} \mathrm{~N}_{3} \mathrm{O}_{2}$, $\left[\mathrm{M}+\mathrm{H}^{+}\right]$412.2020, found 412.2017.

Synthesis of $n$-Butyl (E)-3-[1-(4-n-butyl-1H-1,2,3-triazol-1-yl)naphtalen-2-yl]acrylate (134he)<smiles>CCCCc1cn(-c2c(/C=C/C(=O)OCC)ccc3ccccc23)nn1</smiles> 
The general procedure $\mathbf{E}$ was followed using 4-n-butyl-1-(naphthalene-1-yl)-1H-1,2,3-triazole (123h) $(251.0 \mathrm{mg}, 1.00 \mathrm{mmol}), n$-butyl acrylate $(17 \mathrm{e})(434.0 \mathrm{mg}, 3.00 \mathrm{mmol}),\left[\mathrm{RuCl}_{2}(p-\right.$ cymene) $]_{2}(30.5 \mathrm{mg}, 5 \mathrm{~mol} \%), \mathrm{Cu}(\mathrm{OAc})_{2} \cdot \mathrm{H}_{2} \mathrm{O}$ (399.3 mg, $\left.2.00 \mathrm{mmol}\right)$ and $\mathrm{AgSbF}_{6}(103.0 \mathrm{mg}$, $30 \mathrm{~mol} \%$ ). Purification by column chromatography ( $n$-pentane/EtOAc 6/1) yielded 134he (268 $\mathrm{mg}, 71 \%)$ as a colorless oil.

${ }^{1} \mathrm{H}-\mathrm{NMR}\left(300 \mathrm{MHz}, \mathrm{CDCl}_{3}\right): \delta=8.00(\mathrm{~d}, J=8.7 \mathrm{~Hz}, 1 \mathrm{H}), 7.91(\mathrm{~d}, J=8.0 \mathrm{~Hz}, 1 \mathrm{H}), 7.80(\mathrm{~d}$, $J=8.8 \mathrm{~Hz}, 1 \mathrm{H}), 7.59-7.43(\mathrm{~m}, 2 \mathrm{H}), 7.49$ (ddd, $J=8.2,6.8,1.3 \mathrm{~Hz}, 1 \mathrm{H}), 7.19(\mathrm{~d}, J=16.0 \mathrm{~Hz}$, $1 \mathrm{H}), 7.13(\mathrm{~d}, J=8.7 \mathrm{~Hz}, 1 \mathrm{H}), 6.48(\mathrm{~d}, J=16.0 \mathrm{~Hz}, 1 \mathrm{H}), 4.14(\mathrm{t}, J=6.6 \mathrm{~Hz}, 2 \mathrm{H}), 3.91$ (t, $J=6.6 \mathrm{~Hz}, 2 \mathrm{H}), 1.84-1.75(\mathrm{~m}, 2 \mathrm{H}), 1.67-1.57(\mathrm{~m}, 2 \mathrm{H}), 1.49(\mathrm{~h}, J=7.5 \mathrm{~Hz}, 2 \mathrm{H}), 1.42-1.28$ $(\mathrm{m}, 2 \mathrm{H}), 1.00(\mathrm{t}, J=7.4 \mathrm{~Hz}, 3 \mathrm{H}), 0.93(\mathrm{t}, J=7.4 \mathrm{~Hz}, 3 \mathrm{H})$.

${ }^{13} \mathrm{C}-N M R\left(125 \mathrm{MHz}, \mathrm{CDCl}_{3}\right): \delta=166.2\left(\mathrm{C}_{\mathrm{q}}\right), 148.8\left(\mathrm{C}_{\mathrm{q}}\right), 137.8(\mathrm{CH}), 134.5\left(\mathrm{C}_{\mathrm{q}}\right), 133.3\left(\mathrm{C}_{\mathrm{q}}\right)$, $130.8(\mathrm{CH}), 130.6\left(\mathrm{C}_{\mathrm{q}}\right), 129.6\left(\mathrm{C}_{\mathrm{q}}\right), 128.6(\mathrm{CH}), 128.1(\mathrm{CH}), 128.1(\mathrm{CH}), 124.8(\mathrm{CH}), 123.3$ $(\mathrm{CH}), 122.7(\mathrm{CH}), 122.7(\mathrm{CH}), 64.8\left(\mathrm{CH}_{2}\right), 31.7\left(\mathrm{CH}_{2}\right), 30.8\left(\mathrm{CH}_{2}\right), 25.5\left(\mathrm{CH}_{2}\right), 22.5\left(\mathrm{CH}_{2}\right)$, $19.3\left(\mathrm{CH}_{2}\right), 13.9\left(\mathrm{CH}_{3}\right), 13.8\left(\mathrm{CH}_{3}\right)$.

IR (ATR): $\tilde{v}=2957,1711,1635,1290,1261,1174,978,818 \mathrm{~cm}^{-1}$.

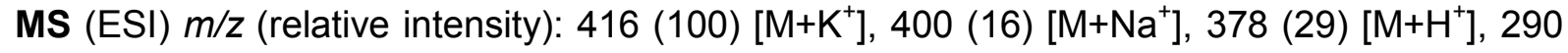
(3), 252 (8), 232 (2), 217 (6), 169 (2) 152 (7), 102 (3).

HR-MS (ESI) $m / z$ calcd for $\mathrm{C}_{23} \mathrm{H}_{28} \mathrm{~N}_{3} \mathrm{O}_{2}$, [M+H'] 378.2176, found 378.2168.

Synthesis of tert-Butyl (E)-3-[1-(4-n-butyl-1H-1,2,3-triazol-1-yl)naphtalen-2-yl]acrylate (134hf)<smiles>CC(C)(C)OC(=O)/C=C/c1ccc2ccccc2c1-n1cc(C(C)(C)C)nn1</smiles>

The general procedure $\mathbf{E}$ was followed using 4-n-butyl-1-(naphthalene-1-yl)-1H-1,2,3-triazole (123h) $(251.0 \mathrm{mg}, 1.00 \mathrm{mmol})$, tert-butyl acrylate $(\mathbf{1 7 f})(386.6 \mathrm{mg}, 3.00 \mathrm{mmol}),\left[\mathrm{RuCl}_{2}(p-\right.$ cymene) $]_{2}(30.5 \mathrm{mg}, 5 \mathrm{~mol} \%), \mathrm{Cu}(\mathrm{OAc})_{2} \cdot \mathrm{H}_{2} \mathrm{O}(399.3 \mathrm{mg}, 2.00 \mathrm{mmol})$ and $\mathrm{AgSbF}_{6}(103.0 \mathrm{mg}$, $30 \mathrm{~mol} \%$ ). Purification by column chromatography ( $n$-pentane/EtOAc 9/1) yielded 134hf (271 $\mathrm{mg}, 72 \%)$ as a colorless oil.

${ }^{1} \mathrm{H}-\mathrm{NMR}\left(300 \mathrm{MHz}, \mathrm{CDCl}_{3}\right): \delta=8.00(\mathrm{~d}, J=8.8 \mathrm{~Hz}, 1 \mathrm{H}), 7.91(\mathrm{~d}, J=8.0 \mathrm{~Hz}, 1 \mathrm{H}), 7.80(\mathrm{~d}, J=$ $8.8 \mathrm{~Hz}, 1 \mathrm{H}), 7.68-7.46(\mathrm{~m}, 3 \mathrm{H}), 7.17-7.04(\mathrm{~m}, 2 \mathrm{H}), 6.43(\mathrm{~d}, J=16.0 \mathrm{~Hz}, 1 \mathrm{H}), 2.91$ (t, 
$J=6.7 \mathrm{~Hz}, 2 \mathrm{H}), 1.81(\mathrm{p}, J=7.5 \mathrm{~Hz}, 2 \mathrm{H}), 1.56-1.38(\mathrm{~m}, 2 \mathrm{H}), 1.47(\mathrm{~s}, 9 \mathrm{H}), 1.00(\mathrm{t}, J=7.3 \mathrm{~Hz}$, $3 \mathrm{H})$.

${ }^{13} \mathrm{C}-\mathrm{NMR}\left(125 \mathrm{MHz}, \mathrm{CDCl}_{3}\right): \delta=165.4\left(\mathrm{C}_{\mathrm{q}}\right), 148.8\left(\mathrm{C}_{\mathrm{q}}\right), 136.9(\mathrm{CH}), 134.4\left(\mathrm{C}_{\mathrm{q}}\right), 133.2\left(\mathrm{C}_{\mathrm{q}}\right)$, $130.7(\mathrm{CH}), 130.6\left(\mathrm{C}_{\mathrm{q}}\right), 129.8\left(\mathrm{C}_{\mathrm{q}}\right), 128.6(\mathrm{CH}), 128.0(\mathrm{CH}), 128.0(\mathrm{CH}), 124.8(\mathrm{CH}), 124.6$ $(\mathrm{CH}), 123.3(\mathrm{CH}), 122.8(\mathrm{CH}), 81.1\left(\mathrm{C}_{\mathrm{q}}\right), 31.8\left(\mathrm{CH}_{2}\right), 28.2\left(\mathrm{CH}_{3}\right), 25.5\left(\mathrm{CH}_{2}\right), 22.6\left(\mathrm{CH}_{2}\right), 14.0$ $\left(\mathrm{CH}_{3}\right)$.

IR (ATR): $\tilde{v}=2929,1704,1260,1144,979,817,751,66 \mathrm{~cm}^{-1}$.

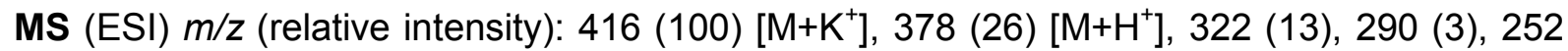
(9).

HR-MS (ESI) $m / z$ calcd for $\mathrm{C}_{23} \mathrm{H}_{28} \mathrm{~N}_{3} \mathrm{O}_{2}$, $\left[\mathrm{M}+\mathrm{H}^{+}\right]$378.2176, found 378.2161.

Synthesis of Ethyl (E)-3-[2-(4-n-butyl-1H-1,2,3-triazol-1-yl)-3-methoxyphenyl]acrylate (134gc)<smiles>CCOC(=O)/C=C/c1cccc(OC)c1-n1cc(C(C)(C)C)nn1</smiles>

The general procedure $\mathbf{E}$ was followed using 4- $n$-butyl-1-(2-methoxyphenyl)-1H-1,2,3-triazole (123c) $(231.0 \mathrm{mg}, 1.00 \mathrm{mmol})$, ethyl acrylate (17c) $(150.0 \mathrm{mg}, 1.50 \mathrm{mmol}),\left[\operatorname{RuCl}_{2}(p-\right.$ cymene $]_{2}(30.5 \mathrm{mg}, 5 \mathrm{~mol} \%), \mathrm{Cu}(\mathrm{OAc})_{2} \cdot \mathrm{H}_{2} \mathrm{O}(239.8 \mathrm{mg}, 1.20 \mathrm{mmol})$ and $\mathrm{AgSbF}_{6}(103.0 \mathrm{mg}$, $30 \mathrm{~mol} \%$ ). Purification by column chromatography ( $n$-pentane/EtOAc $3 / 1 \rightarrow 1 / 1$ ) yielded $134 \mathrm{gc}(175 \mathrm{mg}, 53 \%)$ as a colorless solid.

M.r.: $87-88^{\circ} \mathrm{C}$.

${ }^{1} \mathrm{H}-\mathrm{NMR}\left(400 \mathrm{MHz}, \mathrm{CDCl}_{3}\right): \delta=7.43(\mathrm{dd}, J=8.2,8.2 \mathrm{~Hz} 1 \mathrm{H}), 7.39(\mathrm{~s}, 1 \mathrm{H}), 7.28(\mathrm{~d}$, $J=8.0 \mathrm{~Hz}, 1 \mathrm{H}), 7.09-6.98(\mathrm{~m}, 2 \mathrm{H}), 6.24(\mathrm{~d}, J=16.0 \mathrm{~Hz}, 1 \mathrm{H}), 4.12(\mathrm{q}, J=7.1 \mathrm{~Hz}, 2 \mathrm{H}), 3.73$ (s, 3H), $2.80(\mathrm{t}, J=7.6 \mathrm{~Hz}, 2 \mathrm{H}), 1.76-1.66(\mathrm{~m}, 2 \mathrm{H}), 1.45-1.34(\mathrm{~m}, 2 \mathrm{H}), 1.20(\mathrm{t}, J=7.1 \mathrm{~Hz}$, $3 \mathrm{H}), 0.92(\mathrm{t}, J=7.4 \mathrm{~Hz}, 3 \mathrm{H})$.

${ }^{13} \mathrm{C}-N M R\left(75 \mathrm{MHz}, \mathrm{CDCl}_{3}\right): \delta=166.0\left(\mathrm{C}_{\mathrm{q}}\right), 154.9\left(\mathrm{C}_{\mathrm{q}}\right), 148.1\left(\mathrm{C}_{\mathrm{q}}\right), 138.3(\mathrm{CH}), 133.6\left(\mathrm{C}_{\mathrm{q}}\right)$, $131.0(\mathrm{CH}), 125.6\left(\mathrm{C}_{\mathrm{q}}\right), 124.2(\mathrm{CH}), 122.3(\mathrm{CH}), 118.9(\mathrm{CH}), 113.1(\mathrm{CH}), 60.7\left(\mathrm{CH}_{2}\right), 56.3$ $\left(\mathrm{CH}_{3}\right), 31.5\left(\mathrm{CH}_{2}\right), 25.4\left(\mathrm{CH}_{2}\right), 22.4\left(\mathrm{CH}_{2}\right), 14.2\left(\mathrm{CH}_{3}\right), 13.9\left(\mathrm{CH}_{3}\right)$.

IR (ATR): $\tilde{v}=2953,1709,1478,1263,1172,1963,1038,800 \mathrm{~cm}^{-1}$.

MS (ESI) $\mathrm{m} / \mathrm{z}$ (relative intensity): $368(22)\left[\mathrm{M}+\mathrm{K}^{+}\right], 352(21)\left[\mathrm{M}+\mathrm{Na}^{+}\right], 330(100)\left[\mathrm{M}+\mathrm{H}^{+}\right], 318$ (5), 256 (8), 241 (2).

HR-MS (ESI) $m / z$ calcd for $\mathrm{C}_{18} \mathrm{H}_{24} \mathrm{~N}_{3} \mathrm{O}_{3},\left[\mathrm{M}+\mathrm{H}^{+}\right] 330.1812$, found 330.1818 . 
Synthesis of Ethyl (E)-3-[2-(4-n-butyl-1H-1,2,3-triazol-1-yl)phenyl]acrylate (134bc) and diethyl 3,3'-[2-(4-butyl-1H-1,2,3-triazol-1-yl)-1,3-phenylene](2E, 2'E)-diacrylate (142bc)<smiles>CCCc1cn(-c2ccccc2C=CC=C(OCC)OCC)nn1</smiles>

The general procedure $\mathbf{E}$ was followed using 4-n-butyl-1-phenyl-1 $\mathrm{H}$-1,2,3-triazole (123b) $(100.0 \mathrm{mg}, 0.50 \mathrm{mmol})$, ethyl acrylate (17c) (150.0 mg, $1.50 \mathrm{mmol}), \quad\left[\mathrm{RuCl}_{2}(p \text {-cymene })\right]_{2}$ (15.3 mg, $5 \mathrm{~mol} \%$ ), $\mathrm{Cu}(\mathrm{OAc})_{2} \cdot \mathrm{H}_{2} \mathrm{O}$ (199.6 mg, $\left.1.00 \mathrm{mmol}\right)$ and $\mathrm{AgSbF}_{6}(51.0 \mathrm{mg}, 30 \mathrm{~mol} \%)$. Purification by column chromatography (n-pentane/EtOAc 9/1 $\rightarrow 2 / 1$ ) yielded 134bc (107 $\mathrm{mg}, 71 \%$ ) and $\mathbf{1 4 2 b c}(8 \mathrm{mg}, 4 \%)$ as colorless oil.

${ }^{1} \mathrm{H}-\mathrm{NMR}\left(300 \mathrm{MHz}, \mathrm{CDCl}_{3}\right): \delta=7.78-7.65(\mathrm{~m}, 1 \mathrm{H}), 7.55-7.43(\mathrm{~m}, 4 \mathrm{H}), 7.40(\mathrm{~d}, J=15.9 \mathrm{~Hz}$, $1 \mathrm{H}), 6.35(\mathrm{~d}, J=15.9 \mathrm{~Hz}, 1 \mathrm{H}), 4.19(\mathrm{q}, J=7.2 \mathrm{~Hz}, 2 \mathrm{H}), 2.82(\mathrm{t}, J=7.4 \mathrm{~Hz}, 2 \mathrm{H}), 1.81-1.65$ (m, 2H), 1.52-1.34 (m, 2H), 1.27 (t, J = 7.1 Hz, 3H), 0.95 (t, J=7.2 Hz, 3H).

${ }^{13} \mathrm{C}-\mathrm{NMR}\left(125 \mathrm{MHz}, \mathrm{CDCl}_{3}\right): \delta=166.1\left(\mathrm{C}_{\mathrm{q}}\right), 148.8\left(\mathrm{C}_{\mathrm{q}}\right), 138.6(\mathrm{CH}), 136.5\left(\mathrm{C}_{\mathrm{q}}\right), 130.8(\mathrm{CH})$, $130.4\left(\mathrm{C}_{\mathrm{q}}\right), 129.9(\mathrm{CH}), 127.8(\mathrm{CH}), 126.6(\mathrm{CH}), 123.2(\mathrm{CH}), 122.2(\mathrm{CH}), 60.8\left(\mathrm{CH}_{2}\right), 31.6$ $\left(\mathrm{CH}_{2}\right), 25.4\left(\mathrm{CH}_{2}\right), 22.4\left(\mathrm{CH}_{2}\right), 14.3\left(\mathrm{CH}_{3}\right), 13.9\left(\mathrm{CH}_{3}\right)$.

IR (ATR): $\tilde{v}=2932,1711,1497,1316,1177,1037,764 \mathrm{~cm}^{-1}$.

MS (ESI) m/z (relative intensity): 338 (100) $\left[\mathrm{M}+\mathrm{K}^{+}\right], 322(38)\left[\mathrm{M}+\mathrm{Na}^{+}\right], 300(81)\left[\mathrm{M}+\mathrm{H}^{+}\right], 226$ (14), 189 (1), 173 (3), 146 (2).

HR-MS (ESI) $m / z$ calcd for $\mathrm{C}_{17} \mathrm{H}_{22} \mathrm{~N}_{3} \mathrm{O}_{2}$, [M+H $\left.\mathrm{H}^{+}\right] 300.1707$, found 300.1708 .<smiles>CCCCc1cn(-c2c(/C=C/COCC)cccc2/C=C/C(=O)OCC)nn1</smiles>

M.p.: $100^{\circ} \mathrm{C}$

${ }^{1} \mathrm{H}-\mathrm{NMR}\left(500 \mathrm{MHz}, \mathrm{CDCl}_{3}\right): \delta=7.76(\mathrm{~d}, J=7.9 \mathrm{~Hz}, 2 \mathrm{H}), 7.59(\mathrm{ddt}, J=8.2,7.5,0.7 \mathrm{~Hz}, 1 \mathrm{H})$, $7.43(\mathrm{~d}, J=0.8 \mathrm{~Hz}, 1 \mathrm{H}), 7.00(\mathrm{~d}, J=16.0 \mathrm{~Hz}, 2 \mathrm{H}), 6.30(\mathrm{~d}, J=16.0 \mathrm{~Hz}, 2 \mathrm{H}), 4.18(\mathrm{q}, J=7.1$ $\mathrm{Hz}, 4 \mathrm{H}), 2.87$ (ddd, $J=8.0,7.3,0.7 \mathrm{~Hz}, 2 \mathrm{H}), 1.85-1.67(\mathrm{~m}, 2 \mathrm{H}), 1.49-1.41(\mathrm{~m}, 2 \mathrm{H}), 1.26(\mathrm{t}$, $J=7.1 \mathrm{~Hz}, 6 \mathrm{H}), 0.97(\mathrm{t}, J=7.4 \mathrm{~Hz}, 3 \mathrm{H})$. 
${ }^{13}$ C-NMR (125 MHz, $\left.\mathrm{CDCl}_{3}\right): \delta=165.8\left(\mathrm{C}_{\mathrm{q}}\right), 149.2\left(\mathrm{C}_{\mathrm{q}}\right), 137.6(\mathrm{CH}), 135.3\left(\mathrm{C}_{\mathrm{q}}\right), 133.5(\mathrm{CH})$, $130.8(\mathrm{CH}), 128.6(\mathrm{CH}), 124.4(\mathrm{CH}), 123.2(\mathrm{CH}), 60.9\left(\mathrm{CH}_{2}\right), 31.7\left(\mathrm{CH}_{2}\right), 25.4\left(\mathrm{CH}_{2}\right), 22.4$ $\left(\mathrm{CH}_{2}\right), 14.3\left(\mathrm{CH}_{3}\right), 14.0\left(\mathrm{CH}_{3}\right)$.

IR (ATR): $\tilde{v}=3121,2961,2929,2852,1595,1552,1499,1466,1413,1323,1244,1223$, $1075,1040,990,913,830,758,731,683,525,480 \mathrm{~cm}^{-1}$.

MS (ESI) $m / z$ (relative intensity): $436(2)\left[\mathrm{M}+\mathrm{K}^{+}\right], 420(13)\left[\mathrm{M}+\mathrm{Na}^{+}\right], 398(100)\left[\mathrm{M}^{+} \mathrm{H}^{+}\right], 324$ (2), 300 (1).

HR-MS (ESI) $m / z$ calcd for $\mathrm{C}_{22} \mathrm{H}_{27} \mathrm{~N}_{3} \mathrm{O}_{4}$, $\left[\mathrm{M}+\mathrm{H}^{+}\right]$398.2074, found 398.2079.

\section{Synthesis of Ethyl (E)-3-[2-(4-n-butyl-1H-1,2,3-triazol-1-yl)-5-methylphenyl]acrylate} (134ic) and Diethyl 3,3'-[2-(4-butyl-1H-1,2,3-triazol-1-yl)-5-methyl-1,3-phenylene](2E, 2'E)-diacrylate (142ic)

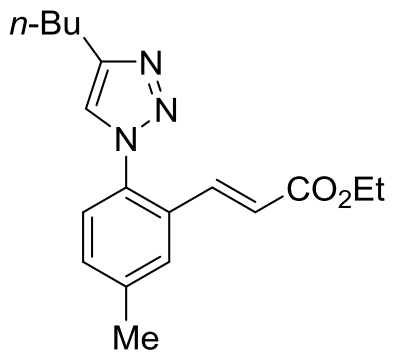

The general procedure $\mathbf{E}$ was followed using 4-n-butyl-1-(4-methylphenyl)-1H-1,2,3-triazole (123i) $(215.0 \mathrm{mg}, 1.00 \mathrm{mmol})$, ethyl acrylate $(17 \mathrm{c})(300.0 \mathrm{mg}, 3.00 \mathrm{mmol}),\left[\mathrm{RuCl}_{2}(p-\right.$ cymene)] $]_{2}(30.5 \mathrm{mg}, 5 \mathrm{~mol} \%), \mathrm{Cu}(\mathrm{OAc})_{2} \cdot \mathrm{H}_{2} \mathrm{O}(399.3 \mathrm{mg}, 2.00 \mathrm{mmol})$ and $\mathrm{AgSbF}_{6}(103.0 \mathrm{mg}$, $30 \mathrm{~mol} \%$ ). Purification by column chromatography ( $n$-pentane/EtOAc 6/1) yielded 134ic (175 mg, $56 \%$ ) and 142 ic (15 mg, $7 \%$ ) as colorless solids.

M.p.: $65^{\circ} \mathrm{C}$.

${ }^{1} \mathrm{H}-\mathrm{NMR}\left(400 \mathrm{MHz}, \mathrm{CDCl}_{3}\right): \delta=7.53(\mathrm{~s}, 1 \mathrm{H}), 7.45(\mathrm{~s}, 1 \mathrm{H}), 7.39-7.28(\mathrm{~m}, 3 \mathrm{H}), 6.33(\mathrm{~d}$, $J=15.9 \mathrm{~Hz}, 1 \mathrm{H}), 4.19(\mathrm{q}, J=7.1 \mathrm{~Hz}, 2 \mathrm{H}), 2.82(\mathrm{t}, J=7.5 \mathrm{~Hz}, 2 \mathrm{H}), 2.44(\mathrm{~s}, 3 \mathrm{H}), 1.76-1.64$ (m, 2H), 1.49-1.35 (m, 2H), $1.26(\mathrm{t}, J=7.1 \mathrm{~Hz}, 3 \mathrm{H}), 0.95(\mathrm{t}, J=7.4 \mathrm{~Hz}, 3 \mathrm{H})$.

${ }^{13}$ C-NMR $\left(100 \mathrm{MHz}, \mathrm{CDCl}_{3}\right): \delta=166.2\left(\mathrm{C}_{\mathrm{q}}\right), 148.7\left(\mathrm{C}_{\mathrm{q}}\right), 140.1\left(\mathrm{C}_{\mathrm{q}}\right), 138.7(\mathrm{CH}), 134.3\left(\mathrm{C}_{\mathrm{q}}\right)$, $131.5(\mathrm{CH}), 130.0\left(\mathrm{C}_{\mathrm{q}}\right), 128.1(\mathrm{CH}), 126.5(\mathrm{CH}), 123.2(\mathrm{CH}), 121.9(\mathrm{CH}), 60.8\left(\mathrm{CH}_{2}\right), 31.6$ $\left(\mathrm{CH}_{2}\right), 25.4\left(\mathrm{CH}_{2}\right), 22.4\left(\mathrm{CH}_{2}\right), 21.4\left(\mathrm{CH}_{3}\right), 14.3\left(\mathrm{CH}_{3}\right), 13.9\left(\mathrm{CH}_{3}\right)$.

IR (ATR): $\tilde{v}=2926,1708,1503,1366,1257,1226,1034,874,559 \mathrm{~cm}^{-1}$.

MS (ESI) m/z (relative intensity): 352 (100) $\left[\mathrm{M}+\mathrm{K}^{+}\right], 336(36)\left[\mathrm{M}+\mathrm{Na}^{+}\right], 314(72)\left[\mathrm{M}+\mathrm{H}^{+}\right], 240$ (10), 173 (2).

HR-MS (ESI) $\mathrm{m} / \mathrm{z}$ calcd for $\mathrm{C}_{18} \mathrm{H}_{24} \mathrm{~N}_{3} \mathrm{O}_{2},\left[\mathrm{M}+\mathrm{H}^{+}\right]$314.1863, found 314.1863. 


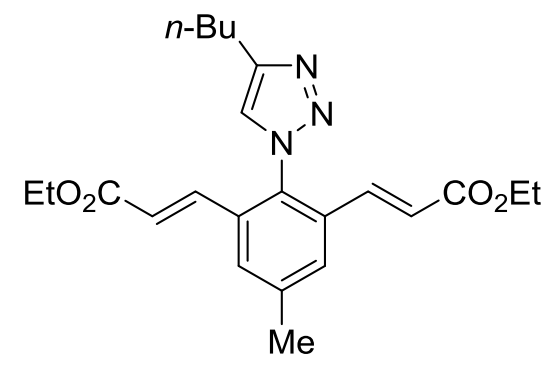

M.r.: $58-60^{\circ} \mathrm{C}$

${ }^{1} \mathrm{H}-\mathrm{NMR}\left(500 \mathrm{MHz}, \mathrm{CDCl}_{3}\right): \delta=8.04(\mathrm{~d}, J=1.7 \mathrm{~Hz}, 2 \mathrm{H}), 7.93(\mathrm{dd}, J=8.1,1.8 \mathrm{~Hz}, 2 \mathrm{H}), 7.46$ $(\mathrm{d}, J=0.8 \mathrm{~Hz}, 2 \mathrm{H}), 7.26(\mathrm{~d}, J=0.9 \mathrm{~Hz}, 2 \mathrm{H}), 2.79-2.52(\mathrm{~m}, 10 \mathrm{H}), 1.57(\mathrm{dt}, J=15.2,7.9 \mathrm{~Hz}$, 4H), 1.39-1.12 (m, 4H), 0.99-0.77 (m, 6H).

${ }^{13} \mathrm{C}$-NMR $\left(125 \mathrm{MHz}, \mathrm{CDCl}_{3}\right): \delta=196.0\left(\mathrm{C}_{\mathrm{q}}\right), 148.8\left(\mathrm{C}_{\mathrm{q}}\right), 138.1\left(\mathrm{C}_{\mathrm{q}}\right), 137.5\left(\mathrm{C}_{\mathrm{q}}\right), 136.2\left(\mathrm{C}_{\mathrm{q}}\right)$, $131.1(\mathrm{CH}), 129.0(\mathrm{CH}), 125.6(\mathrm{CH}), 122.3(\mathrm{CH}), 31.5\left(\mathrm{CH}_{2}\right), 26.8\left(\mathrm{CH}_{3}\right), 25.2\left(\mathrm{CH}_{2}\right), 22.2$ $\left(\mathrm{CH}_{2}\right), 13.9\left(\mathrm{CH}_{3}\right)$.

IR (ATR): $\tilde{v}=3134,3066,2956,2930,2861,1686,1607,1557,1436,1358,1249,1179$, $1038,962,906,830,657,595 \mathrm{~cm}^{-1}$.

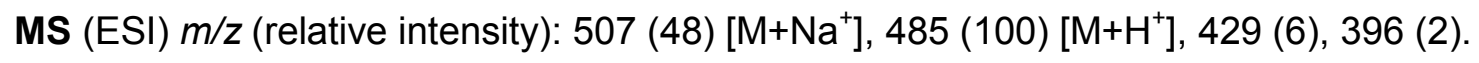

HR-MS (ESI) $m / z$ calcd for $\mathrm{C}_{28} \mathrm{H}_{32} \mathrm{~N}_{6} \mathrm{O}_{2}$, $\left[\mathrm{M}+\mathrm{H}^{+}\right]$485.2659, found 485.2660.

Synthesis of Ethyl (E)-3-[2-(4-n-butyl-1H-1,2,3-triazol-1-yl)-5-chlorophenyl]acrylate (134jc)<smiles>CCOC(=CC=Cc1cc(Cl)ccc1-n1cc(CC)nn1)OCC</smiles>

The general procedure $\mathbf{E}$ was followed using 4- $n$-butyl-1-(4-chlorophenyl)-1H-1,2,3-triazole (123j) $(235.0 \mathrm{mg}, 1.00 \mathrm{mmol})$, ethyl acrylate (17c) $(300.0 \mathrm{mg}, 3.00 \mathrm{mmol}), \quad\left[\mathrm{RuCl}_{2}(p-\right.$ cymene) $]_{2}(30.5 \mathrm{mg}, 5 \mathrm{~mol} \%), \mathrm{Cu}(\mathrm{OAc})_{2} \cdot \mathrm{H}_{2} \mathrm{O}(399.8 \mathrm{mg}, 2.00 \mathrm{mmol})$ and $\mathrm{AgSbF}_{6}(103.0 \mathrm{mg}$, $30 \mathrm{~mol} \%$ ). Purification by column chromatography ( $n$-pentane/EtOAc 19/1) yielded 134jc (177 mg, 53\%) as a colorless solid.

M.p.: $74^{\circ} \mathrm{C}$.

${ }^{1} \mathrm{H}-\mathrm{NMR}\left(300 \mathrm{MHz}, \mathrm{CDCl}_{3}\right): \delta=7.69(\mathrm{~d}, J=2.1 \mathrm{~Hz}, 1 \mathrm{H}), 7.50-7.43(\mathrm{~m}, 2 \mathrm{H}), 7.40(\mathrm{~d}$, $J=8.5 \mathrm{~Hz}, 1 \mathrm{H}), 7.33(\mathrm{~d}, J=15.9 \mathrm{~Hz}, 1 \mathrm{H}), 6.36(\mathrm{~d}, J=15.9 \mathrm{~Hz}, 1 \mathrm{H}), 4.19(\mathrm{q}, J=7.1 \mathrm{~Hz}, 2 \mathrm{H})$, 
$2.79(\mathrm{t}, J=7.4 \mathrm{~Hz}, 2 \mathrm{H}), 1.79-1.62(\mathrm{~m}, 2 \mathrm{H}), 1.50-1.35(\mathrm{~m}, 2 \mathrm{H}), 1.26(\mathrm{t}, J=7.1 \mathrm{~Hz}, 3 \mathrm{H}), 0.94$ (t, $J=7.3 \mathrm{~Hz}, 3 \mathrm{H})$.

${ }^{13}$ C-NMR $\left(125 \mathrm{MHz}, \mathrm{CDCl}_{3}\right): \delta=165.6\left(\mathrm{C}_{\mathrm{q}}\right), 149.0\left(\mathrm{C}_{\mathrm{q}}\right), 137.3(\mathrm{CH}), 135.9\left(\mathrm{C}_{\mathrm{q}}\right), 134.9\left(\mathrm{C}_{\mathrm{q}}\right)$, $131.8\left(\mathrm{C}_{\mathrm{q}}\right), 130.6(\mathrm{CH}), 127.8(\mathrm{CH}), 123.4(\mathrm{CH}), 123.4(\mathrm{CH}), 123.0(\mathrm{CH}), 60.9\left(\mathrm{CH}_{2}\right), 31.5$ $\left(\mathrm{CH}_{2}\right), 25.3\left(\mathrm{CH}_{2}\right), 22.4\left(\mathrm{CH}_{2}\right), 14.3\left(\mathrm{CH}_{3}\right), 13.9\left(\mathrm{CH}_{3}\right)$.

IR (ATR): $\tilde{v}=2931,1712,1493,1241,1178,1038,981,751 \mathrm{~cm}^{-1}$.

MS (ESI) m/z (relative intensity): $372(100)\left[\mathrm{M}+\mathrm{K}^{+}\right], 356(37)\left[\mathrm{M}+\mathrm{Na}^{+}\right], 334(65)\left[\mathrm{M}+\mathrm{H}^{+}\right], 260$ (6), 189 (2), 173 (7).

HR-MS (ESI) $m / z$ calcd for $\mathrm{C}_{17} \mathrm{H}_{21} \mathrm{CIN}_{3} \mathrm{O}_{2},\left[\mathrm{M}+\mathrm{H}^{+}\right]$334.1317, found 334.1317.

Synthesis of Ethyl (E)-3-[2-(4-n-butyl-1H-1,2,3-triazol-1-yl)-5-methoxyphenyl]acrylate (134kc)

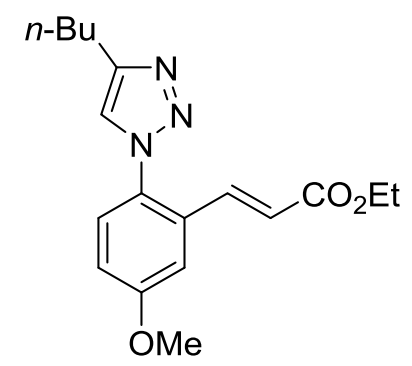

The general procedure $\mathbf{E}$ was followed using 4- $n$-butyl-1-(4-methoxyphenyl)-1H-1,2,3-triazole (123k) (231.0 mg, $1.00 \mathrm{mmol})$, ethyl acrylate (17c) (150.0 mg, $1.50 \mathrm{mmol}), \quad\left[\operatorname{RuCl}_{2}(p-\right.$ cymene) $]_{2}(30.5 \mathrm{mg}, 5 \mathrm{~mol} \%), \mathrm{Cu}(\mathrm{OAc})_{2} \cdot \mathrm{H}_{2} \mathrm{O}(239.6 \mathrm{mg}, 1.20 \mathrm{mmol})$ and $\mathrm{AgSbF}_{6}(103.0 \mathrm{mg}$, $30 \mathrm{~mol} \%$ ). Purification by column chromatography ( $n$-pentane/EtOAc 6/1) yielded 134kc (182 $\mathrm{mg}, 55 \%)$ as a colorless solid.

M.r.: $70-73^{\circ} \mathrm{C}$.

${ }^{1} \mathrm{H}-\mathrm{NMR}\left(500 \mathrm{MHz}, \mathrm{CDCl}_{3}\right): \delta=7.43(\mathrm{~s}, 1 \mathrm{H}), 7.38(\mathrm{~d}, J=8.8 \mathrm{~Hz}, 1 \mathrm{H}), 7.33(\mathrm{~d}, J=16.0 \mathrm{~Hz}$, $1 \mathrm{H}), 7.19(\mathrm{~d}, J=2.8 \mathrm{~Hz}, 1 \mathrm{H}), 7.03(\mathrm{dd}, J=8.7,2.8 \mathrm{~Hz}, 1 \mathrm{H}), 6.33(\mathrm{~d}, J=16.0 \mathrm{~Hz}, 1 \mathrm{H}), 4.21$ (q, $J=7.1 \mathrm{~Hz}, 2 \mathrm{H}), 3.89(\mathrm{~s}, 3 \mathrm{H}), 2.81(\mathrm{t}, J=7.7 \mathrm{~Hz}, 2 \mathrm{H}), 1.81-1.66(\mathrm{~m}, 2 \mathrm{H}), 1.49-1.33(\mathrm{~m}$, $2 \mathrm{H}), 1.28(\mathrm{t}, J=7.1 \mathrm{~Hz}, 3 \mathrm{H}), 0.96(\mathrm{t}, J=7.4 \mathrm{~Hz}, 3 \mathrm{H})$.

${ }^{13} \mathrm{C}$-NMR (125 MHz, $\left.\mathrm{CDCl}_{3}\right): \delta=166.1\left(\mathrm{C}_{\mathrm{q}}\right), 160.5\left(\mathrm{C}_{\mathrm{q}}\right), 148.7\left(\mathrm{C}_{\mathrm{q}}\right), 138.5(\mathrm{CH}), 131.8\left(\mathrm{C}_{\mathrm{q}}\right)$, $129.9\left(\mathrm{C}_{\mathrm{q}}\right), 128.1(\mathrm{CH}), 123.4(\mathrm{CH}), 122.3(\mathrm{CH}), 116.5(\mathrm{CH}), 112.1(\mathrm{CH}), 60.9\left(\mathrm{CH}_{2}\right), 55.9$ $\left(\mathrm{CH}_{3}\right), 31.7\left(\mathrm{CH}_{2}\right), 25.4\left(\mathrm{CH}_{2}\right), 22.5\left(\mathrm{CH}_{2}\right), 14.4\left(\mathrm{CH}_{3}\right), 13.9\left(\mathrm{CH}_{3}\right)$.

IR (ATR): $\tilde{v}=2934,1710,1634,1504,1185,1034,855,499 \mathrm{~cm}^{-1}$.

MS (ESI) $m / z$ (relative intensity): 368 (100) $\left[\mathrm{M}+\mathrm{K}^{+}\right], 352(14)\left[\mathrm{M}+\mathrm{Na}^{+}\right], 330(41)\left[\mathrm{M}+\mathrm{H}^{+}\right], 290$

(2), 255 (5), 217 (17), 190 (2), 169 (7), 152 (24), 108 (13).

HR-MS (ESI) $m / z$ calcd for $\mathrm{C}_{18} \mathrm{H}_{24} \mathrm{~N}_{3} \mathrm{O}_{3}$, $\left[\mathrm{M}+\mathrm{H}^{+}\right] 330.1812$, found 330.1798. 
Synthesis of Methyl (E)-4-(4-n-butyl-1H-1,2,3-triazol-1-yl)-3-(3-ethoxy-3oxyprop-1-n-1yl)benzoate (134Ic)

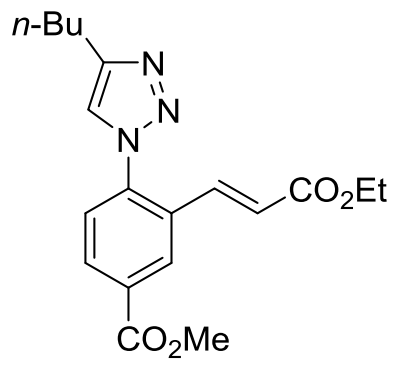

The general procedure $\mathbf{E}$ was followed using methyl 4-(4- $n$-butyl-1H-1,2,3-triazol-1yl)benzoate (123l) $(259.0 \mathrm{mg}, 1.00 \mathrm{mmol})$, ethyl acrylate $(17 \mathrm{c})(300.0 \mathrm{mg}, 3.00 \mathrm{mmol})$, $\left[\mathrm{RuCl}_{2}(p \text {-cymene })\right]_{2}(30.5 \mathrm{mg}, 5 \mathrm{~mol} \%), \mathrm{Cu}(\mathrm{OAc})_{2} \cdot \mathrm{H}_{2} \mathrm{O}(399.3 \mathrm{mg}, 2.00 \mathrm{mmol})$ and $\mathrm{AgSbF}_{6}$ (103.0 mg, $30 \mathrm{~mol} \%$ ). Purification by column chromatography ( $n$-pentane/EtOAc 6/1) yielded 134lc (196 mg, 55\%) as a colorless solid.

M.p.: $55^{\circ} \mathrm{C}$.

${ }^{1} \mathrm{H}-\mathrm{NMR}\left(300 \mathrm{MHz}, \mathrm{CDCl}_{3}\right): \delta=8.40(\mathrm{~d}, J=1.9 \mathrm{~Hz}, 1 \mathrm{H}), 8.15(\mathrm{dd}, J=8.3,1.9 \mathrm{~Hz}, 1 \mathrm{H}), 7.57$ $(\mathrm{d}, J=8.3 \mathrm{~Hz}, 1 \mathrm{H}), 7.54(\mathrm{~s}, 1 \mathrm{H}), 7.48(\mathrm{~d}, J=16.0 \mathrm{~Hz}, 1 \mathrm{H}), 6.49(\mathrm{~d}, J=16.0 \mathrm{~Hz}, 1 \mathrm{H}), 4.21(\mathrm{q}$, $J=7.1 \mathrm{~Hz}, 2 \mathrm{H}), 3.96(\mathrm{~s}, 3 \mathrm{H}), 2.81(\mathrm{t}, J=7.4 \mathrm{~Hz}, 2 \mathrm{H}), 1.80-1.65(\mathrm{~m}, 2 \mathrm{H}), 1.51-1.34(\mathrm{~m}, 2 \mathrm{H})$, $1.28(\mathrm{t}, J=7.1 \mathrm{~Hz}, 3 \mathrm{H}), 0.95(\mathrm{t}, J=7.3 \mathrm{~Hz}, 3 \mathrm{H})$.

${ }^{13} \mathrm{C}-\mathrm{NMR}\left(125 \mathrm{MHz}, \mathrm{CDCl}_{3}\right): \delta=165.8\left(\mathrm{C}_{\mathrm{q}}\right), 165.5\left(\mathrm{C}_{\mathrm{q}}\right), 149.2\left(\mathrm{C}_{\mathrm{q}}\right), 139.5\left(\mathrm{C}_{\mathrm{q}}\right), 137.9(\mathrm{CH})$, $131.5(\mathrm{CH}), 131.4\left(\mathrm{C}_{\mathrm{q}}\right), 130.2\left(\mathrm{C}_{\mathrm{q}}\right), 129.4(\mathrm{CH}), 126.5(\mathrm{CH}), 123.3(\mathrm{CH}), 122.9(\mathrm{CH}), 60.9$ $\left(\mathrm{CH}_{2}\right), 52.8\left(\mathrm{CH}_{3}\right), 31.5\left(\mathrm{CH}_{2}\right), 25.3\left(\mathrm{CH}_{2}\right), 22.4\left(\mathrm{CH}_{2}\right), 14.3\left(\mathrm{CH}_{3}\right), 13.9\left(\mathrm{CH}_{3}\right)$.

IR (ATR): $\tilde{v}=2958,1722,1366,1264,1204,984,769,751 \mathrm{~cm}^{-1}$.

MS (ESI) $m / z$ (relative intensity): $396(100)\left[\mathrm{M}+\mathrm{K}^{+}\right], 380$ (15) $\left[\mathrm{M}+\mathrm{Na}^{+}\right], 358(24)\left[\mathrm{M}+\mathrm{H}^{+}\right], 217$ (10), 169 (3), 152 (9).

HR-MS (ESI) $m / z$ calcd for $\mathrm{C}_{19} \mathrm{H}_{24} \mathrm{~N}_{3} \mathrm{O}_{4},\left[\mathrm{M}+\mathrm{H}^{+}\right]$358.1761, found 358.1752.

\section{Synthesis of Ethyl (E)-3-[1-(4-n-butyl-1H-1,2,3-triazol-1-yl)pyrenyl]acrylate (134pc)}<smiles>CCCCc1cn(-c2c(/C=C/C(=O)OCC)cc3ccc4cccc5ccc2c3c45)nn1</smiles> 
The general procedure $\mathbf{E}$ was followed using 4- $n$-butyl-1-(pyren-1-yl)-1H-1,2,3-triazole (123p) $(162.0 \mathrm{mg}, 0.50 \mathrm{mmol})$, ethyl acrylate $(17 \mathrm{c})(150.0 \mathrm{mg}, 1.50 \mathrm{mmol}), \quad\left[\mathrm{RuCl}_{2}(p-\text { cymene })\right]_{2}$ (15.1 mg, $5 \mathrm{~mol} \%$ ), $\mathrm{Cu}(\mathrm{OAc})_{2} \cdot \mathrm{H}_{2} \mathrm{O}$ (199.6 mg, $\left.2.00 \mathrm{mmol}\right)$ and $\mathrm{AgSbF}_{6}(50.1 \mathrm{mg}, 30 \mathrm{~mol} \%)$. Purification by column chromatography (n-pentane/EtOAc 6/1) yielded 134pc (59 mg, 28\%) as a yellow solid.

M.p.: $123^{\circ} \mathrm{C}$.

${ }^{1} \mathrm{H}-\mathrm{NMR}\left(600 \mathrm{MHz}, \mathrm{CDCl}_{3}\right): \delta=8.46(\mathrm{~s}, 1 \mathrm{H}), 8.26(\mathrm{~d}, J=9.0 \mathrm{~Hz}, 1 \mathrm{H}), 8.23(\mathrm{~d}, J=7.5 \mathrm{~Hz}$, $1 \mathrm{H}), 8.18(\mathrm{~d}, J=9.0 \mathrm{~Hz}, 1 \mathrm{H}), 8.11-8.05(\mathrm{~m}, 3 \mathrm{H}), 7.66(\mathrm{~s}, 1 \mathrm{H}), 7.44(\mathrm{~d}, J=16.0 \mathrm{~Hz}, 1 \mathrm{H}), 7.35$ $(\mathrm{d}, J=9.2 \mathrm{~Hz}, 1 \mathrm{H}), 6.57(\mathrm{~d}, J=16.0 \mathrm{~Hz}, 1 \mathrm{H}), 4.24(\mathrm{q}, J=7.1 \mathrm{~Hz}, 2 \mathrm{H}), 3.98(\mathrm{t}, J=7.7 \mathrm{~Hz}$, $2 \mathrm{H}), 1.93-1.78(\mathrm{~m}, 2 \mathrm{H}), 1.57-1.48(\mathrm{~m}, 2 \mathrm{H}), 1.31(\mathrm{t}, J=7.1 \mathrm{~Hz}, 3 \mathrm{H}), 1.03(\mathrm{t}, J=7.4 \mathrm{~Hz}, 3 \mathrm{H})$.

${ }^{13}$ C-NMR $\left(125 \mathrm{MHz}, \mathrm{CDCl}_{3}\right): \delta=166.2\left(\mathrm{C}_{\mathrm{q}}\right), 148.9\left(\mathrm{C}_{\mathrm{q}}\right), 138.9(\mathrm{CH}), 132.4\left(\mathrm{C}_{\mathrm{q}}\right), 131.3\left(\mathrm{C}_{\mathrm{q}}\right)$, $130.9\left(\mathrm{C}_{\mathrm{q}}\right), 130.3(\mathrm{CH}), 129.8(\mathrm{CH}), 129.6\left(\mathrm{C}_{\mathrm{q}}\right), 129.6\left(\mathrm{C}_{\mathrm{q}}\right), 128.7\left(\mathrm{C}_{\mathrm{q}}\right), 127.4(\mathrm{CH}), 127.1$ $(\mathrm{CH}), 126.8(\mathrm{CH}), 126.6(\mathrm{CH}), 125.5\left(\mathrm{C}_{\mathrm{q}}\right), 125.3(\mathrm{CH}), 123.9\left(\mathrm{C}_{\mathrm{q}}\right), 122.9(\mathrm{CH}), 122.6(\mathrm{CH})$, $121.5(\mathrm{CH}), 60.9\left(\mathrm{CH}_{2}\right), 31.8\left(\mathrm{CH}_{2}\right), 25.6\left(\mathrm{CH}_{2}\right), 22.5\left(\mathrm{CH}_{2}\right), 14.4\left(\mathrm{CH}_{3}\right), 14.1\left(\mathrm{CH}_{3}\right)$.

IR (ATR): $\tilde{v}=2929,1714,1636,1259,1177,1036,821,705 \mathrm{~cm}^{-1}$.

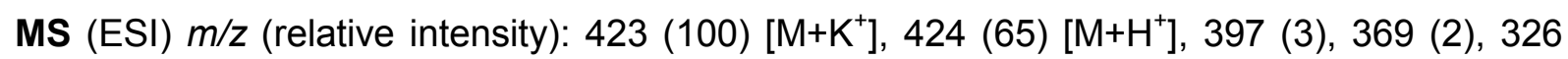
(2), 247 (6), 217 (4), 160 (3), 117 (10).

HR-MS (ESI) $m / z$ calcd for $\mathrm{C}_{27} \mathrm{H}_{26} \mathrm{~N}_{3} \mathrm{O}_{2}$, [M+H'] 424.2020, found 424.2009.

Synthesis of Ethyl (E)-3-[2-(4-n-butyl-1H-1,2,3-triazol-1-yl)-4-methylphenyl]acrylate (134cc)<smiles>CCCCc1cn(-c2cc(C)ccc2/C=C/C(=O)OCC)nn1</smiles>

The general procedure $\mathbf{E}$ was followed using 4- $n$-butyl-1-( $m$-tolyl)-1H-1,2,3-triazole (123c) $(215.0 \mathrm{mg}, 1.00 \mathrm{mmol})$, ethyl acrylate $(\mathbf{1 7 c})(150.0 \mathrm{mg}, 1.50 \mathrm{mmol}), \quad\left[\operatorname{RuCl}_{2}(p-c y m e n e)\right]_{2}$ $(30.5 \mathrm{mg}, 5 \mathrm{~mol} \%), \mathrm{Cu}(\mathrm{OAc})_{2} \cdot \mathrm{H}_{2} \mathrm{O}(239.8 \mathrm{mg}, 1.20 \mathrm{mmol})$ and $\mathrm{AgSbF}_{6}(103.0 \mathrm{mg}$, $30 \mathrm{~mol} \%$ ). Purification by column chromatography ( $n$-pentane/EtOAc $6 / 1 \rightarrow 2 / 1$ ) yielded 134cc (202 mg, 65\%) as a colorless solid.

M.r.: $71-72{ }^{\circ} \mathrm{C}$. 
${ }^{1} \mathrm{H}-\mathrm{NMR}\left(500 \mathrm{MHz}, \mathrm{CDCl}_{3}\right): \delta=7.64(\mathrm{~d}, J=8.0 \mathrm{~Hz}, 1 \mathrm{H}), 7.47(\mathrm{~s}, 1 \mathrm{H}), 7.39(\mathrm{~d}, J=16 \mathrm{~Hz}$, $1 \mathrm{H}), 7.32(\mathrm{~d}, J=8.1 \mathrm{~Hz}, 1 \mathrm{H}), 7.30(\mathrm{~s}, 1 \mathrm{H}), 6.32(\mathrm{~d}, J=16 \mathrm{~Hz}, 1 \mathrm{H}), 4.20(\mathrm{q}, J=7.1 \mathrm{~Hz}, 2 \mathrm{H})$, $2.82(\mathrm{t}, J=7.6 \mathrm{~Hz}, 2 \mathrm{H}), 2.43(\mathrm{~s}, 3 \mathrm{H}), 1.74(\mathrm{p}, J=7.5 \mathrm{~Hz}, 2 \mathrm{H}), 1.49-1.39(\mathrm{~m}, 2 \mathrm{H}), 1.28$ (t, $J=7.1 \mathrm{~Hz}, 3 \mathrm{H}), 0.96(\mathrm{t}, J=7.4 \mathrm{~Hz}, 3 \mathrm{H})$.

${ }^{13} \mathrm{C}-N M R\left(125 \mathrm{MHz}, \mathrm{CDCl}_{3}\right): \delta=166,3\left(\mathrm{C}_{\mathrm{q}}\right), 148.8\left(\mathrm{C}_{\mathrm{q}}\right), 141.7\left(\mathrm{C}_{\mathrm{q}}\right), 138.5(\mathrm{CH}), 136.5\left(\mathrm{C}_{\mathrm{q}}\right)$, $130.8(\mathrm{CH}), 127.6(\mathrm{CH}), 127.5\left(\mathrm{C}_{\mathrm{q}}\right), 127.3(\mathrm{CH}), 123.2(\mathrm{CH}), 121.2(\mathrm{CH}), 60.8\left(\mathrm{CH}_{2}\right), 31.7$ $\left(\mathrm{CH}_{2}\right), 25.4\left(\mathrm{CH}_{2}\right), 22.5\left(\mathrm{CH}_{2}\right), 21.3\left(\mathrm{CH}_{3}\right), 14.4\left(\mathrm{CH}_{3}\right), 13.9\left(\mathrm{CH}_{3}\right)$.

IR (ATR): $\tilde{v}=2929,1705,1634,1510,1365,1179,1035,822,474 \mathrm{~cm}^{-1}$.

MS (ESI) m/z (relative intensity): 352 (94) $\left[\mathrm{M}+\mathrm{K}^{+}\right], 336$ (27) $\left[\mathrm{M}+\mathrm{Na}^{+}\right], 314(100)\left[\mathrm{M}+\mathrm{H}^{+}\right], 240$ (15).

HR-MS (ESI) $m / z$ calcd for $\mathrm{C}_{18} \mathrm{H}_{24} \mathrm{~N}_{3} \mathrm{O}_{2},\left[\mathrm{M}+\mathrm{H}^{+}\right] 314.1863$, found 314.1867.

Synthesis of Ethyl

(E)-3-[2-(4-n-butyl-1H-1,2,3-triazol-1-yl)-4-

(trifluoromethyl)phenyl]acrylate (134mc)<smiles>CCCCc1cn(-c2cc(C(F)(F)F)ccc2/C=C/C(=O)OCC)nn1</smiles>

The general procedure $\mathbf{E}$ was followed using 4- $n$-butyl-1-(3-(trifluoromethyl)phenyl)-1H-1,2,3triazole $(123 \mathrm{~m})(269.0 \mathrm{mg}, 1.00 \mathrm{mmol})$, ethyl acrylate $(17 \mathrm{c})(300.0 \mathrm{mg}, 3.00 \mathrm{mmol}),\left[\mathrm{RuCl}_{2}(p-\right.$ cymene) $]_{2}(30.5 \mathrm{mg}, 5 \mathrm{~mol} \%), \mathrm{Cu}(\mathrm{OAc})_{2} \cdot \mathrm{H}_{2} \mathrm{O}(399.3 \mathrm{mg}, 2.00 \mathrm{mmol})$ and $\mathrm{AgSbF}_{6}(103.0 \mathrm{mg}$, $30 \mathrm{~mol} \%$ ). Purification by column chromatography (n-pentane/EtOAc 19/1 $\rightarrow 2 / 1$ ) yielded $134 \mathrm{mc}(227 \mathrm{mg}, 62 \%)$ as a colorless solid.

M.r.: $93-95^{\circ} \mathrm{C}$.

${ }^{1} \mathrm{H}-\mathrm{NMR}\left(400 \mathrm{MHz}, \mathrm{CDCl}_{3}\right): \delta=7.86(\mathrm{~d}, J=8.8 \mathrm{~Hz}, 1 \mathrm{H}), 7.79-7.75(\mathrm{~m}, 2 \mathrm{H}), 7.54(\mathrm{~s}, 1 \mathrm{H})$, $7.44(\mathrm{~d}, J=16.0,1 \mathrm{H}), 6.45(\mathrm{~d}, J=16.0 \mathrm{~Hz}, 1 \mathrm{H}), 4.23(\mathrm{q}, J=7.1 \mathrm{~Hz}, 2 \mathrm{H}), 2.83(\mathrm{t}, J=7.7 \mathrm{~Hz}$, $2 \mathrm{H}), 1.84-1.67(\mathrm{~m}, 2 \mathrm{H}), 1.51-1.36(\mathrm{~m}, 2 \mathrm{H}), 1.29(\mathrm{t}, J=7.1 \mathrm{~Hz}, 3 \mathrm{H}), 0.97(\mathrm{t}, J=7.4 \mathrm{~Hz}, 3 \mathrm{H})$.

${ }^{13} \mathrm{C}-N M R\left(100 \mathrm{MHz}, \mathrm{CDCl}_{3}\right): \delta=165.6\left(\mathrm{C}_{\mathrm{q}}\right), 149.4\left(\mathrm{C}_{\mathrm{q}}\right), 137.3(\mathrm{CH}), 136.7\left(\mathrm{C}_{\mathrm{q}}\right), 133.8\left(\mathrm{C}_{\mathrm{q}}\right)$, $132.8\left({ }^{2} J_{\mathrm{C}-\mathrm{F}}=34 \mathrm{~Hz}, \mathrm{C}_{\mathrm{q}}\right), 128.7(\mathrm{CH}), 126.6\left({ }^{3} \mathrm{~J}_{\mathrm{C}-\mathrm{F}}=4 \mathrm{~Hz}, \mathrm{CH}\right), 124.5(\mathrm{CH}), 123.8\left({ }^{3} \mathrm{~J}_{\mathrm{C}-\mathrm{F}}=2\right.$ $\mathrm{Hz}, \mathrm{CH}), 123.1\left({ }^{1} \mathrm{~J}_{\mathrm{C}-\mathrm{F}}=273 \mathrm{~Hz}, \mathrm{C}_{\mathrm{q}}\right), 123.0(\mathrm{CH}), 61.2\left(\mathrm{CH}_{2}\right), 31.6\left(\mathrm{CH}_{2}\right), 25.4\left(\mathrm{CH}_{2}\right), 22.4$ $\left(\mathrm{CH}_{2}\right), 14.3\left(\mathrm{CH}_{3}\right), 13.9\left(\mathrm{CH}_{3}\right)$.

${ }^{19} \mathrm{~F}-\mathrm{NMR}\left(283 \mathrm{MHz}, \mathrm{CDCl}_{3}\right): \delta=-62.9(\mathrm{~s})$.

IR (ATR): $\tilde{v}=2959,1705,1469,1323,1273,1123,1941,841 \mathrm{~cm}^{-1}$. 
MS (ESI) m/z (relative intensity): 406 (100) [M+K $\mathrm{K}^{+}$, 390 (23) $\left[\mathrm{M}+\mathrm{Na}^{+}\right], 368(36)\left[\mathrm{M}+\mathrm{H}^{+}\right]$.

HR-MS (ESI) $m / z$ calcd for $\mathrm{C}_{18} \mathrm{H}_{21} \mathrm{~F}_{3} \mathrm{~N}_{3} \mathrm{O}_{2},\left[\mathrm{M}+\mathrm{H}^{+}\right]$368.1580, found 368.1577.

Synthesis of Ethyl (E)-3-[2-(4-n-butyl-1H-1,2,3-triazol-1-yl)-4-methoxyphenyl]acrylate (134dc) and Ethyl (E)-3-[2-(4-n-butyl-1H-1,2,3-triazol-1-yl)-6-methoxyphenyl]acrylate (134dc')

The general procedure $\mathbf{E}$ was followed using 4- $n$-butyl-1-(3-methoxyphenyl)-1H-1,2,3-triazole (123d) (231.0 mg, $1.00 \mathrm{mmol})$, ethyl acrylate (17c) (150.0 mg, $1.50 \mathrm{mmol}), \quad\left[\operatorname{RuCl}_{2}(p-\right.$ cymene) $]_{2}(30.5 \mathrm{mg}, 5 \mathrm{~mol} \%), \mathrm{Cu}(\mathrm{OAc})_{2} \cdot \mathrm{H}_{2} \mathrm{O}(239.6 \mathrm{mg}, 1.20 \mathrm{mmol})$ and $\mathrm{AgSbF}_{6}(103.0 \mathrm{mg}$, $30 \mathrm{~mol} \%$ ). Purification by column chromatography ( $n$-pentane/EtOAc 9/1) yielded 134dc (122 mg, 37\%) and 134dc' (95 mg, 29\%) as colorless solids.<smiles>CCCCc1cn(-c2cc(OC)ccc2/C=C/C(=O)OCC)nn1</smiles>

M.p.: $66^{\circ} \mathrm{C}$.

${ }^{1} \mathrm{H}-\mathrm{NMR}\left(300 \mathrm{MHz}, \mathrm{CDCl}_{3}\right): \delta=7.68(\mathrm{~d}, J=8.7 \mathrm{~Hz}, 1 \mathrm{H}), 7.49(\mathrm{~s}, 1 \mathrm{H}), 7.36(\mathrm{~d}, J=15.9 \mathrm{~Hz}$, $1 \mathrm{H}), 7.05(\mathrm{dd}, J=8.8,2.6 \mathrm{~Hz}, 1 \mathrm{H}), 7.01(\mathrm{~d}, J=2.6 \mathrm{~Hz}, 1 \mathrm{H}), 6.26(\mathrm{~d}, J=15.9 \mathrm{~Hz}, 1 \mathrm{H}), 4.19$ (q, $J=7.1 \mathrm{~Hz}, 2 \mathrm{H}), 3.87(\mathrm{~s}, 3 \mathrm{H}), 2.82(\mathrm{t}, J=7.6 \mathrm{~Hz}, 2 \mathrm{H}), 1.82-1.66(\mathrm{~m}, 2 \mathrm{H}), 1.52-1.36(\mathrm{~m}$, $2 \mathrm{H}), 1.27(\mathrm{t}, J=7.1 \mathrm{~Hz}, 3 \mathrm{H}), 0.96(\mathrm{t}, J=7.3 \mathrm{~Hz}, 3 \mathrm{H})$.

${ }^{13} \mathrm{C}-\mathrm{NMR}\left(125 \mathrm{MHz}, \mathrm{CDCl}_{3}\right): \delta=166.5\left(\mathrm{C}_{\mathrm{q}}\right), 161.5\left(\mathrm{C}_{\mathrm{q}}\right), 148.9\left(\mathrm{C}_{\mathrm{q}}\right), 138.2(\mathrm{CH}), 137.8\left(\mathrm{C}_{\mathrm{q}}\right)$, $128.9(\mathrm{CH}), 123.3(\mathrm{CH}), 122.5\left(\mathrm{C}_{\mathrm{q}}\right), 119.8(\mathrm{CH}), 116.6(\mathrm{CH}), 111.6(\mathrm{CH}), 60.7\left(\mathrm{CH}_{2}\right), 55.9$ $\left(\mathrm{CH}_{3}\right), 31.7\left(\mathrm{CH}_{2}\right), 25.4\left(\mathrm{CH}_{2}\right), 22.5\left(\mathrm{CH}_{2}\right), 14.4\left(\mathrm{CH}_{3}\right), 13.9\left(\mathrm{CH}_{3}\right)$.

IR (ATR): $\tilde{v}=2962,1706,1635,1279,1259,1164,1023,816 \mathrm{~cm}^{-1}$.

MS (ESI) m/z (relative intensity): 368 (100) $\left[\mathrm{M}+\mathrm{K}^{+}\right], 352(37)\left[\mathrm{M}+\mathrm{Na}^{+}\right], 330(64)\left[\mathrm{M}+\mathrm{H}^{+}\right], 256$ (12), 173 (6).

HR-MS (ESI) $m / z$ calcd for $\mathrm{C}_{18} \mathrm{H}_{23} \mathrm{~N}_{3} \mathrm{O}_{3}$, $\left[\mathrm{M}+\mathrm{H}^{+}\right]$330.1812, found 330.1813 .<smiles>CCCCc1cn(-c2cccc(OC)c2/C=C/C(=O)OCC)nn1</smiles> 
M.r.: $94-95^{\circ} \mathrm{C}$.

${ }^{1} \mathrm{H}-\mathrm{NMR}\left(300 \mathrm{MHz}, \mathrm{CDCl}_{3}\right): \delta=7.44-7.37(\mathrm{~m}, 2 \mathrm{H}), 7.28(\mathrm{~d}, J=16.2 \mathrm{~Hz}, 1 \mathrm{H}), 7.08-7.01(\mathrm{~m}$, 2H), $6.32(\mathrm{~d}, J=16.2 \mathrm{~Hz}, 1 \mathrm{H}), 4.14(\mathrm{q}, J=7.1 \mathrm{~Hz}, 2 \mathrm{H}), 3.93(\mathrm{~s}, 3 \mathrm{H}), 2.78(\mathrm{t}, J=7.5 \mathrm{~Hz}, 2 \mathrm{H})$, 1.77-1.61 (m, 2H), 1.47-1.32 (m, 2H), $1.23(\mathrm{t}, J=7.1 \mathrm{~Hz}, 3 \mathrm{H}), 0.93(\mathrm{t}, J=7.3 \mathrm{~Hz}, 3 \mathrm{H})$.

${ }^{13} \mathrm{C}-\mathrm{NMR}\left(125 \mathrm{MHz}, \mathrm{CDCl}_{3}\right): \delta=167.0\left(\mathrm{C}_{\mathrm{q}}\right), 159.4\left(\mathrm{C}_{\mathrm{q}}\right), 148.7\left(\mathrm{C}_{\mathrm{q}}\right), 137.9\left(\mathrm{C}_{\mathrm{q}}\right), 134.6(\mathrm{CH})$, $130.6(\mathrm{CH}), 124.5(\mathrm{CH}), 123.3(\mathrm{CH}), 119.8\left(\mathrm{C}_{\mathrm{q}}\right), 119.3(\mathrm{CH}), 112.4(\mathrm{CH}), 60.6\left(\mathrm{CH}_{2}\right), 56.2$ $\left(\mathrm{CH}_{3}\right), 31.7\left(\mathrm{CH}_{2}\right), 25.4\left(\mathrm{CH}_{2}\right), 22.4\left(\mathrm{CH}_{2}\right), 14.3\left(\mathrm{CH}_{3}\right), 13.9\left(\mathrm{CH}_{3}\right)$.

IR (ATR): $\tilde{v}=2959,1704,1481,1274,1188,1174,797,756 \mathrm{~cm}^{-1}$.

MS (El) m/z (relative intensity): 329 (2) $\left[\mathrm{M}^{+}\right], 256$ (58), 228 (100), 213 (22), 198 (20), 186 (41), 173 (34), 43 (21).

HR-MS (EI) $m / z$ calcd for $\mathrm{C}_{18} \mathrm{H}_{24} \mathrm{~N}_{3} \mathrm{O}_{3},\left[\mathrm{M}^{+}\right] 329.1739$, found 329.1741 .

Synthesis of Ethyl (E)-3-[2-(4-n-butyl-1H-1,2,3-triazol-1-yl)-4-fluorophenyl]acrylate (134ec) and Ethyl (E)-3-[2-(4-n-butyl-1H-1,2,3-triazol-1-yl)-6-fluorophenyl]acrylate $\left(134 e^{\prime}\right)$

The general procedure $\mathbf{E}$ was followed using 4- $n$-butyl-1-(3-fluorophenyl)-1H-1,2,3-triazole (123e) $(219.0 \mathrm{mg}, 1.00 \mathrm{mmol})$, ethyl acrylate (17c) $(300.0 \mathrm{mg}, 3.00 \mathrm{mmol}), \quad\left[\mathrm{RuCl}_{2}(p-\right.$ cymene) $]_{2}(30.5 \mathrm{mg}, 5 \mathrm{~mol} \%), \mathrm{Cu}(\mathrm{OAc})_{2} \cdot \mathrm{H}_{2} \mathrm{O}(399.8 \mathrm{mg}, 2.00 \mathrm{mmol})$ and $\mathrm{AgSbF}_{6}(103.0 \mathrm{mg}$, $30 \mathrm{~mol} \%$ ). Purification by column chromatography ( $n$-pentane/EtOAc 6/1) yielded 134ec (48 mg, 15\%) and 134ec' (133 mg, 42\%) as colorless solids.

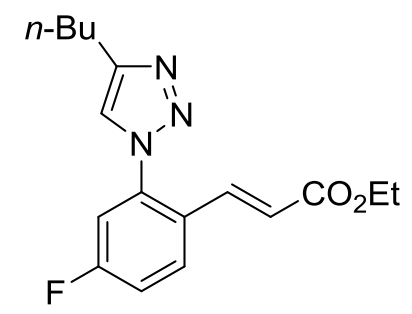

M.p.: $66^{\circ} \mathrm{C}$.

${ }^{1} \mathrm{H}-\mathrm{NMR}\left(300 \mathrm{MHz}, \mathrm{CDCl}_{3}\right): \delta=7.81-7.69(\mathrm{~m}, 1 \mathrm{H}), 7.50(\mathrm{~s}, 1 \mathrm{H}), 7.39(\mathrm{~d}, J=15.9 \mathrm{~Hz}, 1 \mathrm{H})$, 7.30-7.20 (m, 2H), 6.33 (d, J = $15.9 \mathrm{~Hz}, 1 \mathrm{H}), 4.22(\mathrm{q}, J=7.1 \mathrm{~Hz}, 2 \mathrm{H}), 2.82(\mathrm{t}, J=7.4 \mathrm{~Hz}$, $2 \mathrm{H}), 1.85-1.64(\mathrm{~m}, 2 \mathrm{H}), 1.51-1.36(\mathrm{~m}, 2 \mathrm{H}), 1.29(\mathrm{t}, J=7.1 \mathrm{~Hz}, 3 \mathrm{H}), 0.97(\mathrm{t}, J=7.3 \mathrm{~Hz}, 3 \mathrm{H})$.

${ }^{13}$ C-NMR $\left(125 \mathrm{MHz}, \mathrm{CDCl}_{3}\right): \delta=165.9\left(\mathrm{C}_{\mathrm{q}}\right), 163.4\left({ }^{1} \mathrm{~J}_{\mathrm{C}-\mathrm{F}}=254 \mathrm{~Hz}, \mathrm{C}_{\mathrm{q}}\right), 149.2\left(\mathrm{C}_{\mathrm{q}}\right), 137.7$ $(\mathrm{CH}), 137.6\left(\mathrm{C}_{\mathrm{q}}\right), 129.7\left({ }^{3} J_{\mathrm{C}-\mathrm{F}}=9 \mathrm{~Hz}, \mathrm{CH}\right), 126.5\left({ }^{3} J_{\mathrm{C}-\mathrm{F}}=4 \mathrm{~Hz}, \mathrm{C}_{\mathrm{q}}\right), 123.0(\mathrm{CH}), 122.1$ $\left({ }^{5} J_{\mathrm{C}-\mathrm{F}}=2 \mathrm{~Hz}, \mathrm{CH}\right), 117.4\left({ }^{2} J_{\mathrm{C}-\mathrm{F}}=22 \mathrm{~Hz}, \mathrm{CH}\right), 114.1\left({ }^{2} J_{\mathrm{C}-\mathrm{F}}=25 \mathrm{~Hz}, \mathrm{CH}\right), 60.9\left(\mathrm{CH}_{2}\right), 31.6$ $\left(\mathrm{CH}_{2}\right), 25.4\left(\mathrm{CH}_{2}\right), 22.4\left(\mathrm{CH}_{2}\right), 14.4\left(\mathrm{CH}_{3}\right), 13.9\left(\mathrm{CH}_{3}\right)$.

${ }^{19}$ F-NMR $\left(283 \mathrm{MHz}, \mathrm{CDCl}_{3}\right): \delta=-107.8(\mathrm{td}, J=8.1,5.7 \mathrm{~Hz})$. 
IR (ATR): $\tilde{v}=2932,1716,1183,1163,1043,975,509 \mathrm{~cm}^{-1}$.

MS (ESI) $m / z$ (relative intensity): $356(100)\left[\mathrm{M}+\mathrm{K}^{+}\right], 340$ (43) $\left[\mathrm{M}+\mathrm{Na}^{+}\right], 318(66)\left[\mathrm{M}^{+} \mathrm{H}^{+}\right], 244$ (9), 173 (5).

HR-MS (ESI) $m / z$ calcd for $\mathrm{C}_{17} \mathrm{H}_{21} \mathrm{FN}_{3} \mathrm{O}_{2}$, $\left[\mathrm{M}+\mathrm{H}^{+}\right]$318.1612, found 318.1616.

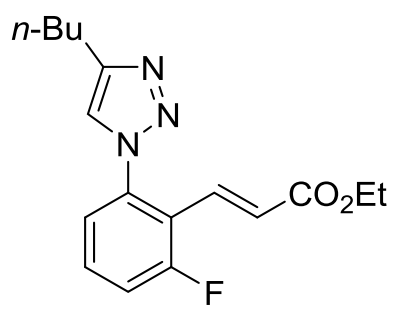

M.r.: $73-74^{\circ} \mathrm{C}$.

${ }^{1} \mathrm{H}-\mathrm{NMR}\left(300 \mathrm{MHz}, \mathrm{CDCl}_{3}\right): \delta=7.52-7.38(\mathrm{~m}, 2 \mathrm{H}), 7.35-7.24(\mathrm{~m}, 2 \mathrm{H}), 7.20(\mathrm{~d}, J=16.3 \mathrm{~Hz}$, $1 \mathrm{H}), 6.42(\mathrm{~d}, J=16.4,1 \mathrm{H}), 4.19(\mathrm{q}, J=7.1 \mathrm{~Hz}, 2 \mathrm{H}), 2.81(\mathrm{t}, J=7.6 \mathrm{~Hz}, 2 \mathrm{H}), 1.79-1.59(\mathrm{~m}$, $2 \mathrm{H}), 1.52-1.36(\mathrm{~m}, 2 \mathrm{H}), 1.27(\mathrm{t}, J=7.1 \mathrm{~Hz}, 3 \mathrm{H}), 0.95(\mathrm{t}, J=7.3 \mathrm{~Hz}, 3 \mathrm{H})$.

${ }^{13} \mathrm{C}-N M R\left(125 \mathrm{MHz}, \mathrm{CDCl}_{3}\right): \delta=166.2\left(\mathrm{C}_{\mathrm{q}}\right), 161.5\left({ }^{1} \mathrm{~J}_{\mathrm{C}-\mathrm{F}}=256 \mathrm{~Hz}, \mathrm{C}_{\mathrm{q}}\right), 149.0\left(\mathrm{C}_{\mathrm{q}}\right), 137.7$ $\left({ }^{3} J_{\mathrm{C}-\mathrm{F}}=5 \mathrm{~Hz}, \mathrm{C}_{\mathrm{q}}\right), 132.3(\mathrm{CH}), 130.9\left({ }^{5} \mathrm{~J}_{\mathrm{C}-\mathrm{F}}=10 \mathrm{~Hz}, \mathrm{CH}\right), 126.3\left({ }^{3} \mathrm{~J}_{\mathrm{C}-\mathrm{F}}=13 \mathrm{~Hz}, \mathrm{CH}\right), 123.1$ $(\mathrm{CH}), 122.8\left({ }^{4} J_{\mathrm{CF}}=3 \mathrm{~Hz}, \mathrm{CH}\right), 119.5\left({ }^{2} J_{\mathrm{C}-\mathrm{F}}=14 \mathrm{~Hz}, \mathrm{C}_{\mathrm{q}}\right), 117.6\left({ }^{2} J_{\mathrm{C}-\mathrm{F}}=23 \mathrm{~Hz}, \mathrm{CH}\right), 60.9$ $\left(\mathrm{CH}_{2}\right), 31.6\left(\mathrm{CH}_{2}\right), 25.3\left(\mathrm{CH}_{2}\right), 22.4\left(\mathrm{CH}_{2}\right), 14.3\left(\mathrm{CH}_{3}\right), 13.9\left(\mathrm{CH}_{3}\right)$.

${ }^{19} \mathrm{~F}-\mathrm{NMR}\left(283 \mathrm{MHz}, \mathrm{CDCl}_{3}\right): \delta=-109.0(\mathrm{dd}, J=10.6,5.6 \mathrm{~Hz})$.

IR (ATR): $\tilde{v}=2961,1712,1315,1182,982,800,751,386 \mathrm{~cm}^{-1}$.

MS (ESI) m/z (relative intensity): 356 (100) $\left[\mathrm{M}+\mathrm{K}^{+}\right], 318$ (40) $\left[\mathrm{M}+\mathrm{H}^{+}\right], 290$ (2), 232 (7), 217 (16), 190 (2), 169 (5), 152 (17), 102 (10).

HR-MS (ESI) $\mathrm{m} / \mathrm{z}$ calcd for $\mathrm{C}_{17} \mathrm{H}_{21} \mathrm{FN}_{3} \mathrm{O}_{2},\left[\mathrm{M}+\mathrm{H}^{+}\right]$318.1612, found 318.1602.

Synthesis of Ethyl (E)-3-[4-acetyl-2-(4-butyl-1H-1,2,3-triazol-1-yl)phenyl]acrylate (134nc) and 1,1'-[2',6-Bis(4-butyl-1H-1,2,3-triazol-1-yl)-(1,1'-biphenyl)-3,4'diyl)bis(ethan-1-one) (143)<smiles>CCOC(=O)/C=C/c1ccc(C(C)=O)cc1-n1cc(CC(C)C)nn1</smiles>

The general procedure $\mathbf{A}$ was followed using 1-[3-(4- $n$-butyl-1H-1,2,3-triazole-1yl)phenyl]ethan-1-one (123e) (242.0 mg, $1.00 \mathrm{mmol})$, ethyl acrylate (17c) (150.0 mg, 1.50 
mmol), $\left[\mathrm{RuCl}_{2}(p \text {-cymene })\right]_{2}(30.5 \mathrm{mg}, 5 \mathrm{~mol} \%), \mathrm{Cu}(\mathrm{OAc})_{2} \cdot \mathrm{H}_{2} \mathrm{O}(239.6 \mathrm{mg}, 1.20 \mathrm{mmol})$ and $\mathrm{AgSbF}_{6}(103.0 \mathrm{mg}, 30 \mathrm{~mol} \%)$. Purification by column chromatography ( $n$-pentane/EtOAc $3 / 1)$ yielded $134 \mathrm{ec}(58 \mathrm{mg}, 17 \%)$ and $143(53 \mathrm{mg}, 11 \%)$ as colorless solids.

M.p.: $35^{\circ} \mathrm{C}$

${ }^{1} \mathrm{H}-\mathrm{NMR}\left(500 \mathrm{MHz}, \mathrm{CDCl}_{3}\right): \delta=8.07$ (ddd, $\left.J=8.2,1.8,0.6 \mathrm{~Hz}, 1 \mathrm{H}\right), 8.01(\mathrm{~s}, 1 \mathrm{H}), 7.83(\mathrm{~d}, J=$ $8.3 \mathrm{~Hz}, 1 \mathrm{H}), 7.54(\mathrm{~s}, 1 \mathrm{H}), 7.43(\mathrm{dd}, J=16.0,0.6 \mathrm{~Hz}, 1 \mathrm{H}), 6.44(\mathrm{~d}, J=16.0 \mathrm{~Hz}, 1 \mathrm{H}), 4.21$ (q, J $=7.1 \mathrm{~Hz}, 2 \mathrm{H}$ ), $2.82(\mathrm{ddd}, J=8.7,7.0,0.7 \mathrm{~Hz}, 2 \mathrm{H}), 2.63(\mathrm{~s}, 3 \mathrm{H}), 1.80-1.65(\mathrm{~m}, 2 \mathrm{H}), 1.43$ (dq, $J=14.7,7.4 \mathrm{~Hz}, 2 \mathrm{H}) 1.27(\mathrm{t}, J=7.2 \mathrm{~Hz}, 3 \mathrm{H}), 0.96(\mathrm{t}, J=7.4 \mathrm{~Hz}, 3 \mathrm{H})$.

${ }^{13} \mathrm{C}-\mathrm{NMR}\left(125 \mathrm{MHz}, \mathrm{CDCl}_{3}\right): \delta=196.0\left(\mathrm{C}_{\mathrm{q}}\right), 165.7\left(\mathrm{C}_{\mathrm{q}}\right), 149.2\left(\mathrm{C}_{\mathrm{q}}\right), 138.7\left(\mathrm{C}_{\mathrm{q}}\right), 137.5(\mathrm{CH})$, $136.7\left(\mathrm{C}_{\mathrm{q}}\right), 134.5\left(\mathrm{C}_{\mathrm{q}}\right), 129.3(\mathrm{CH}), 128.3(\mathrm{CH}), 126.4(\mathrm{CH}), 124.3(\mathrm{CH}), 123.0(\mathrm{CH}), 61.1$ $\left(\mathrm{CH}_{2}\right), 31.6\left(\mathrm{CH}_{2}\right), 26.8\left(\mathrm{CH}_{3}\right), 22.4\left(\mathrm{CH}_{2}\right), 14.3\left(\mathrm{CH}_{3}\right), 13.9\left(\mathrm{CH}_{3}\right)$.

IR (ATR): $\tilde{v}=3139,2957,2928,2857,1682,1604,1556,1490,1398,1287,1264,1242$, $1219,819,796,681,661,586,480 \mathrm{~cm}^{-1}$.

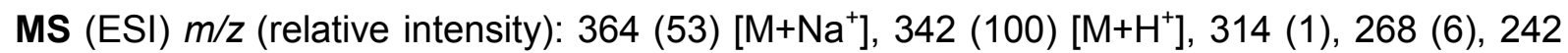
(2).

HR-MS (ESI) $m / z$ calcd for $\mathrm{C}_{19} \mathrm{H}_{24} \mathrm{~N}_{3} \mathrm{O}_{3},\left[\mathrm{M}+\mathrm{H}^{+}\right] 342.1812$, found 342.1818 .

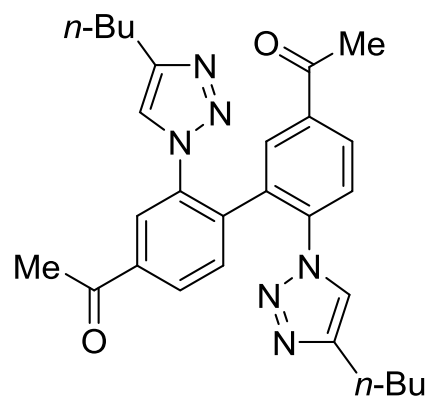

M.r.: $58-60^{\circ} \mathrm{C}$

${ }^{1} \mathrm{H}-\mathrm{NMR}\left(500 \mathrm{MHz}, \mathrm{CDCl}_{3}\right): \delta=8.04(\mathrm{~d}, J=1.7 \mathrm{~Hz}, 2 \mathrm{H}), 7.93(\mathrm{dd}, J=8.1,1.8 \mathrm{~Hz}, 2 \mathrm{H}), 7.46$ $(\mathrm{d}, J=0.8 \mathrm{~Hz}, 2 \mathrm{H}), 7.26(\mathrm{~d}, J=0.9 \mathrm{~Hz}, 2 \mathrm{H}), 2.79-2.52(\mathrm{~m}, 10 \mathrm{H}), 1.57(\mathrm{dt}, J=15.2,7.9 \mathrm{~Hz}$, $4 \mathrm{H}), 1.39-1.12(\mathrm{~m}, 4 \mathrm{H}), 0.99-0.77(\mathrm{~m}, 6 \mathrm{H})$.

${ }^{13} \mathrm{C}-N M R\left(125 \mathrm{MHz}, \mathrm{CDCl}_{3}\right): \delta=196.0\left(\mathrm{C}_{\mathrm{q}}\right), 148.8\left(\mathrm{C}_{\mathrm{q}}\right), 138.1\left(\mathrm{C}_{\mathrm{q}}\right), 137.5\left(\mathrm{C}_{\mathrm{q}}\right), 136.2\left(\mathrm{C}_{\mathrm{q}}\right)$, $131.1(\mathrm{CH}), 129.0(\mathrm{CH}), 125.6(\mathrm{CH}), 122.3(\mathrm{CH}), 31.5\left(\mathrm{CH}_{2}\right), 26.8\left(\mathrm{CH}_{3}\right), 25.2\left(\mathrm{CH}_{2}\right), 22.2$ $\left(\mathrm{CH}_{2}\right), 13.9\left(\mathrm{CH}_{3}\right)$.

IR (ATR): $\tilde{v}=3134,3066,2956,2930,2861,1686,1607,1557,1436,1358,1249,1179$, $1038,962,906,830,657,595 \mathrm{~cm}^{-1}$.

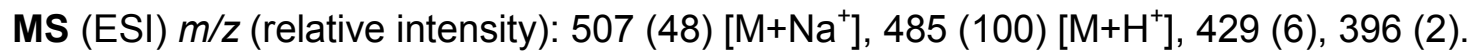

HR-MS (ESI) $m / z$ calcd for $\mathrm{C}_{28} \mathrm{H}_{32} \mathrm{~N}_{6} \mathrm{O}_{2},\left[\mathrm{M}+\mathrm{H}^{+}\right]$485.2659, found 485.2660. 
Synthesis of Ethyl (E)-3-[3-(4-n-butyl-1H-1,2,3-triazol-1-yl)-1-methyl-1H-indol-2yl]acrylate (1340c)

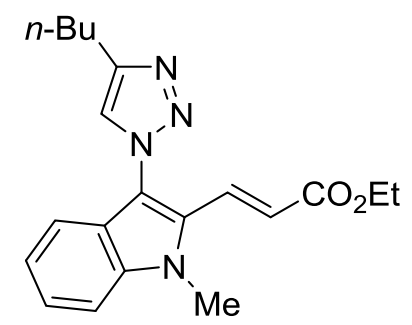

The general procedure $\mathbf{E}$ was followed using methyl 3-(4-n-butyl-1H-1,2,3-triazol-1-yl)-1methyl-1H-indole (123o) (127.0 mg, $0.50 \mathrm{mmol})$, ethyl acrylate (17c) $(150.0 \mathrm{mg}, 1.50 \mathrm{mmol})$, $\left[\mathrm{RuCl}_{2}(p \text {-cymene })\right]_{2}(15.3 \mathrm{mg}, 5 \mathrm{~mol} \%), \mathrm{Cu}(\mathrm{OAc})_{2} \cdot \mathrm{H}_{2} \mathrm{O}(199.6 \mathrm{mg}, 1.00 \mathrm{mmol})$ and $\mathrm{AgSbF}_{6}$ (51.0 mg, $30 \mathrm{~mol} \%$ ). Purification by column chromatography ( $n$-pentane/EtOAc $6 / 1$ ) yielded 1340c (176 mg, 50\%) as a yellow solid.

M.p.: $70^{\circ} \mathrm{C}$.

${ }^{1} \mathrm{H}-\mathrm{NMR}\left(500 \mathrm{MHz}, \mathrm{CDCl}_{3}\right): \delta=7.69(\mathrm{~d}, J=16.3 \mathrm{~Hz}, 1 \mathrm{H}), 7.53(\mathrm{~s}, 1 \mathrm{H}), 7.44-7.33(\mathrm{~m}, 3 \mathrm{H})$, 7.18 (ddd, $J=8.0,6.8,1.0 \mathrm{~Hz}, 1 \mathrm{H}$ ), $5.92(\mathrm{~d}, J=16.3 \mathrm{~Hz}, 1 \mathrm{H}), 4.20(\mathrm{q}, J=7.1 \mathrm{~Hz}, 2 \mathrm{H}$ ), 3.91 (s, 3H), $2.86(\mathrm{t}, J=8.1 \mathrm{~Hz}, 2 \mathrm{H}), 1.83-1.68(\mathrm{~m}, 2 \mathrm{H}), 1.53-1.36(\mathrm{~m}, 2 \mathrm{H}), 1.28(\mathrm{t}, J=7.1 \mathrm{~Hz}$, $3 \mathrm{H}), 0.97$ (t, $J=7.4 \mathrm{~Hz}, 3 \mathrm{H})$.

${ }^{13} \mathrm{C}-\mathrm{NMR}\left(125 \mathrm{MHz}, \mathrm{CDCl}_{3}\right): \delta=166.5\left(\mathrm{C}_{\mathrm{q}}\right), 148.7\left(\mathrm{C}_{\mathrm{q}}\right), 136.8\left(\mathrm{C}_{\mathrm{q}}\right), 129.4(\mathrm{CH}), 129.1\left(\mathrm{C}_{\mathrm{q}}\right)$, $125.2(\mathrm{CH}), 123.6\left(\mathrm{C}_{\mathrm{q}}\right), 123.4(\mathrm{CH}), 122.0(\mathrm{CH}), 121.9(\mathrm{CH}), 118.4(\mathrm{CH}), 115.9\left(\mathrm{C}_{\mathrm{q}}\right), 110.1$ $(\mathrm{CH}), 60.9\left(\mathrm{CH}_{2}\right), 31.6\left(\mathrm{CH}_{2}\right), 31.2\left(\mathrm{CH}_{3}\right), 25.5\left(\mathrm{CH}_{2}\right), 22.4\left(\mathrm{CH}_{2}\right), 14.3\left(\mathrm{CH}_{3}\right), 13.9\left(\mathrm{CH}_{3}\right)$.

IR (ATR): $\tilde{v}=2933,1708,1624,1278,1185,1034,844,738 \mathrm{~cm}^{-1}$.

MS (EI) m/z (relative intensity): 352 (4) [ $\left.\mathrm{M}^{+}\right], 324$ (8), 251 (100), 221 (15), 208 (24), 195 (45), 181 (16), 43 (24).

HR-MS (El) $m / z$ calcd for $\mathrm{C}_{20} \mathrm{H}_{24} \mathrm{~N}_{4} \mathrm{O}_{2},\left[\mathrm{M}^{+}\right]$352.1899, found 352.1897.

Synthesis of Ethyl (E)-1-[2-(3-ethoxy-3-oxoprop-1-en-1-yl)-6-methylphenyl]-1H-1,2,3triazole-4-carboxylate (134qc)<smiles>CCOC(=O)/C=C/c1cccc(C)c1-n1cc(C(=O)OCC)nn1</smiles> 
The general procedure $\mathbf{E}$ was followed using ethyl 1-(o-tolyl)-1H-1,2,3-triazole-4-carboxylate (123q) (115.0 mg, $0.50 \mathrm{mmol})$, ethyl acrylate (17c) (75.0 mg, $1.50 \mathrm{mmol}),\left[\mathrm{RuCl}_{2}(p \text {-cymene })\right]_{2}$ (15.3 mg, $5 \mathrm{~mol} \%$ ), $\mathrm{Cu}(\mathrm{OAc})_{2} \cdot \mathrm{H}_{2} \mathrm{O}$ (119.0 mg, $\left.1.20 \mathrm{mmol}\right)$ and $\mathrm{AgSbF}_{6}(50.0 \mathrm{mg}, 30 \mathrm{~mol} \%)$. Purification by column chromatography ( $n$-pentane/EtOAc 3/1) yielded 134qc (62 mg, 38\%) as a colorless oil.

${ }^{1} \mathrm{H}-\mathrm{NMR}\left(300 \mathrm{MHz}, \mathrm{CDCl}_{3}\right): \delta=8.19(\mathrm{~s}, 1 \mathrm{H}), 7.63-7.58(\mathrm{~m}, 1 \mathrm{H}), 7.49(\mathrm{dd}, J=7.7,7.7 \mathrm{~Hz}$, 1H), 7.40 (ddd, $J=7.7,1.6,0.8 \mathrm{~Hz}, 1 \mathrm{H}), 6.98(\mathrm{~d}, J=15.9 \mathrm{~Hz}, 1 \mathrm{H}), 6.33(\mathrm{~d}, J=15.9 \mathrm{~Hz}, 1 \mathrm{H})$, 4.49 (q, $J=7.1 \mathrm{~Hz}, 2 \mathrm{H}$ ), $4.18(\mathrm{q}, J=7.1 \mathrm{~Hz}, 2 \mathrm{H}), 2.04(\mathrm{~s}, 3 \mathrm{H}), 1.46(\mathrm{t}, J=7.1 \mathrm{~Hz}, 3 \mathrm{H}), 1.26$ $(\mathrm{t}, J=7.1 \mathrm{~Hz}, 3 \mathrm{H})$.

${ }^{13} \mathrm{C}-N M R\left(125 \mathrm{MHz}, \mathrm{CDCl}_{3}\right): \delta=165.9\left(\mathrm{C}_{\mathrm{q}}\right), 160.7\left(\mathrm{C}_{\mathrm{q}}\right), 140.7\left(\mathrm{C}_{\mathrm{q}}\right), 137.5(\mathrm{CH}), 136.5\left(\mathrm{C}_{\mathrm{q}}\right)$, $134.7\left(\mathrm{C}_{\mathrm{q}}\right), 132.6(\mathrm{CH}), 132.6\left(\mathrm{C}_{\mathrm{q}}\right), 131.1(\mathrm{CH}), 130.1(\mathrm{CH}), 125.2(\mathrm{CH}), 123.1(\mathrm{CH}), 61.8$ $\left(\mathrm{CH}_{2}\right), 60.9\left(\mathrm{CH}_{2}\right), 17.5\left(\mathrm{CH}_{3}\right), 14.5\left(\mathrm{CH}_{3}\right), 14.3\left(\mathrm{CH}_{3}\right)$.

IR (ATR): $\tilde{v}=3133,2982,1719,1541,1503,1335,1227,1202,1145,116,1034,987,834$, $764,715,456 \mathrm{~cm}^{-1}$.

MS (ESI) $m / z$ (relative intensity): $352(10)\left[\mathrm{M}+\mathrm{Na}^{+}\right], 330(100)\left[\mathrm{M}+\mathrm{H}^{+}\right]$.

HR-MS (ESI) $m / z$ calcd for $\mathrm{C}_{17} \mathrm{H}_{20} \mathrm{~N}_{3} \mathrm{O}_{4},\left[\mathrm{M}+\mathrm{H}^{+}\right] 330.1448$, found 330.1455 .

\section{Synthesis of Ethyl $(E)-3-[2-(1 H$-benzo[d][1,2,3]triazol-1-yl)phenyl]acrylate (134sc):}

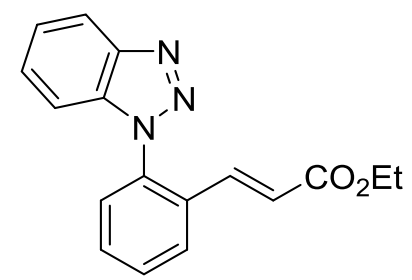

The general procedure $\mathbf{E}$ was followed using 1-phenyl-1H-benzo[d][1,2,3]triazole (123s) $(91.0 \mathrm{mg}, \quad 0.50 \mathrm{mmol})$, ethyl acrylate $(17 \mathrm{c}) \quad(75.0 \mathrm{mg}, \quad 1.50 \mathrm{mmol}), \quad\left[\mathrm{RuCl}_{2}(p \text {-cymene })\right]_{2}$ (15.3 mg, $5 \mathrm{~mol} \%$ ), $\mathrm{Cu}(\mathrm{OAc})_{2} \cdot \mathrm{H}_{2} \mathrm{O}(119.0 \mathrm{mg}, 1.20 \mathrm{mmol})$ and $\mathrm{AgSbF}_{6}(50.0 \mathrm{mg}, 30 \mathrm{~mol} \%)$. Purification by column chromatography ( $n$-pentane/EtOAc 6/1) yielded 134sc (30 mg, 20\%) as a colorless solid.

M.r.: $81-82^{\circ} \mathrm{C}$.

${ }^{1} \mathrm{H}-\mathrm{NMR}\left(300 \mathrm{MHz}, \mathrm{CDCl}_{3}\right): \delta=8.16(\mathrm{dd}, J=8.1,1.0 \mathrm{~Hz}, 1 \mathrm{H}), 7.93-7.80(\mathrm{~m}, 1 \mathrm{H}), 7.65-7.55$ $(\mathrm{m}, 2 \mathrm{H}), 7.55-7.37(\mathrm{~m}, 3 \mathrm{H}), 7.36-7.25(\mathrm{~m}, 1 \mathrm{H}), 7.24(\mathrm{~s}, 1 \mathrm{H}), 6.41(\mathrm{~d}, J=16.0 \mathrm{~Hz}, 1 \mathrm{H}), 4.11$ (q, $J=7.1 \mathrm{~Hz}, 2 \mathrm{H}), 1.18(\mathrm{t}, J=7.1 \mathrm{~Hz}, 3 \mathrm{H})$. 
${ }^{13} \mathrm{C}-\mathrm{NMR}\left(125 \mathrm{MHz}, \mathrm{CDCl}_{3}\right): \delta=166.1\left(\mathrm{C}_{\mathrm{q}}\right), 146.0\left(\mathrm{C}_{\mathrm{q}}\right), 138.5(\mathrm{CH}), 135.5\left(\mathrm{C}_{\mathrm{q}}\right), 134.4\left(\mathrm{C}_{\mathrm{q}}\right)$, $131.6\left(\mathrm{C}_{\mathrm{q}}\right), 131.1(\mathrm{CH}), 130.3(\mathrm{CH}), 128.6(\mathrm{CH}), 128.0(\mathrm{CH}), 127.6(\mathrm{CH}), 124.6(\mathrm{CH}), 122.1$ $(\mathrm{CH}), 120.5(\mathrm{CH}), 110.2(\mathrm{CH}), 60.8\left(\mathrm{CH}_{2}\right), 14.3\left(\mathrm{CH}_{3}\right)$.

IR (ATR): $\tilde{v}=3074,2982,1708,1639,1490,1367,1321,1299,12721179$ 976, 915, 873, $836,750,666,590,574,484,460,435,420 \mathrm{~cm}^{-1}$.

MS (ESI) m/z (relative intensity): $332(33)\left[\mathrm{M}+\mathrm{K}^{+}\right], 316(100)\left[\mathrm{M}+\mathrm{Na}^{+}\right], 294(92)\left[\mathrm{M}+\mathrm{H}^{+}\right], 220$ (19), 166 (6).

HR-MS (ESI) $m / z$ calcd for $\mathrm{C}_{17} \mathrm{H}_{16} \mathrm{~N}_{3} \mathrm{O}_{2}$, [M+H'] 294.1237, found 294.1239.

\subsubsection{Intermolecular Competition Experiment for the Ruthenium-Catalyzed Synthesis of Alkenylated $\mathrm{N}$-Aryl-1,2,3-triazoles}

\section{Competition Experiment between $\mathrm{N}$-Aryl-1,2,3-triazoles $123 \mathrm{c}$ and $123 \mathrm{~m}$}

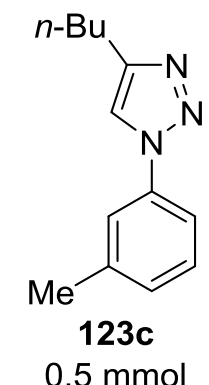

(c)

$0.5 \mathrm{mmol}$

$$
\begin{aligned}
& \text { 17c (1.5 equiv) } \\
& {\left[\mathrm{RuCl}_{2}(p \text {-cymene })\right]_{2}(5.0 \mathrm{~mol} \%)} \\
& \mathrm{AgSbF}_{6}(30 \mathrm{~mol} \%) \\
& \mathrm{Cu}(\mathrm{OAc})_{2} \mathrm{H}_{2} \mathrm{O} \text { (2.0 equiv) }
\end{aligned}
$$

$$
\mathrm{PhMe}
$$
$100^{\circ} \mathrm{C}, 18 \mathrm{~h}$ under air<smiles>CCOC(=CC=Cc1ccc(C)cc1-n1cc(CC(C)C)nn1)OCC</smiles>

134cc: $35 \%$<smiles>CCCCc1cn(-c2cc(C(F)(F)F)ccc2/C=C/C(=O)OCC)nn1</smiles>

134mc: $16 \%$

A mixture of 4- $n$-butyl-1-( $m$-tolyl)-1H-1,2,3-triazole (123c) $(107.0 \mathrm{mg}, 0.50 \mathrm{mmol}), 4-n$-butyl-1[3-(trifluoromethyl)phenyl]-1H-1,2,3-triazole (123m) (134.5 mg, $0.50 \mathrm{mmol})$, ethyl acrylate (17c) $\quad(300.0 \mathrm{mg}, \quad 3.00 \mathrm{mmol}), \quad\left[\mathrm{RuCl}_{2}(p \text {-cymene })\right]_{2} \quad(30.5 \mathrm{mg}, \quad 5 \mathrm{~mol} \%), \quad \mathrm{Cu}(\mathrm{OAc})_{2} \cdot \mathrm{H}_{2} \mathrm{O}$ (399.3 mg, $2.00 \mathrm{mmol})$ and $\mathrm{AgSbF}_{6}(103.0 \mathrm{mg}, 30 \mathrm{~mol} \%)$ in PhMe $(4.0 \mathrm{~mL})$ was stirred at $100{ }^{\circ} \mathrm{C}$ for $18 \mathrm{~h}$ under air. At ambient temperature, the reaction mixture was diluted with sat. aq. $\mathrm{NH}_{4} \mathrm{Cl} / \mathrm{NH}_{3}(1: 1,10 \mathrm{~mL})$ and extracted with $\mathrm{CH}_{2} \mathrm{Cl}_{2}(3 \times 25 \mathrm{~mL})$. The combined organic layers were dried over $\mathrm{Na}_{2} \mathrm{SO}_{4}$. After filtration and evaporation of the solvent in vacuo, the crude product was purified by column chromatography on silica gel ( $n$-pentane/EtOAc 19/1) to yield 134cc (111 mg, 35\%) and 134mc (59 mg, 16\%). 


\subsubsection{Mechanistic Studies on the Ruthenium(II)-Catalyzed Synthesis of Alkenylated $\mathrm{N}$-Aryl-1,2,3-triazoles}

\section{Ruthenium-Catalyced H/D Exchange in Substrates 140 a and $145 a c$ with $D_{2} O$ as the Cosolvent}

The general procedure $\mathbf{E}$ was followed using 4- $n$-butyl-1-(o-tolyl)-1H-1,2,3-triazole (123a) $(107.0 \mathrm{mg}, 0.50 \mathrm{mmol})$, ethyl acrylate $(17 \mathrm{c})(150.0 \mathrm{mg}, 1.50 \mathrm{mmol}),\left[\mathrm{RuCl}_{2}(p \text {-cymene })\right]_{2}$ (30.5 mg, $5 \mathrm{~mol} \%$ ), $\mathrm{Cu}(\mathrm{OAc})_{2} \cdot \mathrm{H}_{2} \mathrm{O}$ (239.8 mg, $\left.1.20 \mathrm{mmol}\right)$ and $\mathrm{AgSbF}_{6}(103.0 \mathrm{mg}, 30 \mathrm{~mol} \%)$ in a solvent mixture of $\mathrm{PhMe}$ and $\mathrm{D}_{2} \mathrm{O}(1.8 / 0.2 \mathrm{~mL})$ at $100{ }^{\circ} \mathrm{C}$ for $6 \mathrm{~h}$. Purification by column chromatography ( $n$-pentane/EtOAc 6/1) yielded [D $]_{n}-134 a c(212 \mathrm{mg}, 68 \%)$ as a colorless oil and reisolated starting material $[D]_{n}-123 a(54 \mathrm{mg}, 25 \%)$. The $D$-incorporation in $[D]_{n}-123 a$ was estimated by ${ }^{1} \mathrm{H}-\mathrm{NMR}$ spectroscopy.

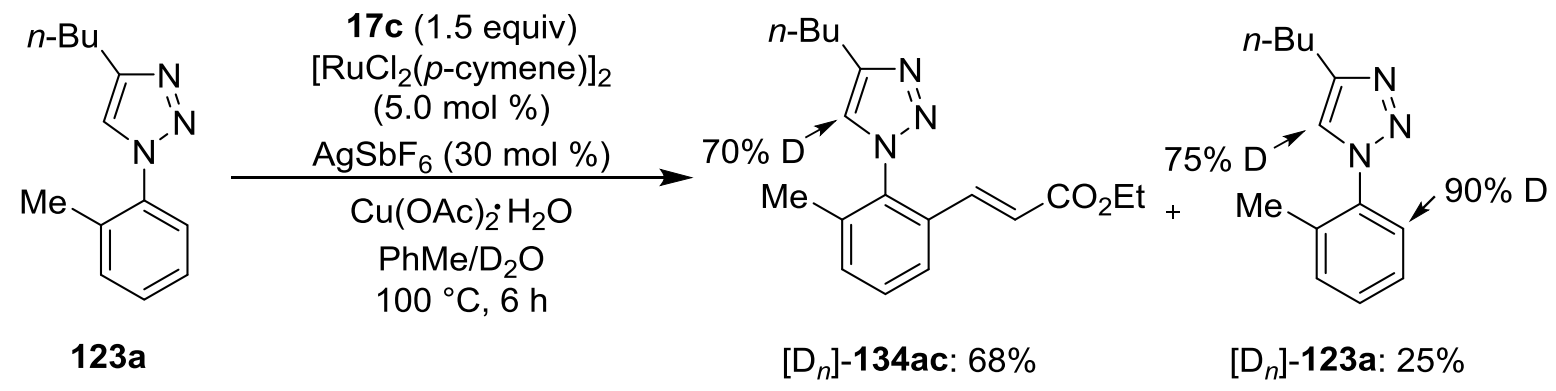

\section{Ruthenium-Catalyzed H/D Exchange in Substrates 123a with $D_{2} O$ as the Cosolvent}

The general procedure $\mathbf{E}$ was followed using 4- $n$-butyl-1-(o-tolyl)-1H-1,2,3-triazole (123a) $(107.0 \mathrm{mg}, \quad 0.50 \mathrm{mmol})$, ethyl acrylate $(17 \mathrm{c}) \quad(150.0 \mathrm{mg}, \quad 1.50 \mathrm{mmol}), \quad \mathrm{Cu}(\mathrm{OAc})_{2} \cdot \mathrm{H}_{2} \mathrm{O}$ $(239.8 \mathrm{mg}, 1.20 \mathrm{mmol})$ and $\mathrm{AgSbF}_{6}(103.0 \mathrm{mg}, 30 \mathrm{~mol} \%)$ in a solvent mixture of $\mathrm{PhMe}$ and $\mathrm{D}_{2} \mathrm{O} \quad(1.8 / 0.2 \mathrm{~mL})$ at $100{ }^{\circ} \mathrm{C}$ for $18 \mathrm{~h}$. Purification by column chromatography ( $n$-pentane/EtOAc 6/1) yielded reisolated starting material $[\mathrm{D}]_{\mathrm{n}}-123 \mathrm{a}$ (103 mg, 96\%). The Dincorporation in $[D]_{n}-123 a$ was estimated by ${ }^{1} \mathrm{H}-\mathrm{NMR}$ spectroscopy.<smiles>CCCCCc1cn(-c2ccccc2C)nn1</smiles>

$123 a$

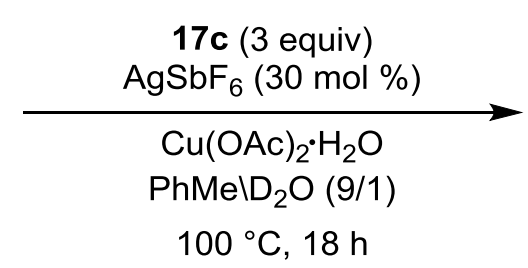

$100{ }^{\circ} \mathrm{C}, 18 \mathrm{~h}$<smiles>Cc1cccc(C)c1-n1nnc(C(=O)O[Na])c1C(=O)O</smiles>

$\left[D_{n}\right]-123 a: 96 \%$ 


\section{Ruthenium(II)-Catalyced H/D Exchange in Substrate 140 a with $\mathrm{D}_{2} \mathrm{O}$ as the Cosolvent}

The general procedure $\mathbf{E}$ was followed using 4- $n$-butyl-1-(o-tolyl)-1H-1,2,3-triazole (123a) $(107.0 \mathrm{mg}, 0.50 \mathrm{mmol})$, ethyl acrylate $(17 \mathrm{c})(150.0 \mathrm{mg}, 1.50 \mathrm{mmol}),\left[\mathrm{RuCl}_{2}(p \text {-cymene })\right]_{2}$ $(30.5 \mathrm{mg}, 5 \mathrm{~mol} \%)$ and $\mathrm{AgSbF}_{6}(103.0 \mathrm{mg}, 30 \mathrm{~mol} \%)$ in a solvent mixture of $\mathrm{PhMe}$ and $\mathrm{D}_{2} \mathrm{O}$ $(1.8 / 0.2 \mathrm{~mL})$ was stirred at $100{ }^{\circ} \mathrm{C}$ for $18 \mathrm{~h}$. Purification by column chromatography (n-pentane/EtOAc 6/1) reisolated starting material $[D]_{n}-123 a(54 \mathrm{mg}, 25 \%)$. The Dincorporation in $[D]_{n}-123 a$ was estimated by ${ }^{1} \mathrm{H}-\mathrm{NMR}$ spectroscopy.<smiles>CCCCc1cn(-c2ccccc2C)nn1</smiles>

$123 a$

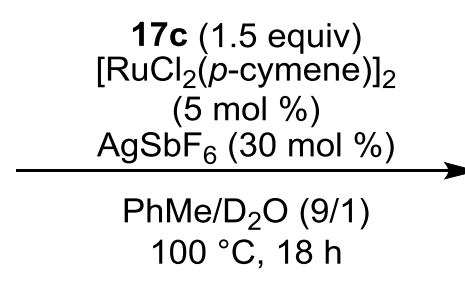
$(5 \mathrm{~mol} \%)$

$\mathrm{PhMe} / \mathrm{D}_{2} \mathrm{O}(9 / 1)$

$100{ }^{\circ} \mathrm{C}, 18 \mathrm{~h}$

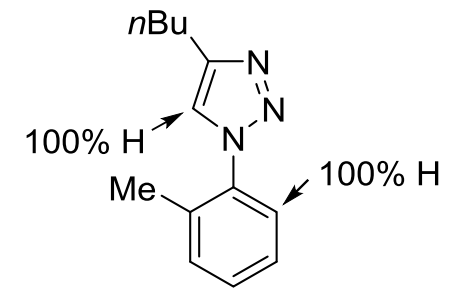

$\left[D_{n}\right]-123 a: 94 \%$ 


\subsubsection{Ruthenium(II)-Catalyzed Synthesis of Isoindolinones}

\section{Synthesis of Ethyl 2-(3-oxo-2-tosylisoindolin-1-yl)acetate 136ac}<smiles>CCOC(=O)CC1c2ccccc2C(=O)N1[13F]</smiles>

The general procedure $\mathbf{F}$ was followed using $N$-tosylbenzamide (135a) (275.3 $\mathrm{mg}, 1.00$ $\mathrm{mmol})$, ethyl acrylate (17c) $(114.0 \mathrm{mg}, 1.05 \mathrm{mmol}),\left[\mathrm{RuCl}_{2}(p \text {-cymene })\right]_{2}(6.1 \mathrm{mg}, 1.0 \mathrm{~mol} \%)$ and $\mathrm{Cu}(\mathrm{OAc})_{2} \cdot \mathrm{H}_{2} \mathrm{O}(419.3 \mathrm{mg}, 2.10 \mathrm{mmol})$. Purification by column chromatography ( $n$-hexane/EtOAc 4/1) yielded 136ac (194 mg, 52\%) as a colorless solid.

M.r.: $138-139^{\circ} \mathrm{C}$.

${ }^{1} \mathrm{H}-\mathrm{NMR}\left(300 \mathrm{MHz}, \mathrm{CDCl}_{3}\right): \delta=8.04(\mathrm{~d}, J=8.4 \mathrm{~Hz}, 2 \mathrm{H}), 7.78(\mathrm{~d}, J=8.4 \mathrm{~Hz}, 1 \mathrm{H}), 7.62$ (ddd, $J=7.8,7.2,1.2 \mathrm{~Hz}, 1 \mathrm{H}), 7.55-7.43(\mathrm{~m}, 2 \mathrm{H}), 7.36-7.30(\mathrm{~m}, 2 \mathrm{H}), 5.60(\mathrm{dd}, J=8.1,3.4 \mathrm{~Hz}$, $1 \mathrm{H}$ ), 4.08 (q, $J=7.2 \mathrm{~Hz}, 2 \mathrm{H}$ ), 3.55 (dd, $J=16.6,3.4 \mathrm{~Hz}, 1 \mathrm{H}), 2.95$ (dd, $J=16.6,8.1 \mathrm{~Hz}, 1 \mathrm{H}$ ), $2.42(\mathrm{~s}, 3 \mathrm{H}), 1.16(\mathrm{t}, J=7.2 \mathrm{~Hz}, 3 \mathrm{H})$.

${ }^{13} \mathrm{C}-N M R\left(125 \mathrm{MHz}, \mathrm{CDCl}_{3}\right): \delta=169.7\left(\mathrm{C}_{\mathrm{q}}\right), 166.4\left(\mathrm{C}_{\mathrm{q}}\right), 145.3\left(\mathrm{C}_{\mathrm{q}}\right), 145.3\left(\mathrm{C}_{\mathrm{q}}\right), 135.8\left(\mathrm{C}_{\mathrm{q}}\right)$, $134.3(\mathrm{CH}), 129.7(\mathrm{CH}), 129.4(\mathrm{CH}), 129.3\left(\mathrm{C}_{\mathrm{q}}\right), 128.4(\mathrm{CH}), 125.0(\mathrm{CH}), 123.1(\mathrm{CH}), 62.2$ $\left(\mathrm{CH}_{2}\right), 58.5(\mathrm{CH}), 39.5\left(\mathrm{CH}_{2}\right), 21.9\left(\mathrm{CH}_{3}\right), 14.2\left(\mathrm{CH}_{3}\right)$.

IR (ATR): $\tilde{v}=2987,2941,2876,1720,1359,1166,1086,824,737,685 \mathrm{~cm}^{-1}$.

MS (ESI) $m / z$ (relative intensity): $396(95)\left[\mathrm{M}+\mathrm{Na}^{+}\right], 374(100)\left[\mathrm{M}+\mathrm{H}^{+}\right]$.

HR-MS (ESI) $\mathrm{m} / \mathrm{z}$ calcd for $\mathrm{C}_{19} \mathrm{H}_{20} \mathrm{NO}_{5} \mathrm{~S}$, $\left[\mathrm{M}+\mathrm{H}^{+}\right]$374.1057, found 374.1054.

The spectral data are in accordance with those reported in the literature. ${ }^{109 \mathrm{~b}}$

\section{Synthesis of $n$-Butyl 2-(3-oxo-2-tosylisoindolin-1-yl)acetate 136ae}<smiles>CCCCCC1c2ccccc2C(=O)N1[AsH-]</smiles>

The general procedure $F$ was followed using $N$-tosylbenzamide (135a) (275.3 mg, 1.00 mmol), $n$-butyl acrylate (17c) $(138.0 \mathrm{mg}, 1.05 \mathrm{mmol}),\left[\mathrm{RuCl}_{2}(p \text {-cymene })\right]_{2}$ (30.5 mg, 
$5.0 \mathrm{~mol} \%)$ and $\mathrm{Cu}(\mathrm{OAc})_{2} \cdot \mathrm{H}_{2} \mathrm{O} \quad(419.3 \mathrm{mg}, 2.10 \mathrm{mmol})$. Purification by column chromatography ( $n$-hexane/EtOAc $4 / 1)$ yielded 136ae (189 mg, 47\%) as a colorless solid.

M.r.: $80-83^{\circ} \mathrm{C}$.

${ }^{1} \mathrm{H}-\mathrm{NMR}\left(300 \mathrm{MHz}, \mathrm{CDCl}_{3}\right): \delta=8.03(\mathrm{~d}, J=8.4 \mathrm{~Hz}, 2 \mathrm{H}), 7.78(\mathrm{~d}, J=7.6 \mathrm{~Hz}, 1 \mathrm{H}), 7.62$ (ddd, $J=8.1,7.2,1.2 \mathrm{~Hz}, 1 \mathrm{H}), 7.51-7.41(\mathrm{~m}, 2 \mathrm{H}), 7.37-7.28(\mathrm{~m}, 2 \mathrm{H}), 5.60(\mathrm{dd}, J=8.1,3.4 \mathrm{~Hz}$, $1 \mathrm{H}), 4.01$ (dd, $J=6.8,0.7 \mathrm{~Hz}, 2 \mathrm{H}), 3.55(\mathrm{dd}, J=16.6,3.4 \mathrm{~Hz}, 1 \mathrm{H}), 2.95(\mathrm{dd}, J=16.6,8.1 \mathrm{~Hz}$, $1 \mathrm{H}), 2.42(\mathrm{~s}, 3 \mathrm{H}), 2.17(\mathrm{~s}, 3 \mathrm{H}) 1.55-1.42(\mathrm{~m}, 2 \mathrm{H}), 1.35-1.17(\mathrm{~m}, 2 \mathrm{H}), 0.89(\mathrm{t}, J=7.3 \mathrm{~Hz}, 3 \mathrm{H})$.

${ }^{13} \mathrm{C}$-NMR $\left(125 \mathrm{MHz}, \mathrm{CDCl}_{3}\right): \delta=169.8\left(\mathrm{C}_{\mathrm{q}}\right), 166.4\left(\mathrm{C}_{\mathrm{q}}\right), 145.4\left(\mathrm{C}_{\mathrm{q}}\right), 145.3\left(\mathrm{C}_{\mathrm{q}}\right), 135.8\left(\mathrm{C}_{\mathrm{q}}\right)$, $134.3(\mathrm{CH}), 129.7(\mathrm{CH}), 129.4\left(\mathrm{C}_{\mathrm{q}}\right), 129.2(\mathrm{CH}), 128.4(\mathrm{CH}), 125.0(\mathrm{CH}), 123.1(\mathrm{CH}), 65.1$ $\left(\mathrm{CH}_{2}\right), 58.6(\mathrm{CH}), 39.5\left(\mathrm{CH}_{2}\right), 30.6\left(\mathrm{CH}_{2}\right), 21.9\left(\mathrm{CH}_{3}\right), 19.2\left(\mathrm{CH}_{2}\right), 13.9\left(\mathrm{CH}_{3}\right)$.

IR (ATR): $\tilde{v}=2957,1718,1348,1295,1166,1092,816,665,653,601 \mathrm{~cm}^{-1}$.

MS (ESI) m/z (relative intensity): 440 (69) [M+K $\left.{ }^{+}\right], 424$ (62) [M+Na $\left.{ }^{+}\right], 402$ (100) $\left[\mathrm{M}+\mathrm{H}^{+}\right]$.

HR-MS (ESI) $m / z$ calcd for $\mathrm{C}_{21} \mathrm{H}_{24} \mathrm{NO}_{5} \mathrm{~S}$, [M+H'] 401.1297, found 402.1370.

\section{Synthesis of Diethyl [(3-oxo-2-tosylisoindolin-1-yl)methyl]phosphonate 136ak}

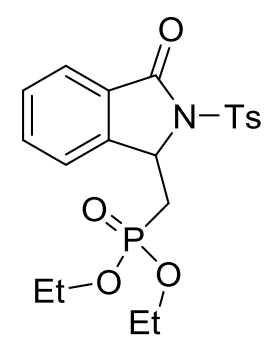

The general procedure $\mathbf{F}$ was followed using $N$-tosylbenzamide (135a) (275.3 mg, 1.00 $\mathrm{mmol})$, diethyl vinylphosphonate (17k) $(158.0 \mathrm{mg}, 1.05 \mathrm{mmol}),\left[\mathrm{RuCl}_{2}(p \text {-cymene })\right]_{2}(30.5 \mathrm{mg}$, $5.0 \mathrm{~mol} \%)$ and $\mathrm{Cu}(\mathrm{OAc})_{2} \cdot \mathrm{H}_{2} \mathrm{O}(419.3 \mathrm{mg}, 2.10 \mathrm{mmol})$. Purification by column chromatography (EtOAc) yielded 136ak (201 mg, 46\%) as a colorless solid.

M.r.: $127-128^{\circ} \mathrm{C}$.

${ }^{1} \mathrm{H}-\mathrm{NMR}\left(300 \mathrm{MHz}, \mathrm{CDCl}_{3}\right): \delta=7.99(\mathrm{~d}, J=8.4 \mathrm{~Hz}, 2 \mathrm{H}), 7.86(\mathrm{~d}, J=7.8 \mathrm{~Hz}, 1 \mathrm{H}), 7.74(\mathrm{~d}$, $J=7.6 \mathrm{~Hz}, 1 \mathrm{H}), 7.62(\mathrm{~d}, J=7.6 \mathrm{~Hz}, 1 \mathrm{H}), 7.45(\mathrm{dd}, J=7.5,7.5 \mathrm{~Hz}, 1 \mathrm{H}), 7.30(\mathrm{~d}, J=7.8 \mathrm{~Hz}$, 2H), 5.47 (ddd, $J=18.9,8.7,2.5 \mathrm{~Hz}, 1 \mathrm{H}), 4.11(\mathrm{~m}, 2 \mathrm{H}), 3.97(\mathrm{dq}, J=8.2,7.1 \mathrm{~Hz}, 2 \mathrm{H}$ ), 3.04 (ddd, $J=21.8,15.5,2.5 \mathrm{~Hz}, 1 \mathrm{H}$ ), $2.53(\mathrm{td}, J=7,61.2 \mathrm{~Hz}, 1 \mathrm{H}$ ), 2.39 (s, 3H), 1.32 (t, $J=7.0$ $\mathrm{Hz}, 3 \mathrm{H}), 1.17$ (t, $J=7.0 \mathrm{~Hz}, 3 \mathrm{H})$.

${ }^{13} \mathrm{C}-N M R\left(125 \mathrm{MHz}, \mathrm{CDCl}_{3}\right): \delta=166.4\left(\mathrm{C}_{\mathrm{q}}\right), 145.3\left(\mathrm{C}_{\mathrm{q}}\right) 145.1\left(\mathrm{~d},{ }^{3} \mathrm{~J}_{\mathrm{C}-\mathrm{P}}=1.4 \mathrm{~Hz}, \mathrm{C}_{\mathrm{q}}\right), 135.7$ $\left(\mathrm{C}_{\mathrm{q}}\right), 134.1(\mathrm{CH}), 129.7(\mathrm{CH}), 129.3(\mathrm{CH}), 129.1\left(\mathrm{C}_{\mathrm{q}}\right), 128.4(\mathrm{CH}), 124.8(\mathrm{CH}), 124.4(\mathrm{CH})$, 
$62.2\left(\mathrm{dd},{ }^{3} \mathrm{~J}_{\mathrm{C}-\mathrm{P}}=50.2,6.6 \mathrm{~Hz}, \mathrm{CH}_{2}\right), 56.9\left({ }^{3} \mathrm{~J}_{\mathrm{C}-\mathrm{P}}=1.6 \mathrm{~Hz}, \mathrm{CH}\right), 31.4\left({ }^{1} \mathrm{~J}_{\mathrm{C}-\mathrm{P}}=139.5 \mathrm{~Hz}, \mathrm{CH}_{2}\right)$, $16.4\left(\mathrm{CH}_{3}\right), 16.3\left({ }^{3} J_{\mathrm{C}-\mathrm{P}}=6.2 \mathrm{~Hz}, \mathrm{CH}_{3}\right)$.

IR (ATR): $\tilde{v}=2979,2926,1722,1360,1173,1095,1035,957,772,665 \mathrm{~cm}^{-1}$.

MS (ESI) $m / z$ (relative intensity): 460 (76) $\left[\mathrm{M}+\mathrm{Na}^{+}\right], 438(100)\left[\mathrm{M}+\mathrm{H}^{+}\right]$.

HR-MS (ESI) $m / z$ calcd for $\mathrm{C}_{20} \mathrm{H}_{25} \mathrm{NO}_{6} \mathrm{PS},\left[\mathrm{M}+\mathrm{H}^{+}\right]$438.1135, found 438.1133 .

\section{Synthesis of Ethyl 2-(4-methyl-3-oxo-2-tosylisoindolin-1-yl)acetate 136bc}<smiles>CCOC(=O)CC1c2cccc(C)c2C(=O)N1[13I]</smiles>

The general procedure $\mathbf{F}$ was followed using 2-methyl- $N$-tosylbenzamide (135b) $(289.3 \mathrm{mg}$, $1.00 \mathrm{mmol})$, ethyl acrylate (17c) $(114.0 \mathrm{mg}, 1.05 \mathrm{mmol}),\left[\mathrm{RuCl}_{2}(p \text {-cymene })\right]_{2}(30.5 \mathrm{mg}$, $5.0 \mathrm{~mol} \%)$ and $\mathrm{Cu}(\mathrm{OAc})_{2} \cdot \mathrm{H}_{2} \mathrm{O} \quad(419.3 \mathrm{mg}, 2.10 \mathrm{mmol})$. Purification by column chromatography ( $n$-hexane/EtOAc 4/1) yielded 136bc (286 mg, 74\%) as a colorless solid.

M.r.: $99-101^{\circ} \mathrm{C}$.

${ }^{1} \mathrm{H}-\mathrm{NMR}\left(300 \mathrm{MHz}, \mathrm{CDCl}_{3}\right): \delta=8.01(\mathrm{~d}, J=8.4 \mathrm{~Hz}, 2 \mathrm{H}), 7.44(\mathrm{dd}, J=7.6,7.6 \mathrm{~Hz}, 1 \mathrm{H}), 7.36-$ $7.28(\mathrm{~m}, 3 \mathrm{H}), 7.28-7.23(\mathrm{~m}, 1 \mathrm{H}), 7.18(\mathrm{~d}, J=7.6 \mathrm{~Hz}, 1 \mathrm{H}), 5.53(\mathrm{dd}, J=7.1,3.5 \mathrm{~Hz}, 1 \mathrm{H}), 4.04$ (q, $J=7.1 \mathrm{~Hz}, 2 \mathrm{H}$ ), 3.45 (dd, $J=16.5,3.4 \mathrm{~Hz}, 1 \mathrm{H}), 2.93(\mathrm{dd}, J=16.5,7.7 \mathrm{~Hz}, 1 \mathrm{H}), 2.58$ (s, $3 \mathrm{H}), 2.40(\mathrm{~s}, 3 \mathrm{H}), 1.12(\mathrm{t}, J=7.2 \mathrm{~Hz}, 3 \mathrm{H})$.

${ }^{13}$ C-NMR (75 MHz, $\left.\mathrm{CDCl}_{3}\right): \delta=169.9\left(\mathrm{C}_{\mathrm{q}}\right), 167.2\left(\mathrm{C}_{\mathrm{q}}\right), 146.0\left(\mathrm{C}_{\mathrm{q}}\right), 145.2\left(\mathrm{C}_{\mathrm{q}}\right), 139.7\left(\mathrm{C}_{\mathrm{q}}\right)$, $136.1\left(\mathrm{C}_{\mathrm{q}}\right), 133.8(\mathrm{CH}), 131.2(\mathrm{CH}), 129.8(\mathrm{CH}), 128.5(\mathrm{CH}), 126.6\left(\mathrm{C}_{\mathrm{q}}\right), 120.4(\mathrm{CH}), 61.1$ $\left(\mathrm{CH}_{2}\right), 57.6(\mathrm{CH}), 39.6\left(\mathrm{CH}_{2}\right), 21.8\left(\mathrm{CH}_{3}\right), 17.8\left(\mathrm{CH}_{3}\right), 14.1\left(\mathrm{CH}_{3}\right)$.

IR (ATR): $\tilde{v}=2932,2921,1715,1379,1190,1170,1102,1043,750,706 \mathrm{~cm}^{-1}$.

MS (El) m/z (relative intensity): 323 (95), 300 (20), 250 (57), 232 (100), 186 (18), 155 (46), 91 (62), 65 (37).

HR-MS (ESI) $m / z$ calcd for $\mathrm{C}_{20} \mathrm{H}_{22} \mathrm{NO}_{5} \mathrm{~S}$, $\left[\mathrm{M}+\mathrm{H}^{+}\right]$388.1213, found 388.1213. 


\section{Synthesis of $n$-Butyl 2-(4-methyl-3-oxo-2-tosylisoindolin-1-yl)acetate 136be}<smiles>CCCCCC1c2cccc(C)c2C(=O)N1[13CH3]</smiles>

The general procedure $\mathbf{F}$ was followed using 2-methyl- $N$-tosylbenzamide (135b) $(289.3 \mathrm{mg}$, $1.00 \mathrm{mmol}), n$-butyl acrylate (17e) $(138.0 \mathrm{mg}, 1.05 \mathrm{mmol}), \mathrm{RuCl}_{2}(p$-cymene $\left.)\right]_{2}$ (30.5 mg, $5.0 \mathrm{~mol} \%)$ and $\mathrm{Cu}(\mathrm{OAc})_{2} \cdot \mathrm{H}_{2} \mathrm{O} \quad(419.3 \mathrm{mg}, 2.10 \mathrm{mmol})$. Purification by column chromatography ( $n$-hexane/EtOAc $4 / 1$ ) yielded 136be (366 mg, 88\%) as a colorless solid.

M.r.: $93-95^{\circ} \mathrm{C}$.

${ }^{1} \mathrm{H}-\mathrm{NMR}\left(300 \mathrm{MHz}, \mathrm{CDCl}_{3}\right): \delta=8.03(\mathrm{~d}, J=8.4 \mathrm{~Hz}, 2 \mathrm{H}), 7.46(\mathrm{dd}, J=7.6,7.6 \mathrm{~Hz}, 1 \mathrm{H}), 7.33$ $(\mathrm{d}, J=8.2 \mathrm{~Hz}, 2 \mathrm{H}), 7.27(\mathrm{~d}, J=6.7 \mathrm{~Hz}, 1 \mathrm{H}), 7.20(\mathrm{~d}, J=7.5 \mathrm{~Hz}, 1 \mathrm{H}), 5.55$ (dd, $J=7.7$, $3.4 \mathrm{~Hz}, 1 \mathrm{H}), 4.00(\mathrm{td}, J=6.7,2.5 \mathrm{~Hz}, 2 \mathrm{H}), 3.48(\mathrm{dd}, J=16.5,3.4 \mathrm{~Hz}, 1 \mathrm{H}), 2.96(\mathrm{dd}, J=16.5$, $7.7 \mathrm{~Hz}, 1 \mathrm{H}), 2.60(\mathrm{~s}, 3 \mathrm{H}), 2.42(\mathrm{~s}, 3 \mathrm{H}), 1.55-1.40(\mathrm{~m}, 2 \mathrm{H}), 1.37-1.10(\mathrm{~m}, 2 \mathrm{H}), 0.88(\mathrm{t}$, $J=7.2 \mathrm{~Hz}, 3 \mathrm{H})$.

${ }^{13} \mathrm{C}-\mathrm{NMR}\left(125 \mathrm{MHz}, \mathrm{CDCl}_{3}\right): \delta=169.8\left(\mathrm{C}_{\mathrm{q}}\right), 167.0\left(\mathrm{C}_{\mathrm{q}}\right), 146.0\left(\mathrm{C}_{\mathrm{q}}\right), 145.1\left(\mathrm{C}_{\mathrm{q}}\right), 139.7\left(\mathrm{C}_{\mathrm{q}}\right)$, $136.0\left(\mathrm{C}_{\mathrm{q}}\right), 133.7(\mathrm{CH}), 131.1(\mathrm{CH}), 129.7(\mathrm{CH}), 128.4(\mathrm{CH}), 126.5\left(\mathrm{C}_{\mathrm{q}}\right), 120.3(\mathrm{CH}), 65.0$ $\left(\mathrm{CH}_{2}\right), 57.6(\mathrm{CH}), 39.6\left(\mathrm{CH}_{2}\right), 30.6\left(\mathrm{CH}_{2}\right), 21.9\left(\mathrm{CH}_{3}\right), 19.2\left(\mathrm{CH}_{2}\right), 17.8\left(\mathrm{CH}_{3}\right), 13.9\left(\mathrm{CH}_{3}\right)$. IR (ATR): $\tilde{v}=2961,1719,1599,1355,1166,1104,815,665,576,543 \mathrm{~cm}^{-1}$. MS (ESI) $m / z$ (relative intensity): $454\left[\mathrm{M}+\mathrm{K}^{+}\right]$(100), 438 (79) $\left[\mathrm{M}+\mathrm{Na}^{+}\right], 416(89)\left[\mathrm{M}+\mathrm{H}^{+}\right]$.

HR-MS (ESI) $m / z$ calcd for $\mathrm{C}_{22} \mathrm{H}_{26} \mathrm{NO}_{5} \mathrm{~S}$, $\left[\mathrm{M}+\mathrm{H}^{+}\right]$416.1526, found 416.1529.

\section{Synthesis of $n$-Butyl 2-(4-fluoro-3-oxo-2-tosylisoindolin-1-yl)acetate 136ce}<smiles>CCCCCC1c2cccc(F)c2C(=O)N1[13CH3]</smiles>

The general procedure $F$ was followed using 2-fluoro- $N$-tosylbenzamide (135c) $(275.3 \mathrm{mg}$, $1.00 \mathrm{mmol}$ ), $n$-butyl acrylate (17e) $(138.0 \mathrm{mg}, 1.05 \mathrm{mmol}),\left[\mathrm{RuCl}_{2}(p \text {-cymene) }]_{2}\right.$ (30.5 mg, $5.0 \mathrm{~mol} \%)$ and $\mathrm{Cu}(\mathrm{OAc})_{2} \cdot \mathrm{H}_{2} \mathrm{O}(419.3 \mathrm{mg}, 2.10 \mathrm{mmol})$. Purification by column chromatography ( $n$-hexane/EtOAc $4 / 1$ ) yielded 136ce (327 mg, 78\%) as a colorless solid. 
M.r.: $98-101^{\circ} \mathrm{C}$.

${ }^{1} \mathrm{H}-\mathrm{NMR}\left(300 \mathrm{MHz}, \mathrm{CDCl}_{3}\right): \delta=8.03(\mathrm{~d}, J=8.4 \mathrm{~Hz}, 2 \mathrm{H}), 7.59(\mathrm{dd}, J=8.0,4.8 \mathrm{~Hz}, 1 \mathrm{H})$, 7.36-7.28 (m, 4H), $5.58(\mathrm{dd}, J=7.9,3.3 \mathrm{~Hz}, 1 \mathrm{H}), 4.12-3.89(\mathrm{~m}, 2 \mathrm{H}), 3.50(\mathrm{dd}, J=16.7$, $3.3 \mathrm{~Hz}, 1 \mathrm{H}), 3.00(\mathrm{dd}, J=16.7,7.9 \mathrm{~Hz} 1 \mathrm{H}), 2.42(\mathrm{~s}, 3 \mathrm{H}), 1.56-1.43(\mathrm{~m}, 2 \mathrm{H}), 1.37-1.19(\mathrm{~m}$, $2 \mathrm{H}), 0.89(\mathrm{t}, J=7.3 \mathrm{~Hz}, 3 \mathrm{H})$.

${ }^{13} \mathrm{C}-N M R\left(125 \mathrm{MHz}, \mathrm{CDCl}_{3}\right): \delta=169.6\left(\mathrm{C}_{\mathrm{q}}\right), 163.0\left({ }^{3} \mathrm{~J}_{\mathrm{C}-\mathrm{F}}=2.5 \mathrm{~Hz}, \mathrm{C}_{\mathrm{q}}\right), 159.4\left({ }^{1} \mathrm{~J}_{\mathrm{C}-\mathrm{F}}=\right.$ $\left.264.4 \mathrm{~Hz}, \mathrm{C}_{\mathrm{q}}\right), 147.6\left({ }^{3} J_{\mathrm{C}-\mathrm{F}}=1.9 \mathrm{~Hz}, \mathrm{C}_{\mathrm{q}}\right), 145.4\left(\mathrm{C}_{\mathrm{q}}\right), 136.3\left({ }^{3} J_{\mathrm{C}-\mathrm{F}}=7.9 \mathrm{~Hz}, \mathrm{CH}\right), 135.5\left(\mathrm{C}_{\mathrm{q}}\right)$, $129.7(\mathrm{CH}), 128.6(\mathrm{CH}), 119.0\left({ }^{4} J_{\mathrm{C}-\mathrm{F}}=4.3 \mathrm{~Hz}, \mathrm{CH}\right), 117.2\left({ }^{2} J_{\mathrm{C}-\mathrm{F}}=13.1 \mathrm{~Hz}, \mathrm{C}_{\mathrm{q}}\right), 116.4\left({ }^{2} J_{\mathrm{C}-\mathrm{F}}=\right.$ $18.6 \mathrm{~Hz}, \mathrm{CH}), 65.2\left(\mathrm{CH}_{2}\right), 58.1(\mathrm{CH}), 39.3\left(\mathrm{CH}_{2}\right), 30.6\left(\mathrm{CH}_{2}\right), 21.9\left(\mathrm{CH}_{3}\right), 13.8\left(\mathrm{CH}_{3}\right)$.

${ }^{19}$ F-NMR $\left(282 \mathrm{MHz}, \mathrm{CDCl}_{3}\right): \delta=-114.9(\mathrm{dd}, J=9.0,4.9 \mathrm{~Hz})$.

IR (ATR): $\tilde{v}=2960,1978,1724,1379,1165,1084,815,692,659,577 \mathrm{~cm}^{-1}$.

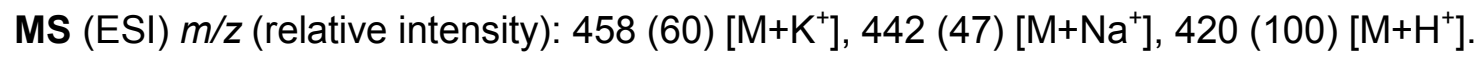

HR-MS (ESI) $m / z$ calcd for $\mathrm{C}_{21} \mathrm{H}_{23} \mathrm{FNO}_{5} \mathrm{~S},\left[\mathrm{M}+\mathrm{H}^{+}\right]$420.1275, found 420.1277.

\section{Synthesis of Ethyl 2-(4-fluoro-3-oxo-2-tosylisoindolin-1-yl)acetate 136cc}<smiles>CCOC(=O)CC1c2cccc(F)c2C(=O)N1[13I]</smiles>

The general procedure $\mathbf{F}$ was followed using 2-fluoro- $N$-tosylbenzamide (135c) $(293.3 \mathrm{mg}$, $1.00 \mathrm{mmol})$, ethyl acrylate (17c) $(114.0 \mathrm{mg}, 1.05 \mathrm{mmol}),\left[\operatorname{RuCl}_{2}(p-c y m e n e)\right]_{2}(30.5 \mathrm{mg}$, $5.0 \mathrm{~mol} \%)$ and $\mathrm{Cu}(\mathrm{OAc})_{2} \cdot \mathrm{H}_{2} \mathrm{O} \quad(419.3 \mathrm{mg}, \quad 2.10 \mathrm{mmol})$. Purification by column chromatography ( $n$-hexane/EtOAc $4 / 1$ ) yielded 136cc (309 mg, 79\%) as a colorless solid.

M.r.: $80-83^{\circ} \mathrm{C}$.

${ }^{1} \mathrm{H}-\mathrm{NMR}\left(300 \mathrm{MHz}, \mathrm{CDCl}_{3}\right): \delta=8.03(\mathrm{~d}, J=8.4 \mathrm{~Hz}, 2 \mathrm{H}), 7.59(\mathrm{dd}, J=8.0,4.8 \mathrm{~Hz}, 1 \mathrm{H}), 7.34-$ $7.26(\mathrm{~m}, 3 \mathrm{H}), 7.15-7.00(\mathrm{~m}, 1 \mathrm{H}), 5.58(\mathrm{dd}, J=7.9,3.3 \mathrm{~Hz}, 1 \mathrm{H}), 4.06(\mathrm{q}, J=7.1 \mathrm{~Hz}, 2 \mathrm{H}), 3.48$ (dd, $J=16.7,3.3 \mathrm{~Hz}, 1 \mathrm{H}), 2.99$ (dd, $J=16.7,7.8 \mathrm{~Hz}, 1 \mathrm{H}), 2.42(\mathrm{~s}, 3 \mathrm{H}), 1.15$ (t, $J=7.2 \mathrm{~Hz}$, $3 \mathrm{H})$.

${ }^{13} \mathrm{C}-N M R\left(75 \mathrm{MHz}, \mathrm{CDCl}_{3}\right): \delta=169.6\left(\mathrm{C}_{\mathrm{q}}\right), 163.1\left({ }^{3} \mathrm{~J}_{\mathrm{C}-\mathrm{F}}=2.7 \mathrm{~Hz}, \mathrm{C}_{\mathrm{q}}\right), 159.6\left({ }^{1} \mathrm{~J}_{\mathrm{C}-\mathrm{F}}=264.7 \mathrm{~Hz}\right.$, $\left.\mathrm{C}_{\mathrm{q}}\right), 147.6\left({ }^{3} \mathrm{~J}_{\mathrm{C}-\mathrm{F}}=1.9 \mathrm{~Hz}, \mathrm{C}_{\mathrm{q}}\right), 145.5\left(\mathrm{C}_{\mathrm{q}}\right), 136.4\left({ }^{3} \mathrm{~J}_{\mathrm{C}-\mathrm{F}}=8.0 \mathrm{~Hz}, \mathrm{CH}\right), 135.6\left(\mathrm{C}_{\mathrm{q}}\right), 129.8(\mathrm{CH})$, $128.6(\mathrm{CH}), 119.1\left({ }^{4} J_{\mathrm{C}-\mathrm{F}}=4.4 \mathrm{~Hz}, \mathrm{CH}\right), 117.2\left({ }^{2} J_{\mathrm{C}-\mathrm{F}}=13.0 \mathrm{~Hz}, \mathrm{C}_{\mathrm{q}}\right), 116.5\left({ }^{2} \mathrm{~J}_{\mathrm{C}-\mathrm{F}}=18.7 \mathrm{~Hz}\right.$, $\mathrm{CH}), 61.2\left(\mathrm{CH}_{2}\right), 58.0(\mathrm{CH}), 39.3\left(\mathrm{CH}_{2}\right), 21.8\left(\mathrm{CH}_{3}\right), 14.1\left(\mathrm{CH}_{3}\right)$.

${ }^{19}$ F-NMR $\left(282 \mathrm{MHz}, \mathrm{CDCl}_{3}\right): \delta=-114.9(\mathrm{dd}, J=9.0,4.8 \mathrm{~Hz})$.

IR (ATR): $\tilde{v}=2988,2952,1731,1379,1358,1171,1090,1020,680,658 \mathrm{~cm}^{-1}$. 
MS (ESI) m/z (relative intensity): 430 (78) [M+K $\left.\mathrm{K}^{+}\right], 414$ (67) [M+Na $\left.{ }^{+}\right], 392(100)\left[\mathrm{M}+\mathrm{H}^{+}\right]$.

HR-MS (ESI) $\mathrm{m} / \mathrm{z}$ calcd for $\mathrm{C}_{19} \mathrm{H}_{19} \mathrm{FNO}_{5} \mathrm{~S}$, [M+H'] 392.0962, found 392.0963 .

\section{Synthesis of Benzyl 2-(4-methyl-3-oxo-2-tosylisoindolin-1-yl)acetate 136bd}<smiles>Cc1cccc2c1C(=O)N([13F])C2CC(=O)OCc1ccccc1</smiles>

The general procedure $\mathbf{F}$ was followed using 2-methyl- $N$-tosylbenzamide (135b) $(145.2 \mathrm{mg}$, $0.50 \mathrm{mmol})$, benzyl acrylate $(\mathbf{1 7 d})(248.0 \mathrm{mg}, 1.50 \mathrm{mmol}),\left[\mathrm{RuCl}_{2}(p \text {-cymene })\right]_{2}(15.3 \mathrm{mg}$, $5.0 \mathrm{~mol} \%)$ and $\mathrm{Cu}(\mathrm{OAc})_{2} \cdot \mathrm{H}_{2} \mathrm{O} \quad(209.7 \mathrm{mg}, \quad 1.05 \mathrm{mmol})$. Purification by column chromatography ( $n$-hexane/EtOAc $4 / 1)$ yielded 136bd (185 mg, 82\%) as a colorless solid.

M.p.: $135^{\circ} \mathrm{C}$.

${ }^{1} \mathrm{H}-\mathrm{NMR}\left(600 \mathrm{MHz}, \mathrm{CDCl}_{3}\right): \delta=8.02(\mathrm{~d}, J=8.3 \mathrm{~Hz}, 2 \mathrm{H}), 7.39(\mathrm{dd}, J=7.6,7.6 \mathrm{~Hz}, 1 \mathrm{H}), 7.38-$ $7.30(\mathrm{~m}, 3 \mathrm{H}), 7.31(\mathrm{~d}, J=8.3 \mathrm{~Hz}, 2 \mathrm{H}), 7.27-7.24(\mathrm{~m}, 2 \mathrm{H}), 7.18-7.15(\mathrm{~m}, 2 \mathrm{H}), 5.56(\mathrm{dd}, J=$ $7.9,3.5 \mathrm{~Hz}, 1 \mathrm{H}$ ), $5.06(\mathrm{q}, J=12.2 \mathrm{~Hz}, 2 \mathrm{H}$ ), 3.54 (dd, $J=16.4,3.5 \mathrm{~Hz}, 1 \mathrm{H}), 2.99$ (dd, $J=16.4$, $7.8 \mathrm{~Hz}, 1 \mathrm{H}), 2.57(\mathrm{~s}, 3 \mathrm{H}), 2.42(\mathrm{~s}, 3 \mathrm{H})$.

${ }^{13} \mathrm{C}-N M R\left(125 \mathrm{MHz}, \mathrm{CDCl}_{3}\right): \delta=169.8\left(\mathrm{C}_{\mathrm{q}}\right), 167.1\left(\mathrm{C}_{\mathrm{q}}\right), 145.9\left(\mathrm{C}_{\mathrm{q}}\right), 145.2\left(\mathrm{C}_{\mathrm{q}}\right), 139.8\left(\mathrm{C}_{\mathrm{q}}\right)$, $136.0\left(\mathrm{C}_{\mathrm{q}}\right), 135.4\left(\mathrm{C}_{\mathrm{q}}\right), 133.8(\mathrm{CH}), 131.2(\mathrm{CH}), 129.8(\mathrm{CH}), 128.7(\mathrm{CH}), 128.6(\mathrm{CH}), 128.6$ $(\mathrm{CH}), 128.5(\mathrm{CH}), 126.5\left(\mathrm{C}_{\mathrm{q}}\right), 120.3(\mathrm{CH}), 67.0\left(\mathrm{CH}_{2}\right), 57.6(\mathrm{CH}), 39.7\left(\mathrm{CH}_{2}\right), 21.8\left(\mathrm{CH}_{3}\right), 17.7$ $\left(\mathrm{CH}_{3}\right)$.

IR (ATR): $\tilde{v}=2953,2189,1731,1424,1238,1203,1129,728,693,666,543 \mathrm{~cm}^{-1}$. MS (El) m/z (relative intensity): 449 (25) $\left[\mathrm{M}^{+}\right], 394$ (43), 250 (28), 236 (13), 186 (12), 155 (23), 91 (100), 65 (17).

HR-MS (ESI) $\mathrm{m} / \mathrm{z}$ calcd for $\mathrm{C}_{25} \mathrm{H}_{23} \mathrm{NO}_{5} \mathrm{~S}$, [M+] 449.1297, found 449.1288 .

Synthesis of Diethyl [(4-methyl-3-oxo-2-tosylisoindolin-1-yl)methyl]phosphonate 136bk<smiles>[B-]N1C(=O)c2c(C)cccc2C1CP(=O)(OCC)OCC</smiles> 
The general procedure $F$ was followed using 2-methyl- $N$-tosylbenzamide (135b) $(289.3 \mathrm{mg}$, $1.00 \mathrm{mmol})$, diethyl vinylphosphonate $(\mathbf{1 7 k}) \quad(158.0 \mathrm{mg}, 1.05 \mathrm{mmol}), \quad\left[\mathrm{RuCl}_{2}(p-c y m e n e)\right]_{2}$ (30.5 mg, $5.0 \mathrm{~mol} \%$ ) and $\mathrm{Cu}(\mathrm{OAc})_{2} \cdot \mathrm{H}_{2} \mathrm{O}(419.3 \mathrm{mg}, 2.10 \mathrm{mmol})$. Purification by column chromatography (EtOAc) yielded $136 \mathrm{bk}(216 \mathrm{mg}, 48 \%)$ as a colorless solid.

M.p.: $121^{\circ} \mathrm{C}$.

${ }^{1} \mathrm{H}-\mathrm{NMR}\left(300 \mathrm{MHz}, \mathrm{CDCl}_{3}\right): \delta=8.01(\mathrm{~d}, J=8.4 \mathrm{~Hz}, 2 \mathrm{H}), 7.66(\mathrm{~d}, J=7.6 \mathrm{~Hz}, 1 \mathrm{H}), 7.33(\mathrm{dd}$, $J=7.8 \mathrm{~Hz}, 1 \mathrm{H}$ ), $7.33(\mathrm{~d}, J=8.0 \mathrm{~Hz}, 2 \mathrm{H}), 7.19$ (dd, $J=7.5,0.8 \mathrm{~Hz}, 1 \mathrm{H}), 5.44$ (ddd, $J=19.2$, 8.5, $2.4 \mathrm{~Hz}, 1 \mathrm{H}$ ), 4.20-4.03 (m, 2H), $3.98(\mathrm{dq}, J=8.0,7.1 \mathrm{~Hz}, 2 \mathrm{H}$ ), 3.01 (ddd, $J=21.8,15.6$, $2.5 \mathrm{~Hz}, 1 \mathrm{H}), 2.59(\mathrm{~s}, 3 \mathrm{H}), 2.58-2.44(\mathrm{~m}, 1 \mathrm{H}), 2.41(\mathrm{~s}, 3 \mathrm{H}), 1.32(\mathrm{t}, J=7.0 \mathrm{~Hz}, 3 \mathrm{H}), 1.18(\mathrm{t}$, $J=7.1 \mathrm{~Hz}, 3 \mathrm{H})$.

${ }^{13}$ C-NMR $\left(125 \mathrm{MHz}, \mathrm{CDCl}_{3}\right): \delta=167.1\left(\mathrm{C}_{\mathrm{q}}\right), 145.6\left(\mathrm{~d},{ }^{3} \mathrm{~J}_{\mathrm{C}-\mathrm{P}}=1.6 \mathrm{~Hz}, \mathrm{C}_{\mathrm{q}}\right), 145.2\left(\mathrm{C}_{\mathrm{q}}\right), 139.4$ $\left(\mathrm{C}_{\mathrm{q}}\right), 136.0\left(\mathrm{C}_{\mathrm{q}}\right), 133.6(\mathrm{CH}), 131.1(\mathrm{CH}), 129.8(\mathrm{CH}), 128.5(\mathrm{CH}), 126.4\left(\mathrm{C}_{\mathrm{q}}\right), 121.7(\mathrm{CH})$, $62.0\left(\mathrm{dd},{ }^{2} J_{\mathrm{C}-\mathrm{P}}=48.9,6.5 \mathrm{~Hz}, \mathrm{CH}_{2}\right), 56.9\left({ }^{2} J_{\mathrm{C}-\mathrm{P}}=1.6 \mathrm{~Hz}, \mathrm{CH}\right), 31.5\left({ }^{1} J_{\mathrm{C}-\mathrm{P}}=139.6 \mathrm{~Hz}, \mathrm{CH}_{2}\right)$, $21.8\left(\mathrm{CH}_{3}\right), 17.7\left(\mathrm{CH}_{3}\right), 16.2\left({ }^{3} J_{\mathrm{C}-\mathrm{P}}=18.0,6.2 \mathrm{~Hz}, \mathrm{CH}_{3}\right)$.

IR (ATR): $\tilde{v}=2990,2930,1715,1362,1311,1173,1093,1022,943,817 \mathrm{~cm}^{-1}$.

MS (ESI) $m / z$ (relative intensity): 474 (100) $\left[\mathrm{M}+\mathrm{Na}^{+}\right], 452(67)\left[\mathrm{M}+\mathrm{H}^{+}\right]$.

HR-MS (ESI) $\mathrm{m} / \mathrm{z}$ calcd for $\mathrm{C}_{21} \mathrm{H}_{27} \mathrm{NO}_{6} \mathrm{PS}$, [M+H'] 452.1289, found 452.1291.

\section{Synthesis of 7-Methyl-3-(2-oxopropyl)-2-tosylisoindolin-1-one 136bj}

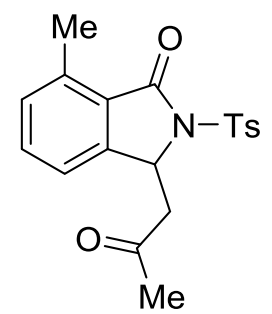

The general procedure $\mathbf{F}$ was followed using 3-methyl- $N$-tosylbenzamide (135b) $(289.3 \mathrm{mg}$, $1.00 \mathrm{mmol})$, methyl vinylketone $(\mathbf{1 7 j})(67.0 \mathrm{mg}, 1.05 \mathrm{mmol}),\left[\operatorname{RuCl}_{2}(p \text {-cymene })\right]_{2}(6.1 \mathrm{mg}$, $1.0 \mathrm{~mol} \%)$ and $\mathrm{Cu}(\mathrm{OAc})_{2} \cdot \mathrm{H}_{2} \mathrm{O} \quad(419.3 \mathrm{mg}, 2.10 \mathrm{mmol})$. Purification by column chromatography ( $n$-hexane/EtOAc $6 / 1)$ yielded 136bj (89 mg, $25 \%$ ) as a colorless solid.

M.r.: $169-172{ }^{\circ} \mathrm{C}$.

${ }^{1} \mathrm{H}-\mathrm{NMR}\left(300 \mathrm{MHz}, \mathrm{CDCl}_{3}\right): \delta=7.97(\mathrm{~d}, J=8.4 \mathrm{~Hz}, 2 \mathrm{H}), 7.42(\mathrm{dd}, J=8.4 \mathrm{~Hz}, 1 \mathrm{H}), 7.35-7.30$ (m, 2H), 7.23-715 (m, 2H), $5.61(\mathrm{dd}, J=8.5,2.9,0.7 \mathrm{~Hz}, 1 \mathrm{H}), 3.77$ (dd, $J=18.0,2.9 \mathrm{~Hz}, 2 \mathrm{H}$ ), 3.77 (dd, $J=18.0,2.9 \mathrm{~Hz}, 1 \mathrm{H}), 2.90$ (dd, $J=18.0,8.5 \mathrm{~Hz}, 1 \mathrm{H}), 2.57$ (s, 3H), $2.40(\mathrm{~s}, 3 \mathrm{H})$, $2.22(\mathrm{~s}, 3 \mathrm{H})$. 
${ }^{13}$ C-NMR $\left(75 \mathrm{MHz}, \mathrm{CDCl}_{3}\right): \delta=205.3\left(\mathrm{C}_{\mathrm{q}}\right), 167.0\left(\mathrm{C}_{\mathrm{q}}\right), 146.9\left(\mathrm{C}_{\mathrm{q}}\right), 145.1\left(\mathrm{C}_{\mathrm{q}}\right), 139.6\left(\mathrm{C}_{\mathrm{q}}\right)$, $135.7\left(\mathrm{C}_{\mathrm{q}}\right), 133.9(\mathrm{CH}), 130.9(\mathrm{CH}), 129.7(\mathrm{CH}), 128.3(\mathrm{CH}), 126.0\left(\mathrm{C}_{\mathrm{q}}\right), 120.6(\mathrm{CH}), 57.0$ $(\mathrm{CH}), 49.2\left(\mathrm{CH}_{2}\right), 30.8\left(\mathrm{CH}_{3}\right), 21.9\left(\mathrm{CH}_{3}\right), 17.8\left(\mathrm{CH}_{3}\right)$.

IR (ATR): $\tilde{v}=3097,3033,2927,1727,1704,1351,1164,1104,821,782 \mathrm{~cm}^{-1}$.

MS (ESI) m/z (relative intensity): 396 (98) [M+K $]$, 391 (100) $\left[\mathrm{M}+\mathrm{Na}^{+}\right], 358(44)\left[\mathrm{M}+\mathrm{H}^{+}\right]$.

HR-MS (ESI) $m / z$ calcd for $\mathrm{C}_{19} \mathrm{H}_{20} \mathrm{NO}_{4} \mathrm{~S},\left[\mathrm{M}+\mathrm{H}^{+}\right]$358.1108, found 358.1105.

\section{Synthesis of Ethyl 2-(4-methoxy-3-oxo-2-tosylisoindolin-1-yl)acetate 136dc}<smiles>CCOC(=O)CC1c2cccc(OC)c2C(=O)N1[AsH3-]</smiles>

The general procedure $\mathbf{F}$ was followed using 2-methoxy- $N$-tosylbenzamide (135d) $(305.3 \mathrm{mg}, 1.00 \mathrm{mmol})$, ethyl acrylate $(17 \mathrm{c})(114.0 \mathrm{mg}, 1.05 \mathrm{mmol}),\left[\mathrm{RuCl}_{2}(p \text {-cymene })\right]_{2}$ $(30.5 \mathrm{mg}, 5.0 \mathrm{~mol} \%)$ and $\mathrm{Cu}(\mathrm{OAc})_{2} \cdot \mathrm{H}_{2} \mathrm{O}(419.3 \mathrm{mg}, 2.10 \mathrm{mmol})$. Purification by column chromatography ( $n$-hexane/EtOAc $4 / 1)$ yielded $136 \mathrm{dc}(210 \mathrm{mg}, 52 \%)$ as a colorless solid.

M.r.: $120-122^{\circ} \mathrm{C}$.

${ }^{1} \mathrm{H}-\mathrm{NMR}\left(300 \mathrm{MHz}, \mathrm{CDCl}_{3}\right): \delta=8.03(\mathrm{~d}, J=8.4 \mathrm{~Hz}, 2 \mathrm{H}), 7.54(\mathrm{dd}, J=8.3,7.7 \mathrm{~Hz}, 1 \mathrm{H})$, 7.37-7.28 (m, 2H), $7.01(\mathrm{~d}, J=7.7 \mathrm{~Hz}, 1 \mathrm{H}), 6.87(\mathrm{~d}, J=8.4 \mathrm{~Hz}, 1 \mathrm{H}), 5.53(\mathrm{dd}, J=7.9$, $3.4 \mathrm{~Hz}, 1 \mathrm{H}$ ), 4.09 (q, $J=7.1 \mathrm{~Hz}, 2 \mathrm{H}), 3.91(\mathrm{~s}, 3 \mathrm{H}), 3.47$ (dd, $J=16.5,3.4 \mathrm{~Hz}, 1 \mathrm{H}$ ), 2.91 (dd, $J=16.5,8.0 \mathrm{~Hz}, 1 \mathrm{H}), 2.40(\mathrm{~s}, 3 \mathrm{H}), 1.17(\mathrm{t}, J=7.1 \mathrm{~Hz}, 3 \mathrm{H})$.

${ }^{13}$ C-NMR $\left(125 \mathrm{MHz}, \mathrm{CDCl}_{3}\right): \delta=169.8\left(\mathrm{C}_{\mathrm{q}}\right), 164.7\left(\mathrm{C}_{\mathrm{q}}\right), 158.5\left(\mathrm{C}_{\mathrm{q}}\right), 147.9\left(\mathrm{C}_{\mathrm{q}}\right), 145.0\left(\mathrm{C}_{\mathrm{q}}\right)$, $136.1(\mathrm{CH}), 135.9\left(\mathrm{C}_{\mathrm{q}}\right), 129.6(\mathrm{CH}), 128.6(\mathrm{CH}), 116.6\left(\mathrm{C}_{\mathrm{q}}\right), 114.7(\mathrm{CH}), 111.0(\mathrm{CH}), 61.1$ $\left(\mathrm{CH}_{2}\right), 57.5(\mathrm{CH}), 56.1\left(\mathrm{CH}_{3}\right), 39.8\left(\mathrm{CH}_{2}\right), 21.9\left(\mathrm{CH}_{3}\right), 13.9\left(\mathrm{CH}_{3}\right)$.

IR (ATR): $\tilde{v}=2987,2944,2247,1742,1710,1597,1487,1378,1184,1168 \mathrm{~cm}^{-1}$.

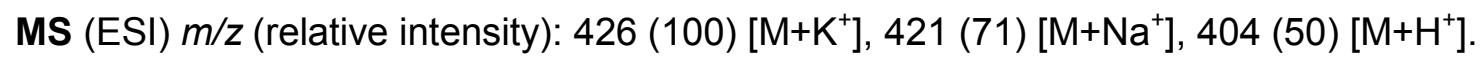

HR-MS (ESI) $m / z$ calcd for $\mathrm{C}_{20} \mathrm{H}_{22} \mathrm{NO}_{6} \mathrm{~S}$, $\left[\mathrm{M}+\mathrm{H}^{+}\right]$404.1162, found 404.1159. 
Synthesis of Ethyl 2-(1-oxo-2-tosyl-2,3-dihydro-1H-benzo[e]isoindol-3-yl)acetate 136ec<smiles>CCOC(=O)CC1c2ccc3ccccc3c2C(=O)N1[13F]</smiles>

The general procedure $\mathbf{F}$ was followed using $N$-tosyl-1-naphtamide (135e) (325.4 mg, $1.00 \mathrm{mmol})$, ethyl acrylate (17c) $(114.0 \mathrm{mg}, 1.05 \mathrm{mmol}),\left[\mathrm{RuCl}_{2}(p-c y m e n e)\right]_{2}(30.5 \mathrm{mg}$, $5.0 \mathrm{~mol} \%)$ and $\mathrm{Cu}(\mathrm{OAc})_{2} \cdot \mathrm{H}_{2} \mathrm{O} \quad(419.3 \mathrm{mg}, \quad 2.10 \mathrm{mmol})$. Purification by column chromatography ( $n$-hexane/EtOAc $4 / 1)$ yielded $136 \mathrm{ec}(288 \mathrm{mg}, 68 \%)$ as a colorless solid.

M.p.: $149^{\circ} \mathrm{C}$.

${ }^{1} \mathrm{H}-\mathrm{NMR}\left(300 \mathrm{MHz}, \mathrm{CDCl}_{3}\right): \delta=9.02(\mathrm{~d}, J=7.6 \mathrm{~Hz}, 1 \mathrm{H}), 8.08(\mathrm{~d}, J=8.4 \mathrm{~Hz}, 3 \mathrm{H}), 7.90(\mathrm{dd}$, $J=8.5,1.2 \mathrm{~Hz}, 1 \mathrm{H}), 7.69-7.48(\mathrm{~m}, 3 \mathrm{H}), 7.34(\mathrm{~d}, J=7.9 \mathrm{~Hz}, 2 \mathrm{H}), 5.68(\mathrm{dd}, J=7.8,3.5 \mathrm{~Hz}$, $1 \mathrm{H}), 4.09$ (q, $J=7.1 \mathrm{~Hz}, 2 \mathrm{H}), 3.59(\mathrm{dd}, J=16.5,3.5 \mathrm{~Hz}, 1 \mathrm{H}), 3.02(\mathrm{dd}, J=16.5,7.8 \mathrm{~Hz}, 1 \mathrm{H})$, $2.42(\mathrm{~s}, 3 \mathrm{H}), 1.14(\mathrm{t}, J=7.3 \mathrm{~Hz}, 3 \mathrm{H})$.

${ }^{13}$ C-NMR $\left(75 \mathrm{MHz}, \mathrm{CDCl}_{3}\right): \delta=170.0\left(\mathrm{C}_{\mathrm{q}}\right), 167.3\left(\mathrm{C}_{\mathrm{q}}\right), 146.9\left(\mathrm{C}_{\mathrm{q}}\right), 145.3\left(\mathrm{C}_{\mathrm{q}}\right), 136.0\left(\mathrm{C}_{\mathrm{q}}\right)$, $135.7(\mathrm{CH}), 133.4\left(\mathrm{C}_{\mathrm{q}}\right), 129.8(\mathrm{CH}), 129.3\left(\mathrm{C}_{\mathrm{q}}\right), 129.2(\mathrm{CH}), 128.5(\mathrm{CH}), 128.5(\mathrm{CH}), 127.5$ $(\mathrm{CH}), 123.9(\mathrm{CH}), 123.3\left(\mathrm{C}_{\mathrm{q}}\right), 119.6(\mathrm{CH}), 61.2\left(\mathrm{CH}_{2}\right), 58.0(\mathrm{CH}), 39.2\left(\mathrm{CH}_{2}\right), 21.8\left(\mathrm{CH}_{3}\right), 14.2$ $\left(\mathrm{CH}_{3}\right)$.

IR (ATR): $\tilde{v}=2966,1721,1360,1324,1165,1113,1092,817,793,772 \mathrm{~cm}^{-1}$.

MS (ESI) $m / z$ (relative intensity): $446\left[\mathrm{M}+\mathrm{K}^{+}\right]$(100), 441 (33) $\left[\mathrm{M}+\mathrm{Na}^{+}\right], 424$ (22) $\left[\mathrm{M}+\mathrm{H}^{+}\right]$.

HR-MS (ESI) $\mathrm{m} / \mathrm{z}$ calcd for $\mathrm{C}_{23} \mathrm{H}_{22} \mathrm{NO}_{5} \mathrm{~S}$, [M+H'] 424.1210, found 424.1213.

\section{Synthesis of $n$-Butyl 2-(1-oxo-2-tosyl-2,3-dihydro-1H-benzo[e]isoindol-3-yl)acetate} 136 ee

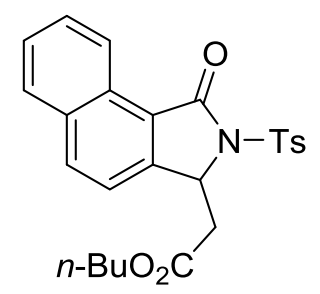

The general procedure $\mathbf{F}$ was followed using $N$-tosyl-1-naphtamide (135e) (325.4 mg, $1.00 \mathrm{mmol}), n$-butyl acrylate (17e) $(138.0 \mathrm{mg}, 1.05 \mathrm{mmol}),\left[\mathrm{RuCl}_{2}(p \text {-cymene })\right]_{2}(15.3 \mathrm{mg}$, 
$2.5 \mathrm{~mol} \%)$ and $\mathrm{Cu}(\mathrm{OAc})_{2} \cdot \mathrm{H}_{2} \mathrm{O} \quad(419.3 \mathrm{mg}, \quad 2.10 \mathrm{mmol})$. Purification by column chromatography ( $n$-hexane/EtOAc $4 / 1$ ) yielded $136 \mathrm{ee}(262 \mathrm{mg}, 58 \%)$ as a colorless solid.

M.r.: $127-130^{\circ} \mathrm{C}$.

${ }^{1} \mathrm{H}-\mathrm{NMR}\left(300 \mathrm{MHz}, \mathrm{CDCl}_{3}\right): \delta=9.01(\mathrm{~d}, J=7.6 \mathrm{~Hz}, 1 \mathrm{H}), 8.08(\mathrm{~d}, J=8.3 \mathrm{~Hz}, 3 \mathrm{H}), 7.90(\mathrm{~d}$, $J=7.4 \mathrm{~Hz}, 1 \mathrm{H}), 7.69-7.57(\mathrm{~m}, 2 \mathrm{H}), 7.53(\mathrm{~d}, J=8.5 \mathrm{~Hz}, 1 \mathrm{H}), 7.34(\mathrm{~d}, J=8.0 \mathrm{~Hz}, 2 \mathrm{H}), 5.67$ (dd, $J=7.8,3.5 \mathrm{~Hz}, 1 \mathrm{H}$ ), 4.02 (q, $J=7.5 \mathrm{~Hz}, 2 \mathrm{H}$ ), 3.59 (dd, $J=16.5,3.5 \mathrm{~Hz}, 1 \mathrm{H}$ ), 3.04 (dd, $J=16.5,7.8 \mathrm{~Hz} 1 \mathrm{H}), 2.41(\mathrm{~s}, 3 \mathrm{H}), 1.53-1.32(\mathrm{~m}, 2 \mathrm{H}), 1,32-1.05(\mathrm{~m}, 2 \mathrm{H}), 0.82(\mathrm{t}, J=7.3 \mathrm{~Hz}$, $3 \mathrm{H})$.

${ }^{13}$ C-NMR $\left(75 \mathrm{MHz}, \mathrm{CDCl}_{3}\right): \delta=170.1\left(\mathrm{C}_{\mathrm{q}}\right), 167.3\left(\mathrm{C}_{\mathrm{q}}\right), 146.9\left(\mathrm{C}_{\mathrm{q}}\right), 145.3\left(\mathrm{C}_{\mathrm{q}}\right), 136.0\left(\mathrm{C}_{\mathrm{q}}\right)$, $135.7(\mathrm{CH}), 133.4\left(\mathrm{C}_{\mathrm{q}}\right), 129.8(\mathrm{CH}), 129.7(\mathrm{CH}), 129.3\left(\mathrm{C}_{\mathrm{q}}\right), 129.2(\mathrm{CH}), 128.5(\mathrm{CH}), 127.5$ $(\mathrm{CH}), 123.9(\mathrm{CH}), 123.3\left(\mathrm{C}_{\mathrm{q}}\right), 119.6(\mathrm{CH}), 65.2\left(\mathrm{CH}_{2}\right), 58.0(\mathrm{CH}), 39.1\left(\mathrm{CH}_{2}\right), 30.6\left(\mathrm{CH}_{2}\right), 21.8$ $\left(\mathrm{CH}_{3}\right), 19.1\left(\mathrm{CH}_{2}\right), 13.7\left(\mathrm{CH}_{3}\right)$.

IR (ATR): $\tilde{v}=2961,1729,1706,1354,1339,1170,1092,965,769,663 \mathrm{~cm}^{-1}$.

MS (El) m/z (relative intensity): 451 (1) $\left[\mathrm{M}^{+}\right], 387$ (35), 336 (14), 296 (100), 286 (46), 240 (12), 196 (55), 155 (32), 126 (22), 91 (86), 65 (16), 57 (31).

HR-MS (ESI) $m / z$ calcd for $\mathrm{C}_{25} \mathrm{H}_{26} \mathrm{NO}_{5} \mathrm{~S}$, $\left[\mathrm{M}+\mathrm{H}^{+}\right]$452.1526, found 452.1526 .

\section{Synthesis of Ethyl 2-(4-nitro-3-oxo-2-tosylisonidolin-1-yl)acetate 136fc}

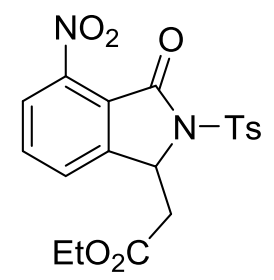

The general procedure $F$ was followed using 2-nitro- $N$-tosylbenzamide (135f) $(320.0 \mathrm{mg}$, $1.00 \mathrm{mmol}$ ), ethyl acrylate (17c) $(114.0 \mathrm{mg}, 1.05 \mathrm{mmol}),\left[\mathrm{RuCl}_{2}(p \text {-cymene })\right]_{2}(30.5 \mathrm{mg}$, $5.0 \mathrm{~mol} \%)$ and $\mathrm{Cu}(\mathrm{OAc})_{2} \cdot \mathrm{H}_{2} \mathrm{O} \quad(419.3 \mathrm{mg}, 2.10 \mathrm{mmol})$. Purification by column chromatography ( $n$-hexane/EtOAc 4/1) yielded $136 \mathrm{fc}(247 \mathrm{mg}, 59 \%)$ as a colorless solid.

M.r.: $151-152^{\circ} \mathrm{C}$.

${ }^{1} \mathrm{H}-\mathrm{NMR}\left(300 \mathrm{MHz}, \mathrm{CDCl}_{3}\right): \delta=8.02(\mathrm{~d}, \mathrm{~J}=8.4 \mathrm{~Hz}, 2 \mathrm{H}), 7.40-7.29(\mathrm{~m}, 3 \mathrm{H}), 7.22-7.09(\mathrm{~m}$, $2 \mathrm{H}$ ), $5.52(\mathrm{dd}, J=8.3,3.3 \mathrm{~Hz}, 1 \mathrm{H}), 4.08(\mathrm{q}, J=7.1 \mathrm{~Hz}, 2 \mathrm{H}), 3.80(\mathrm{~s}, 3 \mathrm{H}), 3.52(\mathrm{dd}, J=16.5$, $3.4 \mathrm{~Hz}, 1 \mathrm{H}), 2.88$ (dd, $J=16.5,8.2 \mathrm{~Hz}, 1 \mathrm{H}), 2.41(\mathrm{~s}, 3 \mathrm{H}), 1.17(\mathrm{t}, J=7.1 \mathrm{~Hz}, 3 \mathrm{H})$.

${ }^{13} \mathrm{C}-N M R\left(125 \mathrm{MHz}, \mathrm{CDCl}_{3}\right): \delta=169.8\left(\mathrm{C}_{\mathrm{q}}\right), 166.4\left(\mathrm{C}_{\mathrm{q}}\right), 160.6\left(\mathrm{C}_{\mathrm{q}}\right), 145.2\left(\mathrm{C}_{\mathrm{q}}\right), 137.7\left(\mathrm{C}_{\mathrm{q}}\right)$, $135.8\left(\mathrm{C}_{\mathrm{q}}\right), 130.6\left(\mathrm{C}_{\mathrm{q}}\right), 129.7(\mathrm{CH}), 128.4(\mathrm{CH}), 124.1(\mathrm{CH}), 122.9(\mathrm{CH}), 107.0(\mathrm{CH}), 61.1$ $\left(\mathrm{CH}_{2}\right), 58.3(\mathrm{CH}), 39.6\left(\mathrm{CH}_{2}\right), 21.9\left(\mathrm{CH}_{3}\right), 14.3\left(\mathrm{CH}_{3}\right)$. 
IR (ATR): $\tilde{v}=3093,2988,1729,1533,1359,1317,1168,1104,830,725 \mathrm{~cm}^{-1}$.

MS (ESI) $m / z$ (relative intensity): 457 (91) [M+K $\left.{ }^{+}\right], 441$ (100) $\left[\mathrm{M}+\mathrm{Na}^{+}\right], 419$ (33) $\left[\mathrm{M}+\mathrm{H}^{+}\right]$.

HR-MS (ESI) $\mathrm{m} / \mathrm{z}$ calcd for $\mathrm{C}_{19} \mathrm{H}_{19} \mathrm{~N}_{2} \mathrm{O}_{7} \mathrm{~S}$, [M+H'] 419.0907, found 419.0909.

\section{Synthesis of $n$-Butyl 2-(4-nitro-3-oxo-2-tosylisonidolin-1-yl)acetate 136fe}<smiles>CCCCCCC1c2cccc([N+](=O)[O-])c2C(=O)N1[AsH3-]</smiles>

The general procedure $\mathbf{F}$ was followed using 2-nitro- $N$-tosylbenzamide (135f) $(320.0 \mathrm{mg}$, $1.00 \mathrm{mmol}), n$-butyl acrylate (17) $(138.0 \mathrm{mg}, 1.05 \mathrm{mmol}),\left[\operatorname{RuCl}_{2}(p \text {-cymene })\right]_{2}$ (30.5 mg, $5.0 \mathrm{~mol} \%)$ and $\mathrm{Cu}(\mathrm{OAc})_{2} \cdot \mathrm{H}_{2} \mathrm{O} \quad(419.3 \mathrm{mg}, 2.10 \mathrm{mmol})$. Purification by column chromatography ( $n$-hexane/EtOAc 4/1) yielded $136 \mathrm{f}(210 \mathrm{mg}, 47 \%)$ as a colorless solid.

M.r.: $107-110^{\circ} \mathrm{C}$.

${ }^{1} \mathrm{H}-\mathrm{NMR}\left(300 \mathrm{MHz}, \mathrm{CDCl}_{3}\right): \delta=8.02(\mathrm{~d}, J=8.4 \mathrm{~Hz}, 2 \mathrm{H}), 7.77(\mathrm{~s}, 3 \mathrm{H}), 7.34(\mathrm{~d}, J=8.2 \mathrm{~Hz}$, $2 \mathrm{H}), 5.62(\mathrm{dd}, J=7.8,3.1 \mathrm{~Hz}, 1 \mathrm{H}), 3.98(\mathrm{t}, J=6.8 \mathrm{~Hz}, 2 \mathrm{H}), 3.53(\mathrm{dd}, J=17.0,3.2 \mathrm{~Hz}, 1 \mathrm{H})$, $3.07(\mathrm{dd}, J=17.0,7.8 \mathrm{~Hz}, 1 \mathrm{H}), 2.43(\mathrm{~s}, 3 \mathrm{H}), 1.58-1.41(\mathrm{~m}, 2 \mathrm{H}), 1.33-1.16(\mathrm{~m}, 2 \mathrm{H}), 0.88(\mathrm{t}$, $J=7.3 \mathrm{~Hz}, 3 \mathrm{H})$.

${ }^{13} \mathrm{C}-\mathrm{NMR}\left(125 \mathrm{MHz}, \mathrm{CDCl}_{3}\right): \delta=169.5\left(\mathrm{C}_{\mathrm{q}}\right), 161.2\left(\mathrm{C}_{\mathrm{q}}\right), 147.7\left(\mathrm{C}_{\mathrm{q}}\right), 147.0\left(\mathrm{C}_{\mathrm{q}}\right), 145.9\left(\mathrm{C}_{\mathrm{q}}\right)$, $135.0\left(\mathrm{C}_{\mathrm{q}}\right), 134.9(\mathrm{CH}), 129.9(\mathrm{CH}), 128.8(\mathrm{CH}), 127.2(\mathrm{CH}), 124.0(\mathrm{CH}), 121.7\left(\mathrm{C}_{\mathrm{q}}\right), 65.4$ $\left(\mathrm{CH}_{2}\right), 57.4(\mathrm{CH}), 38.7\left(\mathrm{CH}_{2}\right), 30.5\left(\mathrm{CH}_{2}\right), 21.9\left(\mathrm{CH}_{3}\right), 19.1\left(\mathrm{CH}_{2}\right), 13.7\left(\mathrm{CH}_{3}\right)$.

IR (ATR): $\tilde{v}=2976,2936,2873,1716,1596,1399,1347,1193,1104,1063 \mathrm{~cm}^{-1}$.

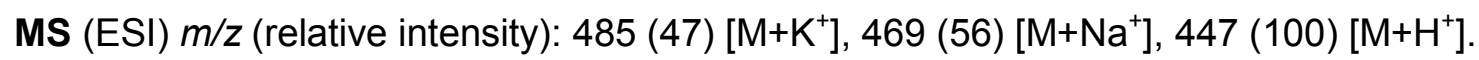

HR-MS (ESI) $m / z$ calcd for $\mathrm{C}_{21} \mathrm{H}_{23} \mathrm{~N}_{2} \mathrm{O}_{7} \mathrm{~S}$, $\left[\mathrm{M}+\mathrm{H}^{+}\right]$447.1220, found 447.1223.

\section{Synthesis of Ethyl 2-(4-chloro-3-oxo-2-tosylisoindolin-1-yl)acetate 136gc}<smiles>CCOC(=O)CC1c2cccc(Cl)c2C(=O)N1[13F]</smiles>

The general procedure $\mathbf{F}$ was followed using 2-chloro- $N$-tosylbenzamide $(\mathbf{1 3 5 g})(309.3 \mathrm{mg}$, $1.00 \mathrm{mmol})$, ethyl acrylate $(\mathbf{1 7 c})(300.0 \mathrm{mg}, 3.00 \mathrm{mmol}),\left[\operatorname{RuCl}_{2}(p-c y m e n e)\right]_{2}(30.5 \mathrm{mg}$, 
$5.0 \mathrm{~mol} \%)$ and $\mathrm{Cu}(\mathrm{OAc})_{2} \cdot \mathrm{H}_{2} \mathrm{O} \quad(419.3 \mathrm{mg}, 2.10 \mathrm{mmol})$. Purification by column chromatography ( $n$-hexane/EtOAc $4 / 1)$ yielded $136 \mathrm{gc}(245 \mathrm{mg}, 60 \%)$ as a colorless solid.

M.r.: $124-125^{\circ} \mathrm{C}$.

${ }^{1} \mathrm{H}-\mathrm{NMR}\left(500 \mathrm{MHz}, \mathrm{CDCl}_{3}\right): \delta=8.04(\mathrm{~d}, J=8.4 \mathrm{~Hz}, 2 \mathrm{H}), 7.52(\mathrm{dd}, J=8.2,7.5 \mathrm{~Hz}, 1 \mathrm{H})$, 7.42-7.38 (m, 2H), 7.35-7.31 (m, 2H), 5.62-5.47 (m, 1H), $4.03(\mathrm{q}, J=7.1 \mathrm{~Hz}, 2 \mathrm{H})$, 3.47-3.41 (m, 1H), 2.99 (dd, $J=16.7,7.7 \mathrm{~Hz}, 1 \mathrm{H}), 2.41(\mathrm{~s}, 3 \mathrm{H}), 1.13(\mathrm{t}, J=7.2 \mathrm{~Hz}, 3 \mathrm{H})$.

${ }^{13} \mathrm{C}$-NMR $\left(125 \mathrm{MHz}, \mathrm{CDCl}_{3}\right): \delta=169.5\left(\mathrm{C}_{\mathrm{q}}\right), 164.0\left(\mathrm{C}_{\mathrm{q}}\right), 147.7\left(\mathrm{C}_{\mathrm{q}}\right), 145.5\left(\mathrm{C}_{\mathrm{q}}\right), 135.6\left(\mathrm{C}_{\mathrm{q}}\right)$, $134.9(\mathrm{CH}), 133.0\left(\mathrm{C}_{\mathrm{q}}\right), 131.0(\mathrm{CH}), 129.8(\mathrm{CH}), 128.7(\mathrm{CH}), 125.7\left(\mathrm{C}_{\mathrm{q}}\right), 121.5(\mathrm{CH}), 61.2$ $\left(\mathrm{CH}_{2}\right), 57.1(\mathrm{CH}), 39.1\left(\mathrm{CH}_{2}\right), 21.8\left(\mathrm{CH}_{3}\right), 14.1\left(\mathrm{CH}_{3}\right)$.

IR (ATR): $\tilde{v}=3091,2982,1728,1600,1498,1380,1363,1210,1118,816 \mathrm{~cm}^{-1}$.

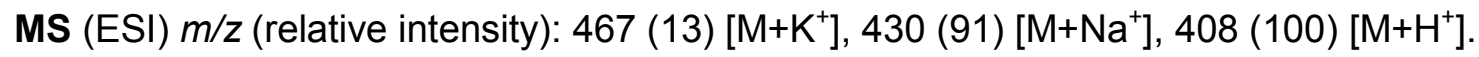

HR-MS (ESI) $m / z$ calcd for $\mathrm{C}_{19} \mathrm{H}_{19} \mathrm{CINO}_{5} \mathrm{~S}$, [M+H+ $\left.{ }^{+}\right]$408.0667, found 408.0662.

\section{Synthesis of Ethyl 2-(5-methyl-3-oxo-2-tosylisondolin-1-yl)acetate 136hc}<smiles>CCOCCC1c2ccc(C)cc2C(=O)N1[AsH3-]</smiles>

The general procedure F was followed using 3-methyl- $N$-tosylbenzamide (135h) $(289.3 \mathrm{mg}$, $1.00 \mathrm{mmol})$, ethyl acrylate $(\mathbf{1 7 c})(114.0 \mathrm{mg}, 1.05 \mathrm{mmol}),\left[\mathrm{RuCl}_{2}(p \text {-cymene })\right]_{2}(6.1 \mathrm{mg}$, $1.0 \mathrm{~mol} \%)$ and $\mathrm{Cu}(\mathrm{OAc})_{2} \cdot \mathrm{H}_{2} \mathrm{O} \quad(419.3 \mathrm{mg}, 2.10 \mathrm{mmol})$. Purification by column chromatography ( $n$-hexane/EtOAc 6/1) yielded 136hc (244 mg, 63\%) as a colorless solid.

M.r.: $154-156{ }^{\circ} \mathrm{C}$.

${ }^{1} \mathrm{H}-\mathrm{NMR}\left(300 \mathrm{MHz}, \mathrm{CDCl}_{3}\right): \delta=8.02(\mathrm{~d}, J=8.4 \mathrm{~Hz}, 2 \mathrm{H}), 7.56(\mathrm{~s}, 1 \mathrm{H}), 7.44-7.29(\mathrm{~m}, 4 \mathrm{H})$, $5.55(\mathrm{dd}, J=8.1,3.4 \mathrm{~Hz}, 1 \mathrm{H}), 4.08(\mathrm{q}, J=7.1 \mathrm{~Hz}, 2 \mathrm{H}), 3.52(\mathrm{dd}, J=16.5,3.4 \mathrm{~Hz}, 1 \mathrm{H}$ ), 2.90 (dd, $J=16.5,8.1 \mathrm{~Hz}, 1 \mathrm{H}), 2.41(\mathrm{~s}, 3 \mathrm{H}), 2.29(\mathrm{~s}, 3 \mathrm{H}), 1.17(\mathrm{t}, J=7.1 \mathrm{~Hz}, 3 \mathrm{H})$.

${ }^{13} \mathrm{C}-N M R\left(75 \mathrm{MHz}, \mathrm{CDCl}_{3}\right): \delta=170.0\left(\mathrm{C}_{\mathrm{q}}\right), 166.6\left(\mathrm{C}_{\mathrm{q}}\right), 145.3\left(\mathrm{C}_{\mathrm{q}}\right), 142.8\left(\mathrm{C}_{\mathrm{q}}\right), 139.6\left(\mathrm{C}_{\mathrm{q}}\right)$, $135.9\left(\mathrm{C}_{\mathrm{q}}\right), 135.5(\mathrm{CH}), 129.7(\mathrm{CH}), 129.5\left(\mathrm{C}_{\mathrm{q}}\right), 128.4(\mathrm{CH}), 125.1(\mathrm{CH}), 122.9(\mathrm{CH}), 61.1$ $\left(\mathrm{CH}_{2}\right), 58.4(\mathrm{CH}), 39.6\left(\mathrm{CH}_{2}\right), 21.8\left(\mathrm{CH}_{3}\right), 21.4\left(\mathrm{CH}_{3}\right), 14.2\left(\mathrm{CH}_{3}\right)$.

IR (ATR): $\tilde{v}=2976,2943,1725,1355,1302,1165,1151,1082,816,659 \mathrm{~cm}^{-1}$.

MS (ESI) $m / z$ (relative intensity): $426(90)\left[\mathrm{M}+\mathrm{K}^{+}\right], 410$ (77) $\left[\mathrm{M}+\mathrm{Na}^{+}\right], 388(100)\left[\mathrm{M}+\mathrm{H}^{+}\right]$.

HR-MS (ESI) $\mathrm{m} / \mathrm{z}$ calcd for $\mathrm{C}_{20} \mathrm{H}_{22} \mathrm{NO}_{5} \mathrm{~S},\left[\mathrm{M}+\mathrm{H}^{+}\right]$388.1213, found 388.1213. 


\section{Synthesis of $n$-Butyl 2-(5-methyl-3-oxo-2-tosylindolin-1-yl)acetate 136he}<smiles>CCCCCC1c2ccc(C)cc2C(=O)N1[13S]</smiles>

The general procedure $\mathbf{F}$ was followed using 3-methyl- $N$-tosylbenzamide (135h) $(289.3 \mathrm{mg}$, $1.00 \mathrm{mmol}), n$-butyl acrylate (17e) $(138.0 \mathrm{mg}, 1.05 \mathrm{mmol}),\left[\operatorname{RuCl}_{2}(p \text {-cymene })\right]_{2}(6.1 \mathrm{mg}$, $1.0 \mathrm{~mol} \%)$ and $\mathrm{Cu}(\mathrm{OAc})_{2} \cdot \mathrm{H}_{2} \mathrm{O} \quad(419.3 \mathrm{mg}, 2.10 \mathrm{mmol})$. Purification by column chromatography ( $n$-hexane/EtOAc 6/1) yielded 136he (248 mg, 60\%) as a colorless solid.

M.p.: $106^{\circ} \mathrm{C}$.

${ }^{1} \mathrm{H}-\mathrm{NMR}\left(300 \mathrm{MHz}, \mathrm{CDCl}_{3}\right): \delta=8.02(\mathrm{~d}, J=8.4 \mathrm{~Hz}, 2 \mathrm{H}), 7.56(\mathrm{~s}, 1 \mathrm{H}), 7.44-7.29(\mathrm{~m}, 4 \mathrm{H})$, $5.54(\mathrm{dd}, J=8.1,3.4 \mathrm{~Hz}, 1 \mathrm{H}), 4.02(\mathrm{td}, J=6.7,0.9 \mathrm{~Hz}, 2 \mathrm{H}), 3.52(\mathrm{dd}, J=16.5,3.4 \mathrm{~Hz}, 1 \mathrm{H}$ ), $2.91(\mathrm{dd}, J=16.5,8.1 \mathrm{~Hz}, 1 \mathrm{H}), 2.40(\mathrm{~s}, 3 \mathrm{H}), 2.29(\mathrm{~s}, 3 \mathrm{H}), 1.63-1.41(\mathrm{~m}, 2 \mathrm{H}), 1.38-1.15(\mathrm{~m}$, $2 \mathrm{H}), 0.89(\mathrm{t}, J=7.3 \mathrm{~Hz}, 3 \mathrm{H})$.

${ }^{13}$ C-NMR $\left(125 \mathrm{MHz}, \mathrm{CDCl}_{3}\right): \delta=170.0\left(\mathrm{C}_{\mathrm{q}}\right), 166.6\left(\mathrm{C}_{\mathrm{q}}\right), 145.2\left(\mathrm{C}_{\mathrm{q}}\right), 142.8\left(\mathrm{C}_{\mathrm{q}}\right), 139.6\left(\mathrm{C}_{\mathrm{q}}\right)$, $135.9\left(\mathrm{C}_{\mathrm{q}}\right), 135.5(\mathrm{CH}), 129.7(\mathrm{CH}), 129.5\left(\mathrm{C}_{\mathrm{q}}\right), 128.4(\mathrm{CH}), 125.0(\mathrm{CH}), 122.9(\mathrm{CH}), 65.0$ $\left(\mathrm{CH}_{2}\right), 58.4(\mathrm{CH}), 39.5\left(\mathrm{CH}_{2}\right), 30.5\left(\mathrm{CH}_{2}\right), 21.8\left(\mathrm{CH}_{3}\right), 21.3\left(\mathrm{CH}_{3}\right), 19.1\left(\mathrm{CH}_{2}\right), 13.8\left(\mathrm{CH}_{3}\right)$.

IR (ATR): $\tilde{v}=2962,1722,1353,1309,1161,1090,811,691,576,544 \mathrm{~cm}^{-1}$.

MS (ESI) $m / z$ (relative intensity): 454 (100) [M+K $\left.{ }^{+}\right], 438$ (74) $\left[\mathrm{M}+\mathrm{Na}^{+}\right], 416(74)\left[\mathrm{M}+\mathrm{H}^{+}\right]$.

HR-MS (ESI) $\mathrm{m} / \mathrm{z}$ calcd for $\mathrm{C}_{22} \mathrm{H}_{26} \mathrm{NO}_{5} \mathrm{~S}$, [M+H'] 416.1526, found 416.1528.

\section{Synthesis of Ethyl 2-(5-methoxy-3-oxo-2-tosylisoindolin-1-yl)acetate 136ic}<smiles>CCOC(=O)CC1c2ccc(OC)cc2C(=O)N1[13F]</smiles>

The general procedure $\mathbf{F}$ was followed using 3-methoxy- $N$-tosylbenzamide (135i) $(305.3 \mathrm{mg}$, $1.00 \mathrm{mmol}$ ), ethyl acrylate (17c) $(114.0 \mathrm{mg}, 1.05 \mathrm{mmol}),\left[\mathrm{RuCl}_{2}(p \text {-cymene })\right]_{2}$ (30.5 mg, $5.0 \mathrm{~mol} \%)$ and $\mathrm{Cu}(\mathrm{OAc})_{2} \cdot \mathrm{H}_{2} \mathrm{O} \quad(419.3 \mathrm{mg}, 2.10 \mathrm{mmol})$. Purification by column chromatography ( $n$-hexane/EtOAc 6/1) yielded 136ic $(219 \mathrm{mg}, 51 \%)$ as a colorless solid. M.r.: $130-132{ }^{\circ} \mathrm{C}$. 
${ }^{1} \mathrm{H}-\mathrm{NMR}\left(300 \mathrm{MHz}, \mathrm{CDCl}_{3}\right): \delta=8.02(\mathrm{~d}, J=8.4 \mathrm{~Hz}, 2 \mathrm{H}), 7.40-7.29(\mathrm{~m}, 3 \mathrm{H}), 7.22-7.09(\mathrm{~m}$, $2 \mathrm{H}$ ), $5.52(\mathrm{dd}, J=8.3,3.3 \mathrm{~Hz}, 1 \mathrm{H}), 4.08(\mathrm{q}, J=7.1 \mathrm{~Hz}, 2 \mathrm{H}$ ), $3.80(\mathrm{~s}, 3 \mathrm{H}), 3.52(\mathrm{dd}, J=16.5$, $3.4 \mathrm{~Hz}, 1 \mathrm{H}), 2.88$ (dd, J = 16.5, 8.2 Hz, 1H), $2.41(\mathrm{~s}, 3 \mathrm{H}), 1.17(\mathrm{t}, J=7.1 \mathrm{~Hz}, 3 \mathrm{H})$.

${ }^{13} \mathrm{C}-N M R\left(125 \mathrm{MHz}, \mathrm{CDCl}_{3}\right): \delta=169.8\left(\mathrm{C}_{\mathrm{q}}\right), 166.4\left(\mathrm{C}_{\mathrm{q}}\right), 160.6\left(\mathrm{C}_{\mathrm{q}}\right), 145.2\left(\mathrm{C}_{\mathrm{q}}\right), 137.7\left(\mathrm{C}_{\mathrm{q}}\right)$, $135.8\left(\mathrm{C}_{\mathrm{q}}\right), 130.6\left(\mathrm{C}_{\mathrm{q}}\right), 129.7(\mathrm{CH}), 128.4(\mathrm{CH}), 124.1(\mathrm{CH}), 122.9(\mathrm{CH}), 107.0(\mathrm{CH}), 61.1$ $\left(\mathrm{CH}_{2}\right), 58.3(\mathrm{CH}), 55.9\left(\mathrm{CH}_{3}\right) 39.6\left(\mathrm{CH}_{2}\right), 21.9\left(\mathrm{CH}_{3}\right), 14.3\left(\mathrm{CH}_{3}\right)$.

IR (ATR): $\tilde{v}=2982,1725,1496,1360,1295,1164,1164,1014,800,779 \mathrm{~cm}^{-1}$.

MS (ESI) m/z (relative intensity): 442 (86) [M+K $], 426$ (100) $\left[\mathrm{M}+\mathrm{Na}^{+}\right], 404(71)\left[\mathrm{M}+\mathrm{H}^{+}\right]$.

HR-MS (ESI) $m / z$ calcd for $\mathrm{C}_{20} \mathrm{H}_{22} \mathrm{NO}_{6} \mathrm{~S}$, $\left[\mathrm{M}+\mathrm{H}^{+}\right]$404.1162, found 404.1162.

\section{Synthesis of $n$-Butyl 2-(5-methoxy-3-oxo-2-tosylindolin-1-yl)acetate 136ie}<smiles>COCCC1c2cc(OC)ccc2C(=O)N1[13F]</smiles>

The general procedure $\mathbf{F}$ was followed using 3-methoxy- $N$-tosylbenzamide (135i) $(305.3 \mathrm{mg}$, $1.00 \mathrm{mmol}), n$-butyl acrylate (17e) $(138.0 \mathrm{mg}, 1.05 \mathrm{mmol}),\left[\mathrm{RuCl}_{2}(p \text {-cymene })\right]_{2}(30.5 \mathrm{mg}$, $5.0 \mathrm{~mol} \%)$ and $\mathrm{Cu}(\mathrm{OAc})_{2} \cdot \mathrm{H}_{2} \mathrm{O} \quad(419.3 \mathrm{mg}, 2.10 \mathrm{mmol})$. Purification by column chromatography ( $n$-hexane/EtOAc 6/1) yielded 136ie (263 mg, 61\%) as a colorless solid.

M.p.: $106^{\circ} \mathrm{C}$.

${ }^{1} \mathrm{H}-\mathrm{NMR}\left(300 \mathrm{MHz}, \mathrm{CDCl}_{3}\right): \delta=8.01(\mathrm{~d}, J=8.4 \mathrm{~Hz}, 2 \mathrm{H}), 7.40-7.29(\mathrm{~m}, 3 \mathrm{H}), 7.23-7.06(\mathrm{~m}$, 2H), 5.52 (ddd, $J=8.2,3.4,0.8 \mathrm{~Hz}, 1 \mathrm{H}$ ), 4.02 (td, $J=6.7,0.9 \mathrm{~Hz}, 2 \mathrm{H}), 3.53(\mathrm{dd}, J=16.5$, $3.4 \mathrm{~Hz}, 1 \mathrm{H}), 2.89(\mathrm{dd}, J=16.5,8.2 \mathrm{~Hz}, 1 \mathrm{H}), 2.41(\mathrm{~s}, 3 \mathrm{H}), 1.57-1.42(\mathrm{~m}, 2 \mathrm{H}), 1.38-1.15(\mathrm{~m}$, $2 \mathrm{H}), 0.89$ (t, $J=7.3 \mathrm{~Hz}, 3 \mathrm{H})$.

${ }^{13}$ C-NMR (125 MHz, $\left.\mathrm{CDCl}_{3}\right): \delta=170.0\left(\mathrm{C}_{\mathrm{q}}\right), 166.5\left(\mathrm{C}_{\mathrm{q}}\right), 160.7\left(\mathrm{C}_{\mathrm{q}}\right), 145.3\left(\mathrm{C}_{\mathrm{q}}\right), 137.8\left(\mathrm{C}_{\mathrm{q}}\right)$, $135.8\left(\mathrm{C}_{\mathrm{q}}\right), 130.7\left(\mathrm{C}_{\mathrm{q}}\right), 129.7(\mathrm{CH}), 128.4(\mathrm{CH}), 124.2(\mathrm{CH}), 122.9(\mathrm{CH}), 107.1(\mathrm{CH}), 65.0$ $\left(\mathrm{CH}_{2}\right), 58.2(\mathrm{CH}), 55.8\left(\mathrm{CH}_{3}\right), 39.5\left(\mathrm{CH}_{2}\right), 30.5\left(\mathrm{CH}_{2}\right) 21.8\left(\mathrm{CH}_{3}\right), 19.1\left(\mathrm{CH}_{3}\right), 13.5\left(\mathrm{CH}_{3}\right)$.

IR (ATR): $\tilde{v}=2960,1725,1624,1597,1495,1463,1357,1322,1281,1164 \mathrm{~cm}^{-1}$.

MS (ESI) $m / z$ (relative intensity): 470 (34) [M+K $\left.{ }^{+}\right], 454$ (26) [M+Na $\left.{ }^{+}\right], 432(100)\left[\mathrm{M}+\mathrm{H}^{+}\right]$.

HR-MS (ESI) $m / z$ calcd for $\mathrm{C}_{22} \mathrm{H}_{26} \mathrm{NO}_{6} \mathrm{~S}$, $\left[\mathrm{M}+\mathrm{H}^{+}\right]$432.1475, found 432.1475. 


\section{Synthesis of 6-Methoxy-3-(2-oxopropyl)-2-tosylisoindolin-1-one 136ij}

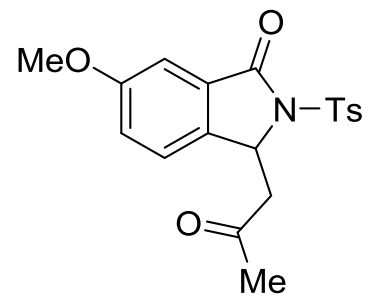

The general procedure $F$ was followed using 3-methoxy- $N$-tosylbenzamide (135i) $(305.3 \mathrm{mg}$, $1.00 \mathrm{mmol})$, methyl vinylketone (17j) $(67.0 \mathrm{mg}, 1.05 \mathrm{mmol}),\left[\mathrm{RuCl}_{2}(p \text {-cymene })\right]_{2}(6.1 \mathrm{mg}$, $1.0 \mathrm{~mol} \%)$ and $\mathrm{Cu}(\mathrm{OAc})_{2} \cdot \mathrm{H}_{2} \mathrm{O} \quad(419.3 \mathrm{mg}, 2.10 \mathrm{mmol})$. Purification by column chromatography ( $n$-hexane/EtOAc $6 / 1)$ yielded $136 \mathrm{ij}(102 \mathrm{mg}, 27 \%)$ as a colorless solid.

M.r.: $170-172{ }^{\circ} \mathrm{C}$

${ }^{1} \mathrm{H}-\mathrm{NMR}\left(300 \mathrm{MHz}, \mathrm{CDCl}_{3}\right): \delta=7.97(\mathrm{~d}, J=8.4 \mathrm{~Hz}, 2 \mathrm{H}), 7.36-7.26(\mathrm{~m}, 3 \mathrm{H}), 7.20-7.03(\mathrm{~m}$, 2H), 5.58 (ddd, $J=9.0,2.9,0.7 \mathrm{~Hz}, 1 \mathrm{H}$ ), 3.83 (dd, $J=18.1,3.0 \mathrm{~Hz}, 2 \mathrm{H}$ ), $3.79(\mathrm{~s}, 3 \mathrm{H}), 2.87$ (dd, $J=18.0,9.0 \mathrm{~Hz}, 1 \mathrm{H}), 2.41(\mathrm{~s}, 3 \mathrm{H}), 2.41(\mathrm{~s}, 3 \mathrm{H}), 2.23(\mathrm{~s}, 3 \mathrm{H})$.

${ }^{13}$ C-NMR $\left(75 \mathrm{MHz}, \mathrm{CDCl}_{3}\right): \delta=205.7\left(\mathrm{C}_{\mathrm{q}}\right), 166.6\left(\mathrm{C}_{\mathrm{q}}\right), 160.6\left(\mathrm{C}_{\mathrm{q}}\right), 145.4\left(\mathrm{C}_{\mathrm{q}}\right), 138.8\left(\mathrm{C}_{\mathrm{q}}\right)$, $135.6\left(\mathrm{C}_{\mathrm{q}}\right), 130.3\left(\mathrm{C}_{\mathrm{q}}\right), 129.8(\mathrm{CH}), 128.4(\mathrm{CH}), 124.7(\mathrm{CH}), 123.1(\mathrm{CH}), 107.0(\mathrm{CH}), 57.8$ $(\mathrm{CH}), 55.8\left(\mathrm{CH}_{3}\right), 49.2\left(\mathrm{CH}_{2}\right), 30.7\left(\mathrm{CH}_{3}\right), 21.8\left(\mathrm{CH}_{3}\right)$.

IR (ATR): $\tilde{v}=3047,3000,2963,2914,2936,1711,1498,1327,1280,1166 \mathrm{~cm}^{-1}$.

MS (ESI) m/z (relative intensity): 396 (97) [M+K $], 391$ (100) $\left[\mathrm{M}+\mathrm{Na}^{+}\right], 374(42)\left[\mathrm{M}+\mathrm{H}^{+}\right]$.

HR-MS (ESI) $m / z$ calcd for $\mathrm{C}_{19} \mathrm{H}_{20} \mathrm{NO}_{5} \mathrm{~S},\left[\mathrm{M}+\mathrm{H}^{+}\right] 374.1057$, found 374.1057.

\section{Synthesis of Ethyl 2-[3-oxo-2-tosyl-5-(trifluoromethyl)isoindolin-1-yl]acetate 136jc}<smiles>CCOC(=O)CC1c2ccc(C(F)(F)F)cc2C(=O)N1[AsH3-]</smiles>

The general procedure $\mathbf{F}$ was followed using $N$-tosyl-3-(trifluoromethyl)benzamide (135j) $(171.5 \mathrm{mg}, 0.50 \mathrm{mmol})$, ethyl acrylate $(17 \mathrm{c})(153.0 \mathrm{mg}, 1.50 \mathrm{mmol}),\left[\mathrm{RuCl}_{2}(p \text {-cymene })\right]_{2}$ $(15.3 \mathrm{mg}, 5.0 \mathrm{~mol} \%)$ and $\mathrm{Cu}(\mathrm{OAc})_{2} \cdot \mathrm{H}_{2} \mathrm{O}(219.0 \mathrm{mg}, 1.05 \mathrm{mmol})$. Purification by column chromatography ( $n$-hexane/EtOAc $4 / 1)$ yielded $136 \mathrm{jc}(172 \mathrm{mg}, 78 \%)$ as a colorless solid.

M.r.: $127-129^{\circ} \mathrm{C}$. 
${ }^{1} \mathrm{H}-\mathrm{NMR}\left(500 \mathrm{MHz}, \mathrm{CDCl}_{3}\right): \delta=7.98-7.96(\mathrm{~m}, 3 \mathrm{H}), 7.86(\mathrm{ddd}, J=8.1,1.7,0.7 \mathrm{~Hz}, 1 \mathrm{H})$, 7.71-5.44 (m, 1H), $7.34(\mathrm{dd}, J=8.0,0.7 \mathrm{~Hz}, 2 \mathrm{H}), 5.64(\mathrm{dd}, J=8.1,3.3 \mathrm{~Hz}, 1 \mathrm{H}), 4.06$ (q, $J=7.2 \mathrm{~Hz}, 2 \mathrm{H}), 3.55(\mathrm{dd}, J=16.9,3.3 \mathrm{~Hz}, 1 \mathrm{H}), 3.01(\mathrm{dd}, J=16.9,8.1 \mathrm{~Hz}, 1 \mathrm{H}), 2.42(\mathrm{~s}, 3 \mathrm{H})$, $1.15(\mathrm{t}, J=7.1 \mathrm{~Hz}, 3 \mathrm{H})$.

${ }^{13} \mathrm{C}-N M R\left(125 \mathrm{MHz}, \mathrm{CDCl}_{3}\right): \delta=169.5\left(\mathrm{C}_{\mathrm{q}}\right), 165.1\left(\mathrm{C}_{\mathrm{q}}\right), 148.5\left(\mathrm{C}_{\mathrm{q}}\right), 145.7\left(\mathrm{C}_{\mathrm{q}}\right), 135.5\left(\mathrm{C}_{\mathrm{q}}\right)$, $132.1\left({ }^{2} J_{\mathrm{C}-\mathrm{F}}=33.4 \mathrm{~Hz}, \mathrm{CH}\right), 131.0\left({ }^{3} J_{\mathrm{C}-\mathrm{F}}=3.5 \mathrm{~Hz}, \mathrm{CH}\right), 130.4\left(\mathrm{C}_{\mathrm{q}}\right), 129.9(\mathrm{CH}), 128.5(\mathrm{CH})$, $124.2\left({ }^{3} J_{\mathrm{C}-\mathrm{F}}=3.8 \mathrm{~Hz}, \mathrm{CH}\right), 123.2\left({ }^{1} \mathrm{~J}_{\mathrm{C}-\mathrm{F}}=274.5 \mathrm{~Hz}, \mathrm{C}_{\mathrm{q}}\right), 122.4\left({ }^{3} \mathrm{~J}_{\mathrm{C}-\mathrm{F}}=7.0,3.5 \mathrm{~Hz}, \mathrm{C}_{\mathrm{q}}\right) 61.3$ $\left(\mathrm{CH}_{2}\right), 58.5(\mathrm{CH}), 38.8\left(\mathrm{CH}_{2}\right), 21.8\left(\mathrm{CH}_{3}\right), 14.1\left(\mathrm{CH}_{3}\right)$.

${ }^{19} \mathrm{~F}-\mathrm{NMR}\left(282 \mathrm{MHz}, \mathrm{CDCl}_{3}\right): \delta=-62.7(\mathrm{~s})$.

IR (ATR): $\tilde{v}=2996,1732,1719,1354,1262,1198,1178,1091,1053,1039 \mathrm{~cm}^{-1}$.

MS (ESI) $m / z$ (relative intensity): $464(70)\left[\mathrm{M}+\mathrm{Na}^{+}\right], 442(100)\left[\mathrm{M}+\mathrm{H}^{+}\right]$.

HR-MS (ESI) $\mathrm{m} / \mathrm{z}$ calcd for $\mathrm{C}_{20} \mathrm{H}_{19} \mathrm{~F}_{3} \mathrm{NO}_{5} \mathrm{~S}$, [M+H+ $\mathrm{H}^{+}$442.0931, found 442.0923 .

\section{Synthesis of Ethyl 2-(4-methyl-3-oxo-4-tosylisoindolin-1-yl)acetate 136kc}<smiles>CCOCCC1c2cc(C)ccc2C(=O)N1[AsH3-]</smiles>

The general procedure $\mathbf{F}$ was followed using 4-methyl- $N$-tosylbenzamide (135k) $(289.3 \mathrm{mg}$, $1.00 \mathrm{mmol})$, ethyl acrylate $(\mathbf{1 7 c})(114.0 \mathrm{mg}, 1.05 \mathrm{mmol}),\left[\mathrm{RuCl}_{2}(p \text {-cymene })\right]_{2}(6.1 \mathrm{mg}$, $1.0 \mathrm{~mol} \%)$ and $\mathrm{Cu}(\mathrm{OAc})_{2} \cdot \mathrm{H}_{2} \mathrm{O} \quad(419.3 \mathrm{mg}, 2.10 \mathrm{mmol})$. Purification by column chromatography ( $n$-hexane/EtOAc 6/1) yielded 136kc (202 mg, 52\%) as a colorless solid.

M.p.: $208^{\circ} \mathrm{C}$.

${ }^{1} \mathrm{H}-\mathrm{NMR}\left(500 \mathrm{MHz}, \mathrm{CDCl}_{3}\right): \delta=8.01(\mathrm{~d}, J=8.8 \mathrm{~Hz}, 1 \mathrm{H}), 7.66(\mathrm{~d}, J=8.2 \mathrm{~Hz}, 1 \mathrm{H}), 7.35-7.30$ $(\mathrm{m}, 2 \mathrm{H}), 7.29-7.24(\mathrm{~m}, 3 \mathrm{H}), 5.55(\mathrm{dd}, J=8.1,3.4 \mathrm{~Hz}, 1 \mathrm{H}), 4.17-4.02(\mathrm{~m}, 2 \mathrm{H}), 3.51$ (dd, $J=16.6,3.5 \mathrm{~Hz}, 1 \mathrm{H}), 2.93(\mathrm{dd}, J=16.6,8.0 \mathrm{~Hz}, 1 \mathrm{H}), 2.43(\mathrm{~s}, 3 \mathrm{H}), 2.41$ (s, 3H), 1.17 (t, $J=7.2 \mathrm{~Hz}, 3 \mathrm{H})$.

${ }^{13} \mathrm{C}-N M R\left(75 \mathrm{MHz}, \mathrm{CDCl}_{3}\right): \delta=170.0\left(\mathrm{C}_{\mathrm{q}}\right), 166.5\left(\mathrm{C}_{\mathrm{q}}\right), 145.9\left(\mathrm{C}_{\mathrm{q}}\right), 145.7\left(\mathrm{C}_{\mathrm{q}}\right), 145.3\left(\mathrm{C}_{\mathrm{q}}\right)$, $136.0\left(\mathrm{C}_{\mathrm{q}}\right), 130.4(\mathrm{CH}), 129.8(\mathrm{CH}), 128.5(\mathrm{CH}), 126.8\left(\mathrm{C}_{\mathrm{q}}\right), 124.9(\mathrm{CH}), 123.5(\mathrm{CH}), 65.1$ $\left(\mathrm{CH}_{2}\right), 58.4(\mathrm{CH}), 39.6\left(\mathrm{CH}_{2}\right), 22.4\left(\mathrm{CH}_{3}\right), 21.8\left(\mathrm{CH}_{3}\right), 14.2\left(\mathrm{CH}_{3}\right)$.

IR (ATR): $\tilde{v}=2966,1715,1617,1354,1168,1087,1033,820,761,656 \mathrm{~cm}^{-1}$.

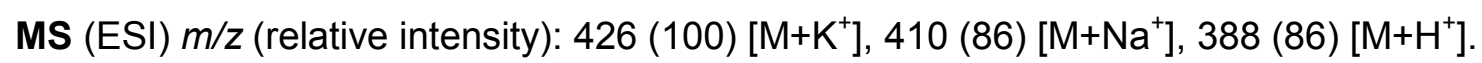

HR-MS (ESI) $\mathrm{m} / \mathrm{z}$ calcd for $\mathrm{C}_{20} \mathrm{H}_{22} \mathrm{NO}_{5} \mathrm{~S},\left[\mathrm{M}+\mathrm{H}^{+}\right]$388.1213, found 388.1214. 


\section{Synthesis of $n$-Butyl 2-(6-methyl-3-oxo-2-tosylisoindolin-1-yl)acetate 136ke}<smiles>CCCCCC1c2cc(C)ccc2C(=O)N1[As]</smiles>

The general procedure $\mathbf{F}$ was followed using 4-methyl- $N$-tosylbenzamide (135k) $(289.3 \mathrm{mg}$, $1.00 \mathrm{mmol}), n$-butyl acrylate (17e) $(138.0 \mathrm{mg}, 1.05 \mathrm{mmol}),\left[\mathrm{RuCl}_{2}(p \text {-cymene })\right]_{2}(6.1 \mathrm{mg}$, $1.0 \mathrm{~mol} \%)$ and $\mathrm{Cu}(\mathrm{OAc})_{2} \cdot \mathrm{H}_{2} \mathrm{O} \quad(419.3 \mathrm{mg}, 2.10 \mathrm{mmol})$. Purification by column chromatography ( $n$-hexane/EtOAc $6 / 1$ ) yielded 136k (208 mg, $50 \%)$ as a colorless solid.

M.r.: $135-136^{\circ} \mathrm{C}$.

${ }^{1} \mathrm{H}-\mathrm{NMR}\left(500 \mathrm{MHz}, \mathrm{CDCl}_{3}\right): \delta=8.10-7.96(\mathrm{~m}, 2 \mathrm{H}), 7.65(\mathrm{~d}, J=8.3 \mathrm{~Hz}, 1 \mathrm{H}), 7.32(\mathrm{~d}$, $J=8.0 \mathrm{~Hz}, 2 \mathrm{H}), 7.28-7.25(\mathrm{~m}, 2 \mathrm{H}), 5.54(\mathrm{dd}, J=8.1,3.4 \mathrm{~Hz}, 1 \mathrm{H}), 4.11-3.89(\mathrm{~m}, 2 \mathrm{H}), 3.52$ (dd, $J=16.5,3.4 \mathrm{~Hz}, 1 \mathrm{H}), 2.93(\mathrm{dd}, J=16.5,8.1 \mathrm{~Hz}, 1 \mathrm{H}), 2.43(\mathrm{~s}, 3 \mathrm{H}), 1.54-1.45(\mathrm{~m}, 2 \mathrm{H})$, 1.34-1.22 (m, 2H), $0.90(\mathrm{t}, J=7.2 \mathrm{~Hz}, 3 \mathrm{H})$.

${ }^{13}$ C-NMR $\left(125 \mathrm{MHz}, \mathrm{CDCl}_{3}\right): \delta=170.1\left(\mathrm{C}_{\mathrm{q}}\right), 166.5\left(\mathrm{C}_{\mathrm{q}}\right), 145.9\left(\mathrm{C}_{\mathrm{q}}\right), 145.7\left(\mathrm{C}_{\mathrm{q}}\right), 145.2\left(\mathrm{C}_{\mathrm{q}}\right)$, $136.0\left(\mathrm{C}_{\mathrm{q}}\right), 130.4(\mathrm{CH}), 129.7(\mathrm{CH}), 128.5(\mathrm{CH}), 126.8\left(\mathrm{C}_{\mathrm{q}}\right), 124.9(\mathrm{CH}), 123.5(\mathrm{CH}), 65.1$ $\left(\mathrm{CH}_{2}\right), 58.3(\mathrm{CH}), 39.5\left(\mathrm{CH}_{2}\right), 30.6\left(\mathrm{CH}_{2}\right), 22.3\left(\mathrm{CH}_{3}\right), 21.8\left(\mathrm{CH}_{3}\right), 19.2\left(\mathrm{CH}_{2}\right), 13.8\left(\mathrm{CH}_{3}\right)$. IR (ATR): $\tilde{v}=2960,1719,1618,1355,1339,1170,1091,857,838,708 \mathrm{~cm}^{-1}$. MS (ESI) $m / z$ (relative intensity): 454 (16) [M+K $\left.\mathrm{K}^{+}\right], 438$ (68) $\left[\mathrm{M}+\mathrm{Na}^{+}\right], 416(100)\left[\mathrm{M}+\mathrm{H}^{+}\right]$. HR-MS (ESI) $\mathrm{m} / \mathrm{z}$ calcd for $\mathrm{C}_{22} \mathrm{H}_{26} \mathrm{NO}_{5} \mathrm{~S}$, [M+H'] 416.1526, found 416.1529.

\section{Synthesis of Ethyl 2-(6-methoxy-3-oxo-2-tosylisoindolin-1-yl)acetate 136lc}<smiles>CCOC(=O)CC1c2cc(OC)ccc2C(=O)N1[AsH3-]</smiles>

The general procedure $\mathbf{F}$ was followed using 4-methoxy- $N$-tosylbenzamide (135I) $(305.3 \mathrm{mg}$, $1.00 \mathrm{mmol})$, ethyl acrylate (17c) $(114.0 \mathrm{mg}, 1.05 \mathrm{mmol}),\left[\mathrm{RuCl}_{2}(p \text {-cymene })\right]_{2}(13.5 \mathrm{mg}$, $5.0 \mathrm{~mol} \%)$ and $\mathrm{Cu}(\mathrm{OAc})_{2} \cdot \mathrm{H}_{2} \mathrm{O} \quad(419.3 \mathrm{mg}, 2.10 \mathrm{mmol})$. Purification by column chromatography ( $n$-hexane/EtOAc $6 / 1)$ yielded 136lc $(223 \mathrm{mg}, 52 \%)$ as a colorless solid.

M.r.: $186-189^{\circ} \mathrm{C}$. 
${ }^{1} \mathrm{H}-\mathrm{NMR}\left(300 \mathrm{MHz}, \mathrm{CDCl}_{3}\right): \delta=8.01(\mathrm{~d}, J=8.4 \mathrm{~Hz}, 2 \mathrm{H}), 7.68(\mathrm{~d}, J=9.0 \mathrm{~Hz}, 1 \mathrm{H}), 7.32(\mathrm{~d}$, $J=8.6 \mathrm{~Hz}, 2 \mathrm{H}), 7.00-6.92(\mathrm{~m}, 2 \mathrm{H}), 5.53(\mathrm{dd}, J=8.3,3.4 \mathrm{~Hz}, 1 \mathrm{H}), 4.11(\mathrm{q}, J=7.1 \mathrm{~Hz}, 2 \mathrm{H})$, $3.84(\mathrm{~s}, 3 \mathrm{H}), 3.54(\mathrm{dd}, J=16.7,3.4 \mathrm{~Hz}, 1 \mathrm{H}), 2.89$ (dd, $J=16.6,8.3 \mathrm{~Hz}, 1 \mathrm{H}), 2.41(\mathrm{~s}, 3 \mathrm{H})$, $1.19(\mathrm{t}, J=7.2 \mathrm{~Hz}, 3 \mathrm{H})$.

${ }^{13} \mathrm{C}$-NMR $\left(75 \mathrm{MHz}, \mathrm{CDCl}_{3}\right): \delta=170.1\left(\mathrm{C}_{\mathrm{q}}\right), 166.1\left(\mathrm{C}_{\mathrm{q}}\right), 164.9\left(\mathrm{C}_{\mathrm{q}}\right), 148.1\left(\mathrm{C}_{\mathrm{q}}\right), 145.2\left(\mathrm{C}_{\mathrm{q}}\right)$, $136.0\left(\mathrm{C}_{\mathrm{q}}\right), 129.7(\mathrm{CH}), 128.4(\mathrm{CH}), 126.8(\mathrm{CH}), 121.6\left(\mathrm{C}_{\mathrm{q}}\right), 116.5(\mathrm{CH}), 107.5(\mathrm{CH}), 61.2$ $\left(\mathrm{CH}_{2}\right), 58.1(\mathrm{CH}), 55.9\left(\mathrm{CH}_{3}\right) 39.7\left(\mathrm{CH}_{2}\right), 21.8\left(\mathrm{CH}_{3}\right), 14.2\left(\mathrm{CH}_{3}\right)$.

IR (ATR): $\tilde{v}=2976,2924,2847,1716,1621,1596,1490,1342,1163,1029 \mathrm{~cm}^{-1}$.

MS (ESI) $m / z$ (relative intensity): $426(100)\left[\mathrm{M}+\mathrm{Na}^{+}\right], 404(55)\left[\mathrm{M}+\mathrm{H}^{+}\right]$.

HR-MS (ESI) $m / z$ calcd for $\mathrm{C}_{20} \mathrm{H}_{22} \mathrm{NO}_{6} \mathrm{~S}$, $\left[\mathrm{M}+\mathrm{H}^{+}\right]$404.1156, found 404.1162.

\section{Synthesis of $n$-Butyl 2-(6-methoxy-3-oxo-2-tosylisoindolin-1-yl)acetate 136le}<smiles>CCCCCC1c2cc(OC)ccc2C(=O)N1[13S]</smiles>

The general procedure $\mathbf{F}$ was followed using 4-methoxy- $N$-tosylbenzamide (135I) (305.3 mg, $1.00 \mathrm{mmol}), n$-butyl acrylate (17e) $(138.0 \mathrm{mg}, 1.05 \mathrm{mmol}),\left[\mathrm{RuCl}_{2}(p \text {-cymene })\right]_{2}(30.5 \mathrm{mg}$, $5.0 \mathrm{~mol} \%)$ and $\mathrm{Cu}(\mathrm{OAc})_{2} \cdot \mathrm{H}_{2} \mathrm{O} \quad(419.3 \mathrm{mg}, 2.10 \mathrm{mmol})$. Purification by column chromatography ( $n$-hexane/EtOAc 4/1) yielded 136le $(220 \mathrm{mg}, 52 \%)$ as a colorless solid.

M.p.: $101^{\circ} \mathrm{C}$.

${ }^{1} \mathrm{H}-\mathrm{NMR}\left(300 \mathrm{MHz}, \mathrm{CDCl}_{3}\right): \delta=8.00(\mathrm{~d}, J=8.4 \mathrm{~Hz}, 2 \mathrm{H}), 7.72-7.59(\mathrm{~m}, 1 \mathrm{H}), 7.30(\mathrm{~d}$, $J=8.1 \mathrm{~Hz}, 2 \mathrm{H}), 6.97-6.91(\mathrm{~m}, 2 \mathrm{H}), 5.51(\mathrm{dd}, J=8.2,3.3 \mathrm{~Hz}, 1 \mathrm{H}), 4.03(\mathrm{t}, J=6.7 \mathrm{~Hz}, 2 \mathrm{H})$, $3.83(\mathrm{~s}, 3 \mathrm{H}), 3.52(\mathrm{dd}, J=16.6,3.4 \mathrm{~Hz}, 1 \mathrm{H}), 2.90(\mathrm{dd}, J=16.7,8.2 \mathrm{~Hz}, 1 \mathrm{H}), 1.58-1.41(\mathrm{~m}$, $2 \mathrm{H}), 1.36-1.21(\mathrm{~m}, 2 \mathrm{H}), 0.88(\mathrm{t}, J=7.3 \mathrm{~Hz}, 3 \mathrm{H})$.

${ }^{13}$ C-NMR $\left(125 \mathrm{MHz}, \mathrm{CDCl}_{3}\right): \delta=170.1\left(\mathrm{C}_{\mathrm{q}}\right), 166.1\left(\mathrm{C}_{\mathrm{q}}\right), 164.9\left(\mathrm{C}_{\mathrm{q}}\right), 148.0\left(\mathrm{C}_{\mathrm{q}}\right), 145.1\left(\mathrm{C}_{\mathrm{q}}\right)$, $136.0\left(\mathrm{C}_{\mathrm{q}}\right), 129.7(\mathrm{CH}), 128.3(\mathrm{CH}), 126.6(\mathrm{CH}), 121.5\left(\mathrm{C}_{\mathrm{q}}\right), 116.4(\mathrm{CH}), 107.4(\mathrm{CH}), 65.0$ $\left(\mathrm{CH}_{2}\right), 58.1(\mathrm{CH}), 55.9\left(\mathrm{CH}_{3}\right) 39.6\left(\mathrm{CH}_{2}\right), 30.5\left(\mathrm{CH}_{2}\right), 21.7\left(\mathrm{CH}_{3}\right), 19.1\left(\mathrm{CH}_{2}\right), 14.2\left(\mathrm{CH}_{3}\right)$. IR (ATR): $\tilde{v}=2958,1722,1343,1248,1172,1085,1027,863,799,761 \mathrm{~cm}^{-1}$. MS (ESI) $m / z$ (relative intensity): 470 (69) [M+K $\left.{ }^{+}\right], 454$ (56) [M+Na $\left.{ }^{+}\right], 432(100)\left[\mathrm{M}+\mathrm{H}^{+}\right]$. HR-MS (ESI) $m / z$ calcd for $\mathrm{C}_{22} \mathrm{H}_{26} \mathrm{NO}_{6} \mathrm{~S}$, $\left[\mathrm{M}+\mathrm{H}^{+}\right]$432.1475, found 432.1475. 


\section{Synthesis of Ethyl 2-(6-fluoro-3-oxo-2-tosylisoindolin-1-yl)acetate 136mc}<smiles>CCOC(=O)CC1c2cc(F)ccc2C(=O)N1[As]</smiles>

The general procedure $F$ was followed using 4-fluoro- $N$-tosylbenzamide $(\mathbf{1 3 5 m})(293.3 \mathrm{mg}$, $1.00 \mathrm{mmol}$ ), ethyl acrylate (17c) $(114.0 \mathrm{mg}, 1.05 \mathrm{mmol}),\left[\mathrm{RuCl}_{2}(p \text {-cymene })\right]_{2}$ (30.5 mg, $5.0 \mathrm{~mol} \%)$ and $\mathrm{Cu}(\mathrm{OAc})_{2} \cdot \mathrm{H}_{2} \mathrm{O} \quad(419.3 \mathrm{mg}, 2.10 \mathrm{mmol})$. Purification by column chromatography ( $n$-hexane/EtOAc $4 / 1$ ) yielded $136 \mathrm{mc}(191 \mathrm{mg}, 49 \%)$ as a colorless solid.

M.r.: $188-191^{\circ} \mathrm{C}$.

${ }^{1} \mathrm{H}-\mathrm{NMR}\left(300 \mathrm{MHz}, \mathrm{CDCl}_{3}\right): \delta=8.02(\mathrm{~d}, J=8.4 \mathrm{~Hz}, 2 \mathrm{H}), 7.77(\mathrm{dd}, J=8.5,5.0 \mathrm{~Hz}, 1 \mathrm{H}), 7.34$ $(\mathrm{dd}, J=8.6,0.8 \mathrm{~Hz}, 2 \mathrm{H}), 7.24-7.11(\mathrm{~m}, 2 \mathrm{H}), 5.64-5.44(\mathrm{~m}, 1 \mathrm{H}), 4.11(\mathrm{q}, J=7.2 \mathrm{~Hz}, 2 \mathrm{H})$, $3.56(\mathrm{dd}, J=16.8,3.2 \mathrm{~Hz}, 1 \mathrm{H}), 2.91(\mathrm{dd}, J=16.8,8.4 \mathrm{~Hz}, 1 \mathrm{H}), 2.42(\mathrm{~s}, 3 \mathrm{H}), 1.20$ (t, $J=7.1 \mathrm{~Hz}, 3 \mathrm{H})$.

${ }^{13}$ C-NMR $\left(75 \mathrm{MHz}, \mathrm{CDCl}_{3}\right): \delta=169.8\left(\mathrm{C}_{\mathrm{q}}\right), 166.7\left({ }^{1} \mathrm{~J}_{\mathrm{C}-\mathrm{F}}=265.4 \mathrm{~Hz}, \mathrm{C}_{\mathrm{q}}\right), 165.4\left(\mathrm{C}_{\mathrm{q}}\right), 148.1$ $\left({ }^{3} J_{\mathrm{C}-\mathrm{F}}=10.3 \mathrm{~Hz}, \mathrm{C}_{\mathrm{q}}\right), 145.5\left(\mathrm{C}_{\mathrm{q}}\right), 135.7\left(\mathrm{C}_{\mathrm{q}}\right), 129.8(\mathrm{CH}), 128.5(\mathrm{CH}), 127.5\left({ }^{3} \mathrm{~J}_{\mathrm{C}-\mathrm{F}}=10.2 \mathrm{~Hz}\right.$, $\mathrm{CH}), 125.5\left({ }^{4} J_{\mathrm{C}-\mathrm{F}}=2.1 \mathrm{~Hz}, \mathrm{C}_{\mathrm{q}}\right), 117.5\left({ }^{2} J_{\mathrm{C}-\mathrm{F}}=23.7 \mathrm{~Hz}, \mathrm{CH}\right), 110.9\left({ }^{2} J_{\mathrm{C}-\mathrm{F}}=24.9 \mathrm{~Hz}, \mathrm{CH}\right), 61.4$ $\left(\mathrm{CH}_{2}\right), 58.1\left({ }^{4} J_{\mathrm{C}-\mathrm{F}}=2.8 \mathrm{~Hz}, \mathrm{CH}\right), 39.3\left(\mathrm{CH}_{2}\right), 21.8\left(\mathrm{CH}_{3}\right), 14.2\left(\mathrm{CH}_{3}\right)$.

${ }^{19}$ F-NMR $\left(282 \mathrm{MHz}, \mathrm{CDCl}_{3}\right): \delta=-101.7(\mathrm{td}, J=8.5,5.0 \mathrm{~Hz})$.

IR (ATR): $\tilde{v}=2977,2938,1731,1605,1480,1362,1171,1086,827,679 \mathrm{~cm}^{-1}$.

MS (ESI) m/z (relative intensity): 430 (86) [M+K $], 414$ (71) [M+Na $\left.{ }^{+}\right], 392(100)\left[\mathrm{M}+\mathrm{H}^{+}\right]$.

HR-MS (ESI) $\mathrm{m} / \mathrm{z}$ calcd for $\mathrm{C}_{19} \mathrm{H}_{19} \mathrm{FNO}_{5} \mathrm{~S}$, $\left[\mathrm{M}+\mathrm{H}^{+}\right]$392.0962, found 392.0962.

\section{Synthesis of 5-Fluoro-3-(2-oxopropyl)-2-tosylisoindolin-1-one 136mj}<smiles>CC(=O)CC1c2cc(F)ccc2C(=O)N1C</smiles>

The general procedure $F$ was followed using 4-fluoro- $N$-tosylbenzamide (135m) $(293.3 \mathrm{mg}$, $1.00 \mathrm{mmol})$, methyl vinylketone (17j) $(67.0 \mathrm{mg}, 1.05 \mathrm{mmol}),\left[\mathrm{RuCl}_{2}(p \text {-cymene })\right]_{2}(30.5 \mathrm{mg}$, 
$5.0 \mathrm{~mol} \%)$ and $\mathrm{Cu}(\mathrm{OAc})_{2} \cdot \mathrm{H}_{2} \mathrm{O} \quad(419.3 \mathrm{mg}, \quad 2.10 \mathrm{mmol})$. Purification by column chromatography ( $n$-hexane/EtOAc $4 / 1)$ yielded $136 \mathrm{mj}(211 \mathrm{mg}, 58 \%)$ as a colorless solid.

M.r.: $177-178^{\circ} \mathrm{C}$.

${ }^{1} \mathrm{H}-\mathrm{NMR}\left(300 \mathrm{MHz}, \mathrm{CDCl}_{3}\right): \delta=7.97(\mathrm{~d}, J=8.4 \mathrm{~Hz}, 2 \mathrm{H}), 7.74(\mathrm{dd}, J=8.1,5.0 \mathrm{~Hz}, 1 \mathrm{H}), 7.32$ $(\mathrm{d}, J=7.9 \mathrm{~Hz}, 2 \mathrm{H}), 7.18-7.08(\mathrm{~m}, 2 \mathrm{H}), 7.18-7.08(\mathrm{~d}, J=7.6 \mathrm{~Hz}, 1 \mathrm{H}), 5.61(\mathrm{dd}, J=9.1$, $2.8 \mathrm{~Hz}, 1 \mathrm{H}$ ), 3.85 (dd, $J=18.3,2.8 \mathrm{~Hz}, 1 \mathrm{H}), 2.91$ (dd, $J=18.3,9.1 \mathrm{~Hz}, 1 \mathrm{H}), 2.41(\mathrm{~s}, 3 \mathrm{H})$, $2.25(\mathrm{~s}, 3 \mathrm{H})$.

${ }^{13} \mathrm{C}$-NMR $\left(125 \mathrm{MHz}, \mathrm{CDCl}_{3}\right): \delta=205.4\left(\mathrm{C}_{\mathrm{q}}\right), 166.7\left({ }^{1} \mathrm{~J}_{\mathrm{C}-\mathrm{F}}=256.1 \mathrm{~Hz}, \mathrm{C}_{\mathrm{q}}\right), 165.4\left(\mathrm{C}_{\mathrm{q}}\right), 148.9$ $\left({ }^{3} J_{\mathrm{C}-\mathrm{F}}=10.3 \mathrm{~Hz}, \mathrm{C}_{\mathrm{q}}\right), 145.6\left(\mathrm{C}_{\mathrm{q}}\right), 135.5\left(\mathrm{C}_{\mathrm{q}}\right), 129.9(\mathrm{CH}), 128.4(\mathrm{CH}), 127.4\left({ }^{3} \mathrm{~J}_{\mathrm{C}-\mathrm{F}}=10.2 \mathrm{~Hz}\right.$, $\mathrm{CH}), 125.1\left({ }^{4} J_{\mathrm{C}-\mathrm{F}}=2.0 \mathrm{~Hz}, \mathrm{C}_{\mathrm{q}}\right), 117.4\left({ }^{2} J_{\mathrm{C}-\mathrm{F}}=23.9 \mathrm{~Hz}, \mathrm{CH}\right), 111.3\left({ }^{1} J_{\mathrm{C}-\mathrm{F}}=25.0 \mathrm{~Hz}, \mathrm{CH}\right), 58.0$ $(\mathrm{CH}), 48.9\left(\mathrm{CH}_{2}\right), 30.5\left(\mathrm{CH}_{3}\right), 21.8\left(\mathrm{CH}_{3}\right)$.

${ }^{19}$ F-NMR $\left(282 \mathrm{MHz}, \mathrm{CDCl}_{3}\right): \delta=-101.5(\mathrm{td}, J=8.7,5.1 \mathrm{~Hz})$.

IR (ATR): $\tilde{v}=2956,2916,1730,1704,1598,1358,1244,1083,1019,877 \mathrm{~cm}^{-1}$.

MS (ESI) $m / z$ (relative intensity): $384(68)\left[\mathrm{M}+\mathrm{Na}^{+}\right], 362(100)\left[\mathrm{M}+\mathrm{H}^{+}\right]$.

HR-MS (ESI) $m / z$ calcd for $\mathrm{C}_{18} \mathrm{H}_{17} \mathrm{FNO}_{4} \mathrm{~S},\left[\mathrm{M}+\mathrm{H}^{+}\right]$362.0857, found 362.0858 . 


\subsubsection{Intermolecular Competition Experiment for the Ruthenium(II)-Catalyzed Synthesis of Isoindolinones}

Competition Experiment between Tosylbenzamides 154h and 154j<smiles>[3H]NC(=O)c1cccc(C)c1</smiles>

$135 h$

$(1.0 \mathrm{mmol})$

$+$<smiles>O=C(N[Te])c1cccc(C(F)(F)F)c1</smiles>

135j

$1.0 \mathrm{mmol})$<smiles>CCOC(=O)CC1c2ccc(C)cc2C(=O)N1[AsH3-]</smiles>

136hc: $36 \%$
$17 \mathrm{c}(0.5 \mathrm{mmol})$

$\underset{\mathrm{Cu}(\mathrm{OAc})_{2} \cdot \mathrm{H}_{2} \mathrm{O}(2.0 \text { equiv })}{\left[\mathrm{RuCl}_{2}(p \text {-cymene })\right]_{2}(5.0 \mathrm{~mol} \%)}$

$\mathrm{H}_{2} \mathrm{O}$ $100{ }^{\circ} \mathrm{C}, 18 \mathrm{~h}$ under air<smiles>CCOC(=O)CC1c2ccc(C(F)(F)F)cc2C(=O)N1[AsH-]</smiles>

136jc: $26 \%$

A mixture of 3-methyl- $N$-tosylbenzamide $(135 \mathrm{~h}) \quad(289.0 \mathrm{mg}, \quad 1.00 \mathrm{mmol}), \quad N$-tosyl-3(trifluoromethyl)benzamide (135j) $(343.3 \mathrm{mg}, 1.00 \mathrm{mmol})$, ethyl acrylate (17c) $(50.0 \mathrm{mg}$, $0.50 \mathrm{mmol}),\left[\mathrm{RuCl}_{2}(p \text {-cymene })\right]_{2}(15.3 \mathrm{mg}, 5.0 \mathrm{~mol} \%)$ and $\mathrm{Cu}(\mathrm{OAc})_{2} \cdot \mathrm{H}_{2} \mathrm{O}(218.0 \mathrm{mg}$, $1.05 \mathrm{mmol})$ in $\mathrm{H}_{2} \mathrm{O}(2.5 \mathrm{~mL})$ was stirred at $100^{\circ} \mathrm{C}$ for $18 \mathrm{~h}$ under air. At ambient temperature, the reaction mixture was diluted with sat. aq. $\mathrm{NH}_{4} \mathrm{Cl} / \mathrm{NH}_{3}(1: 1,10 \mathrm{~mL})$ and extracted with $\mathrm{CH}_{2} \mathrm{Cl}_{2}(3 \times 25 \mathrm{~mL})$. The combined organic layers were dried over $\mathrm{Na}_{2} \mathrm{SO}_{4}$. After filtration and evaporation of the solvent in vacuo, the crude product was purified by column chromatography on silica gel ( $n$-pentane/EtOAc 19/1) to yield 136hc (68 mg, 36\%) and 136jc (56 mg, 26\%). 


\subsubsection{Mechanistic Studies on the Ruthenium(II)-Catalyzed Synthesis of Isoindolinones}

\section{Ruthenium-Catalyced H/D Exchange with Substrate 135a with $D_{2} O$ as the Cosolvent}

The general procedure $\mathbf{F}$ was followed using 2-methyl- $N$-tosylbenzamide (135a) $(2.98 \mathrm{mg}$, $1.00 \mathrm{mmol}$ ), ethyl acrylate (17c) $(105.0 \mathrm{mg}, 1.05 \mathrm{mmol}),\left[\mathrm{RuCl}_{2}(p \text {-cymene })\right]_{2}(30.5 \mathrm{mg}$, $5.0 \mathrm{~mol} \%)$ and $\mathrm{Cu}(\mathrm{OAc})_{2} \cdot \mathrm{H}_{2} \mathrm{O}(419.3 \mathrm{mg}, 2.10 \mathrm{mmol})$ in $\mathrm{D}_{2} \mathrm{O}(5 \mathrm{~mL})$ at $100{ }^{\circ} \mathrm{C}$ for $6 \mathrm{~h}$. Purification by column chromatography ( $n$-pentane/EtOAc 5.6/1) yielded $[D]_{n}-136 a c(212 \mathrm{mg}$, $68 \%$ ) as a colorless solid and reisolated starting material $[D]_{n}-135 a(54 \mathrm{mg}, 25 \%)$ as a colorless solid. The $D$-incorporation in $[D]_{n}-135 a$ and $[D]_{n}-136 a c$ in the ortho-position was estimated by ${ }^{1} \mathrm{H}-\mathrm{NMR}$ spectroscopy.

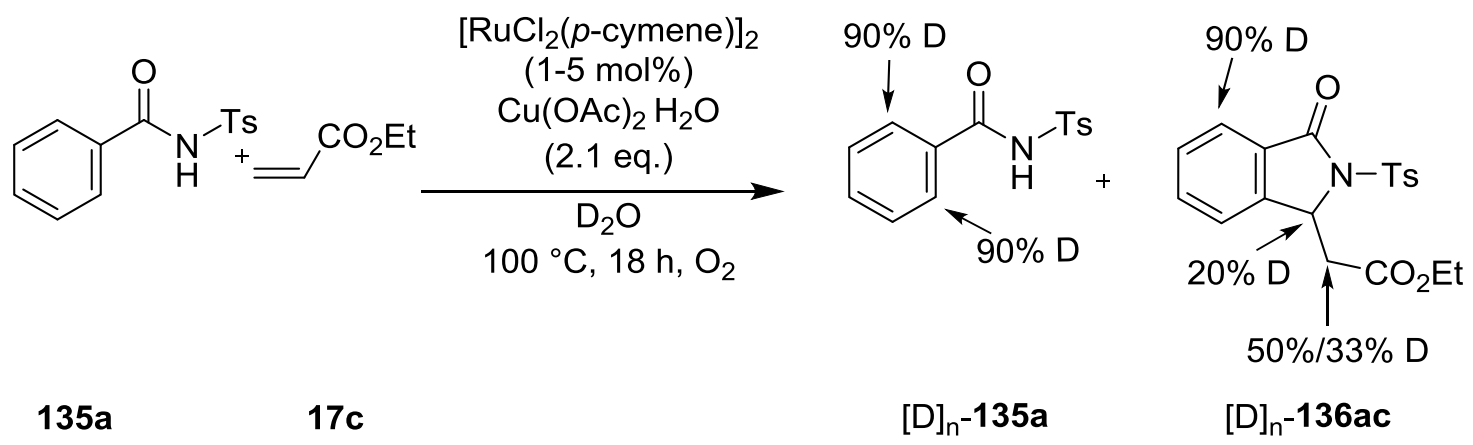



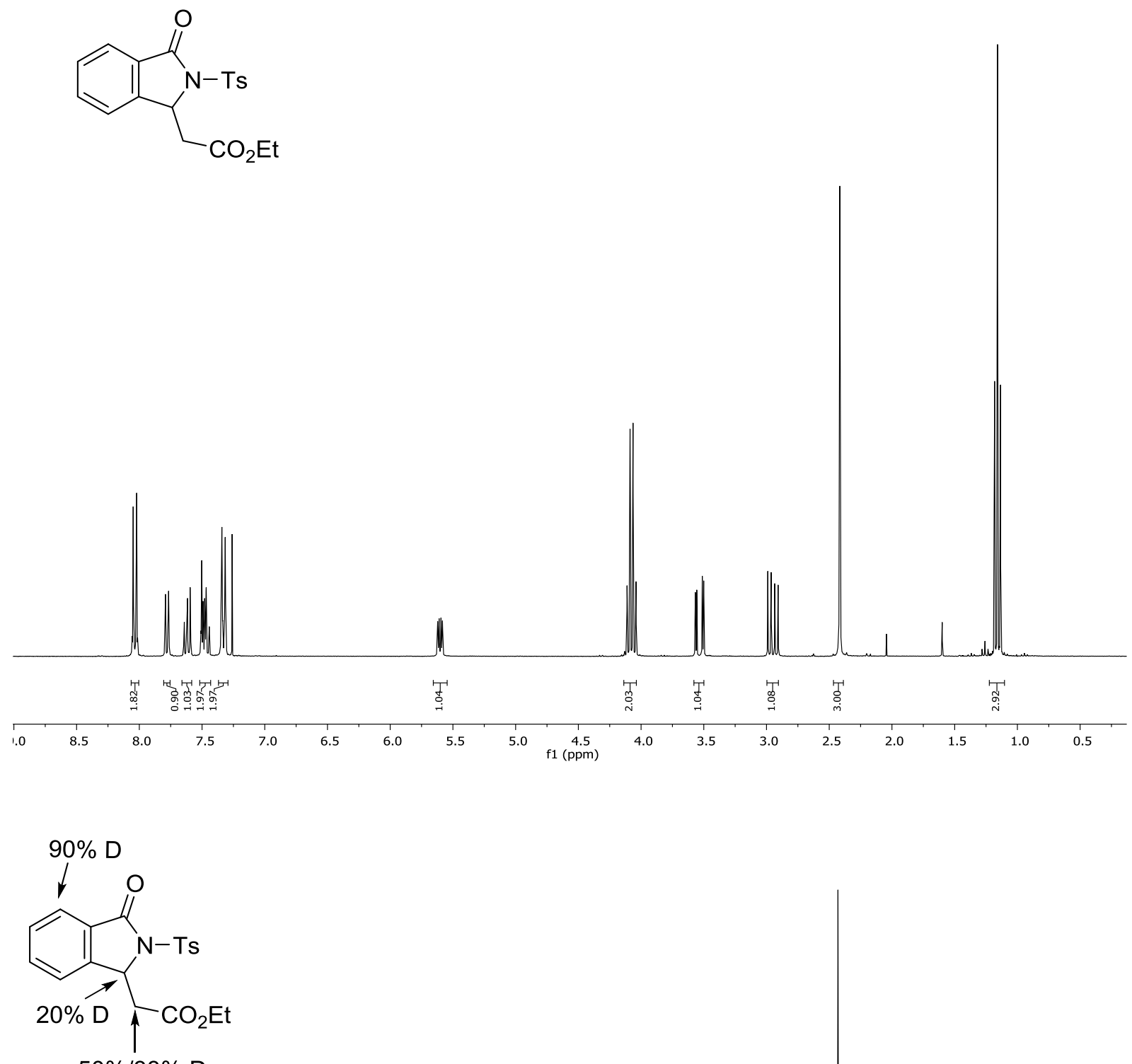

$50 \% / 33 \%$ D

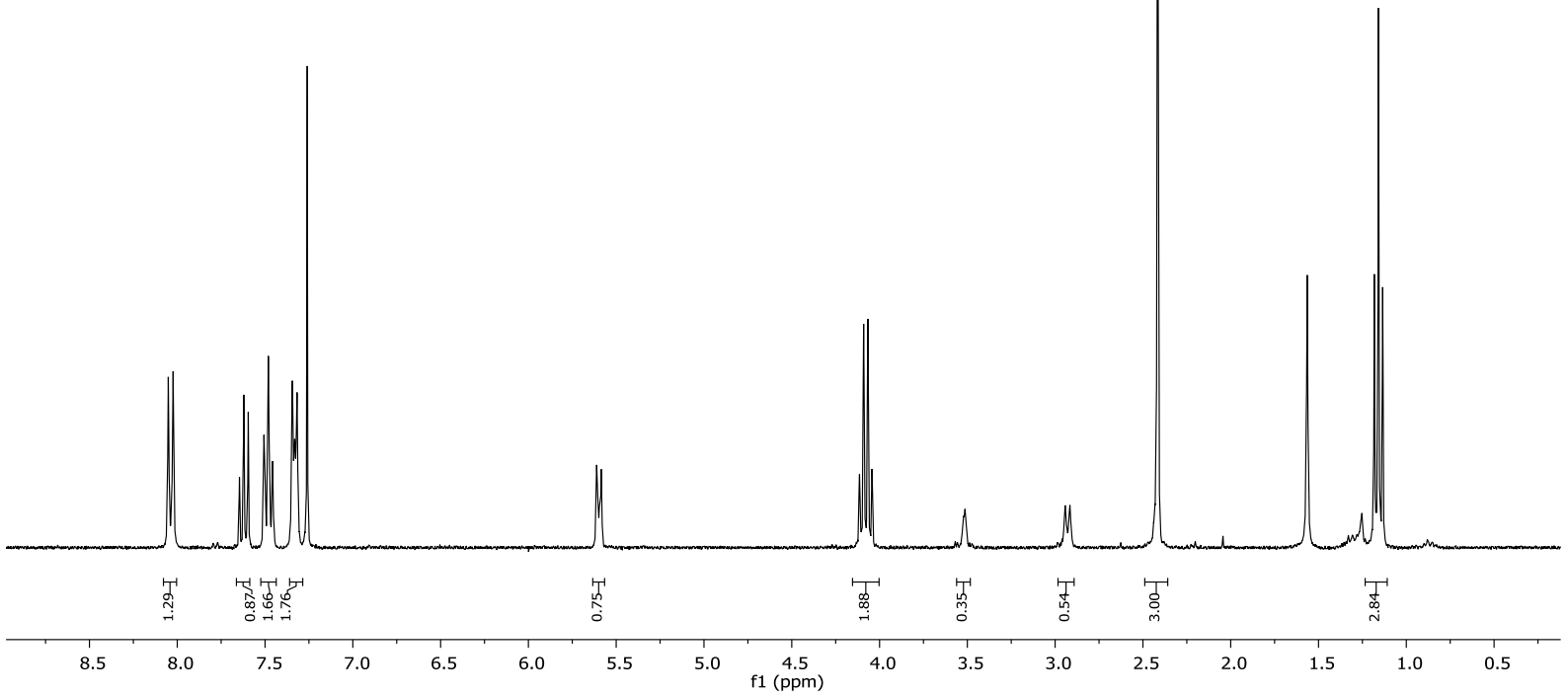




\subsubsection{Ruthenium(II)-Catalyzed Synthesis of Isoindolinones using Oxygen as Sole Oxidant}

Synthesis of Ethyl 2-(4-methyl-3-oxo-2-tosylisoindolin-1-yl)acetate 136bc<smiles>CCOC(=O)CC1c2cccc(C)c2C(=O)N1[I-]</smiles>

The general procedure $\mathbf{G}$ was followed using 2-methyl- $N$-tosylbenzamide (135b) $(145.2 \mathrm{mg}$, $0.50 \mathrm{mmol})$, ethyl acrylate (17c) $(250.0 \mathrm{mg}, 2.50 \mathrm{mmol}),\left[\mathrm{RuCl}_{2}(p-c y m e n e)\right]_{2} \quad(15.3 \mathrm{mg}$, $5.0 \mathrm{~mol} \%)$ and CsOAc $(96.0 \mathrm{mg}, 0.50 \mathrm{mmol})$. Purification by column chromatography ( $n$-hexane/EtOAc $4 / 1)$ yielded $136 \mathrm{bc}(125 \mathrm{mg}, 68 \%)$ as a colorless solid.

The spectral data are in accordance with those reported for $136 \mathrm{bc}$ above (vide supra).

Synthesis of Ethyl 2-(4-methyl-3-oxo-2-tosylisoindolin-1-yl)acetate 136bc<smiles>CCOC(=O)CC1c2cccc(C)c2C(=O)N1[13I]</smiles>

The general procedure $\mathbf{G}$ was followed using 2-methyl- $N$-tosylbenzamide (135b) $(145.2 \mathrm{mg}$, $0.50 \mathrm{mmol})$, ethyl acrylate (17c) $(250.0 \mathrm{mg}, 2.50 \mathrm{mmol}),\left[\mathrm{RuCl}_{2}(p \text {-cymene })\right]_{2} \quad(15.3 \mathrm{mg}$, $5.0 \mathrm{~mol} \%)$ and $\mathrm{KOAC}(49.0 \mathrm{mg}, 0.50 \mathrm{mmol})$. Purification by column chromatography ( $n$-hexane/EtOAc $4 / 1)$ yielded $136 \mathrm{bc}(158 \mathrm{mg}, 86 \%)$ as a colorless solid.

The spectral data are in accordance with those reported for $136 \mathrm{bc}$ above (vide supra).

Synthesis of Benzyl 2-(4-methyl-3-oxo-2-tosylisoindolin-1-yl)acetate 136bd<smiles>Cc1cccc2c1C(=O)N([13F])C2CC(=O)OCc1ccccc1</smiles> 
The general procedure $\mathbf{G}$ was followed using 2-methyl- $N$-tosylbenzamide (135b) $(145.2 \mathrm{mg}$, $0.50 \mathrm{mmol})$, benzyl acrylate $(\mathbf{1 7 d})(380.0 \mathrm{mg}, 2.50 \mathrm{mmol}),\left[\mathrm{RuCl}_{2}(p \text {-cymene })\right]_{2}(15.3 \mathrm{mg}$, $5.0 \mathrm{~mol} \%)$ and $\mathrm{CsOAc}(96.0 \mathrm{mg}, 0.50 \mathrm{mmol})$. Purification by column chromatography ( $n$-hexane/EtOAc 4/1) yielded 136bd (179 mg, 80\%) as a colorless solid.

The spectral data are in accordance with those reported for $136 \mathrm{bd}$ above (vide supra).

\section{Synthesis of Benzyl 2-(4-methyl-3-oxo-2-tosylisoindolin-1-yl)acetate 136bd}<smiles>Cc1cccc2c1C(=O)N([13S])C2CC(=O)OCc1ccccc1</smiles>

The general procedure $\mathbf{G}$ was followed using 2-methyl- $N$-tosylbenzamide (135b) $(145.2 \mathrm{mg}$, $0.50 \mathrm{mmol})$, benzyl acrylate $(\mathbf{1 7 d})(380.0 \mathrm{mg}, 2.50 \mathrm{mmol}),\left[\mathrm{RuCl}_{2}(p \text {-cymene })\right]_{2}$ (15.3 mg, $5.0 \mathrm{~mol} \%)$ and $\mathrm{KOAc}(49.0 \mathrm{mg}, 0.50 \mathrm{mmol})$. Purification by column chromatography ( $n$-hexane/EtOAc 4/1) yielded 136bd (154 mg, 69\%) as a colorless solid.

The spectral data are in accordance with those reported for $136 \mathrm{bd}$ above (vide supra).

\section{Synthesis of tert-Butyl 2-(4-methyl-3-oxo-2-tosylisondolin-1-yl)acetate 136bf}<smiles>Cc1cccc2c1C(=O)N([13S])C2CC(=O)OC(C)(C)C</smiles>

The general procedure $\mathbf{G}$ was followed using 3-methyl- $N$-tosylbenzamide (135b) $(145.2 \mathrm{mg}$, $0.50 \mathrm{mmol})$, tert-butyl acrylate $(\mathbf{1 7 f})(250.0 \mathrm{mg}, 2.50 \mathrm{mmol}),\left[\mathrm{RuCl}_{2}(p \text {-cymene })\right]_{2}(13.5 \mathrm{mg}$, $5.0 \mathrm{~mol} \%)$ and CsOAc $(96.0 \mathrm{mg}, 0.50 \mathrm{mmol})$. Purification by column chromatography ( $n$-hexane/EtOAc 6/1) yielded $136 \mathrm{bf}(109 \mathrm{mg}, 52 \%)$ as a colorless solid.

M.r.: $135-136^{\circ} \mathrm{C}$.

${ }^{1} \mathrm{H}-\mathrm{NMR}\left(400 \mathrm{MHz}, \mathrm{CDCl}_{3}\right): \delta=8.05(\mathrm{~d}, J=8.3 \mathrm{~Hz}, 2 \mathrm{H}), 7.50-7.42(\mathrm{~m}, 1 \mathrm{H}), 7.34$ (dd, $J=8.6,0.7 \mathrm{~Hz}, 2 \mathrm{H}$ ), 7.29 (dd, $J=7.7,0.8 \mathrm{~Hz}, 2 \mathrm{H}), 5.50$ (dd, $J=7.0,3.5 \mathrm{~Hz}, 1 \mathrm{H}$ ), 3.33 (dd, $J=16.4,3.5 \mathrm{~Hz}, 1 \mathrm{H}), 3.03$ (dd, $J=16.4,7.0 \mathrm{~Hz}, 1 \mathrm{H}), 2.42(\mathrm{~s}, 3 \mathrm{H}), 1.21(\mathrm{~s}, 9 \mathrm{H})$. 
${ }^{13}$ C-NMR $\left(100 \mathrm{MHz}, \mathrm{CDCl}_{3}\right): \delta=168.9\left(\mathrm{C}_{\mathrm{q}}\right), 167.3\left(\mathrm{C}_{\mathrm{q}}\right), 146.1\left(\mathrm{C}_{\mathrm{q}}\right), 145.1\left(\mathrm{C}_{\mathrm{q}}\right), 139.6\left(\mathrm{C}_{\mathrm{q}}\right)$, $136.2\left(\mathrm{C}_{\mathrm{q}}\right), 133.7(\mathrm{CH}), 131.0(\mathrm{CH}), 129.7(\mathrm{CH}), 128.6(\mathrm{CH}), 126.9\left(\mathrm{C}_{\mathrm{q}}\right), 120.3(\mathrm{CH}), 81.7$ $\left(\mathrm{C}_{\mathrm{q}}\right), 57.7(\mathrm{CH}), 40.3\left(\mathrm{CH}_{2}\right), 27.7\left(\mathrm{CH}_{3}\right), 21.8\left(\mathrm{CH}_{3}\right), 17.7\left(\mathrm{CH}_{3}\right)$.

IR (ATR): $\tilde{v}=2977,1715,1599,1394,1170,1151,1101,799,744,700,666,574,543 \mathrm{~cm}^{-1}$. MS (ESI) $m / z$ (relative intensity): $438(57)\left[\mathrm{M}+\mathrm{K}^{+}\right], 433(17)\left[\mathrm{M}+\mathrm{Na}^{+}\right], 416(11)\left[\mathrm{M}+\mathrm{H}^{+}\right], 360$ (100).

HR-MS (ESI) $\mathrm{m} / z$ calcd for $\mathrm{C}_{22} \mathrm{H}_{24} \mathrm{NO}_{5} \mathrm{~S}$, [M-H $\left.\mathrm{H}^{+}\right]$414.1381, found 414.1363.

The spectral data are in accordance with those reported in the literature. ${ }^{114 \mathrm{~b}}$

\section{Synthesis of tert-Butyl 2-(4-methyl-3-oxo-2-tosylisondolin-1-yl)acetate 136bf}<smiles>Cc1cccc2c1C(=O)N([13CH3])C2CC(=O)OC(C)(C)C</smiles>

The general procedure $\mathbf{G}$ was followed using 3-methyl- $N$-tosylbenzamide (135b) $(145.2 \mathrm{mg}$, $0.50 \mathrm{mmol})$, tert-butyl acrylate (17f) $(250.0 \mathrm{mg}, 2.50 \mathrm{mmol}),\left[\mathrm{RuCl}_{2}(p \text {-cymene })\right]_{2}(13.5 \mathrm{mg}$, $5.0 \mathrm{~mol} \%)$ and KOAc $(49.5 \mathrm{mg}, 0.50 \mathrm{mmol})$. Purification by column chromatography ( $n$-hexane/EtOAc 6/1) yielded 136bf ( $83 \mathrm{mg}, 40 \%$ ) as a colorless solid.

The spectral data are in accordance with those reported for $136 \mathrm{bf}$ above (vide supra) and in the literature. ${ }^{114 b}$

\section{Synthesis of Ethyl 2-(4-chloro-3-oxo-2-tosylisoindolin-1-yl)acetate 136gc}<smiles>CCOC(=O)CC1c2cccc(Cl)c2C(=O)N1[13I]</smiles>

The general procedure $\mathbf{G}$ was followed using 2-chloro- $N$-tosylbenzamide (135g) $(154.2 \mathrm{mg}$, $0.50 \mathrm{mmol})$, ethyl acrylate (17c) $(250.0 \mathrm{mg}, 2.50 \mathrm{mmol}),\left[\mathrm{RuCl}_{2}(p \text {-cymene })\right]_{2}$ (15.3 mg, $5.0 \mathrm{~mol} \%)$ and CsOAc $(96.0 \mathrm{mg}, 0.50 \mathrm{mmol})$. Purification by column chromatography ( $n$-hexane/EtOAc $4 / 1)$ yielded $136 \mathrm{gc}(110 \mathrm{mg}, 54 \%)$ as a colorless solid.

The spectral data are in accordance with those reported for $136 \mathrm{gc}$ above (vide supra). 


\section{Synthesis of Ethyl 2-(4-chloro-3-oxo-2-tosylisoindolin-1-yl)acetate 136gc}<smiles>CCOC(=O)CC1c2cccc(Cl)c2C(=O)N1[13I]</smiles>

The general procedure $\mathbf{G}$ was followed using 2-chloro- $N$-tosylbenzamide $(\mathbf{1 3 5 g})(154.2 \mathrm{mg}$, $0.50 \mathrm{mmol}$ ), ethyl acrylate (17c) $(250.0 \mathrm{mg}, 2.50 \mathrm{mmol}),\left[\mathrm{RuCl}_{2}(p \text {-cymene })\right]_{2}$ (15.3 mg, $5.0 \mathrm{~mol} \%)$ and KOAc $(49.5 \mathrm{mg}, 0.50 \mathrm{mmol})$. Purification by column chromatography ( $n$-hexane/EtOAc $4 / 1)$ yielded $136 \mathrm{gc}$ (157 $\mathrm{mg}, 77 \%$ ) as a colorless solid.

The spectral data are in accordance with those reported for $\mathbf{1 3 6 g c}$ above (vide supra).

\section{Synthesis of Ethyl 2-(3-oxo-2-tosylisoindolin-1-yl)acetate 136ac}<smiles>CCOC(=O)CC1c2ccccc2C(=O)N1[S-]</smiles>

The general procedure $\mathbf{G}$ was followed using $N$-tosylbenzamide (135a) (138.2 mg, $0.50 \mathrm{mmol})$, ethyl acrylate (17c) $(250.0 \mathrm{mg}, 2.50 \mathrm{mmol}),\left[\mathrm{RuCl}_{2}(p \text {-cymene })\right]_{2}(15.3 \mathrm{mg}$, $5.0 \mathrm{~mol} \%)$ and CsOAc $(96.0 \mathrm{mg}, 0.50 \mathrm{mmol})$. Purification by column chromatography ( $n$-hexane/EtOAc $4 / 1$ ) yielded 136ac (99 mg, 53\%) as a colorless solid.

The spectral data are in accordance with those reported for 136ac above (vide supra).

\section{Synthesis of $n$-Butyl 2-(4-methyl-3-oxo-2-tosylisoindolin-1-1yl)acetate 136be}<smiles>CCCCCC1c2cccc(C)c2C(=O)N1[13CH3]</smiles>

The general procedure $\mathbf{G}$ was followed using 2-methyl- $N$-tosylbenzamide (135b) (145.2 mg, $0.50 \mathrm{mmol}$ ), $n$-butyl acrylate (17e) $(322.2 \mathrm{mg}, 2.50 \mathrm{mmol}),\left[\mathrm{RuCl}_{2}(p \text {-cymene })\right]_{2}(15.3 \mathrm{mg}$, 
$5.0 \mathrm{~mol} \%$ ) and CsOAc $(96.0 \mathrm{mg}, 0.50 \mathrm{mmol})$. Purification by column chromatography ( $n$-hexane/EtOAc $4 / 1$ ) yielded 136be (116 mg, 56\%) as a colorless solid.

The spectral data are in accordance with those reported for 136 be above (vide supra).

Synthesis of Ethyl 2-(4-fluoro-3-oxo-2-tosylisoindolin-1-yl)acetate 136cc<smiles>CCOC(=O)CC1c2cccc(F)c2C(=O)N1[AsH]</smiles>

The general procedure $\mathbf{G}$ was followed using 2-fluoro- $N$-tosylbenzamide (135c) $(147.2 \mathrm{mg}$, $0.50 \mathrm{mmol})$, ethyl acrylate (17c) $(250.0 \mathrm{mg}, 2.50 \mathrm{mmol}),\left[\operatorname{RuCl}_{2}(p-c y m e n e)\right]_{2} \quad(15.3 \mathrm{mg}$, $5.0 \mathrm{~mol} \%)$ and CsOAc $(96.0 \mathrm{mg}, 0.50 \mathrm{mmol})$. Purification by column chromatography ( $n$-hexane/EtOAc 4/1) yielded 136cc (166 mg, 85\%) as a colorless solid.

The spectral data are in accordance with those reported for 136cc above (vide supra).

Synthesis of $n$-Butyl 2-(4-fluoro-3-oxo-2-tosylisoindolin-1-yl)acetate 136ce<smiles>CCCCCC1c2cccc(F)c2C(=O)N1[AsH3-]</smiles>

The general procedure $\mathbf{G}$ was followed using 2-fluoro- $N$-tosylbenzamide (135c) $(146.7 \mathrm{mg}$, $0.50 \mathrm{mmol}), n$-butyl acrylate (17e) $(322.0 \mathrm{mg}, 2.50 \mathrm{mmol}),\left[\mathrm{RuCl}_{2}(p \text {-cymene })\right]_{2}(15.3 \mathrm{mg}$, $5.0 \mathrm{~mol} \%)$ and CsOAc $(96.0 \mathrm{mg}, 0.50 \mathrm{mmol})$. Purification by column chromatography ( $n$-hexane/EtOAc $4 / 1)$ yielded $136 \mathrm{ce}(122 \mathrm{mg}, 58 \%$ ) as a colorless solid.

The spectral data are in accordance with those reported for $136 \mathrm{ce}$ above (vide supra).

Synthesis of Ethyl 2-(4-methoxy-3-oxo-2-tosylisoindolin-1-yl)acetate 136dc<smiles>CCOC(=O)CC1c2cccc(OC)c2C(=O)N1[13CH3]</smiles> 
The general procedure $\mathbf{G}$ was followed using 2-methoxy- $N$-tosylbenzamide (135d) $(152.7 \mathrm{mg}, 0.50 \mathrm{mmol})$, ethyl acrylate $(17 \mathrm{c})(250.0 \mathrm{mg}, 2.50 \mathrm{mmol}), \quad\left[\mathrm{RuCl}_{2}(p \text {-cymene })\right]_{2}$ $(15.3 \mathrm{mg}, \quad 5.0 \mathrm{~mol} \%)$ and $\mathrm{CsOAc}(96.0 \mathrm{mg}, \quad 0.50 \mathrm{mmol})$. Purification by column chromatography ( $n$-hexane/EtOAc 4/1) yielded $136 \mathrm{dc}(105 \mathrm{mg}, 52 \%)$ as a colorless solid. The spectral data are in accordance with those reported for $136 \mathrm{dc}$ above (vide supra).

\section{Synthesis of Ethyl 2-(4-nitro-3-oxo-2-tosylisonidolin-1-yl)acetate 136fc}<smiles>CCOC(=O)CC1c2cccc([N+](=O)[O-])c2C(=O)N1[13F]</smiles>

The general procedure $\mathbf{G}$ was followed using 2-nitro- $N$-tosylbenzamide (135f) $(160.0 \mathrm{mg}$, $0.50 \mathrm{mmol})$, ethyl acrylate (17c) $(250.0 \mathrm{mg}, 2.50 \mathrm{mmol}),\left[\mathrm{RuCl}_{2}(p-c y m e n e)\right]_{2}(15.3 \mathrm{mg}$, $5.0 \mathrm{~mol} \%)$ and CsOAc $(96.0 \mathrm{mg}, 0.50 \mathrm{mmol})$. Purification by column chromatography ( $n$-hexane/EtOAc 4/1) yielded $136 \mathrm{fc}(94 \mathrm{mg}, 45 \%$ ) as a colorless solid.

The spectral data are in accordance with those reported for $136 \mathrm{fc}$ above (vide supra).

Synthesis of Ethyl 2-(1-oxo-2-tosyl-2,3-dihydro-1H-benzo[e]isoindol-3-yl)acetate 136ec<smiles>CCOC(=O)CC1c2ccc3ccccc3c2C(=O)N1[13F]</smiles>

The general procedure $\mathbf{G}$ was followed using $N$-tosyl-1-naphtamide (135e) $(162.7 \mathrm{mg}$, $0.50 \mathrm{mmol})$, ethyl acrylate (17c) $(250.0 \mathrm{mg}, 2.50 \mathrm{mmol}),\left[\mathrm{RuCl}_{2}(p \text {-cymene })\right]_{2}$ (15.3 mg, $5.0 \mathrm{~mol} \%)$ and CsOAc $(96.0 \mathrm{mg}, 0.50 \mathrm{mmol})$. Purification by column chromatography ( $n$-hexane/EtOAc 4/1) yielded $136 \mathrm{ec}$ ( $73 \mathrm{mg}, 45 \%$ ) as a colorless solid.

The spectral data are in accordance with those reported for $136 \mathrm{ec}$ above (vide supra). 


\section{Synthesis of Ethyl 2-(5-methyl-3-oxo-2-tosylisondolin-1-yl)acetate 136hc}<smiles>CCOC(=O)CC1c2ccc(C)cc2C(=O)N1[AsH3-]</smiles>

The general procedure $\mathbf{G}$ was followed using 3-methyl- $N$-tosylbenzamide (135h) $(145.2 \mathrm{mg}$, $0.50 \mathrm{mmol})$, ethyl acrylate (17c) $(250.0 \mathrm{mg}, 2.50 \mathrm{mmol}),\left[\mathrm{RuCl}_{2}(p \text {-cymene })\right]_{2} \quad(15.3 \mathrm{mg}$, $5.0 \mathrm{~mol} \%)$ and CsOAc $(96.0 \mathrm{mg}, 0.50 \mathrm{mmol})$. Purification by column chromatography ( $n$-hexane/EtOAc 6/1) yielded 136hc (126 mg, 65\%) as a colorless solid.

The spectral data are in accordance with those reported for $136 \mathrm{hc}$ above (vide supra).

Synthesis of $n$-Butyl 2-(5-methyl-3-oxo-2-tosylindolin-1-yl)acetate 136he<smiles>CCCCCC1c2ccc(C)cc2C(=O)N1[AsH3-]</smiles>

The general procedure $\mathbf{G}$ was followed using 3-methyl- $N$-tosylbenzamide (135h) $(145.2 \mathrm{mg}$, $0.50 \mathrm{mmol}), n$-butyl acrylate (17e) $(322.0 \mathrm{mg}, 2.50 \mathrm{mmol}),\left[\mathrm{RuCl}_{2}(p \text {-cymene })\right]_{2}(15.3 \mathrm{mg}$, $5.0 \mathrm{~mol} \%)$ and CsOAc $(96.0 \mathrm{mg}, 0.50 \mathrm{mmol})$. Purification by column chromatography ( $n$-hexane/EtOAc $4 / 1$ ) yielded $136 \mathrm{he} \mathrm{(98} \mathrm{mg}, 47 \%$ ) as a colorless solid.

The spectral data are in accordance with those reported for 136 he above (vide supra).

\section{Synthesis of Ethyl 2-(5-methoxy-3-oxo-2-tosylisoindolin-1-yl)acetate 136ic}<smiles>CCOC(=O)CC1c2ccc(OC)cc2C(=O)N1[AsH3]</smiles>

The general procedure $\mathbf{G}$ was followed using 3-methoxy- $N$-tosylbenzamide (135i) $(152.2 \mathrm{mg}$, $0.50 \mathrm{mmol})$, ethyl acrylate (17c) $(250.0 \mathrm{mg}, 2.50 \mathrm{mmol}),\left[\mathrm{RuCl}_{2}(p-c y m e n e)\right]_{2}(15.3 \mathrm{mg}$, 
$5.0 \mathrm{~mol} \%$ ) and CsOAc $(96.0 \mathrm{mg}, 0.50 \mathrm{mmol})$. Purification by column chromatography ( $n$-hexane/EtOAc $4 / 1$ ) yielded 136ic (121 mg, 60\%) as a colorless solid.

The spectral data are in accordance with those reported for 136ic above (vide supra).

Synthesis of Ethyl 2-[3-oxo-2-tosyl-5-(trifluoromethyl)isoindolin-1-yl]acetate 136jc<smiles>CCOC(=O)CC1c2ccc(C(F)(F)F)cc2C(=O)N1S</smiles>

The general procedure $\mathbf{G}$ was followed using $N$-tosyl-3-(trifluoromethyl)benzamide (135j) $(171.5 \mathrm{mg}, \quad 0.50 \mathrm{mmol})$, ethyl acrylate (17c) $(250.0 \mathrm{mg}, 2.50 \mathrm{mmol}), \quad\left[\mathrm{RuCl}_{2}(p \text {-cymene })\right]_{2}$ $(15.3 \mathrm{mg}, \quad 5.0 \mathrm{~mol} \%)$ and $\mathrm{CsOAc}(96.0 \mathrm{mg}, \quad 0.50 \mathrm{mmol})$. Purification by column chromatography ( $n$-hexane/EtOAc 4/1) yielded 136jc (106 mg, 48\%) as a colorless solid.

The spectral data are in accordance with those reported for $136 \mathrm{jc}$ above (vide supra).

\section{Synthesis of Ethyl 2-(4-methyl-3-oxo-4-tosylisoindolin-1-yl)acetate 136kc}<smiles>CCOC(=O)CC1c2cc(C)ccc2C(=O)N1[AsH3]</smiles>

The general procedure $\mathbf{G}$ was followed using 4-methyl- $N$-tosylbenzamide (135k) $(145.2 \mathrm{mg}$, $0.50 \mathrm{mmol})$, ethyl acrylate (17c) $(250.0 \mathrm{mg}, 2.50 \mathrm{mmol}),\left[\mathrm{RuCl}_{2}(p \text {-cymene })\right]_{2}$ (15.3 mg, $5.0 \mathrm{~mol} \%)$ and CsOAc $(96.0 \mathrm{mg}, 0.50 \mathrm{mmol})$. Purification by column chromatography ( $n$-hexane/EtOAc $4 / 1$ ) yielded $136 \mathrm{kc}(116 \mathrm{mg}, 60 \%)$ as a colorless solid.

The spectral data are in accordance with those reported for $136 \mathrm{kc}$ above (vide supra).

Synthesis of Ethyl 2-(6-methoxy-3-oxo-2-tosylisoindolin-1-yl)acetate 136lc<smiles>CCOC(=O)CC1c2cc(OC)ccc2C(=O)N1[I-]</smiles> 
The general procedure $\mathbf{G}$ was followed using 4-methoxy- $N$-tosylbenzamide (135I) (152.7 mg, $0.50 \mathrm{mmol})$, ethyl acrylate (17c) $(250.0 \mathrm{mg}, 2.50 \mathrm{mmol}),\left[\operatorname{RuCl}_{2}(p-c y m e n e)\right]_{2} \quad(15.3 \mathrm{mg}$, $5.0 \mathrm{~mol} \%)$ and CsOAc $(96.0 \mathrm{mg}, 0.50 \mathrm{mmol})$. Purification by column chromatography ( $n$-hexane/EtOAc $4 / 1$ ) yielded 136lc (121 mg, 60\%) as a colorless solid.

The spectral data are in accordance with those reported for 136lc above (vide supra).

\section{Synthesis of Ethyl 2-(6-fluoro-3-oxo-2-tosylisoindolin-1-yl)acetate 136mc}<smiles>CCOC(=O)CC1c2cc(F)ccc2C(=O)N1[13I]</smiles>

The general procedure $\mathbf{G}$ was followed using 4-fluoro- $N$-tosylbenzamide (135m) $(146.7 \mathrm{mg}$, $0.50 \mathrm{mmol})$, ethyl acrylate (17c) $(250.0 \mathrm{mg}, 2.50 \mathrm{mmol}),\left[\mathrm{RuCl}_{2}(p \text {-cymene })\right]_{2}(15.3 \mathrm{mg}$, $5.0 \mathrm{~mol} \%)$ and CsOAc $(96.0 \mathrm{mg}, 0.50 \mathrm{mmol})$. Purification by column chromatography ( $n$-hexane/EtOAc 4/1) yielded $136 \mathrm{mc}(116 \mathrm{mg}, 59 \%$ ) as a colorless solid.

The spectral data are in accordance with those reported for $136 \mathrm{mc}$ above (vide supra). 


\subsubsection{Intermolecular Competition Experiment for the Ruthenium(II)-Catalyzed Synthesis of Isoindolinones}

Competition Experiment between Tosylbenzamides 135h and 135j<smiles>[3H]NC(=O)c1cccc(C)c1</smiles>

$135 h$

$(1.0 \mathrm{mmol})$

$+$<smiles>O=C(N[TeH])c1cccc(C(F)(F)F)c1</smiles>

$135 \mathrm{j}$

$(1.0 \mathrm{mmol})$
$17 \mathrm{c}(5.0 \mathrm{mmol})$ $\left[\mathrm{RuCl}_{2}(p \text {-cymene })\right]_{2}$ $(5.0 \mathrm{~mol} \%)$ $100{ }^{\circ} \mathrm{C}, 18 \mathrm{~h}$ $\mathrm{O}_{2}$<smiles>CCOC(=O)CC1c2ccc(C)cc2C(=O)N1[13I]</smiles>

136hc: $86 \%$<smiles>CCOC(=O)CC1c2ccc(C(F)(F)F)cc2C(=O)N1[13F]</smiles>

136jc: $33 \%$ 


\section{Curriculum Vitae}

Date of birth: $\quad 22$ October, 1985 (Engelskirchen)

Nationality: German

\section{Scientific Education}

12/2011 - present Studies for a doctorate under supervision of Prof. Dr. Lutz Ackermann, Institute of Organic and Biomolecular Chemistry; Georg-August University Göttingen: 'Ruthenium-Catalyzed Synthesis of bioactive Compounds'

24.11.2011

Final examinations in chemistry ('Diplom', grade 'very good')

02/2011-11/2011 Diploma-thesis under supervision of Prof. Dr. Michael Famulok, Life \& Medical Sciences Institute, Rheinische Friedrich-Wilhelms University Bonn: 'Characterization of Secin44: A Putative Cytohesin Inhibitor'

04/2008-02/2011 Advanced studies in chemistry at the Rheinische FriedrichWilhelms University Bonn

03.04.2008

Intermediate examination in chemistry ('Vordiplom', grade 'good')

10/2005-04/2008 Studies of chemistry at the Rheinische Friedrich-Wilhelms University Bonn 


\section{Education}

08/1996 - 06/2005 Paul-Klee-Gymnasium Overath

Abitur with grade 2.6 (Major subjects: History and Biology)

08/1992 - 06/1996 Primary school in Overath

\section{Training}

- Intercultural competency (Prof. S. Klein-Franke)

- Leadership competency (Stefanie Beckmann)

\section{Teaching Experiences}

Assistant for preparative practical and theoretics "Chemical laboratory for Medical Students" (06/2012 - 08/2014)

\section{Conferences}

$10 / 2014$

Poster presentation, Niedersächsisches Katalyse Symposium, Göttingen

$03 / 2015$

Poster presentation, Braunlage

$07 / 2015$

Poster presentation, 7. Göttinger Chemie-Forum 2015, Göttingen

\section{Publications}

C. Tirler, L. Ackermann, "Ruthenium(II)-Catalyzed Cross-Dehydrogenative C-H Alkenylations by Triazole Assistance" Tetrahedron (Symposia in print) 2015, 45434551. 